\title{
Women and housing : gender makes a difference
}

\author{
Citation for published version (APA):
}

Westendorp, I. (2007). Women and housing : gender makes a difference. [Doctoral Thesis, Maastricht University]. Intersentia. https://doi.org/10.26481/dis.20070601iw

Document status and date:

Published: 01/01/2007

DOI:

10.26481/dis.20070601iw

Document Version:

Publisher's PDF, also known as Version of record

\section{Please check the document version of this publication:}

- A submitted manuscript is the version of the article upon submission and before peer-review. There can be important differences between the submitted version and the official published version of record.

People interested in the research are advised to contact the author for the final version of the publication, or visit the DOI to the publisher's website.

- The final author version and the galley proof are versions of the publication after peer review.

- The final published version features the final layout of the paper including the volume, issue and page numbers.

Link to publication

\footnotetext{
General rights rights.

- You may freely distribute the URL identifying the publication in the public portal. please follow below link for the End User Agreement:

www.umlib.nl/taverne-license

Take down policy

If you believe that this document breaches copyright please contact us at:

repository@maastrichtuniversity.nl

providing details and we will investigate your claim.
}

Copyright and moral rights for the publications made accessible in the public portal are retained by the authors and/or other copyright owners and it is a condition of accessing publications that users recognise and abide by the legal requirements associated with these

- Users may download and print one copy of any publication from the public portal for the purpose of private study or research.

- You may not further distribute the material or use it for any profit-making activity or commercial gain

If the publication is distributed under the terms of Article $25 \mathrm{fa}$ of the Dutch Copyright Act, indicated by the "Taverne" license above, 
Women and Housing:

Gender Makes a Difference 



\title{
Women and Housing: Gender Makes a Difference
}

\author{
PROEFSCHRIFT
}

Ter verkrijging van de graad van doctor

aan de Universiteit Maastricht

op gezag van de Rector Magnificus,

Prof. mr. G.P.M.F. Mols,

volgens het besluit van het College van Decanen,

in het openbaar te verdedigen

op vrijdag, 1 juni 2007 om 10.00 uur

door

Ingrid Westendorp 


\section{Promotor:}

Prof. dr. Th.C. van Boven

\section{Copromotor:}

Dr. mr. M.W. Wolleswinkel

\section{Beoordelingscommissie:}

Prof. dr. M.T. Kamminga (voorzitter)

Prof. dr. I. Boerefijn

Prof. dr. A.P.M. Coomans

Prof. dr. C. Flinterman LL.M (Universiteit Utrecht)

Prof. dr. M.L.P. Loenen (Universiteit Utrecht) 


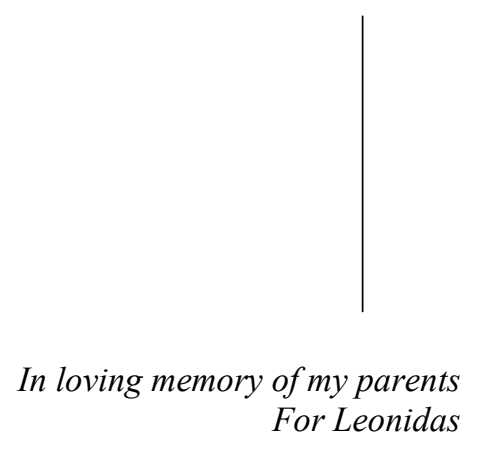

\section{Preface}

From an early age on I was interested in the way people are housed and the enormous differences that exist among people's housing conditions. This interest grew when I started travelling in my early twenties and visited Mexico where I saw for the first time people living in shanty towns and squatting on pavements without any form of shelter whatsoever against abuse or the cold nights. A few years later I settled in Greece and I learned from personal experience what it means to have no indoor plumbing, electricity, gas to cook on, waste disposal, and sometimes in summer, no water from the tap. Still, I realize that I am in a privileged position. I have been born in a prosperous country with a good brain out of parents who considered gender equality as a matter of fact, and who gave me the opportunity to study and learn a profession. The inconveniences I have experienced were only temporary, while others will have to cope with them, and even worse situations, all their lives.

When I started reading law in my early thirties, I was very much surprised to learn that a human right to housing actually exists and that the great majority of States have taken up the obligation to respect, protect and fulfil their population's housing rights. I wrote my final paper on this subject and I decided that I would try to write a doctoral thesis on the right to adequate housing once I had graduated. The more I read about the right to housing, however, the more I was struck by the gender neutral tone of all official norms and statements, especially when I thought of all those women who are expected to cook, clean, wash and raise their children in inadequate housing conditions, as well as those unfortunates who cannot find safety and peace at home because they have an abusive partner. That is why I decided to focus on the gender aspects that influence the fulfilment of the right to housing for women. Although I have done my utmost to imagine the various situations women may encounter, I cannot speak for all of them, especially since it is impossible for me to shake off my Western perspective. Listening carefully to women from different cultural backgrounds was the best I could do.

It was very fortunate, that at precisely the right moment a job opportunity presented itself at the law faculty of Maastricht University and that in due course I found Theo van Boven and Ria Wolleswinkel willing to supervise this doctoral study. I am very grateful to both of them for always believing in me and for giving me so much freedom to pursue my goal, even though they did not always agree with me. Ria was always there for me when I needed a listening ear. Theo never ceased to amaze me with his wealth of knowledge and his quick insights.

I am also indebted to Kees Flinterman. He supported me during a very difficult period in my life and he made it possible for me to study law full-time for six months when I had almost lost heart during my near 'endless' studies with the Open University. It is therefore a great pleasure for me that he is one of the examiners of this study. 
Thanks are also due to the other examiners who put their time and effort into reading my book. Menno Kamminga who I have come to appreciate as a colleague, Titia Loenen and Ineke Boerefijn who have introduced me to the world of feminism and international law, and Fons Coomans whose research on the right to education was a source of inspiration for me and who was also kind enough to supervise my final paper with the Open University.

Many of my (former) colleagues supported and encouraged me in the course of the years and I am grateful to all of them. Special mention deserve Eva Rieter, who kept providing me with useful pieces of information she had found on the internet, and Jotsna Gupta, who taught me so many fascinating facts about Indian customs and culture.

On a personal level I thank my family and friends who showed a great deal of interest in my progress, and who put up with my chronic lack of time for them. A special word of thanks goes to my sister Adinda Creusen for her cover design and my son Leonidas for his cleverly designed database which made the work on my bibliography a piece of cake. Finally, I am grateful to my niece Odette Creusen and my friend and colleague Chantal Kuypers who both so willingly agreed to be my paranimfs and who were even prepared to read this book from cover to cover (including the boring parts). You have made the final stage of my work on this study so much easier and enjoyable with your enthusiasm and assistance. I took great pleasure in our joint luncheons and I really hope that we can keep finding excuses to organize them in future. 


\section{TABLE OF CONTENTS}

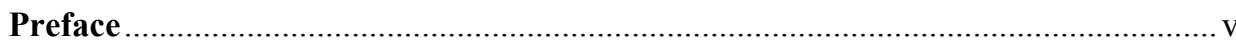

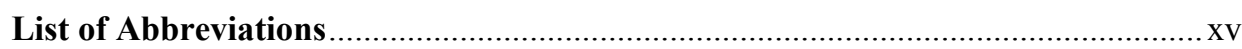

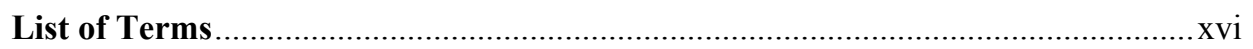

\section{Chapter I}

Introduction

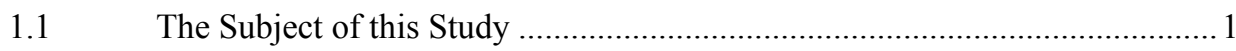

$1.2 \quad$ Research Methods ................................................................................ 2

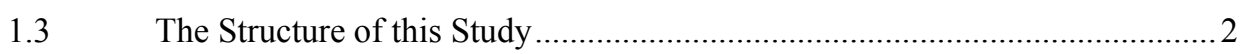

\section{Chapter II}

Analysis of the Right to Adequate Housing

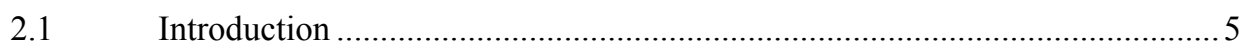

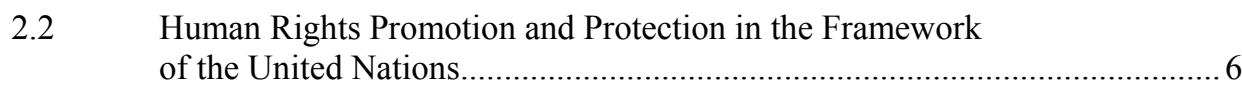

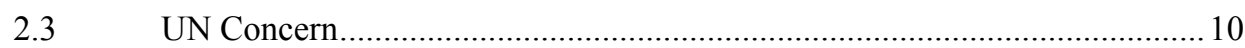

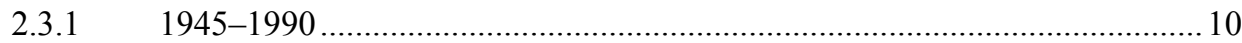

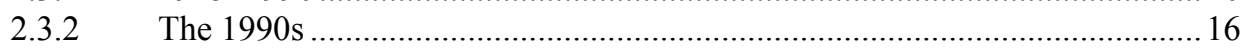

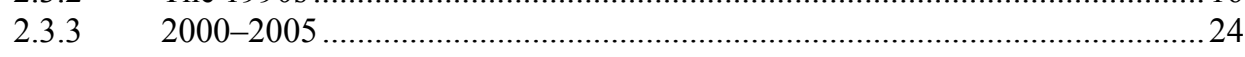

2.4 Content of the Right to Adequate Housing................................................. 33

2.5 State Obligations Pertaining to the Right to Adequate Housing.................... 37

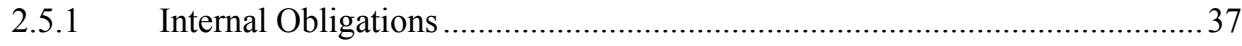

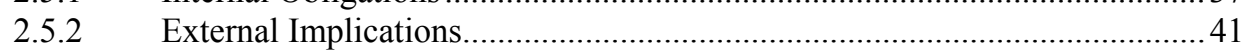

2.6 Housing as a Justiciable Human Right ..................................................... 43

$2.7 \quad$ Women's Right to Adequate Housing ......................................................... 49

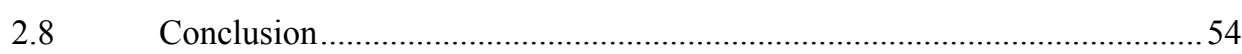

\section{Chapter III}

Relevant Gender Factors

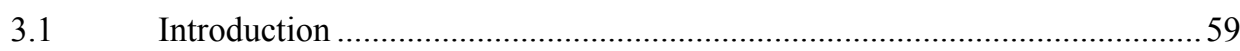


Table of Contents

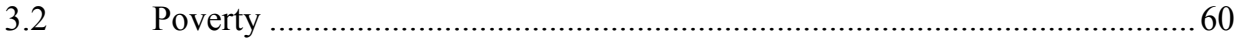

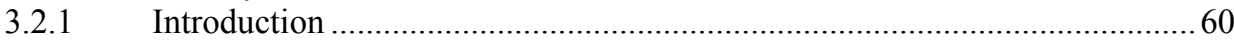

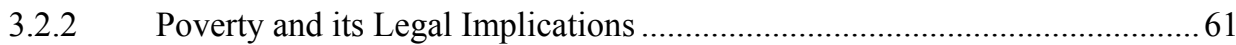

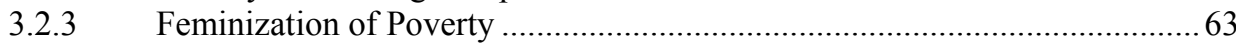

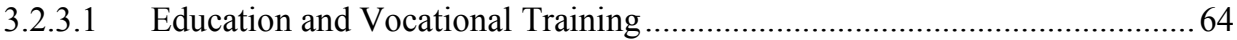

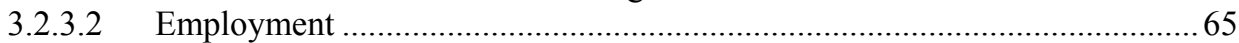

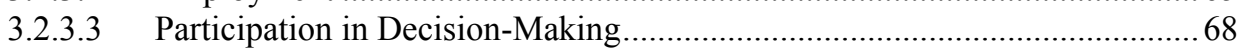

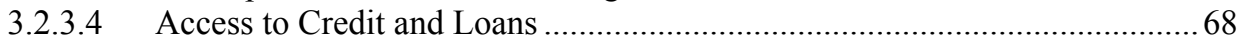

3.2.3.5 Right of Inheritance ........................................................................... 70

3.2.4 Female-Headed Households .................................................................. 70

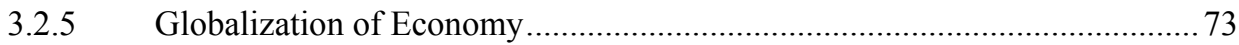

3.2.6 Structural Reform of Economies ........................................................... 76

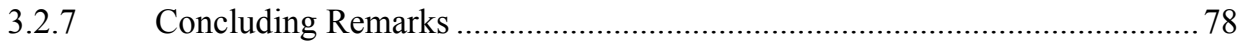

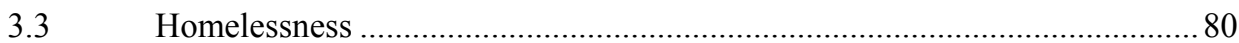

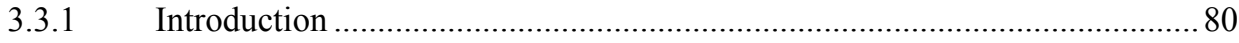

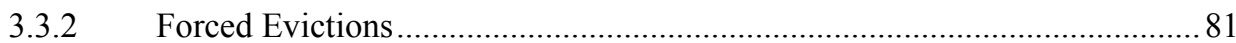

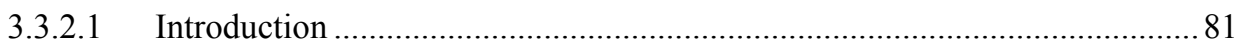

3.3.2.2 The Concept of Forced Evictions ............................................................... 81

3.3.2.3 International Concern with Forced Evictions ....................................... 83

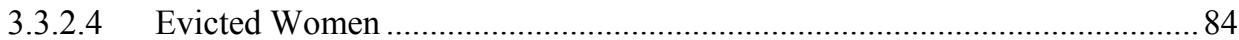

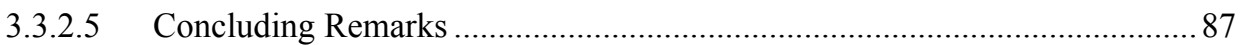

3.3.3 Natural and Human-Made Disasters............................................................ 87

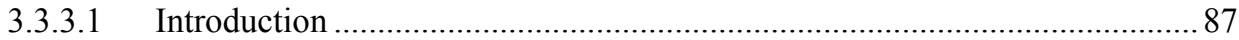

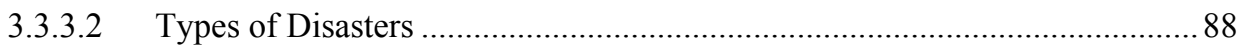

3.3.3.3 Before the Disaster .............................................................................. 90

3.3.3.4 During the Disaster............................................................................... 91

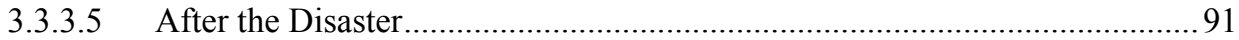

3.3.3.6 Windows of Opportunity ..................................................................... 93

3.3.3.7 Concluding Remarks .......................................................................... 95

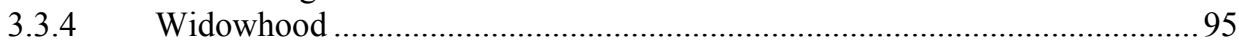

3.3.4.1 Introduction ....................................................................................... 95

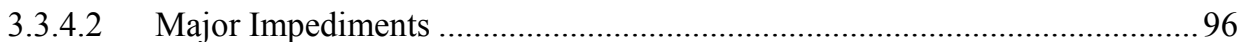

3.3.4.3 Options Open to Widows ........................................................................ 99

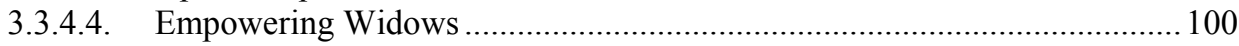

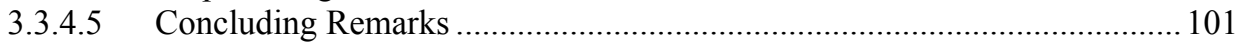

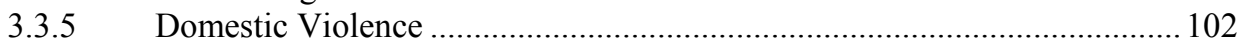

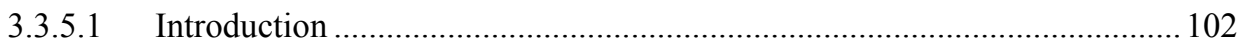

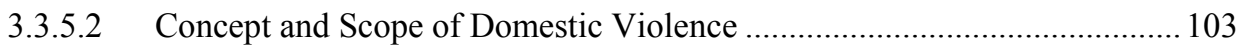

3.3.5.3 Causes of Domestic Violence ........................................................................ 104

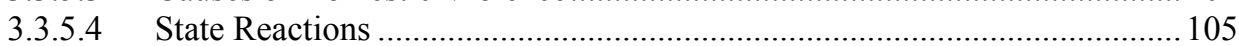

3.3.5.4.1 Criminal Law Measures .............................................................................. 105

3.3.5.4.2 Civil and Administrative Law Measures .................................................... 108

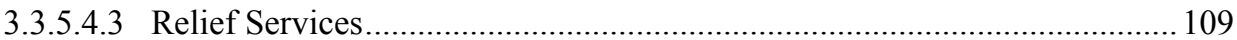

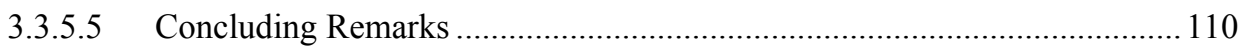

viii 


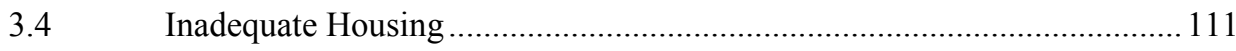

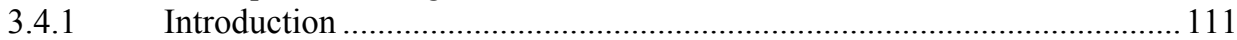

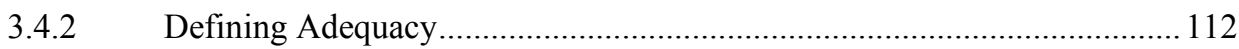

3.4.3 Affordability and Accessibility ............................................................ 114

3.4.4 Technical and Infrastructure Deficiencies .................................................... 114

3.4.4.1 Habitability and Health Problems............................................................... 115

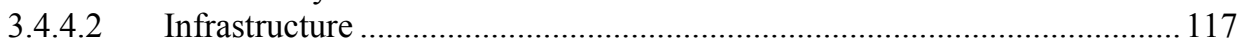

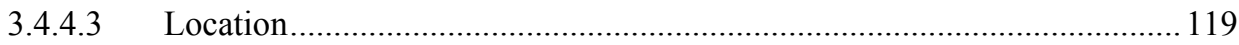

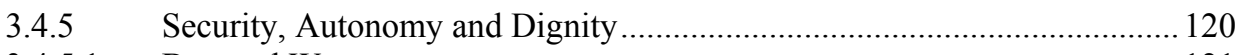

3.4.5.1 Battered Women...................................................................................... 121

3.4.5.2 Single Women, Divorcees and Widows ..................................................... 124

3.4.5.3 Women Migrant Workers........................................................................... 124

3.4.5.4 Female Refugees and Internally Displaced Women.................................... 125

3.4.5.4.1 Differences between Refugees and Internally Displaced

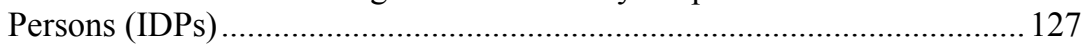

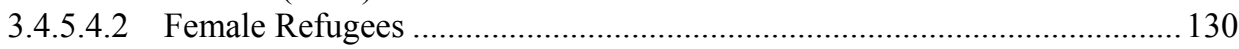

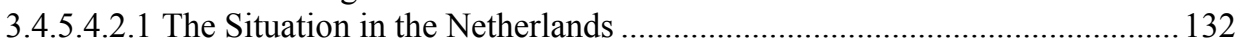

3.4.5.4.3 Internally Displaced Women .................................................................... 133

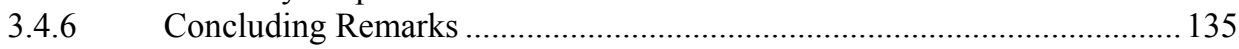

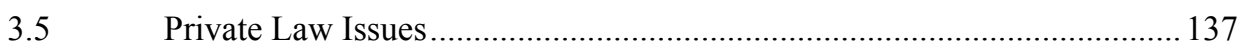

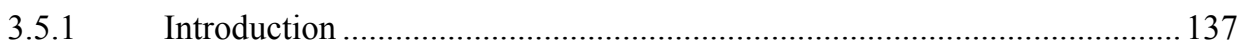

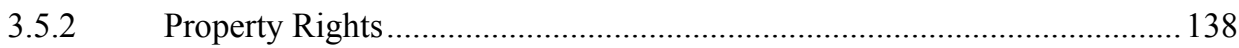

3.5.2.1 Property Rights and Equality ………………………………………….... 139

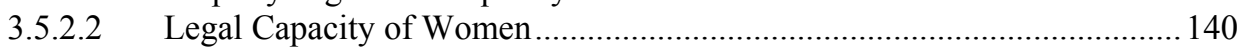

3.5.2.3 Equality as regards Marriage Property ........................................................ 141

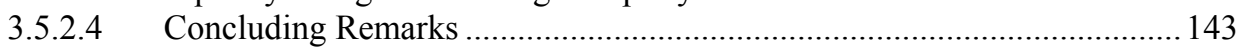

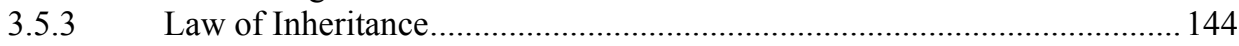

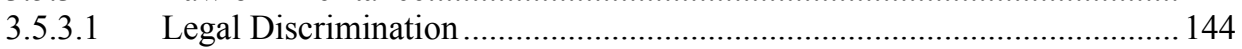

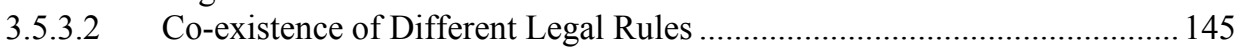

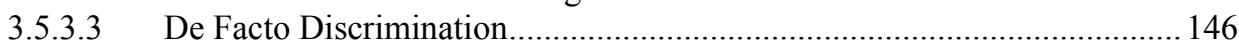

3.5.3.4 De Iure and De Facto Equality ................................................................ 147

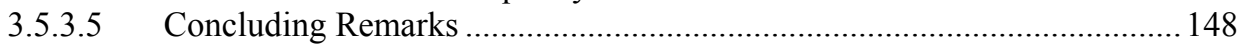

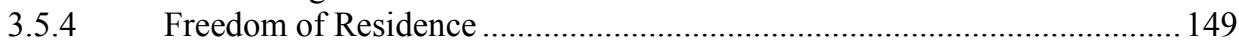

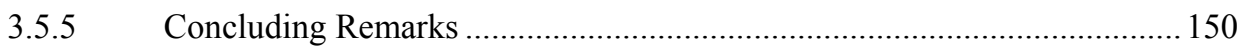

3.6 Human Rights Issues .................................................................................. 151

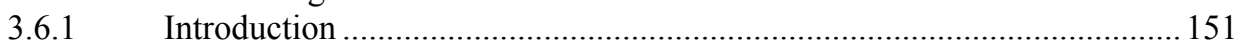

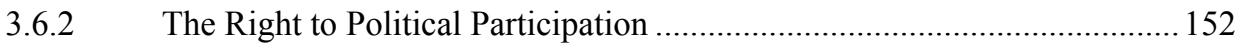

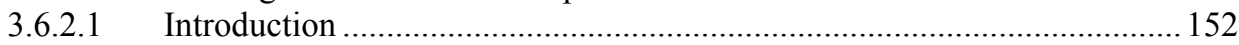

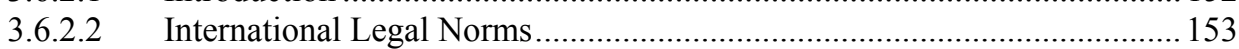

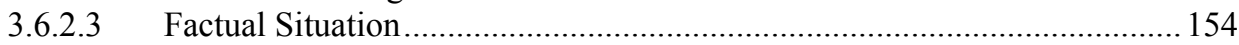

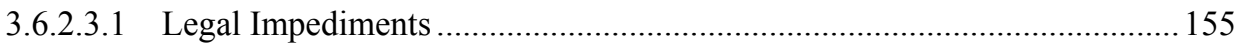

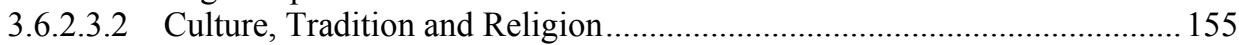

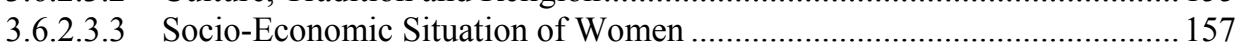

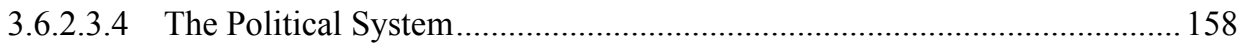


Table of Contents

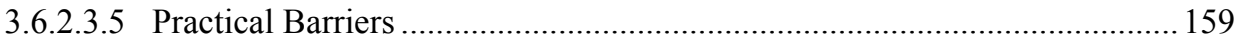

3.6.2.4 Decision-Making at the Local Level ....................................................... 159

3.6.2.5 Does Women's Participation Make a Difference? ......................................... 160

3.6.2.6 Ways to Increase Women's Political Participation........................................ 161

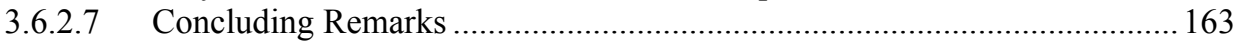

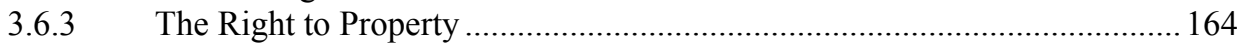

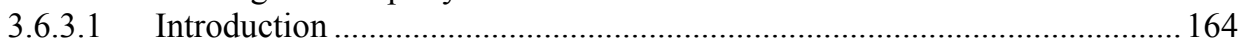

3.6.3.2 Access to and Property Rights of Land and Housing ..................................... 165

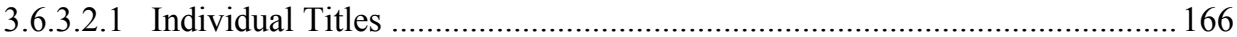

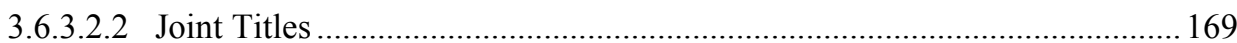

3.6.3.2.3 Common Property (Collective Rights) ........................................................ 170

3.6.3.2.4 The Gap between Property Rights and Effective Control ............................ 171

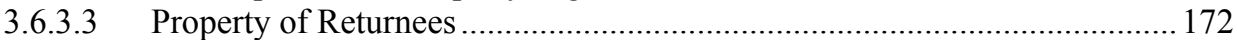

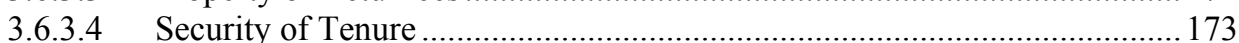

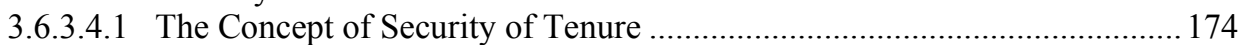

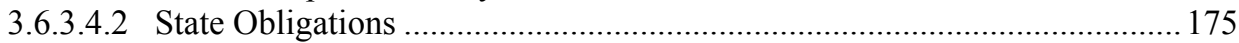

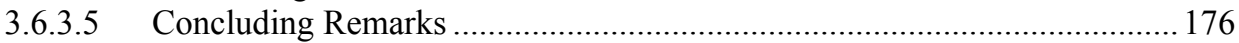

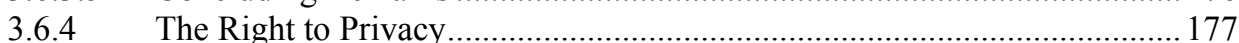

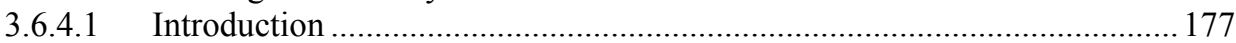

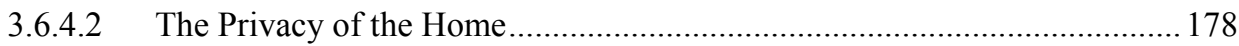

3.6.4.3 Privacy and Domestic Violence ……………........................................... 179

3.6.4.4 Concluding Remarks .............................................................................. 180

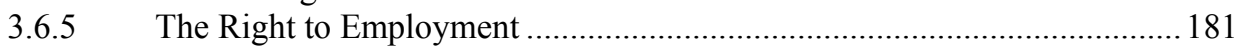

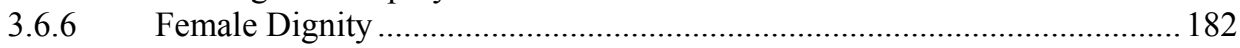

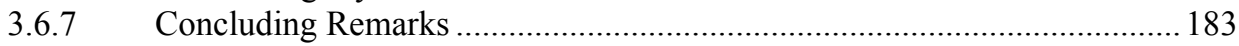

3.7 Structural Discrimination Inherent in Cultural Patterns ............................... 184

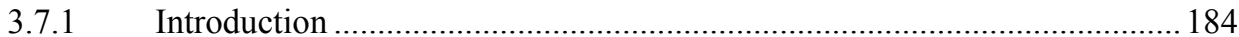

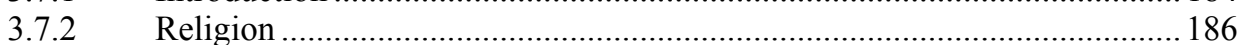

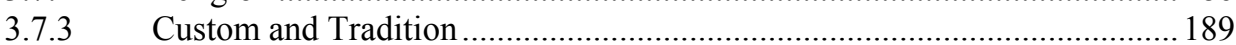

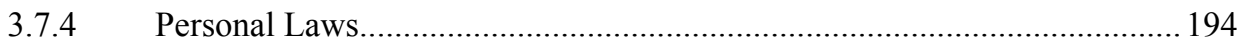

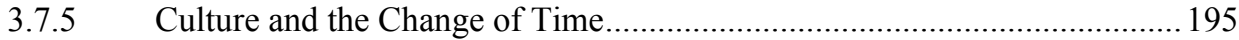

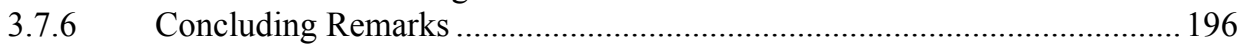

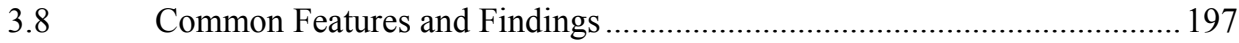

\section{Chapter IV}

The Adequacy of Existing Norms and Procedures for Women's Housing Rights

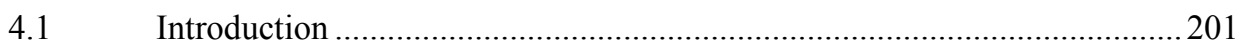

4.2 International Public Law and Gender; Normative and Strategic Issues ......202

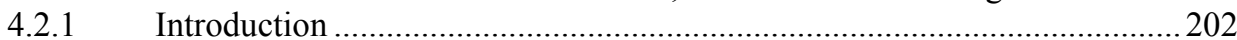

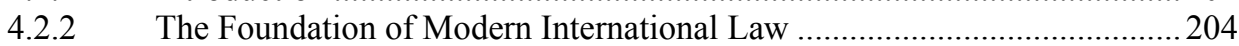

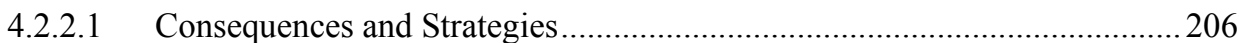

4.2.3 Customary Law and Gender .....................................................................2209

4.2.4 Strategies to Put Women's Issues on the International Agenda ...................213 
4.2.4.1 Women Specific Organs and Instruments ................................................ 213

4.2.4.1.1 Observations as regards the Women Specific Strategy ............................... 217

4.2.4.2 Gender Mainstreaming ......................................................................... 219

4.2.4.2.1 Observations as regards Gender Mainstreaming ......................................... 220

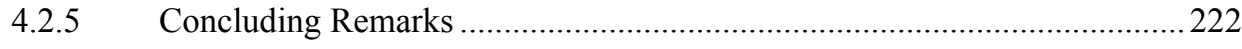

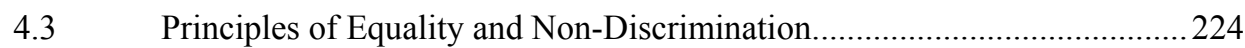

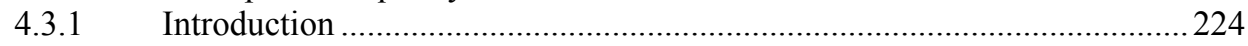

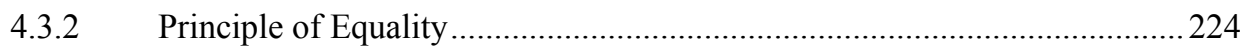

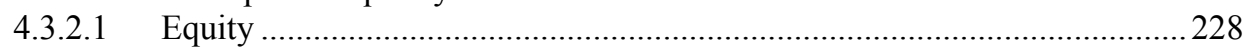

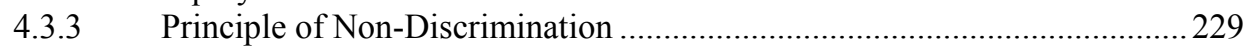

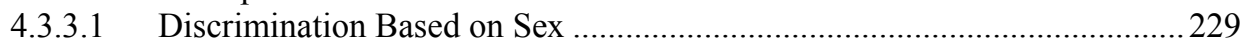

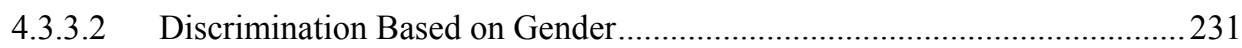

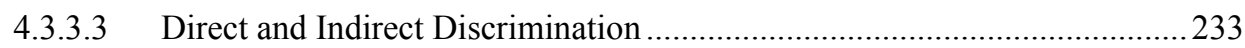

4.3.4 Adequacy and Applicability of the Most Pertinent Provisions.....................2 234

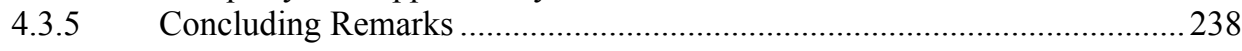

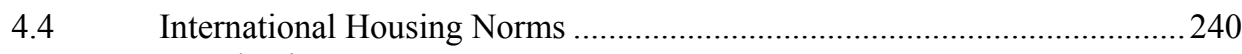

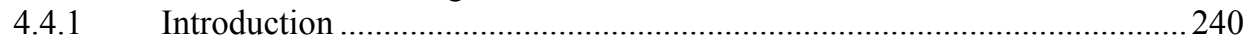

4.4.2 Article 11(1) Covenant on Economic, Social and Cultural Rights ..............240

4.4.2.1 General Comment No. 4 .................................................................. 241

4.4.2.2 General Comment No. 7 ........................................................................ 243

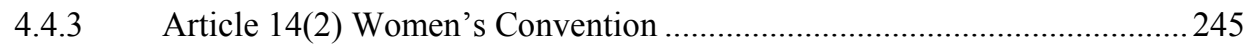

4.4.4 Article 5(e)(iii) Convention on the Elimination of All Forms of Racial Discrimination....................................................................... 246

4.4.5 Article 27(3) Convention on the Rights of the Child.................................247

4.4.6 Article 43(1) Convention on Migrant Workers .........................................248

4.4.7 Concluding Remarks ....................................................................... 248

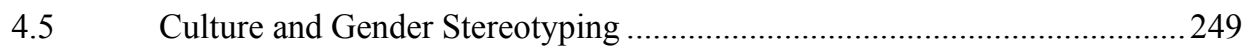

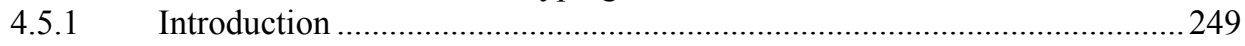

4.5.2 Legal Interference with Cultural Patterns ................................................. 249

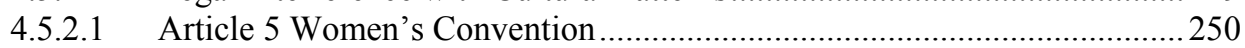

4.5.2.2 Other relevant Human Rights Provisions .................................................. 252

4.5.3 Obstacles for Changing Cultural Patterns............................................ 254

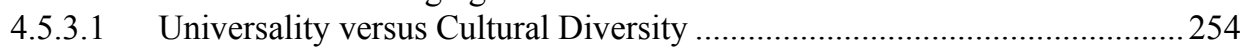

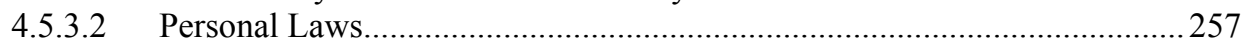

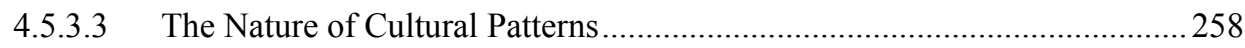

4.5.4 Actors Who May Change Cultural Patterns ........................................... 259

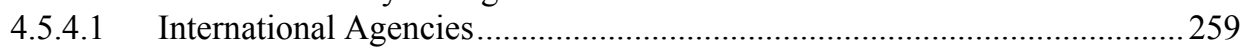

4.5.4.2 Public Authorities ................................................................................. 262

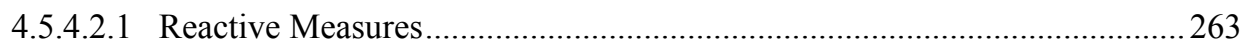

4.5.4.2.2 Pro-active Measures ................................................................................. 264

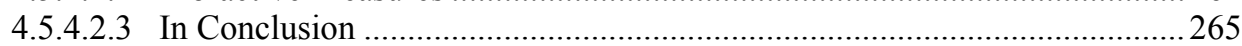

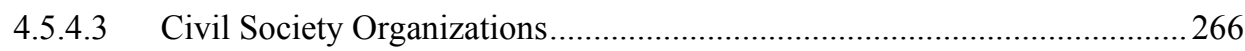

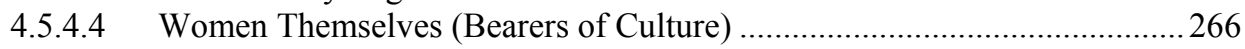


Table of Contents

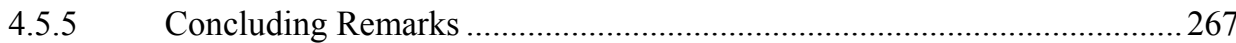

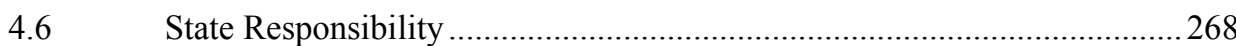

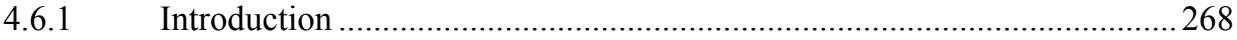

4.6.2 The Concept of State Responsibility .....................................................268

4.6.3 Acts and Omissions that Involve State Responsibility ..............................2 271

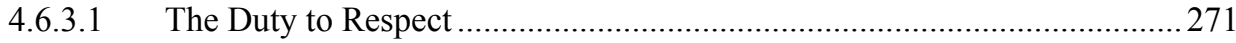

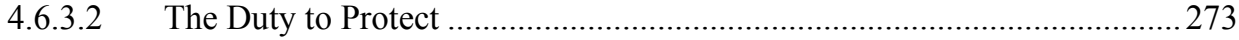

4.6.3.3 The Duty to Fulfil ................................................................................. 275

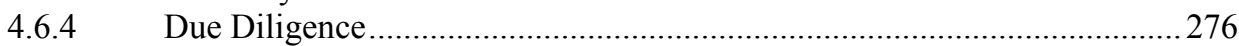

4.6.5 Legal Consequences and Policy Implications of State Responsibility .......279

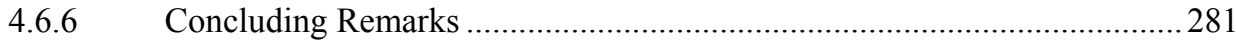

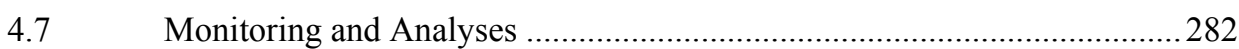

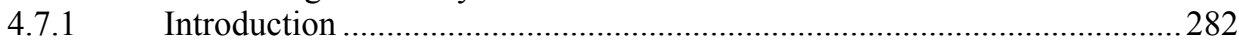

4.7.2 UN Human Rights Treaty Bodies.............................................................. 284

4.7.2.1 Reporting Procedure ............................................................................. 284

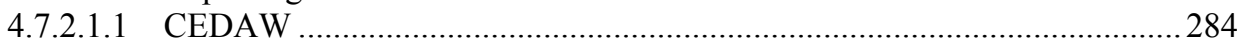

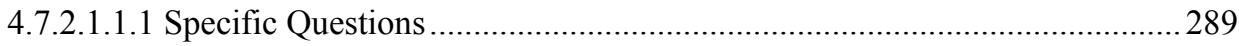

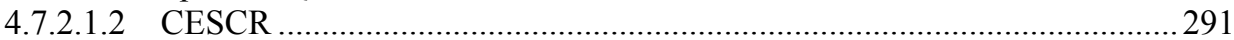

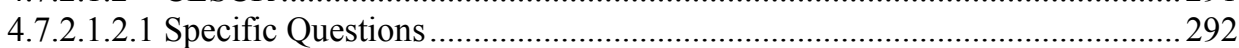

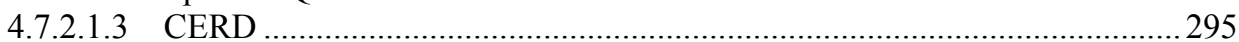

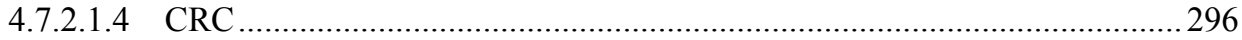

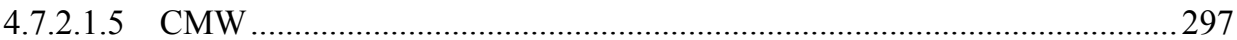

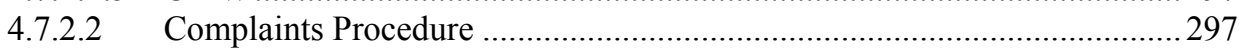

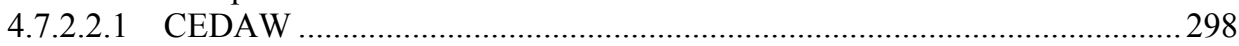

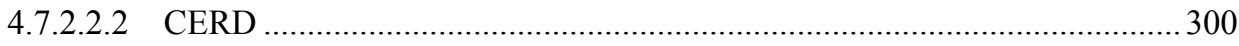

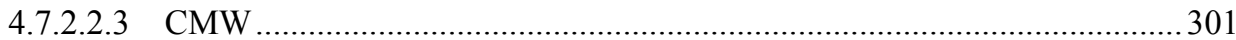

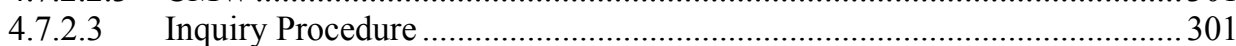

4.7.2.4 General Comments/Recommendations …................................................ 303

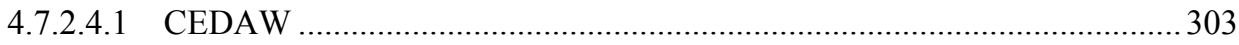

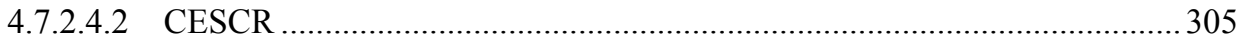

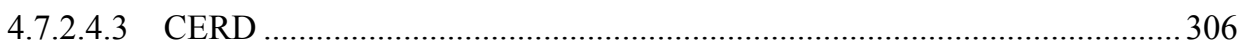

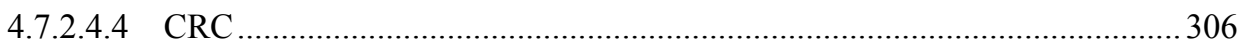

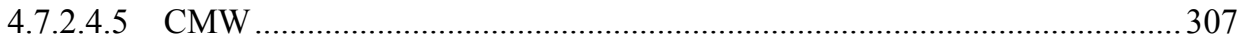

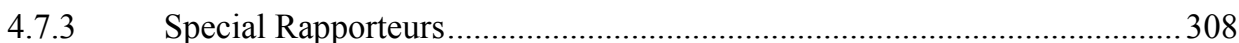

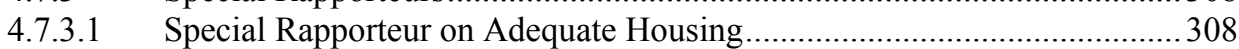

4.7.3.2 Special Rapporteur on Violence against Women ....................................... 310

4.7.3.3 Special Rapporteur on Harmful Traditional Practices ............................... 311

4.7.3.4 Mandates Pertaining to Internally Displaced Persons (IDPs)

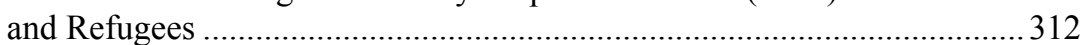

4.7.3.5 Special Rapporteur on Migrant Workers ................................................. 315

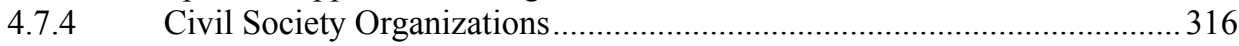

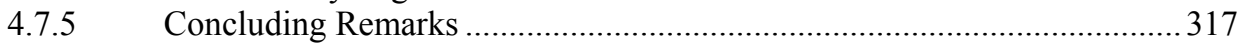

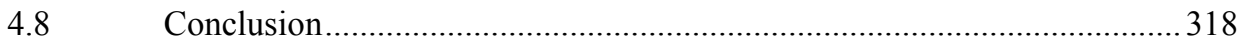

xii 


\section{Chapter V}

Conclusions and Recommendations

5.1 Taking the Gender Perspective into Account ........................................ 325

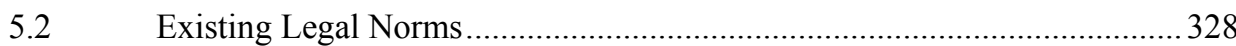

5.2.1 Feminizing Existing Standards ........................................................... 329

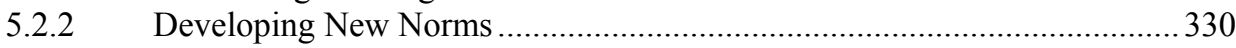

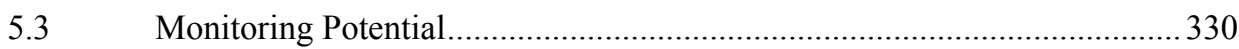

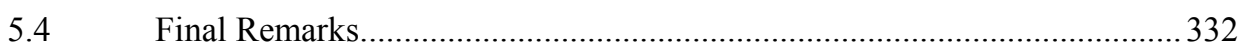

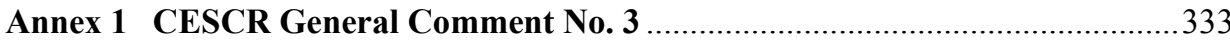

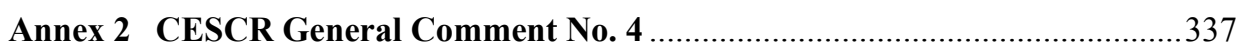

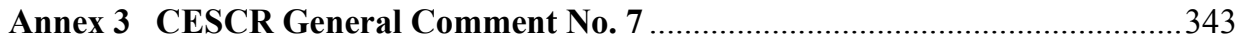

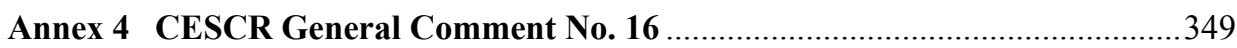

Annex 5 CESCR Reporting Guidelines Pertaining to Article 11 ........................359

Samenvatting: Vrouwen en Huisvesting: Gender maakt verschil ............................363

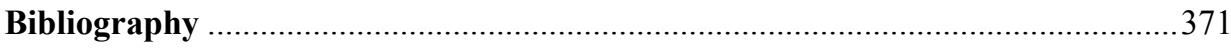

Index

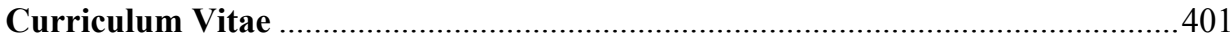





\section{LIST OF ABBREVIATIONS}

CEDAW Committee on the Elimination of Discrimination Against Women

CERD

Committee on the Elimination of Racial Discrimination

CESCR Committee on Economic, Social and Cultural Rights

CMW

Committee on Migrant Workers

CRC

CSO

Committee on the Rights of the Child

CSW

Civil society organization

DAW

Commission on the Status of Women

ECOSOC

Division for the Advancement of Women

FHHs

UN Economic and Social Council

HRC

Female-headed households

ICCPR

Human Rights Committee

ICERD

International Covenant on Civil and Political Rights

ICESCR

International Convention on the Elimination of All Forms of Racial

Discrimination

ICMW

IDPs

International Covenant on Economic, Social and Cultural Rights

International Convention on the Protection of the Rights of All

Migrant Workers and Members of Their Families

ILO International Labour Organization

NGO Non-governmental organization

OHCHR Office of the UN High Commissioner for Human Rights

SGR

UDHR

Representative of the UN Secretary-General

Universal Declaration on Human Rights

UNESCO

UNDP

United Nations Educational, Scientific and Cultural Organization

UNICEF

United Nations Development Programme

UNIFEM United Nations Development Fund for Women

WHO

World Health Organization 


\section{LIST OF TERMS}

Ashram Settlement consisting exclusively of widows and their children in India.

Bustee Squatter camp of widows in Bangladesh.

Charlands Plots of land in or on the banks of rivers that are created by the natural process of accretion, and which are susceptible to erosion and floods.

Dowry (Hindu) system in which it is customary that a bride brings a certain amount of wealth into the family of her husband.

Female exogamy Custom that women marry outside their community and move away thus severing their ties with their families and communities.

Foeticide Custom to abort a (female) foetus, especially practiced in India and China.

Halakhah The collective corpus of Jewish religious law including biblical law, Talmudic and rabbinic law, as well as customs and traditions.

Levirate Also called widow inheritance is a system that entails a union of the widow with a brother-in law (another male relative is also possible) with the object of obtaining children in the name of deceased.

Mitakshara A legal treatise on inheritance, written by Vijnaneshwara, a prominent jurist of $12^{\text {th }}$ century India. It is one of the most influential texts in Hindu law, and its principles regarding property distribution, property rights, and succession are still in practice across most of India.

Mudawwana The Moroccan family law.

Muluki Ain The 1854 codification by Jung Bahadur Rana of the social code that had been in practice for several centuries in Nepal.

Purdah Literally 'curtain'. The practice of requiring women to cover their bodies in order to conceal their form. Also custom among Muslims and some groups of Hindus of keeping women secluded from public observation.

Sororate Custom that entails that a woman is married to her brother-in-law after her sister has died or when her sister is barren. 


\section{CHAPTER I INTRODUCTION}

\subsection{The SUbJECT OF THIS STUdY}

It is the purpose of this study to examine how, and to what extent the realization of the right to adequate housing is determined by a person's gender. Although gender is of itself a neutral term referring to the sex of a human being, it may also be understood as the complex of assumed characteristics and stereotypes that are attached to being a woman or a man. In combination with women's human rights, gender has a rather negative connotation because the expected societal behaviour and stereotypical role of women may inhibit the fulfilment of their rights. It is in the latter sense that the concept of gender is used in this book. If it can be proven, that gender forms a barrier between women and their right to adequate housing, the complexity of the concept suggests that solutions must be found both in legal rules and regulations and in societal change.

Women's right to adequate housing will be examined predominantly in the United Nations human rights law framework. Although actual implementation of the right to housing takes place on the national level, it is important that first clarity exists as to content and scope of this right at the international level. The international housing right norm should be considered as the minimum standard that should at least be realized at the national level. Because of the widespread ratification of human rights instruments, the international supervisory system may exercise some influence by urging States to abide by these rules and in cases of violations, it may offer additional means of recourse and redress. Any reference to national examples in this study should be understood as illustrations of good or bad practices.

It must be stressed, that a study as broad as comprising the UN human rights system, cannot satisfy every aspect and peculiarity and it is therefore unavoidable to generalize. Although attempts will be made to avoid regional or cultural bias, the use of examples is sometimes determined by pragmatic circumstances like available documentation, easy access, or the language in which documents are published.

Because of time and space constraints, regional standard-setting and interpreting work pertaining to the right to adequate housing will not be included. The same constraints prevent the examination of additional factors like race, ethnicity, or disablement, that make the fulfilment of the right to housing even more complicated.

Both in national and international texts and instruments different terms are used for issues pertaining to housing. Sometimes, these terms are used interchangeably although in fact there are important distinctions between them. In older texts frequently the term 'the right to shelter' is used. It seems that at the time it was considered to be synonymous with 'the right to adequate housing', but nowadays, shelter is used in a more restrictive sense indicating temporary, emergency accommodation. As such, it is often left out of the standard clarifying work concerning housing. 'The right to adequate housing' 
Chapter I

is the term used by the United Nations Committee on Economic, Social and Cultural Rights (CESCR) and it indicates all rights and duties ascribed to this right in the legal provisions under human rights law. Adequate housing is much more than having a place to live but encompasses a certain degree of security and comfort. The adjective 'adequate' is sometimes left out for reasons of conciseness. Finally, the term 'housing rights' is even broader, and is frequently used to point out that the right to housing is intrinsically linked to other human rights. In the context of this study the term 'housing rights' will be particularly used to indicate the connection between the right to housing and the right to land. ${ }^{1}$

The legal questions of this study comprise whether, and if so in what way and to what extent, gender may have a negative impact on women's right to adequate housing. If indeed gender inhibits women from exercising their housing rights, the subsequent question is how this barrier may be levelled and which actors may be involved in this process.

\section{2}

\section{RESEARCH METHODS}

Women's right to adequate housing cannot be fully understood if only legal aspects are taken into consideration. That is why the research methods that have been applied, were not restricted to the examination of legal sources, but extended to other disciplines as well. In particular, sociology, anthropology, economics, political science and health sciences proved to be indispensable for grasping the broad implications of gender aspects.

Primarily, a literature search has been done. Much use has been made of primary international legal documents such as treaties, UN resolutions, and documents adopted by UN-Charter and treaty-based organs. Doctrine, both legal and in respect of the other disciplines that have been mentioned above, was used to further clarify and interpret these primary texts. Illustrations of good and bad practices in the framework of housing rights were found in monitoring documents by human rights supervisory organs and special procedures, and by consulting web-sites and texts issued by national and international civil society organizations. Furthermore, a limited amount of fieldwork was done, especially in relation to the housing situation of asylum-seekers. Finally, some exchange of views took place with the UN Committee on Economic, Social and Cultural Rights, the UN Committee on the Elimination of all forms of Discrimination Against Women, and the UN Special Rapporteur on Adequate Housing.

\subsection{The STRUCTURE OF THIS STUDY}

This study will start with an overview of the development of the right to adequate housing between 1945 and 2005 in Chapter II. $^{2}$ Over the past six decades, economic, social, and cultural rights, among which the right to adequate housing, have gained inter-

1 Also see Scott Leckie, 'The Justiciability of Housing Rights', in: Fons Coomans and Fried van Hoof (eds.), SIM Special No. 18; The Right to Complain about Economic, Social and Cultural Rights, Utrecht, 1995, p. 37.

2 Research on this study has been conducted till 31 December 2005. Any materials and documents that have been adopted or issued after that date have not been taken into consideration. 
national attention. As a result of the growing attention for human rights and civil society activism, the right to housing was put on the international agenda. It was particularly the UN Committee on Economic, Social and Cultural Rights that took it upon itself to further clarify and interpret this right and to lay down an international norm. It is for this reason that the work of this Committee receives much attention in this chapter. As from the 1990s, women's civil society groups drew more and more attention to the fact that norms and standard did not reflect women's reality. That is why at the end of Chapter II attention is paid to the growing international concern for women's housing rights.

The third chapter includes a great many topics that influence women's right to housing in a direct or indirect way. First, the causes for homelessness and inadequate housing will be examined. It will be proven that none of these causes is gender neutral. Although some causes may create unfavourable housing conditions for men as well, their implications are different and worse for women. Moreover, some causes exclusively affect women's housing conditions.

Subsequently, the concept of adequacy will be examined. What does adequate housing mean and is this meaning different for women and men. Much attention will be paid to the existing gendered division of work that determines women's outlook and possibilities in society to a large extent. The adequacy of the housing situation of various groups of women will be analysed.

Private law issues may have an enormous impact on women's housing rights at family and community level. This is the reason why specific family law rules and regulations are examined and illustrations are given of how family law may influence the implementation of the human right to adequate housing on the national plane.

Since the right to adequate housing cannot be studied on its own but it has to be put in the context of other economic, social, civil and political rights, those human rights that have specific links to housing rights are also put under scrutiny.

Finally, the last part of Chapter III will recapitulate the most important structural discriminatory patterns that may be found in religion, custom and tradition, and that inhibit the fulfilment of women's housing rights.

Chapter IV examines whether existing international norms and procedures are adequate for promoting and advancing women's housing rights. First, the adequacy of international law is examined. Feminist scholars are of the opinion that international law is gender biased. The question is, therefore, whether international law is a useful medium to advance women's housing rights and if so in what way this law system may be made more susceptible to women's issues. Specific attention is paid to the gender adequacy of the principles that underlie all international human rights instruments: equality and nondiscrimination.

Subsequently, the gender awareness of international housing norms is studied. The clarifying and interpreting work done by the CESCR is of particular importance, because the norms that have been set by this Committee are considered to be the most authoritative.

Since time and again cultural bias and gender stereotyping are put forward as the most powerful obstacles in the context of women's right to housing, it is examined whether international law provides handles to tackle these cultural patterns. 
While States may be responsible for violating women's right to housing through their own actions and omissions, they may also bear responsibility for violations occurring in the private sphere of family and community at the hands of private persons, especially when these violations are structural and widespread. That is why the extent of State responsibility is examined with regard to the States' obligations to respect, protect and fulfil women's housing rights both in the public and the private sphere.

Finally, the role of monitoring and analysis is considered. At the international human rights level several Charter-based and treaty based organs and special procedures have a mandate to promote and protect women's right to adequate housing. Though this task is more prominent or obvious for some of these mechanisms, it will be shown that other bodies may also use their mandate in such a way that they cover women's housing rights. Suggestions for improving monitoring and analysis will be given. In addition to UN bodies and organs, also national and international civil society organizations (CSOs) have a role to play as far as monitoring is concerned. These organizations are particularly important in keeping a watchful eye on how international legal theory is translated into national practice.

In the last chapter, the most important conclusions and recommendations that have been formulated at the end of the foregoing chapters and specific sections will be recapitulated. 


\section{CHAPTER II \\ ANALYSIS OF THE RIGHT TO \\ AdEQUATE Housing}

\section{$2.1 \quad$ INTRODUCTION}

The aim of this chapter is to provide insight into the development of the right to adequate housing from one of the elements of the concept of an adequate standard of living contained in the Universal Declaration of Human Rights, into an autonomous human right that has undergone much interpretative work in order to attain the current understanding of its content and scope.

Before going into the right to housing itself, first the context will be described in which this right is embedded. For a clear understanding of the position of the right to housing it is important to be aware of the fact that in the structure of the United Nations a great diversity of organs is engaged in the promotion and protection of human rights. That is why section 2.2 will briefly describe the most relevant organs and their working methods.

The third section will give a chronological overview of the development of the right to housing in the framework of the United Nations as from the Second World War. The right was first mentioned in Article 25(1) of the Universal Declaration after which it was reiterated in a great many international and regional human rights treaties, ${ }^{1}$ declarations, recommendations, guidelines, and resolutions. The most important provision being Article 11(1) of the Covenant on Economic, Social and Cultural Rights (ICESCR).

The content of the right to adequate housing is the focal point of section 2.4 . Within the United Nations several organs have interpreted this right or shed their light on specific aspects of it. Of particular importance are the two General Comments that have been adopted by the Committee on Economic, Social and Cultural Rights (CESCR) on this issue, but also the work of the Special Rapporteur on Adequate Housing has contributed considerably to the understanding of housing rights.

Besides defining the components that constitute the right to adequate housing, several organs have determined which obligations States take upon themselves when they bestow their citizens with housing rights. Section 2.5 will review the opinion of the most important bodies in this respect.

Section 2.6 will look into the question whether the right to adequate housing is a justiciable human right. Though some argue that adequate housing for everyone is an aspiration rather than a right, others maintain that all human rights, also those that cover economic, social and cultural needs, such as housing, are justiciable or at least contain justiciable elements.

The last section of this chapter will describe the gradual process of understanding that the right to housing should also be regarded from a woman's perspective. In the con-

1 Since this study is focused on the framework of the UN, the regional conventions containing provisions on housing rights fall outside of the scope and consequently will not be discussed. 
text of this study one of the most important steps was the Commission on Human Right's decision to request the Special Rapporteur on Adequate Housing to report specifically on women's housing rights.

\subsection{Human Rights Promotion and Protection in the Framework OF THE UNITED NATIONS}

Before examining the content, nature and scope of the right to adequate housing in international conventions it is useful to put this right in the context of promotion and protection of human rights by the United Nations. The creation of the human rights law system as we know it today began shortly after the Second World War when memories of the atrocities that had been committed were fresh and there was a strong global feeling that such crimes should never happen again. The first instrument that dealt with human rights was the Universal Declaration of Human Rights (UDHR) that was adopted by the General Assembly on 10 December $1948 .^{2}$ Since it is a declaration and not a treaty, at the time of its inception it was considered to be in essence of a moral and political nature. ${ }^{3}$ The Declaration is based on the idea of the inherent equality and dignity of all human beings and the rights enumerated in it, encompassing economic, social, cultural, political and civil rights, are supposed to be universal, indivisible, interdependent, and interrelated. It was envisioned that ultimately all of these rights would be contained in one comprehensive human rights treaty that would be binding upon States parties. Due to the Cold War this never came about, however. ${ }^{4}$ While States in the East emphasized the importance of economic and social rights and even put them before civil and political rights, it was exactly the opposite in Western States where political freedom took prime position and economic and social rights were regarded as taking second place. In the end, it was decided that instead of one all comprising convention, two separate human rights treaties would be adopted.

The International Covenant on Civil and Political Rights (ICCPR) ${ }^{5}$ containing rights like the right to life, to a fair trial, to vote, and freedom of expression and congregation, was written in such a way that these rights are directly awarded to each human person. The State party's obligations are therefore more or less clear and the direct effect of the rights makes it possible that an individual, who thinks that her or his rights are being violated, can base her/his claims on the text of the Covenant's provisions before a court of law.

The other treaty that was adopted, the International Covenant on Economic, Social and Cultural Rights (ICESCR), ${ }^{6}$ was written in a different manner. The treaty does not address individuals, but States. Instead of directly attributing rights to persons, States

2 UN doc. A/RES/217 A (III), Universal Declaration of Human Rights, 10 December 1948.

3 Over the years the UDHR has become an authoritative text, many provisions of which are regarded as forming part of international customary law.

4 Henry J. Steiner and Philip Alston (eds.), International Human Rights in Context; Law, Politics, Morals, Clarendon Press, Oxford, 2000, pp. 138-139.

$5 U N$ doc. A/RES/2200A (XXI), International Covenant on Civil and Political Rights, 16 December 1966.

6 UN doc. A/RES/2200A (XXI), International Covenant on Economic, Social and Cultural Rights, 16 December 1966. 
are urged to take steps with a view to progressively fulfilling all kinds of needs people may have to live a dignified existence, such as an adequate standard of living, education, and employment. It is left to the States parties' discretion to determine the pace of the realization of these rights in conformity with their social and economic development. ${ }^{7}$ The consequence of this difference in approach is that the justiciability of such rights may be more complicated since it may be difficult for a court to decide whether the government has fulfilled its obligations when these are so vague and it is not the Judiciary's task nor competence to determine whether the Executive has allocated sufficient budgetary means towards fulfilling certain socio-economic goals. ${ }^{8}$ In any case the importance of the ICESCR should not be underestimated since it is a binding treaty that contains legal obligations for States parties. ${ }^{9}$ Moreover, all human rights are equally important for people's dignity and well-being. ${ }^{10}$

Besides these two general human rights treaties, other specialised conventions were adopted, the five most important of which are in chronological order: the International Convention on the Elimination of All Forms of Racial Discrimination (ICERD), ${ }^{11}$ which in fact predates the two general conventions with one year; the Convention on the Elimination of All Forms of Discrimination Against Women (Women's Convention); ${ }^{12}$ the Convention Against Torture and Other Cruel, Inhuman or Degrading Treatment or Punishment (CAT); ${ }^{13}$ the Convention on the Rights of the Child (ICRC) ${ }^{14}$ and finally, the International Convention on the Protection of the Rights of All Migrant Workers and Members of their Families (ICMW). ${ }^{15}$

The task to monitor compliance with the above mentioned instruments by States parties was entrusted to autonomous bodies consisting of independent experts. The treaties themselves contain provisions that create these bodies and that specify their tasks and the tools they may use. The one exception is the ICESCR. In this treaty it was foreseen

$7 \quad$ Henry J. Steiner and Philip Alston (eds.), 2000, p. 246.

8 In conformity with Montesqieu's philosophy of Trias Politica, the powers of most modern States have been divided over three main bodies: the Legislature which is the law-making body, at the national level usually the Parliament; the Executive, the policy-making organ that puts the laws into effect, nationally the Government; and finally, the Judiciary, the collective system of courts.

9 The issue of justiciability of the right to adequate housing will be elaborated in section 2.6 infra.

10 The indivisibility of all human rights, civil and political, as well as economic, social and cultural rights, is stressed in the Preambles of both the ICCPR and the ICESCR In the Vienna Declaration this notion is reaffirmed in section 5 in which it is stated that: 'all human rights are universal, indivisible, and interdependent, and interrelated'. $U N$ doc. A/CONF.157/23, 12 July 1993. Also see Abdullahi Ahmed AnNa'im, 'To Affirm the Full Human Rights Standing of Economic, Social \& Cultural Rights', in: Yash Ghai \& Jill Cottrell (eds.), Economic, Social \& Cultural Rights in Practice; The Role of Judges in Implementing Economic, Social \& Cultural Rights, Interights, London, 2004, p. 12.

$11 U N$ doc. A/RES/2106 (XX), International Convention on the Elimination of All Forms of Racial Discrimination, 21 December 1965.

$12 U N$ doc. A/RES/34/180, Convention on the Elimination of All Forms of Discrimination Against Women, 18 December 1979.

13 UN doc. A/RES/39/46, Convention Against Torture and Other Cruel, Inhuman or Degrading Treatment or Punishment, 10 December 1984.

14 UN doc. A/RES/44/25, Convention on the Rights of the Child, 20 November 1989.

$15 U N$ doc. A/RES/45/158, International Convention on the Protection of the Rights of All Migrant Workers and Members of their Families 18 December 1990. 
that the Economic and Social Council (ECOSOC), one of the six main UN organs, ${ }^{16}$ was to monitor observance of the Covenant instead of a body of independent experts. However, the monitoring job that was done by successive Working Groups installed by the Council was not very successful, and in 1986 ECOSOC decided to create the Committee on Economic, Social and Cultural Rights (CESCR). This Committee, like the treaty bodies, consists of independent experts who are entrusted with most of the Council's responsibilities as regards the Covenant. The CESCR held its first session in 1987. ${ }^{17}$

The supervising treaty bodies may be regarded as quasi-judicial organs since they monitor compliance with legal obligations - States have willingly bound themselvesand they have a few tools at their disposal which help them to ascertain whether States parties have complied with their obligations or whether they have violated them.

The most common tool is the reporting procedure which is contained in each of the main human rights instruments. The idea is that States parties report to the supervisory body within a year after ratifying or acceding to the treaty. This first report lays down the state of affairs. Subsequently, follow-up reports must be submitted, the precise time span depends on the particular convention. In this way the monitoring body is able to determine whether any progress has been made since the data in a previous report serve as benchmarks. The supervisory bodies do not exclusively depend on information provided by States' governments. Especially during the last decade it has become usage to make use of information provided by civil society organizations (CSOs) as well. After the State reports have been submitted, the monitoring body will engage the State party in a constructive dialogue. Additional questions may be asked by the Committee, and the State's representatives get the opportunity to answer them and to clarify matters. After deliberations behind closed doors, the Committee will publish its opinion on the State report in the form of so-called concluding observations. These always consist of three parts: positive remarks about obligations that have been fulfilled or progress that has been made; critique of what is wrong or on situations of violations; and lastly, recommendations and suggestions for improvement.

Besides concluding observations pertaining to the situation of one particular State, monitoring bodies also have the possibility to publish general recommendations, also called general comments. These will be adopted when certain situations of violation or certain problems keep coming up in State reports and the Committee wishes to address them in a general way. General recommendations may contain further clarification of certain provisions or they may entail an extension of the contents and scope of the convention.

In addition to the reporting procedure, a few of the treaties mentioned above contain a (optional) State complaint procedure which signifies that States may lodge a com-

16 The United Nations Charter creates six main organs to carry out the organization's tasks: the Security Council (SC), the General Assembly (GA), the Economic and Social Council (ECOSOC), the International Court of Justice (ICJ), the Trusteeship Council (not operational anymore), and finally, the Secretariat.

17 Philip Alston, 'The Committee on Economic, Social and Cultural Rights', in: Philip Alston (ed.), The United Nations and Human Rights; A Critical Appraisal, Clarendon Press, Oxford, 1992, p. 473. 
plaint with the monitoring body about another State party that is allegedly violating its obligations under the treaty. ${ }^{18}$

Moreover, some of the treaties provide their supervisory bodies with still other (optional) tools, ${ }^{19}$ i.e. the individual complaints procedure, which means that the Committee may hear complaints lodged by individuals or groups of individuals,$^{20}$ and the inquiry procedure, which entails that a Committee may conduct a fact-finding inquiry on the territory of a State if reliable information has been provided, for instance by CSOs, that the State party is structurally violating human rights obligations. ${ }^{21}$

Next to these legal mechanisms consisting of independent treaty bodies that monitor compliance with binding human rights instruments, the UN also disposes of a UN Charter-based system to promote and protect human rights. The main Charter-based body is the Commission on Human Rights, a subsidiary organ of ECOSOC, consisting of 53 States members. ${ }^{22}$ ECOSOC has also created a subsidiary organ that deals exclusively with the advancement of women's human rights, the Commission on the Status of Women (CSW). Although in theory these two organs are on the same level, in practice the Commission on Human Rights has much more power and financial possibilities. While the members of the Commission are not independent, but representatives of their Governments, the most important subsidiary body of the Commission, the Sub-Commission on the promotion and protection of human rights (hereafter the Sub-Commission), consists of independent experts. ${ }^{23}$ The Sub-Commission supports the Commission in various ways and carries out important human rights studies.

Furthermore, a structure of 'special procedures' exists. In order to address specific country situations or thematic issues, it is possible for certain Charter-based organs, such as the Commission on Human Rights, its Sub-Commission, and the UN SecretaryGeneral, to establish special mechanisms either in the form of individuals, called Special Rapporteur, representative or independent expert, or groups of individuals, called working group. The mandate-holders of these special procedures are independent and they serve in a personal capacity. Currently, there are over 40 special procedures.

18 The treaties which contain the State complaint procedure are the ICERD (Art. 11), the ICCPR (Art. 41), the CAT (Art. 21), and the ICMW (Art.76). Up till now the State complaint procedure has never been used in the framework of the United Nations, because States prefer to raise such matters through diplomatic channels.

19 Optional signifies that States parties either have to ratify an Optional Protocol (OP) to the treaty or have to agree explicitly with an optional clause in the treaty itself before the tool may be used.

20 The individual complaints procedure is an option with the ICCPR (OP Art.1), the ICERD (optional Art. 14), the CAT (optional Art. 22), and the ICMW (OP Art. 77).

21 Inquiry is only available in respect of the Women's Convention (OP Art. 8), and the CAT (Art. 20).

22 On 15 March 2006, the General Assembly adopted resolution A/RES/60/251 in which the Human Rights Council is established in replacement of the Commission on Human Rights. Since the new organ has become operational after the research for this study was concluded (December 2005) its work is beyond the scope of this study.

23 The Sub-Commission was originally called the 'Sub-Commission on Prevention of Discrimination and Protection of Minorities'. It was established in 1947 with 12 members and renamed in 1999 because it was felt that the name did not do justice to the more general work the body was doing. Today, it is comprised of 26 independent experts in the field of human rights who are elected by the Commission, with due regard to equitable geographical distribution, and who act in their personal capacity. 
Chapter II

Although the mandates given to special procedure mechanisms vary, they usually are to examine, monitor, advise, and report on human rights situations either in specific countries (country mandates), or on specific human rights violations worldwide (thematic mandates). The mandate-holders may undertake various activities, including studies, providing advice, responding to individual complaints, visiting countries (fact-finding missions), and engaging in promotional activities. ${ }^{24}$

The mandate of Special Rapporteurs appointed by the Sub-Commission is restricted to research and study.

Both treaty and Charter-based mechanisms have contributed to the promotion and clarification of the right to adequate housing in their own way and therefore the contributions of both systems will be examined in the subsequent sections.

\subsection{UN CONCERN}

Since 1948 numerous international and regional treaties, declarations, recommendations and resolutions have been adopted that contain the right to adequate housing in one form or another. Because the scope of this study is restricted to the framework of the United Nations, only the most authoritative international treaty provisions will be highlighted. Furthermore, the most important contributions by UN bodies and organs will be discussed while also attention will be paid to those world conferences that have had an impact on the advancement of housing rights. The following chronological overview is divided into three periods. The first starts with the adoption of the Universal Declaration in 1948 and ends with the adoption of the Convention on the Rights of Migrant Workers in 1990. This period is characterized by the adoption of the main UN human rights instruments that contain the right to housing and the deployment of the first activities to put the housing issue on the international agenda. The second period covers the 1990s, a decade in which attention for the plight of the homeless and the content and scope of the right to housing received a boost because of the work of the CESCR, the UN SubCommission and its Special Rapporteur, and the organization of the World Conference on Human Settlement, Habitat II. The third and last period starts with, and is dominated by, the appointment of the UN Commission Special Rapporteur on Adequate Housing in 2000. His general reports up till 2005 are discussed here, while his specific reports on women and housing are dealt with in section 2.7.

\subsubsection{5-1990}

In the first few decades after the Second World War, UN concern with the plight of the homeless in the world was shown by the inclusion of housing rights provisions in human rights instruments which were drafted by the Commission on Human Rights and subsequently adopted by the General Assembly (GA). First of all, this right was incorporated in the Universal Declaration on Human Rights (UDHR), Article 25(1) of which reads:

24 See the site of the Office of the UN High Commissioner for Human Rights at: <www.ohchr.org/english/ bodies/chr/special/index.htm>. 
'Everyone has the right to a standard of living adequate for the health and well-being of himself and his family, including food, clothing, housing and medical care and necessary social services, and the right to security in the event of unemployment, sickness, disability, widowhood, old age or other lack of livelihood in circumstances beyond his control' (emphasis added).

Thus housing is put on an equal footing with food, clothing and health care, as one of the basic needs everyone is entitled to, regardless of one's status or financial circumstances.

The next human rights convention in which the right to housing was included is the 1965 Convention on the Elimination of All Forms of Racial Discrimination (ICERD). ${ }^{25}$ Article 5 provides that racial discrimination as regards the right to housing is prohibited. Literally it says:

'In compliance with the fundamental obligations laid down in Article 2 of this Convention, States Parties undertake to prohibit and to eliminate racial discrimination in all its forms and to guarantee the right of everyone, without distinction as to race, colour, or national or ethnic origin, to equality before the law, notably in the enjoyment of the following rights: [...]

(e) Economic, social and cultural rights, in particular: [...]

(iii) The right to housing'

The significance of Article 5 is that it requires States to guarantee all their inhabitants equal access to and enjoyment of their human rights irrespective of race or ethnic origin. However, Article 5 itself does not create any human rights, such as the right to housing. It is based on the assumption that such a right exists. ${ }^{26}$

The most important provision as regards the right to adequate housing up till now is contained in the International Covenant on Economic, Social and Cultural Rights (ICESCR) which was adopted by the General Assembly on 16 December 1966 and entered into force on 3 January 1976. In Article 11(1) it is stipulated that:

'The States Parties to the present Covenant recognize the right of everyone to an adequate standard of living for himself and his family, including adequate food, clothing and housing and to the continuous improvement of living conditions. The States Parties will take appropriate steps to ensure the realization of this right, recognizing to this effect the essential importance of international co-operation based on free consent' (emphasis added).

Similar to the text of Article 25(1) UDHR the right to housing is formulated as part of the much broader concept of an 'adequate standard of living', but unlike the provision in the UDHR the right is not directly awarded to individuals, but described as an attainment States parties are to achieve. It may therefore be clear that the importance of Article 11(1) cannot be attributed to the text itself, but it is to the credit of the extensive analysis and interpretative work that has been done by the Committee on Economic, Social and Cultural Rights (CESCR). ${ }^{27}$ Furthermore, it should be noted that the right to

The ICERD entered into force on 4 January 1969.

CERD, General Recommendation XX (Forty-eighth session, 1996) contained in UN doc. A/51/18

7 The standard setting work of the CESCR will be thoroughly examined in the subsequent sections of this chapter. 
housing was formulated in a traditional context; it is the male head of household who is the breadwinner and provider who must be enabled to realize this right for himself, his partner the homemaker, and their children. At the time it was not intended to attribute this right to individual women for the simple reason that they were not supposed (or enabled) to earn the family income and thus could not be burdened with the task of providing housing.

Besides adopting the UDHR and the human rights conventions in which the right to housing is contained, the UN also promoted this right in various other ways during the 1970s and 1980s, for instance by making it an important issue at several of the world conferences that have been organized with a view to discussing serious global concerns. As these conferences are attended by almost every State in the world, and the conclusions are reached by consensus, these gatherings may provide an important insight in what States deem to be individuals' rights and corollary States' obligations. At the UN Conference on the Human Environment in Stockholm in 1972, it was proposed that the UN convene a meeting on the serious decline of living conditions caused by the enormous growth of the world population. At the time it was foreseen that within 25 years the world's population would double, thereby doubling the need for all basic needs of subsistence, including food and housing. This first conference in which housing played a prominent part was the 1976 Conference on Human Settlement (Habitat I), which was held in Vancouver, Canada. The conclusions and agreements of this meeting were published as The Vancouver Declaration on Human Settlements and the Vancouver Plan of Action. ${ }^{28}$ It was affirmed that:

\footnotetext{
'Adequate shelter and services are a basic human right which places an obligation on Governments to ensure their attainment by all people, beginning with direct assistance to the least advantaged through guided programmes of self-help and community action. Governments should endeavour to remove all impediments hindering attainments of these goals. Of special importance is the elimination of social and racial segregation, inter alia, through the creation of better balanced communities, which blend different social groups, occupation, housing and amenities. ${ }^{, 29}$
}

Important principles that were accepted are the right of free movement and the right to choose a place of settlement, ${ }^{30}$ and that priority should be given to the needs of the most disadvantaged people, especially the expelled and the homeless. ${ }^{31}$ Furthermore, it was recognized that land is a basic element with regard to human settlements. Therefore, States were urged to maintain public control over the use, possession, disposal and reservation of land. ${ }^{32}$ States were also made aware of the fact that special attention must be devoted to the improvement of living conditions in rural areas. ${ }^{33}$ Finally, full integration

28 The Vancouver Declaration On Human Settlements and the Vancouver Plan of Action, Reports of Habitat: United Nations Conference on Human Settlements, Vancouver, 31 May to 11 June 1976.

The Vancouver Declaration On Human Settlements, section III, para. 8.

Ibidem, section II, General Principles, para. 6.

Ibidem, paras 2 and 15 .

Ibidem, para. 10

Ibidem, section III Guidelines for Action, para. 4. 
of women was advocated in all political, economic and social activities. Particularly, the potentially important role of women as regards the planning of human settlements was stressed. ${ }^{34}$

One of the recommendations of Habitat I to the UN General Assembly was the establishment of a commission that would deal specifically with issues on human settlement. The GA reacted favourably on this recommendation by creating the United Nations Commission on Human Settlements (UNCHS) and the United Nations Centre for Human Settlements (Habitat) on 12 October 1978. ${ }^{35}$ The UNCHS is an intergovernmental policymaking body that meets biennially and that has a membership of 58 States. The members are elected by ECOSOC for a four-year term.

Habitat, which is based in Nairobi, Kenya, is the Commission's secretariat. The Centre's activities are based on a work programme that has been approved by UNCHS. This programme includes policy advice, operational research, technical co-operation, capacity-building and awareness-raising. The Centre especially focuses on four areas: 1) shelter and social services, 2) urban management, 3) environment and infrastructure, and, 4) assessment, information and monitoring. Habitat closely works together with other bodies within the UN such as the United Nations Development Programme (UNDP), the United Nations International Children's Emergency Fund (UNICEF) and the World Health Organization (WHO). Furthermore, the Centre collaborates with international and national CSOs. ${ }^{36}$ The first 17 years of its existence, however, UNCHS (Habitat) hardly concerned itself with the right to housing. ${ }^{37}$

For women a most important step forward was taken in 1979 with the adoption of the Convention on the Elimination of All Forms of Discrimination Against Women (Women's Convention). ${ }^{38}$ The Convention is based on the idea of equality and nondiscrimination of women. Furthermore, it revives the original idea of the indivisibility, interrelatedness and interdependence of all human rights and therefore contains a combination of civil, political, social, economic, cultural and development rights. The right to housing is included in Article 14 that deals specifically with the position of rural women. Paragraph 2 of this Article states:

'States parties shall take all appropriate measures to eliminate discrimination against women in rural areas in order to ensure, on a basis of equality of men and women, that they participate in and benefit from rural development and, in particular, shall ensure to such women the right: ...

4 Ibidem, section II General principles, para. 18 and section III Guidelines for Action, para. 11. UN doc. A/RES/32/162, Commission on Human Settlements, 1 December 1977.

$<$ www.unchs.org/unchs/english/about1.htm>, visited on 10 July 2000.

37 Scott Leckie, Towards an International Convention on Housing Rights: Options at Habitat II, ASIL, No. 4, 1994, pp. 9-11. However, since 1993 there has been a change. In its resolution 14/6 the Commission firmly committed itself to the right to adequate housing and it requested the UNCHS Executive Director to prepare a document that could serve as the basis of Habitat's strategy as regards promoting, ensuring and protecting the realization of housing rights. See UN Commission on Human Settlements Resolution 14/6, 5 May 1993

38 The Women's Convention was adopted by the GA on 18 December 1979 and entered into force on 3 September 1981 . 
(h) To enjoy adequate living conditions, particularly in relation to housing, sanitation, electricity and water supply, transport and communications' (emphasis added).

The strength of this provision is that it mentions housing in the context of the right to land and basic services like sanitation, electricity, and water supply. The obvious weakness is that adequate living conditions are not contained in a separate, comprehensive provision that is applicable to all women irrespective of whether they live in urban or rural areas.

In 1986 the Commission on Human Rights drew attention to the situation of the homeless and inadequately housed by adopting a resolution entitled 'The Realization of the Right to Adequate Housing'. In this resolution the Commission reaffirms that every individual has a right to an adequate standard of living for himself and for his family, including the right to adequate housing. ${ }^{39}$ This resolution initiated a sequence of similar resolutions, thus putting the issue of adequate housing constantly in the picture as one of the areas of special concern. ${ }^{40}$

Meanwhile, in two resolutions on the strengthening of human settlements activities, the GA had expressed its concern that since Habitat I the conditions of human settlements had worsened rather than improved, especially in the urban areas of developing countries. ${ }^{41}$ The thought was launched to devote an international year to the homeless with a view to increasing public awareness at the local, national, regional and global levels and to ignite a process that would lead to improvement for the homeless. ${ }^{42}$ It was decided to proclaim the year 1987 as International Year of Shelter for the Homeless. ${ }^{43}$ The Commission on Human Settlements was designated as the body responsible for organizing the Year, while the Centre for Human Settlements was appointed as the secretariat for the Year and the co-ordinating agency for all relevant programmes and activities. In 1986 the GA reiterated its concern that millions of people did not enjoy the right to adequate housing, and States were called upon to intensify their efforts to achieve the objectives of the International Year of Shelter for the Homeless. ${ }^{44}$ Special measures were recommended in order to provide shelter for the poor and disadvantaged, like providing access to land, to security of tenure in squatter settlements, facilitating community participation, improving access to credit and loans and promoting local and affordable building materials. ${ }^{45}$ At the end of the international Year, the GA ascertained that still more than one billion people were either completely without shelter or living in hovels unfit for human habitation. It acknowledged the multidimensional nature of the shelter problem, caused mainly by poverty and aggravated by scarcity of resources,

39 Commission on Human Rights resolution 1986/36 of 12 March 1986, entitled: The Realization of the Right to Adequate Housing.

40 There are various Commission resolutions and declarations on the realization of the right to adequate housing and also a few on forced evictions. For instance: resolutions 1987/22, 1988/24, 1993/77, 1994/ $14,1995 / 19$ and declarations $1993 / 103$ and 1996/104.

$41 U N$ doc. A/RES/34/116, Strengthening of human settlements activities, 14 December 1979 and A/RES 35/76, Strengthening of human settlements activities, 5 December 1980

42 UN doc. A/RES/36/71, International Year of Shelter for the Homeless, 4 December 1981.

43 UN doc. A/RES/37/221, International Year of Shelter for the Homeless, 20 December 1982.

$44 U N$ doc. A/RES/41/146, Realization of the right to adequate housing, 4 December 1986.

$45 U N$ doc. A/RES/41/190, International Year of Shelter for the Homeless, 8 December 1986. 
inadequate institutional capacities and the lack of a legal and financial framework. It was decided that a global plan of action should be developed that would aim at shelter for everyone by the year $2000 .{ }^{46}$ Guidelines were drawn up for steps to be taken both at the national and at the international level. States should simultaneously build new houses and upgrade existing ones. Housing conditions should improve gradually for both men and women. Nation-wide an 'adequate' standard should be identified on the basis of an analysis of the standards and options that were affordable to the people concerned and society at large. Furthermore, it was stressed that equal participation of women should be ensured at all levels. ${ }^{47}$

The following important human rights convention that comprises the right to housing is the Convention on the Rights of the Child (ICRC). The GA adopted this Convention on 20 November 1989 and it entered into force on 2 September 1990. Children's rights to housing are stated in Article 27(3), which reads in full:

'States Parties in accordance with national conditions and within their means shall take appropriate measures to assist parents and others responsible for the child to implement this right and shall in the case of need provide material assistance and support programmes, particularly with regard to nutrition, clothing and housing' (emphasis added).

According to Article 27, States parties are obliged to assist parents or others who take care of the child if they are not able to provide the child with an adequate standard of living themselves. This implies that the child has no independent right to an adequate standard of living, but that, if necessary, the State must provide this through parents or others responsible. If a child is deprived of the care of others, such as orphans, children who can for some reason no longer remain at home, or under-age refugees, it may be inferred from the texts of Articles 20 and 22 that the State party is under the obligation to provide such children with adequate housing itself since they are entitled to special protection and assistance.

The last human rights instrument that is worth mentioning here is the International Convention on the Protection of the Rights of All Migrant Workers and Members of Their Families (ICMW), which was adopted by the GA on 18 December 1990 but entered into force as late as 1 July 2003 when the 20th State had ratified it. Housing rights of migrant workers are protected in Article 43(1):

'Migrant workers shall enjoy equality of treatment with nationals of the State of employment in relation to ...

(d) access to housing, including social housing schemes, and protection against exploitation in respect of rents.'

Since the supervisory Committee has not yet received any States reports, it is hard to predict what the impact of this provision will be on the housing situation of migrant workers.

$46 U N$ doc. A/RES/42/191, Global Strategy for Shelter to the Year 2000, 11 December 1987.

$47 U N$ doc. A/RES/43/181, Global Strategy for Shelter to the Year 2000, 20 December 1988. 


\subsubsection{The 1990s}

The 1990s was a decade in which attention for the right to housing received a boost. Several UN actors started promoting this right, some of them occupying themselves with the further interpretation and clarification of its contents and related State obligations.

At its fourth session in January $1990,{ }^{48}$ the CESCR held a general discussion on the right to housing. ${ }^{49}$ Several experts were invited to contribute to the discussion, amongst whom representatives from CSOs, Habitat and ILO. The main purpose was to determine issues of principle and to clarify practical and political implications of the right to housing. This general discussion proved to be the prelude to the adoption of a General Comment on the right to adequate housing a year later.

First, however the Committee adopted General Comment No. 3 on the nature of States parties' obligations under Article 2, para. 1 of the Covenant during its fifth session in $1991 .^{50}$ Article 2 is important for a better understanding of all other provisions of the Covenant, since it describes the nature of the legal obligations a State takes upon itself by becoming a party to the Covenant. The content and implications of this General Comment will be discussed in section 2.5 on State obligations pertaining to housing rights.

In the context of this study it is even more significant that during the same session the CESCR adopted General Comment No. 4 on the right to adequate housing. ${ }^{51}$ In section 8 of this General Comment the CESCR elaborates on the elements of adequate housing that according to the Committee form the content of this right and that hold true in all circumstances, regardless of social, economic, cultural, climatic, ecological, and other aspects. ${ }^{52}$ Furthermore, the Committee enumerates several steps pertaining to housing rights that States parties have to take immediately after ratifying the Covenant. ${ }^{53}$ The Committee also comments on the practice of forced evictions and states that forced evictions constitute prima facie a violation of the Covenant. ${ }^{54}$

As from 1991, the Sub-Commission on Human Rights started taking an interest in housing rights. On a yearly basis it adopted a resolution concerning forced evictions. ${ }^{55}$ In these resolutions the Sub-Commission condemns the practice of forced evictions as a gross human rights violation, in particular the right to adequate housing. The Sub-Commission urges that all measures be taken to eliminate the practice and emphasizes that

48 As has been explained in section 2.2 the CESCR only became functional in 1987 since before that time rather ineffective ECOSOC working groups used to supervise adherence to the ICESCR's obligations.

49 UN doc. E/C.12/1990/3, Committee on Economic, Social and Cultural Rights, Report on the Fourth Session, paras 281-285.

50 CESCR General Comment No. 3 on the nature of States parties obligations (Art. 2, para. 1 of the Covenant), 14 December 1990, contained in $U N$ doc. E/1991/23. The text of General Comment No. 3 has been attached to this study as Annex 1 .

51 General Comment No. 4 on the right to adequate housing, 12 December 1991, contained in UN doc. E/1992/23. The text of General Comment No. 4 has been attached to this study as Annex 2 .

52 I will come back to these elements in section 2.4 on the content of the right to adequate housing.

53 The specific steps that have to be taken will be discussed in section 2.5 on State obligations pertaining to the right to adequate housing.

54 CESCR General Comment No. 4, para. 18.

55 Sub-Commission resolutions 1991/12 of 26 August 1991, 1992/14 of 27 August 1992, 1993/41 of 26 August 1993, 1994/39 of 26 August 1994, 1995/29 of 24 August 1995, 1996/27 of 29 August 1996, 1997/6 of 22 August 1997, 1998/9 of 20 August 1998; all entitled Forced evictions. 
adequate compensation and/or alternative housing must be offered to those affected. It strongly advises governments to ensure legal security of tenure for all persons especially those who are threatened with forced evictions. Furthermore, the attention of international financial and development bodies is drawn to the practice of forced evictions, while existing views under international law in this regard are pointed out. Besides paying attention to forced evictions, the Sub-Commission also dealt with furthering the right to adequate housing in a more general sense. Also since 1991, it regularly adopted resolutions in this regard urging Governments to adopt legislation and to take effective measures to promote the realization of the right to adequate housing for their entire population. ${ }^{56}$

Most significant may be, however, that in resolution 1991/26 the Sub-Commission entrusted one of its members with a mandate to produce a working paper on the right to adequate housing. ${ }^{57}$ The aim was to study and determine the best way to recognize and enforce the right to adequate housing.

The Sub-Commission discussed this working paper at its 44th session in $1992 .{ }^{58}$ The Expert begins by pointing out that crucial indicators are either not collected or not published so that it is difficult to determine the exact number of people who are homeless or inadequately housed. However, based on the figures that are available, it seems reasonable to assume that over 100 million people are homeless, that more than 1 billion people are inadequately housed, and that these figures are growing rather than decreasing. Therefore, it can be said that there is a true international housing crisis and it is imperative to identify and analyse the main causes in order to determine which strategies are necessary to tackle it.

The Expert identifies several root causes. ${ }^{59}$ Some of them may exceed a government's capacity to deal with individually, like armed conflicts, poverty, and structural adjustment programmes and debts. Contrary to the prohibitions contained in the Fourth Geneva Convention, ${ }^{60}$ civilians' homes are destroyed during armed conflicts and large streams of refugees and internally displaced persons (IDPs) are created. In many countries of the world large parts of the population are so poor that they live near or below the poverty line and therefore cannot possibly fulfil their own housing needs. Moreover, since the income gap is widening, more and more people face extreme poverty. Poor countries are stuck with enormous debts that may force them to accept the terms of structural adjustment programmes by international money lending institutions that will invariably induce them to cut down public expenditure at the cost of the poorest segment of their population.

56 Sub-Commission resolutions 1991/26 of 29 August 1991, 1992/26 of 22 August 1992, 1993/36 of 26 August 1993, 1994/38 of 26 August 1994, 1995/27 of 24 August 1995; either entitled Promoting the Realization of the Right to Adequate Housing or the Realization of the Right to Adequate Housing.

57 The mandate-holder, who conducted his research as an Independent Expert, was Justice Rajindar Sachar from India.

$58 U N$ doc. E/CN.4/Sub.2/1992/5 of 12 June 1992; The right to adequate housing: Working paper submitted by Mr Rajindar Sachar, expert appointed pursuant to resolution 1991/26 of the Sub-Commission on Prevention of Discrimination and Protection of Minorities.

59 Ibidem, paras $21-57$.

60 Geneva Convention relative to the Protection of Civilian Persons in Time of War, adopted on 12 August 1949, entry into force on 21 October 1950. 
Sometimes governments themselves cause or aggravate the housing crisis. Most States do not collect sufficient and adequate data in respect of their population's housing situation with the result that their assessment of the situation is faulty and they do not allocate sufficient financial means to the housing sector. Crucial information may be withheld so that people do not know where land and housing are available, are not informed about their entitlements as far as water and basic services are concerned, or about the potential danger in a certain area of natural or human-made disasters. In many States the homeless are criminalized instead of supported. Especially desperately poor people living in urban areas of developing countries cannot afford to live by the rules and building codes and therefore fall back on all kinds of 'illegal' means to solve their housing problem; occupying land belonging to the State or private actors, squatting on pavements, and building dwellings of whatever material they can find. In particular, people who have illegally occupied land or who are living in slum areas may become the victims of forced evictions. Governments all over the world evict millions of people every year from their homes because of reasons like beautifying the cities, discouraging future squatting developments, providing infrastructure, meting out punishment or organizing international events, such as the Olympic Games.

Besides actively causing homelessness, governments may also tacitly condone all kinds of practices by non-State actors that aggravate the housing situation like forced evictions or exploitation in the housing sphere. Governments may tolerate segregation with the result that many groups in society are deprived of their right to housing because of discriminatory practices. ${ }^{61}$ Furthermore, governments may accept speculation and commoditization of housing; relying on the working of the free market and treating housing as a commodity that is only accessible to those who have sufficient financial means instead of treating housing as a basic human right that should be attainable for everyone.

As the consequence of governments' actions and inactions the Expert found that homelessness is perpetuated for many people since they remain in the margin of society without any hope of improving their situation while morbidity and mortality rates will increase because many peoples' health is adversely affected by inadequate housing conditions.

In the rest of the Working Paper, the Expert briefly identifies issues that should be subjected to future examination. Based on the discussion of the mandate-holder's work, the Sub-Commission decided to appoint him as Special Rapporteur for a period of three years. $^{62}$

Also in 1992 a UN Conference on Environment and Development (Earth Summit) was held in Rio de Janeiro. One of the five documents that were agreed upon during this meeting is Agenda 21. This document, which was signed by 179 Heads of Government, touches upon various subjects that have a bearing on sustainable development. In the

61 The Expert identifies as excluded groups: ethnic minorities, migrant workers, refugees, sexual minorities, the landless, indigenous communities, the unemployed, the elderly, the ill, and ex-offenders. Note that women are not identified by the Expert as suffering from discrimination.

62 Sub-Commission resolution 1992/26 of 27 August 1992 entitled Promoting the Realization of the Right to Adequate Housing. This decision was endorsed by the Commission on Human Rights in its decision 1993/103 of 4 March 1993 on Promoting the realization of the right to adequate housing. 
framework of housing rights Chapter 7 of Agenda 21 is the most important. The document states as the overall human settlement objective:

'[...] to improve the social, economic and environmental quality of human settlements and the living and working environments of all people, in particular the urban and rural poor. Such improvement should be based on technical co-operation activities, partnerships among the public, private and community sectors and participation in the decisionmaking process by community groups and special interest groups such as women, indigenous people, the elderly and the disabled. [...]

Furthermore, countries should make appropriate provision to monitor the impact of their strategies on marginalized and disenfranchised groups, with particular reference to the needs of women. ${ }^{63}$

Safe and healthy shelter is looked upon as essential for a person's over-all well being and the right to adequate housing is reaffirmed as a basic human right. All States are summoned to provide housing for the homeless poor and international support is called upon in cases where developing countries do not by themselves succeed to house their poor. States should support self-help as much as possible, for instance by easing regulations, facilitating access to land and low-cost building materials and even by upgrading slum areas. ${ }^{64}$

The progress report of the Sub-Commission's Special Rapporteur on housing was issued in 1993. The focus of this report is on clarifying States' obligations. ${ }^{65}$ According to the Rapporteur acceptance and recognition of the right to adequate housing, which will be the case when a State becomes a party to the ICESCR, will create a series of binding obligations. ${ }^{66}$ Economic, social and cultural rights are as legal in nature as civil and political rights, and all human rights must be applied on a basis of equality of access and opportunity. No matter the level of development, States must ensure respect for minimum subsistence rights for everyone. This implies, according to the Special Rapporteur, that the State should make every effort to ensure that everyone has access to housing resources. If a person is homeless or inadequately housed, and her- or himself incapable of acquiring adequate housing, this person has a rightful claim on society to provide the necessary housing means. ${ }^{67}$ In any case, the State must acknowledge the right to housing in its legislation and develop adequate policies immediately after it assumes legal obligations. ${ }^{68}$

In the first part of his second progress report, issued in $1994,{ }^{69}$ the Special Rapporteur focuses on clarifying a number of common misunderstandings that exist in respect

Agenda 21, Chapter 7; Promoting Sustainable Human Settlement Development, 1992, para. 7.4.

Ibidem, paras 7.6-7.9.

65 UN doc. E/CN.4/Sub.2/1993/15, of 22 June 1993 on The right to adequate housing: progress report submitted by Mr Rajindar Sachar, Special Rapporteur.

66 Ibidem, para. 36.

67 Ibidem, para. 41

68 The specifics of the Special Rapporteur's progress report will be dealt with in section 2.5 on State obligations.

69 UN doc. E/CN.4/Sub.2/1994/20 of 21 June 1994 
to the right to adequate housing. ${ }^{70}$ Some of these misconceptions ensue from the laisserfaire attitude many States adopt as far as economic, social and cultural rights are concerned. They may for instance assume that home-ownership and the overall quality of housing will automatically increase when the national wealth grows. Though it is true that the average standard of living may be better in rich countries, there is no invariable correspondence between home-ownership and the quality of housing and the national income. A point in case is the housing situation in Japan which is much worse than in the USA, and only marginally better than in South Africa. Linked to this misunderstanding is the view held in wealthy States that housing is only a problem in developing countries. The Special Rapporteur points out that even in the EU many people are inadequately housed, particularly refugees, asylum seekers and other foreign nationals may be negatively affected by discriminatory practices. Furthermore, many States take the stance that legislative recognition of housing rights is sufficient to ensure the realization of these rights. However, legalization may remain a dead letter when no action is undertaken to effectuate it. Also, it is thought that solving the housing shortage may be left to the private sector, in disregard of the fact that the private sector views land and housing as profitable commodities and will not be bothered with solving the housing problems that the poorest segments of society are faced with. Related to this misunderstanding is the idea that most housing is built by the public and the private commercial sector. The Special Rapporteur shows that only some 30 percent of all housing is built by these sectors and that the other 70 percent is built by the community sector. The result of the focus on the formal sector is that the community sector may fall outside of the scope of plans and policies and that essential support is withheld. After years of disregard of the housing issue, authorities in many States have no clear idea about the scope of the housing crisis. Inadequate data and insights in turn lead to the misconception that public expenditure on housing would be sufficient. According to the mandateholder there is no country in the world in which public expenditure is sufficient enough to solve all housing problems. An additional problem may be that funds are used ineffectively so that they hardly ever benefit the largest number of people possible. Moreover, many authorities are wary of social housing projects. Social housing, i.e. housing built or financed by the State, has a negative image and authorities are afraid of ghetto forming, crime and social problems, while in reality public housing schemes have been a success in many parts of the world and may in fact be the only solution to provide the poor with adequate housing.

Misunderstandings as regards the nature of the right to housing include the view that the right would be unrelated to other social concerns and that housing rights would be less fundamental than property rights. According to the Special Rapporteur, housing is indivisible from a wide range of all kinds of human rights and social issues, while the right to property and the right to housing complement each other and are mutually inclusive. $^{71}$ Another common misunderstanding about the nature of the right is its justiciability. According to the Special Rapporteur many parts of housing rights are justi-

70 See paras $17-45$

71 However, sometimes the right to own property may be restricted in favour of the right to housing, for instance in relations between landlords and tenants. 
ciable which may be proven by the fact that worldwide courts on a daily basis hear cases concerning the rights of tenants, discrimination as regards housing, evictions and land claims.

Lastly, homeless people may be regarded as anti-social elements or even common criminals, which loses sight of the fact that the majority of the homeless is utterly desperate and that many among them have jobs but still cannot afford the cost of housing. If these people occupy waste lands or vacant buildings they do so out of sheer desperation and not because they are criminally inclined.

Prompted by its Special Rapporteur's findings, as from 1994 the Sub-Commission started adopting resolutions on the housing rights of specific groups emphasizing that States must concentrate on vulnerable groups in society and that they should carry out the recommendations contained in the Special Rapporteur's reports. ${ }^{72}$

On February 16, 1995, Habitat issued a report entitled 'Towards A Housing Rights Strategy: Practical Contributions by UNCHS (Habitat) On Promoting, Ensuring and Protecting the Full Realization of the Human Right to Adequate Housing, ${ }^{73}$ In this report, UNCHS (Habitat) admits that the right to adequate housing has not played a prominent role within its programme, but that this document is intended to lay the foundation of UNCHS's incorporation of housing rights activities within its mandate. Another innovative aspect is that UNCHS decides to expand its operational activities to include human rights matters. It is stated that UNCHS thinks that it is beneficial to view housing concerns through the lens of human rights, especially when such perspectives are combined with the key issues involved in promoting sustainable human settlements. The report further contains a comprehensive examination of all existing $\mathrm{UN}$ activities related to housing rights, an outline of the current placement and legal status of the right to adequate housing under international law, including measures relating to the monitoring, implementation and enforcement of housing rights, and suggestions for the development of a framework for monitoring the progressive realization of housing rights and housing adequacy.

In the first part of his final report of 12 July 1995, the Special Rapporteur examines the scope of the right to housing. ${ }^{74}$ This entails a closer look at the rights that are indivisible from housing rights, especially the right to land, food and health, and the identification of particular groups that require extra focus. The particular difficulties encountered by women are recognized and the Special Rapporteur states that in most countries of the world women do not have an autonomous right to land and housing which makes them essentially homeless. ${ }^{75}$ The physical and social development of children is affected when they grow up in unsanitary and unsafe surroundings. Besides the

72 Sub-Commission resolution 1994/8 of 23 August 1994 on Children and the Right to Adequate Housing. Sub-Commission resolutions 1997/19 of 27 August 1997 on Women and the right to adequate housing and to land and property and 1998/15 of 21 August 1998 entitled Women and the right to land, property and adequate housing. Sub-Commission resolution 1998/26 of 26 August 1998 on Housing and property restitution in the context of the return of refugees and internally displaced persons.

$73 U N$ doc. HS/C/15/INF.7, 16 February 1995.

$74 U N$ doc. E/CN.4/Sub.2/1995/12, The right to adequate housing, Final report submitted by Mr Rajindar Sachar, Special Rapporteur,12 July 1995.

75 Ibidem, paras 45-49. 
right to adequate housing, they are also deprived of other human rights such as the right to health, education, and protection from abuse and exploitation. ${ }^{76}$

The Special Rapporteur acknowledges the special link that exists between the right to land and the right to housing by pointing out that for many people land is the primary source of survival. Housing rights encompass a right to live in security and dignity and thus are connected with security of tenure and security of access to land. Landlessness and homelessness deprive people of a possibility to feed themselves. In this way, the right to food is also linked to the right to housing. ${ }^{77}$ Furthermore, inadequate housing and living conditions have an adverse impact on the physical and mental well-being of people. Lack of water, sanitary facilities and adequate drainage may result in epidemic diseases. Adequate housing on the other hand not only provides for better physical health, but also promotes mental health because people feel secure in their homes and in their community. ${ }^{78}$

In conclusion, the Special Rapporteur once again brings to mind the interrelatedness and indivisibility of all human rights. The full realization of the right to adequate housing can only be achieved when all kinds of other civil, political, economic, social and cultural rights are also fulfilled. Special ties exist with the right to privacy, to family life, to gender equality, to security of the person, to freedom of movement and freedom to choose one's residence, to property and many others. ${ }^{79}$

Other important parts of the Special Rapporteur's final report are devoted to the clarification of the justiciability of the right to adequate housing, ${ }^{80}$ and a listing of indicators that may be used to measure State compliance. ${ }^{81}$ The last part of the report contains a series of recommendations directed to a wide range of actors including States, UN human rights organs, Human Rights treaty bodies, regional organizations and civil society organizations. ${ }^{82}$

In view of the numerous cases of forced evictions that had come to the CESCR's attention and the serious implications of such actions for the housing conditions of thousands of people, the Committee adopted General Comment No. 7 on forced evictions in 1997. In this General Comment the CESCR confirms its view that forced evictions are prima facie a violation of the obligations under the ICESCR. ${ }^{83}$

By far the most interesting world conference concerning housing rights is the Second United Nations Conference on Human Settlements (Habitat II). Already in 1991 the General Assembly considered the possibility of organizing another conference on human settlements. ${ }^{84}$ At the Assembly's 93 rd plenary meeting it was decided to convene

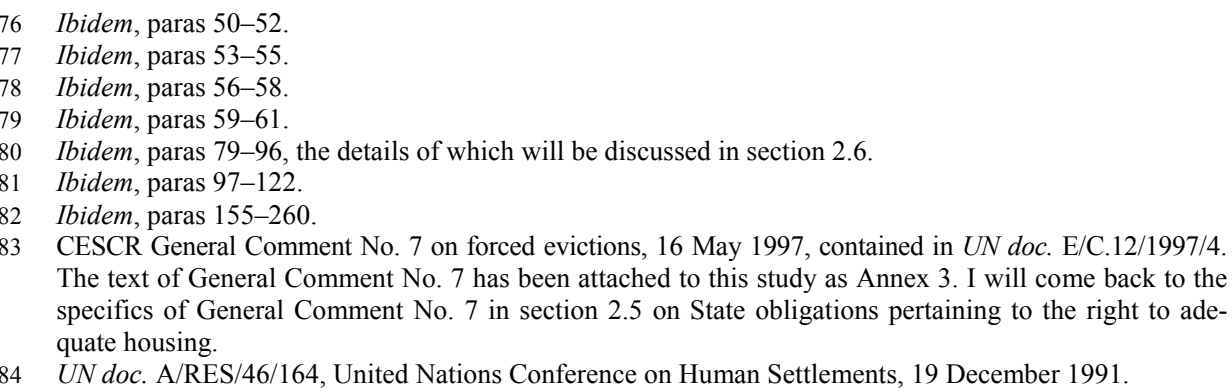


such a meeting in 1996, at the highest possible level of participation. ${ }^{85}$ A Preparatory Committee of the General Assembly was installed and an ad hoc secretariat was set up, which was organizationally part of the United Nations Centre for Human Settlements (Habitat). The purpose of the Conference was to address adequate shelter for all and sustainable human settlements development in an urbanizing world. Habitat II was held in Istanbul from 3-14 June 1996, and resulted in the adoption of The Istanbul Declaration on Human Settlements and The Habitat Agenda at the 18th plenary meeting on 14 June $1996 .{ }^{86}$ The GA endorsed both documents in $1997,{ }^{87}$ and instructed the Commission on Human Settlements to organize a three-day session in June 2001 in order to appraise the implementation of Habitat II. ${ }^{88}$

In the Istanbul Declaration the continuing deterioration of conditions of shelter and of human settlements is recognized, and special attention is drawn to the situation in the developing countries. ${ }^{89}$ It is also acknowledged that some groups of people, such as women, children and youth, have special needs as regards safe, healthy and secure living conditions. $^{90}$ The participating States reaffirm their commitment towards the full realization of the right to adequate housing as provided in international instruments. They pledge to ensure legal security of tenure, protection from discrimination and equal access to affordable, adequate housing for all persons and their families. ${ }^{91}$ Furthermore, they promise to expand the supply of affordable housing and to see to it that access to land and credit is enhanced and that those people are assisted who are not able to participate in the housing market. ${ }^{92}$

The Habitat Agenda elaborates on the subjects mentioned in the Istanbul Declaration. In its preamble it is stated that at the moment more than one billion people have to do without decent living conditions, while it is recognized that safe and healthy housing and basic services are essential to a person's physical, psychological, social and economic well-being. ${ }^{93}$ According to prognosis, the number of people living in urban areas will increase considerably and will amount to three billion people, i.e. half of earth's population, by the year 2000. This puts an enormous stress on cities and towns and it means that homelessness will grow enormously, as well as (illegal) squatting. Cities and towns will be unable to supply sufficient housing and also basic services, including water supply and sanitation, and infrastructure will be inadequate. ${ }^{94}$

$85 U N$ doc. A/RES/47/180, United Nations Conference on Human Settlements (Habitat II), 22 December 1992.

86 Both documents may be found in UN doc. A/CONF.165/14 of 7 August 1996.

87 UN doc. $\mathrm{A} / \mathrm{RES} / 51 / 1977$, Implementation of the outcome of the United Nations Conference on Human Settlements (Habitat II).

$88 U N$ doc. A/RES/53/180, Special session of the General Assembly for an overall review and appraisal of the implementation of the Habitat Agenda, 28 January 1999. Also: resolutions A/RES/54/207, A/RES/ $54 / 208$ and A/RES/54/209 of 27 January 2000.

89 Istanbul Declaration on Human Settlements paras 2 and 4.

$90 \quad$ Ibidem, para. 7.

Ibidem, para. 8, and again, in Chapter II, Goals and Principles, para. 26.

Ibidem, para. 9.

The Habitat Agenda, Chapter I, Preamble, para. 3.

Ibidem, para. 8. 
Chapter II

Rural areas will not fare much better. Many rural settlements lack economic opportunities and have to cope with insufficient infrastructure and services. Problems exist as to water supply, sanitation, health care, education, communication, transportation and energy. It is imperative, however, that conditions in rural areas be drastically improved, since this will reduce the continuous flow of rural-to-urban migration, and thus ease the pressure on urban areas. ${ }^{95}$

The Preamble mentions several groups in need of particular attention. Displaced persons, children, indigenous people, women, persons with disabilities, and the elderly are dealt with respectively. ${ }^{96}$

In Chapter II of the Habitat Agenda the participating States subscribe to a number of goals and principles. The first goal defines equitable human settlements as those where all people, without discrimination of any kind, 'have equal access to housing, infrastructure, health services, adequate food and water, education and open spaces'. Equal access to economic resources is stressed, as well as equal participation in public decision-making processes. At the end of this section it is stated that in order to attain sustainable human settlements development, it is imperative that women are empowered and that they will participate on an equal footing in all spheres of society. ${ }^{97}$

At the sixteenth session of UNCHS in 1997 the Executive Director presented a report entitled: 'Housing Rights: Strategy for the Progressive Realization of the Right to Adequate Housing'. The document makes it clear that the core elements from the Global Strategy for Shelter, the mandate of the Habitat Agenda and the Istanbul Declaration on Human Settlements form the basis of UNCHS's approach for promoting the realization of the human right to adequate housing. Furthermore, a resolution was adopted that recommends that a joint programme be developed between the UN Centre for Human Rights and the UNCHS in order to assist States with the implementation of their commitments to ensure the realization of the right to adequate housing. ${ }^{98}$

\subsubsection{0-2005}

Since the turn of the century, the promotion and development of the right to housing has been primarily in the hands of two organs: the United Nations Centre for Human Settlement (UNCHS/Habitat) and the Special Rapporteur on Adequate Housing, who was appointed by the UN Commission on Human Rights in 2000. First the development of the UNCHS/Habitat will be discussed. The emphasis of this section is, however, on the work done by the Special Rapporteur.

The UNCHS (Habitat) has gone through a remarkable development. While it hardly concerned itself with housing rights in the beginning of its existence, it is now becoming one of the UN's lead agencies for creating awareness of, and seeking solutions for the realization of the right to adequate housing and associated rights. It has an important facilitating task as regards developing countries and a much needed coordinating function

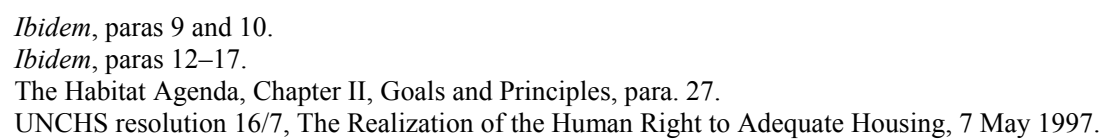


in general. Moreover, the fact that women face particular constraints in realizing their housing rights is looked upon as a major point of concern and UNCHS (Habitat) increasingly advocates gender-sensitive strategies to be applied both at the domestic and at the international level. ${ }^{99}$

In resolution 56/206, the GA decided to upgrade the UNCHS/Habitat by transforming the Commission and its secretariat into the UN Human Settlement Programme (UNHabitat) as a subsidiary organ of the GA as from 1 January $2002 .{ }^{100}$

In 2002 UN-Habitat together with the Office of the United Nations High Commissioner for Human Rights (OHCHR) launched the UN Housing Rights Programme (UNHRP) which focuses on advocacy, support for UN human rights mechanisms on housing, monitoring and evaluation of the progress or realization of housing, research and analysis on issues related to housing rights and capacity-building and training for the monitoring and implementation of housing rights. ${ }^{101}$ Furthermore, UN-Habitat runs two worldwide campaigns; one on Urban Governance and the other on Secure Tenure. ${ }^{102}$

During its fifty-sixth session in April 2000, the UN Commission on Human Rights decided to appoint a Special Rapporteur on the right to adequate housing for a period of three years. ${ }^{103}$ According to his mandate, the Special Rapporteur is to report annually on the status, throughout the world, of the realization of the right to housing, taking into account relevant laws, policies and practices. He may base himself on information received from governments, international organizations and CSOs, and he is specifically requested to include a gender perspective in his work. ${ }^{104}$ The fact that the Special Rapporteur has been appointed by the Commission means that his mandate is much broader than that of the Special Rapporteur on Housing who had been appointed by the UN Sub-Commission at the beginning of the 1990s. While the latter's task was restricted to report on his study and research, the Commission's Special Rapporteur may in addition conduct country missions (with the permission of the States in question of course), maintain close working relations with other UN bodies, specialized agencies and international organizations and CSOs, and react on communications that are addressed to him by sending urgent appeals to the States concerned. ${ }^{105}$ Pursuant to Commission resolution

99 UN-Habitat has a special Gender Policy Unit. See <www.unhabitat.org/programmes/genderpolicy>.

100 GA Resolution A/56/206, Strengthening the mandate and status of the Commission on Human Settlements and the status, role and functions of the United Nations Centre for Human Settlements (Habitat), 21 December 2001.

101 See: $<$ www.unhabitat.org/unhrp $>$.

102 See: <www.unhabitat.org/campaigns/governance $>$ and $<$ www.unhabitat.org/campaigns/tenure/default.asp $>$ respectively.

103 In October 2000, the Commission appointed Mr Miloon Kothari, an Indian architect who has been actively involved with CSO activities in the field of housing rights. In 2003 the mandate was extended with another three years till 2006. Since the Commission has been abolished, it is uncertain whether the newly appointed Council on Human Rights will continue the mandate in the same vein.

$104 U N$ doc. E/CN.4/RES/2000/9, Commission on Human Rights resolution of 17 April 2000, entitled: Question of the realization in all countries of the economic, social and cultural rights contained in the Universal Declaration of Human Rights and in the International Covenant on Economic, Social and Cultural Rights, and study of special problems which the developing countries face in their efforts to achieve these human rights.

105 OHCHR, Methods of work of thematic special procedures serviced by the research and right to development branch. The majority of the cases in which the Special Rapporteur has intervened concerned 
2000/9, the appointed Special Rapporteur conducted a preliminary study that resulted in a first report in January 2001. ${ }^{106}$ In this report he lays the groundwork for his future research and he proposes to use the following working definition for the right to adequate housing:

'The human right to adequate housing is the right of every woman, man, youth and child to gain and sustain a secure home and community in which to live in peace and dignity.,107

The Special Rapporteur stresses the importance of the clarifying and standard-setting work of the CESCR and in this respect he expresses the wish that the Committee's hand be strengthened with the adoption of an Optional Protocol to the ICESCR containing individual and group complaint procedures. The examination of cases of alleged violations of an individual's or a group's housing rights would improve the understanding of the content of these rights and the implications involved. ${ }^{108}$

In the second chapter, the Special Rapporteur maps out priority issues and major impediments to realizing housing rights that need further examination. ${ }^{109}$ As a first impediment he mentions the current trend of globalization and macroeconomic reform programmes that appear to have an adverse impact on the housing situation, particularly, but not exclusively, in developing States. A priority issue he wishes to focus on is safe drinking water as a human right. He stresses that access to safe drinking water is an inseparable aspect of adequate housing.

A very serious impediment to the realization of adequate housing is poverty. It is the Special Rapporteur's intention to look into the widening gap between wealthy and poor States. His special focus will be the Least Developed Countries (LDCs).

Since he has been asked to pay particular attention to the gender dimension of housing and land rights, the Special Rapporteur wants to play a part in promoting awareness of discriminatory practices and contributing to the empowerment of women. Other groups that will receive his special attention are children and indigenous and tribal peoples.

Finally, he intends to devote particular attention to the issues of forced evictions and the domestic applicability and justiciability of housing rights.

The methodology used by the Special Rapporteur is the 'constructive' approach, which means that his focus will be on determining which policy or action contributed to the realization of housing rights. He prefers this method to the so-called 'violations' approach, though he acknowledges that this approach may lead to keen insights into the various dimensions of housing rights. ${ }^{110}$

cases of forced eviction, or the threat of such, e.g. his urgent appeal in relation to alleged mass forced evictions in Zimbabwe in June 2005.

106 UN doc. E/CN.4/2001/51, 25 January 2001, Report of the Special Rapporteur on the right to adequate housing, Mr Miloon Kothari.

107 Ibidem, para. 8.

108 Ibidem, para. 31.

109 Ibidem, paras 56-86.

110 The violations approach entails that a monitoring body identifies violations in order to end and rectify abuses. See for an explanation of this methodology: Audrey R. Chapman, "A "Violations Approach" for Monitoring the International Covenant on Economic, Social and Cultural Rights', in: Human Rights 
In his second report, ${ }^{111}$ the Special Rapporteur emphasizes that housing is a distinct human right. He recalls the universal recognition of this right and the extensive interpretive work done by various UN human rights bodies. Furthermore, he points out that the right to adequate housing has been incorporated in national constitutions and other laws of more than 50 States and that national judges consider it to be a justiciable right. ${ }^{112}$ He recapitulates the clarifying work done in respect of State obligations by the CESCR and the Sub-Commission on the Promotion and Protection of Human Rights, and emphasizes that many obligations under the ICESCR are to be implemented immediately, including the safeguarding of the minimum core of adequate housing. ${ }^{113}$ As far as international cooperation is concerned, the Special Rapporteur recalls CESCR's General Comment No. 4 in which it has been stated that a substantial proportion of international financial help should be used to improve the housing conditions of those persons who are inadequately housed. Moreover, international financial help should never have the effect that the realization of adequate housing for all in a receiving country would stagnate or even regress. He therefore stresses that State parties, as well as international financial institutions, ${ }^{114}$ review the human rights implications of conditions attached to financial help and take measures in order not to endanger the obligations the States took upon themselves towards their citizens when they became party to human rights conventions.

As indicated in his first report, the Special Rapporteur concentrates in his second report on two issues that have his priority attention: non-discrimination and the impact of globalization.

As far as the topic of non-discrimination is concerned, the Special Rapporteur focuses on racial discrimination as a follow-up of the World Conference against Racism, Racial Discrimination, Xenophobia and Related Intolerance, which was held in Durban, South Africa, in September 2001. Based on the Durban commitments, ${ }^{115}$ the mandate holder recommends increased alertness as to discriminatory legislation and policies, and effective remedies and monitoring, and proposes, among other recommendations, that all groups of the population should be included in the preparatory and planning stages of city plans in order to ensure optimal integration. ${ }^{116}$

With regard to the impact of globalization, including effects of privatization, the Special Rapporteur concentrates on the effects of privatization of water services. From case studies it has become clear that privatization and the emphasis on cost-recovery and profit seeking, may lead to the exclusion of vulnerable groups, while some of the best practice examples are to be found in States where water supply is publicly operated ${ }^{117}$ As a result of globalization and free market economy, poverty is rapidly becoming another

Quarterly, Vol. 18, 1996, pp. 23-66

111 UN doc. E/CN.4/2002/59, 1 March 2002, Report of the Special Rapporteur on adequate housing as a component of the right to an adequate standard of living, Mr. Miloon Kothari.

112 Ibidem, paras 20-23.

113 Ibidem, paras 24-28.

114 He specifically mentions the WTO trade agreements, particularly the General Agreement on Trade in Services (GATS) and the Agreement on Trade-Related Aspects of Intellectual Property Rights (TRIPS), country assistance agreements, and agreements with the World Bank and the IMF. Ibidem, para. 36.

115 For the Durban Conference see UN doc. A/CONF.189/12, 2001.

$116 U N$ doc. E/CN.4/2002/59, para. 46.

117 UN doc. E/CN.4/2002/59, paras 49-65. 
ground on which discrimination in the housing sphere occurs according to the Special Rapporteur since the poor are increasingly unable to cope with land speculation, commodification of housing, the increased fees for water, sanitation and electricity, and the repeal of land ceiling and rent control legislation. ${ }^{118}$

In the 2001 report the Special Rapporteur further relates that he sent an extensive questionnaire to governments and CSOs with the aim to gain additional insights in the core content of housing rights and the meaning of adequacy. ${ }^{119}$ Moreover, the Special Rapporteur received his first communications from individuals and CSOs, all concerning forced evictions and demolition of houses in both developed and developing States. ${ }^{120}$ The Special Rapporteur engages in a constructive dialogue with the Governments concerned in the hope of finding satisfactory solutions. ${ }^{121}$

Since the establishment of the Special Rapporteur's mandate, a series of global conferences have taken place that had a bearing on the right to adequate housing. Some of these conferences were mid-term reviews of global conferences held in the 1990s, such as Istanbul +5 in 2001, while others were new initiatives, such as the World Summit on Sustainable Development (WSSD). In his third report, ${ }^{122}$ the Special Rapporteur welcomes that in the Millennium Declaration and Millennium Development Goals (MDGs) two goals are mentioned that are of particular significance in the framework of housing rights: the commitment to halve the proportion of people without access to safe drinking water by 2015, and to significantly improve the living situation of at least 100 million slum dwellers by the year 2020. ${ }^{123}$ However, the Special Rapporteur expresses his concern that references to human rights instruments and the work of human rights bodies are lacking in both outcome documents and background papers. ${ }^{124}$

In view of the fact that many States have incorporated the right to adequate housing in their national law and that some national courts use international law and UN human rights jurisprudence in delivering their judgements, the mandate-holder proposes to develop a database of jurisprudence on housing rights that may be used to raise awareness among judges, lawyers, and practitioners. ${ }^{125}$

Pursuant to Commission resolution 2002/49 requesting the Special Rapporteur to report specifically on women and housing, a specific questionnaire had been developed and sent to States and human rights stakeholders. Furthermore, the Special Rapporteur had initiated a dialogue with CEDAW and a number of UN agencies and CSOs who wish to assist him on gender issues. ${ }^{126}$

118 Ibidem, paras 43-45

119 Ibidem, paras 70-71.

120 Since then the Special Rapporteur has received communications on a regular basis, e.g. in respect to evictions in Afghanistan, Bangladesh, India, Israel, Nigeria, the Philippines, Slovakia, Sri Lanka, the Sudan, and Zimbabwe. (see e.g. E/CN.4/2005/48/Add.1).

121 Ibidem, paras 72-73.

122 UN doc. E/CN.4/2003/5, 3 March 2003, Report of the Special Rapporteur on adequate housing as a component of the right to an adequate standard of living, and on the right to non-discrimination, Miloon Kothari.

123 GA resolution $55 / 2$, para. 19 .

124 UN doc. E/CN.4/2003/5, 3 March 2003, paras 6-10.

125 Ibidem, paras 11-14.

126 The specific study on women and housing, contained in $U N$ doc. E/CN.4/2003/55 will be discussed in section 2.7 . 
The Special Rapporteur regards the principle of non-discrimination as one of the key aspects of his mandate. Discrimination and segregation on the grounds of race, class, gender and economic status impede people from accessing housing and essential services. From his research and country missions it has become clear that a gap exists between legal provisions and reality, and the Special Rapporteur therefore wishes to continue his dialogue with several interested parties amongst which CEDAW and CERD, and he encourages States to take account of relevant recommendations made by these treaty bodies. ${ }^{127}$

During his country missions and other activities the Special Rapporteur has collected and documented good practices on housing rights and he recommends that OHCHR and UN-Habitat develop criteria to define good practices, and organize civil society hearings, country-missions and such to collect more examples in order to incorporate them in the database on good practices in the area of housing rights that will be added to the already existing UN-Habitat best practices database. ${ }^{128}$

In his third report the Special Rapporteur, again, stresses the importance of access to water and sanitation as part of adequate housing conditions. He recalls that the number of urban dwellers without access to safe water has increased from 56 million in 1990 to 118 million in 2000. Therefore, he welcomes the CESCR's General Comment No. 15 on the right to water, ${ }^{129}$ and warns against the negative consequences that privatization of water supply may bring about. ${ }^{130}$

In order to counter any negative effects of globalization, the Special Rapporteur suggests using innovative approaches to improve living conditions based on human rights norms and principles. Local governments may for instance buy large parts of land and allocate them for low-income housing while at the same time establishing low-cost material banks and making technical assistance available. He specifically refers to the MERCOSUR region for examples of good practices. ${ }^{131}$

The Special Rapporteur stresses that indicators be developed as well as methods for monitoring and measuring the development process from a rights perspective. The need for such tools has become even more pressing since the development of the MDGs. First relevant terms should be defined, and it should be checked to what extent a legal framework is in place to guarantee the fulfilment of the rights concerned. Suitable indicators should be designed that reflect human rights principles and that are objective, quantifiable and captured in databases which will make them monitorable. Although the goal is the realization of at least the minimum core content of the right to adequate housing, the principle of progressive realization requires that indicators are also designed in such a way that they can be used to measure progress and intermediate goals. The principle of non-discrimination entails that indicators should reflect the various attainments that have to be fulfilled for each disadvantaged group, which implies that any

127 UN doc. E/CN.4/2003/5, 3 March 2003, paras 19-22.

128 Ibidem, para. 23. See the UN-Habitat database on: <http://www.bestpractices.org $>$.

129 CESCR General Comment No. 15 on the right to water (arts. 11 and 12 of the ICESCR) is contained in UN doc. E/C.12/2002/11, 20 Janaury 2003.

130 UN doc. E/CN.4/2003/5, 3 March 2003, paras 39-46.

131 The MERCOSUR region consists of Montevideo, Uruguay; Porto Alegre, Brazil; Rosario, Argentina. Ibidem, paras 47-50. 
Chapter II

data that is collected must be disaggregated as regards gender, race, ethnicity, or any other distinguishing category that may cause marginalization. ${ }^{132}$

The Special Rapporteur's fourth report is focused on the topic of forced evictions. ${ }^{133}$ After covering the most important international norms and standards that form the legal basis for protection against forced evictions, ${ }^{134}$ the Special Rapporteur goes into a number of causes of forced displacement.

Frequently, groups of people are removed from their homes and lands because of development projects, particularly modernization or industrialization. Globalization is another cause of evictions either because of development projects, or because the growing land speculation and privatization of housing and civic services make it impossible for the poor to maintain their land and housing. In conflict and post-conflict situations the forceful removal of people from their land and housing is quite common. Land and housing are occupied for various reasons such as political control or personal gain, or houses are demolished in order to consolidate occupation, target political opponents, or for security reasons. Lastly, the Special Rapporteur mentions forced evictions as a form of punishment, for instance if residents are suspected of having supported terrorists. ${ }^{135}$

Next, the impact of forced evictions on specific groups of people is discussed. According to the mandate-holder, groups that are already marginalized in society are more likely than others to become the victims of forced evictions, while the consequences of displacement for such groups will be harsher and will impoverish them even more. ${ }^{136}$

The first group under scrutiny are women. In addition to the causes of forced evictions already mentioned, there are also a few gender specific reasons because of which women may be turned out on the street, like domestic violence, divorce, and widowhood. The effects of forced evictions hit women harder than men because of the gender disparities that exist in families and societies. Some women are more vulnerable than others; the very young, the elderly, the infirm, the disabled, those suffering from multiple forms of discrimination, refugees and so on. Compared to men, women's morbidity and mortality rate increases more when they are evicted, they are more likely to loose their livelihood and income since it is more difficult for women to find employment, their workload increases because their household tasks become more arduous, they are likely to be excluded from compensation schemes for various reasons, such as not being considered heads of household, in communities with strict behavioural codes, displacement will result in lack of mobility and access to the public sphere, they are harder hit by the breakdown of community since women depend more on social networks than men, and lastly, eviction will cause an increase in violence against women, including domestic violence, that will continue after resettlement if the new living conditions are inadequate. ${ }^{137}$

132 Ibidem, paras 51-62.

133 UN doc. E/CN.4/2004/48, 8 March 2004, Report of the Special Rapporteur on adequate housing as a component of the right to an adequate standard of living, Miloon Kothari.

134 Ibidem, paras 11-25.

135 Ibidem, para. 27-37.

136 Ibidem, paras 39-40.

137 Ibidem, paras 41 and 50-57. 
The next category that was studied by the Special Rapporteur is children. Children who loose their homes because of eviction not only lack a place where they can be safe, grow up, form their personality, and live in dignity, but also suffer from violations of their rights to health, education, development, and sometimes even their right to life. ${ }^{138}$

Indigenous peoples are particularly hard hit by evictions because of development projects since they are forced to leave their ancestral lands and their traditional way of life. Their social communities may be disrupted and they may suffer from harassment and violence once they have been resettled. ${ }^{139}$

Minorities and other vulnerable groups like refugees and migrants may already face discrimination as regards access to land and housing. For them settlement may inherently incorporate the risk of eviction which ultimately may leave them no other option but to settle in isolated places where they have no access to facilities like health care. ${ }^{140}$

Finally, the Special Rapporteur mentions that human rights defenders who protest against forced evictions and demolition of houses may be targeted with violence or threats thereof themselves. ${ }^{141}$

The 2005 report by the Special Rapporteur concentrates on the issue of homelessness. For the purpose of this report the Special Rapporteur defines homelessness as the lack of the most basic shelter. ${ }^{142}$ According to the Special Rapporteur causes of homelessness are diverse and multifaceted. Structural factors include in the first place poverty, both in urban and rural areas of developed and developing States.

Economic globalization is also mentioned as a cause of homelessness because it is said to create a widening gap between countries and within countries. Especially in the world's 49 LDCs economic globalization is proving to be part of the problem rather than a solution for the poor.

Further, the urbanization trend outpaces the provision of adequate housing resulting in a growing number of slum and pave-dwellers in the cities.

As mentioned in his previous report, forced evictions are also a major cause of homelessness, including evictions caused by large-scale development and infrastructure projects. ${ }^{143}$

Besides structural factors, conflict situations invariably lead to mass destructions of homes, facilities and infrastructure leaving large numbers of people destitute and creating huge streams of IDPs. ${ }^{144}$

Landlessness and homelessness are closely related. Though in many countries access to land may include access to housing, precarious tenure may make it uncertain whether the place to live and grow food may be maintained. According to the Special Rapporteur, the growing urbanisation in most States has less to do with industrialization in cities than with landlessness and land insecurity in rural areas. While the housing

138 Ibidem, paras 58-61.

139 Ibidem, paras 62-63.

140 Ibidem, paras 64-65.

141 Ibidem, paras 66-67.

142 UN doc. E/CN.4/2005/48, Report by the Special Rapporteur on adequate housing as a component of the right to an adequate standard of living, Miloon Kothari, 3 March 2005, para. 14.

143 Ibidem, paras 23-29.

144 Ibidem, paras 35-39. 
situation in urban areas already is bad, the growing influx from rural migrants makes it even worse. ${ }^{145}$

Several categories of people are particularly affected by homelessness. First he deals with the situation of women. Though worldwide women's circumstances may vary according to culture, the socio-economic position of most women is such that they are dependent on others - family members or partners - for their housing conditions. As a result, many women cannot decide where and with whom they live, and they risk homelessness upon dissolution of their marriage or partnership. Further, their inability to provide for their own housing may force them to choose between remaining in abusive relationships or homelessness, especially since the pervasive cultural idea is that it is the battered woman who should leave the family home instead of the male perpetrator. In some cases the law also works to women's detriment. A particular pertinent example the Special Rapporteur mentions is that in many legal systems free or cheap legal aid is only offered in cases of criminal law which greatly disadvantages women who would desperately need sound legal counsel in family law matters. ${ }^{146}$ The Special Rapporteur recommends that women's right to adequate housing, as well as their right to security of home and person should be specifically recognised and included in domestic violence legislation. ${ }^{147}$

According to the Special Rapporteur 12 million children have become homeless in the last decade because of armed conflict situations. Further, many developing countries know huge numbers of street children. Although it is positive that attention for these children is growing, it is bad that it is mostly forgotten that many of these children find themselves in such dire circumstances because their primary care-givers, their mothers, are unable to house them properly. Adolescents and young adults who have not yet reached the age of majority are also a group that needs special attention since they may encounter discriminatory barriers if they claim independent housing. This is particularly serious for those youths who want to flee an abusive home. Like many battered women they are often faced with the choice between the certainty of abuse at home and the risk of being abused while living rough. ${ }^{148}$

Finally, the Special Rapporteur mentions the vulnerable position of indigenous peoples who more often than not depend on their ancestral land for their right to housing, and the discrimination faced by persons with disabilities and by communities of different ethnicity and descent. ${ }^{149} \mathrm{He}$ stresses that legislation and regulation should include all people and that housing programmes are to be based on the principle of non-discrimination.

In addition to his five annual reports, the Special Rapporteur has written five reports on his country missions, ${ }^{150}$ and two reports specifically dealing with women's housing rights. ${ }^{151}$ The latter will be discussed in para. 2.7 .

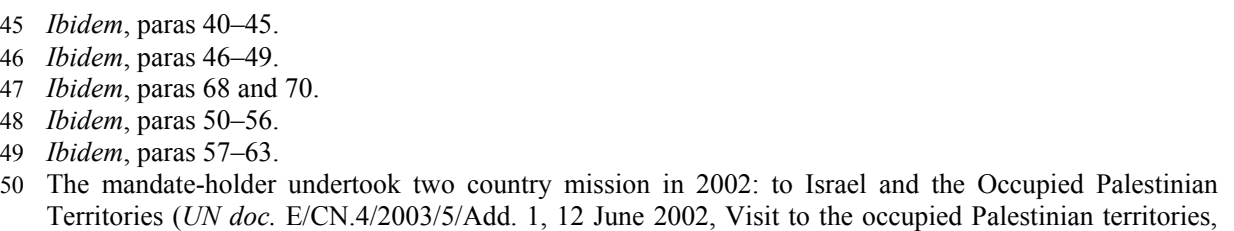




\subsection{CONTENT OF THE Right TO AdEQUATE HOUSING}

From the overview in the preceding section it has become clear that several international human rights instruments contain the right to housing. However, they all have the same shortcoming: they are too vague for normative objectives and control. In most cases the right to housing is included in a general clause on an adequate standard of living which leaves many questions as to the content of the right to housing and the meaning of the adjective 'adequate'. In the course of the years, especially since the 1990s, important norm setting work has been done and it has become more and more clear which elements are considered to be the core of the right to housing and which actions or omissions can be looked upon as violations of this right. Since the most important work has been done by the CESCR, this section is focused on the Committee's achievements.

Interpreting the provisions contained in the ICESCR was made difficult for the CESCR due to several circumstances. First of all, the norms contained in the Covenant are very vague and hardly any attempt had been made to clarify them either before or after the adoption of the instrument. Also at the national level it was not clear what the content is of the various economic, social and cultural rights. Secondly, the international community had not produced any helpful jurisprudence since the adoption of the Covenant. Therefore, the task to interpret the norms was largely left to the Committee. The CESCR has developed several ways to perform this task.

The most logical way is the examination of State reports, including the dialogue with the respective State's representatives. ${ }^{152}$ This method, however, did not prove to be adequate enough due to the fact that reports generally contain only basic information that does not shed a true light on the actual situation. Many States see the writing of the reports as a burdensome chore, which they may do with a minimum investment of time and people. Moreover, States are not always frank and forthcoming and may withhold information that is unfavourable to them. In some cases, the dialogue proves to be inefficient because the State party has dispatched a representative who is not experienced or knowledgeable enough to answer questions. Indeed, in some instances a representative may prove to be quite uncooperative. ${ }^{153}$

5-10 January 2002) and to Romania ( $U N$ doc. E/CN.4/2003/5/Add.2, 3 February 2003, Mission to Romania, 14-19 January 2002). In 2003 the Special Rapporteur went to Peru (UN doc. E/CN.4/2004/48/ Add.1, 11 February 2004, Mission to Peru, 3-15 March 2003). In 2004 Kenya was visited (UN doc. E/CN.4/2005/48/Add.2, 17 December 2004, Mission to Kenya, 9-22 February 2004) and Brazil (UN doc. E/CN.4/2005/48/Add.3, 18 February 2004, Mission to Brazil, 29 May-13 June 2004). In 2005 the Special Rapporteur will visit Cambodia and Iran.

151 The first report on Women and adequate housing was issued in 2003 (UN doc. E/CN.4/2003/55, 26 March 2003) and the second in 2005 (UN doc. E/CN.4/2005/43, 25 February 2005).

152 This was for instance done during the fifth session in December 1990 the Committee commented on the report of the Dominican Republic. It was concluded that this State had violated Article 11 of the Covenant because over 15,000 families had been expelled from their homes in the framework of urbanization plans. The violation was specifically caused by the fact that the expelled people had not been offered a reasonable alternative. Some had been subsequently forced to live in makeshift shelters without sanitation while others had to rent over-prized accommodations. Moreover, in many cases the evictions had taken place without following the proper procedures. UN doc. E/C.12/1990/SR.47, 13 December 1990.

153 Matthew Craven, The International Covenant on Economic, Social and Cultural Rights; A Perspective 
That is why the Committee decided to add another way of filling in the normative framework by inserting a day of general discussion in each of its sessions. During this day a specific right or particular aspect of the Covenant is discussed in detail in order to get a better understanding. The Committee invites all kinds of experts, also from CSOs, to contribute to the discussion. ${ }^{154}$

A third method the Committee uses in its clarifying work is that of General Comments. ${ }^{155}$ The purpose of these Comments is to further interpret the Covenant's provisions and to help States parties to fulfil their reporting obligations. ${ }^{156}$ The General Comments must be seen as very important sources of international jurisprudence. ${ }^{157}$

As regards the clarification of the right to adequate housing the Committee has used all three of these methods: evaluation of State reports with ensuing concluding observations, a day of general discussion, and two specific General Comments. ${ }^{158}$ Furthermore, other, more general, work done by the Committee, for instance specifying its reporting guidelines has also been helpful in determining the content of this right.

As already referred to earlier, the Committee held a day of general discussion on the right to housing in January $1990 .{ }^{159}$ Besides the Committee members a number of experts from CSOs, Habitat and ILO participated in the discussion. Several important observations were made, inter alia, that the right to housing is not reserved to families, but also applies to individuals, and that home ownership by women should be safeguarded especially since female headed households comprise one third of the world's families.

As core elements of the right to housing were mentioned security of tenure, affordability, accessibility, habitability, popular participation in decision-making, choice, equality of access and non-discrimination and availability of legal remedies. Furthermore, it was concluded that people should be free from threats of eviction or demolition of their homes.

The interdependence and interrelatedness of human rights was stressed by the remark that the right to housing is closely connected to several civil and political rights including the right to privacy and the right to family life.

Another important observation was that the right to housing can be subject to violation due to acts and omissions, and it was decided that future work should include looking into evictions.

The Committee further concluded that housing rights are justiciable, particularly those aspects that are connected with the right to privacy, the right to life, the right to freedom from discrimination and the right to be protected from illegal evictions.

on its Development, Clarendon Press, Oxford, 1995, pp. 68-71.

154 Ibidem, pp. 92-94.

155 Such Comments will be of a general nature and are based on the examination of State reports and other information received by the Committee. The possibility of issuing General Recommendations or Comments has been foreseen in Article 21 of the ICESCR.

$156 U N$ doc. E/1989/22, Introduction: the purpose of general comments.

157 Ibidem, pp. 489-496.

158 General Comment No. 7 on forced evictions will be discussed in section 2.5 since it contains an clarification of State obligations in cases of evictions.

159 UN doc. E/C.12/1990/3, Committee on Economic, Social and Cultural Rights, Report on the Fourth Session, paras 281-285. 
On 12 December 1991 General Comment No. 4 on adequate housing was adopted. ${ }^{160}$ The Comment contains a few important general observations as regards housing rights.

First of all, it is stated that the right to adequate housing is of central importance for the enjoyment of all economic, social and cultural rights. ${ }^{161}$ Article 11(1) of the Covenant is regarded by the Committee as the most comprehensive and maybe the most important provision pertaining to housing rights. ${ }^{162}$

According to the Committee it is important to keep in mind that the right to housing applies to everyone without exception. Although the text of the Covenant reads 'himself and his family', this does not imply that women are excluded or that female-headed households would not have housing rights. The Committee regards the phrase simply as an anachronism, referring back to times when gender roles were regarded differently and it was automatically assumed that breadwinners and heads of household were men. ${ }^{163}$

Furthermore, the Committee states that the right to housing must not be interpreted in a narrow or restrictive sense. Thus, shelter does not mean heaving a roof over one's head, but it is the right to live somewhere in security, peace and dignity. The Committee had two reasons in mind when it made this statement. The first one is that housing should be ensured to everyone, irrespective of income or access to economic resources. The second is that the right does not refer to merely housing, but to adequate housing. The Committee underscores the definition of adequacy made by both the UNCHS and in the Global Strategy for Shelter to the Year 2000 stating: 'adequate privacy, adequate space, adequate security, adequate lighting and ventilation, adequate basic infrastructure and adequate location with regard to work and basic facilities - all at a reasonable cost' ${ }^{164}$

Concerning the content of the right to adequate housing, however, the most important part of the General Comment is section 8 in which the Committee analyses seven elements of adequate housing that hold true in all circumstances, no matter what social, economic, cultural, climatic, ecological and other aspects may be relevant.

The first element is legal security of tenure. This means that everyone should enjoy legal protection against forced eviction, harassment and other threats, notwithstanding the form of tenure, i.e. whether the accommodation is bought or rented, whether it concerns permanent or emergency shelter, whether the housing is legal or informal as in the case of land occupation or squatting.

Secondly, adequate housing includes availability of services, materials, facilities and infrastructure. A house can only be adequate when it contains a number of facilities that are necessary to guarantee health, security, comfort and nutrition. This means that access should be available with respect to natural and common resources, safe drinking water, and energy for cooking, heating and lighting, sanitation and washing facilities, means of food storage, refuse disposal, site drainage and emergency services.

The third element concerns the affordability of housing. In any case the costs of housing should not be so high that other basic needs are threatened by it. States should

160 CESCR General Comment No. 4 on adequate housing, 12 December 1991, contained in UN doc. E/1992/23.

161 Ibidem, para. 1

162 Ibidem, para. 3

163 Ibidem, para. 6.

164 Ibidem, para. 7. 
Chapter II

see to it that there is a system of housing subsidies available for those who have insufficient means to afford adequate housing by themselves. Another aspect of affordability is that the state must protect tenants against unreasonable rent levels or rent increases.

Fourthly, habitability is considered to be one of the elements of adequate housing. A house should provide adequate space and protection against cold, damp, heat, rain, wind or other treats to health, structural hazards, and disease vectors. Moreover, the physical safety of the occupants must be guaranteed.

Fifthly, accessibility is mentioned. Adequate housing should be accessible for all. Governments must specifically see to the needs of disadvantages groups. The Committee gives several examples of disadvantaged groups: the elderly, children, the physically disabled, the terminally ill, HIV-positive individuals, persons with persistent medical problems, the mentally ill, victims of natural disasters, people living in disaster-prone areas and other groups. An important aspect of accessibility is that it includes access to land.

In the sixth place location is mentioned. The location should be such that it is possible to reach, without too many costs, basic facilities like schools, hospitals, childcare centres and employment possibilities. Furthermore, housing should not be located on, or in the neighbourhood of polluted sites that constitute a threat to health.

Finally, adequate housing comprises cultural adequacy. This means that there should be room for expressions of cultural identity and diversity of housing, for example with regard to the building materials that are being used.

The interpretative work done by the Committee has had an enormous impact on the clarifying and standard setting activities undertaken by other UN bodies. General Comment No. 4 has proved to be a source of inspiration for instance in the work of the SubCommission's Special Rapporteur. The holistic manner in which housing is perceived in this Comment makes it clear that housing rights cannot be separated from other human rights.

In the Habitat Agenda, States participating in Habitat II have reaffirmed the greater part of the CESCR's findings in General Comment No. 4. It was acknowledged that adequate housing would mean much more than having a roof over one's head. According to the participating States the current understanding of adequacy includes: 'adequate privacy; adequate space; physical accessibility; adequate security; security of tenure; structural stability and durability; adequate lighting, heating and ventilation; adequate basic infrastructure, especially water-supply, sanitation and waste-management facilities; suitable environmental quality and health-related factors; and adequate and accessible location with regard to work and basic facilities: all of which should be available at an affordable cost'. It was recognized that the standard of adequacy may not be the same all over the world; what exactly is adequate in a certain region, country, or part of a country, is determined by several factors such as economic development, culture, social patterns and environmental aspects. ${ }^{165}$

165 The Habitat Agenda, Chapter IV, Global Plan of Action: Strategies for Implementation, under B. Adequate shelter for all, para. 60 . 
State obligations concerning housing rights may be divided into two categories: internal obligations towards the State's own citizens, and external implications towards other States and the CESCR. First the internal obligations will be dealt with after which attention will be paid to the external implications.

\subsubsection{Internal Obligations}

Two different methods have been developed in order to establish governmental legal obligations as regards economic, social and cultural rights. These methods overlap and complement one another.

First the typology of obligations was developed in legal doctrine. This method distinguishes different levels of obligations that must be completed in order to ultimately lead to the full realization of these rights. According to the original methodology as created by Henry Shue, ${ }^{166}$ there are only three layers and they comprise to respect, to protect and to fulfiil. ${ }^{167}$ Failure to perform any one of these three levels will constitute a violation of the right concerned. ${ }^{168}$ Using this method and adapting it to housing rights, the Sub-Commission's Special Rapporteur on the right to adequate housing discerns the obligations to recognize, to respect, to protect, to promote and to fulfil. ${ }^{169}$

'To recognize' would entail that the right to adequate housing is recognized as a human right, and that no measures are taken to undermine the legal status of the right. Legislative steps must be taken and housing policy must be developed. States should make up the balance as regards the realization of the right to housing. To a certain degree, the right may already be enjoyed, but it is important to ascertain the degree to which the right is not enjoyed. Gaining insights in these matters is necessary to determine which future measures and resources may be needed. ${ }^{170}$

The obligation 'to respect' means that the authorities must abstain from any acts or measures that may impede the way in which individuals manage to realize their own housing rights. This entails for example that States should allow their poor to build their own shelters uninhibited by unnecessary bureaucratic rules as to appearance and/or building materials, and that self-help initiatives should be encouraged and facilitated rather

166 Henry Shue, Basic Rights, Subsistence, Affluence and US Foreign Policy, Princeton, New Jersey 1980, particularly Chapter 2 .

167 The methodology was subsequently successfully applied by the Sub-Commission's Special Rapporteur Asbjørn Eide in his reports on the right to food as contained in Article 11(1) ICESCR. See UN documents E/CN.4/Sub.2/1983/25, E/CN.4/Sub.2/1984/22, and E/CN.4/Sub.2/1987/23.

168 The Maastricht Guidelines on Violations of Economic, Social and Cultural Rights, guideline 6, contained in: Theo van Boven, Cees Flinterman, Ingrid Westendorp (eds.), Human Rights, Maastricht Perspectives, Maastricht Centre for Human Rights, Maastricht 1999.

169 UN doc. E/CN.4/Sub.2/1993/15, The right to adequate housing: progress report submitted by $\mathrm{Mr}$ Rajindar Sachar, Special Rapporteur, para. 46.

170 Ibidem, paras 62-65. 
than hampered. ${ }^{171}$ Another aspect of 'to respect' is that States must honour the right to privacy of the home and other related rights. ${ }^{172}$

The most obvious duty in this regard may be, however, that States should refrain from forced evictions. ${ }^{173}$ The CESCR has been very alert as to detecting and condemning acts of forced evictions. ${ }^{174}$ In their reports States parties have to deal with several aspects of evictions. For instance, they have to state whether they have taken any legislative measures prohibiting illegal forms of evictions and they must give insight in the number of people that have been evicted during the previous period. In the concluding observations of the Committee's comments on these State reports, the Committee deals extensively with the problem of evictions. ${ }^{175}$

Besides these concluding observations that are primarily concerned with individual States, the CESCR has adopted General Comment No. 7 on forced evictions. ${ }^{176}$ In this General Comment, the Committee confirms its views that forced evictions are prima facie incompatible with the requirements of the Covenant on Economic, Social and Cultural Rights, ${ }^{177}$ and it defines the term 'forced evictions' as: 'the permanent or temporary removal against their will of individuals, families and/or communities from the homes and/or land which they occupy, without the provisions of, and access to, appropriate forms of legal or other protection. The prohibition on forced evictions does not, however, apply to evictions carried out by force in accordance with the law and in conformity with the provisions of the International Covenants on Human Rights'. ${ }^{178}$

Punitive measures in the form of forced evictions and/or demolition of houses are held to be incompatible with the Covenant. ${ }^{179}$ In cases where governments claim that they had no other option but to resort to eviction, they must prove that they have exhausted all possible alternatives. Furthermore, consultations with the affected persons must have taken place and the use of violence must be avoided as much as possible. Moreover, procedural protection and due process must have been followed. ${ }^{180}$ The evictees must be adequately compensated for any loss of property and, most importantly, they must have been offered alternative housing. The Committee stresses that the result of forced evictions should not be that people are rendered homeless or that they

171 CESCR General Comment No. 4, para. 10.

172 UN doc. E/CN.4/Sub.2/1993/15, paras 66-68.

173 Maastricht Guidelines, guideline 6.

174 Scott Leckie, When Push Comes to Shove; Forced Evictions and Human Rights, Habitat International Coalition, 1995, pp. 61-64.

175 Excerpts of the most important concluding observations on this subject have been published in: Forced Evictions and Human Rights; a manual for action (Sources No. 3), Centre on Housing Rights and Evictions (COHRE), Geneva, 1999, pp. 16-32.

176 CESCR General Comment No. 7 on forced evictions, 16 May 1997, contained in UN doc. E/C.12/ 1997/4. The text of General Comment No. 7 has been attached to this study as Annex 3.

177 Ibidem, para. 1.

178 Ibidem, para. 4.

179 Ibidem, para. 13

180 In para. 16 of General Comment No. 7 the Committee specifies what it means by appropriate procedural protection and due process. The rules mentioned include genuine consultation with those affected, adequate and reasonable notice prior to the scheduled date of eviction, evictions should not take place in bad weather circumstances nor at night, and provision of legal remedies. 
become vulnerable to the violation of other human rights. ${ }^{181}$ Furthermore, the Committee points out that certain groups in society are disproportionately affected by forced evictions. Particularly the women of these groups are vulnerable since it is, due to discriminatory practices, in many cases very difficult for them to obtain access to property or accommodation, while they are also prone to sexual and other violence once they have become homeless. It is therefore the duty of States parties to be especially wary of any discrimination when evictions do occur. ${ }^{182}$

It should be noted that if evictions are justifiable, for instance because tenants have refused to pay the rent for a long time or if they have damaged the rented property without any reasonable cause, these practices do not fall under the definition used in General Comment 7 as long as they have been carried out in accordance with the law and the requirements made by the Covenant. ${ }^{183}$

The duty 'to protect' demands that the housing conditions of the population should in any case not decline. States should give priority to those groups of the population that live in the most unfavourable circumstances. No matter what difficulties a State may encounter, even if they are of external origin, a general deterioration of living and housing conditions that may be attributed to the State's policy and legislative decisions would constitute a violation of the obligations under the ICESCR. ${ }^{184}$

The cost of housing should remain within reasonable boundaries and a system of subsidies should be established for those who cannot secure housing themselves. ${ }^{185}$

Moreover, the obligation to protect comprises that everyone is guaranteed legal security of tenure. This involves that States must prevent third parties from violating housing rights such as forced evictions, harassment and other threats. Where infringements do occur, States must provide legal remedies and reparations and prevent further dispossessions. ${ }^{186}$ In case States fail to exercise due diligence in controlling the behaviour of non-State actors, States themselves will be held responsible for the violations. ${ }^{187}$

'To promote' means that States should adequately emphasize the importance of the realization of the right to housing for everyone, and further this cause by way of all kinds of measures. ${ }^{188}$

'To fulfil' is the ultimate level of obligations. It entails the realization of the right to adequate housing for everyone. This goal can only be achieved by means of housing measures and specific budget allocations by the State so that also the housing needs of those people are satisfied, who would not be capable of obtaining adequate housing by their own efforts. ${ }^{189}$

The second method of ascertaining governmental legal obligations was established by the CESCR when it issued General Comment No. 3 on the nature of States parties'

181 Ibidem, para. 17

182 Ibidem, para. 11.

183 Ibidem, para. 12.

184 CESCR General Comment No. 4, para. 11

185 UN doc. E/CN.4/Sub.2/1993/15, para. 71.

186 Ibidem, para. 69. CESCR General Comment No. 7, paras 1, 9 and 10.

187 Maastricht Guidelines, guideline 18. Also see section 4.6.4 on Due diligence.

188 Ibidem, para. 73.

189 Ibidem, paras 74-78 
obligations under Article 2(1) ICESCR. ${ }^{190}$ Article 2 is important for a better understanding of all other provisions of the Covenant, since it describes the nature and scope of the legal obligations a State takes upon itself by becoming a party to the Covenant. The text of Article 2(1) reads:

'Each State Party to the present Covenant undertakes to take steps, individually and through international assistance and co-operation, especially economic and technical, to the maximum of its available resources, with a view to achieving progressively the full realization of the rights recognized in the present Covenant by all appropriate means, including particularly the adoption of legislative measures.'

Three phrases of this provision are of particular importance: 'to take steps $[\ldots]$ by all appropriate means'; 'to achieving progressively; and 'to the maximum of its available resources'.

The phrase 'to take steps [...] by all appropriate means' means that while the full realization of a right may be achieved progressively, States parties have an immediate obligation to take steps towards that goal. The concept 'appropriate means' includes legislative, administrative, judicial, economic, social and educational measures. ${ }^{191} \mathrm{With}$ regard to housing rights this might entail reviewing national legislation i.e. repealing all laws and policies that are not compatible with international legal obligations, and adopting a national housing strategy which is drawn up in consultation with, and participation of, all affected groups. ${ }^{192}$

The words 'to achieving progressively' imply that States are obliged to choose the fastest and most effective way possible in order to meet the end of full realization of the right to housing. Some steps must be taken immediately upon ratification independent of availability of resources, like adopting non-discriminatory legislation and monitoring the housing situation. ${ }^{193}$ A general decline in housing conditions, that is directly attributable to the government, can only be justified by reference to the totality of the rights provided for in the Covenant and in the context of the full utilization of a State's maximum available resources.

In this context it is pertinent to note that the Committee also determined that from the moment they become a Party to the Covenant, States are duty-bound to fulfil at least the minimum essential level of each of the enumerated rights. As far as housing rights are concerned, the Committee explicitly mentions that if any significant number of individuals lacks basic shelter and housing, a State is prima facie failing to fulfil its obligations under the Covenant. ${ }^{194}$

The phrase 'to the maximum of its available resources', refers to both the resources within a State and those obtained from the international community in the framework of

190 General Comment No. 3 on the nature of State Parties obligations, contained in UN doc. E/1991/23.

191 The Limburg Principles on the Implementation of the International Covenant on Economic, Social and Cultural Rights, UN doc. E/CN.4/1987/17, Annex, section 17.

192 General Comment No. 4 on adequate housing, para. 10.

193 UN doc. E/CN.4/2002/59, Report of the Special Rapporteur on adequate housing as a component of the right to an adequate standard of living, Mr. Miloon Kothari, 1 March 2002, para. 27.

194 General Comment No. 3, para. 10. Also Maastricht Guidelines, guideline 9. 
international co-operation and assistance. ${ }^{195}$ The Committee has stated that even when available resources are demonstrably inadequate, States must strive to ensure the widest possible enjoyment of the relevant rights under prevailing circumstances. ${ }^{196}$ If a State fails to meet even the minimum core obligations due to lack of resources, it must demonstrate that every effort has been made to use all resources that are at its disposition in an effort to satisfy, as a matter of priority, these minimum responsibilities. Moreover, even in times of severe resources constraints, States retain the obligation to protect the most vulnerable members of society. ${ }^{197}$

Finally, it should be noted that although governments, without exception, are responsible for housing, the government is not the only body that needs to take action. All sections of society, as well as the international community, should pull their weight. The action they should take must be focused on enablement, and participation. ${ }^{198}$

\subsubsection{External Implications}

Besides the individual responsibility States have as regards the housing rights of their citizens, States also have international obligations towards other States. For human rights in general, the obligation to assist and co-operate with other States can be based on Articles 55 and 56 of the United Nations Charter. ${ }^{199}$ For economic, social and cultural rights, and the right to housing specifically, this obligation may be derived from Articles $2(1)^{200}$ and $11(1)^{201}$ ICESCR respectively. It may be clear that although the provision of financial and technical assistance is a moral duty of all States ${ }^{202}$ it is particularly expected of those States which are in a position to assist others and in situations where States

195 The Limburg Principles, principle 26.

196 General Comment No. 3, para. 10.

197 Ibidem, para. 12.

198 The Habitat Agenda, Chapter IV, Global Plan of Action: Strategies for Implementation, under B. Adequate shelter for all, para. 60 .

199 The relevant Articles of the UN Charter read:

"Article 55: With a view to the creation of conditions of stability and well-being which are necessary for peaceful and friendly relations among nations based on respect for the principle of equal rights and selfdetermination of peoples, the United Nations shall promote: a) higher standards of living, full employment, and conditions of economic and social progress and development; b) solutions of international economic, social, health, and related problems; and international cultural and educational co-operation; and c) universal respect for, and observance of, human rights and fundamental freedoms for all without distinction as to race, sex, language, or religion.

Article 56: All Members pledge themselves to take joint and separate action in co-operation with the Organization for the achievement of the purposes set forth in Article 55.'

200 The relevant excerpt from Article 2(1) ICESCR reads: 'Each State Party to the present Covenant undertakes to take steps, individually and through international assistance and co-operation, especially economic and technical [...].'

201 The relevant part of Article 11(1) reads: 'The States Parties will take appropriate steps to ensure the realization of this right, recognizing to this effect the essential importance of international co-operation based on free consent.'

202 During the World Summit held from 14 to 16 September 2005, many developed States agreed to set the target of 0.7 per cent of their gross national product to be achieved for official development assistance by 2015. UN doc. A/RES/60/1, 2005 World Summit Outcome, 24 October 2005. 
are struck by any kind of natural or manmade disaster which has resulted in the destruction of homes and settlements. ${ }^{203}$

The other side of the coin is that States parties to the ICESCR that are unable to fulfil even the basic obligations as regards the core housing rights are obligated to seek international help. ${ }^{204}$ States that offer financial or economic support to another State, either individually or in concert, may not make conditions that would jeopardize the assisted State's housing rights obligations as regards its population. ${ }^{205}$ Particularly international financial institutions, such as the World Bank and the IMF are time and again reminded that they have to be careful not to demand any economic measures, such as structural adjustment, that would infringe upon peoples' right to housing. ${ }^{206}$ The CESCR has explicitly stated that international agencies should avoid involvement in projects which entail large-scale evictions or displacement of persons without the provision of all appropriate protection and compensation and that when relocation and/or resettlement is unavoidable, this should be done with a view to limiting the human suffering associated with forced evictions as much as possible. ${ }^{207}$

Furthermore, States are called upon to condemn behaviour by other States that violates the right to housing. ${ }^{208}$

States parties to the ICESCR have undertaken the duty to report on a regular basis on the measures they have taken to further the economic, social and cultural rights as contained in the Covenant. ${ }^{209}$ In June 1991 the CESCR adopted revised reporting guidelines. ${ }^{210}$ For housing this means that States parties must include in their reports detailed information about vulnerable and disadvantaged groups especially the number of homeless and inadequately housed persons and the number of evictees; the existence of any laws affecting the realization of the right to housing; an enumeration of the measures that the State has taken to fulfil the right to housing; and any changes in policies, laws and practices that have had a negative impact on the realization of the right to adequate housing. ${ }^{211}$

203 CESCR General Comment No. 3, para. 14. Limburg Principles, principles 29-34.

204 According to the CESCR, the words 'to the maximum of its available resources' refers to both resources within a State and those which are available from the international community through international cooperation and assistance'. CESCR General Comment No. 3, para. 13. Furthermore, State parties that receive help should ensure that a substantial proportion of the international financial assistance is spent on creating conditions leading to a higher number of people being adequately housed. CESCR General Comment No. 4, para. 19

205 UN doc. E/CN.4/2001/51, 25 January 2001, Report of the Special Rapporteur on the right to adequate housing, Mr Miloon Kothari, para. 34.

$206 U N$ doc. E/CN.4/2001/51, 25 January 2001, para. 36.UN doc. E/CN.4/Sub.2/1993/15, para. 82. CESCR General Comment No. 4, para. 19.

207 CESCR General Comment No. 2, international technical assistance measures, para. 6, 1990, contained in UN doc. E/1990/23, Annex III. CESCR General Comment No. 7, forced evictions, 1991, para. 19.

$208 U N$ doc. E/CN.4/Sub.2/1993/15, paras 80 and 81.

209 ICESCR, Articles 16 and 17.

210 UN doc. E/C.12/1991/1, 17 June 1991.

211 The specific guidelines on the right to adequate housing are attached to this study as Annex 5. 
After having covered the specific content of the right to adequate housing and the ensuing State obligations, it is useful to pay attention to any doubts that may exist about adequate housing being a human right and whether it is a justiciable human right.

In view of the numerous international, regional and national provisions ensuring the right to adequate housing any issue pertaining to the existence of such a right seems to be settled. Still, time and again some States and scholars raise the question whether adequate housing for all should not be considered a mere aspiration rather than a right. ${ }^{212}$ One of the most important incidences in this regard happened during the preparatory phase of the Habitat II Conference. ${ }^{213}$ During the second meeting of the Preparatory Committee in Nairobi in April 1995, the very existence of a right to adequate housing was questioned, especially by the United States' delegation. This delegation even stated that it would oppose any reference to the right to housing in any form whatsoever in the final document of the Conference. ${ }^{214}$ As a result of this discussion, the Commission on Human Settlements adopted resolution 15/2 in which the Executive Director was requested to review the Housing Rights Strategy report while taking into account views and concerns expressed by some Member States, 'including those regarding the existence and/or legal status of the right to adequate housing'. ${ }^{215}$ The Special Rapporteur on the Right to Housing was appalled. ${ }^{216}$ He strongly rejected the questioning of the existence of the right to housing and implored the CESCR to take action. ${ }^{217}$ On behalf of the Committee its chairperson addressed a letter to the Assistant Secretary-General of the UN Centre for Human Settlements, stating that the right to adequate housing is recognized both in international human rights law and in international treaties. He emphasized that denial of the existence of the right to housing 'is a strategy fraught with danger and one which cannot help but undermine the international legal regime'. Furthermore, he stressed that since neither the Commission on Human Rights nor the CESCR have an operational role or capacity, and neither has any influence on discussions on housing policy, it was especially the Commission on Human Settlements that had to use its influence to put the right to adequate housing high on the agenda of the Habitat II conference. ${ }^{218}$

The final outcome was that the United States retraced its steps during the Conference and that the right to adequate housing was reaffirmed as a human right. ${ }^{219}$

$212 U N$ doc. E/CN.4/2002/59, Report of the Special Rapporteur on adequate housing as a component of the right to an adequate standard of living, Mr. Miloon Kothari, 1 March 2002, para. 24.

213 The preparatory work for this conference was done by a special Preparatory Committee of the General Assembly and an ad hoc secretariat, which was organizationally part of the UN Centre for Human Settlements (Habitat).

214 UN doc. A/50/37, Report of the Preparatory Committee for the United Nations Conference on Human Settlements (Habitat II), 25 July 1995.

215 Commission on Human Settlements resolution 15/2, Report on housing rights strategy, 1 May 1995.

$216 U N$ doc. E/CN.4/Sub.2/1995/12 of 12 July 1995, paras 67 and 68.

217 Ibidem, para. 76. In fact, the Special Rapporteur met with the Committee in Geneva on 16 May 1995.

218 UN doc. E/C.12/1995/11, letter addressed by the chairperson of the Committee on Economic, Social and Cultural Rights Mr. Philip Alston to Mr. Wally N'Dow, Assistant Secretary-General, UN Centre for Human Settlements, 21 July, 1995.

219 'We reaffirm our commitment to the full and progressive realization of the right to adequate housing as 
Considering the political weight of consensus that was reached at a World Conference in which housing played a vital role and the legal reality that the great majority of States have willingly taken it upon themselves to ensure housing rights for those who fall under their jurisdiction, it might have been expected that the discussion would have come to an end. That still doubts are raised whether adequate housing is a 'true' human right is especially fuelled by qualms about the justiciability of this right.

Before examining justiciable possibilities of the right to adequate housing, it should be pointed out that justiciability is not a prerequisite that has to be fulfilled before a certain entitlement can be regarded as a human right. An international human right is created when an entitlement is recognized to be so either by international customary law or by treaty law and States have taken up the obligation to promote and protect it as such. Justiciability is usually seen as a last resort, when the normal implementation and protection of a right has gone wrong and a person's right has been infringed. ${ }^{220}$

Even if justiciability is not crucial to characterize adequate housing as a human right, from a victim's point of view it may be vital whether or not housing rights violations can be brought before a court of law. ${ }^{221}$ Moreover, judicial control may be needed to ensure that the State fulfils its obligations beyond what political and administrative organs are willing to provide on their own accord. Especially when the State itself is party to a dispute, referral to a judiciary organ may be warranted. ${ }^{222}$

As regards international obligations under the ICESCR, the Limburg Principles ${ }^{223}$ indicate that justiciability of economic, social and cultural rights is possible and that States parties to the ICESCR shall 'use all appropriate means, including [...] judicial [...] measures, consistent with the nature of the rights in order to fulfil their obligations under the Covenant'. ${ }^{224}$ Furthermore, 'State parties shall provide for effective remedies including, where appropriate, judicial remedies'. 225

The CESCR states in its General Comment No. $3^{226}$ that among the 'appropriate' measures which States parties have to take under Article 2(1) of the Covenant, is the

provided for in international instruments.' Istanbul Declaration on Human Settlements, para. 8, contained in $U N$ doc. A/CONF.164/14, 7 August 1996.

220 Also Jill Cottrell \& Yash Ghai, 'The Role of the Courts in the Protection of Economic, Social \& Cultural Rights', in: Yash Ghai \& Jill Cottrell (eds.), Economic, Social \& Cultural Rights in Practice; The Role of Judges in Implementing Economic, Social \& Cultural Rights, Interights, London, 2004, p. 88.

221 A specific human rights' violation is justiciable if it can be dealt with in court and if the court can provide a remedy. Rolf Künnemann, 'Justiciability of the Right to Food', in: Right to Food Journal, December 2003, p. 3.

222 Abdullahi Ahmed An-Na'im ,'To Affirm the Full Human Rights Standing of Economic, Social \& Cultural Rights', in: Yash Ghai \& Jill Cottrell (eds.), Economic, Social \& Cultural Rights in Practice; The Role of Judges in Implementing Economic, Social \& Cultural Rights, Interights, London, 2004, p. 14.

223 A group of distinguished experts in international law convened in Maastricht in June 1986 and agreed on a set of principles, 'The Limburg Principles' as regards the nature and scope of the obligations of States parties to the ICESCR.

224 The Limburg Principles on the Implementation of the International Covenant on Economic, Social and Cultural Rights, June, 1986, principle17, contained in Theo van Boven, Cees Flinterman, Ingrid Westendorp (eds.), Human Rights, Maastricht Perspectives, Maastricht Centre for Human Rights, Maastricht 1999.

225 The Limburg Principles, principle 19.

226 CESCR General Comment No. 3 on the nature of States parties obligation, 14 December 1990. 
provision of judicial remedies with respect to rights which may be considered justiciable in accordance with the national legal system. In any case, the CESCR holds that the enjoyment of the rights without discrimination is justiciable. In addition, the Committee mentions a non-exhaustive list of Covenant provisions which would be capable of immediate application by judicial and other organs in many national legal systems. ${ }^{227}$ The CESCR elaborates the concept of justiciability further in its General Comment No. 9 in which it is mentioned that notwithstanding the fact that the ICESCR lacks a direct counterpart to Article 2(3) of the ICCPR obliging State parties to 'develop the possibilities of judicial remedy', a State party to the ICESCR that fails to provide domestic legal remedies for violations of economic, social and cultural rights would need to show that such remedies are not 'appropriate means' within the terms of Article 2(1) or that, in view of other means used, they are unnecessary, which will be very hard if not impossible to prove. ${ }^{228}$ In the Committee's opinion, there is no Covenant right which does not possess at least some dimensions that should be considered justiciable. The argument that courts should not be involved in matters concerning budgetary decisions is rejected by the CESCR by recalling that courts already are involved in many cases that have important financial implications. Keeping only cases concerning economic, social and cultural rights beyond the reach of the court may thus be considered as arbitrary and moreover, it would be incompatible with the principle that the two sets of human rights are indivisible and interdependent. ${ }^{229}$

In 1995, the Sub-Commission's Special Rapporteur devoted a chapter of his final report to the question of justiciability of the right to adequate housing. ${ }^{230} \mathrm{He}$ based himself on the national, regional and international experiences that had been gained in respect to housing rights cases. The international experience relates particularly to the monitoring function of the CESCR. According to the Special Rapporteur at least the following elements of the right to adequate housing are deemed to be justiciable: 'a) Protection against arbitrary, unreasonable, punitive or unlawful forced evictions and/or demolitions; b) Security of tenure; c) Non-discrimination and equality of access in housing; d) Housing affordability and accessibility; e) Tenants' rights; $f$ ) The right to equality and equal protection and benefit of the law; g) Equality of access to land, basic civic services, building materials and amenities; $h$ ) Equitable access to credit, subsidies and financing on reasonable terms for disadvantaged groups; i) The right to special measures to ensure adequate housing for households with special needs or lacking necessary resources; $\mathrm{j}$ ) The right to the provision of appropriate emergency housing to the poorest section of society; k) The right to participation in all aspects of the housing sphere; and l) The right to a clean environment and safe and secure habitable housing. ${ }^{231}$

227 CESCR General Comment No. 3, para. 5. The Articles mentioned by the Committee are: 3; 7(a)(i); 8; $10 ; 13(2)(a),(3)$ and (4); and 15(3).

228 CESCR General Comment No. 9 on the domestic application of the Covenant, 3 December 1998, contained in $U N$ doc. E/C.12/1998/24.

229 Ibidem, para. 10.

230 UN doc. E/CN.4/Sub.2/1995/12 of 12 July 1995, Chapter III. Clarifying and Detailing the Justiciability of the Human Right to Adequate Housing.

231 Ibidem, paras 79-96. Also see the listing of Scott Leckie included in his paper 'The Justiciability of Housing Rights', in: Fons Coomans and Fried van Hoof (eds.), SIM Special No. 18; The Right to 
Also the Commission's Special Rapporteur dealt with the issue of justiciability of the right to adequate housing in his first three reports. Particularly in his 2002 report he recalled that since already more than 50 States have incorporated the right to adequate housing or elements thereof in their national constitutions judges are increasingly called upon to decide in matters concerning housing rights. At a workshop for judges organized by OHCHR in New Delhi, judges from South-East Asia could agree that the right to adequate housing is a justiciable right. They were of the opinion that judges have a particular role to play as regards the protection of the vulnerable against homelessness ensuing from arbitrary and discriminatory action, in ensuring that no retrogressive laws and policies concerning the right to housing would be taken and, in keeping a watchful eye that no forced evictions would be carried out and that if, in exceptional circumstances, evictions are unavoidable, they would be surrounded by all procedural safeguards and guarantees for adequate alternative housing. ${ }^{232}$

At the domestic level, especially India and South-Africa are notable for their efforts to judicially enforce economic, social and cultural rights, among which the right to adequate housing. In many States judicial enforcement is thought to be impossible either because the decisions on budgetary allocations that are involved are supposed to be the prerogative of the Legislature/Executive, or because judges are supposed to lack the qualifications to evaluate and determine issues of social policy. ${ }^{23}$

In India, the instrument of public interest litigation (PIL) was devised in the $1980 \mathrm{~s}$ so as to enable easier access to justice for the vast majority of the poor and as a tool to achieve social justice. ${ }^{234}$ The Indian Supreme Court paved the way for housing rights litigation by creatively interpreting the (negative) Article 21 of the Indian Constitution to include: 'the right to live with human dignity and all that goes with it, namely, the bare necessities of life such as adequate [...] shelter [...] . ${ }^{235}$ This PIL jurisdiction was for instance used by the Court in the famous Olga Tellis case, in which the right of pavement dwellers to due process was protected when they faced forced eviction and where the Court ruled that, although the eviction order was valid, actual eviction of the around 10,000 squatters could only be carried out after alternative accommodation had

Complain about Economic, Social and Cultural Rights, Utrecht, 1995, pp. 68-75.

232 UN doc. E/CN.4/2002/59, Report of the Special Rapporteur on adequate housing as a component of the right to an adequate standard of living, Mr. Miloon Kothari, 1 March 2002, paras22 and 23.

233 According to An-Na im this is also true for civil and political human rights, but the justiciability of these rights is not questioned. Abdullahi Ahmed An-Na‘im, 2004, pp. 13-14. Lord Lester and Colm O’Cinneide are of the opinion that decisions about resource allocation should be left to the Legislature and Executive for reasons of democratic legitimacy, the more so since members of the Judiciary are usually individuals from national socio-economic elites who may lack detailed financial and political expertise as far as resource allocation is concerned. Lord Lester of Herne Hill QC \& Colm O'Cinneide, 'The Effective Protection of Socio-Economic Rights', in: Yash Ghai \& Jill Cottrell (eds.), Economic, Social \& Cultural Rights in Practice; The Role of Judges in Implementing Economic, Social \& Cultural Rights, Interights, London, 2004, pp. 20-21.

234 Dr S. Muralidhar, 'Economic, Social \& Cultural Rights: An Indian Response to the Justiciability Debate', in: Yash Ghai \& Jill Cottrell (eds.), Economic, Social \& Cultural Rights in Practice; The Role of Judges in Implementing Economic, Social \& Cultural Rights, Interights, London, 2004, p. 25.

235 Francis Coralie Mullin v. The Administrator, Union Territory of Delhi (1981) 2 SCR 516, at 529, see Muraldihar, 2004, p. 25. 
been arranged. ${ }^{236}$ Unfortunately, however, since the Olga Tellis case the Indian Courts have not been very consistent in their judgments. ${ }^{237}$ The most shocking disregard of peoples' housing rights may have been the ruling in the Narmada Bachao Andolan v. Union of India case, where the right to housing and livelihood of 41,000 families had to give way to the building of 3,000 dams in the Narmada River in order to provide for water for people living in Gujarat and Rajasthan. ${ }^{238}$ According to the Court justiciability was restricted to the rehabilitation of those people who were displaced because of the Sardar Sarovar Project (SSP), the largest of all the dams. ${ }^{239}$ It further held that it should not investigate into policy decisions pertaining to infrastructural projects by the Executive that were not in conflict with the law. ${ }^{240}$

The landmark decision as far as the right to adequate housing is concerned is to be found in South African jurisprudence. From the Grootboom case ${ }^{241}$ an interpretation may be discerned concerning the obligations to respect, promote, protect and fulfil the right of access to adequate housing as contained in Article 26 of the South African Constitution. ${ }^{242}$ The facts in Grootboom concerned a group of 390 adults, among whom Ms Irene Grootboom, and 510 children who were living in appalling circumstances and who decided to illegally occupy privately owned land in the hope of improving their housing conditions. The owner subsequently obtained an eviction order and while the group was forcefully removed, their houses were demolished and all their belongings were destroyed. They had nowhere to go since meanwhile other people had occupied the land where they formerly used to live. Although South Africa has a government housing programme, it was not an option to wait until housing would be made available to them since the waiting list is so long that applicants have to wait sometimes as long as 20 years. When the Government made it known that it could not and would not assist in any way, the group applied to Court in order to obtain an order on the Government to provide them with housing and basic services.

236 Olga Tellis v. Bombay Municipal Corporaton (1985) 3 SCC 545, see Muraldihar, 2004, p. 25.

237 The Olga Tellis judgement was upheld in Shantistar Builders v. Narayan K. Totame, Chameli Singh v State of UP and Ahmedabad Municipal Corporation v. Nawab Khan Gulab Khan. In all these cases, the Supreme Court reiterated the right to adequate housing under the right to life and under Article 19(1)(e) of the Constitution which guarantees the right to reside and settle in any part of the country. Jayna Kothari, 'A Right to Housing?', April 2002, published in: India Together, available on the internet at: $<$ www.indiatogether.org/opinions/rhousing02.htm>, consulted on 30 June 2006.

238 Narmada Bachao Andolan v. Union of India, (2000) 10 SCC 664. See Muraldihar, 2004, pp. 26-27.

239 The Court rejected the argument that by building the SSP the basic rights of the tribal people who had lived in the area had been violated with the argument that the amenities would be better at the sites to which they had been relocated irrespective of the fact that displacement would disconnect the tribes from their culture, customs and traditions. Muraldihar, 2004, p. 27.

240 Muraldihr, 2004, p. 27

241 See Government of the Republic of South Africa v. Grootboom (2001) 4 SA 46 (CC)

242 Article 26 of the South African Constitution (1996) reads:

'(1) Everyone has the right to have access to adequate housing.

(2) The state must take reasonable legislative and other measures, within its available resources, to achieve the progressive realization of this right.

(3) No-one may be evicted from their home, or have their home demolished, without an order of court made after considering all of the relevant circumstances. No legislation may permit arbitrary evictions. 
The Court interpreted the duty to respect the right to housing as 'a negative obligation upon the state and all other entities/persons to desist from preventing or impairing the right of access to housing'. ${ }^{243}$ A violation of the obligation to respect would give rise to a justiciable dispute in two different types of situations. First, when a law would permit unfair evictions, the validity of this law could be challenged and second, when persons who had been evicted would remain homeless. The duty to protect the right to housing would entail the enactment of laws and regulations which guarantee fair procedures and criteria for evictions. ${ }^{244}$ The duty to promote the right to housing was in Grootboom explained to mean the duty to enable individuals by legislative and other measures to provide housing. 'The state must create the conditions for access to adequate housing for people at all levels of our society. ${ }^{245}$ Finally, the duty to fulfil the right to housing was understood to denote that the State has the duty to take 'reasonable legislative and other measures, within its available resources, to achieve the progressive realisation' of the right of access to adequate housing. As regards the question whether or not the measures that had been taken were reasonable, the Court noted that it was not its task to enquire whether other measures could have been taken or whether public money could have been spent in a better way. The Court would have to restrict itself to determine whether the measures were reasonable. ${ }^{246}$ However, since the State had taken up the responsibility to ensure that the most basic needs of life would be provided to all, the nationwide housing programme obviously fell short of the State's obligation since it failed to provide for relief for the most desperate. ${ }^{247}$

In conclusion it can be said that at the very least several elements of the right to housing are justiciable. That some sectors of the Judiciary are of the same opinion may be proven by the emerging jurisprudence. From the case law it becomes clear that up till now justiciability has concentrated on cases concerning eviction or the threat thereof and cases of discrimination as regards housing rights. ${ }^{248}$ From the South African Grootboom case it has become obvious that the Courts' role does not have to be restricted to issues pertaining to a State's obligations to respect and protect the right to adequate housing but that they may also rule in cases where the State's obligation to fulfil this right is at stake, even in situations where the State's financial situation is under great constraints. $^{249}$

243 Government of the Republic of South Africa v. Grootboom (2001) 4 SA 46 (CC), at 34. On the Grootboom case see Geoff Budlender,'Justiciability of Socio-Economic Rights: Some South African Experiences', in: Yash Ghai \& Jill Cottrell (eds.), Economic, Social \& Cultural Rights in Practice; The Role of Judges in Implementing Economic, Social \& Cultural Rights, Interights, London, 2004, pp. 33-41.

244 Budlender, 2004, p. 35.

245 Grootboom, at. 35

246 Fons Coomans, 'Reviewing Implementation of Social and Economic Rights: An Assessment of the "Reasonableness" test as Developed by the South African Constitutional Court', in: Zeitschrift für ausländisches öffentliches Recht und Völkerrecht, Heidelberg Journal of International Law, Band 65, Nr. 1, 2005, pp. 175-176.

247 Budlender, 2004, pp. 40-41.

248 See $<$ ESCR-Net.org $>$, in particular the Library of ESCR Case Law, which is a database where inter alia housing rights jurisprudence is collected by the International Network for Economic, Social and Cultural Rights, a coalition of organizations and activist from around the world.

249 See CESCR General Comment No. 3 (1990), para. 10. Government of the Republic of South Africa $v$ Grootboom \& Ors (2000) 11 BCLR 1169, at 29. 
As far as the justiciability of the right to housing of women is concerned, it should be noted that in many cases there is a danger that the emphasis will be on the question whether women are granted equality with men. Although admittedly in some cases the infringement of women's housing rights may consist of denying them equality, there is a danger that justiciability of women's housing rights is understood too narrowly. Besides equality aspects, also the justiciability of the right to housing as such should be under scrutiny. Focusing on equality may leave both women and men with an empty shell if the housing rights of neither gender are fulfilled. ${ }^{250}$ Moreover, adequate housing may entail different aspects for women if compared to men. ${ }^{251}$

\subsection{Women's Right To AdeQuATE Housing}

As has become clear from the previous sections, awareness of gender specific difficulties and requirements as regards women's right to adequate housing has been growing gradually since the 1990s. From more general statements, commitments and recommendations at world conferences and by UN bodies and agencies, this attention has become more specific and recently culminated in the special reports on women's right to adequate housing submitted by the Commission on Human Rights' Special Rapporteur on adequate housing.

At the World Conference on Human Rights in Vienna, which was held from 14-25 June 1993 and which resulted in the Vienna Declaration and Programme of Action, ${ }^{252}$ the universality and indivisibility, interrelatedness and interdependence of all human rights were re-stated. However, economic, social and cultural rights only played a minor role, and the right to adequate housing is not brought up in the Declaration. That nevertheless this Conference is mentioned in this context is due to the fact that the human rights situation of women was at the centre of attention. Violence against women was condemned and it was strongly urged to integrate the equality of women and their human rights into the mainstream of UN world-wide activities.

The next important event was the Fourth World Conference on Women, held in Beijing from 4-15 September 1995, where the Beijing Declaration and Platform for Action was adopted. ${ }^{253}$ In this document it is stated that women face various barriers because of their gender. They are, inter alia, denied their human rights, such as access to housing. ${ }^{254}$ Governments are therefore summoned to take action in order to enable women to obtain affordable housing and access to land by removing-particularly gender-specific - obstacles to access. In doing so, governments should focus on women living in poverty and female heads of household. ${ }^{255}$ Another governmental task that was

250 Also Abdullahi Ahmed An-Na'im , 2004, p. 15 where he states that exclusive focus on equality would confine the special protection of housing as a human right to non-discrimination instead of ensuring the actual provision of shelter.

251 This is the premise that will be examined in Chapters III and IV infra.

252 UN doc. A/CONF.157/23, Vienna Declaration and Programme of Action, 12 July 1993.

253 Beijing Declaration and Platform for Action, Fourth World Conference on Women, UN doc. A/CONF. 177/20 and UN doc. A/CONF. 177/20/Add.1, 15 September 1995.

254 Beijing Declaration and Platform for Action, para. 33.

255 Ibidem, para. 60(n). 
referred to, was the provision of shelters for women and girls who are victims of violence. ${ }^{256}$ The Conference also pointed to the connection between poor health of women and deficient housing conditions. ${ }^{257}$

A noteworthy outcome of the Habitat II conference is the participating States' commitment in the Habitat Agenda to provide equal access to land for everyone, including women and the poor, and the reform of legislation and administration in order to give women full and equal access to economic resources. Economic resources are considered to include the right to inheritance, ownership of land and other property, access to credit, natural resources and appropriate technologies. ${ }^{258}$ Participating States commit to integrating gender perspectives with regard to human settlements, and express their intention to achieve this goal by collecting sex-disaggregated data and information, developing gender sensitive indicators and strategies to secure women's full participation in human settlements planning and decision-making. ${ }^{259}$ Five years later, at the special session of the General Assembly to review the implementation of the Habitat Agenda, sex equality in respect to adequate shelter and access to economic resources is repeated. ${ }^{260}$

Even more recently, at the 2005 World Summit, the General Assembly adopted a Resolution in which sex equality and empowerment of women was reaffirmed and in which it is specifically agreed that pervasive gender discrimination must be eliminated among other measures by: 'guaranteeing the free and equal right of women to own and inherit property and ensuring secure tenure of property and housing by women' ${ }^{261}$

Looking into the housing situation of specific groups, the Sub-Commission's Special Rapporteur comes in his final report to the conclusion that women all over the world suffer from discrimination with respect to all kinds of aspects related to housing rights. These include access to land, inheritance of land and property, access to credits, access to information with respect to housing, availability of essential housing services such as water and sanitation. ${ }^{262}$ In most parts of the world, women are essentially homeless since they have no right to either the house of their father, or the house of their husband. Even in countries where women are equal before the law, they are often not able to exercise their rights to home ownership and security of tenure. Furthermore, women are hardest hit in situations of relocation and eviction since they are particularly vulnerable when they are homeless. Women suffer most when basic services are not

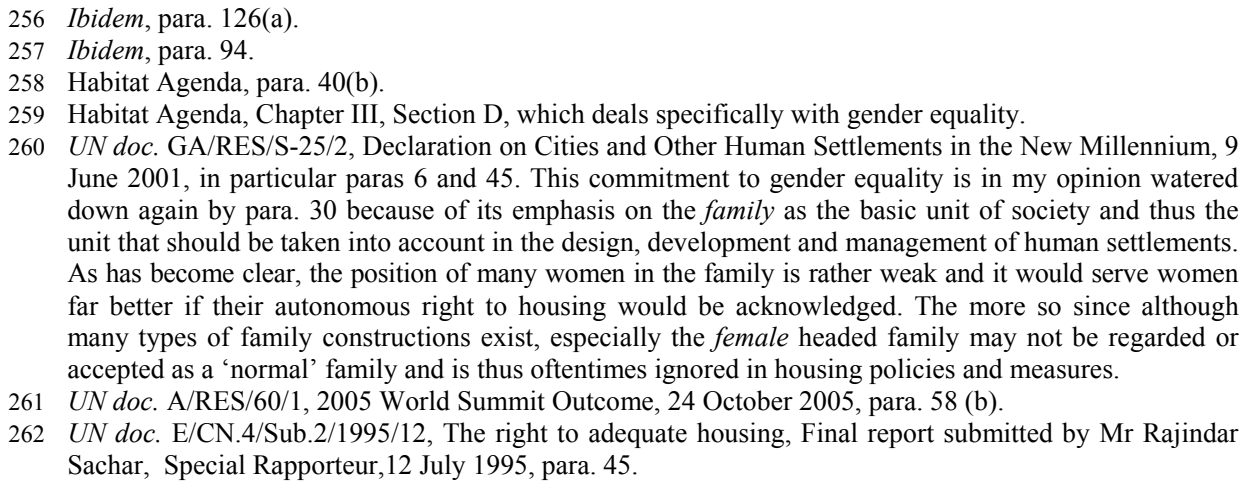

$262 U N$ doc. E/CN.4/Sub.2/1995/12, The right to adequate housing, Final report submitted by Mr Rajindar Sachar, Special Rapporteur,12 July 1995, para. 45. 
provided for because they are the ones who have to fetch water, fodder and fuel over long distances. ${ }^{263}$

Over the last decade, UN-Habitat, formerly the UNCHS (Habitat), has increasingly paid attention to women's position as regards housing rights. It has been recognized that women face discrimination in respect of their housing rights and that they are the worst affected in situations of forced evictions, resettlement schemes, slum clearance, development projects, and globalization policies. ${ }^{264}$

Habitat's Women in Human Settlements Development Programme (WHSDP) initiated the inclusion of human settlements on the agenda of the Fourth World Conference on Women in Beijing, and also encouraged inclusion of women's rights to land and property in the Beijing Global Platform for Action.

At the UNCHS's $16^{\text {th }}$ session a resolution was adopted on 'Women in human settlements development'. Based on the realization that women constitute the majority of people living in poverty, and that women face particular difficulties in obtaining adequate shelter, the Commission urged governments to ensure a gender-sensitive implementation of their national plans of action and requested the creation of a gender co-ordination unit directly under the Executive Director. The task of this unit would be to mainstream the gender perspective in all policies, projects, programmes and activities of the Centre. ${ }^{265}$ At its $17^{\text {th }}$ session the Commission recalled this resolution and requested that the empowerment of women, which was put forth as one of the primary indicators in the strategic vision for a revitalized UN Centre for Human Settlements, be translated into clear policy and action and be promptly implemented in the Centre's work. ${ }^{266}$

Worth mentioning is also UN-Habitat's resolution 19/16 in which the organization specifically encourages States to:

'[...] support the transformation of customs and practices that discriminate against women and deny women security of tenure and equal ownership of, access to and control over land and equal rights to own property and to adequate housing, ${ }^{267}$

At the end of the 1990s, the Sub-Commission adopted several resolutions in which it drew attention to the particular plight of women. ${ }^{268}$ The Sub-Commission recognises that women face particular difficulty in obtaining and maintaining housing because of

263 Ibidem, paras 46-48.

264 See: <www.unchs.org/print.asp?cid=2798\&catid=283typeid=24>, consulted on 20 December 2005.

265 UNCHS resolution 16/6, Women in human settlements development, 7 May 1997. The Gender Mainstreaming Unit is part of the Monitoring and Research Division of UN-Habitat. It strives to broaden gender equality and women's rights into all of the UN-Habitat's activities by supporting and strengthening gender awareness. See: $<$ www.unhcs.org/categories.asp?catid=327>.

$266 U N$ doc. HS/C/17/L.8, Women in Human Settlements Development and in the UN Centre on Human Settlements (Habitat), 10 May 1999.

267 UN doc. HSP/GC/19/16, Resolution on Women's Role and Rights in Human Settlements Development and Slum Upgrading, 9 May 2003, para. 5.

268 Sub-Commission resolution 1997/19 of 27 August 1997 on Women and the right to adequate housing and to land and property; resolution 1998/15 of 21 August 1998 entitled Women and the right to land, property and adequate housing and resolution; resolution 1999/15 of 25 August 1999, entitled Women and the right to development. 
Chapter II

gender-biased laws, policies and practices that exclude them from obtaining land or property. Because of these circumstances more women than men live in absolute poverty and households headed by women are among the poorest in the world. ${ }^{269}$ Lack of or inadequacy of housing causes millions of women to suffer from ill-health. Moreover, women seem to bear the brunt of inadequate housing, forced relocation or eviction since these conditions seem to trigger domestic violence, while homelessness in general makes girls and women vulnerable to sexual and other forms of violence or harassment.

The Sub-Commission further points out that identical treatment of women and men will not always remedy women's inequality and that, due to the specific socio-economic circumstances of women, adequate remedies may require that women be treated differently from men.

Governments are urged to take all necessary measures to amend and repeal laws and policies and to change customs and traditions that prohibit women from acquiring and keeping land, property and housing. In these resolutions the Sub-Commission also calls upon other UN bodies to occupy themselves with the right to adequate housing and to land and property for women.

As from 2000 the Commission on Human Rights started to adopt a series of resolutions in which it recognizes that women are discriminated against as far as equal ownership of, access to and control over land, equal rights to own property and to adequate housing are concerned. ${ }^{270}$ Governments are encouraged to take measures to increase land and housing availability to women living in poverty and to ensure that financial lending institutions do not discriminate against women. Moreover, it is also recommended that all measures be taken with special consideration to single women and female heads of households.

In accordance with Commission on Human Rights resolution 2002/49, ${ }^{271}$ the Special Rapporteur on adequate housing submitted his first report on women and adequate housing in $2003 .^{272}$ In preparation to this report, the Special Rapporteur had disseminated a questionnaire on women and adequate housing to all States and to civil society organizations so that he could integrate their answers with his own studies and findings. ${ }^{273}$ The Special Rapporteur comes to the conclusion that although there is a global recognition of the right to adequate housing for women, ${ }^{274}$ there is a huge gap between the legal theory and the actual practice. ${ }^{275}$ One of the main reasons why this gap continues to exist is the predominance of customary, traditional and social norms and attitudes,

269 For women and poverty see section 3.2 of this study.

270 Commission on Human Rights resolutions 2000/13 of 17 April 2000, 2001/34 of 23 April 2001, 2002/49 of 23 April 2002, 2003/22 of 22 April 2003, and 2005/25 of 15 April 2005, all entitled: Women's equal ownership of, access to and control over land and the equal rights to own property and to adequate housing.

271 Commission on Human Rights resolution 2002/49, 23 April 2002, para. 13.

272 UN doc. E/CN.4/2003/55, Women and adequate housing, study by the Special Rapporteur on adequate housing as a component of the right to an adequate standard of living, and on the right to non-discrimination, Miloon Kothari, 26 March 2003.

273 Ibidem, para. 5. An updated version of the questionnaire can be found at <www.ohchr.org/english/issues/ housing/docs/questionnaireEn.doc>.

274 Ibidem, paras 11-19.

275 Ibidem, paras 21 and 45-48. 
which is exacerbated by the unwillingness of the judiciary and public administration to implement gender equality. ${ }^{276}$ Furthermore, women often do not know about their legal rights and if they do, they usually lack the money and the time to pursue legal remedies. ${ }^{277}$ States should therefore see to it that they make policy decisions/choices that are targeted to overcome these obstacles. ${ }^{278}$

In order to ameliorate women's housing situation, the Special Rapporteur stresses the importance of the involvement of a variety of actors, most of whom have already shown an interest in the subject and acted upon it. Especially the treaty bodies, such as the CESCR, CERD, the CRC and CEDAW, UN agencies like UNIFEM, UNICEF, UNHabitat and UNHCR, and civil society organizations all have an important role to play in promoting and protecting women's housing rights. ${ }^{279}$

In response to Commission on Human Rights resolution 2003/22 the Special Rapporteur submitted a progress report on women and adequate housing in $2005 .{ }^{280}$ One of the most important points that is made in this report is that States have an immediate obligation to eliminate gender discrimination, and that the failure to do so will constitute a human rights violation. ${ }^{281}$ The Special Rapporteur stresses that not only direct, but also indirect discrimination against women must be combated. ${ }^{282}$ From his consultations and country missions the Special Rapporteur has come to the conclusion that in view of the complex contexts in which women experience discrimination and violence, an indivisible human rights approach is required since violation of women's housing rights usually does not stand alone, but will be caused by violations of other basic rights, such as the right to education, equal access to land and inheritance and political participation, and in its turn housing rights will result in the violations of yet other human rights, like the rights to water, health, secure tenure and physical integrity. ${ }^{283}$

Furthermore, the mandate holder distinguishes several key themes that have surfaced as critical issues with respect to women's housing rights. First of all, violence against women is closely linked to women's right to adequate housing. Many women who are battered are for several reasons impeded from leaving their violent surroundings. That is why the Special Rapporteur calls on States to take more legislative and policy measures to prevent violence against women and to raise awareness of the link between violence and housing. ${ }^{284}$ Secondly, forced evictions seem to have a much greater impact on women than on men because of women's central role at home. ${ }^{285} \mathrm{~A}$ third issue is that the threat of homelessness hangs over many women's heads and there are not enough shelters to house homeless women since shelters are scarce all over the world. ${ }^{286}$ In the

276 Ibidem, paras 49-50. On customary and traditional patterns see section 3.7 of this study.

277 Ibidem, para. 51

Ibidem, para. 77

79 Ibidem, paras 56-73.

280 UN doc. E/CN.4/2005/43, Women and adequate housing, Study by the Special Rapporteur on adequate housing as a component of the right to an adequate standard of living, Miloon Kothari, 25 February 2005.

281 Ibidem, para. 62.

282 For a detailed explanation of direct and indirect discrimination see para. 4.3.3.3 of this study.

283 Ibidem, paras 17 and 40.

284 Ibidem, paras 41-48.

285 Ibidem, para. 49

286 Ibidem, para. 51 
fourth place, the Special Rapporteur reiterates the impact of culture. Cultural norms and practices may undermine any legal guarantees as to equality and non-discrimination that have been afforded to women with regard to enjoying their rights to housing and land. Furthermore, in many parts of the world customary practices that were favourable to women, such as collective property rights, have been ousted, while some harmful practices, such as patriarchy, have been retained, and some new practices that have turned out to be harmful for women, like individual titling systems, have been introduced. ${ }^{287} \mathrm{~A}$ fifth issue is that in addition to cultural factors, women face numerous other barriers in realizing their rights to property, inheritance and access to land, for instance increasing poverty leading to increasing disinheritance of widows. As a sixth topic of concern the Special Rapporteur mentions the fact that many women suffer from multiple forms of discrimination which will make access to housing even harder. ${ }^{288}$ Finally, the existing gap between legal recognition and the implementation of women's rights to adequate housing and land is mentioned. The gap remains wide and in many States significant conflicts exist between equality provisions in constitutions and discriminatory personal, customary and inheritance laws. ${ }^{289}$

\subsection{CONCLUSION}

The right to adequate housing has undergone a remarkable development over the last few decades. From an inconspicuous element in the provision on the right to an adequate standard of living in the Universal Declaration of Human Rights, it has developed into an independent human right. Notwithstanding the results that have been achieved, there is still much work to be done as regards promotion, creating awareness, standard-setting, and acceptation of housing rights. Most important is of course that the translation be made from theory into actual practice.

As has been shown in this chapter, the right to housing is included in several major international instruments. Besides the Universal Declaration, the main international human rights conventions have a provision on this right. In the framework of the UN, it can be noted that over the years increasingly more bodies, both Charter-based and treatybased, have become involved with housing rights, and their involvement has become ever more intense. Their work is diverse and ranges from creating awareness, standardclarifying, defining terms and determining State obligations to detecting and ending violations.

The highest political UN organ, the General Assembly, has consistently put housing rights on the international agenda over the last few decades. Establishing an International Year of Shelter for the Homeless in 1987 and issuing the Global Strategy for Shelter to the Year 2000, it was the first body to touch upon issues like security of tenure, access to land, and the determination of the adjective 'adequate' in connection to

287 Ibidem, paras 53-58.

288 Many women suffer from combinations of discriminatory grounds. In addition to sex discrimination, they may be discriminated against because of their race, class, ethnicity, caste, health, disability and sexual orientation, to name but a few possible combinations. UN doc. E/CN.4/2005/43, paras 62-69.

289 Ibidem, para. 70 
housing. It is also important that the General Assembly has pushed UN-Habitat (the former UNCHS) into a leading role as regards housing rights. This development is the more noteworthy since the right to housing used to rank very low on the list of priorities UN-Habitat had set itself during the first 17 years of its existence. Nowadays, this body is trying very hard to create awareness of the global housing problems and to seek solutions for them, especially in co-operation with developing countries. Encouraging is also that UN-Habitat seems to be keenly aware of the particular plight of women and tries to integrate gender-sensitive strategies in all of its programmes.

The Commission on Human Rights has contributed by its frequent resolutions on the right to adequate housing and on evictions, and, in the year 2000, by its decision to appoint a Special Rapporteur whose work has been extensively discussed in this chapter. Most importantly, the Commission's Rapporteur has been given the chance to study in depth the specific situation of women and adequate housing.

The Commission has also fully endorsed its Sub-Commission when it wished to call attention to the miserable conditions of the homeless and the inadequately housed. The Sub-Commission created the possibility to do an in depth study into housing rights by appointing a Special Rapporteur whose four reports not only recapitulate the work that had been done up till then, but also enhance the perception of the problems that have to be faced.

Over the years, the Sub-Commission has taken up the specific position of women and regularly adopted resolutions in order to create awareness of their special circumstances and needs.

Of the treaty-based bodies it is clear that the body that has played the most important part as regards housing rights is the UN Committee on Economic, Social and Cultural Rights. The standard-clarifying work it has done has had a great impact on the activities undertaken by other UN bodies, both political and treaty-based. The holistic approach of the right to housing and the detailed definition of the relevant elements, have given this right an enormous boost. Particularly General Comment 4 has been a source of inspiration for other actors involved in the field. Moreover, the Committee very aptly uses its ability to remind governments time and again of their obligations in the housing sector while scrutinizing State reports. The fact that there is also room for CSO input in the Committee's work adds to the relevance and practicability of the ideas that are expressed.

Besides the involvement of bodies and mandates with the housing issue, it is also noteworthy that the world community in concert has shown a great interest in determining and solving the problems. Though housing rights stood on the agenda of several world conferences, the prime example is of course Habitat II. The participating States agreed on important matters such as the content of the right to adequate housing as a human right for everyone, and the relevant State obligations.

There is no doubt that housing rights are inextricably bound up with other human rights. The range of these human rights is very broad and includes civil and political rights as well as social, economic and cultural rights. Special links exist with the principles of equality and non-discrimination, the right to a livelihood (work), the right to land and property, the right to health and a safe environment, education, food, informa- 
tion, privacy and family life, security of the person, freedom of expression, association, and movement, including freedom to choose one's residence, and participation in public decision-making.

As far as the scope is concerned, it must also be noticed that over the years awareness has arisen that some groups in society have specific interests or needs, or whose conditions differ from those of the average person. The poor, the homeless, the elderly, the sick, persons with disabilities, children, refugees and internally displaced persons, migrants, indigenous peoples and women have all been mentioned as groups that require special attention.

In the framework of this study the special attention for women is most pertinent. The fact that it is acknowledged that women have a right to housing and that their housing needs differ from those of men, is a major step in the right direction. Especially if one realizes that in such documents as the Universal Declaration of Human Rights and the International Covenant on Economic, Social and Cultural Rights the point of departure still was that the man as the traditional breadwinner was entitled to an adequate standard of living for himself and his family, thus implying that women were taken care of. In that point of view women remained dependent on their fathers and husbands and did not have an autonomous right. Nowadays almost all bodies that deal with housing rights try to create awareness of the gender perspective and equality of women is put forward as a prerequisite for sustainable development. Gender equality was even a major issue at Habitat II.

It should be borne in mind, however, that although specific attention for women is needed, they are not per se a vulnerable group. They are not so much in need of protection, but of empowerment. What is necessary is to get rid of all the impediments caused by traditional views and discriminatory laws and practices that stand between them and their rights.

Already at a very early stage it was acknowledged that the right to adequate housing entails more than living in a structure of four walls and a roof. Housing must be 'adequate' and this means that some requirements must be met. Housing cannot be separated from the availability of basic services like water, sanitary facilities, sewage and an appropriate infrastructure in general. Several bodies have tried to define the content of housing rights, and over the years new elements were added which were believed to be intrinsically part of the adequacy. The most authoritative enumeration of elements that constitute adequate housing may be found in CESCR's General Comment No. 4 and comprises: legal security of tenure, availability of services, materials, facilities and infrastructure, affordability, habitability, accessibility, location, and cultural adequacy.

It is important to remark, however, that it is understood that the standard of adequacy is not the same everywhere. Depending on factors like economic development, climatic conditions, culture and social patterns, the adequacy may differ.

Though it is agreed that the fulfilment of the right to housing is a gradual process that may take many years, and that depends on the economic and social level of development of a State, there are some obligations that should be met immediately. Foremost, States should abstain from and prohibit any practices that concern the illegal eviction of people from their homes and their land. Everyone is entitled to live some- 
where in security and in dignity and security of tenure therefore plays a key role. Selfhelp may not be obstructed, but, on the contrary, should be stimulated if it is the only way in which poor people may obtain housing.

Furthermore, States must bring their legislation in conformity with international instruments and thus ban all provisions that are discriminatory. Access to housing must be equal for all persons, without distinction as to gender, race, ethnicity, religion, age, or any other ground. Homelessness and squatting should be decriminalized, since people will find themselves in these circumstances because they lack adequate financial means and not because they are criminally inclined.

The right to housing does not mean that States are obliged to provide housing for every individual who asks for it, but they are obliged to realize at least the core elements of housing rights for those people who are not able to provide for these themselves. Sufficient public resources should be allocated to meet this end. It is presupposed that a State in which a substantive percentage of the population is structurally homeless is prima facie violating its obligations.

There has been much debate on the question whether socio-economic rights can be enforced through legal processes. After thorough examination of national, regional and international case law, it may be concluded that at least several elements of the right to adequate housing are justiciable. Courts pass judgments on such issues as illegal evictions and demolitions, security of tenure, non-discrimination and equal access in the housing sphere, affordability and accessibility of housing, the rights of tenants, equal protection of the law, equal access to land and basic services, equal access to credit and subsidies, special measures for destitute households, the right to emergency shelter for the poorest, equal participation in decision-making processes concerning housing matters and the right to a clean environment.

Recent landmark decisions in South Africa and India have shown that the Courts' role does not have to be restricted to issues pertaining to a State's obligations to respect and protect the right to adequate housing, but that they may even rule in cases where the State's obligation to fulfil this right is at stake irrespective of the State's financial situation.

As far as the justiciability of women's housing rights is concerned it should be noted that though equality between women and men is of the utmost importance, it is but one of the aspects that should be under judicial scrutiny. Equality in the context of the right to adequate housing is a relative facet which does not define the level or quality of the housing situation. The pursuit of equality is devoid of any meaning in situations where violations of housing rights are in the order of the day and is even dangerous when States in an attempt to fulfil their obligations as to gender equality 'downgrade' men's situation in order to achieve the required equal level. Furthermore, in comparison to men women's housing rights may comprise different elements which may not be taken into account if the concept of equality is applied too narrowly.

In spite of the steadily growing attention for women's right to adequate housing expressed in numerous declarations and resolutions, it must be noted that still all internationally adopted and agreed norms on the right to adequate housing have been formu- 
lated in a gender neutral way. ${ }^{290}$ That is why new authoritative norms and interpretations are needed that comprise women's specific needs and circumstances. ${ }^{291}$ Furthermore, it has become clear that women's housing rights cannot be pursued in an isolated way, but an indivisible human rights approach is required in order to tackle the complex disadvantaged socio-economic position women find themselves in. It has also become obvious that an immense gap has to be bridged between the legal recognition of women's housing rights, and everyday practice in which women are denied the fulfilment of these rights, in particular due to discriminatory cultural and traditional patterns.

290 A notable exception is of course Article 14(2) of the Women's Convention. Also see, Giulia Paglione, 'Domestic Violence and Housing Rights', in: Human Rights Quarterly, Vol. 28, Number 1, February 2006, p. 125.

291 For suggestions and recommendations see section 4.8 and Chapter V of this study. 


\section{CHAPTER III RELEVANT GENDER FACTORS}

\subsection{INTRODUCTION}

This chapter will deal with a number of issues that in some way or other influence people's housing rights. Some of these issues affect both women and men but may have typical gender effects, while others only influence women's housing situation. The goal of this chapter is to show to what extent and in what way gender makes a difference when women's right to adequate housing is concerned.

The first section (3.2) will examine poverty since this is one of the main reasons why people are homeless or inadequately housed. At first blush it would seem that poverty is gender neutral, however, it will be shown that there is an ongoing feminization of poverty which means that women run greater risks of being poor, that the great majority of the world's poor is female, and that the gap between women and men as regards their financial means and assets is increasingly widening. Women's poverty is predominantly caused by discriminatory practices that affect seminal rights such as education and employment, but also rights like political participation, access to credit and loans, and inheritance that all have the potential to enable a person to escape the poverty trap and to realize basic socio-economic rights among which housing. Two important contemporary economic trends that seem to exacerbate women's poverty, i.e. economic globalization and structural reform of economies, are also discussed in this section.

Section 3.3 concerns the causes of homelessness of women. Forced evictions by or condoned by the authorities and by private parties such as landlord and land-owners affect men as well as women, and the same can be said about natural and human-made disasters. Still, it will be proven that these causes are not entirely gender neutral since they have typical gendered effects for women. In addition, there are a few causes of homelessness that will affect only women and not men, such as forced evictions by intimates, widowhood and domestic violence.

In section 3.4 on inadequate housing first the current definition of adequacy will be dealt with. Next, the meaning of adequate housing for women will be discussed. Besides the elements that constitute adequacy for everyone, some additional factors have to be fulfilled before housing is also adequate according to women's standards. A woman's socio-economic position, the technical quality of her housing situation and, the security, autonomy and dignity she enjoys at home will determine whether her housing situation is adequate.

The last part of this section is concerned with analyzing the housing situation of several groups of women who are inadequately housed, especially because they lack safety, dignity, autonomy and secure tenure. Particularly disturbing is the situation of women who seek refuge from violence, and who are harassed and abused in the very shelters where they seek protection. 
Although discrimination against women is not predominantly to be found in legislation, still in some States and societies legal rules are used to curb women's rights. In particular property rights, both in and outside marriage, rights to inheritance and legal capacity of women may seriously impinge on women's housing rights. That is why these private law issues are taken into consideration in section 3.5.

Women's right to housing cannot be studied on its own since, like all human rights, it is closely connected to other economic, social, political and civil human rights. In section 3.6 some of the human rights whose fulfilment or infringement will have an effect on the right to adequate housing are discussed. Subsequently, attention will be paid to the right to political participation, the right to property, the right to privacy, the right to dignity, and finally, the right to employment.

The last section of this chapter goes into the existing structural discrimination that is inherent in cultural patterns and that is capable of inhibiting or annihilating the enjoyment of the right to housing for women.

\subsection{POVERTY}

\subsubsection{Introduction}

According to estimations world-wide about 1.3 billion people live in extreme poverty. ${ }^{1}$ Although it is clear that the problem is worse and far more widespread in poor, developing countries, poverty also manifests itself in rich, developed countries. ${ }^{2}$ In fact, the world has known an increasing inequality in the division of wealth over the last few decades that crosses the North/South division and makes it more blurred. Although some parts, or even specific countries in a certain region, have become wealthier, other parts of the world have not succeeded in improving their economic and financial situation, or have even witnessed a decline. ${ }^{3}$

The concept of poverty is pertinent in the framework of this study because lack of money and assets is the main reason why people are homeless or inadequately housed. Studies indicate that the majority of people living in poverty are women and that there is a growing feminization of poverty. ${ }^{4}$ What is meant with this concept is that a disproportionate number of women is poor and that the gap between men and women is still

1 P.K. Rao, Sustainable Development; Economics and Policy, Center for Development Research Princeton, NJ, Blackwell Publishers, Malden, 1999, p. 236. Also UN doc. E/CN.4/1999/48, Human rights and extreme poverty, Report submitted by Ms A.-M. Lizin, 29 January 1999, para.1 and para. 49.

2 UN doc. E/CN.4/Sub.2/1993/16, Preliminary report on human rights and extreme poverty by Special Rapporteur Mr Leandro Despouy, 2 July 1993, para. 12.

3 Positive examples are Hong Kong, Singapore, South Korea, Taiwan, China, Brazil and Mexico where industrialization has led to a growth of the economy. In many other South American, Central Asia and sub-Saharan African States, however, the economic growth was either very low or negative. Some of these States have become known as the Least Developed Countries. Alan Thomas, 'Poverty and the End of Development', in: Tim Allen and Alan Thomas (eds.), Poverty and Development into the $21^{\text {st }}$ Century, Oxford University Press, Oxford, 2000, pp. 4-8. Also UN doc. A/55/342, Globalization and its impact on the full enjoyment of all human rights, Preliminary report of the Secretary-General, 31 August 2000, para. 46.

4 For instance $U N$ doc. A/55/342, para. 46, and UNDP, Human Development Report 1999. 
growing. Should this be true, it would mean that an increasing amount of women is, and will be unable to realize their right to adequate housing.

Since the meaning of poverty is not very clear, and no internationally acknowledged definition exists, first the various concepts of poverty will be looked into. Furthermore, it will be examined what the legal implications of poverty are.

Section 3.2.2 will deal with feminization of poverty as a multifaceted phenomenon. Gender discrimination is firmly based in all kinds of aspects of the social, cultural and economic sphere that play a role in causing and maintaining poverty. People may escape the poverty trap if they are enabled to earn an adequate income or to acquire property in another way. That is why the problems women encounter as to access to education, gainful employment, credit and loans, inheritance and decision-making processes will be looked into more closely.

Specific attention will be paid in section 3.2.4 to the group that is considered to be the poorest of the poor, the female-headed households (FHHs).

Two major economic trends that seem to exacerbate poverty and inequality in the world, i.e. globalisation of economy and structural economic reform programmes, will be studied in sections 3.2.5 and 3.2.6 respectively.

\subsubsection{Poverty and its Legal Implications}

Poverty is a vague notion since it is not clear when exactly people are to be called poor. The confusion is heightened because all kinds of institutions that occupy themselves with poverty use their own criteria and no internationally recognized definition exists. ${ }^{5}$

The World Bank for instance measures poverty in absolute terms. Everyone earning less than 1US $\$$ a day is considered to be extremely poor. ${ }^{6}$ At the same time, however, it is acknowledged that this criterion is inadequate to determine groups of poor people who live in developed countries. That is why the World Bank recently has developed a separate standard for poverty for industrialized countries. ${ }^{7}$ This is more in line with those who think that poverty is a relative phenomenon. According to their reasoning a person is poor when she or he is incapable of maintaining a standard of living that is customary in the society she or he is part of. In this sense poverty means that a person cannot choose among the various goods on offer, but has to restrict expenses to the bare necessities of life. ${ }^{8}$ In fact, being poor means being excluded from full participation in society. ${ }^{9}$

5 The Committee on Economic, Social and Cultural Rights uses the following definition: '[...] a human condition characterized by sustained or chronic deprivation of the resources, capabilities, choices, security and power necessary for the enjoyment of an adequate standard of living and other civil, cultural, economic, political and social rights.' Poverty and the International Covenant on Economic, Social and Cultural Rights, Statement adopted by the Committee on 4 May 2001, UN doc. E/C.12/2001/10, 10 May 2001, paras 7-8.

6 Alan Thomas, 'Poverty and the End of Development', in: Tim Allen and Alan Thomas (eds.), Poverty and Development into the $21^{\text {st }}$ Century, Oxford University Press, Oxford, 2000, pp. 10-11.

$7 \quad$ People in those countries are considered poor when they earn less than 14.40 US \$ per day.

8 A good example is Canada. Though it is known as an affluent country, it has 2.8 million women living in poverty. Their poverty is not the same poverty as experienced by the poor in some developing countries in the world, but it means that they are surrounded by wealth and do not have access to it. They are faced with everyday choices between paying their rent, bills, food stuffs, transportation and buying necessary 
Sometimes a distinction is made between poverty and extreme poverty. Poverty is considered to be a state in which access to basic needs is denied. This situation becomes extreme poverty when people find themselves in a vicious circle so that their poverty becomes a permanent state, maybe even over generations. Characteristics are that the poverty affects not only the economic, social and cultural rights, but also the civil and political rights, and therefore causes exclusion from full participation in society. ${ }^{10}$

The UNDP uses yet another angle and distinguishes between income poverty and human poverty. Income poverty comes down to lack of material well-being. Human poverty refers to the denial of opportunities and choices for living a most basic or tolerable human life. Human poverty also includes the denial of access to clean water, health services and the level of literacy. It focuses on the causes of poverty and not on the symptoms. ${ }^{11}$

In the framework of this study I find it most useful to consider poverty as a relative phenomenon since the standard and the costs of adequate housing are regionally and locally determined. Furthermore, to do justice to the complexity of the problem, poverty will be viewed in a holistic way as a multidimensional problem that affects all human rights.

Poverty can be considered a legal problem, with ensuing obligations of States to take measures to alleviate and eradicate it. Indeed, freedom from want and dignity of the human person are concepts that form the foundation of the main international human rights instruments. ${ }^{12}$ Poverty may create a situation in which the realization of all human rights becomes void and people's right to dignity is violated. ${ }^{13}$

In situations of poverty the interrelatedness and indivisibility of all human rights becomes apparent, since it not only denies the poor the realization of their economic, social and cultural rights, but may also affect the fulfilment of their civil and political rights. ${ }^{14}$ For example, poverty may deny people their right to an adequate standard of living, including adequate housing, ${ }^{15}$ but at the same time it may be a threat to the right

medical supplies. Marika Morris, Women, poverty and Canadian public policy in an era of globalization, at <www.criaw-icref.ca/Poverty_and_globalization.htm>, 29 May 2000.

$9 \quad U N$ doc. E/CN.4/1995/101, Report of the seminar on extreme poverty and the denial of human rights, 15 December 1994, paras 18-29.

$10 U N$ doc. E/CN.4/Sub.2/1993/16, Preliminary report on human rights and extreme poverty by Mr Leandro Despouy, paras 32-39, also UN doc. E/CN.4/2000/52, Human rights and extreme poverty, Report by Ms A.-M. Lizin, paras 8-9.

11 Nilüfer Çağatay, Gender and Poverty, UNDP, Social Development and Poverty Elimination Division, Working Paper Series, May 1998, p. 7

12 See for instance the preambular paragraphs of the UN Charter, the Universal Declaration of Human Rights, and the Covenants on Civil and Political Rights and Economic, Social and Cultural Rights.

13 UN doc. E/CN.4/Sub.2/1993/16, para. 51.

14 This was already recognized by the Special Rapporteur on the realization of economic, cultural and social rights, Mr Danilo Türk, E/CN.4/Sub.2/1989/19, paras 38-51 and E/CN.4/Sub.2/1990/19, paras 139-217. See also the Special Rapporteur on Human rights and extreme poverty, Mr Leandro Despouy, e.g. in E/CN.4/Sub.2/1993/16, paras 1-9, and Special Rapporteur on Human rights and extreme poverty, Ms A.-M. Lizin, e.g. in E/CN.4/2000/52, paras 7-12.

15 The main human rights instruments that contain the right to an adequate standard of living, including adequate housing are the Universal Declaration on Human Rights (Art. 25); The International Covenant on Economic, Social and Cultural Rights (Art. 11(1)); The Convention on the Rights of the Child (Art. 27(1)). 
to life. ${ }^{16}$ From General Comment No. 3 of the Committee on Economic, Social and Cultural rights it has become clear that State parties have a core obligation to ensure that minimum essential levels of the rights contained in the Covenant are satisfied. ${ }^{17}$ States are prima facie failing their obligations under the Covenant when any significant number of people is structurally deprived of essential foodstuffs, primary health care, the most basic forms of education and basic shelter and housing. ${ }^{18}$ This means that even in very difficult times, like when a State's economy is undergoing a transition period, the rights of the most vulnerable groups of society must be protected. ${ }^{19}$

\subsubsection{Feminization of Poverty}

The last few decades there is a discernible 'feminization' of poverty which means that women account for a growing proportion of those below the poverty line and that the gap between women and men caught in the cycle of poverty is widening. ${ }^{20}$ Estimates show that about $70 \%$ of the poor are women. Women are disproportionately represented among the lowest income groups all over the world and particularly in developing countries and in countries with economies in transition. ${ }^{21}$ For instance, in rural areas of developing countries the number of poor women has increased with $50 \%{ }^{22}$ According to the World Bank the poorer a family is, the more likely it will be that it is headed by a woman. ${ }^{23}$ Gender discrimination is one of the main reasons why more women than men live in poverty. ${ }^{24}$ Gender inequality is a multi-faceted phenomenon in a complex socioeconomic structure. ${ }^{25}$ That is why not a single most important cause for female poverty can be discerned, but several causes that interact and enforce one another. These causes

16 The right to life as laid down in Article 6(1) of the International Covenant on Civil and Political Rights should, according to the Human Rights Committee, not be interpreted in a narrow sense, but also comprises situations in which people die from malnutrition. See CCPR General Comment 6, The right to life (Art. 6), 30 April 1982, para. 5. Also UN doc. E/CN.4/1994/18, Human Rights and extreme poverty, 1 February 1994

17 UN doc. E/1991/23, CESCR General Comment No. 3, The nature of States parties obligations (Art. 2, para. 1 of the Covenant on Economic, Social and Cultural Rights), para. 10.

18 Para. 10 of General Comment No. 3 was reconfirmed in clause 9 of the Maastricht Guidelines on Violations of Economic, Social and Cultural Rights, January 1997, published a.o. in: Theo van Boven, Cees Flinterman, Ingrid Westendorp (eds.), Human Rights, Maastricht Perspectives, Maastricht Centre for Human Rights, Maastricht University, 1999

19 UN doc. E/CN.4/1999/48, Human rights and extreme poverty, Report submitted by Ms A.-M. Lizin, 29 January 1999, para. 24-26.

20 Division for the Advancement of Women, The Feminization of Poverty, Women 2000, Gender Equality, Development and Peace for the Twenty-first Century, New York, 5-9 June 2000, at: <www.un.org/ womenwatch/daw/followup/session/presskit/fs $1 . h t m>$.

21 Beijing Platform for Action, Fourth World Conference on Women, A/CONF.177/20/Add.1, Beijing 15 September 1995, para. 50.

22 P.K. Rao, Sustainable Development; Economics and Policy, Center for Development Research Princeton, NJ, Blackwell Publishers, Malden,1999, p. 246-247.

23 Ruth Pearson, 'Sustainable globalization? The global politics of development and exclusion in the new world order', in: Tim Allen and Alan Thomas (eds.), Poverty and Development into the $21^{\text {st }}$ Century, Oxford University Press, Oxford, 2000, p. 399.

24 P.K. Rao, 1999, p. 236.

25 Beijing Platform for Action, para. 49. 
include girls' lack of education, women's absence of economic opportunities, and economic resources like remunerated employment, limited possibilities to access credit, own land and other property, unequal sharing of inheritance, lack of adequate pension schemes, and minimal participation in decision-making mechanisms. Moreover, in some cultures resource allocation within households is biased against women and girls so that even in non-poor households the women may be poor. ${ }^{26}$

Below, the most important reasons for women's poverty will be studied more closely starting with girls' and women's unequal access to education and vocational training.

\subsubsection{Education and Vocational Training}

The right to education is a human right laid down in several widely ratified international human rights instruments among which the Covenant on Economic, Social and Cultural Rights, the Convention on the Rights of the Child, and the Convention on the Elimination of All Forms of Discrimination Against Women. ${ }^{27}$ Education creates the prime opportunity to escape poverty because it opens up all kinds of possibilities for people to develop themselves, and significantly increases their chances to find remunerated employment. An adequate income in its turn enables people to afford adequate housing.

However, although the main international human rights treaties are based on the principle of sex equality, more boys than girls receive education and more women than men are illiterate. At least $60 \%$ of the children who do not attend primary school are girls, and two thirds of the world's 855 million illiterate adults are women. ${ }^{28}$ The situation is the worst in some parts of Africa, particularly sub-Saharan countries, and in Central Asia, where female literacy rate is less than half the male rate. ${ }^{29}$ In many developed countries, however, there is parity between girls and boys in primary education while the enrolment of girls in secondary education almost equals that of boys. Moreover, the participation of girls in tertiary education has increased considerably. ${ }^{30}$ Still, also in developed countries there is room for improvement.

In developing countries poverty affects the access to education for all children, but particularly for girls. When poor families have to make a choice, they prefer to give boys an education over girls, because boys are viewed as future breadwinners and girls as future homemakers. ${ }^{31}$ Especially in countries where early marriages and pregnancies

26 Household resources like food, education and health services are not shared equally among family members; boys and men are favoured above girls and women. UN. doc. E/CN.4/1999/48, 29-01-1999, para. 44. Also Beijing Platform for Action, paras 52-54 and Nilüfer Çağatay, Gender and Poverty, UNDP, Social Development and Poverty Elimination Division, Working Paper Series, May 1998, p. 4.

27 Article 13 of the Covenant on Economic, Social and Cultural Rights on the right to education, while Article 3 establishes gender equality. Article 28 of the Convention on the Rights of the Child, which expresses sex equality in Article 2. The Convention on the Elimination of All Forms of Discrimination Against Women provides for the right to education in Article 10.

28 UNICEF, The State of the World's Children, 1999. Also World Bank, World Development Report 2000/2001: Attacking Poverty, Oxford University Press, p. v.

29 UNESCO, Education for All, The challenge of achieving gender parity in basic education; a statistical review, 1990-1998, 2002, p. 5.

30 Beijing Platform for Action, 1995, para. 72.

31 UNESCO, 2002, p. 20 
are usual, girls do not attend school or only for a limited period. Moreover, in many cultures it is usual that girls from a very early age on help their mothers in the household. ${ }^{32}$ The combination of schoolwork and domestic responsibilities is one of the reasons why the drop-out rates for girls are higher than for boys in most developing countries. ${ }^{33}$

Teaching materials very often reflect traditional female and male roles in society, which does not stimulate girls to use their full potential. Furthermore, some curricula, particularly science curricula, are gender biased. Many girls do not receive lessons in mathematics, science and technical training. Even in developed countries where there is parity as regards school attendance between girls and boys, girls are concentrated in a limited number of fields of study. ${ }^{34}$ The consequence is that the choices of vocational training and future employment also are limited, and that work that is well paid, like in the finance or technology sector, becomes unattainable for women. Vocational training for girls mainly concentrates on careers in the less paid service, and caring labour sector. ${ }^{35}$

\subsubsection{Employment}

The right to employment and the stipulation that women and men should receive equal pay for work of equal value can be found, among other instruments, in the Universal Declaration for Human Rights, the Covenant on Economic, Social and Cultural Rights, the ILO Equal Remuneration Convention, and the Women's Convention. ${ }^{36}$ Remunerated employment is the best guarantee to keep poverty at bay, at least when the remuneration is adequate to sustain oneself and one's dependants. Among other things, it will enable people to fulfil their housing needs.

Women encounter several impediments when they try to gain access to employment, and the right to equal remuneration for work of equal value has yet to be realized in large parts of the world.

There may be some confusion as regards the difference between 'work' and 'employment'. Though in both cases human energy is used for a certain purpose, it is only called employment if a form of remuneration counterbalances it. ${ }^{37}$ This means that a lot of work that is being done, like domestic work, some agricultural work, work done in kind and voluntary work, is not considered as employment and is not counted as economic activity. In some countries, like Chile, Mexico, China and Indonesia, employment is mainly the prerogative of men, while in many western and eastern European countries

Beijing Platform for Action, para. 73.

P.K. Rao, Sustainable Development; Economics and Policy, 1999, p. 246.

Beijing Platform for Action, paras 76-78.

5 CEDAW stresses the need for equality of access to the same type and same quality of education for girls, since inequality in education will result in inequalities in the labour force, in decision-making, and in public and private life. Margaret E. Galey, 'Women and education', in: Kelly D. Askin, Dorean M. Koenig (eds.), Women and International Human Rights Law, Volume 1, Transnational Publishers, Inc. Ardsley, New York, 2000, p. 424.

36 Article 23 Universal Declaration only stipulates that women are entitled to equal remuneration for equal work which is a lot less progressive. Also see Covenant on Economic, Social and Cultural Rights, Articles 6 and 7, Convention on the Elimination of All Forms of Discrimination Against Women, Article 11

37 David Wield, Joanna Chataway, 'Unemployment and Making a Living, in: Tim Allen and Alan Thomas (eds.), Poverty and Development into the $21^{\text {st }}$ Century, Oxford University Press, Oxford, 2000, p. 105. 
almost as many women as men are employed. World-wide, however, the economic activity rates of women are a little over two-thirds of those of men. ${ }^{38}$

Across cultures and levels of economic development there is a discernible gendered division of work throughout the world. Some work, particularly reproductive work, ${ }^{39}$ is considered to be typically 'women's work', while men tend to specialize in production work. The first step of reproduction, i.e. biological reproduction, may logically be referred to the female realm since only women can bear children. The other steps of reproduction, however, like child rearing, provision and preparation of food and drink, maintenance of the dwelling, washing of clothes, are not logically female, since they are not biologically, but culturally determined as being women's work. ${ }^{40}$ A characteristic of reproductive work is that it is economically and socially less valued than productive work. The remuneration for reproductive work is low or zero.

The gendered division of work also has implications for the gainful employment of women. Their domestic chores lay heavy claims on their time so that many of them cannot also do remunerated work on the side. A huge barrier is the lack of, or cost of, day-care centres for children and the inflexibility of working hours that, even if women have left enough energy to do a certain job, they cannot combine it with their household chores. ${ }^{41}$ Considering also their lack of education and few marketable skills, it is no wonder that in many countries women are over-represented in informal and non-standard work like temporary, contract, home-based and part-time work. ${ }^{42}$ Typical for work in the informal sector and non-standard work is, however, that it pays less ${ }^{43}$ and that the overall working conditions are less favourable. ${ }^{44} \mathrm{~A}$ comparison between full-time and part-time work shows that full-timers are the first to be offered skill or knowledge improving courses. They are sooner employed on a regular basis and have better chances for promotion, and thus better-paid positions. Furthermore, as casual and informal labourers women are not or less organized in trade unions which undermines their bargaining power. ${ }^{45}$

38 David Wield, Joanna Chataway, 2000, pp. 102-105.

39 With the term productive work is meant that human labour is used to create new products or services. When we speak of reproductive work, the inputs of production are themselves produced. Reproduction is necessary to maintain the human species. Biological reproduction involves child-bearing and childrearing while daily reproduction involves the provision of human needs like food and shelter. Idem, p. 117.

40 David Wield, Joanna Chataway, 2000, p. 117.

41 Beijing Platform for Action, paras 153-154.

42 Beijing Platform for Action, para. 155. Women are heavily represented in part-time work. Examples are Greece and Germany, where $61 \%$, respectively $88 \%$ of the part-timers are women. David Wield, Joanna Chataway, 2000, p. 113. Job training courses for women with children will fail if there is no provision to substitute for the women's unpaid labour at home because she will simply lack the time to follow such a course. Idem, p.123.

43 Next to children, women are the cheapest labourers in many parts of the world. Since women in most countries are viewed as only secondary wage earners, they are more likely than men to accept jobs paying individual rather than family wages. Rebecca P. Sewall, 'Reconstructing Social and Economic Rights in Transitional Economies', in: Margaret A. Schuler (ed.), From Basic Needs to Basic Rights, 155, 1995, p. 160.

44 Occupational benefits, like occupational pension schemes, are often lacking.

45 Nilüfer Çağatay, Gender and Poverty, UNDP, Social Development and Poverty Elimination Division, Working Paper Series, May 1998, p. 13. 
Stereotypical ideas and expectations about gender-typical behaviour also induce individuals to seek gender-typical jobs, and perpetuate gender discrimination in hiring policies by employers. ${ }^{46}$ As a consequence, women cannot acquire certain skills and knowledge that would enhance their chances on the labour market or are stuck in certain jobs, especially in caring labour, without a chance for promotion. ${ }^{47}$ In this way their personal possibilities of economic development are restricted. ${ }^{48}$

The high representation of women in part-time jobs and the fact that the wages women earn lag far behind, also has consequences for the occupational pensions they will receive in old age. Most pension schemes are based on the principle of continuous, full-time employment. A principle that causes many women to fall into the poverty-trap in old age. ${ }^{49}$

In an attempt to improve women's lot, one is caught in a dilemma. If solutions are found to enlighten women's burden as far as their gendered responsibilities are concerned, like improving sanitation, supply of water, providing family health facilities, child care facilities, one is responding to women's practical needs, but in fact accepts and perpetuates the gendered division of labour and its implied subordinated position of women in society.

Another possibility is to see to women's strategic gender needs. The focus is on attaining equality for women and challenging their subordinate position. The first structure that has to be demolished according to this course would be the gendered division of work itself..$^{50}$

The gender-based division between unpaid work and paid labour renders women economically and socially more insecure and vulnerable to chronic poverty. ${ }^{51}$ Feminization of labour in remunerated employment will not only alleviate women's poverty, but will also lead to an increased bargaining power for women and is therefore potentially empowering.

46 Karen Christopher et al., Gender Inequality in Poverty in Affluent Nations: The Role of Single Motherhood and the State, Center for Research on Child Wellbeing, Working Paper \#00-12, 28-01-2000, pp. 6-7.

47 For instance, the top 10 of most common jobs for women in Canada is: retail salesperson, secretary, cashier, registered nurse, accounting clerk, elementary teacher, food server, general office clerk, babysitter and receptionist. All jobs that have a low status and are not paid very well. Marika Morris, 2000. Also see Beijing Platform for Action, paras 163-164.

48 David Wield, Joanna Chataway, 2000, p. 118.

49 Beijing Platform for Action, Fourth World Conference on Women, A/CONF.177/20/Add.1, Beijing 15 September 1995, para. 54. Also Sara McLanahan and Erin Kelly, The Feminization of Poverty: Past and Future, at $<$ www.olin.wustl.edu/Macarthur/working\%20papers/wp-mclanahan3.htm>, consulted at 10-06-2002.

50 Ruth Pearson, 'Rethinking Gender Matters in Development', in: Tim Allen and Alan Thomas (eds.), Poverty and Development into the $21^{\text {st }}$ Century, Oxford University Press, Oxford, 2000, pp. 386-387.

51 Nilüfer Çağatay, Gender and Poverty, UNDP, Social Development and Poverty Elimination Division, Working Paper Series, May 1998, pp. 8-9. 


\subsubsection{Participation in Decision-Making ${ }^{52}$}

Although the right to political participation is recognized as a human right, ${ }^{53}$ the poor in general hardly ever participate in political or decision-making bodies. They experience exclusion from society, exacerbated by their lack of education. The result is, however, that all kinds of decisions are being made with regard to economy, finance, taxes, infrastructure and housing that have a large, sometimes very negative, impact on the situation of the poor without their opinions being heard or their needs being taken into consideration.

Globally the situation for women is far worse than for men. Women are grossly under-represented in local, national, regional and international decision-making organs. ${ }^{54}$ The low representation of women can be attributed to structural and attitudinal barriers. Structural barriers for women to get involved with politics include the length and the inflexibility of the working hours that make it difficult to combine a political career with domestic duties. Lack of education is also a structural barrier that makes participation on a high level of politics impossible. Far more important, however, are attitudinal barriers that are formed by gender stereotyping. Women are regarded as unfit for leadership positions. Moreover, the public/political sphere is seen as men's sphere, while women would belong in the private/family sphere. ${ }^{55}$

Women's participation in decision-making processes is very important because it will put women's issues on the agenda. Legislative and policy-making bodies will be made aware of women's plight and, if women have sufficient impact, ${ }^{56}$ decisions will be avoided that hit women disproportionately hard. ${ }^{57}$

\subsubsection{Access to Credit and Loans}

For several reasons, women have considerable difficulty in getting access to credit. ${ }^{58}$ In general women own less property than men, and earn less income, which makes them

52 Political participation of women, and particularly participation in decision making bodies concerned with building and infrastructure, will be dealt with more extensively in section 3.6 on human rights issues.

53 For instance Article 25 of the Covenant on Civil and Political Rights and Articles 7 and 8 of the Convention on the Elimination of all Forms of Discrimination Against Women.

54 A few examples. Between 1945 and 1997, 28 women were elected as heads of State or Government. The number of women ministers was $6.8 \%$ in 1996 . Only $12 \%$ of the members of legislative bodies are female. Women 2000, Women and decision-making, DAW, October 1997, at <www.un.org/womenwatch/ daw/public/w2oct97/Part3en.htm>, consulted on 11-07-2002.

55 Women 2000, DAW, 1997.

56 Marked differences both in content and priorities of decision-making bodies will be achieved when women's representation reaches the 'critical mass' of 30-35\%. Women 2000, DAW, 1997.

57 For instance, the gender-insensitiveness of the rules and regulations issued by the WTO can to some degree be attributed to the fact that hardly any women participate in the WTO decision-making structures. UN doc. E/CN.4/Sub.2/2000/13, Globalization and its impact on the full enjoyment of human rights, Preliminary report by J. Oloka-Onyango and Deepika Udagama, 15 June 2000, para. 15.

58 UNIFEM estimates that at the beginning of the 1990 s, only $5 \%$ of the total of credit given by financial institutions to rural areas went to women. Statement by Noeleen Heyzer, Executive Director, UNIFEM on 5 June 2000, at <www.unifem.undp.org/newsroom/speeches/mcpanel.html $>$. At the end of the 1990s only $10 \%$ of the beneficiaries of credit programmes in Africa and Latin America were women. P.K. Rao, Sustainable Development; Economics and Policy, 1999, p. 246. 
unattractive borrowers for commercial banks who demand security. In some countries, there are legal restrictions because women have the status of minors and cannot loan money without their husband's or legal guardian's approval. Women often lack information about the availability of credit, or credit is tied to crops or activities in which women do not participate..$^{59}$

For the majority of women borrowers, credit means a way to lift themselves out of poverty and to fulfil their basic needs, among which adequate housing. It is a way to achieve economic and political empowerment both at home and in the community.

A very good alternative to help women achieve their goals are micro finance plans. ${ }^{60}$ These entail very small loans to people in order to enable them to set themselves up as self-employed or start their own micro businesses. These schemes are so adequate for women's need because they often include job training and child-care provision, ${ }^{61}$ or a woman can start some small scale home production with the advantage that she does not have to learn new skills and can remain in her own house to supervise her children, and do what she always does but now making money out of it. ${ }^{62}$ Furthermore, the need for collateral is replaced by a group guarantee of repayment. ${ }^{63}$ Microfinance is most helpful in combination with measures that make access to land and technology possible. ${ }^{64}$

The Grameen Bank of Bangladesh is the prime example of a successful micro credit programme.$^{65}$ Although it was initially not the Bank's intention to focus on women, women proved to be very reliable as regards repaying their loans. That is why at the moment $96 \%$ of the Grameen Bank's customers are female. ${ }^{66}$ The Grameen Bank example was widely followed in a great many other countries in the world. In 2004 3,164 micro credit institutions have reported reaching $92,270,289$ clients, $83.5 \%$ of whom are women. ${ }^{67}$

59 The World Bank, Credit and financial services at <www.worldbank.org/gender/module/issues/credit. htm>, consulted at 16-04-2003.

60 Ruth Pearson, 'Rethinking Gender Matters in Development', in: Tim Allen and Alan Thomas (eds.), Poverty and Development into the $21^{\text {st }}$ Century, Oxford University Press, Oxford, 2000, p. 396.

61 The best known examples of micro finance initiatives are the Grameen Bank in Bangladesh and the Banco Sol in Bolivia. David Wield, Joanna Chataway, 2000, p. 122.

62 Ruth Pearson, 2000, p. 397.

63 P.K. Rao, Sustainable Development; Economics and Policy, 1999, p. 248.

$64 U N$ doc. E/CN.4/1999/48, Human rights and extreme poverty, Report submitted by Ms A.-M. Lizin, 29 January 1999 , paras $78-79$.

65 The Grameen Bank was founded by Prof. Muhammad Yunus in 1976 and was an immediate success in the first villages of Bangladesh were it was introduced. With the sponsorship of the country's Central Bank and support of the nationalized commercial banks, the project was extended all over the country. Borrowers of the Bank own $90 \%$ of its shares, while the remaining $10 \%$ is owned by the Government. See: <www.grameen-info.org/bank/hist.html >.

66 Statement by Mr Anwarul K. Chowdhury, High Representatitve for the Least Developed Countries, Landlocked Developing Countries and Small Island Developing States, to the Second Committee of the $59^{\text {th }}$ session of the General Assembly on 15 November 2004. Also: P.K. Rao, Sustainable Development; Economics and Policy, 1999, p. 248.

67 Sam Daley-Harris, State of the Microcredit Summit Campaign Report 2005, The Microcredit Summit Campaign, Washington, 2005, pp. 22-24. 
Governments can stimulate women's access to credit by strengthening links between formal banks and intermediary lending organizations in order to mobilize capital for such organizations and thus increase the availability of credit. ${ }^{68}$

Microfinance by itself is of course no guarantee that the borrower will manage to escape poverty. The ensuing income generating activities must be successful, because otherwise it will become very difficult to pay back the loan.

\subsubsection{Right of Inheritance $e^{69}$}

In some cultures women and men do not share alike in the inheritance. Wives, daughters and sisters may only get part of what husbands, sons and brothers receive, and sometimes they may even get nothing at all. ${ }^{70}$ This may be laid down in legal rules and regulations, but it is also possible that the law treats women and men equally, but custom and tradition stipulate otherwise. ${ }^{71}$

Denying women their rightful share in the inheritance, or giving them only part of what their male counterparts get, may seriously affect women's right to adequate housing. ${ }^{72}$ In countries where agriculture is the main source of income, barring women from access to land robs them of the most obvious way of making a living. Thus unequal inheritance rights do contribute to the impoverishment of women. Still, I do not believe that in the context of feminization of poverty, the right to inheritance plays as important a role as the rights to education and employment. The ability to earn an adequate income is worldwide the most secure way to keep poverty at bay. Inheritance only plays a role if there are indeed assets to inherit, and it is, moreover, an insecure and ad hoc way of acquiring property; somebody has to die first. For the 1.3 billion poor in the world, the right of inheritance will be rather insignificant. The meagre possessions they leave behind will hardly tip the balance when it comes down to crossing the poverty line.

\subsubsection{Female-Headed Households}

A group that gives reason for special concern is the female headed households (FHHs). The last few decades their number has grown considerably. ${ }^{73}$ Though the increase of

68 Beijing Platform for Action, Fourth World Conference on Women, A/CONF.177/20/Add.1, Beijing 15 September 1995, para. 64.

69 The right of inheritance will be dealt with in more detail in section 3.5 on private law issues.

70 For instance, according to the law of inheritance of the Qur'an, a husband inherits half of the property of his wife while a wife inherits a quarter of the property of her husband. A son inherits double the share of a daughter, and a brother double the share of a sister. Qur'an, Chapter 4, verses 11, 12 and 176 respectively.

71 In India, for example, The Hindu Succession Act of 1956 established complete equality between sons and daughters as to the parental property. However, socio-economic structures inhibit women to claim their rightful share. Sonalde Desai, 'Engendering Population Policy', in: M. Krishnaraj, R. Sudarshan, A. Shariff (eds.), Gender, Population and Development, Oxford University Press, Delhi, 1998, p. 53.

72 It may even cause homelessness. See sub-section 3.3.4 on the housing situation of widows.

73 In Western Europe the number of FHHs grew from 24\% in 1980 to $31 \%$ in 1990. In developing countries, the number varies from less than $20 \%$ in certain Southern and South-eastern Asian countries to almost $50 \%$ in certain African countries and the Caribbean. International Labour Organization, The Feminization of 
FHHs is universal, the reasons why more women have become heads of households is more regionally determined. In the rich, affluent countries of the North and in Latin America, social changes have led to an enormous increase in divorces. ${ }^{74}$ In more than $90 \%$ of the cases, women get custody of the children. ${ }^{75}$ Furthermore, some women become single mothers by choice. ${ }^{76}$

In Africa and Asia the main reason of FHHs is armed conflicts and AIDS which have caused the death or disability of many men. Another cause that is mentioned in literature is the migration of men from rural to urban areas or to other countries in order to find jobs. ${ }^{77}$ This type of de facto female-headed household falls in a somewhat different category, since the men, although not living with the family, may still provide for the (greater part of) the family income. ${ }^{78}$ The women in such a family will be extra burdened because at home they have to cope with everything alone, but they are not necessarily worse off financially. ${ }^{79}$ Therefore, when FHHs are studied in the context of poverty, it is more correct to focus on those households of which a woman is the main breadwinner. Most of these families are de iure headed by a woman, because she is the sole present adult. It is also possible that the woman is the de facto head because there is a male adult present, but he is unable to work because of disability or illness.

In view of the various aspects that have been discussed above, it is not difficult to imagine that families headed by women are more likely to be poor than those headed by men. ${ }^{80}$ First of all, finding employment, particularly with small children, is very difficult because working conditions are inflexible, there is no-one to share the family responsibilities with, and there are no or inadequate means to pay for child care ${ }^{81}$ If there is an income, on average it will be low. ${ }^{82}$ Not only is the height of this income determined by

Poverty, at $<$ www.ilo.org/public/english/bureau/inf/pkits/women3.htm $>$, consulted at 10-06-2002.

74 For instance, in the USA today over half of the marriages end in divorce. Sara McLanahan and Erin Kelly, The Feminization of Poverty: Past and Future, at <www.olin.wustl.edu/Macarthur/working\%20 papers/wp-mclanahan3.htm>, consulted at 10-06-2002.

75 It should be noted that most mothers prefer to have custody over their children despite the high financial price they have to pay for it. Sara McLanahan and Erin Kelly, 2002.

76 This seems to be particularly a trend among highly educated professional women and, in North America, among poor black teenagers.

77 This is particularly true for many developing countries undergoing structural adjustment programmes. UN doc. E/CN.4/1999/50, Effects of structural adjustment policies on the full enjoyment of human rights, Report by Mr Fantu Cheru, 24 February 1999, para. 85.

78 Provided, of course, that the men actually do support their family financially. Some men will keep the money for themselves, and others may start a family with another woman and abandon their original families. In these cases the wives that are left behind also fall fully in the FHHs category.

79 Studies in Kenya and Zambia show that FHHs headed by divorcees or widows are likely to be poor, while households headed by the wives of migrants are likely to belong to the non-poor. IFAD, The Issue of Poverty among Female-Headed Households in Africa, at <www.ifad.org/gender/learning/challenges/ women/60.htm>, consulted at 15-04-2003.

80 For example, if poverty is defined as having an income below half the median for their respective nation, $25 \%$ of single mothers in the Netherlands and in France is poor. These figures are for Sweden $3 \%$, and or the USA 7\%. K. Christopher, 2000, pp. 2 and 21 respectively.

81 Beijing Platform for Action, UN doc. A/CONF.177/Add.1, 1995, para. 160.

82 In Bangladesh, for instance, the average income of FHHs is $55 \%$ of the average income of poor households as a whole. A. Rahman, I. Hossain, Birds in a larger cage, Social Watch/87, 2001. In Canada $56 \%$ of FHHs are low-income. Marika Morris, Women, poverty and Canadian public policy in an era of globalization, 29 May 2000, at <www.criaw-icref.ca/Poverty_and_globalization.htm>. 
the generally low level of education and job-training of the woman, but she is also faced with discrimination and gender-bias on the labour market. ${ }^{83}$ That is why many mothers are compelled to accept jobs or types of work that are not well-paid, but have the advantage that they are flexible as regards place or time so that they can combine their remunerated jobs with their care-taking responsibilities. ${ }^{84}$

In only a few countries the poverty gap between FHHs and other households is nonexistent or minimal. The only country where female-headed households are not poorer than male-headed is Sweden. The main reason is that the majority of women have remunerated jobs and that there is an abundance of day-care centres. ${ }^{85}$ In the Netherlands, where only a small percentage of mothers retain a full-time job, the poverty gap is minimal because of the welfare system. ${ }^{86}$ The government transfers to single mothers are high enough to avoid sex differences in poverty rates. This does not mean, however, that single mothers in the Netherlands are not relatively poor, but they are not much poorer than poor men.

The growth of FHHs is closely linked to the feminization of poverty in the world. States have a legal obligation to help FHHs to overcome their poverty. If female heads of households do not receive any help, the risk that their poverty will be transmitted to their children is very high. ${ }^{87}$ They are faced with so many problems that mere financial aid is not enough, but an all-encompassing help programme is called for. Besides schooling, they need housing, health care, child-care facilities and access to credit. ${ }^{88}$ Though the short-term costs of this help may be high, the result will be that these women are empowered and can fend for themselves and their dependants in the long run. In view of the sheer number of FHHs, States simply cannot afford it economically to let their productive potential go to waste.

83 In some cultures widows, divorcees and abandoned women suffer from additional discrimination because they are ostracized by society on account of their status. This makes it even harder for them to maintain themselves and their families. Nilüfer Çağatay, Gender and Poverty, UNDP, Social Development and Poverty Elimination Division, Working Paper Series, May 1998, p. 3.

84 ILO, The Feminization of Poverty, consulted at 10-06-2002

85 Karen Christopher et al., Gender Inequality in Poverty in Affluent Nations: The Role of Single Motherhood and the State, Center for Research on Child Wellbeing, Working Paper \#00-12, 28-01-2000, p. 31.

86 Sara McLanahan, Erin Kelly, 2002. Also K. Christopher et al., 2000, p. 32.

87 Especially the eldest girls will be kept out of school to help their mothers taking care of smaller children and with household chores. Thus their chances to ever overcome poverty become very slim. ILO, The Feminization of Poverty, consulted at 10-06-2002. Also IFAD, Asia-The Role of Women's Workload in Passing on Poverty to the Next Generation, at $<$ www.ifad.org/gender/learning/role/workload/in generation. $\mathrm{htm}>$, consulted on 15-04-2003.

88 In Chile an interesting programme was started in 1991. Instead of cash the Government provided a pilot group of 2,500 female heads of households with job training, social services including child care, health care services, house improvement and legal aid. The project was such a success that is has become an important part of the Government's strategy to combat poverty. Nilüfer Cağatay, 1998, p. 4. 


\subsubsection{Globalization of Economy}

Globalization is mentioned as one of the reasons why there is an increase in poverty and inequality in the world today. ${ }^{89}$ The purpose of this sub-section is to determine what is meant by globalization, why it would cause poverty and whether it has a particular impact on the poverty of women.

Globalization is a process in which all parts of the world become more interconnected, not only through economic forces, but also by technological change, cultural exchange and political shifts. ${ }^{90}$

The ideas behind globalization of economy are liberal capitalism and free trade. ${ }^{91}$ The opening up of markets and demanding that governments do not interfere but practise a laisser faire strategy, also means that governments are losing part of their sovereignty and autonomy. The role of States changes and they have to share their power and influence with transnational companies, international organizations and CSOs. ${ }^{92}$

By the early 1990s it became increasingly clear that globalization of trade, finance and production has important consequences for economies both in the North and in the South. The effects are positive as well as negative, creating new patterns of wealth and poverty both among and within countries. Up till now globalization has had a negative impact on the economies of the Least Developed Countries. ${ }^{93}$ They have become even poorer. Especially the fact that countries in the South were more or less forced to open up their markets, while countries in the North retained their trade barriers, had a disastrous impact on the agricultural sector of some poor countries. ${ }^{94}$ Their markets were flooded with cheap products undermining their domestic production and making competition for local producers impossible. ${ }^{95}$

89 The Special Rapporteurs on Globalization and its impact on the full enjoyment of human rights maintain that although globalization did not create inequality and discrimination, it clearly exacerbated both phenomena. UN doc. E/CN.4/Sub.2/2000/13, Preliminary report by J. Oloka-Onyango and Deepika Udagama, 15 June 2000, para. 26.

90 Anthony McGrew, 'Sustainable globalization? The global politics of development and exclusion in the new world order', in: Tim Allen and Alan Thomas (eds.), Poverty and Development into the 21st Century, The Open University in association with Oxford University Press, Oxford, 2000, pp. 346-348.

91 The international organization that is most closely associated with globalization is the World Trade Organization (WTO). WTO promotes a set of principles that should be applied to economies all over the world. They include free trade, open markets and reduction of tariffs. Alan Thomas, 'Poverty and the "end of development", in: Tim Allen and Alan Thomas (eds.), Poverty and Development into the 21st Century, The Open University in association with Oxford University Press, Oxford, 2000, p. 10.

92 Anthony McGrew, 2000, p. 352.

93 For the least developed countries (that harbour 10 per cent of the world's population) the percentage of their share in global exports declined from 0.6 per cent in 1980 to 0.4 per cent in 1998. UN doc. $\mathrm{A} / 55 / 342$, Globalization and its impact on the full enjoyment of all human rights, Preliminary report of the Secretary-General, 31 August 2000, para. 32. Also UN doc. E/CN.4/Sub.2/2001/10, Globalization and its impact on the full enjoyment of human rights, Progress report by J. Oloka-Onyango and Deepika Udagama, 2 August 2001, para. 17.

$94 U N$ doc. E/CN.4/Sub.2/2000/13, para. 14. See also UN doc. A/55/342, para. 34.

95 A case in point is Guyana where the domestic production of fruit juices was undermined by the import of cheap products. UN doc. E/CN.4/2002/54, Globalization and its impact on the full enjoyment of human rights, report of the High Commissioner for Human Rights, 15 January 2002, paras 21 and 36. 
Because of the removal of trade barriers the mobility of capital increased. A new global division of labour emerged when manufacturing production in developed countries, particularly in Europe, Japan and the USA, moved to developing countries. ${ }^{96}$ The ensuing unemployment led to social exclusion and poverty in some parts of the North. ${ }^{97}$

The loss of the North was of course the gain of the South, where many new job opportunities were created and where States saw their General National Product increase.

Looking at the effects of economic globalization on the position of women, again a mixed image arises. There is an enormous increase in female labour in developing countries, especially caused by the 'soft' industries that settled there. ${ }^{98}$ Women are the preferred workers, although this preference is mostly induced by stereotyped ideas about women. ${ }^{99}$ Contrary to what one would logically expect, this increase in demand for women workers has not led to higher wages or better positions for women, but rather sex discrimination has grown and women's wages have decreased. ${ }^{100}$ This can be explained by the fact that poor developing countries take all kinds of measures to attract foreign capital and investment to the detriment of working conditions of their nationals, and in violation of their Constitutions, the International Labour Organisation standards, and international human rights instruments. ${ }^{101}$ Many of them create Export Processing Zones (EPZs) or Special Economic Zones (SEZs), which are geographically defined areas that are characterized by the deregulation of taxes, wages and labour standards. ${ }^{102}$

Women employed in the agricultural sector are also negatively affected by exportoriented economic policies and trade liberalization. Emphasis on export crops has dis-

96 At the moment about $50 \%$ of the total amount of jobs in the manufacturing business are located there. Anthony McGrew, 2000, p. 356.

97 For instance in the 25 countries that belong to the Organization for Economic Co-operation and Development (OECD). Anthony McGrew, 2000, p. 354.

98 In countries that have liberalized their economies, women's economic activity rate has risen to $70 \%$. Soft industries include apparel, shoe- and toy-making, data processing and semi-conductor assembling industries. The characteristics of these industries are that they require unskilled to semi-skilled labour, are labour intensive, service oriented and poorly paid. UN doc. E/CN.4/Sub.2/2000/13, para. 31.

99 In order to reduce fixed labour costs employers prefer to hire casual and short-term labourers, rather than full-time salaries workers. Since men are perceived as breadwinners who have to earn family wages, women are supposed to be satisfied with much lower, individual incomes since what they earn will be additional to the family income. Moreover, women are supposed to be more docile and agreeing to lower-paid, less-secure, casual, short-term, or contract jobs. Another reason is that the work is viewed as typically 'women's work' because of the need of nimble fingers and patience to do meticulous, boring and extremely repetitious jobs. Valerie L. Oosterveld, 'Women and Employment', in: Kelly D. Askin, Dorean M. Koenig (eds.), Women and International Human Rights Law, Volume 1, Transnational Publishers, Inc. Ardsley, New York, 2000, pp. 389-390.

100 An example of sex discrimination can be found in the Maquiladoras in Mexico, where manufacturing industries are concentrated on the border with the USA. Before they are hired, women must undergo a pregnancy test. Pregnant women are not hired. If a woman who is already employed becomes pregnant, she may be mistreated or forced to resign. Within the Maquiladoras women fill in the least-skilled jobs, and thus less-paid jobs. They receive much less training than men do and they do not move from unskilled to skilled jobs after acquiring seniority. Valerie L. Oosterveld, 2000, pp. 394-395.

$101 U N$ doc. E/CN.4/Sub.2/2000/13, paras 38-44. Also UN doc. A/55/342, para. 38.

102 In 2000, 93 developing countries had EPZs. In a few of these countries it is the main employer of women. On average women provide $80 \%$ of the labourers in EPZs. UN doc. E/CN.4/Sub.2/2000/13, paras 35-38. Also Valerie L. Oosterveld, 2000, pp. 388-389. 
placed women from permanent agricultural employment and subsistence farming into seasonal employment. ${ }^{103}$

In the North, economic globalization created unemployment especially for women because they used to be the cheap, unskilled workers in the industry sectors that have moved away. ${ }^{104}$

Economic liberalization also caused a huge growth in the informal sector and the increased female participation therein. It is no wonder that most labourers in the informal sector are women because it offers the better opportunities to combine a job with household duties. However, working conditions in the informal sector are very bad. Women work long hours without the normal occupational benefits like health insurance and social security. ${ }^{105}$

In many developing countries, economic globalization has a negative impact on all human rights. ${ }^{106}$ Especially these countries are compelled to take measures that negatively impact the enjoyment of those rights and therefore they cannot fulfil their international human rights obligations. ${ }^{107}$ Although it is clear that globalization changes the role of States and affects their sovereignty and to some extent their self-determination, this does not mean that States carry less responsibility when people's human rights are violated in the process. ${ }^{108}$ Especially now the world gets more complex and all kinds of international and non-State actors influence the human rights situation, States should heighten their vigilance to uphold justice and respect for human rights. ${ }^{109}$

In conclusion it can be said that globalization and poverty stand in a very complex relationship with one another. Though it cannot be denied that some women have benefited from it and the participation of women on the labour market has increased, the deterioration of working conditions of many women all over the world is mentioned as one of the major causes of the feminization of poverty. ${ }^{110}$

103 UN doc. E/CN.4/Sub.2/2000/13, para. 37.

$104 U N$ doc. A/CONF.177/20/Add.1, Beijing Platform for Action, 1995, para. 159.

105 UN doc. E/CN.4/Sub.2/2000/13, para. 32-33. Also UN doc. A/55/342, para. 38.

106 Besides the deteriorating economic and social rights situation, it also negatively affects civil and political rights because democratic input and control dwindles when States' sovereignty is reduced, and decisions are taken elsewhere, particularly by international institutions and transnational corporations.

107 UN doc. E/CN.4/Sub.2/2000/13, paras 41-44.

108 As far as economic, social and cultural rights are concerned that are included in the ICESCR, clause 25 of the Limburg Principles stipulates that no matter the level of economic development, States parties are held to ensure respect for minimum subsistence rights for all. The Limburg Principles on the Implementation of the International Covenant on Economic Social and Cultural Rights, June 1986, published a.o. in: Theo van Boven, Cees Flinterman, Ingrid Westendorp (eds.), Human Rights, Maastricht Perspectives, Maastricht Centre for Human Rights, Maastricht University, 1999.

109 With regard to obligations under the ICESCR, the Maastricht Guidelines specifically state that notwithstanding changing structures, States remain ultimately responsible for the realization of the rights contained in the Covenant. Moreover, they are responsible for violations of these rights caused by acts of non-state actors under their jurisdiction if they do not exercise due diligence in controlling the behaviour of such actors. The Maastricht Guidelines on Violations of Economic, Social and Cultural Rights, clauses 2 and 18. Also $U N$ doc. E/CN.4/Sub.2/2000/13, para. 11.

110 UN doc. E/CN.4/Sub.2/2000/13, para. 39. 


\subsubsection{Structural Reform of Economies}

The last two decades the economies of many countries in the world have undergone structural reform. There are several reasons for this. The 1980s was the onset of neoliberalism. Its effect was that the countries belonging to the Organization of Economic Co-operation and Development (OECD) slowed down their economies, interest rates rose and subsequently, the debt of the developing countries became ever larger. ${ }^{111}$ The latter were offered loans and other help to boost their economies, under the condition that they agreed to undergo structural adjustment programmes. The ultimate aim of this help is of course to enable them to repay their debts. ${ }^{112}$ Meanwhile, the influence of the World Bank and IMF redoubled and today half of the world's population and two-thirds of its governments depend more or less on the rules and regulations dictated by these money lending institutions (MLIs), either through economic stabilization programmes of the IMF or through loans by the World Bank. ${ }^{113}$

Another reason for structural reform was the downfall of communist systems in Eastern Europe and the subsequent embrace of capitalism and free trade. ${ }^{114}$

The neo-liberalists were convinced that the same economic structure would work in all countries of the world, no matter the level of development or the social background. All confidence was put in the free play of market forces, and States should refrain as much as possible from interfering. Amongst other measures this means no intervention in the labour market, removing import quotas, stimulating privatization, lifting price controls, devaluing the currency, and cutting government expenditure. ${ }^{115}$ Production should concentrate on commodity goods, cash crops and export products.

Structural adjustment programmes aggravated the economies of some developing countries $^{116}$ and had devastating effects on the most vulnerable social groups, because changes in public expenditure put an end to social programmes that were meant to protect them. ${ }^{117}$

Measures like freezing wages and lifting price controls diminish the purchasing power of the population, hitting the poor the hardest. ${ }^{118}$ The shift in economies to export products and cash crops means that in some branches people become redundant, while

111 Tom Hewitt, 'Half a century of development' in: Tim Allen and Alan Thomas (eds.), Poverty and Development into the 21st Century, The Open University in association with Oxford University Press, Oxford, 2000, p. 300

$112 U N$ doc. $\mathrm{A} / 55 / 342$, Globalization and its impact on the full enjoyment of all human rights, Preliminary report of the Secretary-General, 31 August 2000, para. 23.

113 Anthony McGrew, 'Sustainable Globalization? The Global Politics of Development and Exclusion in the New World Order', in: Tim Allen and Alan Thomas (eds.), Poverty and Development into the $21^{\text {st }}$ Century, Oxford University Press, Oxford, 2000, p. 350.

$114 U N$ doc. E/CN.4/1999/50, Effects of structural adjustment policies on the full enjoyment of human rights, Report by Mr Fantu Cheru, 24 February 1999, para. 32.

115 P.K. Rao, Sustainable Development; Economics and Policy, Center for Development Research Princeton, NJ, Blackwell, Malden,1999, pp. 250-251. Also Tom Hewitt, 2000, p. 302.

116 The number of Least Developed Countries (LDCs) increased from 31 to 42. Tom Hewitt, 2000, pp. 301-305.

117 P.K. Rao, 1999, pp. 250-251.

$118 U N$ doc. E/CN.4/1999/50, 1999, para. 63. 
in others new employment can be found. Some groups in society, however, will be unable to respond effectively to the changed market incentives.

Particularly disastrous for the poor are the removal of subsidies and the privatization of basic needs like drinking water, food, shelter, energy and health care. ${ }^{119}$ The result is that people not only experience income poverty, but are also excluded from basic necessary services. ${ }^{120}$

According to UNICEF women, and particularly mothers of young children, are the most vulnerable to economic adjustment programmes. ${ }^{121}$ The vulnerability of women is caused by the gendered roles and responsibilities of poor women. Although economic policies in themselves are gender neutral, their impact is likely to have a greater negative effect on women because cross culturally they have to fulfil their traditional roles as mothers and nurturers. ${ }^{122}$

Changes in the nature of employment mean loss of jobs even for skilled and professional women. ${ }^{123}$ In many cultures there is a certain rigidity in the gendered division of labour. It is social practice to determine certain kinds of jobs unsuitable for women. This forms a barrier to switch labour, especially when it entails a switch from subsistence to commodity production.

It is more difficult for women than for men to start their own business because on average women do not own as much property and therefore lack the required collateral to get credit and loans from banks. ${ }^{124}$ The lack of opportunities in the formal sector pushes women into the informal sector with the most unfavourable working conditions. ${ }^{125}$

The second characteristic of structural reform, the reallocation of public expenditure, also has a gender typical impact on women. Measures like withdrawal of subsidies on basic services, and curtailing the provision of basic needs have important implications for women's unpaid domestic and reproductive work. ${ }^{126}$ Women's work for the family and the community will replace the former public services that no longer exist or have become too expensive. Where people are excluded from health care, women's care taking work of the sick, the disabled and the elderly will increase. When there is a cut back in medical centres, women have to travel further and pay more for their families' health care. Inadequacies in water supply, sanitation and waste removal, means more work for and energy of women. The soaring of food prices will induce women to buy un-

$119 U N$ doc. E/CN.4/1999/50, 1999, paras 42 and 45. Also P.K. Rao, 1999, p. 252.

120 Ruth Pearson, 'Rethinking Gender Matters in Development', in: Tim Allen and Alan Thomas (eds.), Poverty and Development into the $21^{\text {st }}$ Century, Oxford University Press, Oxford, 2000, p. 393.

121 Ruth Pearson, 2000, p. 393.

122 Ruth Pearson, 2000, p. 394.

123 For example in Bulgaria structural adjustment has had the effect that female unemployment has risen from $52 \%$ to $68 \%$. UN doc. E/CN.4/1999/48, Human rights and extreme poverty, Report submitted by Ms A.-M. Lizin, 29 January 1999, paras 100-102. Because of economic transition in Moldova a disproportionate number of women have been deprived of jobs, adequate health care and participation in government. Nilüfer Çağatay, Gender and Poverty, UNDP, Social Development and Poverty Elimination Division, Working Paper Series, May 1998, p. 17.

124 See sub-section 3.2.3.4 on access to credit and loans.

125 Beijing Platform for Action, para. 153.

$126 U N$ doc. E/CN.4/2003/10, Effects of structural adjustment policies and foreign debt on the full enjoyment of human rights, particularly economic, social and cultural rights, Report by Mr Bernards Mudho, 23 October 2002, para. 35 
processed food and process it themselves or, if possible, grow it themselves. In short, women's unpaid work is used as a buffer zone to ensure survival of the family, however, to the detriment of women's ability to put their time and energy in remunerated labour. $^{127}$

Of the international financial institutions, the World Bank has done most to address the critique that they exacerbate the human rights situation of numerous people. It has moved away from 'shock-therapy' measures of structural adjustment and has issued a set of guidelines in order to link its money lending activities to its human rights obligations. ${ }^{128}$ Although up till now, the effect was not nearly enough. ${ }^{129}$

The International Monetary Fund (IMF), however, sticks to its narrow task to deal with finance, trade, and taxation and its guidelines make no mention of human rights. ${ }^{130}$ At the very least MLIs should take measures that maintain the level of existing social achievements. ${ }^{131}$

With a view to the effects on women, governments and MLIs alike, need to make gender specific assessment of the impact of economic reform programmes. Reallocation of public expenditure must not exacerbate inequality between the sexes as to access to economic resources and opportunities, but on the contrary should stimulate more equitable sharing of public resources among the population. ${ }^{132}$

\subsubsection{Concluding Remarks}

Poverty is one of the main reasons for homelessness and inadequate housing conditions. In view of the considerable differences in welfare-levels of the countries in the world, the notion of poverty should be regarded in a relative sense, since the costs of housing and the standards of adequacy also differ greatly. Also in rich, developed countries, groups of people are too poor to be able to afford adequate housing. Since world-wide $70 \%$ of the poor are women, it stands to reason that women will have more difficulties than men to realize their housing rights.

Poverty of women is as old as the gendered division of work. Age old stereotyped ideas about what the ideal family should look like with a male provider and a female home-maker, make it difficult for women to become economically independent. The fact that it is accepted as a fact of life that women are responsible for the unremunerated reproductive work that has to be done like raising children, cooking, cleaning and taking care of the sick and elderly, causes both income poverty and chronic time poverty.

127 Ruth Pearson, 2000, p. 394.

128 The World Bank created an Inspection Panel which sees into complaints about human rights violations in 1993, and issued guidelines, Development and Human Rights, in 1998. UN doc. E/CN.4/Sub.2/2001/ 10 , para. 54.

$129 U N$ doc. E/CN.4/Sub.2/2000/13, Globalization and its impact on the full enjoyment of human rights, Preliminary report by J. Oloka-Onyango and Deepika Udagama, 15 June 2000, para. 21.

$130 U N$ doc. E/CN.4/Sub.2/2000/13, para. 22

131 UN doc. E/CN.4/Sub.2/2001/10, para. 63.

132 International actors that have been created by States, such as the World Bank, the IMF and WTO, have a responsibility under international law to uphold international human rights standards. $U N$ doc. E/CN.4/ Sub.2/2000/13, paras 49-50. Also see Beijing Platform for Action, Fourth World Conference on Women, A/CONF.177/20/Add.1, Beijing 15 September 1995, paras 60-62. 
Moreover, the expectation that a girl will be a future housewife hardly is an incentive to provide her with a good education. Women do a lot of work they are not paid for and this work costs them so much time and energy, and puts such a strain on their daily schedule, that it becomes very hard for them to also do a remunerated job that would provide them with an adequate income.

Moreover, the stereotyped ideas of men's and women's roles have permeated the labour market to such an extent that if women do find a job it will most likely be in a typically 'female' profession. Unfortunately, the social and economical value attached to female jobs is less than that attached to what are perceived as male jobs, and as a result the average income of women is lower than that earned by men.

Stereotyped ideas about the nucleus family also explain why discriminatory laws, policies and customs as regards women are so persistent. In the traditional view women are taken care of by their partners or male relatives and consequently they do not need a share of the inheritance and they do not need loans because they are not viewed as independent entrepreneurs. Their home-centred lives in the private sphere, also makes the minimal participation of women in decision-making processes understandable.

Meanwhile, the world is changing and a growing number of women are becoming heads of their households. If it is very difficult for single women to keep out of poverty, it is well nigh impossible for women who also have several dependants to take care of. Once they are caught in the vicious circle of poverty it is almost unachievable for them to get out of it again. Moreover, what is even worse, their poverty will be transmitted to the next generation because they cannot give their children a better chance in life.

Since poverty undermines and violates all human rights, States have to take their responsibilities and their obligations under human rights instruments seriously, and do their utmost to alleviate and eradicate poverty. As the majority of the poor is female, poverty combating programmes must be properly gender focused. Laws and policies should be scrutinized and discrimination based on gender should be abolished. Furthermore, a two-track approach is called for to combat the gendered division of work. Shortterm measures should enlighten women's burden as far as their gendered responsibilities are concerned, so that they have more time to improve their skills or be active on the labour market. Although this will take care of women's immediate practical needs, it should not be forgotten that measures like these in fact implicitly accept and perpetuate the gendered division of work and its implied subordinated position of women in society. Therefore, simultaneously also measures are needed that bring about an attitudinal change and work in the long run, such as government campaigns that promote gender equality and challenge stereotypical ideas. ${ }^{133}$

Since feminization of poverty is for a large part caused by the growth of FHHs, these households need specific attention. All-encompassing programmes that offer the female heads of households schooling, housing, social services, child-care facilities and credit programmes, should help them to escape from the poverty trap and enable them to earn

133 In 2003 an extensive government campaign has started in the Netherlands that questions gender stereotyped roles in households (Wie doet er thuis nu eigenlijk wat?). People are made aware that it is not obvious that women do all the reproductive work, but that this work should be shared. 
an income adequate enough to fulfil their economic and social rights, among which housing.

Economic trends like globalization of economy and structural reform programmes are not designed to promote and protect human rights. They are meant to give economies a boost and so enhance the financial positions of nations. The situation is too complex to maintain that capitalism, liberalism and free trade autonomously cause feminization of poverty, but they do cause poverty for certain groups and they do strengthen the already existing discriminatory patterns of gendered division of labour. As an effect of free trade labour conditions of women have deteriorated and great numbers of them have been pushed into the informal sector. Abolition or privatization of basic public services excludes the poor in general from fulfilment of their needs, but they hit women the hardest because they have to compensate with their unremunerated work.

With a view to the effects on women, international financial institutions need to make careful gender specific assessments of the impact their measures will have. In any case, they must not aggravate the poverty level of the population or exacerbate inequality between the sexes.

\subsection{HOMELESSNESS}

\subsubsection{Introduction}

Millions of people all over the world are homeless. An obvious cause of homelessness is poverty, since those who are affluent will find ways to secure adequate living conditions everywhere, even if they have been forced to leave their region or country. As I have already discussed poverty and the feminization of it in the previous section, I will not go into it again, but in this section I will discuss several other causes of homelessness. Some causes affect women as well as men, like forced evictions (section 3.3.2) and natural and human-made disasters (section 3.3.3), but still there is a gender dimension to be found here since they may affect women differently. Other causes are definitely gender determined and exclusively or predominantly affect women, such as widowhood (section 3.3.4) and domestic violence (section 3.3.5). Widowhood as a cause of homelessness is more or less regionally determined because it applies especially in societies in Africa and South Asia where a widow is viewed as an outsider in the family and a harbinger of bad luck. The last cause that will be dealt with, domestic violence, is quite universal and causes housing problems for women all over the world.

An important issue that keeps surfacing is whether there are any legal reasons or obligations that States should take responsibility for preventing, mitigating or influencing the causes mentioned afore. Wherever relevant, these legal aspects will be taken up, but these issues are the subject of detailed discussion in the framework of Chapter IV.

In my opinion, homelessness is both harder and more dangerous for women than for men. Harder because many women not only have to fend for themselves (and many of them are ill equipped to do so), but they may also have to take care of their children and other dependents. Homelessness is more dangerous for women because they are very vulnerable without the security of the home. When they are unaccompanied, women 
often fall victim to abuse of all kinds at the hands of strangers, and when they have a partner, women run the risk of bearing the brunt for the deplorable situation they live in since the incidence of conjugal abuse increases when couples are homeless.

In some conditions, there is only a fine line between homelessness and inadequate housing because it is not clear what the definition of homelessness is. People sleeping in the streets in the open air are definitely homeless, but what about pave or slum dwellers or people who have found accommodation in a refugee camp and who have managed to build a similitude to a dwelling with cardboard, corrugated iron or plastic sheets and who manage to cook and wash and raise children under such circumstances? De facto they are homeless, and at best their housing situation can be defined as shelter. Yet, the question is whether their situation is temporary or permanent. Because of these definitional difficulties, all groups of women who are in fact homeless and those whose housing conditions are for some reason or other not up to standard are dealt with in section 3.4 on inadequate housing.

\subsubsection{Forced Evictions}

\subsubsection{Introduction}

World-wide forced evictions are one of the most important causes of homelessness and inadequate housing. ${ }^{134}$ The purpose of this section is to show that this practice has a gendered component. Women are affected differently by forced evictions in several ways. For a better understanding of the problem, I will start with discussing the concept and scope of forced evictions. Successively, the following topics will be addressed. The meaning of the term forced evictions and the reasons why, and the way in which they are carried out. Who are the evictors and who the evictees. To what extent does international concern exist, and does this concern have any impact on the domestic situation? The final part of this section will be devoted to the evicted women themselves. I will look into their experiences and examine to what extent they suffer differently or sooner from evictions than men.

\subsubsection{The Concept of Forced Evictions}

In literature, several different terms are being used to refer to the practice of removing people from their land and homes against their will. Sometimes it is called resettlement, relocation, expropriation, or displacement. ${ }^{135}$ In United Nations documents, however, the term 'forced evictions' is always used. Implicitly this concept consists of two elements. First that people are leaving their home and/or their land involuntarily and secondly, that the forced removal is illegal, i.e. that it is carried out contrary to national

134 Special Rapporteur Sachar recognizes forced evictions as one of the primary causes of the current housing crisis in his Working Paper on the Right to Adequate Housing, UN doc. E/CN.4/Sub.2/1992/15.

135 See Scott Leckie, When Push Comes to Shove; Forced Evictions and Human Rights, Habitat International Coalition, Primavera, Amsterdam, 1995, pp. 11-12 where many more expressions are mentioned. 
and/or international law. ${ }^{136}$ This implies that sometimes evictions are not illegal, c.q. can be justified. ${ }^{137}$ These cases fall outside the scope of human rights law. ${ }^{138}$

According to several sources the scale on which forced evictions are carried out is enormous. $^{139}$

Conscious of the existing national and international disapproval of the practice, evictors bring forward various reasons and justifications for carrying out forced evictions. The most commonly heard reasons are beautifying the city, new housing development schemes, the building of public utilities like roads and road side drainage, the building of dams, ${ }^{140}$ preserving historical sites for tourism, the holding of international events like the Olympic Games, visits by foreign dignitaries, and the need to claim the house for one's personal or one's family's habitation. ${ }^{141}$ Sometimes evictions are planned well in advance and have been announced to the people who will be evicted. On other occasions, the evictions come totally unexpected, surprising people in their sleep or giving them just a few hours' notice. ${ }^{142}$ Many forced evictions are violent. ${ }^{143}$ Evictors may employ armed police forces, like Special Weapons And Tactics (SWAT) teams, or hired thugs to carry them out. Bulldozers may be used to eradicate the shelters, or everything is set on fire, so that the evictees not only lose their place to live, but also all of their possessions.

136 In General Comment No. 7 on forced evictions, the CESCR defines forced evictions as: 'the permanent or temporary removal against their will of individuals, families and/or communities from the homes and/or land which they occupy, without the provision of, and access to, appropriate forms of legal or other protection'. UN doc. E/C.12/1997/4, para. 4.

137 Leckie identifies the following justifiable reasons for removing people from their homes: a racist attitude of a tenant against his neighbours, unjustifiable destruction of rented property, persistent non-payment of rent, anti-social behaviour as regards the neighbours, criminal behaviour threatening the rights of others, illegal occupation of property that was being used at the time of occupation, and occupation of land and homes by nationals of an occupying country. Leckie, 1995, p. 32.

138 It should be borne in mind, however, that in cases where evictions are deemed justified, they must be carried out in compliance with the relevant provisions of international human rights law, and they may not result in rendering people homeless. States have to provide for legal remedies, adequate alternative housing and compensation. General Comment No. 7, contained in UN doc. E/C.12/1997/4, paras 14-17.

139 Leckie maintains that since 1945 many tens of millions of persons have been forcibly evicted. Leckie, 1995, p. 7. According to Eviction Watch Asia about 1,525,032 people were evicted in thirteen Asian countries in the years 1996 and 1997. Kenneth Fernandes (ed.), Forced Evictions and Housing Right Abuses in Asia, City Press, Karachi, 1998, pp. 8 and 10. Sachar esteems that world-wide millions of people are evicted every year, UN doc. E/CN.4/Sub.2/1992/15 (Working paper), para. 41.

140 Examples are the dams in Karnataka (India) which caused the upheaval of 240,000 people and the world's largest dam on the Yangzi river in China, where between 700,000 and 2 million people were displaced. See respectively World Bank Operations Evaluation Department, 'Involuntary Resettlement; The Large Dam Experience’, Précis, Winter 2000, Number 194, p. 3, and Fernandes, 1998, p. 33.

141 Leckie enumerates many other justifications, both with respect to multi-household and individual cases. Leckie, 1995, pp. 27-28. See Also Sachar, Working Paper, 1995, paras 43-44.

142 In Kuala Lumpur (Malaysia), for example, squatters were served with notices, sometimes even up to three times, whereas in Bhabrekar Nagar (India) the demolition happened so suddenly that people did not have time to collect their belongings. See Fernandes, pp. 93 and 61 respectively.

143 CSOs report many cases of violence. It may take the form of abuses and threats, pulling by the hair, beating, kicking, raping and even killing. See, for instance, COHRE, Forced Evictions; Violations of Human Rights, Global Survey on Forced Evictions No. 7, Geneva, September 1998, p. 9. 
Evictors may be found in the public as well as in the private sector. In the first place, evictions are carried out by public authorities, both on a central and local level. ${ }^{144}$ Other evictors that are commonly mentioned include private landlords or landowners and property developers. In South Korea, for example, evictions were carried out by the Ministry of Construction and Transportation, by local governments and by private construction companies. ${ }^{145}$ Special mention should be made of the role of the World Bank. Many development projects that involve large-scale displacement of people are made possible because governments receive large sums from the World Bank to carry them out. Notwithstanding international criticism and the subsequent adoption of an Operational Directive on Involuntary Resettlement, the World Bank's policy is still held responsible for mass displacements every year. ${ }^{146}$

Since all evictors have in common that they have economic power and authority, it stands to reason that in the majority of the cases the evictees are the poor and the vulnerable, the people with no political influence. ${ }^{147}$ Besides being poor, people living on the streets or in slums also bear the stigma of being anti-social, and even criminally inclined. ${ }^{148}$ This makes it easier for the evictors to justify their actions.

\subsubsection{International Concern with Forced Evictions}

Since the 1990s several UN bodies have taken up the issue of forced evictions. The Commission on Human Rights, its Sub-Commission, the Sub-Commission's Special Rapporteur on the Right to Housing, the UN Secretary-General, and the CESCR, all have issued reports, adopted resolutions, declarations or quasi-judicial decisions in which they have addressed the practice of forced evictions. ${ }^{149}$ Since their involvement was already discussed in chapter II, I will not go into it again in this place. Suffice it to state that the overall conclusion of these bodies is that forced evictions are a violation of human

144 Leckie argues that mass evictions will occur sooner in authoritative countries than in democracies. Leckie, 1995, p. 21.

145 Fernandes, 1998, p. 86.

146 In June 1990 the World Bank adopted Operational Directive 4.30 on Involuntary Resettlement in which it is provided in Article 3 (a) that 'Involuntary resettlement should be avoided or minimized where feasible, exploring all viable alternative project designs', and under 3(b) that 'Where displacement is unavoidable, resettlement plans should be developed. [...] Displaced persons should be (i) compensated for their losses (ii) assisted with the move [...] and (iii) assisted in their efforts to improve their former living standards, $[\ldots]$ or at least to restore them. Particular attention should be paid to the needs of the poorest groups to be resettled.' Though this Operational Directive did not have the effect that mass displacements caused by World Bank projects diminished, the Bank drafted Operational Policies 4.12 on Involuntary Resettlement (the latest draft is of March 2001) in which the point of view towards displacement seems to have become even more lenient. Definitions have been changed, and words have been left out so that the overall protection of the evictees seems to have weakened. See also the comment on the Draft OP 4.12 by the Center for International Environmental Law, Washington, 1999, to be found on the internet on $<$ http://wbln0018.worldbank.org >, consulted on 19-06-01.

147 There are, however, exceptions like the white farmers/landowners in Zimbabwe who are being evicted from their farms.

148 Kothari maintains that being poor is a new, independent ground for discrimination. UN doc. E/CN.4/ 2001/51, 25 January 2001, para. 64.

149 Of all these documents on forced evictions to date the most authoritative is the CESCR's General Comment No. 7 on forced evictions. 
rights and particularly of the right to adequate housing. Other human rights, or aspects thereof, that may be infringed include security of tenure, security of the person, sanctuary of the home, freedom of settlement and movement, and the rights to property, privacy and family life.

To what extent the evictors are influenced by the international condemnation of forced evictions is hard to say. World-wide evictions continue to occur on a large scale. However, in some cases where governments have been tackled directly about their involvement, this did seem to have the desired effect. ${ }^{150}$ In the case of the Dominican Republic, for instance, the CESCR's opinion that the eviction practices constituted a violation of Article 11 of the Covenant on Economic, Social and Cultural Rights, resulted in a change of government policy. Forced evictions by public organs were suspended while a plan was adopted to provide adequate alternative housing for people who had been displaced. ${ }^{151}$

\subsubsection{Evicted Women}

In its General Comment No. 7, the CESCR points out that evicted women are in a particularly precarious position. Homeless women are vulnerable to acts of violence and sexual abuse, and they experience huge difficulties when they try to find alternative housing because they are discriminated against with regard to procuring property or gaining access to accommodation or credit. ${ }^{152}$ States have been urged to prevent evictions in general and of women in particular, and to provide safe alternative housing when evictions cannot be avoided.

It is interesting to examine whether women themselves feel that they are particularly affected by forced evictions and how they substantiate that they are indeed worse off than men.

Because the predicament of evicted women has the attention of several CSOs, women's views on eviction and its consequences have been accumulated. ${ }^{153}$ From the information that has been gathered, it can be inferred that women feel that they suffer gender specific physical, economic, social and psychological harm.

150 This is also the view of Scott Leckie who states that sometimes pronouncements will set political and legal processes in motion that will lead to changes in law and policy. Leckie, 1995, p. 64.

151 See $U N$ doc. E/C.12/1990/SR of 13 December 1990, and E/C.12/1997/10, paras 206-207 respectively. However, on the downside, the Committee also concluded that forced evictions in the private sector still occurred and that the authorities had not taken adequate measures to address this problem. E/CN.12/ $1997 / 10$, para. 225

152 General Comment No. 7, para. 11.

153 The data on which this sub-section is based were accumulated by several CSOs in 2001, but especially by the Centre on Housing Rights and Evictions (COHRE) in Geneva. COHRE's programme co-ordinator for women's housing rights at the time, Ms Leilani Fahra, initiated a list service on the internet and women from all over the world (North and South), with a wide variety of backgrounds, responded. Some women had been victims of forced evictions themselves. Others worked for women's CSOs or UN bodies. It should be borne in mind, however, that the victims who responded cannot be seen as representative for the target group, since the majority of evicted women obviously does not have access to computers and internet. Nevertheless, the experiences that were accumulated are helpful in gaining insights. 
As far as physical harm is concerned, some women report that they have experienced rape and sexual assault prior to, during and immediately after eviction. Alleged perpetrators that have been mentioned include landlords, who harass female tenants under the threat of eviction, the actual evictors (military, police, and armed thugs) during the eviction itself and others who seize the opportunity to abuse women when they lack the protection of their homes.

Other physical harm that is blamed on eviction is woman battering. Women maintain that they bear the brunt of eviction because poor living conditions, and ensuing frustration, trigger male aggression.

A specific economic effect that is mentioned is that informal income generating activities become impossible. Many women succeed in marketing vegetables, eggs or other produce or to do some kind of cottage industry. Such activities require a home and/or a parcel of land.

The social effects of eviction on women are manifold. In the first place they relate to the fact that most women's lives are home-centred. ${ }^{154}$ Many women are more attached to their house than men are because they spend far more time there. It is the place where they raise their children and do their household chores. Once evicted, normally 'simple' tasks like drawing water and putting food on the table become very burdensome. Women's social life is anchored in the house and the neighbourhood. Because of forced evictions, women lose their social contacts and social networks that are critical for survival. Sometimes kinship bonds are severed because families are scattered.

Furthermore, social rights are infringed. Many girls have to stop their education after the eviction while their brothers are allowed to continue. Some girls are morally forced by their parents to enter into early marriage so that the burden on the family is somewhat alleviated.

The psychological harm that is reported includes a feeling of prolonged insecurity and fear that eviction may happen again. Women feel that they have the burden of the whole family (parents, children) on their shoulders. Lastly, especially female heads of household report that they experience guilt because they are regarded by society as being poor providers.

When they attempt to secure alternative housing, women encounter gender specific legal, cultural and traditional discrimination.

Gender biased laws bar women from owning and inheriting land, property and housing. Women feel like they are evicted once over when they try to return to their homes in a post-conflict situation, and find that they cannot own or inherit their former homes. A particularly striking example was reported from Kosovo, where women who had returned were evicted by their late husbands' brothers from their houses that had just been rebuilt with the help of the UN and CSOs. ${ }^{155}$

154 Traditional patterns, both in developing and in developed countries, relegate women to the home where they are burdened with household and child raising duties. Whether this situation is desirable or not is not under discussion here, it is simply a factual situation.

155 This particular information was provided by a UNHCR officer in the field. In Kosovo the statutory laws, that date back to the communist period, give equal rights to women. In large parts of Kosovo, however, rules of family life are laid down in traditional codes of law that are patriarchal in essence, endowing only few rights on women. Under these codes women do not have the right to own property. 
With regard to discriminatory practices, indigenous, disabled and minority women are even worse off than other women.

Besides the evictions executed or condoned by the authorities and those carried out by third parties such as landlords and land owners, women may experience evictions by intimates, in particular their in-laws. Women, who cannot legally or customarily claim property rights of land and housing, may become homeless because they are forced to leave when their father or husband dies, or when their relationship ends. African women maintain that, though every form of eviction is terrible, those that happen in the framework of traditions and customs are even worse than others because of their intimate character. Large-scale, spectacular evictions, such as those caused by conflict situations, are in the centre of attention, while micro-scale evictions, induced by custom, are hardly taken notice of, although they happen continuously and affect far more women than the highly publicised evictions. Up till now, any norm interpreting work that has been done with respect to forced evictions, such as CESCR General Comment No. 7, has failed to recognize and to include evictions by intimates as a common cause of homelessness for women.

Many women, particularly from developed countries, mention as one of the most important causes of homelessness eviction because of persistent non-payment of rent. They maintain that rent increases hit women far worse than men. The reason why women, especially heads of households, cannot cope with increased rent levels is their weaker economic position. The average income of women is lower than that of men because of several reasons. ${ }^{156}$ As a result, women are poorer than men are and they are sooner the victims of this form of eviction. ${ }^{157}$

Structural non-payment of rent may be a legitimate reason to evict a person. However, in the light of the low-income level of women, eviction because of non-payment of rent may under certain circumstances be considered as forced eviction. The CESCR has stipulated in its General Comment No. 4 that one of the core elements of adequacy of housing is affordability. ${ }^{158}$ This entails that State parties must ensure that the costs of housing are commensurate with income levels. Furthermore, they must protect tenants from unreasonable rent increases and they should provide housing subsidies for those who cannot obtain affordable housing by themselves. When so many single women are unable to pay the rent, it seems logical to deduce that the costs of housing are not proportionate to their income. Subsequently, the question arises which income levels are used to calculate the amount that is deemed reasonable for housing costs. Is the income discrepancy between women and men taken into account, or are income levels of male breadwinners considered to be the norm. Moreover, when women are indeed evicted,

156 There reasons include that world-wide women have enjoyed less education and job training than men, so they have to work in low-paid jobs. Traditional 'women's work' is held in lower esteem and is therefore paid less than 'men's work'. Many women can only work part-time because they also have to raise their children and do the household. Many women work in the informal sector where the wages are often below the legal minimum. Also see section 3.2.3.2 on employment.

157 In Canada, for example, the number of homeless women, especially sole support mothers, has increased enormously because of non-payment of rent. Single parent families enter the shelter system at twice the rate of two parent families. Between 1988 and 1996 the number of female-headed families in the hostel system increased by $13 \%$.

158 Affordability is dealt with in para. 8(c) of General Comment No. 4 on the right to adequate housing. Also see section 2.4 on the content of the right to adequate housing. 
and have no other option than to enter the shelter system or live on the streets, the government's subsidy programme, if it has introduced such a programme, has obviously failed.

\subsubsection{Concluding Remarks}

The practice of forced evictions is one of the main causes of homelessness and inadequate housing conditions. There is international consensus that this practice constitutes a violation of human rights, particularly the right to adequate housing. On face value, forced evictions seem to be gender neutral. However, on further examination there appear to be several aspects and consequences that apply specifically to women. Women experience gender specific physical, economic, social and psychological harm as a consequence of forced evictions. Furthermore, they are subjected to discriminatory laws and practices when they attempt to obtain alternative housing. It seems therefore justified that States pay particular attention to the situation of women. Evictions should be prevented as much as possible, but when they have already taken place, or when they are unavoidable, it is imperative that States provide secure alternative housing. Legal obstacles as regards inheritance and property rights should be brought in alignment with international obligations, and traditions and customs that inhibit women from obtaining land and housing should be banned as soon as possible.

Furthermore, women may experience a gender-specific form of forced evictions because they may be evicted by relatives or other intimates, such as their partners or inlaws. Particularly in developing States where no safety-nets in the form of security services and welfare benefits are available, this form of eviction, that is psychologically much more damaging, may result in homelessness.

Affordability of adequate housing is a factor that should be closely watched, especially in view of women's weaker financial position. If a growing number of people who are gainfully employed no longer can afford to pay the rent, the government has failed in its obligation to keep housing costs at an affordable level. Moreover, if substantial groups of people are actually turned out into the streets because of arrears of rent, the government has failed to establish an adequate housing subsidies programme.

\subsubsection{Natural and Human-Made Disasters}

\subsubsection{Introduction}

All kinds of disasters yearly cause temporary or permanent homelessness for millions of people. The number of great natural disasters has increased dramatically over the last decades. During the 1990s there were three times as many natural disasters as in the 1960 s. ${ }^{159}$ Each year from 1991 to 2000 , an average of 211 million people were killed or affected by natural disasters, while in the year 2000 this number increased to 256

159 Environmental Management and the Mitigation of Natural Disasters: a Gender Perspective, Report of the Expert Group Meeting, Ankara, Turkey, 6-9 November 2001, Division for the Advancement of Women, Department of Economic and Social Affairs, EGM/NATDIS/2001/Rep.1, 15 November 2001, I. Introduction 
million. ${ }^{160}$ Since the average number of people who are annually killed or affected by armed conflicts amounts to 31 million, this brings us to a total of 287 million disaster victims every year. Ninety-eight per cent of the victims are from developing States. ${ }^{161}$

In this section it will first be determined what a disaster is and which kinds of disasters exist. There is a difference between disasters that are purely natural and those that are partially or totally brought about by people. It is important to distinguish because anthropogenic disasters can be influenced. In some instances they may be avoided, while in others their effects may be mitigated.

Once the different types of disasters have been explored, it will be examined whether gender specific aspects may be discerned before, during and after disasters.

The questions I try to answer pertain to whether women and men run the same chance of being rendered homeless by a disaster and whether they encounter the same sort of difficulties during a disaster. In the period after a disaster people have to build up their lives again, sometimes from scratch. In some situations, like armed conflicts, it will be impossible to return home, so a new life must be sought elsewhere. In other circumstances, like after an earthquake, people may return to their original habitats but the conditions will have changed. Relatives may have died and houses may have been destructed. The question is whether women encounter different problems from men in this reconstruction phase.

The total disruption of society caused by a disaster may also open new windows of opportunity for women. In the last part of this section I will go into the various new possibilities that may be created for more equality between the sexes in the aftermath of a disaster, specifically with regard to securing a place to live.

\subsubsection{Types of Disasters}

Disasters that are not caused by conflict situations are defined as:

'Damaging events that represent the actualization of pre-existing risk conditions. They are a serious disruption, caused by a natural, social or technological hazard/phenomena, of the functioning of a society, with consequent widespread human, material or environmental losses which exceed the ability of the affected society to cope using only its own resources. ${ }^{162}$

Although the world media will focus on a few large-scale, relatively infrequent, disasters every year, the vast majority of disasters are small local events. ${ }^{163}$ These smaller-

160 International Federation of Red Cross and Red Crescent Societies, World Disasters Report 2001, $<$ www.ifrc.org/publicat/wdr2001>, consulted on 16 August 2001, Introduction.

161 World Disasters Report 2001, Chapter 1; Relief, recovery and root causes, and Chapter 8, Disaster data: key trends and statistics.

162 Definition used for disasters in the UN World Food Programme Guidelines for WFP Assistance to Disaster Mitigation.

163 For example, in Guatemala and El Salvador there were between 1991 and 1997414 disaster events (small, medium and large scale) registered in the DesInvental database, versus 11 large-scale disasters registered in the global CRED-EMDAT database. Nora Sequeira, Risk Management: an Alternative Perspective in Gender Analysis, EGM/NATDIS/2001/EP.7, 6 November 2001, p. 7 
scale disasters are in fact more important because they cover a large territory and they are annually recurring events that have a disproportionately high impact on the most vulnerable sectors of society. ${ }^{164}$

Some disasters are completely caused by human behaviour. The most obvious examples of anthropogenically caused disasters are armed conflicts. Civil strives and international wars cause death and destruction and displacement of millions of people. Other examples of human-made disasters are accidents with nuclear power plants, chemical factories, fires and explosions. ${ }^{165}$

The opposite of human-made disasters is natural disasters. Only those of a geophysical origin, like earthquakes and volcanic eruptions, can truly be called natural. Those of a hydro meteorological origin are to a greater or lesser extent 'un'natural. They are caused or exacerbated by unsound development and environmental practices, like deforestation, destruction of wetlands and building on unsafe hillsides. Environmental degradation will cause erosion, desertification, droughts, landslides, mudslides, floods, and flash floods. Global warming induced by air pollution, causes climate changes. ${ }^{166}$ Disasters that are specifically caused by or aggravated by human behaviour are droughts, floods and landslides. ${ }^{167}$

The increase of catastrophes cannot be explained by the occurrence of geophysical disasters since their number has remained fairly steady. The amount of hydro meteorological disasters, however, has more than doubled since $1996 .{ }^{168}$ Disasters cause so much displacement and destruction because in developing countries poverty and population growth force increasing numbers of the poor to settle in disaster-prone areas like flood-plains, earthquake-prone zones, unstable slopes, or in the vicinity of volcanoes. Sometimes, people are not aware of the danger because in many cases governments do not inform them. ${ }^{169}$ But since no alternatives are offered, awareness often does not make a difference since the poor have no other option. ${ }^{170}$ Furthermore, poor people cannot afford to build their houses in a disaster-resistant manner. Only in the rich countries in the North construction methods are used that withstand earthquakes and storms. ${ }^{171}$

164 Nora Sequeira, 2001, pp. 9-10.

165 Cases in point are the accident with the nuclear power plant in Tsjernobyl, the Ukraine, in 1986 as a result of which more than a hundred thousand people had to be evacuated, and the explosion of S.E. Fireworks in Enschede, the Netherlands, in 2001 resulting in the destruction of about 350 houses.

166 Kofi A. Annan, An Increasing Vulnerability to Natural Disasters, in: The International Herald Tribune, 10 September 1999.

167 Environmental Management and the Mitigation of Natural Disasters: a Gender Perspective, 2001, III Summary of the debate, A. Background.

168 World Disasters Report 2001, Chapter 8, Disaster data: key trends and statistics.

169 Samia Galal Saad, Environmental Management and Natural Disasters Mitigation: Middle Eastern Gender Perspective, EGM/NATDIS/2001/EP.3, 22 October 2001, p. 5.

170 Kofi A. Annan, An Increasing Vulnerability to Natural Disasters, in: The International Herald Tribune, 10 September 1999. Also Worldwatch Organization on <www.worldwatch.org >, consulted on 26 March 2002 and Shubh Kumar-Range, Environmental Management and Disaster Risk Reduction: A Gender Perspective, EGM/NATDIS/2001/BP.1, 4 November 2001, p. 8.

171 Environmental Management and the Mitigation of Natural Disasters: a Gender Perspective, 2001, III Summary of the debate, A. Background. 


\subsubsection{Before the Disaster}

Vulnerability to disasters is not a neutral characteristic. It is a complex of poor economic and social circumstances, and of having no political influence. The poor and marginalized are forced to live in overcrowded, dangerous sites. ${ }^{172}$ Particularly in developing countries the poorest of the poor are women. They lack education, salaried jobs, (legal) access to land, they have no security of tenure, no property, their mobility is restricted because of their care giving tasks. They do not take part in decision-making bodies and they cannot influence their own lives. Not all women are equally vulnerable to disasters. ${ }^{173}$ Those in awkward positions are mostly single women, widows, elder and disabled women, women belonging to ethnic minorities and, most of all, female heads of households. ${ }^{174}$

Besides the dangerousness of location another reason why so many women fall victim to disasters is the lack of information and preparedness. ${ }^{175}$ Information of upcoming catastrophes many times does not reach women or not in time because it is spread in public places that are not frequented by women or the information is in writing, while the majority of the illiterate are female. ${ }^{176}$ Sometimes governments announce warnings only in the official language that cannot be understood by ethnic minorities.

172 Nora Sequeira, 2001, pp. 4-5, also Shubh Kumar-Range, 2001, p. 18, and Irene Dankelman, Gender and Environment: Lessons to Learn, EGM/NATDIS/2001/OP.2, 2001, p. 16.

173 Elaine Enarson, 'Gender issues in natural disasters: talking points on research needs', Chapter 2 in ILO Working Paper 7, Crises, Women and other Gender Concerns, Recovery and Reconstruction Department, Geneva, February, 2002, p. 8.

174 One of many examples is the situation of the people living on the charlands of Bangladesh. Charlands are plots of land that emerge in a river or adjacent to its banks and can disappear again because of the continuing process of accretion and erosion. More than 600,000 people live on the charlands, the vast majority of whom are women. Since the land is very fickle, people who have resources or opportunities will not choose to live there. Single women, widows and divorcees have no other choice. Not all women who have settled there are de iure heads of their households, many of them are de facto in this position because their husbands live and work on the mainland. Life on the charlands is very hard because there is a constant threat of flooding with the danger of losing the house and the standing crops. The women have adapted very well to these surroundings. They build their houses low to protect them against the fierce storms and they cultivate crops that grow very vast. Notwithstanding their surviving skills and factual independence, these women run enormous risks once the flooding starts. Culture dictates that they may not take decisions independently, but that they have to follow the advice of their husbands or male guardians. Therefore, they have to wait for permission before they can move. When they see the danger coming they send messages to the mainland and stay put, even if this means that they will lose all their possessions, until permission to move is granted. Mahjabeen Chowdhury, Women's Technological Innovations and Adaptations for Disaster Mitigation: A Case Study of Charlands in Bangladesh, EGM/NATDIS/2001/EP.6, 1 November 2001, pp. 4-10.

175 Samia Galal Saad, 2001, p. 7.

176 A case in point was the cyclone and flood in Bangladesh in 1991. Information was spread in public spaces where men congregate in the understanding that they would inform the women, which did not happen in many instances. Women who were warned were constrained by cultural norms that restrict women's mobility rights. They had to wait for their husbands to return and to take them to safety. Many of them perished together with their children. Among women aged 20-44 the death rate was 71 per 1000, compared to 15 per 1000 for men. Maureen Fordham, Challenging Boundaries: A Gender Perspective on Early Warning in Disaster and Environmental Management, EGM/NATDIS/2001/EP.5, 26 October 2001, p. 10. 
Though women cannot be held responsible for the environment, it certainly does not help that women hardly ever own the land they till. Since they realize that they are mere birds of passage they put short-term goals and will not invest their time, labour and scarce resources in long term soil preserving methods like drip irrigation instead of inundation. Even if they are willing to make more ecologically sound decisions, they do not get access to credits to invest in modern technologies. ${ }^{177}$

\subsubsection{During the Disaster}

Female victims and women CSOs complain that the media picture women as the helpless victims and men as the glorious saviours. ${ }^{178}$ Even during disasters, the work that is done by women and men follows traditional patterns. The multifaceted work done by women, like taking care of children, the elderly, the sick and the wounded, securing the bare necessities of life like water and food, preserving seeds, securing shelters, cooking and cleaning, remains invisible and is shaken off as of minor importance. ${ }^{179}$ The spotlights are on the men who take up leadership positions and who are publicly visible while rescuing people or clearing up the rubble. ${ }^{180}$ Though all activities are equally important, this focus on men again marginalizes women and the roles they play in society. Also national and international disaster responders sometimes reinforce the gender-based inequality. They too consider women as passive victims. Food and other supplies are distributed among male heads of households. ${ }^{181}$ And although it is well known that women have specific needs and problems during disasters, it is accepted that men represent them. ${ }^{182}$ Many times shelters are not equipped to the needs of menstruating, lactating or pregnant women. ${ }^{183}$

The specific situation of female refugees and internally displaced women is dealt with in section 3.4.5.4 of this chapter.

\subsubsection{After the Disaster}

Obviously, the poor have the least resilience to cope with a disaster. They do not have savings or well paid jobs that allow them to start anew. But although the recovery

177 Maureen Fordham, 2001, p. 12

178 Environmental Management and the Mitigation of Natural Disasters: a Gender Perspective, 2001, III Summary of the debate, C. The 'window of opportunity' in recovery.

179 Feride Acar, Gamze Ege, Women's Human Rights in Disaster Contexts: How can CEDAW help?, EGM/NATDIS/2001/EP.4, 25 October 2001, p. 2-3. Also Angeles Arenas Ferriz, The Relevance of Considering a Gender Perspective in Damage Assessment and Recovery Strategies. A Case Study in El Salvador, Central America, EGM/NATDIS/2001/EP.9, 26 November 2001, p. 1, and Samia Galal Saad, 2001, p. 4.

180 Environmental Management and the Mitigation of Natural Disasters: a Gender Perspective, 2001, III Summary of the debate, B. Integrating a gender perspective into environmental management and risk reduction.

181 UN doc. E/CN.4/2005/43, Study by the Special Rapporteur on adequate housing as a component of the right to an adequate standard of living, Miloon Kothari, 25 February 2005, para. 5.

182 Feride Acar, Gamze Ege, 2001, p. 3.

183 Maureen Fordham, 2001, p. 21. 
capacity of the high and medium classes is bigger, also in these classes the possibility to cope is better for men than for women. ${ }^{184}$ Besides the general destitute situation, many women are faced with additional problems. Stereotyped roles are often reconfirmed, especially in patriarchal societies. Gender-based segregation forces women to remain in the invisible private sphere. This not only inhibits their participation in the decisionmaking ${ }^{185}$ and rebuilding process, but also makes them unattainable for relief workers. ${ }^{186}$ Particularly for rural women, losing their dwelling means much more than losing a place to live. Homes are also production units where they grow agricultural products and keep animals for consumption and for marketing, their sole source of income. ${ }^{187}$ Women's mobility is restricted, sometimes because of cultural inhibitions, but also because their care giving tasks increase. ${ }^{188}$ They have to take care of the children, the elderly, the sick and the injured and they do the cooking and cleaning in the shelters so that they cannot find time or opportunity for a paid job like men. ${ }^{189}$

Women's access to land and property after the disaster may be a problem. ${ }^{190}$ In many countries in Asia and Africa women who have lost their husbands or male relatives are confronted with the fact that they cannot inherit the land or houses that have been left behind. ${ }^{191}$ Moreover, women's access to credit and loans is far more limited than men's. ${ }^{192}$

A specific situation presents itself to refugees and internally displaced persons (IDPs) who return to find their homes occupied by others. ${ }^{193}$ Although the domestic governments have the obligation to protect property from the unlawful occupation by third

184 Angeles Arenas Ferriz, 2001, pp. 4-5.

185 In El Salvador after the January and February 2001 earthquakes the activities of a group of people was closely surveyed. Although the women greatly participated in the community activities during the emergency and rehabilitation process did not mean that they played a significant part in decisionmaking. Only $6 \%$ of the rural women and $15 \%$ of the urban women participated in decision-making processes of community organization on emergency and rehabilitation tasks, relief distribution and recovery plans. Angeles Arenas Ferriz, 2001, p. 13.

186 Feride Acar, Gamze Ege, 2001, p. 4.

187 Mahjabeen Chowdhury, 2001, p. 5, and Angeles Arenas Ferriz, 2001, pp. 7-14.

188 Shubh Kumar-Range, 2001, pp. 5-6.

189 To take the example of El Salvador again: The urban women dedicated an average of 14 hours and rural women of 16 hours a day to emergency and rehabilitation tasks, consisting of taking care of children and injured, cooking and cleaning in the shelter, washing clothes, carrying water or firewood and queuing up for food supplies. Because schools and transportation systems had been destroyed, children who would normally go to school, had to stay at home which meant that $60 \%$ of the urban women and $48 \%$ of the rural women had less time for income generating activities. Angeles Arenas Ferriz, 2001, p. 11-12. Also, more generally, Shubh Kumar-Range, 2001, pp. 5-6.

190 For instance in the Bangladeshi charlands women are dependent on men's decisions and activities for resettlement. The women lack decision-making powers and they cannot negotiate land for resettlement when they have been displaced because of the erosion. This is a particular predicament for those women who do not have a male guardian. Mahjabeen Chowdhury, 2001, p. 10

191 Simon Bagshaw, 'Property Restitution and the Development of a Normative Framework for the Internally Displaced', in: Refugee Survey Quarterly, Vol. 19, No. 3, 2000, p. 219.

192 See section 3.2.3.4 on access to credit and loans.

193 A famous example is the Loizidou case before the European Court of Human Rights. Ms Loizidou was prevented to return to her property in Northern Cyprus because of the presence of Turkish forces there. Loizidou v. Turkey (Article 50) - 15318/89 [1998] ECHR 60 (28 July 1998). 
parties, ${ }^{194}$ this is not always so easy. ${ }^{195}$ This problem is also gendered because the great majority of IDPs are women and children. ${ }^{196}$ As is the case after forced evictions, women will suffer at the hands of intimates because instances of domestic violence take an enormous flight after disasters ${ }^{197}$ while also many women will be abandoned by their partners. ${ }^{198}$

As is to be expected, female heads of household are the worst off because they are economically, socially, and politically in the most disadvantaged position. Their access to help is impeded by traditional stereotyped ideas of male nucleus families. ${ }^{199}$ Not only should they have access to the normal relief programmes, but in addition, special programmes should be developed that take into account that these women must combine productive and reproductive tasks.

\subsubsection{Windows of Opportunity}

Although it is rather cynical since disasters are devastating events, some good may come of them when those in charge seize the opportunity to create a more equitable society.

194 See Guiding Principles on Internal Displacement presented to the Commission on Human Rights by the UN Special Rapporteur on Internally Displaced Persons in $U N$ doc. E/CN.4/1998/53/Add. 2. Under domestic laws the authorities may have a legal obligation to protect property from unlawful interference by third parties and to restore property to rightful owners following a period of de facto dispossession. According to the Basic Principles and Guidelines on the Right to a Remedy and Reparation for Victims of Gross Violations of International Human Rights Law and Serious Violations of International Humanitarian Law, the right to restitution includes: '[the right to] return to one's place of residence' and the 'return of property'. GA Resolution 60/147, 16 December 2005, Annex, para. 19. Also Simon Bagshaw, 2000, p. 212. Also CERD, General Comment No. 22, Article 5 and refugee and displaced persons, 24 August 1996, para. 2(c) of which reads: 'All such refugees and displaced persons have, after their return to their homes of origin, the right to have restored to them property of which they were deprived in the course of the conflict and to be compensated appropriately for any such property that cannot be restored to them. Any commitments or statements relating to such property made under duress are null and void'.

195 In Kosovo, for example, the Serbian Parliament adopted a bill in 1991 that restricted the sale of houses by Serbs to Albanians in order to make it harder for Serbs to leave Kosovo. The result of this legislation was that sales took place through informal contracts that were not notarized as required by law. After the conflict in Kosovo an additional problem to illegal occupation of houses of returnees presented itself because the cadastre and other property records have become incomplete and thus unreliable so that it has become extremely difficult to prove who is entitled to a certain property. Hans Das, Regularizing Housing and Property Rights in Kosovo, Habitat Debate, Focus on Kosovo, www.unchs.org/unchs/ english/hdv6n2/Habitat_kosovo.html, consulted on 26 March 2002, pp. 1-2.

196 Bagshaw, 2000, p. 219. Also see section 3.6.3.3 on property of returnees.

197 Although violence against women is endemic, during and after disasters, this violence increases. The special circumstances around catastrophes prevent women from reporting the violence or from seeking help. Lack of transportation, lack of means of communication, closed or damaged courtrooms or police stations and/or living in refugee camps. Lynn Orstad, Tools for Change: Emergency Management for Women, EGM/NATDIS/2001/EP.2, 22 October 2001, p. 2. E.g. In the period after Hurricane Andrew, there was a sharp rise of cases of domestic violence in Florida, USA, Shubh Kumar-Range, 2001, p. 6.

198 There is a discernible trend for poor men to abandon their families after natural disasters. This has for instance happened in northeastern Brazil, where female heads of household are even nicknamed 'widows of the drought' and in the poorest regions of Bangladesh and the Caribbean. Shubh Kumar-Range, 2001, p. 6.

199 Unequal access to assistance for female heads of households also happens in rich countries, like in Oakland, California, after the 1991 firestorm. Shubh Kumar-Range, 2001, p. 21. 
During post-disaster periods people are more than ever prepared to work together and to adopt new ideas like local co-operative enterprises to create jobs and saving schemes for micro-level credit facilities. ${ }^{200}$ Especially on the local, neighbourhood, level women play an important part. Even in societies where women normally remain in the background, disasters create legitimate reasons and opportunities for women to come out in the open and to participate on all levels of rebuilding their community. This in turn makes women more aware of their own potential and thus contributes to their empowerment. $^{201}$

As far as housing is concerned, a few examples can be mentioned of new, genderequal ideas that were introduced in post-disaster periods.

After the 1989 floods in Pakistan co-ownership of houses by husbands and wives was introduced. The result is that women are far better protected in the event of a separation or divorce since the partner who wishes to remain in the house, is obliged to pay the other half of the value of the house. ${ }^{202}$ The same concept was introduced in India after the earthquake in Latur (Maharashtra) funded by a World Bank loan. ${ }^{203}$

That ideas like these cannot be forced upon societies from the outside can be illustrated by an example from Nicaragua. After Hurricane Mitch the American Red Cross and Save the Children USA, put the titles of the newly built houses in the names of the women. This seemed a logical choice since the women had all helped in rebuilding the houses and they stayed there all year round, while the men regularly went away to work elsewhere. However, many men did not agree and tensions arose. Some women were battered and many men abandoned their wives leaving them without a source of income. $^{204}$

Another promising example can be found in Rwanda where in March 2000 the Rwanda National Assembly passed a new law that enables women and girls to inherit land and own property. This 'Matrimonial Regimes, Liberties and Succession Law' allows women, the majority of the population, to become heads of the family. This puts an end to discriminatory customary laws that rendered girls and women homeless when their fathers and husbands had passed away. ${ }^{205}$

200 International Federation of Red Cross and Red Crescent Societies, World Disasters Report 2001, published on the internet on www.ifrc.org/publicat/wdr2001, consulted on 16 August 2001, Chapter 2, The ecology or disaster recovery.

201 Sengul Akçar, Grassroots Women's Collectives-Roles in Post-Disaster Effort: Potential for Sustainable Partnership and Good Governance (Lessons learned from the Marmara Earthquake in Turkey), EGM/ NATDIS/2001/EP.11, 7 November 2001, pp. 4-5.

202 Farzana Bari in Fernando and Fernando, 1997 and Maureen Fordham, 2001, p. 25.

203 Maureen Fordham, 2001, p. 27.

204 Maureen Fordham, 2001, p. 27

205 Women and girls comprised a large majority of returnees and orphans. More than 45,000 households in Rwanda are headed by orphaned children; of these $90 \%$ are headed by girls. Rasna Warah, Rwanda Passes Succession Law, at www.unchs.org/unchs/english/hdv6n2/Habitat_kosovo.html, consulted at 26 March 2002, pp. 9-10. 


\subsubsection{Concluding Remarks ${ }^{206}$}

Homelessness caused by disasters, particularly natural disasters, is not a gender-neutral phenomenon. Specifically women, making up the majority of the poor in developing countries, live in disaster prone areas. Some hydro meteorological disasters can be avoided or mitigated when governments develop plans for land use. Dangerous areas are unfit for habitation and should be used for other purposes like forestation while affordable alternatives are offered to the poor so they are not forced to settle illegally on risky sites. In order to achieve sustainable development money should be invested in soil preserving methods.

Another failure by States that unnecessarily causes many, especially female, victims is that the population is inadequately or not at all informed of an upcoming disaster. Information spread in public spaces in societies that are in principle sex-segregated runs the risk of not reaching women at all. Information spread in writing or only in the official language is inaccessible for illiterates, the majority of whom are women, or ethnic minorities.

During disasters, the specific needs and problems of women should be taken into account. Emergency shelters should be equipped to the needs of women. Distribution of help should not be focused on the male heads of households since this will exclude single women, widows and female family heads.

In the post-disaster period, opportunities for social change should be seized. Gender biased property and inheritance laws should be altered so that daughters and wives are enabled to return to and maintain their former homes. Women's equal right to land should be ensured since ownership of the land by the people who till it will promote methods that are ecologically sound.

New concepts like co-ownership of houses, or female participation in local governments and other decision-making bodies should be introduced at times that societies are susceptible to ideas of co-operation and partnership.

\subsubsection{Widowhood}

\subsubsection{Introduction}

In some developing countries, particularly in Africa and South Asia, widowhood may cause homelessness or inadequate housing for women. ${ }^{207}$ Since there are many differences between countries, tribes, and even among ethnic and religious groups, it is impossible to generalize. However, societies where women run the risk of becoming homeless when they lose their spouse, have in common that women are looked upon as being

206 The legal implications as to States' obligations and responsibility that are mentioned here, are dealt with more extensively in section 4.6 on State responsibility.

207 Discriminating laws or customs that negatively effect widows' rights to own or inherit property, including housing and land, exist in several countries of the world. The States that came to my knowledge are Bangladesh, Ghana, India, Malawi, Mozambique, Niger, Nigeria, Tanzania, Uganda, Zambia, and Zimbabwe, but undoubtedly there are many more. 
inferior to men in a specific way. They are outsiders in the families they live with all their lives. Other common features are that they live according to customs and traditions that hamper women's independent status in society, and that widows are stigmatized and shunned. ${ }^{208}$ The result is that in these countries widows are the poorest and the most discriminated against.

In the following I will first enumerate the most important factors that impede widows from securing their housing and property rights. After that I will discuss the options that are open to women once they have become widows, followed by some notions on possible ways of empowering them.

\subsubsection{Major Impediments}

Factors that have an adverse impact on the realization of widows' rights may be of a legal or cultural nature. In some States the law discriminates, e.g. prohibits women to own property or inherit land, or accords them a smaller portion than men. ${ }^{209}$ Another problem is that in many countries there is not just one law. In Nigeria, for example, inheritance and succession are ruled by the modern law, the Islamic law, customary law and local practice. To complicate matters even more, there are also differences between matrilineal and patrilineal ethnic groups. ${ }^{210}$

Where the law does proclaim equality between the sexes, it may be largely ignored in favour of personal laws, traditional practices and customs. ${ }^{211}$ Sometimes even courts do not apply the law. ${ }^{212}$

208 It is very hard to change the attitude towards widows since both superstitious fears and hatred play an important role. In the countries that were examined, widows are stigmatized as bringing bad luck, and in one way or the other they are held responsible for their husband's death. See Margaret Owen, Empowering Widows in Development; the Status of Widows in 10 countries, Seclusion and Exclusion, Report for the Oak Foundation, 1999 to be found on <http://www.oneworld.org/empoweringwidows/10countries/ index.html>, visited on 18 April 2001.

209 Under Islamic law, widows are entitled to inherit at least one eighth of their husband's estate. According to Hindu law the property passes to the adult sons, but when they are still minors, the widow becomes the temporary owner. Owen, Report on Bangladesh, p. 2. In Tanzania, the Inheritance Law has not been changed for 30 years with the result that even on paper widows do not have any rights. CEDAW has urged Tanzania to change its laws so that women are guaranteed inheritance and ownership of land and property. UN doc. A/53/38/Rev 1, 6 July 1998, paras 235-236.

210 Matrilineal inheritance means that the inheritance goes down through the woman's brothers and their sons, whereas in the patrilineal system the property is divided among the brothers of the deceased. The matrilineal system is slightly better for the position of the widow since the men that inherit the property are her own blood relatives and there is a chance that they will treat her better than her in-laws. Both systems have in common that a woman herself can never inherit.

211 In Ghana for instance the law has been changed after this country became a party to the Women's Convention. The 'Intestate Succession Law II' of 1991 entitles the widow and her children to the greater part of the matrimonial property and it criminalises the eviction of the widow from her husband's house without a court order. However, enforcement of this laws has been impeded by many factors. Harassment by in-laws, corruption of officials and illiterateness of the widows among them. Owen, 1999, Report on Ghana, p. 1. In Niger the law does not distinguish between girls and boys with regard to inheritance, but by custom girls do not inherit from their fathers. See Final Report Special Rapporteur Warzazi, UN doc. E/CN.4/Sub.2/1996/6, 14 June 1996, para. 45.

212 In 1999 the Zimbabwe Supreme Court ruled against a daughter who claimed part of the estate of her dead father. According to the Court: 'the nature of African society relegates women to a lesser status, 
The way in which the concept of property is viewed in these States, impedes equal sharing between women and men. The home and the land are not owned by individuals, but are the common property of (extended) families. ${ }^{213}$ Daughters are expected to marry and move away (female exogamy), and when they do, their ties to the family are severed. For this reason they are denied any claims to their fathers' house or land because this would compromise the integrity of the family's assets. ${ }^{214}$ Once married, women remain foreign elements in the family of their in-laws. They will have access to a home and may use the land, but they will be denied a share of their husband's property. ${ }^{215}$ Male offspring may enhance the status of a woman, however, and in some cases having sons will guarantee a place in the community when a woman has been widowed. ${ }^{216}$

Customary and traditional patterns in many developing countries have undergone major changes due to colonialism and consequent Western influences. New ideas and concepts have mingled with traditional practices. Particularly the upcoming individualization and urbanization affect the situation of widows. The ideals and safeguards of the extended family are dissolving, and many women are left to fend for themselves without having the necessary tools to do so. Having sons no longer is a guarantee that a widow will be looked after, since many young men will take care of their immediate families (wife and children) first, and many rural boys leave their communities to move away to big cities.

Another system that has changed to the disadvantage of women, is the dowry system. ${ }^{217}$ Traditionally, the dowry was meant to compensate the daughter for her part of the inheritance. Since whatever estate her parents might leave after death would be

especially in the family. A woman should not be considered an adult but only a junior male'. This ruling is in contradiction to Zimbabwe's national laws and its obligations under the Women's Convention. Owen, 1999, Report on Zimbabwe, p. 3

213 According to Desai the argument of fragmentation of agricultural land is nothing more than a pretext some Indian states have used to exclude women from inheriting land. Sonalde Desai, 'Engendering Population Policy', in: M. Krishnaraj, R. Sudarshan, A. Shariff (eds.), Gender, Population and Development, Oxford University Press, Delhi, 1998, p. 53.

214 Women's CGOs in Zimbabwe that tried to empower women by educating them on their equal property rights were told off by President Mugabe in 1996 when he remarked: 'If these are ideas being brought by whites amongst you as they came from Europe, they are bringing terrible ideas. I cannot have it that property that is family property should be registered in two names. If the woman wants property in her own right, why did she get married in the first place?', Owen, 1999, Report on Zimbabwe, p. 2.

215 In Nigeria most women are denied inheritance to land belonging to their husband's family. Some of the ethnic groups, e.g. the Igbo, have a rule that determines that a widow may inherit some property depending on the sex and age of her children. Owen, 1999, Report on Nigeria, p. 2. In Zambia women cannot own anything according to tradition, not even their children. It is considered that anything a man accumulated during his life should be viewed as compensation for the care he has received from his family during childhood. Owen, Report on Zambia, p. 1. In Zimbabwe the general rule under customary law is that the widow and her children are evicted from her husband's home. Owen, 1999, Report on Zimbabwe, p. 1.

216 For both men and women having sons is important in old age. But since men have access to land and property, income and saving, and they mostly have a (much) younger wife, sons merely function as extra safeguards. For women giving birth to sons is the only way in which they may gain prestige with their in-laws and it can legitimize their place in the family. When they are widowed, most women have to rely completely on their sons. Desai, 1998, p. 52.

217 There are several systems, but the dowry system meant here is the (Hindu) system in which it is customary that a bride brings a certain amount of wealth into the family of her husband. 
divided among her brothers, the daughter was given gold and precious stones as a substitute. These remained her personal property so that she had some security. Nowadays, however, the husband to be and the in-laws most of the time demand consumer goods as the bride prize. Parents will give their daughter such goods as television sets and refrigerators. Goods that lose their value after a few years, leaving her empty handed. ${ }^{218}$

Furthermore, the system of levirate ${ }^{219}$ is on the decline. However degrading and unwanted this might be for a widow, it secured her a place within the family of the inlaws. ${ }^{220}$

What did remain, however, is the low esteem in which women are held in general and the stigma that widows bear in particular. ${ }^{221}$ Widows still are a taboo subject. In many cultures they are blamed for the death of their husband. They are regarded as unclean, a danger to society. ${ }^{222}$ They are expelled or kept in isolation in order to protect the community from their influence. ${ }^{223}$

Customary rules often restrict women's mobility rights, while it may be a prerequisite that a woman can travel in order to exercise her inheritance rights. This is for instance the case when she has to register her property at a Land Registry, or when she has to contact a lawyer. Travelling is out of the question for women living in purdah, ${ }^{224}$ and in those communities where widows are supposed to undergo their mourning rites in seclusion.

218 Amanda Hitchcock, Rising number of dowry deaths in India, <http://www.wsws.org/articles/2001/ jul2001/indj04.shtml>, visited on 9 July 2001, p. 4.

219 Levirate or widow inheritance is a system that entails a union of the widow with a brother-in-law (another male relative is also possible) with the object of obtaining children in the name of the deceased. The dead man's successor or levir has the duty to look after the widow and her children and to manage the deceased's property. See e.g. Chima Jacob Korieh, Widowhood among the Igbo of Eastern Nigeria, University of Bergen, Norway, Spring 1996, para. 3.3.1 on Widow Inheritance (Levirate)-Nkushi.

220 Special Rapporteur Warzazi considers the levirate system as a violation of women's rights since most women are thus remarried against their will. UN doc. E/CN.4/Sub.2/1996/6, 14 June 1996, para. 50.

221 In Brahmanical pratriarchy, a woman is only considered to be a person when she has a husband. Outside of the husband, a woman has no recognized existence, but she is a threat because of her alleged sinful and lustful character. It is believed that a truly good and pure woman will never be a widow. She has either predeceased her husband or she will join him in death, like Savitri did for Satyavan (hence the term sati for widow immolation). Therefore a widow is a condemnable creature who must be kept under constant surveillance in the darkest recesses of the house. Uma Chakravarti, 'Widowhood as social death', in: Martha Alter Chen (ed.), Widows in India: Social Neglect and Public Action, Sage, 1998. Also Courtney W. Howland, 'Women and Religious Fundamentalism' in: Kelly D. Askin and Dorean M. Koenig (eds.), Women and International Human Rights Law, Vol. 1, Transnational Publishers, Inc. Ardsley, New York, 1999, pp. 558-559.

222 This is for example true in Nigeria and Ghana where women are often accused of murder, and have to prove their innocence by way of undergoing all kinds of degrading mourning rites. See Margaret Owen, 1999, Report on Nigeria, p. 1, Report on Ghana, p. 3.

223 Korieh, 1996, para. 4.1.3 on Customary Rights to Land, where he explains that among the Igbo a widow without a son has no right to remain a member of her late husband's family and will be expelled from the compound.

224 Purdah is the custom among Muslims and some Hindus of secluding women from public observation. Strict purdah requires a woman to cover her face in front of her husband and older men. It also restrict a woman's travel alone which otherwise would 'contaminate' her character. Courtney Howland, 1999, p. 557. 
The widespread illiteracy among women also is a factor that hampers them from getting what they are entitled to. They have no knowledge of their rights to property or inheritance. ${ }^{225}$ In some cases where women are aware of what they are entitled to, they do not wish to sour the relationship with their brothers over their father's estate, since the time may come when they have to fall back on them for help. The same may apply with regard to the in-laws. Women do not claim their rights in order not to jeopardize the relationship. Sometimes they are bullied by their in-laws not to stake any claims. They may be threatened with beatings or even death. Lastly, most women simply do not have the money to seek legal assistance. ${ }^{226}$

\subsubsection{Options Open to Widows}

In order to secure a place to live, several possibilities are open to widows, though many of them cannot really make a choice for themselves, but have to wait and see what will be decided for them.

In the first place, if relations are good, they can remain with their in-laws. If a woman has an adult son, it might be an option to live with him and his family. Sometimes it is possible to return to the natal home and live under the roof of father or brother. ${ }^{227}$ Where the levirate system still exists, a woman may (have to) accept the substitute husband. Some women become unpaid domestic servants in a relative's house in return for shelter and food. There are few data on the living conditions of women living in a host household, but according to CSO information they may experience abuse, be deprived of food, forced to sleep in sheds and are virtual prisoners within the home. ${ }^{228}$

Sometimes remarriage is an option. ${ }^{229}$ Remarriage outside the family may entail, however, that the widow loses any access to property and her children to her deceased husband's kin. ${ }^{230}$

When in-laws have evicted them, tens of thousands of widows in South Asia migrate to urban centres where they live together in a bustee (squatter camp) ${ }^{231}$ or an ashram

225 Owen, 1999, Reports on Nigeria and India. Many women are ignorant of the rules, they cannot fill in a form and they cannot even sign their names.

226 UN doc. E/CN.4/2003/55, para. 51.

227 An Indian woman becomes the 'property' of her in-laws. They decide what to give her and how to treat her when her husband dies. Since her ties with her birth family have been severed, she is not free to return to her parental home. Owen, 1999, Report on India, p. 2.

228 See Owen, 1999, Report on Bangladesh, p. 1.

229 Remarriage is hardly ever an option for Hindu women since certain castes prohibit remarriage under Hindu Law, while it is taboo for the others. Only under exceptional circumstances (the widow is still a child or is very young and does not have any children) remarriage is a possibility. For Muslim widows the situation is different. The Koran even recommends remarriage, but only if the widow is very young or childless this is an option. Both Muslim and Hindu widows who want to remarry have in common that they may not chose themselves whom to marry. Marriage is more of a contract between families than between individuals. See: Owen, 1999, Reports on India and Bangladesh.

230 This is for example true in Zimbabwe where remarriage means that the ties to the deceased husband's relatives (including their own children) are severed completely, and the woman undergoes a total change of family relationship, identity and domicile. Owen, 1999, Report on Zimbabwe, p. 3. In India marrying away from the family (going for nata) has the same effect. Report on India, p. 3.

231 Bustees are found in Bangladesh where widows live in great squalor, constantly afraid of being evicted 
(widow city like Vrindavan in Northern India). Here they survive by working in the informal sector, begging, chanting temple hymns, or prostituting themselves. ${ }^{232}$

The fact that widows are denied access to land is most cynical when one realizes that rural women have a special attachment to the land and that they produce about $70 \%$ of the agricultural produce. ${ }^{233}$ For most women tilling the soil is the only 'work' they know, but when this is no longer an option, some women turn to other methods of sustenance to provide in their own livelihood and accommodation, like brewing beer or trading. Those who are educated may find remunerated employment.

\subsubsection{Empowering Widows}

Empowerment entails that women become aware of their situation and their rights, and that they can make their own choices as to how to solve their problems. ${ }^{234}$ Women should be viewed as active, responsible participants in society, but it is the State's duty to eradicate the obstacles that stand between them and the rights they are entitled to.

The most obvious step the State should take is to reform discriminating laws. ${ }^{235}$ Though equality before the law is no guarantee for equal treatment, and may remain a dead letter, it is imperative that the law bestows equality upon women so that they can have recourse to it to claim their rights. A logical next step is that governments see to it that the national law is implemented and enforced above and before personal laws and customs and traditions. ${ }^{236}$ Improvement of the living conditions of widows could be achieved by addressing family law, and especially inheritance and property law. ${ }^{237}$ It is imperative that women gain access to housing and land. The growing individualization

by the authorities. Owen, 1999, Report on Bangladesh, p. 1.

232 Owen, 1999, Reports on Bangladesh and India.

233 In Nigeria $80 \%$ of the women of 15 years and older are engaged in agricultural production. Owen, 1999 , Report on Nigeria, p. 3. In Mozambique $68 \%$ of the agricultural production is done by women. Owen, 1999, Report on Mozambique, p. 2.

234 'We understand empowerment to be a process that enables women to analyze their own situation, decide their priorities, develop solutions to their problems, and take collective action to improve various aspects of their lives. Empowerment goals view women as active subjects, determinants and agents, not as passive objects or pawns of social change.' See Bishakha Datta and Geetanjali Misra, 'Advocacy for Sexual and Reproductive Health: The Challenge in India', in: Reproductive Health Matters, Vol. 8, No. 16, November 2000, p. 29.

235 Most States already have committed themselves to do so under the obligations they have taken upon themselves when they became parties to human rights treaties. In the Women's Convention this commitment is specifically laid down in Article 2(f).

236 That this is no easy task becomes clear from the experience in India. A case in point is the Shah Bano case where Religious pressure groups succeeded in overruling the national law and a Supreme-Court judgment in favour of their personal laws. Shah Bano was a divorcee who, based on the Muslim personal law, was denied maintenance from her ex-husband, though the Indian Criminal Code and a Supreme Court ruling specifically stipulated that she was entitled to it. For further information see Radhika Coomaraswamy, 'To Bellow like a Cow: Women, Ethnicity, and the Discourse of Rights', in: Rebecca Cook (ed.), Human Rights of Women; National and International Perspectives, University of Pennsylvania Press, Philadelphia, 1994, pp. 53-54. Also Courtney Howland, 1999, p. 558 and Ayelet Shachar, Multicultural Jurisdictions; Cultural Differences and Women's Rights, Cambridge University Press, Cambridge, 2001, pp. 81-83.

237 Private law issues will be elaborated in section 5 of Chapter III. 
of societies, that so far seems to be only negative for women, could be turned into a positive aspect if it would mean that women, too, as a matter of course are entitled to equal parts of an estate as men. However, land reforms that have been introduced so far, should be reviewed with great caution. When individual titles are handed out, it will be the (male) head of the household or the (male) village eldest who will register the house and the land and, again, women tend to end up with nothing. ${ }^{238}$

Besides legal reforms, it is essential that States address the eradication of superstitious fears and harmful traditions pertaining to widows. All kinds of public information methods, such as school books, radio and television programmes, should be used to change attitudes. It must be made clear that widows cannot be held responsible for their husband's death, that they are not evil or threatening, but that they are human beings who are entitled to the enjoyment of their human rights, just like everyone else. Women's equal rights can only be realized when public opinion is convinced that they do indeed have these rights, and that any stereotyped ideas about women's position in society are archaic and should be eradicated.

Not just women, but whole communities and especially village elders and councils, should be enlightened about women's rights through government campaigns. Women's education, not only literacy but also income-generating skills, should be a priority. When they are more knowledgeable, women become less vulnerable, and it would be a good thing if they would become less dependent of the land. Access to legal remedies is of course always important, but in the case of these destitute, badly informed widows, the usual remedies will not work. Women are awed by the system and even if they would have the courage to seek justice in this way, they lack the necessary financial means. Therefore, alternative dispute resolutions should be sought. Preferably procedures involving already existing village or community councils. This would make remedies more easily accessible, cheaper and speedier.

Credit facilities are important to all women, but should especially be made available for projects of widows and other female heads of household who want to set up small income-generating businesses. ${ }^{239}$

\subsubsection{Concluding Remarks}

In some societies losing her husband may cause deplorable living conditions or even homelessness for a woman. Traditional views that value a woman only as a wife and a mother discard widows as useless and even potentially dangerous when there is no longer a man from whom they derive their status in society. The housing options that are open to widows lack all the core elements international law has ascribed to the concept of adequacy. Living on the streets as beggars and prostitutes, as unpaid domestic servants with in-laws or other relatives, being forced to remarry in order to secure a roof over their heads, or living in seclusion for the rest of their lives, widows are deprived of security and human dignity.

238 See Ellen-Rose Kambel, 'Mijn land of ons land', in: Nemesis, No. 5, 1999, p. 149. Also Desai, 1998, p. 53.

239 In Ghana income-generating projects are developed by CSOs that provide grants. Owen, 1999, Report on Ghana, p. 3. Also see section 3.2.3.4 on access to credit and loans. 
The way in which widows in the States concerned are being treated runs counter to legal obligations their governments have taken upon themselves. Besides setting aside constitutions, national provisions on equal treatment and access to resources and inheritance, also international obligations are ignored. All States mentioned are Parties to the Women's Convention, and it may be clear that several articles of this Convention are violated when women are denied property and land rights, are restricted in their mobility rights and suffer discrimination because of harmful traditional practices and stereotypical patterns. $^{240}$

\subsubsection{Domestic Violence}

\subsubsection{Introduction}

Domestic violence is a topic that is pertinent in the context of this chapter since it is the cause of homelessness of numerous women. ${ }^{241}$ Like widowhood, it is a gendered cause since men will hardly ever be forced to leave their home because they are being battered by their partner. Besides violating several other human rights, such as the rights to property, privacy, physical integrity, ${ }^{242}$ and sometimes even the right to life, domestic violence infringes women's right to housing since it renders illusory the basic aspects of living someplace in peace, security and dignity. ${ }^{243}$ Being (structurally) battered induces many women to leave their homes, thus becoming homeless and depending on their own resources or whatever help is available to them to find alternative housing, or risking their health and further abuse while living rough when no resources or help is on hand.

First, the concept and scope of domestic violence will be discussed. There are several types of this kind of violence, and it may take different forms. The type that is relevant here is woman or wife battering. It is the most widespread type of domestic violence and it is prevalent all over the world, both North and South, in all layers of society. The reason why this phenomenon is so pervasive will be explained when the most prevalent causes of domestic violence will be discussed.

Next, the reactions of States will be reviewed. After centuries of inattention, domestic violence has now been acknowledged as a violation of human rights with concomitant State responsibility. ${ }^{244}$ Many governments no longer look the other way, but actively

240 The articles that are particularly violated are Article 2, that condemns discrimination of women in all forms; Article 5 which obliges States to eradicate social patterns and stereotyped roles that perpetuate the inequality between the sexes; Article 14 which pertains to rural women and specifically stipulates their right to housing; and Article 16 that obliges States to eradicate discrimination in matters of marriage and family relations.

241 Domestic violence may also be the cause of inadequate housing if women do not leave the abusive relationship but for some reason or other decide to endure it or, if they do leave, they are unable to obtain adequate housing. These situations will be discussed in section 3.4 on inadequate housing.

242 Under certain conditions, domestic violence may even be equated to torture. See Theo van Boven and Sabina Puig, 'Domestic violence against women and torture', in: Ingrid Westendorp and Ria Wolleswinkel (eds.), Violence in the domestic sphere, Intersentia, Antwerp-Oxford, 2005, pp. 67-69.

243 Also, Giulia Paglione, Domestc Violence and Housing Rights', in: Human Rights Quarterly, Vol. 28, Number 1, February 2006, p. 126.

244 Domestic violence has not always been perceived as a human rights violation. For many centuries, inter- 
respond when women's rights are violated at home at the hands of private persons. Advantages and disadvantages of the different ways in which States respond to domestic violence will be reviewed with the aim of determining which actions will ameliorate the housing situation of battered women best.

\subsubsection{Concept and Scope of Domestic Violence}

Regardless of the level of development or the cultural or religious background, domestic violence seems to be ubiquitous in all countries of the world. ${ }^{245}$ The problem of domestic violence has long remained taboo and gender-based violence was not even covered by the Women's Convention. ${ }^{246}$ Both in national and international law it was regarded as a private or family affair, and its scope and seriousness were greatly underestimated. ${ }^{247}$ The adjective 'domestic' is not to be understood in a narrow way. It is not restricted to the home but it concerns the domestic sphere of the victim and thus encompasses permanent residences but also shelters, refugee camps, asylum-seeker centres or any other form of temporary housing. ${ }^{248}$ Perpetrators may be parents, husbands, wives, in-laws, children, house friends, superiors, or any other person who has an intimate relationship with the battered person. Victims may be children, women, men, parents, the elderly, the sick, the disabled, subordinates or any other person in a more or less dependent relationship. The most prevalent of all these abusive relationships is, however, a man abusing his wife or female partner, ${ }^{249}$ since this is common both in rich and poor countries, irrespective of culture, development or societal class. ${ }^{250}$

national law only occupied itself with the acts of States. Therefore, the only violence that could be dealt with under international law, was violence between States or inflicted by States upon their subjects. Violence occurring in the home was considered to be a private matter, falling outside the scope of international law. See e.g. Hilary Charlesworth, Christine Chinkin, \& Shelley Wright's article 'Feminist Approaches to International Law', in: American Journal of International Law, Vol. 85, 1991, pp. 613-645, in particular p. 627. Issues of State responsibility will be discussed further in section 4.6 of this study.

245 Cheryl Thomas, 'Domestic Violence', in: Kelly D. Askin, Dorean M. Koenig (eds.), Women and International Human Rights Law, Vol. 1, 1999, p. 219. Also Rhonda Copelon, 'Intimate Terror: Understanding Domestic Violence as Torture', in: Rebecca J. Cook (ed.), Human Rights of Women; National and International Perspectives, University of Pennsylvania Press, Philadelphia, 1994, p. 117. Also $U N$ doc. E/CN.4/1995/42, Preliminary report submitted by the Special Rapporteur on Violence Against Women, paras 120-121.

246 Meanwhile, this has been mended by the adoption by CEDAW of General Recommendation No. 19 on Violence Against Women, UN doc. A/47/38, 1992.

247 Hilary Charlesworth and Christine Chinkin, The boundaries of international law; A feminist analysis, Manchester University Press, Manchester, 2000, p. 12. See section 4.2 on international public law and gender; normative and strategic issues.

248 Radhika Coomaraswamy, Lisa M. Kois, 'Violence Against Women', in: Kelly D. Askin, Dorean M. Koenig (eds.), Women and International Human Rights Law, Vol. 1, 1999, p. 185.

249 Rhonda Copelon, 1994, p. 120. Also, Radhika Coomaraswamy, Preliminary report submitted by the Special Rapporteur on Violence Against Women, UN doc. E/CN.4/1995/42, para. 118.

250 Research in the Netherlands into the risk factors has shown that woman battering cannot be linked with any specific social class. Comparison with other countries indicates that the situation in this country fits in the general picture. Renée Römkens, 'Geweld in de Huiselijke Sfeer', in: I. Boerefijn, M. van der Liet-Senders, T. Loenen (red.), Het voorkomen en bestrijden van geweld tegen vrouwen; Een verdiepend onderzoek naar het Nederlandse beleid in het licht van de verplichtingen die voortvloeien uit het Vrouwenverdrag, Ministerie van Sociale Zaken en Werkgelegenheid, Den Haag, juli 2000, p. 111. 
The UN Centre for Social Development and Humanitarian Affairs has defined domestic violence as:

'[...] the use of force or threats of force by a husband or boyfriend for the purpose of coercing and intimidating a woman into submission. The violence can take the form of pushing, hitting, choking, slapping, kicking, burning or stabbing., ${ }^{251}$

Besides physical mistreatment 'violence' may also consist of psychological abuse like uttering threats to harm either the woman herself, her children or other relatives, using abusive language, humiliating or belittling women, also in front of others, and thus undermining their self-esteem. ${ }^{252}$ In this study the term domestic violence will be understood as woman battering.

\subsubsection{Causes of Domestic Violence}

The Special Rapporteur on Violence Against Women has enumerated several causes that have been analysed by the United Nations. These include alcohol and drug-abuse and/ or an abusive childhood of the perpetrator, provocative behaviour of the victim, economic and social factors among which inadequate housing, cultural factors and structural inequality. Inadequate housing conditions, induced by unfavourable economic circumstances, or overcrowded living spaces, trigger violent behaviour because they cause stress and frustration. However, since woman battering also takes place in well-to-do families, inadequate housing is not considered so much as a cause, but rather as an aggravating factor for domestic violence. The same holds true for alcohol and drug abuse or the psychological predisposition of the perpetrator. ${ }^{253}$

What is considered to be the most important cause of domestic violence is the perception of women as subordinate to men. Unequal power positions facilitate men's dominance and lead to discrimination against women. ${ }^{254}$ Culture perceives a man to be

In the Netherlands it is estimated that every year 40 children die because of child abuse, whereas the number of women who die of the consequences of domestic violence is believed to be between 60 and 80. Child abuse seems to occur more frequently (though certainly not exclusively) in the socio-economic weaker sections of society. Partij van de Arbeid, Stop Huiselijk Geweld!, Manifest aangeboden aan de Minister van Justitie en de Minister van Binnenlandse Zaken op 9 mei 2000.

251 United Nations Centre for Social Development and Humanitarian Affairs, Strategies for Confronting Domestic Violence: A Resource Manual 7, 1993, UN doc. ST/CSDHA/20. It is to be noted that neither CEDAW General Recommendation No. 19 on violence against women, nor the UN Declaration on Violence Against Women contain a definition on domestic violence. The definitions that are used in these two documents refer to violence against women in general.

252 For a recount on several kinds of physical and psychological abuse common in the framework of domestic violence see Rhonda Copelon, 1994, pp. 122-126.

$253 U N$ doc. E/CN.4/1995/42, para. 119.

254 Cheryl Thomas, 1999, p. 249. Renée Römkens, 2000, p. 119. Rhonda Copelon, 1994 at p. 121, where she points out that most studies of domestic violence come from modern countries that are supposed to have done away with patriarchal systems like the US and the UK. Coomaraswamy concurs with the view that the male patriarchal ideology is the main cause for domestic violence in her report of 10 March 1999, UN doc. E/CN.4/1999/68, para. 31. 
the king of the castle, practically untouchable within his own four walls. ${ }^{255} \mathrm{He}$ is the usual breadwinner and in return he may expect his wife to carry out certain duties. If she fails to carry them out properly, or if she rebels against this unequal power position, it is thought that she might expect him to become violent. In many parts of the world the woman herself is blamed if she is being battered. It is believed that she must be a bad wife, because men do not beat for nothing. ${ }^{256}$

\subsubsection{State Reactions}

After ages of non-interference some States have taken up their responsibility and give attention to domestic violence. ${ }^{257}$ Especially during the last three decades, State interference has increased. States respond in several ways. Basically, a distinction can be made between criminal law measures, civil law measures, and administrative law measures. In most countries also relief services may be found for both victims and perpetrators, but these may also be initiated and financed by non-State actors. The different actions and measures are not strictly divided, but rather they exist side by side and complement each other.

\subsection{Criminal Law Measures}

In the criminal law sphere, domestic violence may be treated as a separate criminal offence ${ }^{258}$ or it may be brought under another, more general crime, like assault or abuse. ${ }^{259}$ The advantage of making domestic violence a separate offence is that it stresses its importance and that it emanates a clear signal that battering is regarded as unacceptable and serious. Many States, however, treat domestic violence as a form of assault or abuse which clouds the specificities of domestic violence, especially the intimacy between victim and perpetrator and the intimate sphere in which the battering takes place. Either way, if perpetrators are structurally prosecuted and punished the message will come across that the State does not tolerate this form of violence and it may deter men from attacking their partners. In some States arrest and (temporary) detention of the perpetrator is seen as the best action against domestic violence especially since it provides the woman with immediate safety and gives her some breathing space. ${ }^{260}$

255 Rhonda Copelon, 1994, pp. 132-133.

256 Very insightful in this regard is a report carried out by Human Rights Watch in Uzbekistan, entitled: Sacrificing Women to Save the Family; Domestic Violence in Uzbekistan, HRW Publications, Vol. 13 No. 4(D), July 2001. Particularly pp. 15-18.

257 For a discussion on State responsibility see section 4.6.

258 According to UNICEF 44 countries, including Argentina, Bangladesh, Brazil, Canada, China, Czech Republic, Denmark, France, Guatemala, Israel, Malawi, Mexico, New Zealand, South Africa and Tunisia, have specific legislation against domestic violence. For a complete overview see <www.unicef.org/ pon97/le4to48.htm>, last visited 20 December 2005.

259 This is the case in the Netherlands where the Criminal Code does not include a specific provision on domestic violence. See Römkens, 2000, p. 135 and Ministerie van Justitie, Project voorkomen en bestrijden 'huiselijk geweld'; plan van aanpak, Den Haag, 14 februari 2001, pp. 7-8.

260 This policy is for instance predominant in Australia, Canada and the United Kingdom. UN doc. E/CN.4/ $1995 / 42$, para. 128 
There are many examples of States, however, where criminalization does not work out well. In the first place, victims complain about police attitude. Despite the fact that domestic violence can be brought under or is included in the Criminal Code, the police may agree with public opinion which in many cases still is that woman battering is a family affair and that the authorities should not interfere. Especially in traditional societies where it is felt that the break-up of a family is to be avoided at all cost since it is shameful and contrary to custom, the police may be highly reluctant to respond to domestic violence incidents and if they do, they try to mediate and persuade the victim not to press charges rather than arrest the batterer. ${ }^{261}$ A positive example of police attitude may be found in Brazil, where special women's police stations have been created that deal exclusively with domestic violence. ${ }^{262}$

It is also possible that, a procedural distinction is made between assault committed by a stranger and by an intimate. In the first case, the crime is regarded as grave and the perpetrator, if known, will be prosecuted. In the latter case, however, the crime may not be regarded as a serious offence but merely as a lovers' tiff. ${ }^{263}$ Mostly, prosecution will only take place if the victim has lodged a complaint. ${ }^{264}$ Information by relatives or other witnesses may not result in an investigation. ${ }^{265}$ Subsequently, the case will be closed when the complaint is withdrawn. ${ }^{266}$ Furthermore, domestic violence may be an 'excusable'

261 In a survey on the status of women throughout the entire Central and South-Eastern European region the following examples have been documented. In Belarus family conflicts are one of the most common reasons why the police are called, but their role is rather limited If a violent husband is arrested it is mostly on grounds of drunkenness, hooliganism or resisting a police officer (p. 76). In Croatia the police call incidents of domestic violence 'kitchen violence'. Usually they do not intervene, but tell the victim that she asked for it or that it is her choice to stay (p.130). In Hungary the police do not intervene unless blood is spilled, i.e. when injuries are life threatening or the victim is dead. The same is said to be true for Lithuania and Slovania (pp. 206, 288 and 421 respectively). In Moldova the police often accept the men's excuse that his wife provoked him and take no further action (p. 318). Persuading the victim to drop the charges is often experienced in Turkey ( p. 455). International Helsinki Federation for Human Rights, Women 2000, An Investigation into the Status of Women's Rights in Central and South-Eastern Europe and the Newly Independent States, Agens-Werk, Geyer \& Reisser, Vienna, Austria, 2000.

262 The first woman's police station was established in Sao Paolo in 1985. In 1996 there were already 152 of such stations all over the country, with a heavy concentration in Sao Paolo (124). Nevertheless the bulk of domestic violence cases is still dealt with by regular police stations. Report on the mission of the Special Rapporteur on Violence Against Women to Brazil, UN doc. E/CN.4/1997/47/Add. 2 of 21 January 1997 , paras $47-50$

263 The reasoning may be that after all family members love each other and will never seriously harm each other. Moreover, the (female) victim is often blamed as much as the (male) perpetrator, and in police reports they may speak about a 'violent couple'.

264 Often, this complaint must be backed up with testimonies by witnesses, and extensive medical and forensic evidence.

265 Though in some countries it is possible or even compulsory that in cases of suspicion of child abuse, others such as relatives, physicians, teachers, and neighbours report this to the police, this is nowhere possible as regards woman battering. Reporting suspicion of child abuse is compulsory in the USA, while in the Netherlands, reporting takes place on a voluntary basis. However, the willingness to report child abuse is not very great in the Netherlands because people respect each other's right to privacy and are reluctant to interfere in family situations. See Jan Willems, Wie zal de Opvoeders Opvoeden? Kindermishandeling en het Recht van het Kind op Persoonswording [Who will educate the educators? Child abuse and the right of the child to become a person], T.M.S. Asser Press, The Hague, 1998, pp. 545-554, particularly on p. 546.

266 Examples may be found in Albania, Armenia, Bulgaria, Czech Republic, and Lithuania. Women 2000, pp. $30,45,115,148$ and 288 respectively. 
offence which entails that even when proceedings have already started, all charges will be dropped if the victim 'forgives' the perpetrator. ${ }^{267}$ Under these circumstances, it is understandable that the police are reluctant to put much time and effort in domestic violence cases since all their work may have been in vain when the victims decides, or is coerced, to back out. ${ }^{268}$

A complicating factor is of course, that the offence takes place in a private place, where police action is limited. Though the right to privacy is a much-desired guarantee against State interference, it is also an instrument in the hands of the abusive man at the expense of the woman (and children). ${ }^{269}$

If a case is tried in court, judges may pass a much more lenient judgment in cases of domestic violence than they would do in similar cases of assault by a stranger. Oddly enough, instead of an aggravating factor, battering by an intimate may be seen as an attenuating factor ${ }^{270}$ In particular, the 'honour defence' may be accepted as a mitigating circumstance. ${ }^{271}$

In addition, a major drawback of criminalization in general is that the whole family may suffer financially if a man is arrested or fined for his crime. Usually, the man will be the main breadwinner and when he is incarcerated, the family income is dramatically reduced. If he is fined, the money that has to be paid will come out of the housekeeping allowance.

In the USA criminalization also has another, unintended but serious, side effect on the situation of the family when the couple lives in a subsidized rented house. If a man has a history of domestic violence, the whole family may be evicted. Thus the woman (and children) is two times victimized; not only has she been battered, but she is also rendered homeless. ${ }^{272}$

267 For instance in Romania reconciliation with the husband (which often occurs under pressure) exonerates him from criminal responsibility. Women 2000, p. 361.

268 This point is made by the Czech and Ukraine police. Women 2000, pp. 148 and 487.

$269 U N$ doc. E/CN.4/1995/42, para. 127. Also see section 3.6.4 on the right to privacy.

270 I would have expected that to be the other way around since maltreatment by intimates surely is the ultimate betrayal and must make a person lose all hope. Causing grievous bodily harm to one's child, mother, father or partner is for instance seen as more serious, deserving a higher penalty than when this crime is committed by a stranger in the Netherlands. Netherlands Criminal Code, Article $304 \mathrm{j}^{\circ}$ Articles $300-303$.

271 This is particularly true for countries in Eastern Europe, South East Asia and Latin America. Cheryl Thomas, 1999, pp. 228-230. Also Ineke Boerefijn, 'Domestic violence against women in international human rights law', in: Ingrid Westendorp and Ria Wolleswinkel (eds.), Violence in the domestic sphere, Intersentia, Antwerp-Oxford, 2005, pp. 40-42.

272 In several States of the USA, inter alia Oregon, California, Colorado, Louisiana, Massachusetts and Michigan, subsidized-housing policies have been developed that provide for affordable housing to lowincome groups. To be eligible for such a housing subsidy, people have to meet with certain criteria. These include that no member of the family must have a history of criminal activity, disturbing the neighbours, or destroying property. The aim is to make housing in subsidized buildings for all tenants as safe as possible. The result is, however, that when one of the members, behaves violently, the whole family may be evicted. Eviction is possible even if the tenant was not actually arrested or convicted. In this way not only the perpetrator, but the victims of domestic violence are rendered homeless as well. Moreover, once one has been evicted it is very difficult to qualify for future housing programmes. See Robin Hammeal-Urban and Jill Davies, Building Comprehensive Solutions to Domestic Violence, Publication \#6, A Policy and Practice Paper, Federal Housing and Domestic Violence: Introduction to Programs, Policy and Advocacy Opportunities, http://www.vaw.umn.edu/FinalDocuments/fedhouse.asp, 


\subsection{Civil and Administrative Law Measures}

Instead of, or in addition to criminal law measures, many States try to find solutions for domestic violence cases in civil or administrative law. In some States civil or administrative law judges may order injunctions or interdicts stipulating for example that the batterer may not have any contact with his partner, or that he may not enter the house, the street or the neighbourhood where the house is situated. Usually, these orders only concern a limited period of time while in the meantime a solution may be sought in the form of reconciliation or separation of the couple.

The advantage of such measures is that the violence stops and that the couple has time to work out a solution, but the offender is not arrested with all the disadvantages connected to falling foul of the police. ${ }^{273}$ Nevertheless, the perpetrator has to leave the house, while the victim (and their children) can remain in the family home.

An interesting new policy that up till now has only been adopted by a few States, is to provide for eviction of the perpetrator from the family home. Argentina, Austria and Germany, are examples of States where such legislation is already working. ${ }^{274}$ While the police can evict the perpetrator for a short period, the victim may request for a civil law order that compels the perpetrator to vacate the premises on a more permanent basis. If a victim wishes to do so, she is permitted by law to stay in the family home (whether the house is rented, or the property of the couple, or even of the husband alone) at least until another solution has been found, while the husband will be evicted. ${ }^{275}$ Some women will have too many bad memories and will prefer to leave, but if a victim is mentally up to it, it seems appropriate that the victim should stay in the family home while the perpetrator should seek lodgings elsewhere. Besides the moral justice aspect it is also a pragmatic solution. In general, men have more financial means at their disposal than their partners so they will sooner be in a position to find adequate alternative housing while it is also easier to find housing for just one person than for several persons. Moreover, this solution seems to be better for the children; they are not uprooted, but

consulted on 28 August 2001. Also Tamar Lewin, Zero-Tolerance Policy Is Challenged, The New York Times, 11 July 2001.

273 An obvious disadvantage of arrest is its stigmatizing effect. Katinka Lünnemann, 'The legal arrangement of eviction', in: Ingrid Westendorp and Ria Wolleswinkel (eds.), Violence in the domestic sphere, Intersentia, Antwerp-Oxford, 2005, p. 145.

274 The Austrian law is called the Bundesgesetz zum Schutz vor Gewalt in der Familie [Federal law to protect the family against violence] which entered into force in 1997 and was reformed in 2000 and 2004. On the Argentinean legislation see $U N$ doc. E/CN.4/1999/68, Report by the special Rapporteur on Violence Against Women, para. 74. The German law is called the Gewaltschutsgesetz (Gesetz zur Verbesserung des zivilgerichtlichen Schutzes bei Gewalttaten und Nachstellungen sowie zur Erleichterung der Überlassung der Ehewohnung bei Trennung) [Private law act to protect against acts of violence and threats thereof and measures to make it easier to turn over the marital home in cases of separation or divorce] that entered into force on $1^{\text {st }}$ January 2002. In the Netherlands the Labour Party (Partij van de Arbeid) has requested the Government to introduce a similar law. See Manifest Stop Huiselijk Geweld! [Stop Domestic Violence!], Report submitted to the Netherlands Minister of Justice and the Minister of Internal Affairs on 9 May 2000.

275 While police eviction orders will not extend a period of ten days, civil law eviction in Austria is three months with a possible extension of three months, and in Germany, depending on who owns the house or whether it is rented, the maximum term is six months or indefinite. See Lünnemann, 2005, pp. 148-149. 
they can stay in their own familiar surroundings where they have their friends and where they go to school.

An obvious problem with this measure is that many women are afraid to remain in a place so well known to their (former) partner. They may feel like sitting ducks, especially if they have already experienced ongoing harassment. The eviction of the batterer may of course be accompanied by injunctions against the perpetrator, but since the victim will not receive around the clock police protection these may prove to be ineffective if the offender is revengeful and returns to the home, street or neighbourhood to harass his (former) partner.

A major advantage of civil/administrative law measures is that the batterer is not incarcerated or fined so that he can continue to earn money and be ordered to pay maintenance and/or contribute to the housing costs of his (former) partner and children.

Finally, in many States domestic violence is downplayed and left out of family law legislation. In my opinion, however, it is in the interest of women's right to adequate housing that domestic violence should be made a reason for divorce

\subsection{Relief Services}

As has been mentioned before, in some States domestic violence is still primarily looked upon as a private matter the couple, or more specifically the woman, has to cope with. ${ }^{276}$ That is why in addition or prior to legal options the police or local authorities, but also CSOs like churches, may provide for mediation and conciliation services. ${ }^{277}$ States often take measures to help and protect the victim, including the provision of maintenance, and counselling services for the survivors of abuse. ${ }^{278}$

When alcohol or drugs abuse are considered to be the cause of the violent behaviour, or when the batterer is suspected to have a violent predisposition, in some States the abuser is offered counselling and treatment. ${ }^{279}$

In many States, battered women have the option to go to shelters. Not all shelters are financed by the State, however, and in almost every country in the world there is a great shortage of such safe houses. ${ }^{280}$ A great advantage of the shelter system is that the victim

276 That domestic violence is still viewed as a private family problem that must be solved by the woman herself becomes for instance clear from the investigation that was carried out by the International Helsinki Federation for Human Rights (IHF) in 29 central and south-eastern European countries and published in: Women 2000; An Investigation into the Status of Women's Rights in Central and SouthEastern Europe and the Newly Independent States, IHF, Agens-Werk, Geyer \& Reissen, Vienna, 2000.

277 In countries like Egypt, Greece, Malaysia, Nigeria and Thailand the police officers try to conciliate and dissuade the victims to take legal action. Cheryl Thomas, 1999, p. 222. In Uzbekistan cases of domestic violence are first and foremost dealt with by the mahalla, a form of local government. The chairperson of the mahalla will form a reconciliation commission with the objective to eliminate the need for legal action in what is considered a family affair. Victims may be subjected to conciliation attempts for months, or even years, before they are 'allowed' to go to the police or to divorce. See Sacrificing Women to Save the Family; Domestic Violence in Uzbekistan, 2001, pp.19-23.

278 Cheryl Thomas, 1999, p. 239.

279 UN doc. E/CN.4/1995/42, paras 123-142.

280 Many of the shelters are financed by national or international CSOs. The shelters in the Netherlands, for instance, were initially established by the churches and by the 'Blijf van mijn lijf' foundation, a national women's CSO. Meanwhile, however, the (local) government is now financing most of the shelters. Römkens, 2000, p. 139. The only shelter that is available in Bulgaria is run by NOVIB, a Dutch CSO. 
can escape the violence at home. However, there are also several disadvantages. First of all, the woman (and her children) has to leave her familiar surroundings. Although it seems to be generally accepted that in cases of domestic violence it is the victim who should leave, in my opinion it is rather inappropriate that the batterer is allowed to stay comfortably in the family home, while his victim has to find accommodation in a shelter. In the second place, most shelters provide for inadequate housing conditions. They are usually cramped, uncomfortable and they lack privacy. Moreover, there may be security issues. In some States it is quite easy to get hold of the addresses of safe houses and consequently some women are threatened, harassed and abused by their (ex-)partners who track them down. ${ }^{281}$

\subsubsection{Concluding Remarks}

Domestic violence has an enormous impact on women's right to adequate housing. Home is supposed to be a sanctuary; a safe haven where the family lives in peace and security and where outside interference is unwanted. For many women, however, life at home may be even more dangerous than living in the streets. In view of their disadvantaged socio-economic position many women who break-up an abusive relationship run the risk of becoming homeless, or dependent on relatives or State services, maybe even for the rest of their lives.

In recent times international law recognizes domestic violence as a human rights abuse and under certain conditions States have to take responsibility for the acts of the abusive partners. ${ }^{282}$ If domestic violence is to be eradicated as the cause of homelessness for thousands of women, the best option is to relinquish traditional laws and stereotypical views as regards women's subordinate role in family and society, and improve women's socio-economic position. This requires a change of mentality, not only of ordinary women and men, but also of police officers and members of the judiciary. This is of course no easy task. Information, including the media and education, encompassing human rights education, are good but slow instruments. Meanwhile other, more short-term measures should be taken that give a clear signal that domestic violence is not tolerated by the State. When the government strongly condemns the practice of domestic violence, this will influence public opinion.

Perhaps the clearest signal of disapproval is making domestic violence a separate criminal offence for which perpetrators are consistently prosecuted and punished. However, though this may be the best response in situations where the abuse is so serious and structural that it is life-threatening, on the whole, it is more in the interest of women's right to adequate housing if measures are implemented in the private or administrative law sphere.

Women 2000, p. 116. In Albania there is just one shelter, situated in Tirana and financed by a Women's CSO. Women 2000, p. 30. In Lithuania there are 5 shelters, 2 of which are financed by the Government. Women may stay there up to 6 months. Women 2000, p. 289. In Russia there are shelters in St. Petersburg and in several provincial cities, but none in Moscow. Women 2000, p. 382. In Tajikistan there are no shelters at all. Women 2000, p. 437.

281 On the adequacy of shelters see section 3.4.5.1 on battered women.

282 See section 4.6 on State responsibility. 
States should start with acknowledging women's equal and individual right to live in adequate, safe and private housing conditions. In what form protection against domestic violence is offered should depend on the circumstances and the victim's needs and wishes. Interdicts and eviction orders seem to guarantee women's housing rights best since the victim can continue to live in the family home while the perpetrator has to find accommodation elsewhere but is still able to earn an income and support her. This may prove to be a good solution in the Western world. However, in the great majority of the States, and for that matter, in the great majority of the cases where women wish to separate from their partners because of abuse, victims will be unable to remain in the family home. Besides the fact that the battered woman may feel vulnerable at the place where she used to be battered and susceptible to renewed attacks, in many cultures, the family home will be the man's or the in-law's property and it will never be given up to the victim of battery. That is why it is in most cases more important that all kinds of relief services should be available including first and foremost adequate and safe shelters. Furthermore, domestic violence should be listed in the civil law code as a reason for divorce and entitlement to alimony, should a woman be in need of financial support.

Some actions, such as conciliation programmes and policies that aim at dissuading or preventing women from taking domestic violence cases to court in order to keep families together, should be avoided because they sustain serious violations of women's human rights including their right to housing. These measures fail to recognize the gravity of the situation and allow the traditional subordination of women to perpetuate. Moreover, conciliation is based on the presupposition that there are two conflicting parties that are to blame and that have to give in to make a peaceful co-existence possible. In domestic violence situations, however, there is just one party to blame, since there is no excuse for violent behaviour. Women do not 'deserve' being battered.

\subsection{INADEQUATE HoUSING}

\subsubsection{Introduction}

It is the object of this section to determine what is meant by the concept of adequate housing and to find out what adequacy means to women and in which ways they may be inadequately housed. In the framework of the United Nations several organs, and especially the Committee on Economic, Social and Cultural Rights, have interpreted the meaning of adequate housing. It has been agreed that several elements must be fulfilled before housing can be called adequate. In the following these elements will be scrutinized and applied to women's situation. It will also be explored whether there are other, additional elements that should be fulfilled in accordance with women's perception of adequate housing. Furthermore, it will be discussed if, and to what extent, inadequate housing conditions have different consequences for women in comparison to men especially in view of the gendered division of work.

Under the heading of security and autonomy, in the last part of this section, the housing situation of particular groups of women will be reviewed who are not safe in the place where they live or whose housing situation depends on others. Some of these 
women are actually homeless, but instead of living in the streets, they have found shelter in some way or other. The reason why these groups of women are discussed here is that living in shelters is their day to day reality and their temporary housing should meet a certain standard of adequacy as well. Consecutively, attention will be paid to battered women both those living in abusive households and those living in safe houses; single women, divorcees and widows who completely depend on others for their accommodation; women migrant workers who live in with their employers; and female refugees and internally displaced women who live in camps and shelters.

\subsubsection{Defining Adequacy}

Since the 1980s, UN organs have further determined the meaning of adequate housing. The General Assembly has stated that housing is adequate when such elements are fulfilled like privacy, space, security, lighting and ventilation, basic infrastructure and facilities, and a convenient location. Moreover, all of these elements should be affordable. $^{283}$

The Committee on Economic, Social and Cultural Rights elaborated on this basic idea of adequacy in its General Comment No. 4 on adequate housing. Since the Committee's analysis of the constituent elements of housing has already been discussed in section 2.4, I merely recapitulate here that according to the CESCR adequacy consists of: legal security of tenure; availability of services, materials, facilities and infrastructure; affordability; habitability; accessibility; location; and cultural adequacy. It must be noted that the Committee has pointed out that although the adequacy is partly influenced by the social, economic, cultural, climatic, ecological or other circumstances, all the elements of the right must be taken into account irrespective of the particular context. ${ }^{284}$

During Habitat II, the participating States reaffirmed that adequate housing means much more than having a roof over one's head. They agreed that adequacy consists of privacy, space, physical accessibility, security, security of tenure, structural stability and durability, lighting, heating and ventilation, basic infrastructure, especially water-supply, sanitation and waste-management facilities, suitable environmental quality and healthrelated factors, and an accessible location with regard to work and basic facilities. It was also reconfirmed that all these elements should be available at reasonable costs. Room for differentiation of adequacy was left as regards economic development, cultural and social patterns and environmental circumstances. ${ }^{285}$

Living someplace in peace, security and dignity is considered to be the basis of the right to housing. ${ }^{286}$ This is understood as being free from harassment by the outside world, be it the government or third parties. Particularly in the context of forced evictions, the element of security plays an important part.

$283 U N$ doc. A/43/8/Add. 1, Global Strategy for Shelter to the Year 2000, 1988.

284 CESCR General Comment No. 4 on adequate housing, UN doc. E/1992/23, para. 8.

285 The Habitat Agenda, Chapter IV, Global Plan of Action: Strategies for Implementation, under B. Adequate shelter for all, para. 60 .

286 CESCR General Comment No. 4, para. 7. 
A right that is closely linked to the right to housing is the right to liberty of movement and residence. It is generally recognised that people are free to move and choose their own residence. This includes the right of refugees and internally displaced persons (IDPs) to return to their former homes. ${ }^{287}$

All elements of adequacy are of course important for both women and men. However, for women it is more difficult to obtain and maintain adequate housing. Furthermore, inadequate housing has a greater effect on women since, on average, their lives are more home-centred and they take care of the majority of household chores. ${ }^{288}$ Lastly, there are certain factors that influence the adequacy of living conditions of women more or differently than men.

That is why I think that whether, and to what extent a woman is adequately housed is determined by three sets of elements: her socio-economic position, the technical quality of her housing situation and, the security, autonomy and dignity she enjoys at home.

Women's (subsidiary) role in society directly influences their affordability and accessibility of housing and land, and their ability to obtain legal security of tenure.

Technical and infrastructure aspects determine the habitability of a home and the access to basic facilities and services. If something is wrong with these aspects this will cause health problems particularly, though not exclusively, for women, and it will make women's lives harder because due to the gendered division of work, it is women who have to put more effort in coping with household chores and other gender determined tasks.

For women security inside the home, i.e. being free from domestic violence and harassment is one of the main factors that determine the quality of living conditions. Another important factor is the dependency many women experience. Dependency creates insecurity as regards housing tenure since it is up to other people to decide whether the woman will be privileged to stay someplace or whether she has to go. Sometimes this lack of autonomy forces a woman to remain in an abusive situation, or it means that she has to live under the roof of others where she knows no privacy or has no control over how she is housed. Linked to dependency is the restriction of women's freedom of residence. In some societies, particularly those that know arranged marriages in combination with female exogamy, women cannot choose where they settle down.

The general (in)ability of women to gain and retain housing is dealt with in other parts of this study. ${ }^{289}$ In this section it will be analyzed what the element 'adequate' in the concept of adequate housing entails for women who actually do have a roof over their heads but this roof is deficient, or temporary, or belongs to someone else.

287 Article 13 of the Universal Declaration of Human Rights states that: '[...] Everyone has the right to freedom of movement and residence within the borders of each State' and [...] Everyone has the right to leave any country, including his own, and to return to his country'.

Article 12 of the Covenant on Civil and Political Rights reads: (para. 1) 'Everyone lawfully within the territory of a State shall, within that territory, have the right to liberty of movement and freedom to choose his residence.' (para. 2) 'Everyone shall be free to leave any country, including his own' and, (para. 4) 'No one shall be arbitrarily deprived of the right to enter his own country'.

288 Andrew Byrnes, 'Enforcement Through International Law and Procedures', in: Rebecca J. Cook (ed.), Human Rights of Women; National and International Perspectives, University of Pennsylvania Press, Philadelphia, 1994, p. 194

289 Particularly the sections on poverty (3.2), private law issues (3.5), human rights issues (3.6) and structural discrimination inherent in cultural patterns (3.7). 


\subsubsection{Affordability and Accessibility}

Obviously, the socio-economic position influences the degree to which a person is able to have access to and to enjoy all kinds of economic and social rights. The low social esteem in which many women are held explains their subordinate position in the family and in society. Why they do not get the same education as men do, why they get no or a lesser portion of the inheritance, why they are denied property rights, why their work is not valued very high, why they have little political and decision-making influence, and so on. This inferior position has severe repercussions for the financial situation of women. Poverty under women is widespread, and in the end having no or inadequate housing often boils down to pecuniary distress. For women the affordability of housing is even more precarious than for men. As has already been pointed out in the context of evictions, ${ }^{290}$ even in affluent, developed countries, women become homeless or inadequately housed because the costs of housing are too high. Affordability should therefore be carefully considered from a gender perspective. The average income of women is lower than the average income of men. That is why in general women, and especially female heads of household, will sooner be unable to afford adequate housing than men should the costs of housing be raised. A structural, long-term solution would be an overall increase of women's income to a level equal to that of men. This will take a long time, however, since it requires the abolition of gender discrimination. In the meantime, there are two short-term solutions. States could bring and/or keep the costs of housing at such a level that it is proportionate with women's average income, and/or they create a safety net in the form of housing subsidies for those women who are unable to afford adequate housing. Both of these short-term measures have their disadvantages, though. Lowering the costs of housing so that they are affordable for the average woman maintains the existing income gap between women and men, while creating a financial safety net perpetuates women's dependency for their housing situation albeit this dependency would be on the State rather than on private persons which in my opinion is slightly better. If, however, a large number of women would require such financial support, the costs of housing are obviously too high.

Accessibility may be improved by abolishing discriminatory legislative and customary rules that deny women equal access to property and land. ${ }^{291}$

\subsubsection{Technical and Infrastructure Deficiencies}

Inadequacy of housing may be caused by material circumstances. The construction of the house may be deficient so that climatic influences cannot be kept at bay or the available space is too small to house the number of people who have to live in it. Basic facilities like running water, electricity, sewage, and garbage collection may be lacking. Roads and public transportation may not be up to standard, and the location is inconvenient because there are no schools, day-care centres, shops or hospitals in the neigh-

290 See section 3.3.2.4 on evicted women.

291 Further details are discussed in sections 3.5.2 and 3.6.3 on access to property and land. 
bourhood, or the location is dangerous because it is disaster-prone or in the vicinity of dumps of garbage or toxic wastes or open sewers.

All these deficiencies that reduce the quality of housing hit women harder than men because women do the majority of household chores, whether they also have a (remunerated) job on the side or not. That is why they spend more time there and thus are confronted with unhealthy circumstances or inconveniences more often and during longer periods. Their health is impaired and/or coping with household chores becomes such an arduous task that it can only be fulfilled to the detriment of women's well being.

First a description is given of the specific health problems that women acquire if the habitability of their home is of poor quality. Next the difficulties will be discussed that are encountered by women if the infrastructure is deficient. Finally, the consequences of an inconvenient or dangerous location will be looked into.

\subsubsection{Habitability and Health Problems}

Health problems that are caused by inadequate housing conditions are undoubtedly more prevalent in poor, developing States. Still, poor sections of society in developed States may also suffer from health conditions that can be directly linked to their housing situation. ${ }^{292}$

In cold and humid climates, poor families may not have enough resources to heat the house properly. When a house is too cold, damp or mouldy, this may cause musculoskeletal diseases like rheumatism, but also respiratory diseases like chronic bronchitis, asthma and pneumonia. ${ }^{293}$

Particularly in developing countries, there is a fuel shortage and women will try to obtain low budget fuels, like wood, dung, and agricultural residues to cook their meals. When ventilation is poor, the indoor smoke fires that result from these burning materials are another important cause of respiratory diseases. ${ }^{294} \mathrm{~A}$ step up the fuel ladder is kerosene oil and liquid petroleum gas. Ironically, however, these more expensive fuels produce toxic smoke that contains carcinogens and carbon monoxide and therefore are not really healthier. ${ }^{295}$

292 The European branch of the World Health Organization (WHO) has a specific programme on Housing and Health, called LARES (Large Analysis and Review of European housing and health Status) is aiming at a comprehensive understanding of housing and health. See: $<$ www.euro.who.int/Housing/ activities/20020711_1>, last consulted at 2 December 2005.

293 EUR/04/5046267/BD/1, Review of evidence on housing and health, WHO Europe, Fourth Ministerial Conference on Environment and Health, Budapest, 23-25 June 2004, Background document, 28 April 2004, pp. 8-9.

294 Research has been done in India and Nepal, under rural African women and in China. In all cases lung and heart diseases with women, like chronic bronchitis, emphysema, hut lung and cor pulmonale, were ascribed to indoor air pollution. Cooking is done in shallow pits that are not ventilated. When men suffer from these diseases this is mostly attributed to smoking; a habit hardly acquired by women or to a much lesser extent. Men do not come into contact with indoor pollution like women do because tending fires and cooking meals is regarded as a woman's job and men spend many hours outside the house every day. Anthology on Women, Health and Environment, World Health Organization doc. WHO/EHG/94.11, Geneva, 1994, pp. 92-94 and 98-105. Also P.K. Rao, Sustainable Development; Economics and Policy, 1999 , p. 246.

295 WHO report, 1994, pp. 95-97. 
If there is no safe water available, ${ }^{296}$ especially women run the risk of water-based diseases like cholera, typhoid fever, hepatitis, and schistosomiasis because they come into contact with the water more often. ${ }^{297}$ Fetching water is gender determined as are cleaning the house, cooking, bathing the children, and washing the dishes and the clothes. When safe water is only available at a certain distance, while polluted water is more easily obtainable, women are many times faced with a dilemma. Fetching the safe water will take up so much time, that women's other tasks are at risk. Particularly during periods when their labour in the fields is most needed, women do not have the time and energy to fetch the safe water when they also have to combine their agricultural labour with raising children, cooking meals and other domestic chores. ${ }^{298}$ When women and girls have to walk long distances with heavy water tanks or fuel loads this also threatens their health in other ways. ${ }^{299}$

Overcrowded living conditions cause physical as well as mental problems. Wellknown physical consequences of cramped living quarters are infectious diseases like tuberculosis and enteric diseases such as diarrhoea. ${ }^{300}$ Less known is Chagas disease, which is a heart disease that leads to disability. ${ }^{301}$ This disease is caused by triatomine insects that live in the cracks of walls, and in dirt or wooden floors. Women are at higher risk of acquiring Chagas because they spend more time in the house. Overcrowding also leads to stress sometimes resulting in mental diseases such as depression. ${ }^{302}$ Especially women who are culturally or traditionally confined to the house have no privacy and they are constantly confronted with too many people in too small a space. Another consequence of overcrowding is that the stress it causes with men is often vented in the form of woman battering, yet another health hazard. ${ }^{303}$

296 About 1.2 billion people in developing countries have no access to safe water. Janusz Niemczynowicz, 'Water, sanitation and sustainability: an opinion on future directions', in: WHO, Environmental Health Newsletter No. 27, October 1997.

297 Schistosomiasis is the second most prevalent parasitic disease in Africa. The disease is caused by a parasite that enters the body through the skin in contaminated water. WHO report, 1994, pp. 8-10. See also WHO Environmental Health Newsletter No. 28, April 1998, Chapter on Water Supply and Sanitation: the Foundation to Public Health.

298 The outcome of a survey done in Ghana shows that time and distance are the main factors why women chose a certain water source even though they know that further away the quality of the water is better. Furthermore, using a hand pump is frequently dismissed as an option because it costs the already overburdened women too much energy to use it. WHO report, 1994, pp. 2-4.

299 Hauling heavy loads from an early age affects girls' and women's health in general because the energy it costs is very high and combined with the preponderant malnutrition and anemia this makes them susceptible to other diseases. Another possible consequence is skeletal damage, especially to the vertebral column. Disks will become thinner losing part of their shock-absorbing quality while vertebrae themselves may change form and lead to cyphosis, the rounding of the spine which impedes mobility. Environmental Health Newsletter, World Health Organization, December 1995 (No. 25) at <www.who. int/peh/ehn/ehn25.htm>, consulted on 7 May 2002.

300 Diana Wilkinson, Poor Housing and Ill Health; A Summary of Research Evidence, The Scottish Office, Central Research Unit, Crown Copyright, 1999, p. 8.

301 Chagas disease is particularly endemic in many South American States. WHO report, 1994, pp. 65-67.

302 WHO Europe, Review of evidence on housing and health, 2004, p. 12. Also Wilkinson, 1999, p. 18.

$303 U N$ doc. E/CN.4/1995/42, Preliminary report by the Special Rapporteur on violence against women, Ms Radhika Coomaraswamy, 1995, p. 119. 
The fact that so many girls and women are ill because of their unhealthy housing situation is also a fact that goes largely unnoticed and untreated. In developing countries more boys and men are treated in hospitals than girls and women because poor families are more willing to invest in the health of their sons than in their daughters. ${ }^{304}$ Furthermore, women are taught that pain and suffering is a lot they have to endure without complaining. Some diseases may stigmatize a woman and not a man. No medical help is sought because the woman herself or her family feel ashamed because it is assumed that the woman has brought the illness upon herself and they want to keep it a secret. ${ }^{305}$

\subsubsection{Infrastructure}

In many developing countries there is no adequate sanitation system. ${ }^{306}$ Poor sanitation is a potential source of all kinds of gastroenteric diseases like diarrhoea, dysentery, typhoid and cholera. Especially when excreta are kept in the house and latrines have to be emptied with buckets, this poses a major health risk. The flush toilet in combination with a sewerage system, which is used in developed countries, is no option for many poor developing countries or rural areas especially when water is scarce and population density is low. Unfortunately, many other low-costs methods are not safe enough, particularly during epidemics. ${ }^{307}$

Infrastructure services that are delivered through networks like in-house piped water, electricity and gas mains are mostly unattainable for the world's poor. ${ }^{308}$ Therefore, alternatives have to be sought. When there is no piped water, women have to fetch water elsewhere. Only a minority uses unimproved water sources, most obtain their

304 In some countries many girls and women are not taken to hospital until their illness has reached a critical stage. Radhika Coomaraswamy, Cultural practices in the family that are violent towards women, $U N$ doc. E/CN.4/2002/83 of 31 January 2002, para. 77, Also Beijing Platform for Action, UN doc. A/CONF 177/20, 1995, para. 92 and WHO report, 1994, pp. 9, 35 and 99.

305 This is for example the case with schistosomiasis haematobium. When girls catch it they are almost unmarriageable since with them it is considered to be an infectious venereal disease. Married women may be evicted for the same belief. In contrast, if a man falls ill with this disease it is looked upon as a sign of virility. WHO report, 1994, p. 9.

306 According to the World Health Organization about 3,000 million people in developing countries lack appropriate sanitation. $80 \%$ of these people live in rural areas. WHO, Environmental Health Newsletter No. 27, Focus on Sanitation, October 1997, Introduction.

307 A safe alternative may be the Ventilated Improved Pit latrine (VIP), which has a ventilation pipe and mosquito netting to drive odours out of the latrine and which traps flies and makes it impossible for them to exit. Refugee Camp Project on http://www.refugeecamp.org/learnmore/latrines/vip_latrine.htm, consulted on 6 June 2002, also WHO Environmental Health Newsletter No. 27, October 1997.

308 According to a World Bank publication, of all infrastructure services, electricity is the widest spread. Even the very poor often have access to electricity if they live in urban areas. In the 15 countries screened in the World Bank research, $65 \%$ of the households had access to electricity, while only $38 \%$ had in-house water taps and $36 \%$ was connected to a sewer. Kristin Komives, Dale Whittington, Xun $\mathrm{Wu}$, Infrastructure Coverage and the Poor; A Global Perspective, Policy Research Working Paper, World Bank, February 2001, pp. 2-3. 
water from informal, private, or improved sources. ${ }^{309}$ When water is not available close to home, girls and women spend many hours every day to fetch it. ${ }^{310}$

When energy to cook or heat the house is not distributed by way of electricity networks or natural gas mains, all kinds of alternatives are being used. From expensive to cheap the following options are possible: generators and bottled gas, kerosene, LPG, coal and charcoal and, as the most basic fuels, wood, straw, thatch and dung. ${ }^{311}$ The cheapest alternatives cost women the most time and energy. ${ }^{312}$

When there is no public garbage collection, wastes heap up and become a risk of pollution and infection. Though the health effects of uncollected refuse is not gender specific, women's domestic tasks expose them more to wastes and the pollutants resulting from wastes than men. ${ }^{313}$

Public transportation is important as a means to have access to work and medical care, to go to markets and to attend school. When public transportation is absent, women have to spend time on walking to markets and medical centres.

The last few decades many governments of developing countries who want to provide their populations with all kinds of basic services but who do not have the means to do so, or do not wish to spend the budget needed, turn to the private sector as an alternative. Sometimes the World Bank encourages this development and offers loans to enable the privatization of services and infrastructure. Also in developed countries there is a tendency to leave former public services to private companies. The question is whether this development benefits the poor since the first goal of private companies is to make a profit. ${ }^{314}$

309 Unimproved sources are rivers and streams, while improved sources are such sources as yard taps, public taps, wells, water vendors, or rainwater collection, Komives e.a, 2001, p. 15.

310 In places and at times when water is scarce, up to eight hours a day may have to be spent on collecting water. WHO, Environmental Health Newsletter No. 25, Chapter on Water, sanitation and women's health.

311 For about 2 billion people in the world wood, dung and crop residues are the only source of energy. Irene Dankelman, Gender and Environment: Lessons to Learn, UN doc. EGM/NATDIS/2001/OP.2, para. 2.2. Also Komives e.a, 2001, pp. 14-15.

312 Due to deforestation and general degradation of the environment it is not so easy anymore to find fuel wood. That is why in many urban areas, wood has become almost as expensive as kerosene or gas, while in rural areas the collection of wood costs women an excessive amount of energy and time. In a study carried out by the ILO in several countries in Asia, Africa and Latin America, it was shown that women's tasks are heavily burdened with this constant energy quest. Cooking and collecting fuels are two of the most time-consuming activities for women who, on an average, work considerably longer hours every day (11-14 hrs) than men (8-10 hrs). Using dung as a cooking fuel is also time consuming. If the family does not own cattle, women have to put time in collecting dung in public places. Furthermore, making dung-cakes may take about two hours a day. WHO report, 1994, pp.83-84 and 89-90.

313 WHO, Environmental Health Newsletter No. 25, Chapter on Impact on Women's Health of Waste Mismanagement.

314 Kothari rightly points out that the best examples of basic services providers are all publicly operated. $U N$ doc. E/CN.4/2002/59, para. 62. The World Bank extensively examines the impact of privatization of services on the poor. Many of these reports reveal that privatization may indeed have a favourable impact on the connection rate, but if the poor benefit at all, it is the poor who live in urban areas. Private companies are hardly ever interested in investing in rural areas where in many cases the poorest part of the population lives. Reports are published on the web site of the World Bank: <http://rru.worldbank. org $>$. Privatization and its impact on the poor is also discussed in section 3.2.6 on structural reform of economies. 


\subsubsection{Location}

Housing cannot be called adequate when it is situated in an isolated place far away from schools, day-care centres, hospitals, markets and shops, and where there is no possibility for employment. The location is also unsuitable when the soil is polluted, it is in the vicinity of hazardous industries, dumps and open sewers, and when the area is disaster prone. $^{315}$

When a family settles down, the location is usually determined by a number of factors. The most important one is the opportunity of employment of the man and breadwinner. The second is the vicinity of schools for the children. The last determining factor is the income generating possibilities of the woman. ${ }^{316}$

As stated before, women's access to health care is lower than men's. ${ }^{317}$ When hospitals and medical centres are at a considerable distance from the living location, in developing countries this may mean that women have to walk long stretches, often accompanied by their children. This is yet another hurdle to take and it may prove to be too burdensome to seek medical care. Especially in cultures where women are not supposed to move unaccompanied in public, this poses a problem because there is not always a man available to go with them. ${ }^{318}$

Since selling agricultural or home-made products is for many rural women their sole source of income, the distance to a market influences their financial situation and economic independence.

If the walking distance to schools is very long, this may be a reason why girls are kept at home.

If there are no day-care centres in the neighbourhood of the home, this impedes women from being gainfully employed outside the home.

The poor live in the most unattractive areas since those are either free of costs or the cheapest for settling down. These areas may be prone to natural disasters, in the direct surroundings of dangerous industries, or in the vicinity of dumps, open sewers or other disease vectors or the soil may be polluted. ${ }^{319}$ Especially female heads of households are to be found in unfavourable living locations because they are the world's poorest.

315 See section 3.3.3 on natural and human-made disasters for the consequences of living in disaster prone areas for women.

316 This was investigated in Nigeria, but in my opinion this is also true for other countries, developed and developing alike. See WHO report, 1994, Housing and family maintenance, p. 69.

317 This is caused by a number of reasons, e.g. discrimination of girls and women, women's financial situation, their shame and modesty, their care-taking tasks that make it difficult to leave home, their unwillingness or impossibility to present themselves in public. See section 3.4.4.1 supra.

318 In Saudi Arabia for instance, women may not travel without a male companion. Coomaraswamy, E/CN.4/2002/83, para. 84. The same is true for Bangladeshi women. Mahjabeen Chowdhury, Women's Technological Innovations and Adaptations for Disaster Mitigation: A Case Study of Charlands in Bangladesh, EGM/NATDIS/2001/EP.6, 1 November 2001, pp. 4-10.

319 P.K. Rao, Sustainable Development; Economics and Policy, Center for Development Research Princeton, NJ, Blackwell Publishers, Malden, 1999, p. 240. For instance the poor who lived in the area of the chemical plant in Bhopal, India, when it exploded. The victims were particularly women and children. Dankelman, 2001, para. 3. See also WHO, Environmental Health Newsletter No. 26, October 1996, under Applying the Healthy City concept in the Eastern Mediterranean. 
Closely connected to location is the freedom of movement and residence. Many women lack the ability to choose where they wish to settle down. In many countries it is a legal obligation or a culturally determined tradition, such as female exogamy, that married women settle down where their husbands live. ${ }^{320}$ For a woman this may mean that she will have to leave her own familiar environment where she has her social network. Settling elsewhere may also mean that a woman's economical opportunities may be negatively affected thus making her more dependent on her male partner. Women who are gainfully employed may have to give up their jobs when the new place of living is too far away, or the new place lacks the land or the space to continue her usual agricultural work or other home-bound business activities.

In some cultures, women's right to movement in the private sphere is also curtailed because they are confined to the house.

While examining the situation of some groups of returnees, the United Nations High Commissioner of Refugees noticed that the decision to return to the original habitat often is a decision taken by the men of the community. In many cases women wanted to return sooner but were prevented to do so, while in other situations women were forced to return although they did not wish to do so because they felt unsafe and were afraid that their and their children's safety was still at risk. ${ }^{321}$

\subsubsection{Security, Autonomy and Dignity}

In the context of housing security can mean two different things. In the first place it refers to safety from external forces e.g. freedom from harassment from government interference in the private sphere or being protected against attacks by third parties. However, security may also mean being safe from attacks inside the house, shelter or other place where a person has taken refuge. In this sense it is important mainly for women and children, because they are the victims of violence in the domestic sphere in the great majority of the cases. When security at home is in jeopardy, the right to security of the person is juxtaposed to the right to privacy. For victims of domestic violence the former may weigh heavier than the latter, and in this case interference by authorities may well be welcomed. ${ }^{322}$

In the same vein, security of tenure may be understood in an external and internal sense. In all official documents on housing rights secure tenure is used in connexion with protection against forced evictions by authorities/third parties and is greatly valued by women and men alike. However, as has been discussed in section 3.3.2, many women are threatened by, or are faced with eviction from their home by intimates, especially their in-laws.

320 E.g. the Yemen Personal Status Act No 20 of 1992 determines inter alia that a wife must move into the husband's home and that she may not leave the house without his permission. Coomaraswamy, E/CN.4/ 2002/83, para. 84 .

321 UN doc. EC/SCP/67, UNHCR's Guidelines on the Protection of Refugee Women, 1991, para. 68.

322 See section 3.6.4 on the right to privacy. 
The internal dimension of security and secure tenure for women is closely connected to whether or not it is accepted by society that they have an autonomous right to housing and/or are able to fulfil their housing rights independently.

In this section, several groups of women will be discussed whose housing situation is deficient because they lack security and/or autonomy.

Domestic violence has already been discussed as a probable cause of homelessness for women ${ }^{323}$ but it is also a factor that determines the degree of adequacy of housing. First the actual housing situation of battered women will be discussed. Not only at home, but also of those women who have taken refuge in shelters and safe houses. Next, the circumstances of single women, divorcees and widows will be reviewed who do not have the financial means to afford adequate housing by themselves and/or who lack the autonomy to take their own housing decisions and consequently have to turn to relatives and friends or welfare programmes for shelter. Attention will also be paid to the situation of living-in domestic servants who in many cases cannot leave their employer's home. The last part of this section is devoted to the adequacy of camps and shelters available to female refugees and internally displaced women.

\subsubsection{Battered Women}

In section 3.3.5 on domestic violence, causes and consequences of domestic violence have already been discussed. When a woman is battered in her own home, her housing rights are infringed, and housing becomes inadequate, no matter how habitable or luxurious the premises, and how well fitted up with every modern convenience, since the basic notion of living somewhere in peace, security and dignity is obliterated. Security of the person, being free from physical and mental abuse and humiliation, surely is the first prerequisite of living someplace in peace and dignity. Home is supposed to be a safe haven where the family can retire upon itself, step away from the pressures of society at large and enjoy privacy. Living in such unsafe conditions makes this potential haven into hell. Some women are virtual prisoners within their own homes. They may not leave without permission and their every move is monitored. Every 'wrong' step may trigger a bout of violence, though many times it will be unclear why fault was found with their behaviour and indeed the 'punishment' they receive may be meted out quite randomly. ${ }^{324}$

While many women leave the home in which they are abused and find a new place to live, sometimes even preferring homelessness to remaining in an abusive relationship, other women decide to endure the violence. The reasons why battered women stay may be practical, sociological and psychological. Many women who would wish to break-up an abusive relationship simply have nowhere to go. They are economically dependent on their partners and the only alternative they may have is to live in the streets facing all the health and violence hazards involved with that. Many will be unwilling to

323 See section 3.3.5 on domestic violence.

324 See for instance Rhonda Copelon, 'Intimate Terror: Understanding Domestic Violence as Torture', in: Rebecca J. Cook (ed.), Human Rights of Women; National and International Perspectives, University of Pennsylvania Press, Philadelphia, 1994, pp. 116-152. 
take this risk, especially if they have children they do not want to leave behind. ${ }^{325}$ In many countries of the world, lone women, and in some societies in particular divorcees, face discrimination when they try to gain access to land and/or housing. ${ }^{326}$ In China for instance, most married couples live in a house that has been allocated by the husband's employer. That it why it is the woman who has to leave after the divorce, and she is faced with homelessness. ${ }^{327}$ In many States there are no or not enough shelters. ${ }^{328}$ It may be an option to return to the parents' home or live with other relatives, but this is certainly not an ideal situation if it is at all possible. Many families already live in inadequate, cramped spaces and a woman will feel that she imposes upon her relatives when she comes to live with them indefinitely, especially if her children accompany her.

In many cultures domestic violence is seen as an acceptable method for a man to discipline his wife. ${ }^{329}$ Furthermore, women face being ostracized when they leave their husbands. A woman who leaves her husband brings shame not only on herself, but also on the whole family. ${ }^{330}$ Therefore, parents will urge their daughters to stay with or return to their husbands and undergo the violence, particularly since in many traditional societies domestic violence is tolerated and the blame will be put on the woman herself. ${ }^{331}$

Women may also stay for emotional or family-related reasons; they love their husband or they have sympathy for him and/or they want to keep the family together for the sake of their children. ${ }^{33}$

Psychologists claim that many women remain in abusive relationships because they suffer from Battered Woman Syndrome. Their self-esteem will be almost non-existent and they start to believe that they are indeed to blame for their husbands' violence. After some time they are emotionally drained so they stop thinking of a way out. More-

325 Economic dependency is frequently mentioned as a reason to stay in spite of the recurring violence. Examples are Croatia, Lithuania, and Turkmenistan, Women 2000, pp. 130, 288 and 469 respectively.

326 In Kazakhstan it is impossible for a woman to rent or buy a house. Women 2000, p. 229.

327 Leilani Farha, 'Women and Housing', in: Kelly D. Askin, Dorean M. Koenig (eds.), Women and International Human Rights Law, Vol. 1, Transnational Publishers, Inc. Ardsley, New York, 1999, p. 516.

328 A few examples. In Albania there is just one shelter, situated in Tirana and financed by a Women's CSO. Women 2000, p. 30. In Lithuania there are 5 shelters, 2 of which are financed by the Government. Women 2000 , p. 289. In Russia there are shelters in St. Petersburg and in several provincial cities, but none in Moscow. Women 2000, p. 382. In Tajikistan there are no shelters at all. Women 2000, p. 437. In Canada the number of shelters has been considerably decreased due to expenditure cuts. Farha, 1999, p. 516.

329 This is for instance true in Nigeria where the law, custom and practice sanction correcting a wife on the same footing as correcting children. Pat Mahmoud, 'Patterns of Violence Against Women in Nigeria with Specific Focus on Domestic Violence', in: International League for Human Rights, Combatting Violence Against Women, New York, March 1993, p. 7. Also see the situation in Romania where it is commonly believed that the woman has either provoked the violence in which case she deserves it, or she is a 'bad' wife which justifies her being disciplined. Women 2000, p. 361.

330 In Poland the plans to establish shelters (for a total of maximum 180 women and 360 children) with the help of the UN Development Programme were suspended by the Government because it was feared that helping women outside the family home would contribute to the family break-up, an unacceptable option. Women 2000, pp. 334-335. Divorcing a husband in societies where marriages are arranged are particularly shameful for the family and the woman may even be killed by her own relatives. Coomaraswamy, E./CN.4/2002/83, para. 36 .

331 See for instance Sacrificing Women to Save the Family; Domestic Violence in Uzbekistan, Human Rights Watch Publications, Vol. 13 No. 4(D), July 2001, p. 19.

332 This has for example been mentioned by battered women in Armenia, Bosnia, the Czech Republic, and Hungary, Women 2000, pp. 45, 96, 148, and 206 respectively. 
over, they are too afraid to leave because they fear their husband will harm them or their children if they do, and they assume that it is impossible to find a place where they can escape their husbands' wrath. ${ }^{333}$

If an abused woman decides to leave, she may also be faced with inadequate housing. If she is not able to finance adequate housing herself, she may be able to find a host home, mostly with relatives. This may entail that she loses her freedom and her privacy and that she becomes dependent on others. Her home is no longer her own space where she can keep house as she pleases. She will have to adapt, perhaps for the rest of her life.

If she has an income, she may be able to secure a place to live, but since women's average incomes are generally lower than men's, it will be difficult to obtain adequate housing because there is a world-wide lack of affordable housing, also in developed countries. Mostly, there are long waiting lists for subsidized housing. Chances are that she will end up living in a slum.

In some States, especially developed ones, battered women have the option to go to shelters and safe houses. ${ }^{334}$ Ideally, there are specific shelters for battered women and general shelters for other homeless people. In countries where there are enough safe houses, the usual policy is to send the woman (and her children) to a shelter in another city. For the safety of the women the addresses of these shelters are kept secret as much as possible. ${ }^{335}$ The shelters may be State supported or financed by churches and other CSOs. Normally, women can stay only a limited period in these homes while they are advised and helped to get their life back on the rails. ${ }^{336}$ Unfortunately, in many countries there are too few shelters and those that are present are constantly filled to capacity. ${ }^{337}$ Sometimes there are no specific women's shelters or those present are full, and women and their children are put in general shelters, together with drug addicts, alcoholics and mentally disturbed people. This is particularly bad for the children.

Most of the time, there is hardly any room for privacy in these homes, because of the cramped living space. Sometimes women and their children cannot sleep together because

333 Battered Woman Syndrome is a psychological reaction that occurs when normal people are exposed to repeated trauma. The syndrome is a subgroup of Post-traumatic Stress Disorder and has four general characteristics: 1) the woman believes that the violence is her fault; 2) she is unable to place the responsibility for the violence elsewhere; 3) she fears for her life (and for her children's lives); 4) she has an irrational belief that the abuser is omnipresent and omniscient so there is no possibility for escape. Lenore E. Walker, The Battered Woman Syndrome, Springer Publications, New York, 1984, pp. 94-96. See on the internet $<$ http://www.divorcenet.com/or/or-art02.html $>$, consulted on 17 September 2001.

334 Though shelters are meant for women with their children in the Netherlands, many of these homes have as a rule that sons may only stay with their mothers until they are twelve years old.

335 Sometimes there are safety problems, however, when addresses of these shelters are easily obtainable.

336 Usually the maximum period that women can stay in these safe houses is six months.

337 In the Netherlands, almost half of the women who seek refuge have to be turned away because the shelters are full. Women who are (still) illegally in the country are not even included in the figures, because they may not be taken in. 'Mishandelde vrouwen staan vaak in de kou', NRC, 28 November 2001. In Albania there is just one shelter, situated in Tirana and financed by a Women's CSO. Women 2000, p. 30. In Lithuania there are 5 shelters, 2 of which are financed by the Government. Women may stay there up to 6 months. Women 2000, p. 289. In Russia there are shelters in St. Petersburg and in several provincial cities, but none in Moscow. Women 2000, p. 382. In Tajikistan there are no shelters at all. Women 2000, p. 437. In Canada the number of shelters has been considerably decreased due to expenditure cuts. Farha, 1999, p. 516. 
there are separate dormitories. Women are completely dependent on the authorities or CSOs for their admission to these homes and for the time span they may stay there. In spite of all these shortcomings, however, the presence of shelters is very much needed and desired because the immediate threat to life and health is absent there, and therefore security inside the home is, at least temporarily, guaranteed.

\subsubsection{Single Women, Divorcees and Widows}

In many societies, women obtain their status in society from the fact that they are married. Women living alone are considered to be an anomaly and in some countries they cannot even function independently. ${ }^{338}$ Single women, divorcees and widows in many countries find themselves in a predicament when there is no male partner to fall back on. Independent living quarters are often out of the question because of pecuniary or customary reasons and therefore the only solution, besides living in the streets, is to move in with relatives, in-laws or friends. These women, often accompanied by children, have to give up their freedom and adapt themselves to the household of their hosts. Especially when there are children, women will go to great lengths to avoid living in the streets. How many women are dependent in this way is hard to say for their kind of homelessness remains hidden from statistics.

\subsubsection{Women Migrant Workers}

Every year thousands of poor women from developing countries like Sri Lanka, the Philippines, Pakistan, India and Bangladesh leave their homes to find employment in other countries as living-in domestic servants. ${ }^{339}$ It is believed that globalization favours migrant labour and that the number of women who try to find employment abroad is growing each year. ${ }^{340}$ Many of these women become victims of sexual or other abuse in the house of their employer. ${ }^{341}$ The contracts they work under may be unfavourable or there is no contract at all. ${ }^{342}$ Some are not paid or are subjected to debt bondage. ${ }^{343}$ Their passports and other documents may be taken from them so that they cannot flee the country and in some countries they cannot even go into the streets because being in public places without the proper documents is an offence that may lead to arrest and detention. In this way, these women's right to movement is restricted and they become totally isolated. Some find themselves in slavery-like positions and are virtual prisoners

338 For instance in Bangladesh where every woman must have a male guardian because she cannot take any decisions on her own.

339 C.M. Cancel, Domestic Servants Overseas, Global Women's Rights, at <http://www.globalwomens rights.net/library/weeekly/aa032197.htm>, consulted on 10 June 2002.

340 Report of the Secretary-General on violence against women migrant workers, UN doc. E/CN.4/2000/76 of 9 December 1999, para. 7.

341 Already in her Preliminary Report the Special Rapporteur on Violence Against Women included violence against domestic servants in her definition of domestic violence.Coomaraswamy, E/CN.4/1995/42 of 22 November 1994, para. 118, and again in E/CN.4/1999/68 of 10 March 1999, para. 17.

342 UN doc. E/CN.4/2000/76, para. 8.

343 Debt bondage entails that a person pledges to provide personal services in order to pay off his or her debt. This practice is forbidden by international law. 
kept under lock and key, who are not even allowed to have contact by mail or telephone. Reports from women who have escaped relate about inhumane working conditions, starvation, denial of health care, physical assault, and rape. ${ }^{344}$ It goes without saying that the housing conditions of these women are appalling. The actual space where they have to live may be inadequate, such as kitchen floors and sheds as sleeping places, while they may also have to do without any degree of safety, security and privacy. ${ }^{345}$

\subsubsection{Female Refugees and Internally Displaced Women}

About 32 million people ${ }^{346}$ all over the world have been forced to flee their homes for various reasons. In most cases, these reasons are international or internal armed conflicts. To a lesser extent, people have left their homes for such reasons as forced relocation, natural or human-made disasters. Large groups of homeless people hope to find shelter in refugee-camps. Besides a roof over their heads, food, water, sanitation and health care, people who seek refuge in camps also expect to find security of their person. That the vast majority, about $80 \%$, of these people are women and children is no wonder. ${ }^{347}$ Since most people flee in times of war, husbands and fathers will have been killed in battle, are still fighting or have simply disappeared. As a result, the number of single, unaccompanied women and female-headed households is disproportionately high.

Study of the situation in such camps is pertinent in the context of the right to housing, since emergency shelter is a certain form of housing and it is interesting to examine if, and in what ways, it affects women differently from men.

344 See for instance the chapter on Asian Domestic Workers in Kuwait in The Human Rights Watch Global Report on Women's Human Rights, at $<\mathrm{http}$ //www.hrw.org/about/projects/womrep>, consulted at 21 June 2002, the Concluding observations of the Committee on the Elimination of Racial Discrimination on Kuwait, UN doc. A/48/18 of 15 September 1993, in particular paras 369 and 376, or the Concluding observations of the Committee on Economic, Social and Cultural Rights on Sri Lanka, UN doc. E/C.12/ 1/Add.24 of 16 August 1998, para. 13. Although the situation of living-in domestic servants is bad all over the world, the situation in Kuwait is particularly serious. Especially after the end of the Iraqi invasion in 1993 domestic servants are discriminated against because of their sex and ethnicity.

345 See UN doc. E/CN.4/2004/76, Migrant workers, report of the Special Rapporteur, Ms Gabriela Rodríguez Pizarro, 12 January 2004, paras 70-92. Also see section 4.7.3.5.

346 It is estimated that at the end of 2005 the number of refugees had decreased to 8.4 million. This is the lowest level since 1980 and current trends indicate that in future the number of refugees will decline even further. For comparison: in 1995 the UNHCR estimated that there were 20 million refugees. Detailed statistics on refugees may be found at the internet site of the UNHCR at: $<$ http://www.unhcr. org/statistics>. In 2005 there is an estimated number of 23.7 million Internally Displaced Persons. This is 1.6 million less than in 2004. Since the 1990s the number of IDPs increased dramatically until it reached the number of 25 million in 2001, which remained unchanged until 2004. See: Internal Displacement: Global Overview of Trends and Developments in 2005, Global IDP Project, Norwegian Refugee Council, December 2005

347 Sources mention different numbers and some of them maintain that 80 percent of all refugees are women. This seems not to be correct, however. According to the UNHCR statistics about 50 percent of the refugees are women, and about 25-30 percent are children below the age of 15 . Also see Thomas Spijkerboer, Gender and Refugee Status, Ashgate, Aldershot, 1999, pp. 15-17, and Susan Forbes Martin, Refugee Women, Zed Books Ltd., London/New Jersey, 1992, p. 1. According to the Global Overview of Trends and Developments in 2005, women and children make up for 70 to 80 percent. 
As all homeless women, female refugees and internally displaced women are very vulnerable to gender-specific violence and other human rights abuses. ${ }^{348}$ They are especially prone to rape and sexual abuse as well as to sexual exploitation by those who are supposed to be of their assistance. ${ }^{349}$ Furthermore, sexual discrimination may take place with regard to the distribution of goods and services. ${ }^{350}$

Women who have suddenly become head of their household, are faced with the responsibility of raising their children, taking care of the sick and the elderly, while at the same time they must provide for the material needs of those who have become solely dependent on them. ${ }^{351}$ On the whole, many women are ill equipped for this responsibility. They may come from communities where they have been raised to perform within a certain role model. They are not used to public dealings and their education and professional skills are either lacking or inadequate so that it is difficult for them to participate in income generating projects. They are not used to fending for themselves and lack the protection of a husband or male relatives. Sometimes, they have no choice but to succumb to those who are in authority. They are often forced to prostitute themselves in return for food or other relief provisions, or to receive the necessary documentation. ${ }^{352}$ However, when these practices become known, it is the women who are often stigmatized and run the risk of being excluded from their community. ${ }^{353}$

Camps are often situated in dangerous locations, especially near war zones. If girls and women have to leave the camp and walk for miles in order to fetch water or to gather firewood, they are easy targets for enemy attacks. ${ }^{354}$

Because of the extraordinary circumstances, and the ensuing breakdown of communities, traditional norms are sometimes abandoned and women and girls are sexually intimidated and abused by fellow refugees. ${ }^{355}$ Furthermore, women may be sold into prostitution or marriage or forced to marry. ${ }^{356}$

It has been noted that the percentages of wife battering and marital rape increases when couples are housed in refugee-camps. ${ }^{357}$

348 Report of the Special Rapporteur on violence against women, its causes and consequences, Ms Radhika Coomaraswamy, UN doc. E/CN.4/1998/54, paras 208-211, also General Comment No 7, E/C.12/1997/4, para. 11. Also Susan Forbes Martin, 1992, pp. 16-22.

349 Report of the Representative of the Secretary General, Mr Francis M. Deng, UN doc. E/CN.4/1999/ 79/Add. 2, para. 50.

350 UNHCR's Guidelines on the Protection of Refugee Women, UN doc. EC/SCP/67, 1991, para. 3.

351 UN doc. E/CN.4/1999/79/Add. 2, para. 49.

352 Report of the Representative of the Secretary General, Mr Francis M. Deng, UN doc. E/CN.4/1996/ 52/Add. 2, para. 132. See also: Charlotte Bunch, 'Women's Rights as Human Rights: Towards a ReVision of Human Rights', in: Human Rights Quarterly 12 (1990), pp. 493-494.

$353 U N$ doc. E/CN.4/1999/79/Add. 2, para. 50.

354 Odd Einar Olsen and Kristin S. Scharffscher, 'Rape in Refugee Camps as Organisational Failures', in: International Journal of Human Rights, Vol. 8, Number 4, Winter 2004, p. 391. AlsoUN doc. E/CN.4/ 1998/54, para. 209

355 UN doc. E/CN.4/1998/54, para. 210. As an example the Special Rapporteur on Violence Against Women mentions that in the refugee camps around Rwanda in 1994, almost all the women and girls were reported to have been raped or sexually assaulted. The situation in these camps was such that there were frequent occasions and opportunities for rape.

$356 U N$ doc. E/CN.4/1996/52, para. 47.

357 UN doc. E/CN.4/1996/52, para. 46. Also, EC/SCP/67, para. 38. 
It may be clear from the above that, though an overwhelming part of refugees and internally displaced persons (IDPs) is female, refugee camps are not adequately equipped for the special needs of women. This fact has been recognized both by the United Nations High Commissioner for Refugees (UNHCR) ${ }^{358}$ and by the Special Representative of the UN Secretary-General (RSG) on Internally Displaced Persons. ${ }^{359}$ Both mechanisms have analysed the problems and made suggestions for improvements. Before I discuss their findings in the sections 3.4.5.4.2 and 3.4.5.4.3 respectively, it is useful first to go into the differences, both practically and legally, between refugees and IDPs.

\subsection{Differences between Refugees and Internally Displaced Persons (IDPs)}

The number of IDPs has by far surpassed the number of refugees. In the last decade, the number of refugees declined from 25 million in 1995 to 8.4 million in 2005, whereas the number of IDPs is believed to be around 23.7 million. ${ }^{360}$ The working definition of IDPs is:

'Persons or groups of persons who have been forced or obliged to flee or to leave their homes or places of habitual residence, in particular as a result of, or in order to avoid the effects of armed conflict, situations of generalized violence, violations of human rights or natural or human-made disasters, and who have not crossed an internationally recognized State border. ${ }^{361}$

The 1951 Convention Relating to the Status of Refugees defines a refugee as:

'Any person who [...] As a result of events occurring before 1 January 1951 and owing to well-founded fear of being persecuted for reasons of race, religion, nationality, membership of a particular social group or political opinion, is outside the country of his nationality and is unable, or owing to such fear, is unwilling to avail himself of the protection of that country; or who, not having a nationality and being outside the country of his former habitual residence as a result of such events, is unable or, owing to such fear, is unwilling to return to it. 362

Many of the people who are qualified as IDPs would also fall within the definition of refugees if they had crossed a border. However, the definition of IDPs is broader, because it also covers people who were forced to leave their homes because of natural or humanmade disasters. Refugees are always uprooted because of violence.

358 The UNHCR is mandated by the UN Statute and guided by the 1951 UN Convention relating to the Status of Refugees and its 1967 Protocol.

359 Mr Francis M. Deng was appointed by the UN Commission on Human Rights as Representative of the UN Secretary-General on internally displaced persons by its resolution 1992/73 of 5 March 1992.

360 For refugees see the at the internet site of UNHCR: $<$ http://www.unher.org/statistics $>$. For the number of internally displaced persons see the overview in: Internal Displacement: Global Overview of Trends and Developments in 2005, Global IDP Project, Norwegian Refugee Council, December 2005.

361 Report of the Representative of the Secretary General, Mr Francis M. Deng, UN doc. E/CN.4/1998/53, para. 19.

362 Convention Relating to the Status of Refugees, 1951, Article 1(A)(2). 
The consequences of remaining within the borders are grave. ${ }^{363}$ Refugee law is only applicable when people have left their own country. It implies a well-established system of protection, the most important element of which is the principle of non-refoulement; the right not to be forcibly returned to one's own country if one's life or freedom is in danger. A logical result of this principle is that refugees have the right to seek asylum in another country. IDPs, however, cannot escape their own government. ${ }^{364}$

As far as which international legal norms are applicable with regard to IDPs, three situations can be recognized which are each governed by a different set of rules.

In the first place, people may be displaced because of tensions or disturbances. Though there is no armed conflict, people are victims of the use of force or repressive measures by governments. In the same category fall those that have left their homes because of natural or human-made disasters, such as floods, earthquakes, typhoons, droughts or nuclear disasters. In these situations human rights law is applicable.

In the second place, non-international armed conflicts may be the cause of people leaving their homes. Under these circumstances, the core principles of humanitarian law are applicable, as well as many, non-derogable, human rights guarantees.

The third situation is that of inter-State armed conflict. In this case, the whole set of humanitarian law rules applies, as well as human rights guarantees. ${ }^{365}$

Although it would seem that the rights of IDPs are fairly well covered by the abovementioned rules, there are nevertheless important gaps in their legal protection. The RSG on Internally Displaced Persons has pointed out that there are for instance no rules dealing with adequate compensation for the loss of property or for the provision of personal documentation. ${ }^{366}$ Furthermore, in many cases internal upheaval is caused by rebel groups or insurgents and, notwithstanding the tendency to treat such groups as subjects of international law, at least at the individual criminal responsibility level, it is still very difficult to hold them accountable for their deeds.

In most cases, IDPs will not receive the same assistance and protection by the international community as refugees. The responsibility for IDPs lies first and foremost with the home country itself. This is exactly the reason why the Special Rapporteur on Violence Against Women has maintained that internally displaced women are even more vulnerable to abuse than refugee women. In some cases, internally displaced women depend for their aid and security on the very government that is responsible for their displacement, ${ }^{367}$ or they live in a territory where the rebel forces that are in control, are the cause of their predicament. ${ }^{368}$

363 UN doc. E/CN.4/2005/84, Mass Exoduses and Displaced Persons, Report of the Representative of the Secretary-General on the human rights of internally displaced persons, Walter Kälin, 31 December 2004, para. 39.

364 UN doc. E/CN.4/1994/44, Report of the Representative of the Secretary General, Mr Francis M. Deng, para. 26.

$365 U N$ doc. E/CN.4/1996/52/Add. 2, paras 27-38.

366 UN doc. E/CN.4/1996/52, para. 9

367 Preliminary report submitted by the Special Rapporteur on violence against women, its causes and consequences, Ms Radhika Coomaraswamy, UN doc. E/CN.4/1995/42, para. 302.

368 Statement by Mrs Sadako Ogata, UN High Commissioner for Refugees, to the 56th session of the UN Commission on Human Rights, Geneva, 11 April 2000. 
Some governments do not have sufficient means at their disposal to help their internally displaced. According to the principle of State sovereignty, international assistance can only be given if the government concerned accepts this help. There are States that refuse help because they consider it as unwanted interference, but, on the other hand, there have also been examples of governments that did seek international assistance, but were offered none or only little such assistance. ${ }^{369}$

The international community itself may deal with the sovereignty principle in two different ways. Sometimes it uses sovereignty as an excuse not to aid the internally displaced, while it may also do just the opposite and override it with the use of force, as was done in the case of Iraq in $1991 .^{370}$

Generally, refugees are protected and assisted by an international agency, but there is no specific international organization that is responsible for the internally displaced. This may lead to a situation where people, who have fled for exactly the same reasons, may receive a much higher level of protection and assistance when they have, more or less by incident, crossed the border, than those who have fled to another region within their own country. This happened for example with the Rwandese who had crossed the border into Burundi. ${ }^{371}$ In fact, the RSG on Internally Displaced Persons is the only 'mechanism' mandated by the UN to deal with the needs of IDPs and his mandate is limited. His main tasks are to study, to inform, to advise and to develop a legal framework. However, over the last decade international organizations are giving more attention to IDPs than ever before. Especially the UNHCR is taking up more and more responsibility for the internally displaced. At the moment about 6.6 million IDPs benefit from the UNHCR's help and assistance, although IDPs formally do not fall within the UNHCR's mandate. ${ }^{372}$

Other organizations that deal with the internally displaced, are the UN Department of Humanitarian Affairs (DHA), the International Committee for the Red Cross (ICRC) as far as IDPs are concerned that are victims of internal strife, the World Food Programme (WFP), the United Nations Development Programme (UNDP), the International Organizations for Migration (IOM) and the UN International Children's Emergency Fund (UNICEF) through its involvement with health care, education, nutrition and sanitation for women and children. ${ }^{373}$

Another difference that reflects housing conditions is that refugees who seek asylum in another country will generally be housed in special camps or refugee centres, while internal displacement may manifest itself in different ways. The displaced may live in camps not unlike refugee camps, but it is also possible that they have settled in rural areas

369 Roberta Cohen, 'Protecting the Internally Displaced', in: World Refugee Survey, US Committee for Refugees, 1996, p. 1. According to the author this happened to the Governments of Peru and Colombia. 370 Ibidem, p. 2

371 Report of the Special Representative of the Secretary General, Mr Francis M. Deng, UN doc. E/CN.4/1995/50, para. 34.

372 In fact, IDPs protected or assisted by UNHCR are the second largest group under the Office's mandate accounting for 32 percent. UNHCR 2005 Global Refugee Trends, Statistical overview of populations of refugees, asylum-seekers, internally displaced persons, stateless persons, and other persons of concern to UNHCR, para.3

$373 U N$ doc. E/CN.4/1994/44, paras 30-33, and UN doc. E/CN.4/1995/50, paras 144-162. 
or live in the shantytowns near major cities. The RSG on Internally Displaced Persons distinguishes between these two forms of settlement. He calls the IDPs living in camps 'displaced', while he terms the others as 'dispersed'. ${ }^{374}$ In some countries both forms exist. A case in point is the civil war in Rwanda where the 'displaced' generally consisted of members of the Tutsi who sought protection in the approximately 75 administrative centres or army camps managed by the Tutsi-dominated military, while the 'dispersed' were mostly Hutus. Since the dispersed try to hide from the military, they flee to the marshes, the valleys and the woods. It goes without saying that the dispersed face even more protection and assistance problems than the displaced. ${ }^{375}$

\subsection{Female Refugees ${ }^{376}$}

As early as 1985 the UNHCR acknowledged that, in addition to the basic needs that all refugees have, women and girls have special protection needs that reflect their gender. ${ }^{377}$ That is why over the years the UNHCR developed several policies and guidelines on the protection of refugee women. ${ }^{378}$ These guidelines are intended both to inform and assist UNHCR officials who work in the field and to assist States that host refugees and that are as a consequence responsible for their safety. Furthermore, the Guidelines stress the need that refugees, and especially female refugees, receive education and training in legal awareness

Refugee women are particularly vulnerable when they are unable to sustain themselves and their dependants, when they are detained among strangers and in circumstances where traditional social protection systems no longer exist. ${ }^{379}$ Problems occur especially in camps where unrelated groups of men and women are forced to live together, where sanitation facilities are communal and/or situated at some distance from the living quarters and where the distribution of goods is put into the hands of male community leaders. Sometimes, mere pragmatic decisions about the physical lay out of a camp already heighten women's physical safety. ${ }^{380}$

One of the most important suggestions for improvement that has been made by the UNHCR is that women should be involved in the planning and decision-making in refugee camps from the beginning. Letting women participate in decision-making processes is not so easy, however. Women themselves may not be used to vent their opinions in public, relief workers are often afraid to interfere with cultural patterns, while communities that are not used to women taking part in such decisions, may object.

$374 U N$ doc. E/CN.4/1995/50, para. 23.

375 Examples of special protection problems were manifest in El Salvador and in Burundi. See, Frances Deng, Internal Displacement in Context: Theses from Country Missions, Refugee Policy Group, Washington Geneva, Summer 1995 and $U N$ doc. E/CN.4/1995/50/Add. 2, para. 12

376 For a general study on female refugees see Thomas Spijkerboer, Gender and Refugee Status, Ashgate, Aldershot, 1999.

377 UNHCR Executive Committee Conclusion No. 39, 1985.

378 UN doc. EC/SCP/67, UNHCR's Guidelines on the Protection of Refugee Women, 1991; UNCHR, Sexual Violence Against Refugees: Guidelines on Prevention and Response, 1995; and UNCHR, Sexual and Gender-Based Violence Against Refugees, Returnees, and IDPs: Guidelines for Prevention and Response, 2003

379 Ibidem, para. 9.

380 Olsen and Scharffscher, 2004, pp. 382 and 383. 
However, the UNHCR points out that women find themselves in extraordinary circumstances in which it is badly needed that their voices be heard. They are preeminently qualified to identify risky situations. Furthermore, in their traditional communities, many women did have the opportunity to let their opinions and wishes be known either through their husbands or through other traditional networks. Now that their world has come apart, they need other ways of communication. ${ }^{381}$

Some women run higher risks than others. Especially unaccompanied adolescent girls and women, female heads of household, elderly women and disabled women are easy targets for abuse. Relief workers should ensure that these women have access to food and other relief items. After all, malnutrition is the principle cause of death in refugee camps. ${ }^{382}$ Usually, international organizations and host countries decide about the distribution of relief goods in consultation with the male leaders of the camp. The latter are, however, not the ones who know what difficulties are encountered or what exactly is needed for cooking the food or clothing the family. As a result, the items that are distributed may be inappropriate. Other problems with food distribution may arise because of the prevalence of son preference, when certain food taboos exist (pregnant or menstruating women are not allowed to eat or to prepare certain food stuffs) or when it is customary that the men are fed first. ${ }^{383}$ In some cases where goods were distributed through male networks, food was diverted to resistance forces or sold on the black market. In many other cases, women only had access to food and other items in exchange for sexual favours. ${ }^{384}$

As far as access to health care is concerned, it is noted in the UNHCR report that adequate access is not only important to the women themselves, but also to larger parts of the refugee communities, since women are the prime providers of health care to their family members. A problem in many camps is that there are no female health practitioners. In some cultures, a woman may not consult a male doctor, especially not when she is unaccompanied. Further problems arise because health services tend to overlook typical female needs, like gynaecological and birth control services or even basic hygienic facilities for menstruating women. Moreover, harmful practices, like female genital mutilation do occur. ${ }^{385}$

Some camps may offer possibilities for income-generating or skills-training programmes, but in many cases women do not participate, while self-sufficiency is an important handle against abuse. There are various reasons why women do not take part. For instance, there may be cultural impediments that prevent women from working outside the home or perform certain kinds of work, women do not have the required

381 Ibidem, paras $10-15$

382 Ibidem, para. 82

383 Son preference leads to gender difference in nutrition since the most nutritious food is given to the boys in the family. In many societies dietary restrictions exist to which pregnant women are subjected. See Preliminary report by the Special Rapporteur on violence against women, Ms Radhika Coomaraswamy, UN doc. E/CN.4/1995/42, paras 158 and 166 and Preliminary Report by the Special Rapporteur on traditional practices affecting the health of women and children, Mrs Halima Embarek Warzazi, UN doc. E/CN.4/Sub.2/1995/6, para. 46

$384 U N$ doc. EC/SCP/67, paras 82-85.

385 Ibidem, paras 89-94. 
educational level, like literacy, or there are no day care facilities where women can take their children. ${ }^{386}$

In the next section I will assess the situation of refugee women in the Netherlands as just one example of what women may experience when they are (temporarily) housed in one of the host countries.

\subsection{The Situation in the Netherlands}

Every year thousands of people from all over the world turn to the Netherlands in order to seek asylum against violence and discriminatory practices in their own countries. ${ }^{387}$ In view of the special problems and needs women encounter, the question is whether the Netherlands has a special policy with regard to female refugees and, more specifically, whether there are special rules as regards housing facilities. It turns out that the Netherlands Department of Justice, which is responsible for the procedure and reception of asylum-seekers, has not developed a special policy with regard to women, nor are there any specific policy rules as regards housing facilities. The Department's point of view is that in principle all refugees are equal, and that only unaccompanied minors should be treated differently. There exists, indeed, a special policy with regard to minors and they are housed in separate centres. ${ }^{388}$

As to where and how asylum-seekers are housed, a distinction must be made according to the different phases of the procedure. When aliens apply for asylum they are housed in one of the two registration centres (Aanmeldcentra; AC's). ${ }^{389}$ The application is prima facie examined there, and within 48 hours a decision is made whether the asylum-seeker has to leave the country immediately or whether she or he may temporarily stay pending further investigation. At the registration centres people are offered a place to sleep, they can shower and they are provided with a meal. From these centres, the asylum-seeker goes to one of the eleven reception and investigation centres (Ontvangsten Onderzoekscentra; $O C^{\prime}$ 's) where people are housed on a short-term basis. They get a medical examination and they must relate in as detailed a fashion as possible the situation in their home countries and explain clearly their motives for requesting asylum so that the Immigration and Naturalisation Service (IND) has sufficient information for further investigation and reaching a decision. In these centres people eat and sleep in common rooms. Pending the decision whether they will receive a residence permit, applicants go to one of the about 55 asylum-seekers centres (Asielzoekerscentra; AZC's). ${ }^{390}$ Though the authorities do their best to keep the procedure as brief as possible, and try to restrict the stay of asylum seekers in these centres to a maximum of six months, in

386 Ibidem, paras 107-108

387 This is the number of asylum-seekers over 2005. Netherlands Department of Justice, Rapportage Vreemdelingenketen over de periode september $t / m$ december 2005 [Report on the influx of aliens over the period September till December 2005], p.6 For comparison, in 2001 the influx of asylum-seekers was about 40.000 persons. Netherlands Department of Justice, Factsheet Vreemdelingenbeleid, [Factsheet on the Policy with regard to aliens], p. 5, <www.minjust.nl/a beleid/fact/cfact3.htm>, visited on 10-10-2001.

388 In fact, the Netherlands is the only country in Europe that has a separate policy for minors who seek asylum. Netherlands Department of Justice, Beleidsnota alleenstaande minderjarige asielzoekers [Policy document on single minor asylum-seekers], the Hague, 24 March 2000.

389 These registration centres, 'Aanmeldcentra', are at Schiphol (Amsterdam airport), Zevenaar and Rijsbergen.

390 Information on the different types of centres is to be found on $<\mathrm{http}: / /$ coa.nl $>$, last visited on 10-10-2001. 
practice people stay much longer. Even after the introduction of the new Aliens Act in 2001, CSOs report that tens of thousands of people have to stay as long as three years or longer in these asylum-seekers centres. Whole families have to live in one room, while singles have to share a room with strangers. ${ }^{391}$

Meanwhile complaints about the housing facilities for women in these asylumseekers centres $\left(A Z C^{\prime} s\right)$ are abundant. ${ }^{392} \mathrm{~A}$ frequently heard complaint is that common spaces in centres, meant for living and recreation, are occupied by men, thus more or less forcing women to retreat, together with their children, to bedrooms, which are already cramped. This means that there is little diversion for women and they suffer from a lot of stress.

Single women and girls complain about sexual intimidation and abuse which is caused primarily because they have to live in quarters together with unrelated males or even males who would have been their enemies in their home countries. Most centres have communal showers and latrines (i.e. not segregated by sex), which makes unaccompanied women feel unsafe. In several centres women have complained about the fact that the doors of the (communal) showers are open at the bottom. This induces some men to have a look underneath, which has made the women feel unsafe and exposed. Women who live in the centre together with their husband, will be accompanied by him when they take a shower, and single women ask girl-friends to keep a look-out. ${ }^{393}$

Women and girls who are harassed, have nowhere to take their complaints. Since they are completely dependent on the authorities, they are very much afraid that complaining will have an adverse effect on their application for asylum. If they do have the courage to come out in the open, there is no complaint procedure available and there are no (female) confidential agents that women could turn to when fellow refugees or others intimidate them.

\subsection{Internally Displaced Women}

Since the appointment of the Representative of the Secretary-General on Internally Displaced Persons some 20 countries have been visited, but serious problems with IDPs exist in more than 35 countries. ${ }^{394}$ Housing is a grave problem for all the internally displaced. As has already been mentioned above, not all of them live in camps but many are 'dispersed' ${ }^{395}$ Those women who seek refuge in the suburbs of towns, in rural areas, or hide in marches and woods, try to merge with the local population in order to become

391 Vluchtelingenwerk Nederland, at: <www.vluchtelingenwerk.nl/72-Opvang.html>, July, 2006. Vluchtelingenwerk is a Dutch CSO dealing with refugees.The Netherlands Parliament passed a bill on new aliens legislation, the 'Vreemdelingenwet 2000' (Kst 26975). This new Aliens Act became operational as from 1 April 2001. One of the objectives of the bill is to shorten the procedure considerably.

392 Based on information received from several CSOs, among which Humanistisch Overleg Mensenrechten (HOM), Utrecht, VluchtelingenWerk Nederland Amsterdam, and especially Vluchtelingen Organisaties in Nederland (VON), Utrecht.

393 Vluchtelingen Organisaties in Nederland, Vrouwen in Asielzoekerscentra; Een ongevraagd advies, 1996, p. 3.

394 See the homepage of the Representative of the Secretary-General for a current overview at: <www. ohchr.org/english/issues/idp/index.htm>. The countries visited by the RSG include: Angola, Armenia, Azerbaijan, Bosnia and Herzegovina, Burundi, Colombia, El Salvador, Indonesia, Mozambique, Peru, Uganda, the Russian Federation, Rwanda, Somalia, Sri Lanka, the Sudan, Tajikistan, and Turkey.

395 UN doc. E/CN.4/1995/50, para. 23 
more or less invisible. Just because of this situation they will be deprived of any help, if any is offered, and their security risk is very high, even more so because, when detected, they may be perceived as the 'enemy'. ${ }^{396}$ In his studies and on-site visits the RSG on Internally Displaced Persons tries to take the situation of the dispersed into account, but it stands to reason that most of the information he collects refers to the IDPs who form a much more obvious problem because they live in large clusters in camps. Therefore, this section will reflect primarily the situation of internally displaced women who are indeed 'displaced'.

Standards to address the special protection needs of IDPs are necessary and many of the guidelines and principles that have been developed in the framework of the UN with regard to refugees may be applied to IDPs analogously. ${ }^{397}$ This is particularly true for the principles and guidelines that have been developed with regard to refugee women, since the situation of refugee women and internally displaced women is very similar. ${ }^{398}$ Women and children are disproportionately represented in internally displaced populations, ${ }^{399}$ especially female heads of household. Both the UN General Assembly and the Commission on Human Rights have requested the RSG to pay special attention to the situation of internally displaced women ${ }^{400}$ and he has done so by taking the UNHCR guidelines as his point of departure.

From his reports it becomes clear that women not only constitute the largest group among the IDPs, but that they also run high risks as to human rights abuses. They are particularly vulnerable to gender-specific violence, because they lack the security of their homes and communities and they may, moreover, become the punch ball of partners frustrated by the stress of displacement. The violations they suffer include physical and sexual attacks, rape, forced prostitution, coercion into providing sexual favours in return for essential food, shelter, security, documentation or other forms of assistance, sale into marriage, forced marriage, domestic violence including marital rape. ${ }^{401}$ All these different forms of gender-specific violence concern a broad range of norms enshrined in international, regional and national human rights instruments and impair or nullify enjoyment of the rights to liberty, security and integrity of person, and freedom from gender discrimination.

Housing consists in many instances of temporary accommodations like tents, dilapidated railway cars and public buildings,${ }^{402}$ or mud huts which have roofs made of plastic or tin sheeting and that house both people and animals. In the slums there is often no water, electricity, sewage or public transportation. Nevertheless, the living conditions of those who live on the outskirts of towns are often better than of those who live in rural areas, where there is neither water nor access to basic services. Women and girls often have to walk for miles to fetch water.

$396 U N$ doc. E/CN.4/2005/84, para. 49. Also, UN doc. E/CN.4/1996/52, para. 4.

397 UN doc. E/CN.4/1994/44, para. 27.

398 Susan Forbes Martin, 1992, pp. 28-31.

399 UN doc. E/CN.4/1999/79/Add. 2, para. 6.

$400 U N$ doc. E/CN.4/1996/52, para. 45.

$401 U N$ doc. E/CN.4/1996/52, para. 46.

$402 U N$ doc. E/CN.4/1999/79, para. 75, this is for instance the case in Azerbaijan. 
An additional problem of the dispersed is that they often occupy land that has been claimed by others so that they live in constant fear of being evicted. In some countries, single women, especially widows, cannot build their own huts because of practical or cultural impediments. Subsequently, they have no alternative but to sleep outside, which constitutes grave health and security risks. ${ }^{403}$

During his visits to IDP camps, the RSG was struck by the fact that, though women and their dependent children form the majority of the displaced, women are hardly ever involved in planning and programming the various aspects of life in camps such as decisions on the camp lay out, distribution of goods or general organization. In one camp in Burundi, for instance, there lived about 5,000 people and only 25 of them were men. When the RSG asked to discuss the problems of the camp with several representatives, only men stepped forward. ${ }^{404}$

According to the Representative generally, life in camps is determined by gender based discrimination and treatment which results in unequal access to food, water, clothing, housing, adequate medical care, and sanitation for women. ${ }^{405}$

\subsubsection{Concluding Remarks}

Adequate housing is both different and more important for women in societies that are based on gender stereotypes that privilege men and burden women with the greatest part of household chores.

The adequacy of women's housing is determined by their socio-economic position, the technical and infrastructure quality of their house and surroundings, and the security, autonomy and dignity they experience at home, whether this is a permanent residence or a temporary shelter.

Women's marginalized position in society reflects on their economic and financial situation. Salaried jobs that are considered to be typically female are valued less and consequently are paid less than male jobs that in fact may require similar types of training or skill. Even women doing exactly the same jobs as male colleagues run the risk of being paid less. Hardly ever economic value is assigned to the domestic work women do. Women's inheritance rights are curtailed in some cultures and they may also be denied the right to own property and land. The ensuing poverty affects women's capacity to afford adequate housing. As long as the income gap between women and men exists, the costs of housing should be commensurate with women's average income. In addition, States should provide for housing subsidies for those people, especially female heads of household, who are unable to gain and maintain adequate housing by themselves. This will require the development of legislation and policies.

Technical deficiencies of housing affect men to a much lesser extent than women, because of the universal pattern of role modelling that refers a whole set of household chores to the female realm. Whether in rich or in poor countries, progressive or conservative, and independent from culture and religion, women all over the world do more

$403 U N$ doc. E/CN.4/1996/52/Add. 1, para. 77; this occurs for instance in Peru.

$404 U N$ doc. E/CN.4/1995/50, para. 29.

$405 U N$ doc. E/CN.4/1996/52, para. 48. 
household work than men and therefore are much more hindered by inadequacies in amenities, facilities and services. The food is supposed to be put on the table by them, the house cleaned, the clothes washed, the children raised no matter what difficulties have to be surmounted. Men have their businesses outside the home, and even when they are unemployed or retired, they do not, or to a much lesser extent, get involved in what is considered to be 'a woman's' work. In many countries some tasks have a very low status or are thought to be typically female so a man will feel ashamed or incompetent to perform them, even if he himself would wish to help his partner. This gender stereotyping of domestic work has the effect that unhealthy conditions resulting from inadequate housing conditions affect women's health more than men's. It also means that deficiencies will render women's life much harder. They have to put in a greater effort and work longer hours to perform the duties that are expected of them to the detriment of their own well-being.

Besides the elements that have already been determined by international fora as constituting adequacy, there are certain conditions that have so far insufficiently been taken into account but that should be fulfilled before housing can be called adequate for women. The first of these conditions is security inside the home. Women should feel safe in their own surroundings and should be able to live a dignified life, free of humiliation. Violence in the domestic sphere spoils any otherwise technically adequate housing situation. States are under the obligation to protect women from violence at the hands of private persons in private surroundings. ${ }^{406}$

The second important element is autonomy. Many traditional practices and cultural patterns deny women their independence and see them as annexed to a man. That is why too many women may not choose where and how they are housed but depend on others to determine this most basic living condition for them.

States should not hide behind the excuse of culture, but should see to it that women have an independent right to housing for two reasons. In the first place, because States otherwise violate their international law obligations. The major human rights instruments do not distinguish between women and men but, on the contrary, stipulate that States parties must ensure that women and men have equal access to and enjoyment of these rights. $^{407}$

406 See section 4.6 on State responsibility. After the Velásquez-Rodriguez case, it has become clear that States should show due diligence when citizens' rights are violated by third parties. Inter-American Court of Human Rights in the Velásquez-Rodriguez v. Honduras case, Judgment of 29 July 1988, OAS/ser.L./V./III.19, doc. 13 Article 18 of the Maastricht Guidelines on 'Acts by Non-State Entities' provides that 'The obligation to protect includes the State's responsibility to ensure that private entities or individuals, $[\ldots]$ do not deprive individuals of their economic, social and cultural rights. States are responsible for violations of economic, social and cultural rights that result from their failure to exercise due diligence in controlling the behaviour of such non-State actors.' Maastricht Guidelines on Violations of Economic, Social and Cultural Rights, SIM Special No. 20, Utrecht, 1998, p. 9. International provisions like Article 4 (c) of the Declaration on the Elimination of Violence against Women and General Comment No. 19 of CEDAW condemn violence against women as a violation of women's human rights.

407 Particularly Articles 2 and 5 of the Women's Convention, Article 3 of the Covenant on Economic, Socia and Cultural Rights, and Articles 3 and 12 of the Covenant on Civil and Political Rights. Also see section 4.3 on principles of equality and non-discrimination. 
In the second place because traditional views that housing rights should be conferred upon families rather than upon individuals disregard the fact that this puts women in a vulnerable and subordinate position. Furthermore, stereotypical ideas that men are breadwinners and women are homemakers do not take into account that almost one third of all the households in the world are female headed. ${ }^{408}$ The living conditions of these women and their dependants are seriously affected if women cannot claim their housing rights.

In view of the great number of women who live in temporary housing conditions, such as shelters, safe houses, asylum-seeker centres, refugee and IDP camps, it is imperative that standards of adequacy are applied to such housing situations as well. In particular, access to facilities, habitability, privacy, secure tenure at least until satisfactory alternative housing has been found, and security from both external and internal threats, should be safeguarded in order to provide at least some degree of dignity and humanity to women living in provisional homes.

\subsection{Private LaW Issues}

\subsubsection{Introduction}

In the context of this study it is pertinent to look into a few aspects of private law that directly or indirectly influence women's right to adequate housing. Although many human rights instruments may award women equal rights with men and particularly Article 2 of the Women's Convention demands that all national laws and policies should be in conformity with the principle of equality and that discrimination against women should be eliminated, it is highly relevant to find out whether these equality standards have indeed been implemented on the national level.

The first issue that will be dealt with in section 3.5.2 is the right to property. If women are denied the right to acquire, administer and dispose of property, they cannot autonomously conduct their financial affairs and they may be denied the acquisition of real estate, including housing and land, for themselves.

An important aspect of property rights is to have legal capacity. A right to property may be of little use when a woman cannot conclude contracts or is denied the right to administer her property.

A particular way of acquiring property is inheritance. World-wide many different legal and customary rules and traditional practices pertain to the right of inheritance of women. Several of these rules and practices do not accord women the same rights to inherit as their male counterparts. If girls and women are not entitled to their parents' or husband's estate this may entail that they are denied this possibility of procuring adequate housing. The law of inheritance is the subject of section 3.5.3.

The last issue that will be discussed is the freedom of residence. Family law provisions sometimes determine that married women may not decide where they want to

408 Moreover, States parties to the Women's Convention violate Article 5 if they condone the continuance of traditional patterns and gender stereotyping that put women in an inferior position in society. See section 4.5 on culture and gender stereotyping. 
settle down but have to comply with their husbands' wishes in this regard. Though it seems logical that married couples have to come to an agreement where to reside, the place of settlement determines to a certain extent the adequacy of the housing situation. That is why, women should have an equal say in the matter.

\subsubsection{Property Rights ${ }^{409}$}

The right to own and administer property is highly relevant with a view to the right to housing. Property rights may enable people to obtain and retain a dwelling of their own. If women lack this right, they are deprived of a chance to procure adequate housing.

In line with international human rights law obligations, any property rights people may have under national constitutions and other laws and acts must be in conformity with the principle of equality. ${ }^{410}$

Particularly important for women's property rights are Articles 15 and 16 of the Women's Convention. ${ }^{411}$ Article 15 stipulates that there should be gender equality as to the administration of property in general, while Article 16 adds that married women should have, on an equal footing with their spouses, the right to own, acquire, manage, administer, enjoy and dispose of marriage property. ${ }^{412}$

Below, examples will be discussed of national situations in which legal or customary and traditional rules may bestow or deny women equal property rights. Separate attention will be paid to the legal capacity of women since the right to property can only be adequately exercised when women can conclude contracts and administer property without restrictions.

409 Property rights may be viewed both from a private law and a public law perspective. Public law aspects of this right will be discussed in section 3.6.3 infra, while this section focuses on private law aspects.

410 Gender equality and non-discrimination on the basis of sex is, among other instruments, included in The Universal Declaration of Human Rights (Art. 1 and 2), International Covenant on Civil and Political Rights (Art. 3 and 2(1)), International Covenant on Economic, Social and Cultural Rights (Art. 3 and 2(2)), Convention on the Elimination of all Forms of Discrimination Against Women (Art. 2). Also see section 4.3 principles of equality and non-discrimination.

411 Out of the 180 State parties to the Women's Convention in December 2005, 29 have made reservations pertaining in part or wholly to the Articles 15 and 16 of the Convention. These States are: Algeria, the Bahamas, Bangladesh, Belgium, Egypt, India, Iraq, Republic of Ireland, Israel, Jordan, Kuwait, Lebanon, Libyan Arab Jamahiriya, Luxembourg, Malaysia, Maldives, Malta, Mauritania, Mauritius, Morocco, Niger, Pakistan, Republic of Korea, Saudi Arabia, Singapore, Switzerland, Thailand, Tunisia and Turkey.

412 Convention on the Elimination of All Forms of Discrimination against Women, Article 15 reads in full: '1. States Parties shall accord to women equality with men before the law. 2. States Parties shall accord to women, in civil matters, a legal capacity identical to that of men and the same opportunities to exercise that capacity. In particular, they shall give women equal rights to conclude contracts and to administer property and shall treat them equally in all states of procedure in courts and tribunals. 3. States Parties agree that all contracts and all other private instruments of any kind with a legal effect which is directed at restricting the legal capacity of women shall be deemed null and void. 4. States Parties shall accord to men and women the same rights with regard to the law relating to the movement of persons and the freedom to choose their residence and domicile.' Article 16 reads in part: '1. States Parties shall take all appropriate measures to eliminate discrimination against women in all matters relating to marriage and family relations and in particular shall ensure, on a basis of equality of men and women: [...] (h) The same rights for both spouses in respect of the ownership, acquisition, management, administration, enjoyment and disposition of property, whether free of charge or for a valuable consideration'. 


\subsubsection{Property Rights and Equality}

As far as equal rights of women to property are concerned Article 15(1) of the Women's Convention is particularly relevant since this provision calls upon States parties to 'accord to women equality with men before the law'. Consequently, private law provisions that deal with property rights matters are not to discriminate against women because of their sex.

In many countries, such as Bhutan, Greece, Mexico and the Netherlands, ${ }^{413}$ there is de iure equality between women and men as regards the law of property and family law. ${ }^{414}$ In others, such as Bangladesh, Cameroon, Guinea, India and Tanzania there is de iure inequality, since several legal provisions discriminate against women, particularly against married women. ${ }^{415}$ For instance in Bangladesh the Constitution awards women equal rights with men in the public sphere, but allows inequality to persist in the private law sphere because the legality of discriminatory personal laws is acknowledged. One of the consequences is that rural women experience problems as regards ownership of land. ${ }^{416}$ Article 216 of the Civil Code of Cameroon stipulates that the legal capacity of married women is in some respects limited, but this is not true for married men. ${ }^{417}$ In Guinea the law also permits limitations of married women's right to purchase and dispose of property. ${ }^{418}$ The Hindu Succession Act of India was a step in the right direction because it awarded women more property rights. Prior to the act they could not sell or alienate their property. However, the Act excludes the Mitakshara joint family property from its application. ${ }^{419}$ This means that the Mitakshara personal Law prevails over more than two-thirds of India so that a great many women are debarred from inheriting property on the same terms as their male counterparts. This is clearly discrimination on the grounds of sex, which is contrary to the provisions of the Indian Constitution. ${ }^{420}$ Though the Constitution of Tanzania embodies the principle of equality before the law, this is undermined by the legal requirement that in family law cases, particularly with respect to division of property and inheritance, courts are to take customs and traditional practices of the parties into consideration. ${ }^{421}$

413 The countries that are mentioned have all ratified the Women's Convention without reservations as regards Article 15 of the Convention.

414 Bhutan; see UN doc. CEDAW/C/BTN/1-3, 20 January 2003, Greece; see Carolyn Hamilton, Kate Standley (eds.), Family Law in Europe, Butterworths, London, Dublin, Edinburgh, 1995, pp. 197-230, Mexico; see UN doc. CEDAW/C/MEX/3-4, 7 March 1997, the Netherlands; see Family Law in Europe, 1995, pp. 299-324.

415 This is the more striking since the countries that are mentioned have all ratified the Women's Convention without making a reservation as to Article 15(1)

$416 U N$ doc. CEDAW/C/BGD/3-4, 1 April 1997, para. 1.6, and $U N$ doc. A/52/38/Rev.1, 1997, para. 453.

$417 U N$ doc. CEDAW/C/CMR/1, 9 May 1999, p. 87 English version.

$418 U N$ doc. CEDAW/C/GIN/1-3, 6 March 2001, para. 16.16, also UN doc. A/56/38, 2001, para. 99.

419 The Mitakshara is a legal treatise on inheritance, written by Vijnaneshwara, a prominent jurist of $12^{\text {th }}$ century India. It is one of the most influential texts in Hindu law, and its principles regarding property distribution, property rights, and succession are still in practice across most of India.

420 Kirti Singh, 'Obstacles to Women's Rights in India', in: Rebecca J. Cook (ed.), Human Rights of Women; National and International Perspectives, University of Pennsylvania Press, Philadelphia, 1994, p. 381. Also see $U N$ doc. A/53/38, 2000, paras 82-83.

$421 U N$ doc. CEDAW/C/TZA/2-3, 30 September 1996, para. 113, also UN doc. A/53/38/Rev.1, 1998, para. 229. 
In still other countries particular customs and traditional practices create de facto inequality for women. For example in Burkina Faso where a new law on land reform gives women equal rights with men as far as access to land is concerned, but where implementation of that law is adversely affected by prejudice and custom. ${ }^{422}$ In Guinea, where equality between women and men is a fundamental principle of the Constitution, it is customary for a childless widow to marry a relative of her deceased husband (levirate). When she does so, she may continue to live in the marital home. If she refuses, she has to leave the home, while her deceased husband's relatives will appropriate all his property for themselves. ${ }^{423}$

\subsubsection{Legal Capacity of Women}

In order to be able to enjoy their property rights fully, women, regardless of their marital status, must have the legal capacity to conclude contracts and be able to administer their property autonomously. ${ }^{424}$ Legal provisions and customary practices that curtail women's rights by denying them legal capacity or demanding their husband's or a male relative's consent, or deny them the right to own, acquire, manage and dispose of their property, seriously undermine women's financial independence and thus affect their ability to provide for an adequate standard of living, including housing, for themselves. ${ }^{425}$

In some States legal provisions discriminate against women in this regard. South Africa for example has acceded to the Women's Convention without reservations, but the Customary Marriage Act determines that a woman married under this Act is considered to be a minor and is put under the guardianship of her husband. ${ }^{426}$ In Nepal the Muluki Ain customary law, ${ }^{427}$ restricts women from independent use of their property. ${ }^{428}$ Married Tamil ${ }^{429}$ women in Sri Lanka cannot alienate their property without their husband's consent. ${ }^{430}$ Jordanian law prohibits women from concluding contracts in their own name. ${ }^{431}$ In several Latin American States civil law provisions deny married women

$222 U N$ doc. $\mathrm{A} / 55 / 38,2000$, paras 259 and 277.

423 UN doc. CEDAW/C/GIN/1-3, 6 March 2001, paras 15.1, 15.3.1 and 16.4.

424 Articles 15(2) and 16(1)(h) of the Women's Convention overlap and complement each other. The denial of legal capacity of married women also violates Article 23(4) of the ICCPR which stipulates that 'State parties to the present Covenant shall take appropriate steps to ensure equality of rights and responsibilities of spouses as to marriage, during marriage and at its dissolution.'

425 CEDAW General Recommendation No. 21 (thirteenth session): Equality in marriage and family relations, paras $7-8$ and $25-26$.

$426 U N$ doc. $\mathrm{A} / 53 / 38 /$ Rev. 1, 1998, para. 107.

427 The Muluki Ain is the codification by Jung Bahadur Rana in 1854 of the social code that had been in practice for centuries in Nepal.

428 Nepal has ratified the Women's Convention without reservations, $U N$ doc. A/54/38/Rev. 1, 1999, paras 119 and 138 .

429 The Tamil are an ethnic group from south Asia. The oldest Tamil communities live in southern India and northeastern Sri Lanka.

430 Radhika Coomaraswamy, 'To Bellow like a Cow: Women, Ethnicity, and the Discourse of Rights', in: Rebecca Cook (ed.), Human Rights of Women; National and International Perspectives, Pennsylvania University Press, Philadelphia, 1994, p. 45.

431 UN doc. $\mathrm{A} / 55 / 38,2000$, para. 172. 
the capacity to administer marital or even their own property, ${ }^{432}$ and in Burundi women have no economic control over the goods they produce. ${ }^{433}$

Hardly any better off are women who are legally entitled to administer their property autonomously, but who are de facto deprived of this right. In Tanzania's matrilineal societies, for instance, property is inherited through a wife's lineage. This does not mean, however, that a woman has effective control over or ownership of the family land, because land and other property are traditionally controlled by the male members of the woman's family, i.e. her father, brothers, and uncles. ${ }^{434}$ Article 444 of the Guinean Civil Code holds that a woman has legal capacity and enjoys all civil and political rights on an equal footing with men. In practice, however, it is very difficult for women to exercise their rights because of illiteracy, their low levels of income, and the fact that they are discriminated against because they are women. ${ }^{435}$ In theory, women in Bangladesh can administer property and have the right to enter into contracts, including real estate, in their own names. De facto they cannot exercise these rights in the same way as men can because of their low socio-economic status and persisting discriminatory customs and practices. ${ }^{436}$

\subsubsection{Equality as regards Marriage Property}

Some countries do not accord a woman the right to own an equal share of the property with her husband during marriage, or deny her the right to administer the property on an equal footing. In other States these rights are recognized, but women are prevented from exercising them because of restricting customs.

When marital property has to be divided upon divorce, in some States only women have to prove that they are entitled to a share because they contributed to the acquisition of the marital property. Moreover, some systems put a higher value on the financial contribution that was made to acquire the property, while they attach much less value or completely dismiss other contributions to the joint household like taking care of the children, and doing the household chores. ${ }^{437}$

In European countries the property during marriage either falls in a community of property regime $e^{438}$ or remains individual property on the basis of the principle of sepa-

432 Cecilia Medina, 'Towards a More Effective Guarantee of the Enjoyment of Human Rights by Women in the Inter-American System', in: Rebecca J. Cook (ed.), Human Rights of Women; National and International Perspectives, University of Pennsylvania Press, Philadelphia, 1994, p. 260.

433 UN doc. A/56/38, 2001, para. 39.

434 Florence Butegwa, 'Using the African Charter on Human and Peoples' Rights to Secure Women's Access to Land in Africa', in: Rebecca Cook (ed.), Human Rights of Women; National and International Perspectives, Pennsylvania University Press, Philadelphia,1994, pp. 497-498.

$435 U N$ doc. CEDAW/C/GIN/1-3, 6 March 2001, para. 15.2.

$436 U N$ doc. CEDAW/C/BGD/3-4, 1 April 1997, paras 1.2, 1.6 and 2.14.

437 CEDAW General Recommendation No. 21 on Equality in marriage and family relations, paras 30-32.

438 This is for instance the case in Belgium, Denmark, France, the Netherlands, Portugal, Spain and Switzerland. Family Law in Europe, 1995, pp. 9-10, 39-40, 134-135, 307, 385, 450 and 520 respectively. The limited community system may also be found in Central and Eastern Europe, e.g. in the Czech Republic and in Russia. Walter Pintens, 'Europeanisation of Family Law', in: Katharina Boele-Woelki (ed.), Perspectives for the Unification and Harmonisation of Family Law in Europe, Intersentia, AntwerpOxford-New York, 2003, p. 9. 
rate property. ${ }^{439}$ Parties are free to make other arrangements by drawing up a marriage contract. However, whatever the statutory regime is in these States, both marriage parties will have equal rights to own and administer the marriage property. Furthermore, in several west European States special legal rules apply to the marital home. No matter whether both parties or only one of them is the owner or lessee of the matrimonial home, both parties' consent is needed to sell, give away, mortgage, or give notice to quit. Without the other spouse's consent these legal acts are voidable. ${ }^{440}$ Thus the non-owning and non-renting party is protected from having the home sold or quit over her or his head.

Inequality between women and men as regards ownership and administration of marriage property may for instance be found in Cameroon where Articles 213 and 214 of the Civil Code stipulate that the husband shall be the head of the family, and Articles 1421 and 1428 entrust him with the sole right to administer the community property, and even his wife's personal property. He may sell, transfer or mortgage the community property without her consent, but he may not dispose of her personal real property without her permission. ${ }^{441}$ In Guinea a married woman's freedom to dispose of her personal fixed assets or land is restricted because she needs her husband's consent. ${ }^{442}$ The current Name Law and other laws in Thailand restrict a woman's land ownership when she marries a foreigner, ${ }^{443}$ and in Chile women are discriminated against under the family law, inter alia as far as their ability to administer their own and joint marriage property is concerned. $^{444}$

An example of a religious law that discriminates in this respect may be found in Israel where married Jewish fundamentalists live according to three halakhah rules. ${ }^{445}$ The first of these rules specifies that during marriage, the husband is entitled to his wife's earnings and the produce of the property owned by her before the marriage. ${ }^{446}$

Upon divorce the basic principle in most European countries is that all common assets are to be divided equally. Some of these States have a special arrangement as regards the family home. In France for instance, the family judge can determine that the sole owner of the home is to leave the house to the other spouse after the divorce. ${ }^{447}$ And in Sweden the matrimonial home may be allocated to the spouse who has the greatest need for that property i.e. in most cases the spouse with whom the children will stay. ${ }^{448}$

439 This system is followed in Austria, Switzerland and some Scandinavian legal systems. Pintens, 2003 , p. 9. It may also be found in England and Wales, Germany, Greece, Republic of Ireland and Scotland. Family Law in Europe, 1995, pp. 71, 170, 237, 406-407 respectively.

440 This system is applied in Belgium Denmark, France, Republic of Ireland, the Netherlands, Portugal, Spain and Switzerland. Family Law in Europe, 1995, pp. 10, 41, 135-136, 241, 310, 386, 452 and 523.

$441 U N$ doc. CEDAW/C/CMR/1, 9 May 1999, pp. 88 and 96 of the English version.

442 UN doc. CEDAW/C/GIN/1-3, 6 March 2001, para. 16.17.

443 UN doc. A/54/38/Rev. 1, 1999, para. 247.

$444 U N$ doc. A/54/38/Rev. 1, 1999, paras 221-222.

445 The halakhah is the collective corpus of Jewish religious law including biblical law, Talmudic and rabbinic law as well as customs and traditions.

446 Courtney W. Howland, 'Women and Religious Fundamentalism', in: Kelly D. Askin, Dorean M. Koenig (eds.), Women and International Human Rights Law, Volume 1, Transnational Publishers, Inc. Ardsley, New York, 2000, p. 573.

447 Family Law in Europe, 1995, pp. 146-147.

448 Family Law in Europe, 1995, p. 491. 
In Cameroon, assets are divided in accordance with the legal regime or the regime chosen upon marriage. Women who have been married according to customary law are in a disadvantageous position because they have to prove that they have contributed financially to the common property before they are entitled to part of it. ${ }^{449}$ Case law shows that courts tend to decide against women, especially as regards the family home ${ }^{450}$ In Benin the husband is automatically considered to be the sole owner of all matrimonial property and upon divorce women have a very hard time convincing the court otherwise. ${ }^{451}$ In Guinea divorce entails that the wife removes her personal effects from the marital home and leaves. ${ }^{452}$ In Bangladesh the wife is only entitled to the property she owns in her own name. ${ }^{453}$ The second and third halakhah rules of fundamentalist Jews in Israel pertain to divorce. The second rule accords the husband the exclusive power to end the marriage and the third gives him the right to obtain a divorce when his wife is 'rebellious' ${ }^{454}$ The consequences of these rules are that the husband has a veto right to end the marriage and he may abuse this power by coercing his wife to give him property or money in exchange for his consent to a divorce. When a wife is divorced because she has been found to be rebellious, she is financially punished because she will forfeit a divorce settlement. ${ }^{45}$ In Albania it is tradition for a woman to move into the house of her husband, who is often the sole owner of the premises. Upon divorce the family judge may decide that the wife and children are entitled to live in the family home, but in most cases the property right of the husband will prevail and the wife and children are evicted. ${ }^{456}$

\subsubsection{Concluding Remarks}

Apparently in many States it is felt that when equality is a fundamental principle of the Constitution, and women are accorded equal rights with men in public life, they have complied with their obligations as regards equality rights in general and with those ensuing from the Women's Convention in particular. What happens in the private sphere, and thus touches upon women's private law rights, is still felt to be a private matter that can be relegated to personal law systems and customary rules and traditional practices. Especially in the private sphere, however, women are discriminated against. If their

449 UN doc. CEDAW/C/CMR/1, 9 May 1999, p. 92 English version.

450 Florence Rita Arrey, 'Legislative and Judicial Treatment of Family Relations in Cameroon', in: Bringing International Human Rights Home; Judicial Colloquium on the Domestic Application of the Convention on the Elimination of All Forms of Discrimination against Women and the Convention on the Rights of the Child, United Nations, New York, 2000, pp. 139-140.

451 Conceptia Ouinsou, 'Inheritance Rights or Women's Role in Succession in the Customary Law of Benin', in: BringingInternational Human Rights Home, 2000, p. 131.

452 UN doc. CEDAW/C/GIN/1-3, 6 March 2001, para. 15.3.2.

453 UN doc. CEDAW/C/BGD/3-4, 1 April 1997, para. 2.15.3.

454 A wife may be deemed rebellious when she refuses sexual intercourse, fails to do household chores without a valid reason, or leaves her husband because he has beaten her. Courtney W. Howland, 2000, pp. 573-574.

455 Courtney W. Howland, 2000, pp. 573-574.

456 Women 2000; An Investigation into the Status of Women's Rights in Central and South-Eastern Europe and the Newly Independent States, International Helsinki Federation for Human Rights, 2000, p. 26. 
property rights are curtailed this has directly or indirectly an impact on their right to adequate housing. If women are denied the right to legal capacity or are discriminated against as regards the right to own and administer their own and common property during marriage, or an equal share upon dissolution of the marriage on the ground of divorce, women's ability to fend for themselves financially and to provide for adequate housing for themselves and their dependants is seriously undermined. Human rights of women remain a dead letter when they are not adequately implemented in the national legal systems. Therefore, in the first place national private laws should be reviewed and redrafted in order to align them with international human rights obligations. Particularly harrowing is the situation of women in whose countries dual or triple legal systems co-exist. Although the Constitution or other statutory laws may bestow equal rights on both sexes, this is of no use to those women who have been born into a certain ethnic or religious group. The only adequate solution to this unfortunate situation is the abolition of the personal law systems so that just one, general family law system will remain that is in conformity with the Women's Convention. It goes without saying that besides discriminatory legal systems, also customs and traditional practices that deny or curtail women's equal property rights should be revised or abolished.

\subsubsection{Law of Inheritance}

In spite of the existing international and regional human rights instruments that proclaim gender equality and prohibit discrimination on the ground of sex, many girls and women all over the world are deprived of a share in the inheritance. This may drastically affect their right to adequate housing, since the death of a father or husband may entail that they no longer have the right to reside in the family or the matrimonial home. In the framework of this study it is not my intention to go into the law of inheritance extensively, but just to illustrate by way of a few examples the effects of legal and customary rules.

\subsubsection{Legal Discrimination}

World-wide different situations may be encountered. In some States, particularly Islamic countries, the law determines that women do not have the same rights to the inheritance as their male counterparts. ${ }^{457}$ Islamic inheritance law is primarily an intestate system. ${ }^{458}$

457 If these States are parties to the Women's Convention, their law of inheritance will conflict with Article 2 of the Convention in which States parties are called upon to deploy all kinds of legal and policy methods to eliminate discrimination against women and to embody the principle of equality in all aspects of society. Most crucial is perhaps paragraph (f) according to which States are 'To take all appropriate measures, including legislation, to modify or abolish existing laws, regulations, customs and practices which constitute discrimination against women'. Some Islamic States, such as Egypt and Iraq, solve this problem by making a general reservation as regards Article 2 by stating that they comply with the content if this article as long as compliance does not run counter to Shari'a law. Niger, for instance, is more explicit by stating that 'The Government of the Republic of the Niger expresses reservations with regard to Article 2, paragraphs (d) and (f), concerning the taking of all appropriate measures to abolish all customs and practices which constitute discrimination against women, particularly in respect of succession' (italics added).

458 Susanne Rutten, Erven naar Marokkaans recht; Aspecten van Nederlands international privaatrecht bij de toepasselijkheid van Marokkaans erfrecht, Intersentia, 1997, p. 24. 
The Qur'an determines in Chapter 4 who the legal (al-farâ'id) heirs are and to which part of the inheritance they are entitled. For instance, it is stipulated that a son gets twice the share of a daughter, a brother double the share of a sister, and a husband half of his wife's inheritance, while a wife is only entitled to a quarter of her late husband's estate. ${ }^{459}$ The Qur'an, however, establishes these legal claims only as regards two-thirds of the estate. The last third may be 'freely' bequeathed by the deceased in his testament, although this freedom is rather restricted, since the majority of Islamic scholars are of the opinion that this part of the inheritance may not be left to the legal heirs mentioned in the Qur'an. ${ }^{460}$ If the deceased has not made a testament, this part will traditionally be inherited by the closest male relative in the agnatic line. ${ }^{461}$

\subsubsection{Co-existence of Different Legal Rules}

It is also possible that in one country different legal inheritance systems co-exist. This is typically a remnant of colonial times. When they seized power, the colonial powers changed many existing laws, but in many instances they did not dare or want to interfere in family law matters. The latter were left to be regulated by custom and tradition. In India, for example, a general law system exists that is based on the written Constitution, containing basic rights like the principle of equality. At the same time personal law systems are operative. ${ }^{462}$ Since approximately $85 \%$ of the population is Hindu, for them the Hindu personal law is applicable, while the Muslim personal law affects the rights and duties of the approximately $12 \%$ Muslims in the country. As far as the law of inheritance is concerned, the Hindu Succession Act (1956) proclaims more or less equality between male and female heirs. ${ }^{463}$ However, the Act is undermined by individual Indian 'state' laws that stipulate that with a view to avoiding land fragmentation,

459 Qur'an Chapter 4, verses 11, 12 and 176 respectively mention these al-farâ'id heirs. However, the division is equal between the mother and the father, i.e. each one-sixth, as regards the estate of a deceased child. Position Paper on Islamic Inheritance, at <www.jannah.org/sisters/inheritance.html $>$, consulted on 17-4-03.

460 It is interesting to note that there is a difference of opinion as to whom this last part of the estate may be bequeathed. The majority of Sunni schools of thought is of the opinion that this part may not be left to any Qur'anic (al-farâ'id) heirs, like wife and children. Once they have received their legal share according to the Qur'an they are not entitled to anything else. Shiites, however, disagree with this limitation. Position Paper on Islamic Inheritance, at www.jannah.org/sisters/inheritance.html, consulted on 17-4-03. Rutten is of the opinion that it is forbidden to leave more to the al-fara 'id heirs than the share stipulated in the Qur'an. Susanne Rutten, 1997, p. 24.

461 These male relatives are the so-called 'asaba' heirs. They stem from pre-Islamic inheritance law. In fact, chances of inheriting anything were rather slim for women before the Qur'an was introduced. Susanne Rutten, 1997, pp. 21-22. Also Moiz Amjad, Understanding the Law of Inheritance of the Qur'an, at $<$ www.understanding-islan.com/related/text.asp?type=article\&aid=14\&sscatid $>$, consulted on 17-4-03.

462 The 'personal law' is a system of rules that are applicable to an individual in accordance with his or her religious or ethnic group. Personal laws will be discussed in more detail in section 3.7.4 infra.

463 An example of unequal treatment may be found in section 23 of the Hindu Succession Act in which it is determined that if a woman inherits a house in which at the time relatives are staying she may not claim a partition of the house for herself. She could only reside in it when she is single or has been separated. Kirti Singh, 'Obstacles to Women's Rights in India', in: Rebecca J. Cook (ed.), Human Rights of Women, National and International Perspectives, University of Pennsylvania Press, Philadelphia, 1994, p. 381. 
wives are excluded from their husband's inheritance. ${ }^{464}$ Muslims are of course bound by the Islamic inheritance law as explained above.

In Nigeria, marriages may be contracted under customary law, Islamic law and statutory law (the Nigerian Marriage Act). The legal status of the widow and her rights of inheritance depend on the regime under which the marriage was concluded. Customary laws stipulate that, in violation of principles of equality and non-discrimination that have been laid down in the Constitution, women do not have the same rights of inheritance as men, or rights to own or to dispose of family or communal land. ${ }^{465}$ Under the customary system the inheritance will go to the male heir, usually the eldest son and a widow cannot inherit at all from her deceased husband. ${ }^{466}$ Consequently, customary law widows who do not have a source of income of their own desperately need a son to secure a roof over their heads. ${ }^{467}$ Statutory law widows, however, are entitled to part of their husband's estate. ${ }^{468}$

\subsubsection{De Facto Discrimination}

Sometimes there is a large discrepancy between theory and practice. In some cultures, although the law stipulates that a daughter, sister or wife may inherit, custom and tradition prevent her from getting or claiming her rightful share.

For example, since the law of inheritance in the state of Maharashtra (India) has been changed in the early 1990s, daughters are entitled to the same share of the inheritance as sons. In practice, however, many daughters will refrain from claiming their share. In the first place, because they may already have received their share in the form of a dowry upon marriage. Although officially the dowry system is illegal, the custom is very persistent. It is considered to be a girl's first duty to marry and her chances for a good party will enhance considerably when her parents pay a generous dowry. Moreover, it is felt that the in-laws should be compensated for taking the girl in since custom inhibits particularly higher caste women to find employment and thus the daughter-inlaw will not contribute to the family's income. Generally, domestic work is not considered to be a contribution. Furthermore, the girls' brothers will remain in the parental home, taking care of the parents and tilling the family's land. Many years may pass between the girl moving out and the death of the parents. That is why it is felt that the family's wealth that has meanwhile accumulated is owed to the sons' labour, and it

464 Sonalde Desai, 'Engendering Population Policy', in: M. Krishnaraj, R. Sudarshan, A. Shariff (eds.), Gender, Population and Development, Oxford University Press, Delhi, 1998, p. 53.

465 Adetoun O. Ilumoka, 'African Women's Economic, Social and Cultural Rights', in: Rebecca J. Cook (ed.), Human Rights of Women; National and International Perspectives, University of Pennsylvania Press, Philadelphia, 1994, pp. 316-317.

466 Chima Jacob Korieh, Widowhood among the Igbo of Eastern Nigeria, Thesis for the Degree of Master of Philosophy, Bergen, Norway, 1996, at www.uib.no/hi/korieh/chima.html, consulted on 9-5-01, paras 1.5.4 and 3.1. Desai thinks these land laws are a pretext to exclude widows and daughters from inheriting land. Sonalde Desai, 1998, p. 53.

467 Margaret Owen, Empowering Widows in Development, the Status of Widows in 10 countries, Seclusion and Exclusion, at www.oneworld.org/empoweringwidows/10countries/Nigeria.html, consulted on 18-4-01.

468 A statutory law widow is entitled to one-third of her late husband's estate when she has children, and to half of it if she is childless. Chima Jacob Korieh, 1996, para. 4.1.2. 
would be unfair if a daughter would claim any part of it, since she has not contributed to it. Lastly, if a woman becomes a widow ${ }^{469}$ without adult sons, and her in-laws refuse to support her any longer ${ }^{470}$ she will have to fall back on her brothers. Therefore, she will be very wary not to compromise her relationship with her brothers by claiming a share of the inheritance. ${ }^{471}$

Although a woman married under statutory law in Nigeria (the Nigerian Marriage Act) is entitled to part of her late husband's estate,${ }^{472}$ in practice her rights may be completely ignored by the male relatives of her husband who regard his property as their birth right and seize it upon his demise, leaving her and her children destitute.

In Uganda, the Succession Act and the Succession Decree allow a woman to inherit all property, including land, bequeathed to her in her husband's will. However, since it is considered to be a bad omen to make a will, hardly anyone makes one. According to intestate inheritance law the widow is not entitled to her late husband's estate. The land will go to the customary law heir, normally the eldest son. Although traditionally, the widow would stay on the land until her death or remarriage, nowadays heirs tend to sell the land for their own profits thus forcing the widow to leave. ${ }^{473}$

\subsubsection{De Iure and De Facto Equality}

In many countries of the world women and men are treated equally as regard their inheritance rights both de iure and de facto. However, vigilance is called for since sometimes certain circumstances may have an inadvertent indirect discriminatory effect on women. This can be clarified by looking at the situation in the Netherlands before the new law of inheritance entered into force on 1 January $2003 .{ }^{474}$ Problems could arise when one of the spouses of a couple married under a community of property regime died intestate ${ }^{475}$ The law of inheritance stipulated that the surviving spouse and each of the children shared equally in the inheritance. If a child immediately claimed his or her share, in many cases the surviving parent had no other choice but to sell the assets, particularly the house she or he was living in, in order to be able to pay the child his or her share. ${ }^{476}$ Since the average life span of women is longer than the average life span of men in the Netherlands, particularly elderly widows with no income of their own were forced to leave their homes. With the new law this is no longer necessary. Children still

469 The chances that she will be a widow are very high since she will typically be much younger than her husband.

470 For homelessness of widows also see section 3.3.4 supra.

471 Annabelle Perkins, Gender and Inheritance Law Reform in Maharashtra, 1994, at <www.prout.org/pna/ inheritance-india.html>, consulted on 17-4-03. Also Sonalde Desai, 1998, p. 53.

472 See note 14 supra.

473 Florence Butegwa, 'Using the African Charter on Human and Peoples' Rights to secure Women's Access to Land in Africa', in: Rebecca J. Cook (ed.), Human Rights of Women; National and International Perspectives, University of Pennsylvania Press, Philadelphia, 1994, p. 497.

474 Wet nr 27021 (Bezemwet), M.J.A. van Mourik, Nieuw Erfrecht, Studiepockets Privaatrecht 59, derde druk, Kluwer, Deventer, 2002, p. 6.

475 This is the most common situation. Van Mourik, 2002, p. 10.

476 Van Mourik, 2002, pp. 46-49. Also Nieuw Erfrecht; De veranderingen, at <www.notaris.nl/nieuws/nieuwerfrecht/nl.html $>$, consulted on 1-5-2002 
inherit equally with the surviving parent, but they do not get their share while their parent is alive. In fact, they do have a claim on their parent for their share of the inheritance but this claim can only be cashed in when both parents have deceased. ${ }^{477}$ The reason why the law was changed was that the surviving parent should be enabled to have an undisturbed continuance of her or his standard of living.

\subsubsection{Concluding Remarks}

In many States in the world there is no discrimination of women as regards their inheritance rights. In others, however, women are discriminated against either by law or by custom and tradition. In these countries women run the risk of becoming homeless or totally dependent on others for their housing situation because they are not entitled to the same share of the inheritance as their brothers or husbands. If these States are parties to human rights instruments, particularly the Women's Convention, they are under the obligation to repeal all laws that discriminate against women on the ground of sex. ${ }^{478}$ Very complex and misleading is the situation in countries in which co-existing systems of law prevail. Though in these countries the general legal system will outlaw discrimination and propagate gender equality, at the same time they allow personal law systems to exist that perpetuate subordinate positions for women in society and prevent them from enjoying the rights they are entitled to according to the constitution and other national laws.

Perhaps the most difficult to eradicate are customs and traditions that persist to treat women and men differently in spite of inheritance laws that dictate gender equality. These are based on ideas and perceptions firmly embedded in male and female images. The only solution is a change of mentality that may be brought about by (human rights) education, and by overcoming gender stereotyping. ${ }^{479}$

An extra barrier that affects equality between women and men in matters of inheritance is the making of a will. ${ }^{480}$ For common people this is the exception rather than the rule. That is why gender equality of intestate inheritance law should be the first priority with the result that in the absence of a testament intestate law will provide for equal shares between women and men.

477 There are a few exceptions, e.g. when the surviving parent goes bankrupt, the children are immediately entitled to their share of the inheritance. Van Mourik, 2002, p. 46.

478 Those countries that made reservations as to Article 2 of the Convention, are consistently requested by CEDAW to withdraw these reservations when the Committee discusses their reports. E.g. Bangladesh in $U N$ doc. A/52/38/Rev. 1, 1997, para. 449; Iraq in $U N$ doc. A/55/38, 2000, paras 186-188, Singapore in UN doc. A/56/38, 2001, paras 73-74; Egypt in $U N$ doc. A/56/38, 2001, paras 326-327.

479 States parties to the Women's Convention must modify social and cultural patterns of conduct of men and women and eliminate prejudices and customary and other practices based on the idea of inferiority or superiority of either of the sexes or on gender stereotyping on the basis of Article 5 of the Convention.

480 Some people may not be aware of the contents of the law of inheritance, others feel superstitious about making a will, while still others are deterred by the costs involved, etc. 


\subsubsection{Freedom of Residence}

This last part devoted to private law issues will touch upon the right to freely choose a place of residence. This right was first stated in Article 13(1) of the Universal Declaration of Human Rights which reads: 'Everyone has the right to freedom of movement and residence within the borders of each State'. It is reiterated in Article 15(4) of the Women's Convention that stipulates that 'States Parties shall accord to men and women the same rights with regard to the law relating to the movement of persons and the freedom to choose their residence and domicile'.

Being able to choose a preferred place of residence is intrinsically linked to 'location' which is one of the aspects that determine the adequacy of one's housing according to the Committee on Economic, Social, and Cultural Rights. ${ }^{481}$ The location determines whether there is easy access to employment, health services, schools, day care centres and other facilities. Furthermore, pollution of soil, water or air, the proximity of dangerous industries, or the disaster proneness of a certain area, may make it an inadequate place to settle. It is therefore important that women have the freedom to choose their residence on an equal footing with men. However, in several States they are denied this right.

In general women's freedom of residence is denied in States that have legal or customary rules that determine that the husband is the head of the family and that relegate women to an inferior position in the family, sometimes equating them with minors. Specific examples of legal provisions may be found in Jordan where married women are legally prohibited to choose their place of residence, ${ }^{482}$ and in Cameroon where Article 215 of the Civil Code grants the husband the sole right to determine the family's residence. $^{483}$

Though the law provides equality in matters of freedom of movement and the choice of residence and domicile in Bangladesh, in practice a woman's residence is determined by her father while she is unmarried and by her husband while married. When a woman is separated or divorced her place of residence becomes that of her father or her broth$\mathrm{er}(\mathrm{s}){ }^{484}$ The custom that women cannot decide independently where they are to reside is particularly hard on those women who live in the charlands, the plots of land in or on the banks of the large rivers that are regularly flooded. Since in most cases the husbands, fathers or male guardians live at some distance on the main land, these women run the risk of losing all of their possessions and even their lives when a flood is coming and they have to stay put awaiting permission to move. After the flood has drawn back they, again, have to wait for permission before they can settle some place else. ${ }^{485}$

481 CESCR General Comment No. 4 on the right to adequate housing (Art. 11(1) of the Covenant), Sixth session, 1991. Para. 8 identifies seven aspects that must be taken into account when determining whether housing can be called adequate. The other six aspects being legal security of tenure, availability of services, materials, facilities and infrastructure, affordability, habitability, accessibility and cultural adequacy. See section 2.4 on the content of the right to adequate housing.

$482 U N$ doc. $\mathrm{A} / 55 / 38,2000$, para. 172.

$483 U N$ doc. CEDAW/C/CMR/1, 9 May 1999, p. 90 of the English version and $U N$ doc. A/55/38, 2000, para. 32.

$484 U N$ doc. CEDAW/C/BGD/3-4, 1 April 1997, para. 2.14.

485 Mahjabeen Chowdhury, Women's Technological Innovations and Adaptations for Disaster Mitigation: A Case Study of Charlands in Bangladesh, EGM/NATDIS/2001/EP.6, 1 November 2001, pp. 4-10. Also see section 3.3.2.2 on Natural and human-made disasters. 
In Morocco, a husband cannot force his wife to move in with her in-laws. ${ }^{486}$ However, the husband has powerful instruments at his disposal to determine his wife's place of residence in two particular instances. A married woman's entitlement to maintenance is terminated when she refuses to return to the marital home, and a wife who has been revocably repudiated must stay during the prescribed waiting period (iddad) in the house that has been designated for this purpose by her husband. If she leaves this house without his permission or without a valid reason, she loses her right to housing. ${ }^{487}$

Freedom of residence is an important right in the context of housing because the place of settlement may determine whether women are able to find a job, whether they can make use of public facilities and whether the environment is safe, a feature that is particularly important for women who live home-centred lives. Women's right to be treated as autonomous persons and their entitlement to adequate housing is affected when they have to depend on others to determine where they must reside.

\subsubsection{Concluding Remarks}

The actual enjoyment and realization of human rights by women is to a great part determined by how their national private law systems abide by and enforce the internationally binding obligations of treating women equally with men and to what extent discriminatory legal rules, customs and traditional practices are abolished. Thus women's right to adequate housing is influenced by private law rules and customs that affect their ability to procure and administer property and that determine where they may reside.

In the examples discussed above, it has become clear that in many countries all over the world the property rights of women, including their right to autonomous legal capacity and their ability to acquire property by way of inheritance, are unequal to those of men. This is the more striking if one considers that almost all the countries that are mentioned are parties to the Convention on the Elimination of All Forms of Discrimination Against Women. Most of them even ratified or acceded to this Convention without reservations. Problems especially seem to arise in countries where the population is not a homogenous group, but where religious and ethnic differences exist. Too many States still think that issues like property and legal capacity belong to the private sphere and that governments should refrain from interfering. Though States sometimes show admirable dedication to equality and non-discrimination principles in their constitutions and other statutory acts, at the same time they condone the existence of personal laws or customs and traditions that rule the private lives of great parts of their population and that totally contradict their lofty ideals to uphold human rights standards.

Many personal or religious laws grant women a lower status than men. They openly declare that they consider the man to be the head of the household and thus the person who makes the decisions. Women who by chance of birth belong to a group that adheres

486 According to Moroccan marital law, the married couple is legally obliged to live together (Article 51(1) Mudawwana). However, the Moroccan Supreme Court has decided that a wife cannot be forced to live in the home of her husband's relatives. Maurits Berger, Mudawwana, Marokkaanse familiewet (nieuwe wet van 2004), derde herziene editie, Ars Aequi Libri, Nijmegen, 2004, p. 23.

487 Articles 195 and 196 Mudawwana respectively. Ibidem, p. 53 
to these personal or religious rules simply have no choice. No matter how equal their rights may be according to the general law of their country, it will not apply to them. If women's housing rights are taken seriously, this will mean that treating them equally in public life is not enough since discrimination against women particularly happens in the private sphere. Discriminatory personal and religious laws, customary rules and traditional practices should not be allowed to persist.

Only when women, on an equal footing with men, have the right to buy, rent, inherit, and administer property, including real estate, and have the freedom to choose their place of residence, their chances of procuring adequate housing for themselves and their dependants will increase.

\subsection{HUMAN RightS ISSUES}

\subsubsection{Introduction}

In this section a selection of human rights will be discussed that may all have a bearing on the right to adequate housing for women, either directly or indirectly.

The first right that will be under scrutiny in section 3.6.2 is the right to political participation. The link with housing may be both direct and indirect. Indirectly, politicians influence the housing situation of large parts of the population because they control the public budget and may thus determine whether and which part of the public expenditure will be spent on the housing sector. Directly, politicians take decisions pertaining to concrete housing situations such as if and where council housing will be built, which facilities will be located where, or which particular citizens will be entitled to housing subsidies. That is why the involvement of women in politics is important if they want to have some influence on the overall housing situation. Moreover, involvement of female politicians may make a difference if they put women's specific needs and problems, for instance with regard to the right to adequate housing, on the political agenda.

The second right that will be studied is the right to property as a civil and political human right. Internationally, most States have bound themselves not to prevent people from acquiring property. Highly relevant in the framework of this study is that thus people must be enabled to have access to and have property rights of housing and land. However, in many countries it is more difficult for women than for men to obtain property. In section 3.6.3 the question why women generally have fewer property rights than men will be discussed. Furthermore, the right to property will be linked to the subject of security of tenure, one of the constituent elements of adequate housing.

The third section will be devoted to the right to privacy. Since the scope of this right is rather broad, the focus will be on the privacy of the home and the right to live as one wishes. The right to be let alone and to live in security and dignity in one's own home determines to a large extent the adequacy of the housing situation. In most cases, however, the legal focus of respecting and protecting the right to privacy is on violations from the outside, for example by State authorities or by third parties. Although this is as important for women as for men, many women are faced with additional threats in the 
domestic sphere, especially by their male partners, which are usually not taken into consideration. In cases of domestic violence, besides the victim's right to physical integrity, the right to privacy and thus to adequate housing are being violated.

The right to employment has already been discussed in the context of female poverty. In this section, the accent will be on labour laws and regulations that ban women from certain types of employment or that discriminate against (potentially) pregnant women with the effect that women's ability to earn an income sufficient enough to provide for adequate housing will be hampered.

Finally, a few remarks will be made on the subject of the right to dignity. Though this right is not included as a separate right in the major human rights instruments, but is rather seen as one of the basic prerequisites that must be fulfilled if a person is to live a humane life, attention is drawn to it in this context in order to emphasize that in view of the prevalent and manifold infringements women may experience in the domestic sphere, their dignity may be seriously impaired.

\subsubsection{The Right to Political Participation ${ }^{488}$}

\subsubsection{Introduction}

World-wide only a small percentage of politicians are female. This not only influences women's power but also the topics that are being discussed and decided upon. A woman's perspective is needed to further women's equality in all fields. In the context of housing, women's participation is particularly important since women's input can hardly be missed as far as decisions on housing and infrastructure are concerned. Most women's lives are home-centred and therefore they may be considered to be experts in this field. Their expertise will be wasted when they are not consulted and do not have a voice in decision-making.

Various causes may be discerned as to women's lack of participation. Since it is extremely rare that women are legally restricted from taking part in politics, the main reasons for their absence find their origin in culture, tradition, religion and the socioeconomic position women take up in society.

In this section attention will first be paid to the existing international legal norms that guarantee women equal rights with men as to political participation. Next the factual situation, and the causes for women's under-representation will be under scrutiny. Since the local level is important as regards decisions pertaining to housing and infrastructure, women's share in decision-making at this level is looked into as well. Further, the question is answered whether and to what extent women's participation in politics will make any difference. Lastly, several ways to increase women's political participation are discussed.

488 The term political participation is used in a broad sense; taking part in decision-making either at the national, municipal, or provincial level. This is in conformity with the way CEDAW uses the term in its General Recommendation No. 23 on Articles 7 and 8, section 5, 1997. 


\subsubsection{International Legal Norms}

There are several international instruments in which women's equal right to political participation is laid down. More generally, the Universal Declaration on Human Rights ${ }^{489}$ and the Covenant on Civil and Political Rights grant women equal political rights. ${ }^{490}$ More specifically targeted on women's political rights are the Convention on the Political Rights of Women, ${ }^{491}$ and the Convention on the Elimination of all forms of Discrimination Against Women. The relevant Articles 7 and $8^{492}$ of the latter Convention have been further interpreted in CEDAW's General recommendation No. $23 .{ }^{493}$

The Convention on the Political Rights of Women has been ratified by 116 States, ${ }^{494}$ while in 2005180 States were parties to the Women's Convention, and hardly any reservations have been made pertaining to Article 7 and none with regard to Article 8. ${ }^{495}$

From the above, it can be maintained, that political equality of women enjoys a widespread acceptance. Most countries in the world have accepted the international norms as regards political participation of women. Almost everywhere women have the right to vote and to stand for election, and mostly they vote in the same proportion as

489 See Article 21 in conjunction with Article 2.

490 See Article 25 in conjunction with Article 3.

491 The Convention on the Political Rights of Women entered into force on 7 July, 1954. The Convention has three core articles that read: 'Art. 1: Women shall be entitled to vote in all elections on equal terms with men, without any discrimination; Art. 2: Women shall be eligible for election to all publicly elected bodies, established by national law, on equal terms with men, without any discrimination; Art. 3: Women shall be entitled to hold public office and to exercise all public functions, established by national law, on equal terms withy men, without any discrimination.'

492 Article 7 reads: 'States Parties shall take all appropriate measures to eliminate discrimination against women in the political and public life of the country and, in particular, shall ensure to women, on equal terms with men, the right:

(a) To vote in all elections and public referenda and to be eligible to elections to all publicly elected bodies;

(b) To participate in the formulation of government policy and the implementation thereof and to hold public office and perform all public functions at all levels of government;

(c) To participate in non-governmental organizations and associations concerned with the public and political life of the country'.

Article 8 states that: 'States Parties shall take all appropriate measures to ensure to women, on equal terms with men and without any discrimination, the opportunity to represent their Governments at the international level and to participate in the work of international organizations.'

493 Committee on the Elimination of Discrimination against Women, General recommendation No. 23 (1997) (Art. 7 and 8).

494 At <http://untreaty.un.org/English/bible/englisinternetbible/partI/chapterXVI/treaty1.asp>, consulted on 30 April 2004

495 Two States had made a reservation as regards Article 7(a): Kuwait, which had reserved the right to be eligible for election and to vote to males, withdrew this reservation on 9 December 2005. The only now remaining reservation has been made by the Republic of Maldives which states that Article 7(a) will not be applied in so far as it conflicts with Article 34 of the Constitution. Suffrage is universal though for adults in the Maldives. Furthermore, three States have made reservations pertaining to Article 7(b): Israel because it wants to reserve the appointment of judges of religious courts for men; Luxembourg because the transmission of the crown is restricted to male ascendants; and Malaysia because it wants to exclude women from public offices like Mufti Syariah Court judge and Imam; No reservations have been made with regard to Article 7(c). For a current overview see CEDAW's internet site on Declarations, Reservations, and Objections at: <www.un.org/womenwatch/daw/cedaw/reservations-country.htm>. 
men. Yet, there are only a few countries in the world where the proportion of women participating in decision-making is large enough that they can really have an impact. ${ }^{496}$ This factual situation is the subject of the next section.

\subsubsection{Factual Situation}

In most countries in the world women have only taken part in the highest level of governmental decision-making for the last few decades, and the number of female ministers is still very small. Moreover, if women are appointed as minister or junior minister, they are specifically found in what are considered to be typically 'female' Ministries, like social affairs, health care, education, and 'women's ministries' ${ }^{497}$ Unfortunately, these ministries are also considered to be of less importance than the 'powerful' ministries of economics, finance, internal or foreign affairs. Furthermore, many female ministers are without portfolio and are administratively located at the prime minister's office. Hardly any women attain the position of head of State. ${ }^{498}$

Recent statistics on the number women in national parliaments reveal that only in two countries almost half of the representatives are female. ${ }^{499}$ The world's average is $16.6 \%,{ }^{500}$ while there are still a number of countries that have no female members of parliament at all. ${ }^{501}$

Besides the number of women in Parliament and Cabinet, it is also relevant to look at the number of women who hold senior positions in the civil service, since civil ser-

496 United Nations, Women in Politics and Decision-Making in the Late Twentieth Century, A United Nations Study, United Nations Office at Vienna, Centre for Social Development and Humanitarian Affairs, Martinus Nijhoff Publishers, Dordrecht, Boston, London, 1992, pp. 1-4.

497 Ruth Henig and Simon Henig, Women and Political Power; Europe since 1945, Routledge, LondonNew York, 2001, pp. 58-61 and 63-65.

498 Up till 1991 only 18 women had been elected as head of State or Government. This means that at the time only 9 per cent of the world's countries had been led by women. About half of them entered politics by way of their family connections. Corazón Aquino, Siramavo Bandaranaike, Violeta Chamorro, Isabel Perón and Khaleda Zia took up leadership after the death of their husbands. Indira Ghandi and Benazir Bhutto were daughters of previous prime ministers. Women in Politics and Decision-Making in the Late Twentieth Century, 1992, pp. 59-60. Between 1991 and 2005, 28 women were elected head of State or Government, which means that the percentage of States that have been led by a woman has now risen to $14 \%$, at: <womenshistory.about.com/od/rulers20th/a/women heads.htm>. In western Europe, only four women have succeeded in becoming Prime Minister: Margaret Thatcher (Great Britain, 1979-1990), Gro Harlem Bruntland (Norway, on three occasions in the 1980s and 1990s), Edith Cresson (France, 19911992), and Angela Merkel (Germany, 2005-). Women Prime Ministers, 1945-2005, at: <www.terra.es/ personal2/monolith/00women3.htm>, October 2006.

499 In Rwanda $48.8 \%$ of the members of parliament is female, while the percentage in Sweden is $45.3 \%$. The Netherlands rank $7^{\text {th }}$ with $36.7 \%$, while the USA ranks $67^{\text {th }}$ with only $15.2 \%$. Women in National Parliaments, data compiled by the Inter-Parliamentary Union, situation as of 31 July 2006, at the internet at: $<$ http://www.ipu.org/wmn-e/classif.htm>, last consulted on 21 August 2006.

500 Data collected by the Inter-Parliamentarian Union; Women in National Parliaments, world average, at $<$ http://www.ipu.org/wmn-e/world.htm>, the situation as of 31 July 2006.

501 These countries are: Bahrain, Kuwait, Kyrgyzstan, Micronesia, Nauru, Palau, Qatar, Saint Kitts and Nevis, Saudi Arabia, Solomon Islands, Tuvalu and the United Arab Emirates. See: <http://www.ipu.org/wmn-e/ classif.htm>, the situation as of 31 July 2006. 
vants may yield considerable power and it is a pool for recruiting politicians. ${ }^{502}$ Unfortunately, the great majority of female civil servants are to be found in the lower ranks.

There are various explanations for the under-representation of women in politics. In spite of the wide variety of causes, it should be borne in mind that they are all related and interdependent and may in fact reinforce one another.

\subsection{Legal Impediments}

The first explanation why women would be under-represented could be because they were legally excluded or restricted from taking part in politics. This is in fact highly unusual. ${ }^{503}$ From the previous section it has become clear that most countries of the world adhere to the existing international legal standards and have incorporated equal political participation of women into their constitutions and legal acts. To my knowledge, the last country that explicitly barred women from politics, Kuwait, made female suffrage possible in June 2005 while the only country remaining where women cannot vote or stand for election is the United Arab Emirates, but then neither can men. ${ }^{504}$

\subsection{Culture, Tradition and Religion}

A much more common situation is that political participation of women is inhibited as a result of cultural factors.

Gender division of tasks and jobs may be culturally determined. Both in developed and developing countries strict notions exist as to the roles men and women should play in society. ${ }^{505}$ As it is regarded as typically male to take care of public and community affairs, and as female to stay at home and nurture the family, politics, which take place in the public sphere, are regarded as a man's job. ${ }^{506}$ Since for centuries only men partici-

502 Women in Politics and Decision-Making in the Late Twentieth Century, 1992, p. 57.

503 An example of a restriction was the 1956 Egypt Constitution in which it was stipulated that all adult men were to be automatically registered to vote, while adult women had to lodge a request to be registered. The result was that especially rural and illiterate women did not take part in politics, and that only $1 \%$ of the total number of registered voters was female in 1956. Mervat F. Hatem, 'The Paradoxes of State Feminism in Egypt', in: Barbara Nelson and Najma Chowdhury, Women and Politics Worldwide, Yale University, 1994, pp. 234-235.

504 In the United Arab Emirates, Parliament is officially appointed and neither men not women have the right to vote or to stand for election. In Saudi Arabia, men took part, in 2005, in the first local elections ever held. Women were not allowed to exercise their right to vote or stand for election on that occasion, but they will be next time. Inter-Parliamentary Union, Women's Suffrage, at <www.ipu.org/wmn-e/ suffrage.htm>, consulted on 21 August 2006

505 In its General Recommendation No. 23 on Articles 7 and 8 of the Women's Convention, CEDAW states in section 8: 'Public and private spheres of human activity have always been considered distinct, and have been regulated accordingly. Invariably, women have been assigned to the private or domestic sphere, associated with reproduction and the raising of children, and in all societies these activities have been treated as inferior. By contract, public life, which is respected and honoured, extends to a broad range of activity outside the private and domestic sphere. Men historically have both dominated public life and exercised the power to confine and subordinate women within the private sphere.'

506 An example of a country where women are culturally restricted to move in public is Greece. Especially in the rural areas it is highly unusual for women to take part in politics since public decision-making is regarded as a man's job. Women's minimal participation in politics (only 8.7 of the members of parliament are female) is all the more striking if one considers that Greeks of all ages argue about politics all the time, and it may be considered the number one topic in conversations. Ann R. Cacoullos, 1994, pp. 314 and 321. 
pated in decision-making, it is not surprising that the competence of men to deal with public decision-making is accepted without question, while there is still doubt about the suitability of women as politicians, especially since there are as yet so few successful female politicians who can serve as examples. ${ }^{507}$ Connected to this is the popular belief that women are less interested in politics and are less suited for leadership positions. Women, who grow up with these ideas, may feel insecure to participate in decisionmaking. ${ }^{508}$

The media often reinforce stereotyped thinking of male and female roles in society. Female politicians are followed more closely and the media pay more attention to how they look and how they dress than to their political mission.

Traditional and religious norms and practices also influence women's possibilities and readiness to enter into politics. ${ }^{509}$ In most countries men are considered as the heads of household and that is why they are regarded as the natural representatives of their families. The result may be that women are not even taken into consideration as members of decision-making bodies. ${ }^{510}$

In some African societies it is unthinkable that a married woman would be involved in politics in the same village or town where she lives with her husband. It will be regarded as a violation of traditional roles and as undermining the husband's authority at home.

507 Women in Politics and Decision-Making in the Late Twentieth Century, 1992, pp. 52-54.

508 This is perceived to be the reason why so few women participate in politics in China. Since the Chinese revolution women have equal rights with men to enter into politics. However, Chinese women are so used to being subordinate that they are very wary to take up leadership positions. It is felt that the only reason why about $20 \%$ of the Chinese politicians is female, is because there is a quota system. Yue Daiyun, Li Jin, 'Women's Life in New China', in: Barbara Nelson and Najma Chowdhury, Women and Politics Worldwide, Yale University, 1994, p.162. Also: Women in Politics and Decision-Making in the Late Twentieth Century, 1992, pp. 33.

509 In India, for example, both Islamic and Hindu fundamentalist have tried to hold back progress and women's equality and instead proclaim traditional patriarchy. Hem Lata Swarup, Nrioj Sina, Chitra Ghosh, Pam Rajput, 'Women's Political Engagement in India: Some Critical Issues', in: Barbara Nelson and Najma Chowdhury, Women and Politics Worldwide, Yale University, 1994 p. 375. In the Netherlands confessional parties restrained women's participation for a long time because they made it clear that women were not welcome in politics since their proper role was to be at home as a wife and mother. Monique Leijenaar, Kees Niemöller, 'Political Participation of Women: The Netherlands', in: Barbara Nelson a.o.,1994, pp. 498 and 503.

510 For instance, the Mexican agrarian legislation established legal equality between men and women already in 1971. This means that both men and women can become an ejidatario and participate in ejido decision-making. However, only one member may represent a family and traditionally this will be the male head of household. Thus while women legally have equal decision-making power, in practice tradition restricts women's ability to make use of this right and keeps them out of these decision-making bodies. A similar situation may be found in Peru. Men and women have equal rights to be members of the official peasant communities since 1987 . However, only qualified comuneros have decision-making powers in the community assembly. In theory both men and women can be comuneros. In practice, however, only the head of household become comunero. As a result the only women who participate in communal decision-making are widows. Carmen Diana Deere and Magdalena León, 'Neo-liberal agrarian legislation, gender equality, and indigenous rights: the impact of new social movements', in: Annelies Zoomers and Gemma v.d. Haar (eds.), Current Land Policy in Latin America: Regulating Land Tenure under Neo-liberalism, Royal Tropical Institute, Amsterdam, 2000, pp. 85-86. 
For women who are kept in purdah for religious and traditional reasons it is obviously well nigh impossible to participate in public decision-making. They are not even allowed to buy foodstuffs at the market, let alone participate in debate in a typically male environment like the political arena. ${ }^{511}$

Overall, the culturally determined general status of women in society is an important indication of women's political participation. In societies where equality of women is generally accepted, the chances that women participate in politics are much better. There appears to be a correlation between a wholehearted acceptance of the Women's Convention, i.e. ratification without any reservation, and the participation of women in politics. International standards also seem to have a favourable influence on the degree to which parties are willing to nominate women. ${ }^{512}$

\subsection{Socio-Economic Situation of Women}

The next group of reasons that influence women's participation in decision-making is of economic and social origin.

In general, women more than men lack education suitable for a political career. Politicians, especially at the national level, for the greater part have enjoyed a high level of education. In many countries of the world women are underrepresented at the higher levels of education.

There is a clear link between the number of women in paid employment and women in decision-making. The higher the employment rate of women, the higher their participation in government will be. However, due to gender segregation in the labour market, women may not have had the job training or working experience that is deemed adequate for a career in politics. ${ }^{513}$ Most women who are employed can be found in the sphere of social services, like teachers, nurses, and secretaries. This is not a background that is regarded as suitable for political leadership. ${ }^{514}$

Due to their different socio-economic position, many women may lack the required money or property to get into politics. In some systems money is needed to finance political campaigns. ${ }^{515}$ This may mean that they lack the resources to run for a certain office. In some rural societies possession of a plot of land is a prerequisite to become a member of a local council. Since women may face particular difficulties as regards pro-

511 For instance purdah reinforces the dichotomy between public and private life and also the stereotyped roles in society in Bangladesh. Purdah and poverty combined deprive girls and women of education, employment and their own identity. Najma Chowdhury, 'Bangladesh: Gender Issues and Politics in a Patriarchy', in: Barbara Nelson and Najma Chowdhury, Women and Politics Worldwide, Yale University, 1994, p. 94. Purdah also plays an important part in inhibiting women to participate in public life in some parts of Nigeria. Kamene Okonjo, 'Reversing the Marginalization of the Invisible and Silent Majority: Women in Politics in Nigeria', in: Barbara Nelson and Najma Chowdhury, 1994, p. 515.

512 Women in Politics and Decision-Making in the Late Twentieth Century, 1992, pp. 51-52 and 101-104.

513 Ruth Henig and Simon Henig, 2001, p. 50.

514 Ibidem, p. 99.

515 This is for instance the case in Bangladesh where women's lack of money is one of the main reasons why they cannot win elections. Najma Chowdhury, 1994, p. 100. Also see Women in Politics and Decision-Making in the Late Twentieth Century, 1992, pp. 34-35. 
perty rights to land, the consequence is that they are denied participation in decisionmaking. 516

The overall economic situation of a country also influences women's political participation. There is a link between the amount spent on public expenditure and women's involvement in decision-making. The reason for this connection is that in a State where much money is spent on public services, much of this money will go to education and government employment and women will profit from it. Availability of education is not only a precondition for individual professional development of female politicians, but it will also mean that large numbers of women in the electorate will be educated which is a prerequisite for them to act and vote autonomously. The chance that they will find women's issues important, and that they will vote for a female candidate will thus increase. There is no link, however, between the per capita gross domestic product (GDP) and the participation of women in decision-making. This entails that a country does not have to be rich in order to have a high percentage of women in politics. ${ }^{517}$

\subsection{The Political System}

The way politics are structured is a highly determining factor as far as women's participation is concerned. In a system of direct elections, parties will prefer male candidates, and the electorate will also put more confidence in a male politician. Therefore, women's entry into politics seems to be easiest under a system of proportional representation. ${ }^{518}$ However, decisions are not only made during elections. In most countries political parties are very influential and the way in which they recruit and select their representatives will affect the chances of female candidates. Much will depend on whether parties are willing to put women on eligible places on their lists. ${ }^{519}$

A party's ideology also plays a major part. ${ }^{520}$ Generally, religious parties are less inclined to push women forward as their representatives. This is because religious ideology is conservative and women's role in society is still restricted to being wives and mothers. ${ }^{521}$ In the Netherlands for instance, there is one confessional right-wing party that up till recently did not allow female membership and that totally opposes the idea of women taking part in public decision-making. ${ }^{522}$ Left wing and green parties on the

516 See section 3.6.3 on the right to property.

517 Women in Politics and Decision-Making in the Late Twentieth Century, 1992, p. 92-93.

518 Wendy Stokes, Women in Contemporary Politics, Polity Press, Cambridge, 2005, p. 44. Also, Ruth Henig and Simon Henig, 2001, p. 95.

$519 U N$ doc. E/CN.6/1995/3/Add.6, Inequality between men and women in the sharing of power and decision-making at all levels, Monitoring the Implementation of the Nairobi Forward-Looking Strategies for the Advancement of Women, 1 February 1995, para. 28. Also, Women in Politics and DecisionMaking in the Late Twentieth Century, 1992, p. 40.

520 In Europe, there is a discernable left-right divide. Left wing socialist parties are generally in favour of balanced lists of candidates, i.e. equal numbers of male and female candidates, and quota systems, while right wing parties usually oppose quota and other positive action measures. Ruth Henig and Simon Henig, 2001, pp. 52-54.

521 In the Netherlands the religious parties criticized women's participation in the public sphere. At the beginning of the 20th century they opposed women's suffrage on the ground that politics should be considered a man's job. Women in Politics and Decision-Making in the Late Twentieth Century, 1992 pp. $47-48$.

522 This party is the SGP (Staatkundig Gereformeerde Partij). CEDAW, in its concluding comments on the 
other hand are the most willing to back-up women candidates. ${ }^{523}$ It is reported that in some countries these parties put as many male as female candidates on their lists. ${ }^{524}$

\subsection{Practical Barriers}

Lastly, there are practical barriers that impede women's participation in public decisionmaking. Of course these inhibitions are closely connected to cultural, religious, traditional, economic and social factors.

First of all, women may find it hard to combine a political career with care-taking responsibilities. The gendered division of work, especially the fact that women do the bulk of non-paid work, is the cause of women's time constraint. This will be exacerbated by a high fertility rate and the fact that day-care centres are too scarce and/or too expensive. Moreover, women with care-taking duties are not very flexible as regards the time they can spend away from home, while flexibility is a prerequisite for a politician. Therefore, most female politicians enter politics between the age of forty and fifty; when their children are grown up. ${ }^{525}$

Tax laws and other financial regulations may make a wife's employment highly unattractive because the family's financial situation is best off in the traditional situation of a one male breadwinner pattern.

Finally, when there is physical danger to be involved in politics, this will sooner withhold women from participating than men. ${ }^{526}$

\subsubsection{Decision-Making at the Local Level}

It would seem logical, and it is often assumed, that more women would participate in decision-making organs at the local level, especially municipal and provincial councils, than at the national level. Firstly, because the subjects that are discussed might be closer to women's interests and expertise, like housing, schools, childcare, roads and traffic. Secondly, because participating in local government may be easier to combine with family responsibilities because it is usually less time consuming since it is not a full-time job and normally less time has to be spent on travelling. ${ }^{527}$ However, figures are sparse and not conclusive. In some countries the percentage of women participating in local councils is higher than at the national level, ${ }^{528}$ while in others it is lower or there is no

second and third periodic reports of the Netherlands, severely criticizes the existence of a political party that bans women from its membership and concludes that this is in violation of Article 7 of the Women's Convention. Consequently the Netherlands are advised to take measures, including legislation that makes exclusive male membership of political parties unlawful. UN doc.CEDAW/C/2001/II/Add.7, paras 219 and 220 .

523 In Argentina only the Socialist Party takes up women's issues and has allotted women leadership positions within the party. María Del Carmen Feijoó, 1994, p. 63.

524 Ruth Henig and Simon Henig, 2001, pp. 52-54.

525 Women in Politics and Decision-Making in the Late Twentieth Century, 1992, pp. 37-40. Also María Del Carmen Feijoó, 1994, p. 70 as regards the situation in Argentina.

526 Women in Politics and Decision-Making in the Late Twentieth Century, 1992, p. 31

527 Ruth Henig and Simon Henig, 2001, p. 67.

528 An example is Canada where female politicians are disproportionately found at the municipal level. This phenomenon is explained by the lower costs (both financial and personal) that are involved for local 
difference. ${ }^{529}$ The Secretary-General of the UN used the (meagre) data that were available in his 1989 report and concluded that: 'in general the participation of women in local representative bodies is slightly higher than in national parliaments, although the pattern is by no means uniform'. ${ }^{530}$ A CSO supported by the Netherlands Ministry of Foreign Affairs, has been collecting data on women in local decision-making since 2003. According to its database, in 2005 only $20 \%$ of the councillors and $6 \%$ of the Mayors in the world were women, but the participation of women in local politics is increasing steadily. ${ }^{531}$

\subsubsection{Does Women's Participation Make a Difference?}

On the whole it can be said that if women are underrepresented this will affect the democratic legitimacy. It can hardly be maintained that public opinion is expressed in decision-making when the female perspective is not taken into consideration.

Women will regard issues from a different angle than men do. The differing values and perspectives are not confined to the sphere of women's rights. They extend to questions of peace and war, the environment and social services. Participation of women will broaden the scope of the subjects that are dealt with because topics that used to be regarded as belonging to the private sphere will be brought into the public sphere. In the context of housing a case in point is domestic violence. This used to be regarded as a private matter, but increasingly women succeed in putting it on the political agenda as one of the most urgent social problems women, both in developed and developing countries, are faced with. It also sheds a different light on the issues of safety and security since women's experience with violence has dimensions that differ from men's. ${ }^{532}$

It is expected that women's participation will also result in a general shift in expenditure in favour of the public sector. Since many aspects of adequate housing are influenced by how much money will be spent on the public sector, this could make an important difference. If housing and the environment receive priority, money will go to

politicians and the fact that there is less competition because a council seat is not valued so much since the power and influence involved are limited. Sylvia Bashevkin, 'Building a Political Voice: Women's Participation and Policy Influence in Canada', in: Barbara Nelson and Najma Chowdhury, Women and Politics Worldwide, Yale University, 1994, p. 150. In Britain, France and Italy, the percentage of women involved in local politics is (significantly) higher than the percentage of women in national politics. For Britain: $26 \%$ and $18 \%$, France: $23 \%$ and $11 \%$, and Italy: $15.2 \%$ and $11 \%$ respectively. Ruth Henig and Simon Henig, 2001, pp. 67-68.

529 In the Netherlands, Germany and Denmark, the percentage of women participating in national politics is higher than in local politics. In the Netherlands these percentages are $36.7 \%$ and $23 \%$, Germany: $31 \%$ and 25\%, and Denmark: 37\% and 27\% respectively. Ruth Henig and Simon Henig, 2001, p. 68.

530 UN doc. E/CN.5/1989/7, Peace: Full participation of women in the construction of their countries and in the creation of just social and political systems, report by the Secretary General, para. 55 .

531 United Cities and Local Governments (UCLG), on the internet at: <www.cities-localgovernments.org/ uclg/index.asp?pag=nesD.asp\&l=EN\&ID=116>, consulted on 21 August 2006.

532 Najma Chowdhury and Barbara J. Nelson, 'Redefining Politics: Patterns of Women's Political Engagement from a Global Perspective', in: Barbara Nelson and Najma Chowdhury, Women and Politics Worldwide, Yale University, 1994, p. 11. Also see section 3.3.5 on domestic violence. 
housing subsidies, council housing, sewerage systems, waste removal, electricity provision, water supply, and infrastructure. ${ }^{533}$

Since most women's lives are home-centred they are the experts as far as building and planning are concerned. If they do not participate in decision-making concerning man's habitat their expertise will be wasted..$^{53}$

It should be noted, however, that women's influence on decision-making can only be felt when the percentage of female politicians increases to about 30 to $35 \%$; the socalled 'critical mass' ${ }^{535}$ If the percentage remains below this number, women will often have no choice but to adapt to the male values that are predominant in political culture and system. As soon as the critical mass has been reached, women are influential enough to have an impact, particularly because they are in a position to form alliances. ${ }^{536}$

\subsubsection{Ways to Increase Women's Political Participation}

There are several possible methods to increase women's political participation. In many countries where the participation of women is highest, this result has been achieved by temporary special measures. Sometimes a certain number of seats in parliament or other decision-making organs is legally reserved for candidates of the female sex. It is also possible to stipulate that political parties have to set targets or quotas for female representatives. ${ }^{537}$ Very good results by way of quota setting have been achieved in the Nordic countries, where female politicians now form a critical mass and can indeed influence politics. ${ }^{538}$ The introduction of a quota system may be encountered by resistance. Oppo-

533 Positive examples of women's influence on the housing situation after they were able to take part in public decision-making may for instance be found in India and Bangladesh. Village panchayats in Madhya Pradesh in India that are female dominated differ from male dominated panchayats in the priorities they set as to housing concerns. For instance they will initiate the provision of taps and covered toilets, and install pumps in village wells. Bina Agarwal, A field of one's own; Gender and land rights in South Asia, Cambridge University Press, Cambridge, 1994, pp. 484-485.

534 About 200 municipalities in the Netherlands have Women's Advice Commissions (Vrouwen Advies Commissies) or Housing Advice Commissions (Woon Advies Commissies), commissions established by the councils and consisting of (mostly female) volunteers who visit building sites and give practical advice on how to build or improve houses and the living environment. See the Dutch newspapers Dagblad De Limburger, 23 February 2002 and NCR Handelsblad, 5 February 2004. Also see: Women in Politics and Decision-Making in the Late Twentieth Century, 1992, pp. XII-XIII.

535 This is also confirmed by CEDAW in General Recommendation No. 23, section 16 and by the UN Secretary-General in his report 'Inequality between men and women in the sharing of power and decision-making at all levels, Monitoring the Implementation of the Nairobi Forward-Looking Strategies for the Advancement of Women', UN doc. E/CN.6/1995/3/Add.6, 1 February 1995, para. 20.

In 2003 there were 14 countries in the world where the critical mass of at least $30 \%$ female representatives had been reached in the national parliament. These are from highest till lowest percentage: Rwanda (48.8), Sweden (45.3), Denmark (38), Finland (37.5), Netherlands (36.7), Norway (36.4), Cuba (36), Belgium (35.3), Costa Rica (35.1), Austria (33.9), Germany (32.2), Argentina (30.7), Iceland (30.2) and Mozambique (30). Inter-Parliamentary Union, Women in National Parliaments, situation as of 30 October 2003.

536 There is still too little research available. It is expected that it will take another ten years before it may be clear if and to what extent female politicians that serve in national and local governments with $40 \%$ or more female members will make a difference. Ruth Henig and Simon Henig, 2001, pp. 79-80.

537 The difference between target and quota-setting is that targets are indicative, while quotas are mandatory.

538 Ruth Henig and Simon Henig, 2001, pp. 51-52. The quota system was also a success in Cuba, where im- 
nents will say that it is undemocratic and that unqualified women will fill in posts that might otherwise have been occupied by qualified men. ${ }^{539}$ Women also may resist quota systems. They may feel that they should be elected because of their qualities and not because they are women. However, once a quota system is working and women are getting the chance to influence politics, many times, especially when they function well, this may have the effect that traditional views of the suitability of masculine characteristics for leadership and decision-making will be altered, and 'female' qualities will also be regarded as suitable and valuable. In principle, quota setting, like all affirmative action, is a temporary measure, to be abolished once parity has been achieved. Since this is perceived as the critical mass, the usual goal is 30-35\%. Experience from Eastern European countries shows that when the quota system is abolished too soon, women's role in politics will diminish very rapidly. Before 1987, under the quota systems of the communist regimes, women's participation in these countries was $26.6 \%$; i.e. twice as high as in the Western industrialized countries. After the 'democratic' return, women's participation dropped to a mere world average. ${ }^{540}$

It is important to note, however, that quotas will not work if there is no sanction when they are not respected. Furthermore, there is a danger that quotas function as a maximum rather than a minimum number of female representatives. ${ }^{541}$

A good way to improve women's interest and participation in politics is by raising public awareness. By way of education and the media, the opinion about women functioning in public decision-making organs will change for the better, and the image of a typical politician will no longer exclusively be a male image. Radio and television may prove to be important means to change public opinion. ${ }^{542}$ The role of women's CSOs is very important in this respect. Especially in countries where culture tends to subordinate

mediately after the introduction in $1980,22.6 \%$ of the National Assembly was female. Jean Stubbs, 'Revolutionizing Women, Family and Power', in: Barbara Nelson and Najma Chowdhury, Women and Politics Worldwide, Yale University, 1994, p. 196. Meanwhile the percentage has risen to $36 \%$.

539 The proposal to introduce a quota system in Costa Rica met with great resistance. It was said that quotas would restrict individual liberty and threaten equality. Moreover, it was argued that 'women would be elected to fill the quota and not because of their abilities'. Mirta González-Suárez, 'With Patience and Without Blood: The Political Struggles of Costa Rican Women', in: Barbara Nelson and Najma Chowdhury, Women and Politics Worldwide, Yale University, 1994, p. 186.

540 When parliamentary representation was based on a quota basis parliament represented a cross-section of the population. The population did not deem parliament very important because the actual influence was considered to be very small. Since the political change, however, parliament has increased in importance; it now reflects the real power in society. The effect is that more men are interested to become a member than before and therefore competition is keen. Since the return to democracy also meant a return to more traditional values, it is not surprising that male candidates were more successful in elections than female candidates. Thus more democratization has paradoxically been accompanied by a reduced female representation. Women in Politics and Decision-Making in the Late Twentieth Century, 1992, pp. 15-16.

A case in point is the former Czechoslovakia. Under the communist regime women made up 25.4\% of the Lower House. In 2003 the percentage is 19.3 for Slovakia, and 17 for the Czech Republic. See Sharon L. Wolchik, 'Czechoslovakia in the Communist and Postcommunist Periods', in: Barbara Nelson and Najma Chowdhury, Women and Politics Worldwide, Yale University, 1994, p. 209 and Inter Parliamentary Union, Women in National Parliaments, Situation as of 30 October 2003, respectively.

541 Women in Politics and Decision-Making in the Late Twentieth Century, 1992, p. 45.

542 The radio played a very important role in making women aware about politics in Nigeria. In fact, rural women were more politically aware than their husbands. Kamene Okonjo, 1994, p. 516. 
women, it is imperative for the acceptance of a change of women's position in society that it will come from the inside, since external interference will immediately be rejected or even be counterproductive. Women's grassroots organizations are highly suitable to influence public opinion.

If public perception about which characteristics are needed and important for good politicians would change and also include those that are considered to be female, this would considerably broaden the pool from which candidates may be chosen and more women will stand a chance to be elected. ${ }^{543}$

Training programmes for women, both by governments and political parties are important to help them over the threshold. Public life may be so alien to a woman's life that special schooling will help her to take the step to enter politics. ${ }^{544}$

Moreover, as long as there is under-representation of women, it is very helpful if political parties have women's sections where women candidates have a forum to discuss those topics that have their special interest. A special women's branch may remove barriers that would ordinarily prevent women from taking part in politics. It should be avoided, however, that these special sections become women ghettos that restrict female candidates from attaining important positions in the main party body. ${ }^{545}$

\subsubsection{Concluding Remarks}

If more women would participate in decision-making bodies this would not only improve the democratic legitimacy, but it might also influence the political agenda. Though there seems to be an almost universal acceptance of the right of women to participate equally with men in politics, most of the States go no further than formal acknowledgement. They ratify international norms and lay down women's political rights in their constitutions and other acts, thus fulfilling the formal criteria, but when it becomes clear that merely bestowing women with equal rights to participate is not enough, many countries do not undertake any additional action to improve the situation. Due to women's socio-economic position, however, additional steps are needed. Especially positive action measures like reserving seats for women and setting quotas will yield results. Furthermore, stereotyped ideas about male and female roles in society, and particularly the ageold image of the male politician, should be made to disappear. Special emphasis should be put on furthering women's chances and possibilities as to education, job training and gainful employment.

Not only States have a part to play. Political parties should create women's branches that inform and train women, and they should see to it that women's chances to be elected are enhanced by recruiting them as candidates and putting them on eligible places

543 Women in Politics and Decision-Making in the Late Twentieth Century, 1992, p. 112.

544 In several cities in the Netherlands free programmes are organized especially for women who consider to stand for election as council members, but who do not have any experience. In small groups they are informed about the ins and outs of local politics, with the effect that uncertainties are taken away uncertainties women's way into politics is eased. Stichting Habitat Platform, Van Shanghai tot Terneuzen Voorbeelden van vrouwen in lokaal bestuur, Den Haag, 2000, pp. 42-44.

545 Women in Politics and Decision-Making in the Late Twentieth Century, 1992, pp. 49-50. 
on their lists. Women's CSOs should use their influence to alter the stereotyped ideas about male and female roles in society.

Political participation of women will help to put women's issues in the spotlight, while improving women's socio-economic position will in its turn influence the number of women who will take part in decision-making.

As far as housing rights are concerned, it is quite likely that participation of women may make an important difference, but in view of the fact that only in a handful of States the number of female politicians constitutes a critical mass and thus can actually influence politics, at the moment this is still speculation. However, already in many countries increasing political participation of women has led to putting domestic violence on the agenda. This issue, which used to be regarded as a private or family matter, now is looked upon as a matter of public concern. If domestic violence is prioritized, and the victims will receive assistance and relief, this means that one of the most important aspects of adequate housing, safety and security at home, will be improved for many women.

Furthermore, in some developing States, female politicians have shown a special interest in housing conditions. Their influence has resulted in the drawing of wells, installation of piped water or extra money for sanitation. It would seem that women should especially be encouraged to take part in local political bodies since in many instances those are the organs that may directly influence the living environment.

\subsubsection{The Right to Property ${ }^{546}$}

\subsubsection{Introduction}

The right to property may be considered as a human right. Its basis can be found in Article 17 of the Universal Declaration of Human Rights. ${ }^{547}$ International disagreement prevented the right to property from being included in either of the two UN Human Rights Covenants; ${ }^{548}$ still the entitlement to property has been recognized by many States, both in national laws and in regional human rights instruments. ${ }^{549}$ Though they do not acknowledge an obligation to provide people with property, many States bind themselves in their Constitution or other national acts to create enabling circumstances so that people may acquire property by themselves. ${ }^{550}$ Even more common may be a negative approach to property rights in the sense that States acknowledge the obligation to refrain from arbitrary deprivation of property. ${ }^{551}$

546 In section 3.5.2 supra the right to property is viewed from a private law perspective.

547 Universal Declaration of Human Rights. Article 17 reads: '1) Everyone has the right to own property alone as well as in association with others; 2) No one shall be arbitrarily deprived of his property.'

548 Theo van Banning, The Human Right to Property, School of Human Rights Research Series, Volume 14 Intersentia, Antwerpen, Oxford, New York, 2002, pp. 42-46.

549 E.g., Article 21 of the American Convention on Human Rights; Article 14 of the African Charter on Human and Peoples' Rights; and Article 1 of the First Protocol to the European Convention on Human Rights.

550 For instance Portugal, Venezuela, Colombia and South Africa. Theo van Banning, 2002, pp. 147-150.

551 Examples of States that have a negative formulation of property rights in their Constitution include the 
International case law, particularly on the European Convention on Human Rights, supports a very broad definition of the right to property equating it with any 'vested right ${ }^{552}$ Understanding the right to property in this way is very useful since it is not restricted to ownership, but also encompasses tenancy rights, usufruct rights or mere user rights.

In the framework of this study it is most logical to focus on just two property rights: the right to land and the right to housing, particularly since these two rights are practically inseparable in many situations. ${ }^{553}$ The right to land has been qualified as the most important property right since it not only may provide a livelihood and a place to reside, but it also empowers and it gives status. Generally speaking, however, women are faced with the situation that they have fewer property rights and less control over their property than men, which has direct repercussions on their housing rights. ${ }^{554}$

In the following sub-sections first the more positive aspects of property will be dealt with as regards people's, and particularly women's, rights of access to and property rights of land and housing, while the second sub-section goes into the negative obligation of States of refraining from arbitrary deprivation, linking it to the issue of security of tenure.

\subsubsection{Access to and Property Rights of Land and Housing}

In order to effectuate the right to property, many States have taken it upon themselves to enable people, without discrimination on any ground including sex, to access land and to rent, lease and own land and housing. This does not mean that the State has to provide people with property, but as far as housing is concerned, it may entail that those who lack the means and possibilities to secure adequate housing on their own accord, may receive help in the form of subsidies. Furthermore, access to land may be brought about by letting state-owned land at a fair price or setting up micro credit systems for the poor. Moreover, land (re)distribution or land reform programmes may be used to the advantage of the poor and landless. ${ }^{555}$

Land distribution may take various forms. Giving out individual or joint titles is possible, but it may also be an option to allot plots of land to communities. Whichever method is preferred, the principles of equality and non-discrimination demand that women and men are treated equally. ${ }^{556}$ Yet, world-wide women have less property rights than men,

USA, Belgium, the Netherlands, India, Israel, Luxembourg, the Philippines, Ethiopia, Greece and Norway. Theo van Banning, 2002, pp. 140-141.

552 Theo van Banning, 2002, pp. 11-12.

553 For instance, in Ethiopia the 1974 land reform act did not differentiate between land used for housing and land used for agricultural purposes. This is quite logical since in rural areas dwellings will be built directly on the land that is to be cultivated. Tadesse Zenabaworke, 'Women and Land Rights in the Third World: The Case of Ethiopia', in: L. Muthoni Wanyeki (ed.), Women and Land in Africa: Culture, Religion and Realizing Women's Rights, Zed Books Ltd, London, New York, 2003, p. 85.

554 This is also recognized by UN organs. See for instance Sub-Commission resolution 1997/19 on Women and the right to adequate housing and to land and property, $U N$ doc. E/CN.4/SUB.2/RES/1997/19 of 27 August 1997, and Sub-Commission resolution 1998/15 on Women and the right to land, property and adequate housing, UN doc. E/CN.4/SUB.2/RES/1998/15 of 21 August 1998.

555 Land reform is an important policy issue in a number of countries. Theo van Banning, 2002, p. 329.

556 As far as women's access to land is concerned, Article $14(\mathrm{~g})$ of the Convention on the Elimination of All 
and women's access to land lags far behind. To understand this discrepancy first the gender aspects of individual and joint titling will be discussed, followed by the issue of common property. Lastly, effective control by women of their property will be looked into.

\subsection{Individual Titles}

Gender equality as regards access to and property rights of real estate is most acute in those countries where land is becoming scarce and agriculture is either the primary source of income or a vital supplement to the family's income. Although there are several differences and it is hard to generalize, nevertheless, important similarities may be detected between the situations of rural Latin America, South East Asia and large parts of Africa. A common denominator is that all countries concerned are former colonies and that in pre-colonial days land used to be considered as common property. ${ }^{557}$ This meant that mere membership of a certain people, clan or family was in principle enough to guarantee access to a plot of land; not only to live on but also to grow food on. Colonial powers brought many changes. In some instances all the land was confiscated by the authorities and people were granted usufruct rights or could rent plots of land, or titles of ownership were given to certain people, mostly to foreigners while the indigenous population had user rights. ${ }^{558}$ In the post colonial period almost everywhere land reform programmes were issued. In the interest of efficiency and greater profit subsistence agriculture had to make way for cash crops. Since common property was deemed inefficient, there was a general move away from common land systems to individual titling. In some countries certain groups, however, especially indigenous peoples, strongly resisted this tendency and sometimes with success. ${ }^{559}$ In these States individual titling and common property co-exist. ${ }^{560}$ Where the States gave out individual titles, ${ }^{561}$ be it of ownership, usufruct

forms of Discrimination Against Women explicitely stipulates that women should be treated on an equal footing with men as far as land and agrarian reform is concerned.

557 See, for instance, Florence Butegwa and Adetoun Ilumoka in: Rebecca J. Cook (ed.), Human Rights of Women; National and International Perspectives, University of Pennsylvania Press, Philadelphia, 1994 on pp. 497-500 and 317 respectively; Carmen Diana Deere and Magdalena León, 'Neo-liberal agrarian legislation, gender equality, and indigenous rights: the impact of new social movements', in: Annelies Zoomers and Gemma v.d. Haar (eds.), Current Land Policy in Latin America: Regulating Land Tenure under Neo-liberalism, Royal Tropical Institute, Amsterdam, 2000, p. 75; and Bina Agarwal, 1994, p. 21.

558 This happened, for instance, in Rwanda where most of the land titles issued according to statutory law were held by religious institutions, like the Catholic and Protestant churches, while the native population had usufruct rights in accordance with customary law, but could not receive land titles. Jennie E. Burnet and the Rwanda Initiative for Sustainable Development, 'Culture, Practice and Law: Women's Access to Land in Rwanda', in: L. Muthoni Wanyeki (ed.), Women and Land in Africa; Culture, Religion and Realizing Women's Rights, Zed Books, New York, 2003, p. 181.

559 An important back-up in this regard was the 1989 ILO Convention Number 169 Concerning Indigenous and Tribal Peoples in Independent Countries which stipulates that indigenous peoples have special ties to the land they occupy. These ties should be respected and eviction should be avoided. If eviction is unavoidable, in consultation with the indigenous people an alternative site should be offered by way of reparation. See in particular Part II of the Convention.

560 For example in Mexico. Carmen Diana Deere and Magdalena León, 2000, p. 75.

561 Although the land that was distributed was State-owned, the actual (re)distribution took place at the local level by local councils that could differ as to their composition and the level at which they operated, but had in common that they almost always exclusively consisted of male members. Small wonder, therefore, that in many cases they were biased. Bina Agarwal, 1994, pp. 276-277. 
rights, rent or lease, the general trend was to give them to men as heads of their families. ${ }^{562}$ It was felt that men as breadwinners would take care of their families so that it was unnecessary to give titles to women. However, this is based on the presumption that resources are equally shared within a household, and that women are treated with respect and dignity. ${ }^{563}$ Sometimes, when it was obvious that women were family heads they were given individual titles as well, but in many cases women were not acknowledged as breadwinners and did not get anything or a smaller plot than male heads of household. ${ }^{564}$

Other reasons to allot land only to men were that women were held incapable of managing real estate. Women were not looked upon as independent farmers but were considered to be at most farmers' helps. ${ }^{565}$

In States where the land used to be in the hands of clans, titles to land were only given to men because of the age-old idea that should women be given land, this land would be lost to the clan if the woman would marry a non-clan member. Strangely enough, however, male title-holders were not restricted in any way as regards their control over the land. As a result, many, particularly young men, sold their land to the highest bidder and moved away, thus discarding another age-old tradition that widows and unmarried daughters could live on the clan land for the rest of their lives. ${ }^{566}$

In some societies a good reputation was a prerequisite for receiving a title to a plot of land and single mothers, divorcees and widows did not meet this requirement. Either their chastity was called in question or they were blamed for their husband's death. ${ }^{567}$

The consequence of denying women individual property rights is that they are made totally dependent on men for their access to land and housing. Therefore, good relationships with men are of vital importance for women. This may result in submissiveness to fathers, husbands and in-laws, remaining in abusive relationships, but also in giving up claims of inheritance in favour of brothers.

Another important consequence of denying property rights is that women's political power and participation in decision-making is affected. Property rights, particularly to real estate, are closely linked to power and status.568 In many rural societies having prop-

562 Tadesse Zenabaworke, 2003, pp. 73, 75, 76 for respectively, Latin America, Asia and Sub-Sahara Africa

563 A household, however, is not a unitary body, since important inequalities may exist within the household as regards the distribution of resources and decision-making. Tadesse Zenabaworke, 2003, pp. 67-68 Also, Bina Agarwal, 1994, p. 3, on the situation in South Asia.

564 In Honduras, for example when widows and single women were allotted plots of land, these were of very poor quality. Tadesse Zenabaworke, 2003, p. 73.

565 A striking example may be found in El Salvador where the agrarian law stipulates that to be entitled to a plot of land a person must be an agricultural producer, 16 years or older, and have the Salvadoran nationality. At first blush, these requirements seem to be totally gender neutral. However, according to cultural views a farmer is a man and a woman can never be more than a farmer's help. Consequently, the local committees that were in charge of allotting land, hardly ever selected women. Tadesse Zenabaworke, 2003 , p. 72.

566 The effect was that widows and unmarried girls were left behind without a place to live or a source of income. Florence Butegwa, 1994, pp. 497-500.

567 Tadesse Zenabaworke, 2003, p. 73. For taboos around widowhood also see section 3.3.4.

568 Having property rights, especially with respect to land, may entail prestige and power over others, while belonging to the 'have-nots' implies vulnerability and subordination. Rosió Córdova Plaza, 'Gender roles, inheritance patterns, and female access to land in an ejidal community in Veracruz, México', in: 
erty rights automatically means being entitled to membership of local decision-making bodies. ${ }^{569}$ Landless people, like most women, are excluded from decision-making.

The benefits of autonomous property rights and the enormous growth of femaleheaded households induced many women's organizations and CSOs to plead for individual land titles for women. This strategy was successful in a number of Latin American States. A woman's perspective has been included in legislation and policy because of pressure from women's organizations. ${ }^{570}$ The land distribution and land titling that is taking place is much more focused on gender equality than in the past. ${ }^{571}$ Several of the new agrarian codes stipulate that land ownership is vested in all natural persons, thus implying that both men and women may benefit from State programmes. ${ }^{572}$ Other codes go even further by explicitly establishing that women and men have equal rights to own land, independent of their marital status. ${ }^{573}$ The most advanced legal rules adjudicate land and titles to couples and/or give priority to female heads of households. ${ }^{574}$

Besides claiming equal treatment of women as regards distribution of publicly held land, women's organizations also have focused on the law of inheritance, since in many States this is the most feasible way of coming into possession of a plot of land. ${ }^{575}$ Many governments are sympathetic to women's plight and have changed the law in such a way that daughters and wives may inherit real estate, albeit sometimes smaller shares than brothers and husbands. ${ }^{576}$

However, several customs and traditions serve as barriers when it comes down to effectuating inheritance rights. The most important and most wide-spread custom is that of patrilocal residence and village exogamy for married women. ${ }^{577}$ As has been mentioned before, in many societies it is considered a hard and fast rule that when daughters marry they have to leave their own community or village. It is therefore seen as a waste

Annelies Zoomers and Gemma v.d. Haar (eds.), Current Land Policy in Latin America: Regulating Land Tenure under Neo-liberalism, Royal Tropical Institute, Amsterdam, 2000, p. 161. Also Bina Agarwal, 1994, p. 2.

569 In Mexico for instance, women used to have explicit land rights. Since the reform only recognized ejido members may decide about the future of the ejido. Since only one family member may be an ejidatario, it is customary that this is to be the male head of household. As a result less than $20 \%$ of the ejido membership are women. Carmen Diana Deere and Magdalena León, 2000, p. 86. In Ethiopia the Peasant Association is relatively powerful since it manages and implements the land reform in addition to its function as judicial tribunal. Since only heads of households are allowed to become a member, only 20 and $25 \%$ of the membership was female in the 90 s. Tadesse Zenabaworke, 2003, p. 82.

570 Carmen Diana Deere and Magdalena León, 2000, p. 75.

571 Ibidem, p. 76.

572 E.g. the codes of Ecuador, Honduras, Mexico and Peru. Carmen Diana Deere and Magdalena León, 2000 , p. 82.

573 Such provisions may be found in the codes of Bolivia, Brazil, Costa Rica, Guatemala, and Nicaragua, while in the Colombian code it is provided that male and female heads of household have equal right to be adjudicated land. Carmen Diana Deere and Magdalena León, 2000, p. 82.

574 Female household heads are favoured in Chile, Colombia, Guatemala, and Nicaragua.

575 Inheritance is for instance the most common type of land transfer in Sub-Saharan Africa. Tadesse Zenabaworke, 2003, p. 77. This is also true for South Asia, Bina Agarwal, 1994, p. 259.

576 For details on the different laws of inheritance and the problems women may encounter see section 3.5.3.

577 Patrilocal residence and village exogamy means that after marriage a man will take his wife to live in his or his parents' home, while his sisters go to live with their respective husbands. Rosió Córdova Plaza, 2000, p. 161. Also Bina Agarwal, 1994, p. 260. 
of family property to give daughters a share of it. When they are married, women will settle down in their husband's community and will thus gain access to his or his family's house and land. In most cases, however, married women do not have a legal claim on any of the real estate; they just have user rights as long as the relationship will hold. Since married women realize that their access to their husband's and in-laws' property is far from secure, ${ }^{578}$ and they fear that they may have to leave the marital home should the relationship end in any way, they more or less willingly give up their rights of inheritance, especially of land, in exchange for the goodwill and the security their brother(s) may offer ${ }^{579}$ Especially when they are childless or sonless or when they refuse to enter into a levirate relationship, their in-laws may turn them out on the street. ${ }^{580}$ Under these circumstances a good relationship with her brother may proof to be a woman's last resort. Her brother may welcome her back in the natal home thus offering her a roof over her head and maybe even letting her cultivate a plot of land. ${ }^{581}$

An interesting solution to women customarily losing their claim to land of their community when they marry may be found in China. Article 30 of the Law on the Protection of Rights and Interests of Women states that her fields and her land for housing construction shall remain under protection after she gets married, divorced or is widowed. Any community that violates such rights shall bear civil liability for cessation of violations, restitutions, rehabilitation and compensation for losses. ${ }^{52}$ This provision greatly enhances women's chances to having a roof over their heads, irrespective of the circumstances. It remains to be seen, however, whether women will manage to effectuate it.

\subsection{Joint Titles ${ }^{583}$}

In some States where women's problems are acknowledged, and where there is still land to be distributed, joint titling is seen as a solution. ${ }^{54}$ Not an individual man, but a man and a woman together as a couple will receive a title to a piece of real estate. It goes without saying that this is a great improvement to giving titles to individual men. Women holding joint titles with their husbands may enjoy more respect and status in their families

578 This is particularly true for those women who are married under customary law and those who are involved in polygamous marriages. Especially when customary marriages and polygamy are illegal, these women have no legal claim whatsoever when they are sent away or when their husband dies.

579 Some male relatives are hostile to the idea that daughters and sisters could share in the inheritance. They may intimidate and threaten them, or even use actual force to dissuade them from claiming their share. Some men resist the increased power of women who hold property and/or the fact that the women's share of the inheritance will be at the expense of their own. Bina Agarwal, 1994, p. 271-276.

580 Levirate means that a woman is 'inherited' by a (younger) brother of her late husband. The dead man's successor or levir has the duty to look after the widow and her children and to manage the deceased's property. Usually, the woman will remain inthe marital home and any children that are born are regarded as being her deceased husband's.

581 Bina Agarwal, 1994, pp. 260-268.

$582 U N$ doc. CEDAW/C/CHN/5-6, Combined fifth and sixth report of China, 10 June 2004, p. 53 (English version).

583 Undoubtedly the concept of joint titles may also be used in another sense, but in this study it is exclusively reserved for the situation in which a man and a woman as a couple together hold property rights to the same property.

584 In some States, like Colombia, Costa Rica, Ecuador, Guatemala, Nicaragua, and Peru, joint titling is mandatory, while in others, such as Brazil and Honduras, it is only optional. 
and communities. ${ }^{585}$ Another benefit is that these women cannot be sent away emptyhanded after separation or divorce, and that they cannot be disinherited.

A disadvantage in comparison to individual titling is, however, that joint titling may force women to stay in abusive relationships since it may not be so easy to leave when land or housing is jointly owned, and it may be difficult for women to realize their landuse priority should this differ from what their husbands want, and to gain control over the produce. ${ }^{586}$ Furthermore, most communities where joint titling has been introduced have formal rules as regards the status of the couple. ${ }^{587}$ In most cases only married people can obtain a joint title and only legal marriages concluded in a civil law ceremony are acknowledged. This proves to be a very high barrier in societies where it is common for couples to live together in informal relationships or where most marriages are concluded under customary law. ${ }^{588}$

Also for second, and following wives of polygamous marriages, joint titling is legally impossible. ${ }^{589}$

\subsection{Common Property (Collective Rights)}

Another possibility of avoiding individual titling is a system of common property, either in the form of common ownership of or common usufruct rights of land. These rights may be shared with the family, clan, the village, an indigenous people, or a co-operation. A great advantage of common rights seems to be that women belonging to a certain group automatically have access to land and housing. However, in many cases girls and women, unlike boys and men, have to meet certain demands. For instance, a daughter will only have access as long as she is not married. Once she marries, she will leave her family/ clan/village and thus she will lose her access to the land. In many cases this loss is permanent, so when her marriage turns sour, she cannot reclaim her former membership. ${ }^{590}$ A famous case in this regard is that of Sandra Lovelace, a Maliseet Indian woman in Canada who lost her rights and status, and thus access to land and the right to reside on reserve land, because she married a non-Indian. However, Indian men who married non-Indian women did not lose their rights and could continue to live on the reservation and claim a house. ${ }^{591}$ Another demand may be that a woman must be legally

585 All decisions as regards sale, rental or mortgage must have the woman's approval, thus greatly enhancing her bargaining power and her status in the family. Carmen Diana Deere and Magdalena León, 2000, p. 84.

586 Bina Agarwal, 1994, p. 20.

587 Where this issue comes up only heterosexual couples are taken into consideration.

588 In many Latin American countries like Honduras, it is quite usual for couples to live in consensual unions rather than formal marriage, it is very important that joint titling is applicable to both types of couples. Carmen Diana Deere and Magdalena León, 2000, p. 84

589 For instance in Rwanda especially women in informal marriages and polygamous marriages are faced with the problem that they lose their claim after their husband's death and that the land and house is seized either by brothers-in-law or by the legally married first wife. Jennie E.Burnet, 2003, pp. 200-201.

590 In Bihar, India, the custom that girls who marry have to move away and to waive their share of the inheritance induces some women of the Ho tribe to remain unmarried, while in Tibet many women in the Ladhakh community remained unmarried and become Buddhist nuns because then they were entitled to a house and independent usufruct rights of land. Bina Agarwal, 1994, p. 254.

591 Human Rights Committee, Communication No. 24/1977: Canada. 30/07/81. CCPR/C/13/D/24/1977. It is regrettable that the Committee did not find that Ms Lovelace in particular, and Indian women in general, 
married before she can claim access. This may prove problematic for women in customary or polygamous marriages. Furthermore, women's access may depend on their sexual chastity. ${ }^{592}$ Especially when she is a widow, a woman may only be allowed to remain in the marital home and have access to the in-laws' land if she is either sexually chaste or if she agrees to a levirate relationship. ${ }^{593}$

Furthermore, many women who have access to community land are legally in a weak position, because when common property is registered more often than not only the names of the adult males of the community are mentioned. It is for women's ability to claim their rights very important that their names appear on the deed as well.

A rather new concept in some countries is that groups of women form co-operatives that buy or lease land. Together they stand a better chance of getting credit and they can chose to either cultivate the land together or to divide it into separate plots. Since this is totally against tradition, there may be some (male) opposition against such schemes. ${ }^{594}$

\subsection{The Gap between Property Rights and Effective Control}

Many of the women who do come into possession of real estate are subsequently faced with the problem of having no effective control. The reason is that, though property rights of women may be legally recognized, they are not socially accepted. ${ }^{595}$ Culture and tradition may inhibit women from exercising their rights. ${ }^{596}$

In some cultures managing real estate is regarded as a man's job and it is simply unthinkable that a woman would manage her own land, even in matrilineal systems. ${ }^{597}$ A custom that greatly influences women's control is the ideology of purdah. ${ }^{598}$ The effect of purdah is that a woman's freedom of movement is severely restricted. If she has

were discriminated against by the Canadian Indian Act because of their sex. Canada was advised to allow Ms Lovelace to live on the reservation and to allot her a house not because of violation of Articles 2 (non-discrimination) and 3 (gender equality) of the Convention, but because of her rights under Article 27 (rights of minorities). According to the Committee Ms Lovelace should still be considered as belonging to the ethnic minority of the Maliseet Indians and should therefore benefit from the special rights under Article 27. The Committee emphasized that Ms Lovelace was meanwhile divorced and had only been away from the reservation for a few years. I think the individual opinion of Mr Nejib Bouziri put the case in a much better perspective by stating that not only Article 27, but also Articles 2(1), 3, 23(1,4) (family life) and 26 (equality before the law) had been breached because the provisions of the Indian Act are discriminatory as between men and women.

592 Bina Agarwal, 1994, p. 254.

593 Ibidem, p. 273.

594 Farming co-operatives or women's associations were for example founded in Rwanda where they were allotted state-owned land and sometimes received assistance from national and international CSOs. Jennie E. Burnet, 2003, p. 199.

595 Tadesse Zenabaworke, 2003, pp. 84-85. Also Bina Argawal, 1994, pp. 294

596 Bina Agarwal, 1994, pp. 249-260.

597 See for instance Rosió Córdova Plaza, 2000, p. 161 on Mexico, Tadesse Zenabaworke, 2003, p. 74 on Ethiopia, and Bina Argarwal, 1994, p. 295 on South Asia.

598 Purdah literally means curtain. The purpose of purdah is the seclusion of women in order to guarantee their chastity. Purdah takes various forms. The most known, put in fact the most rare, is veiling. Veiling, which varies from covering the head till totally covering the body-and even hiding the eyes behind netting - with a burqa, is common only in a few Islamic States and among Hindus in Northern India. The most pervasive form, however, is gender segregation of space, especially outside the house, and the gendered determination of how to behave. Purdah ideology factually denies women access to public spaces where men congregate, like banks and markets, but also prevents them to attend schools and to 
property, she will need male mediation to manage it since she cannot conduct business by herself. ${ }^{599}$ Since purdah also restricts adolescent girls' access to school, many women are less educated than men and in many cases unaware of their rights. This makes women susceptible to deceit. ${ }^{600}$

Another custom that hinders women in effecting control over their land is that in many communities it is forbidden for women to plough or sow, ${ }^{601}$ or, more in general, they are denied access to technological development. Here, again, women cannot act autonomously, but depend on male mediation and co-operation. ${ }^{602}$

\subsubsection{Property of Returnees}

A final pertinent question in this context is whether governments and international organizations see to it that land and housing are returned or compensated fairly and equally among women and men who are returnees, either refugees or IDPs who return to their homes after periods of (human-made) disasters, particularly armed conflicts.

Internationally, it is increasingly acknowledged that refugees, IDPs and other displaced persons who have been forced to leave their homes because of natural or humanmade disasters, have a right to return to their homes and their places of origin. Restitution, by way of returning to people the house and land they were forced to abandon, is not always easy or possible. ${ }^{603}$ Judicial remedies may be absent, other people may occupy the house (secondary occupation), abandonment laws ${ }^{604}$ may deny people's property rights, property registration and other official records proving ownership and occupancy rights may have been destroyed, or people may have been coerced to selling their property before fleeing. ${ }^{605}$ In addition to these impediments that are true for both women and men, female returnees may experience still other barriers to return to their original homes.

take up employment. Women valueing their good reputation restrict their visits to the public sphere to an absolute minimum. Bina Agarwal, 1994, pp. 268-269 and 298-311. Tadesse Zenabaworke, 2003, p. 74.

599 Bina Agarwal, 1994, p. 268.

600 Ibidem, pp. 270 and 304.

601 In some societies women may be severely punished when they plough their own land by themselves. Bina Agarwal, 1994, pp.312-313. This cultural taboo also exists in Ethiopia. Tadesse Zenabaworke, 2003, p. 81 .

602 Bina Agarwal, 1994, pp. 311-315.

603 The term 'restitution' is used to indicate that persons who have suffered loss or injury are returned to their original pre-loss or pre-injury position, i.e. they will be enabled to live again in their old home and occupy their original land. The term 'compensation' is reserved for the situation where a person receives a monetary payment for the harm he or she has suffered because it has become impossible to restore the person's property or house. GA Resolution 60/147, 16 December 2005, Annex, Basic Principles and Guidelines on the Right to a Remedy and Reparation for Victims of Gross Violations of International Human Rights Law and Serious Violations of International Humanitarian Law, paras 19 and 20. Also see Committee on the Elimination of Racial Discrimination General Recommendation No. 22: Article 5 and refugees and displaced persons, 24 August 1996, para. 2.

604 Abandonment laws will determine that a person who flees his domicile forfeits his future claims thereof. In fact, abandonment laws are often discriminatory and fit into a policy of ethnic cleansing of demographic manipulation.

605 In his Working Paper, E/CN.4/Sub.2/2002/17, Special Rapporteur Pinheiro lists these impediments to return in paras $44-54$. Unfortunately, he does not pay any attention to the cultural and legal difficulties encountered by female returnees. 
Particular vigilance is called for in countries where cultural and legal rules bar women and girls from owning or inheriting real estate. A negative example in this regard may be found in Kosovo, where returning widows whose houses had been restored with international help (the UN and CSOs), were prevented from occupying them. Since culture dictates that a widow cannot inherit real estate from her husband, their homes were claimed by the male relatives of their husbands. In many cases, the international community was not alert enough to prevent this. ${ }^{606}$

In Rwanda the first wave of refugees returned after the end of the genocide in 1994, and the second influx was between late 1996 and early $1997 .{ }^{607}$ The majority was housed in imidugudu (villages) constructed by the United Nations High Commission for Refugees (UNHCR) and international CSOs. According to the 1993 Arusha Accords refugees who returned after more than ten years could not reclaim their former property, but would be resettled with government assistance. The imidugudu resettlement schemes did not discriminate against women in allotting land. Sometimes genocide victims, single mothers, widows and female-headed households even enjoyed preferential treatment. Only in some cases elderly, widows and child-headed (mostly girl-headed) households did not receive any assistance with constructing housing for themselves. ${ }^{608}$ In 1999 the law was changed so as to enable women and girls to inherit land and housing from husbands and fathers so they could return to their original abodes and homesteads. ${ }^{609}$ Today the vast majority of household heads in Rwanda are widows, orphaned girls and women whose husbands are still imprisoned. ${ }^{610}$ Another positive example may be found in the 1994 Peace Accord of Guatemala after the civil war in which the resettlement schemes for refugees and IDPs give priority to female heads of household as regards the distribution of land. ${ }^{611}$

Though the task of housing and property commissions who have to examine and confirm real property rights is pretty arduous, it is imperative that they be aware of, and take account of special circumstances that may apply to women and girls.

\subsubsection{Security of Tenure}

This section will focus on the right contained in the second paragraph of Article 17 of the Universal Declaration; the right not to be arbitrarily deprived of one's property or, to put it otherwise, the right to peaceful enjoyment of one's property. As far as State obligations are concerned, these entail both negative and positive aspects. Negative be-

606 This particular information was provided by a UNHCR officer in the field. In Kosovo the statutory laws, that date back to the communist period, give equal rights to women. In large parts of Kosovo, however, rules of family life are laid down in traditional codes of law that are patriarchal in essence, endowing only few rights on women. Under these codes women do not have the right to own property.

607 In 1994 about 800,000 people returned and in 1996-97 the number was about 1,200,000 people. Jennie E. Burnet, 2003, p. 184.

608 Jennie E. Burnet, 2003, p. 185-186.

$609 U N$ doc. E/CN.4/Sub.2/2003/11, Housing and property restitution in the context of the return of refugees and internally displaced persons, Preliminary report of the Special Rapporteur, Paulo, Sérgio Pinheiro, 16 June 2003, para. 33.

610 Jennie E. Burnet, 2003, p. 191.

611 Carmen Diana Deere and Magdalena León, 2000, p. 84 
cause governments may not interfere with a person's property rights without a legitimate reason. Positive because peaceful enjoyment of property requires the State to protect people's property against third parties and to provide a form of reparation if deprivation is unavoidable. Before these negative and positive obligations of States will be discussed, first the concept of security of tenure will be dealt with.

\subsection{The Concept of Security of Tenure}

Security of tenure means that, irrespective of which property rights are involved, be it ownership, rent, lease, usufruct or user rights, or whether or not these rights are held individually, jointly with others or as a community, the enjoyment of occupied land and housing will be peaceful and undisturbed from interference from either the authorities or third parties. According to the Committee on Economic, Social and Cultural Rights legal security of tenure is the first of seven aspects that determine to what extent housing may be called 'adequate'. ${ }^{612}$

It goes without saying that the stronger the property right, the better the security against interference. Legal recognition of a right like ownership will deter others from interfering with it because it is embedded in legal safeguards. Domestic criminal law will threaten with sanctions when individuals violate it and administrative law rules will safeguard against arbitrary interference from the authorities and guarantee possible forms of reparation should the public interest demand that the property be expropriated. ${ }^{613}$ Nevertheless, also weak and informal rights, like user rights or mere occupation are considered to be property rights that may not be arbitrarily tampered with. ${ }^{614}$ In the context of the right to housing protection of informal property rights is of vital importance since a large percentage of the urban population in developing countries lives in informal housing and about half of the agricultural land in these countries is held without formal titles. ${ }^{615}$ Sometimes property rights of collectivities, like indigenous peoples, may give better protection than individual rights, particularly when these rights are internationally acknowledged. ${ }^{616}$

612 Literally the Committee states: 'Legal security of tenure takes a variety of forms, including rental (public and private) accommodation, cooperative housing, lease, owner-occupation, emergency housing and informal settlements, including occupation of land and property. Notwithstanding the type of tenure, all persons should possess a degree of security of tenure which guarantees legal protection against forced eviction, harassment and other threats. States parties should consequently take immediate measures aimed at conferring legal security of tenure upon those persons and households currently lacking such protection, in genuine consultation with affected persons and groups.' CESCR General Comment No. 4, The right to adequate housing, 1991. Also see section 2.4 on the content of the right to adequate housing.

613 This is why land titling is seen in Latin American States as highly important to enhance security of tenure. Carmen Diana Deere and Magdalena León, 2000, p. 77.

614 For instance in Könkämä and 38 other villages vs. Sweden the exclusive hunting and fishing rights of the Saami villages were regarded as possessions. Theo van Banning, 2002, p. 84.

615 Theo van Banning, 2002, p. 85.

616 For instance State parties to ILO Convention 169 have bound themselves to protect the rights of indigenous peoples to their ancestral lands. Only in the most extreme circumstances, when no other solution is feasible, is it possible to remove these peoples from the land they occupy. Even then relocation must be done in consultation and the alternative site must at least equal the abandoned one in quality and legal status. ILO Convention 169, Part II, Land, particularly Article 16. 
Internationally, the focus of security of tenure is on safeguarding against State interference. For many women, however, the greatest insecurity as regards tenure is caused by social structures and their relationship to other citizens, particularly their own clan or community members. That is why individual property rights may give women more security of tenure than joint or collective rights. Individual rights provide autonomy and independence. The more women depend for their land and housing rights on others, the weaker and more insecure their tenure may be. Women who have rights in joint property may become victims of an abusive relationship and they may be forced to leave their land or house because it may not be so easy to claim what is theirs. Women, who are members of a community that holds a collective right, or who have mere user rights, may be subjected to discriminatory rules and regulations, and their tenure may depend on their chastity, their conformity to community rules, but also on whether or not they are married or widowed. Women's security of tenure therefore increases proportionally the less it depends on others or on how their behaviour is judged.

\subsection{State Obligations}

The basic rule is that governments respect people's property rights and do not interfere when citizens manage to provide for land and housing by themselves. Forced evictions are prima facie violations of the Covenant on Economic, Social and Cultural Rights. ${ }^{617}$ Deprivation of property rights may only be acceptable under exceptional circumstances when the public interest is so important that it is justified to let it prevail over the interests of one or more individuals. In this way, land and housing of individuals may be expropriated by the State in order to construct housing for many, to provide necessary infrastructure, or to enable many people to access land where land used to be in the hands of only a few. ${ }^{618}$ States should be extremely vigilant as regards equal treatment and nondiscrimination when they affect property rights in any way. ${ }^{619}$

In several Sub-Saharan African countries, for instance, the transition from common land into individual land ownership led to the violation of the right to security of tenure of particularly those people who have weaker property rights, such as tenants, and vulnerable groups as women and illiterates. ${ }^{620}$ Furthermore, if expropriation is unavoidable it may only be performed in strict conformity with the law and international human rights rules. A consequence may be that alternative housing or land is offered or that compensation must be paid. ${ }^{621}$

617 CESCR General Comment No. 4 on adequate housing, 1991, Article 18. In General Comment No. 7, the Committee defines 'forced evictions' as: 'The permanent or temporary removal against their will of individuals, families and/or communities from the homes and/or land which they occupy, without the provision of, and access to, appropriate forms of legal or other protection. The prohibition on forced evictions does not, however, apply to evictions carried out by force in accordance with the law and in conformity with the provisions of the International Covenants on Human Rights'. CESCR General Comment No. 7 on Forced Evictions, 1997.

618 Theo van Banning, 2002, p. 105

619 On forced evictions and their effect on women, see section 3.3.2.

620 Theo van Banning, 2002, p. 62.

621 In Tanzania security of tenure was undermined by absence of legal rules pertaining to common land held under customary land titles. The Tanzanian Rural Land Act (1973) allowed the authorities to declare any part of the country a specified area which could be seized without compensation. Theo van Banning, 2002, p. 62. 
States also have an obligation to protect citizens in their property rights against third parties. This means for instance that governments closely guard that the rents landlords ask are within certain legal limits so that the cost of housing remains proportionate with income levels.

Furthermore, protection may entail that a system of housing subsidies is established for those who cannot afford adequate housing. ${ }^{622}$

\subsubsection{Concluding Remarks}

Women's right to adequate housing is negatively influenced by the fact that they experience more difficulties in acquiring property rights of land and housing than men do. Legal impediments and social constrains serve as barriers against gaining and retaining access to real estate. Moreover, many women who succeed in securing property subsequently are faced with the problem that they are hampered in exercising effective control.

In order to improve women's property rights several measures are needed. First of all, legal changes must be made as regards discriminating land distribution and agrarian reform laws. States must stop regarding households as unitary entities where resources are pooled and shared equally. In the interest of equality and non-discrimination individual titles should be distributed equally between women and men. If joint titles are issued, the rights of women married under customary law or living in consensual relationship should be safeguarded. Where common property is seen as the best solution, women's names along with men's should be mentioned on the deeds, and discriminatory community rules and regulations that make it possible to rob women of their rights should be prohibited. Furthermore, the inheritance law needs to be changed where this has not already been done. Daughters and sons, wives and husbands, brothers and sisters, should be entitled to equal shares, also of real estate.

Probably even more important, however, is that women's property rights be socially accepted. This requires a change in mentality and traditional perceptions. Though this is usually a slow process, it is not impossible. Especially with the help of legal measures and government campaigns, changes may be feasible and sometimes even rather quick. This becomes clear from the example of Rwanda, where the sheer number of female heads of household made it impossible to cling to traditional patterns. Issuing plots of land to individual women, making it possible that women, too, are heads of household, and changing the law of inheritance in such a way that women and men are treated equally, brought about an enormous cultural change. Suddenly women are seen in a different light, as persons who can function independently from men.

Another way of improving women's plight is building up support groups, especially from the grassroots. The success of women's CSOs in Latin America proves that social pressure may result in gender-specific laws and policies. Also the women's co-operatives in South Asia show that when women stand together they can manage to claim land and build up an autonomous livelihood.

622 The last two examples refer to 'affordability' as one of the aspects constituting 'adequacy'. CESCR, General Comment No. 4 on the right to adequate housing, 1991, Article 8 (c). 
Internationally, the right to property is interpreted in a very broad sense. It encompasses ownership, rental and lease rights, usufruct rights, occupancy rights or mere user rights. According to legal theory, all these property rights, when referring to land and housing, should offer security of tenure.

However, in practice, security of tenure is hard to obtain when it is based on an informal right, like mere user rights, or when people are illegally squatting on land owned by the State or another citizen. Sometimes, when a large group of desperately poor illegal squatters is forcefully removed, and their dwellings are bulldozed, there will be enough commotion to alert the press and it may even be a topic discussed in an international forum. However, in the end publicity may be the only result. At best there is international political rejection and a State sees to it that these people are relocated or are offered some compensation. If it is already so hard for a group of people who may receive support from CSOs and may even get international political attention to effectuate their right to security of tenure, what chances will an individual widow stand, who had mere user rights of her in-laws estate while her husband was alive, but who is evicted after his death. Whom can she rely on to help her to effectuate her tenure right? That is why women's security of tenure only stands a chance of being respected if they not only have legal claims to land and housing, but can also enforce these claims in practice.

\subsubsection{The Right to Privacy}

\subsubsection{Introduction}

The right to privacy belongs to the category of civil and political rights. It is a right that imposes a negative obligation on the State because it entails the right of citizens to be let alone and thus the authorities should back off and not interfere with the private sphere of individuals. ${ }^{623}$ However, since the State should ensure respect for this right, it will also entail the positive obligation to protect individuals from interference of their privacy by third parties. ${ }^{624}$ Besides operating vertically, i.e. in the relationship between the State and the individual, the right also operates horizontally, i.e. in relationships between individual citizens. ${ }^{625}$

623 Already in 1890 Samuel Warren and Louis Brandeis characterized the right to privacy as 'the right to be let alone'; they assumed that the right to isolate oneself from the public sphere was 'sacred'. Later scholars called the right to privacy an 'inalienable right'. Amitai Etzioni, The Limits of Privacy, Basic Books, New York, 1999, 190.

624 Henry J. Steiner, Philip Alston, International Human Rights in Context; Law, Politics, Morals, $2^{\text {nd }}$ ed., Oxford University Press, Oxford, 2000, pp. 181-183. The Dutch Government e.g. declared in 1984 that in light of Articles $8 \mathrm{ECHR}$ and 17 ICCPR it considered it her duty to protect the right to privacy of its citizens also against third parties. Lucas Verhey, Horizontale werking van grondrechen, in het bijzonder van het recht op privacy, Tjeenk Willink, Zwolle, 1992, p. 405.

625 As acknowledged for instance by the Human Rights Committee in its General Comment 16, The right to respect of privacy, family, home and correspondence, and protection of honour and reputation (Art. 17), 8 April 1988, para. 1. 
The scope of the right to privacy is rather broad. ${ }^{626}$ Though opinions on the exact contents vary, on the whole it is accepted that privacy comprises among other rights: privacy of the home, family life, to live as one wishes, correspondence and telephone conversations, protection of honour and reputation, and the right to protection of personal data.

In the framework of this study the right to the privacy of the home, and in connection to that the right to live as one wishes, are particularly important. That is why the focus will only be on these aspects of the right to privacy.

The purpose of discussing the right to privacy is twofold: to determine the positive and the negative sides of privacy protection of the home with regard to the housing rights of women. Privacy is one of the factors that determine the degree of adequacy of the housing situation. The home is pre-eminently the place where an individual should feel safe and secure, and where she/he can do what she/he pleases and live her/his life in the way she/he prefers. For women and men both, interference by authorities or by third parties will undermine the adequacy of the housing situation, the more so when this interference happens arbitrarily or on a structural basis. This positive side of privacy protection of the home will be discussed in section 3.6.4.2.

In cases of domestic violence, however, the vulnerable parties, in most cases women and children, may be ill served by too stringent a protection of the right to privacy. The victims may want and need interference in their homes and private lives by the authorities because otherwise the perpetrator is free to do as he pleases behind the front door. This reverse side of the privacy of the home is the subject of section 3.6.4.3.

\subsubsection{The Privacy of the Home}

An age-old English proverb says that 'An Englishman's home is his castle'. This proverb pinpoints the essence and the importance of privacy protection of the home. ${ }^{627}$ Home should be the place where the individual can live a free and dignified life and say and do whatever she or he likes without running the risk of interference ${ }^{628}$ Housing cannot be called adequate when an individual's way of life is constantly monitored from the outside. That is why protection of, and ensuring respect for the right to privacy is inextricably linked to the right to adequate housing.

In most countries, both criminal and civil laws will ensure that individuals do not have to tolerate interference of their privacy either by the authorities or by third parties.

Internationally, the right to privacy is protected by the Universal Declaration (Art. 12), ${ }^{629}$ and the International Covenant on Civil and Political Rights (Art. 17). ${ }^{630}$

626 The scope of what is considered to be a matter of privacy varies not only among countries, societies and cultures, but also changes during the course of time. Etzioni, 1999, p. 202.

627 At the same time it is also proof of age-old gender bias, since it reflects the idea of the pater familias who is master in his own home and rules over wife and children.

628 Karen Engle takes a stance against the negative image of the private sphere and points out that it may offer protection to many women. Karen Engle, 'After the Collapse of the Public/Private Distinction: Strategizing Women's Rights', in: Dorinda G. Dallmeyer (ed.), Reconceiving Reality: Women and International Law, The American Society of International Law, Washington D.C., 1993, p. 146.

629 Article 12 Universal Declaration of Human Rights reads: 'No one shall be subjected to arbitrary interference with his privacy, family, home or correspondence, nor to attacks upon his honour and reputation. Everyone has the right to the protection of the law against such interference or attacks.' 


\subsubsection{Privacy and Domestic Violence $e^{631}$}

Although the privacy of the home may in many States be well protected against outside interference, it is not always recognized that this right may also be violated from the inside. ${ }^{632}$ Home is regarded as a safe haven where all family members equally enjoy their privacy and where all are equally averse to outside interference. This approach passes over the fact that not all family members are equally empowered and capable of realizing their rights. ${ }^{633}$ In cases of domestic violence and child abuse the victim, contrary to the perpetrator, will need and benefit from outside interference and may gladly waive her or his right to privacy in order to be protected against physical violence. In many States, however, the authorities are reluctant to cross the threshold because the right to privacy of the home is regarded as sacred when the right to family life is concerned. ${ }^{634}$ That is why the police will much sooner enter a house when inhabitants are suspected of traffic in drugs or weapons than when they have received a report of domestic violence. Whatever happens behind the front door between family members may in many States be regarded as a private or family matter in which they do not want to interfere to the detriment of the victim. ${ }^{635}$

What is overlooked, however, is that domestic violence and subsequent non-interference will entail a violation of the victim's right to privacy, because the suppressed party is no longer capable of doing and saying whatever she pleases in her own home. Some batterers police their partner's every move and treat them like servants or prisoners. This is why arguments of non-interference by the authorities because of respect for the privacy of the home and family life cut no ice. Non-interference means that the right to privacy of the perpetrator is respected, while the right to privacy of the victim is vio-

630 Article 17 of the ICCPR: (1) 'No one shall be subjected to arbitrary or unlawful interference with his privacy, family, home or correspondence, nor to unlawful attacks on his honour and reputation. (2) Everyone has the right to the protection of the law against such interference or attacks.'

631 Domestic violence is also discussed in sections 3.3.5 and 3.5.1.

632 For example, as far as the situation in the USA is concerned, the right to privacy is rather well protected from violation by the State, but the defense is weak against violations by non-State actors. Etzioni, 1999, p. 10.

$633 U N$ doc. E/CN.4/1995, 42, Preliminary Report of the Special Rapporteur on Violence against Women, 22 November 1994, para. 54

634 Typically, out of respect for the right to privacy, the State will wait with taking action until the results of the acts that have happened behind the front door have become visible in the public sphere and can be backed up with evidence. Etzioni, pp. 196 and 211. Sometimes there may be several reports of abuse but the authorities will wait until serious harm has been done. E.g. in Bulgaria there is a policy of nonintervention unless the case is extremely serious. In Hungary the attitude of the police is only to intervene when 'blood is spilled'. In Lithuania the police only intervenes in cased of serious bodily injury or murder. In Uzbekistan the police will not investigate domestic violence unless it results in the victim's death. See: International Helsinki Federation for Human Rights, Women 2000; An Investigation into the Status of Women's Rights in Central and South-Eastern Europe and the Newly Independent States, IHF, Vienna, 2000, pp. 115, 206, 288 and 503 respectively.

635 The police regard domestic violence as a private or family matter and will subsequently not intervene e.g. in Bulgaria, Croatia, Czech Republic, Hungary, Kyrgyzstan, Lithuania, Macedonia, Romania, Slovakia, Tajikistan and Uzbekistan. IHF Women 2000, pp. 115, 130, 148, 205, 244, 288, 309, 363, 404, 437 and 503 
lated. ${ }^{636}$ States do not show due diligence, and therefore become responsible, when they are unresponsive and thus fail to protect the victim's right to privacy. ${ }^{637}$

After their separation or divorce, women's right to privacy may continue to be violated by their former partners. Many of these women do not get the chance to live their lives in peace because their ex-partners are stalking and harassing them. A solution may be that the victim obtains an injunction against her former partner forbidding him to come near her home or even her neighbourhood. ${ }^{638}$

The authorities downright fail to protect the rights of battered women who have found refuge in safe houses, when the addresses of such shelters are publicly known or can easily be obtained. ${ }^{639}$ Survivors of domestic violence should have the opportunity to start their lives anew in an environment where their privacy is protected and where they can live in security.

\subsubsection{Concluding Remarks}

The right to privacy of the home is an essential element of the right to adequate housing. It is therefore important that this right is respected and protected both against interference from the authorities and from third parties. Privacy of the home may not only be threatened and violated from the outside, but also from the inside. The right to live her life in any way she wishes and the right to feel safe and secure in her own home, is totally undermined when a woman is the victim of, or lives in fear of domestic violence.

Some States do not want to be bothered by what happens in the private sphere. Others are reluctant to interfere with family life, even after cases of abuse have been reported, and may still believe in the myth that home is a sanctuary for all family members or that no serious harm can be done within the family. Whatever their reasoning, the result is that these States are respecting the right to privacy of the perpetrator, while they are failing to protect the right to privacy of the victim because victims of abuse need outside interference and/or assistance and relief in order to be able to live in peace and dignity. In cases of domestic violence the victim's rights to physical integrity, privacy, dignity and adequate housing should take priority over the perpetrator's right to privacy.

636 Rebecca Cook maintains that the fact that States allow women's rights to be violated at home contributes to the total subjugation of women. The authorities should not only defend women's rights in the public, but also in the private sphere. Rebecca Cook, 'Accountability in International Law for Violations of Women's Rights by Non-state Actors', in: Dorinda G. Dallmeyer (ed.), Reconceiving Reality: Women and International Law, The American Society of International Law, Washington D.C., 1993, p. 94.

637 State responsibility is dealt with in section 4.6 supra.

638 In the Netherlands e.g. there are many cases dealing with such situations. However, if the woman obtains an injunction, the court order is mostly based on the right to security of the person and hardly ever refers to the right to privacy. Verhey, 1992, p. 243.

639 In the Netherlands, e.g. addresses of safe houses are not so difficult to obtain. Many women living in such shelters are harassed by their former partners who make it very unsafe for them to leave the house. In March 2004 a man succeeded in tracing his wife time and again by way of accessing internet data of their common health insurance company. When he caught her in front of the fourth shelter she had taken refuge in, he killed her in front of their three children. See the Dutch newspaper NRC Handelsblad, 26 March, 2004. 


\subsubsection{The Right to Employment}

Nothing empowers women more than having remunerated employment that enables them to be self-supportive. As has already been discussed in the context of poverty, a steady income is the best guarantee to obtain and maintain adequate housing and it enables women, at least financially, to leave an abusive relationship. However, the traditional division of work and the lack of education and job training, form obstacles that prevent many women from entering the labour market. ${ }^{640}$

Despite the fact that many States are parties to ILO Conventions and Human Rights instruments which oblige them to achieve equality between women and men as regards equal rights in the field of employment, ${ }^{641}$ many national labour laws and regulations may still be based on traditional, gender stereotyped ideas that have repercussions for the organization of labour. In industrialized countries, for instance, the whole labour system is tailored to employees who do not have to combine remunerated work with care-taking responsibilities. Many jobs have inflexible working hours that are hard to combine with the care for small children. Career moves may be reserved for those employees who are able to work full-time and/or who are prepared to work overtime. Statesupported day-care centres for children or sick and disabled people may be non-existent, scarce, or very expensive because societies have come to depend on (female) care-takers and volunteers who work for free instead of pursuing a remunerated career.

Stereotyped patterns also have an effect on job assessments that may be backed up by labour law regulations. The so-called 'reproductive' work where the majority of female employees are to be found generally is perceived as less important and is economically less valued than 'productive' work where the majority of male workers are engaged. ${ }^{642}$ Moreover, part of the, mostly better paid, 'male' segment of the labour market may be closed for women because they are legally barred from certain professions either because these are recognized as typically male or because women's potential capacity to become pregnant has resulted in protective legislation that bans them from certain hazardous or arduous work because it may have a negative effect on a potential foetus. ${ }^{643}$ Furthermore, some national labour laws fail to protect women from sex discrimination by private employers.

640 See section 3.2.3.2 on employment

641 See e.g. Article 11 of the Women's Convention which should be read in conjunction with Article 5 as to the elimination of prejudice and gender stereotyping that negatively affect women's equal opportunities concerning remunerated employment. ILO Convention 156 on Workers with Family Responsibilities (1981) reminds States parties in the Preamble that the traditional role of men and women in society and in the family needs to be changed before equality between men and women can be achieved, and in Article 3 that in order to create equality of opportunity and treatment for male and female workers, a national policy must be devised to enable persons with family responsibilities to exercise their right to employment without discrimination and, as much as possible, without conflict between their employment and their family responsibilities.

642 David Wield, Joanna Chataway, 'Unemployment and Making a Living, in: Tim Allen and Alan Thomas (eds.), Poverty and Development into the $21^{\text {st }}$ Century, Oxford University Press, Oxford, 2000, p. 117.

643 Valerie Oosterveld, 'Women and Employment', in: Kelly D. Askin, Dorean M. Koenig (eds.), Women and International Human Rights Law, Volume 1, Transnational Publishers, Inc. Ardsley, New York, 2000, pp. 370-375. Catharine MacKinnon somewhat exaggerates by remarking that women get protected out of jobs because of their fertility. Catherine MacKinnon, 'Difference and Dominance: On Sex 
Worst off may be the women who are not at all protected by labour laws, like women who work in the informal sector or those who are employed in Export Processing Zones (EPZs). ${ }^{644}$ Such areas may for instance be found in Latin America and South-East Asia where States have foreclosed their labour laws in favour of accommodating foreign investment. Thus any equality between women and men that may have been achieved in national labour law legislation or in international labour law obligations is declared inapplicable in the EPZ with the result that only short-term working contracts are concluded, pregnancy tests are held, pregnant women are fired, women are paid less than minimum wages or less than their male colleagues, and social security laws are shut out. ${ }^{645}$

States that wish to empower women and enable them to acquire their own adequate housing must see to it that women get a fair chance to enter the labour market where they are to be remunerated on par with male colleagues who do work of equal value. It is also in the interest of society at large when women, especially female heads of household, do not require State support such as housing subsidies, but can manage on their own.

\subsubsection{Female Dignity}

There is no separate human right to dignity, but it is assumed that dignity and equal worth are inherent characteristics of all human beings. That is why dignity is one of the bases of all major human rights instruments, ${ }^{646}$ and was also seen as the starting point of adequate housing by the CESCR in its General Comment No. 4 on adequate housing. ${ }^{647}$ The importance of human dignity is not further stressed, however, nor is it brought up as a quality seriously lacking in respect to the housing situation of millions of women. Though there may be little dignity in being homeless or inadequately housed for all who experience it, degrading and humiliating situations in the context of housing are especially part and parcel of women's lives. ${ }^{648}$

Women who are victims of domestic violence, either physical or psychological, may be humiliated on a daily basis, oftentimes even in front of others, especially their children. But also women, who on the basis of their socio-economic position are kept totally dependent on others, may experience hardly any dignity in respect of their housing situation. Dignity is linked to autonomy, self-respect and honour, qualities highly valued in men's lives. It is high time women claim these merits for themselves and that they are supported by human rights norms and organs to do so.

Discrimination', in: Feminism Unmodified: Discourses on Life and Law I, Ch. 2, 1987, p. 150.

644 An EPZ is a geographically defined area within which tax laws and labour laws and regulations are not valid.

645 Valerie Oosterveld, 2000, pp.388-395.

646 Starting with the Universal Declaration on Human Rights, all subsequent preambles of major international human rights instruments mention inherent dignity as an inalienable right of all people.

647 Literally the CESCR says that 'it [the right to housing] should be seen as the right to live somewhere in security, peace and dignity'. GESCR General Comment No. 4 on adequate housing, para. 7.

648 Also, Giulia Paglione, Domestc Violence and Housing Rights', in: Human Rights Quarterly, Vol. 28, Number 1, February 2006, pp. 126-127. 


\subsubsection{Concluding Remarks}

From this section it has become clear that rights as diverse as political participation, property, privacy, employment and dignity all may have a bearing on the realization of the right to adequate housing for women.

Political participation of women, especially in organs that take decisions pertaining to the spending of the budget or in those that take decisions as regards concrete housing situations, may entail an improvement of women's housing conditions when female politicians are aware of the special problems women encounter and are willing, and able, to put those issues on the agenda. With a world average of about $16 \%$, female politicians are still thin on the ground, and this of course has repercussions on the influence they may have. Still, in many States women's participation in politics has led to public attention for, and remedies pertaining to, the problem of domestic violence. Thus some advancement has been made towards women's safety and security at home.

Although it is still early days, and there is not yet much proof, it would seem that an increased female participation in decision-making organs would also be in the interest of realizing improved housing conditions for women. Women should particularly be encouraged to take part in local political bodies since in many instances those are the organs that may directly influence the living environment.

Measures to achieve a higher percentage of female participation will have to be diverse. Since there are hardly any legal barriers for women to participate in politics, the causes for their absence lie in their socio-economic status in society. Positive action like reserved seats and quota setting has proved to yield results. Most importantly, a cultural change is needed that will break through the gender stereotyping which puts women in the private sphere of the home and which questions their suitability for public office. Not only the authorities, but also non-State parties like political parties and women's CSOs have an important role to play here.

From studying the right to property it has become clear that women's right to adequate housing is negatively influenced by the fact that they experience more difficulties in acquiring property rights of land and housing than men do. Not only may legal barriers be encountered, but in many countries there are also economic and social impediments that prevent women from accessing and owning land and housing. In addition, women may experience problems in exercising effective control over their possessions.

If women's property rights are to be improved, which may also mean that their right to security of tenure is guaranteed, discriminatory laws have to be abolished. Moreover, social and cultural changes have to be effectuated since various traditions and habits cause women to be dependent on others for their housing situation. Autonomy and individual property rights for women are regarded as unwanted in many countries of the world. If States are serious about equal rights for women they should no longer treat households as unitary entities where resources are shared, but admit that in many families women are in a less favourable position than men. If individual property rights for women are seen as a bridge too far, joint titles and/or common or community property might be a solution provided women's equality rights are safeguarded by legal rules and remedies that guarantee that women are entitled to an equal share and have the same power to effectively 
control their property as men do. As far as discriminatory customary rules are concerned, yet again it is not only a task for the authorities to modify cultural patterns but also for (women's) CSOs. It is imperative that awareness is created, both among men and women about women's legal rights. Furthermore, the harmful consequences in keeping up certain discriminatory habits should be pointed out.

An important aspect of the right to adequate housing is the right to privacy of the home. Most States acknowledge this right and have adopted laws to protect it against unlawful and arbitrary interference from State authorities or third parties. Though the reasoning behind this protection may be that the home and family life are regarded as a sphere in which the authorities should not interfere, on the other hand it is also induced by a strict division between public and private spheres and governments do not care about what happens in the private sphere. The price for this attitude, however, has to be paid by the numerous women and children all over the world who are victims of abuse at home. That is why States should respect and protect the right to privacy of individuals and not of households. Moreover, when the right to physical integrity of the victim is at stake, this right should get priority over the right to privacy of the perpetrator. Noninterference in the private life of some citizens may in fact result in condoning violation of several human rights of women among which their right to privacy and their right to adequate housing.

Women's capacity to realize their housing rights is negatively affected by discriminatory employment rules and regulations that are premised on prejudice and gender stereotyping particularly the gendered division of work. Moreover, women who do succeed in entering the labour market, run the risk of not being paid the same salary as their male colleagues when they do work of equal value, or they earn considerably less than standard because they are employed in a 'female' profession. As a result, the average income women earn is less than that of men so that many women who work still are unable afford adequate housing. Reparation of the income gap between women and men will empower women considerably and will take a burden off State funds that are now used to alleviate poor women's needs by subsidizing their housing and related facilities.

Great scores are set by the right to dignity. It is seen as an inherent right that has to be fulfilled in the context of housing before any other aspect of adequacy come into the picture. Still, remarkable little attention is paid to the fact that the housing conditions of millions of women are completely undignified and humiliating. It is high time that in addition to material requirements of housing also immaterial aspects are put under scrutiny.

\subsection{Structural Discrimination Inherent in Cultural Patterns}

\subsubsection{Introduction}

In the previous sections of chapter III besides the right to housing itself various other legal rights have been under scrutiny in order to explain why it is different or more difficult for women to enjoy their right to adequate housing. As has already become clear, the causes of non-realization do not always lie in the legal sphere. Sometimes it even became obvious that legally there were no impediments for women to realize their 
rights to the same measure as men, because de iure gender equality was guaranteed. That the de facto situation may be quite different, however, is the result of the social constructions that determine women's status in society. Women's legal rights may be affected by it in such a way that it becomes difficult or even impossible to realize them.

How people act and think, and how they are supposed to behave, is to a large degree regulated by their culture. Culture is a broad concept. It determines how a certain society functions and encompasses aspects as different as language, religion, cultural heritage, customs, values, norms, practices, arts, literature and sports. ${ }^{649}$ In the context of this study those aspects of culture are relevant that lay down behavioural patterns for women and men. Particularly religious prescriptions and other practices and customs that ascertain that women and men should have different, mostly unequal, roles in society determine to a large degree women's possibilities to fulfil their human rights.

Women may greatly benefit from cultural patterns in the sense that they can rely on a certain system in which it is clear which behaviour is expected of them and what they can expect in return. It will give them a sense of safety and security because complying with desired behaviour will guarantee them the right to belong to a certain group and to be taken care of. Some cultural practices, however, even if they are intended to protect them, may subjugate women and stand in the way of empowering them. ${ }^{650}$ It is my belief that there is no culture today that does not to some degree curb women's rights. Cultural rules may inhibit women to develop themselves fully and to become autonomous persons, endowed with the full scale of human rights, on an equal footing with men. Culture may be used as an excuse and a pretext to violate women's rights. Women, who try to realize the rights they are entitled to, may be regarded as traitors and are accused of undermining their own group's culture. Defying cultural rules may ultimately lead to a woman's exclusion from her cultural group; a situation that is very bleak since particularly women lack resources that would support them outside their community.

It is of course very difficult to write about the influence of culture in general since there are so many different cultures in the world. That is why everything that is written in this section cannot be anything other than illustrative. However, in spite of all the differences, a few common features may be detected that more or less explicitly or implicitly may be found in almost all cultures. These are patriarchy, the gendered division of work, and violence against women. ${ }^{651}$ Other features that are discussed are typical for certain societies only.

Furthermore, it is very hard to distinguish exactly which behavioural rules derive from either religion, custom or traditional practices since they mutually influence each other. An age-old tradition may in the course of time have become a religious rule, while an

649 Christina M. Cerna and Jennifer C. Wallace. 'Women and Culture', in: Kelly D. Askin and Dorean M. Koenig (eds), Women and International Human Rights Law, Vol. 1, Transnational Publishers, Inc., Ardsley, New York, 1999, pp. 634-625, Mahnaz Afkhami, 'Cultural Relativism and Women's Human Rights', in: Kelly D. Askin and Dorean M. Koenig (eds), Women and International Human Rights Law, Vol. 2, Transnational Publishers, Inc., Ardsley, New York, 2000, p. 482. Also see Yvonne M. Donders, Towards a Right to Cultural Identity?, Intersentia, Antwerpen, 2002, p. 13.

650 Cerna and Wallace, 1999, p. 623.

651 Although some forms of violence are typical for a certain society, in general it can be said that violence against women may be found in every culture.UNIFEM Report on Violence Against Women, 1992. 
originally religious habit may nowadays be regarded as customary in a secular State. Some habits are so ingrained in society that it has been forgotten why they are applied or what their origin is. That is why the distinction made between religion, custom and tradition in the next sub-sections is sometimes arbitrary, and another indication may be equally justified. Classification of rules into these three categories is not important, however, since they all derive from the same murky quagmire that is called 'culture'.

In the next section the influence of religion on cultural patterns will be looked into. Religion may have a massive influence on people's behaviour. Religious rules may be found in their purest form in fundamentalist societies, but may even have an influence on the behaviour of people living in secular States.

Custom and tradition are the subject of section 3.7.3. They are taken together since the dividing line is sometimes very narrow. ${ }^{652}$ They may have a religious origin, but that is not necessarily the case. The difficulty with tradition and custom is that they seem to belong to the realm of 'natural law'; rules that have always existed and that cannot be deviated from. It is often forgotten, however, that traditional practices and customs started at some point in time when people began behaving in a certain way. Therefore, customs and traditions are not fixed but flexible and may change, though this may take a long time.

The most pervasive influence of religion, custom and tradition is felt when the rules ensuing from these cultural determinants are laid down in so-called 'personal laws', a term that gives them a semi-legal and official status. Personal laws may be written or unwritten and in some States may take precedence over national laws and even over the constitution. Personal laws are found in multicultural societies that struggle with the desire to treat all societal groups equally, and to retain each group's identity, while some, at the same time, also attempt to do justice to each individual's human rights. The subject of personal laws will be looked into in section 3.7.4.

Finally, in section 3.7.5 a few examples will be given of the danger of changing cultural practices without paying heed to the existing balance within a group, with the result that women's position may become worse than before. Though this situation may arise in any culture, the examples that are given specifically refer to the situation in former colonies because they are so clear.

\subsubsection{Religion}

There are of course numerous religions in the world. This study is restricted, however, to five major religions: Buddhism, Christianity, Hinduism, Islam, and Judaism, since together they affect the majority of the world's population. Religious rules and norms may be observed in their purest forms in fundamentalist societies, ${ }^{653}$ but traces may also

652 According to the Oxford Advanced Learner's Dictionary of Current English 'custom' is defined as 'accepted behaviour among members of a social group' and '[a] particular way of behaving which, because it has been long established, is observed by individuals and social groups'. The term 'tradition' is reserved for 'opinions, beliefs, customs, etc. handed down from generation to generation'.

653 Fundamentalists, regardless of their denomination, almost always put society first, and the individual second. They create an image of a 'traditional' society, while in reality this may never have existed. This fabricated traditional way of living is given 'an aura of cultural authenticity' which they want to apply to present-day life. Mahnaz Afkhami, 2000, p. 485. 
be found in less conservative or even secular societies. Over the centuries, these rules have become so much part of people's identities that they may not even remember their origin anymore. It thus becomes very difficult to be aware of them at a conscious level or to view them objectively, let alone to shake loose from them. ${ }^{654}$ Comparison among these religions results in finding striking resemblances. ${ }^{655}$ Irrespective of how much religions may differ in other aspects, traditionally they all hold similar views as regards the position and desired role of women in society. ${ }^{656}$

Regarding women's sexuality in a certain, unfavourable light, is the first of these common features. Women's sexual powers are feared ${ }^{657}$ Although women are generally perceived, and are supposed, to be passive, meek, and submissive, as far as their sexuality is concerned they cannot be trusted and should be closely guarded. The ideal girl is a virgin, the ideal woman is chaste. Although men are supposed to be slightly elevated above women and more cerebral-oriented while women are more earthly-bound, still women are supposedly capable of corrupting and seducing men with their sexuality. ${ }^{658}$ The response to this potential danger may differ in the religions under scrutiny. It may range from total seclusion in the home, veiling or other dress code, ${ }^{659}$ female circumcision, denying girls and women access to schools, work, markets and the streets, to applying double standards as far as sexual behaviour of women and men is concerned.

The obedience rule follows logically from the desire to keep women's sexuality in check. Besides referring them as much as possible to the private sphere, women are required to submit to men. When they are girls they must obey their fathers, after marriage they must submit to their husbands and sometimes even to their sons if their husbands

654 Women may also identify with their culture and may resent outsiders who criticize their way of living. Identification with the cultural identity and loyalty with the community will be particularly strong when the group is oppressed and discriminated against by a cultural majority. UN doc. E/CN.4/2002/83, Cultural practices in the family that are violent towards women, Report of the Special Rapporteur on violence against women, its causes and consequences, Ms Radhika Coomaraswamy, 31 January 2002, para. 5. Also see Cerna and Wallace, 1999, pp. 624-625.

655 Courtney W. Howland, 'Women and Religious Fundamentalism', Kelly D. Askin and Dorean M. Koenig (eds), Women and International Human Rights Law, vol. 1, Transnational Publishers, Inc., Ardsley, New York, 1999, p. 543.

656 The foundation was laid in ancient cultures that form the basis of modern society. Cultures as different as the Chinese, Egyptians, Babylonians, Persians, Greeks, Israelites, Christians and Muslims, all held a similar view as regards the positions of women; they were regarded as secondary citizens, not just in society, but also, according to these cultures, in God's view. Mahnaz Afkhami, 2000, p. 483.

657 Courtney Howland, 1999 , p. 541 and pp. 548-549 for Christianity, pp. 562-563 for Islam. According to Hinduism women pose such a forceful threat that men cannot help but succumb. Women should therefore be kept at home under their husband's thumb otherwise society may be in danger. Yasmeen Hassan, 2000, p. 589. Also see $U N$ doc. E/CN.4/2002/83, Cultural practices in the family that are violent towards women, 2002, paras 99-104.

658 This ingrained view may come to the surface in rape cases. In almost all cultures, also modern Western ones, the female victim's behaviour may be the focal point of the investigation. The first thing that will be examined is whether the victim may have brought it upon herself by dressing provocatively, or walking in the streets alone after dark. In some countries even the victim's sex life is an important aspect in the investigation. In a few Muslim countries a woman will not be believed until she can procure male witnesses (sometimes as many as four). If she fails to do so, she herself may be convicted to a prison sentence for having had illegal sex.

659 Purdah is the name of the joint concept of veiling and secluding women to the home. Yasmeen Hassan, 2000 , p. 588. 
are away or have died. ${ }^{660}$ Religious women may be raised with the idea that it is not only their cultural duty to be obedient and submissive, but even that this attitude is required from them by God. ${ }^{661}$ Disobedience therefore also means that a woman has forsaken her religious duties. ${ }^{662}$ In fundamentalist societies the obedience rule may even go as far as to sanction domestic violence. ${ }^{663}$

The desire to keep women confined to the private sphere and under the thumb of men in its turn smoothes the way for patriarchy. Without exemption the main religions propagate a patriarchal society in which men take up authority and women play secondary roles. ${ }^{664}$ According to religious ideals a family should consist of a male breadwinner and a female homemaker with their children. It is the man's task to earn an income, to take the most important (financial) decisions, and to represent his family in the public sphere. Raising children and putting herself in the service of her family is seen as the natural role of women. Women are expected to sacrifice any ambitions they may have in order to be better wives and mothers. Since women are taken care of materially and financially, it is unnecessary, and undesirable, for them to venture outside the home to seek employment. ${ }^{665}$ The result is that women do not learn how to earn an adequate income and become financially dependent on men, which puts them in a vulnerable position. ${ }^{666}$ According to fundamental religious ideas it is unwanted for women to be economically independent. It is feared that autonomous women may no longer choose to put their

660 In the Laws of Manu, the Code of Hindu law that instructs people on moral and social matters it is e.g. written that: 'in childhood a female must be subjected to her father, in youth to her husband, when her lord is dead to her sons, a woman must never be independent'. Christina M. Cerna and Jennifer C. Wallace, 1999, p. 645.

661 Hindu girls learn that the prototypes of ideal women are Sita and Sati. The first was known for her chastity, obedience and self-sacrifice. The latter was a goddess whose name means virginity and who sacrificed herself to safe the honour of her husband by burning herself to death on her husband's funeral pyre. Courtney Howland, 1999, pp. 554-555.

662 Courtney Howland, 1999, p. 541.

663 In Thailand a husband is entitled to discipline his wife. Women who are being abused subscribe their bad luck to 'bad karma', which she deserves because of bad things she has done in a previous life. Courtney Howland, 1999, p. 546. Hindu men are also entitled to enforce their wife's obedience by beatings. Ibidem, p. 557. According to Muslim fundamentalism a man whose wife is disobedient should 'appeal to her good sense, and if she does not improve, then he may abandon her in her marital bed. Thereafter, it is permissible for him to give her a good, but gentle, beating.' Ibidem, p. 564. Beating a wife to discipline her is both culturally and religiously acceptable in Pakistan. It is estimated that about $80 \%$ of the women in Pakistan are victims of domestic violence. Yasmeen Hassan, 2000, p. 591. Examples in Eastern Europe (Christians) may be found in International Helsinki Federation for Human Rights, Women 2000; An Investigation into the Status of Women's Rights in Central and South-Eastern Europe and the Newly Independent States, Agens-Werk, Geyer + Reisser, Vienna, 2000.

664 Some scholars explain this by pointing out that these religions developed in societies that already knew patriarchal family structures, and that is why they based their traditions on this pattern.Courtney Howland, 1999, p. 538.

665 According to Buddhism the only proper role for a woman is to be a wife and a mother. Women who do not conform to this role may be stigmatized and ostracized. Courtney Howland, 1999, p. 545. In Pakistan it is said that when a woman abandons her home for the public sphere, her family will suffer. Yasmeen Hassan, 'Stove burning, acid throwing, and honor killings', in: Askin, Kelly D. and Dorean M. Koenig (eds), Women and International Human Rights Law, vol. 2 Transnational Publishers, Inc., Ardsley, New York, 2000, p. 589.

666 Courtney Howland, 1999, p. 542. 
lives in the service of their family. ${ }^{667}$ States of course also have an interest at stake, since taking care of children, the sick and the elderly is no task that career women are willing or able to shoulder, which will mean that, in the absence of free labour and volunteer aid, governments will have to find other (costly) solutions.

Fear of economic independence also lies at the heart of unequal inheritance rights of women and men and all kinds of laws and practices that deny women access to, and property rights of, land and housing. ${ }^{668}$

It is very hard for religious women to go against religious rules, since they will have more impact on them than any other rules. Disobedience will not only be regarded as morally reprehensible, but also as defying the deity's will. Since only few women are involved in the process of interpreting religious manuscripts or drawing up religious rules, it is almost impossible for them to question the validity of these rules, let alone to change them.

\subsubsection{Custom and Tradition}

Women are regarded as the bearers of culture. They are also supposed to pass the culture on to the following generation. ${ }^{669}$ In light of their capacity as culture bearers, women's behaviour is customarily closely linked to their families' honour. In fact, a family's honour may depend on the chastity of its female members. This explains why women's behaviour may be closely scrutinized and why violence against women who have behaved improperly may be justified. ${ }^{670}$ Men may use force to keep their women in line because when they lose control they are perceived as having lost their masculinity. ${ }^{671}$

Patriarchy is an institution that may be found in most cultures in the world today. It is a system that is accepted and defended by both women and men. ${ }^{672}$ Regarding a man as head of the household and giving him authority, which in turn means that he may rule over his wife and children and other persons belonging to his household, creates the unequal power relationship between women and men that is the most common basis of domestic violence. ${ }^{673}$

667 For instance, Buddhist fundamentalists fear that an independent woman will reduce her inclination to submit to patriarchy. The same is true for fundamentalist Christians. Courtney Howland, 1999, p. 546, p. 551, and also for Muslim fundamentalists, p. 565.

668 See section 3.5.2. on property rights and section 3.5.3 on the law of inheritance.

669 Ayelet Shachar, Multicultural Jurisdictions; Cultural Differences and Women's Rights, Cambridge University Press, Cambridge, 2001, p. 50.

670 The concept of honour is very powerful and heinous crimes may be committed in the defense of it According to Coomaraswamy the concept of honour is abused to masquerade 'men's need to control women's sexuality and their freedom'. UN doc. E/CN.4/2002/83, Cultural practices in the family that are violent towards women, 2002, paras 27-28.

671 Yasmeen, Hassan, 2000, p. 590.

672 The wish to cling to the tradition of patriarchy makes it so very hard for rural women's organizations in Latin America to introduce a system of joint land titling. Carmen Diana Deere and Magdalena León, 2000, p. 89.

673 Special Rapporteur Radhika Coomaraswamy states that the unequal division of power between men and women is the most important cause for domestic violence. UN doc. E/CN.4/1999/68, 10 March 1999, para. 31. For domestic violence also see section 3.3.2.4. 
Domestic violence is endemic and may be found in every country in the world and in every layer of society. In many cultures, it is customarily accepted that a man beats his wife. Sometimes the victim's parents or her community presses her to remain with her abusing husband since she is supposed to take the abuse as her lot. Moreover, in many societies it is believed that the victim must have deserved the abuse because a man would not beat his wife unless she has misbehaved. ${ }^{674}$

Regarding the nucleus family as the cornerstone of society is a custom that has been spread to many parts of the world as the result of colonialism. Nowadays, it may be found in societies that used to know totally different systems, like extended families living together, or clans, or societies where women and men lived in separate living groups. ${ }^{675}$ Promoting small living units consisting of a male breadwinner, a female homemaker and children as the most fundamental group in society, ${ }^{676}$ consequently means a gendered division of work, a wage system that favours the male breadwinner who should earn enough to support a family while any woman's income would be regarded as merely additional. ${ }^{677}$ Again, it is a custom that lays the basis for an unequal power structure and financial dependency of women with all the well-known consequences. ${ }^{678}$

The gendered division of work that is to be found everywhere in the world entails that the burden of unpaid, care-taking work is almost exclusively on the shoulders of women. ${ }^{679}$ The idea that women are naturally suited to take care of others, will curb their opportunities to find adequately paid employment. Doing the household, raising the children, taking care of the sick and elderly puts so much strain on a woman's time and energy, that any paid work she may manage to do on the side typically will be in the low-paid sector, since the combination of household and employment will make it impossible to adhere to the male standard work-week with inflexible hours that is applied to well-paid jobs that hold a possibility for promotion. Lack of time and energy are also the reason why many women content themselves to work only part-time. ${ }^{680}$

Another effect of women's supposedly suitability for certain kind of work is that they are directed towards certain jobs that are closely connected to what they do at home.

674 See for instance Human Rights Watch in Uzbekistan, entitled: Sacrificing Women to Save the Family; Domestic Violence in Uzbekistan, HRW Publications, Vol. 13 No. 4(D), July 2001. Particularly pp. 1518. Also section 3.3.5 on domestic violence.

675 Among the Aboriginals for instance women were used to live in all-women groups. Bell, 1992, p. 341

676 See e.g. Article 16(3) Universal Declaration of Human Rights which reads: 'The family is the natural and fundamental group unit of society and is entitled to protection by society and the State'.

677 Bell, 1992, p. 346.

678 The ideology of the family is so powerful in Sri Lanka, for example, that women make their own individual rights subordinate to it. Plans to replace the fault-based divorce law with no-fault divorce met with such resistance from women and women's organizations, that the reform was discarded. According to Coomaraswamy an additional reason for this reaction may have been fear the responsibility that comes with empowerment. Radhika Coomaraswamy, 'To Bellow like a Cow: Women, Ethnicity, and the Discourse of Rights', in: Rebecca J. Cook (ed.), Human Rights of Women; National and International Perspectives, University of Pennsylvania Press, Philadelphia, 1994, pp. 51,52 and 55.

679 Janet Saltzman Chafetz, Gender Equity; An Integrated Theory of Stability and Change, Sage Publications, Newbury Park/London/New Delhi, 1990, p. 31.

680 In the Netherlands the large majority of married women work part-time. This is bad for their career possibilities since the promotion system is based on the male model of a full-time worker. In most cases the income that can be earned with part-time work is inadequate to be economically independent. 
Typical women's jobs may be found in the care-taking, cleaning, nursing and servicing sector; jobs that have the common characteristics of low status, low pay and hardly any career possibilities. It is very difficult for women to manifest themselves in supposedly male kind of jobs and to break through the glass ceiling of leadership positions. ${ }^{681}$

A harmful tradition that is found in patrilineal societies and that may affect women's right to food, health, education, employment and property, and thus their ability to procure adequate housing, is that of 'son preference'. ${ }^{62}$ Son preference means that male human beings are favoured because it is believed that they are more valuable than females. ${ }^{683}$ Only sons can inherit the family name and the family property, and as adults they will contribute to the family's welfare, while daughters are merely an economic burden who should be get rid of by marrying them off as soon as possible. Son preference is therefore the origin of practices like abortion of female foetuses, ${ }^{684}$ infanticide of female babies, deprivation of food of girls and women, withholding medical treatment from girls and women, keeping girls at home to help in the household while their brothers go to school, favouring men to women for certain jobs, bestowing husbands and sons with greater shares of the inheritance than wives and daughters, and so on. The result of son preference is that girls and women are marginalized. ${ }^{685}$ Their opportunities to develop themselves are checked from an early age on and they are manoeuvred in such a way that it becomes impossible for them to function independently. ${ }^{686}$ Lack of education not only inhibits their development, but may also keep them ignorant of their rights. ${ }^{67}$ Lack of job-training may entail that women are not able to attain positions that would earn them an adequate income. Being regarded all her life as less worthy than a man or even worthless, also has repercussions on a woman's self-image. It will make her feel insignificant, insecure, and powerless. Even if women have the courage and the resourcefulness to want to change these traditional practices, it will be very hard since they lack status in society. Moreover, attempts to deviate from traditional role patterns may be punished

681 See section 3.2.3.1 on education and vocational training.

682 Among other States son preference may be found in Afghanistan, Burkina Faso, China, India, Indonesia, Nepal, Pakistan and Yemen. Cerna and Wallace, 1999, pp. 632-633.

683 Cerna and Wallace,1999, pp. 623-624.

684 In India sex identification is a booming business. On large billboards the text is advertised that it is better to spend 500 rupees now, than 5,000 rupees later, meaning that it is far more profitable to pay for sex identification of the foetus and have an abortion if it turns out to be female, than to give birth to a baby girl who will only be a financial burden to the family. UN doc. E/CN.4/2002/83, Cultural practices in the family that are violent towards women, 2002, para. 73 .

685 Girls are impregnated with the idea that they are a burden to their family. The Asian saying: 'To have a son is good economics and good politics, whereas bringing up girls is like watering the neighbour's garden' is typical for this attitude. The birth of a boy is celebrated with joy, while the birth of a girl leaves the family indifferent or is even regarded as a tragedy. Consequently, a woman who gives birth to a son rises in esteem, while the mother of a daughter causes shame to her family. Cerna and Wallace, 1999, p.631. In Arabic Abu-banat is an insult meaning the father of daughters, while in Taiwan people speak about daughters as 'goods on which one loses' and 'water spilled on the ground'. UN doc. E/CN.4/ 2002/83, Cultural practices in the family that are violent towards women, 2002, para. 75.

686 It is symbolic for the dependency of women in patrilineal societies that daughters take the name of their husband when they marry. Cerna and Wallace, 1999, p. 631.

687 Many women are not aware that their rights are being violated or that they have rights at all. Cerna and Wallace, 1999, p. 624. 
severely. Particularly feared is ostracism since it may leave a woman completely destitute, even without a roof over her head. ${ }^{688}$

The custom of child marriage is induced by the fear that a girl who reaches puberty may lose her virginity. Since in many cultures virginity is a prerequisite for marriage, or marrying a good party, parents arrange their daughters' marriage at a very young age so their virginity is unquestioned. Once the girl-bride has moved in with her husband or inlaws it is up to them to guard her chastity. ${ }^{689}$ The effect of child-marriage for a woman's status in society is that she does not have the opportunity to develop herself. Her schooling is stopped at an early age and she may be subjected to early and multiple pregnancies. ${ }^{690}$ Instead of getting an education, the girl immediately has to assume tasks that are unfit for her age. A girl who is married off as a child becomes extremely vulnerable and it will be almost impossible for her to take up an independent position in society when she is an adult.

Female exogamy means that a girl or woman who marries will leave her own community and starts to live with the community of her husband, and in his, or his family's, home. The ties with her blood-relatives are formally severed. This system makes a woman very vulnerable because she is put at her husband and her in-law's mercy and there is virtually no way back. It also may have severe consequences for her housing situation. In the house of her husband or his family she may be mistreated or abused and if her husband repudiates or divorces her, or if he dies, she may be turned out in the streets. ${ }^{691}$

The practices of bride price and dowry also contribute to women's inferior position in society. ${ }^{692}$

Bride price means that in order to compensate her family for the loss of their daughter's labour, the husband must pay an amount of money to the bride's family. Dowry on the other hand entails that the family of the bride enhances her possibilities of marrying a good party by giving her property or money so that she can contribute to her future family's wealth. Both practices degrade women because they treat them as commodities. In cases where the husband has to pay a bride price, he will regard his wife-and their mutual offspring - as his property and consequently will deny her the right to make her own decisions. ${ }^{693}$ Since her father has 'sold' her, it becomes very difficult for a woman to turn to him or other relatives for help when her husband abuses her.

Since the new bride is not expected to contribute economically to her future family's welfare (raising children and doing the household are not economically valued) the dowry is her only contribution to her in-laws' wealth. Moreover, the dowry means that the ties with her blood-relatives are economically severed, since she has been gifted with her share in the family's wealth and cannot claim for more. ${ }^{694}$ Families hope that

688 Ibidem, p. 631

689 ibidem, p. 636

$690 U N$ doc. E/CN.4/2002/83, Cultural practices in the family that are violent towards women, 2002, para. 56.

691 For female exogamy or patrilocal residence also see section 3.6.3.2.1 on individual titles.

692 Bride price is a practice that occurs in the Middle East and in Africa, while dowry is customary in Asia.

693 UN doc. E/CN.4/2002/83, Cultural practices in the family that are violent towards women, 2002, para. 60. Also Cerna and Wallace, 1999, p. 634.

694 Originally the dowry consisted of money or jewelry that was given to the daughter as compensation for not sharing in the inheritance. The daughter would leave the control over the dowry to her husband, but it 
by giving a daughter a generous amount of gifts for her future in-laws, will guarantee that she will be treated well. Unfortunately, in modern times the demands seem to have grown. Consumerism and materialism induce families to demand televisions and refrigerators as dowry, and after marriage, the in-laws may still not be satisfied and may yet make additional demands. Arguments over dowry increasingly lead to harassment and abuse, and sometimes even to the death of the bride. ${ }^{695}$

Son preference, the dowry system, and female exogamy combined explain why it is customary in certain, particularly Hindu, societies for daughters not to claim the part of the inheritance they are legally entitled to when their parents die. Sons are supposed to remain at home after marriage, and they will look after their parents in old-age. That is why they have a moral right to any land and housing the family may possess. Daughters will leave the home and their community after marriage and will take part of the family's wealth with them in the form of a dowry. Since their brothers, and the (former) parental home, may be the ones and the place they may need later in life if anything goes wrong with their marriage or if they are widowed, they are very wary not to rub their relatives up the wrong way by claiming their inheritance. ${ }^{696}$

Levirate or widow inheritance is still practiced in some African societies, in Israel and in other countries of the Middle East. ${ }^{697}$ Originally, the intention was to protect the widow and to provide her and her children with a home and an income. The deceased's brother or other close male relative who inherited the widow merely kept her financially. Nowadays, however, it is common that the new husband lives with her and demands sexual relations. ${ }^{698}$ This puts widows before the choice of either accepting the new groom or declining with the effect that she loses her claim to the home she is living in and she has to provide for herself. It is of course considered impossible that a woman who herself is regarded as part of the estate would be able to claim her late husband's inheritance.

Women's lower and dependent status in life makes it difficult for them to change customs and traditions. However, the gendered division of work and the fact that they are regarded as the bearers of culture provides women with a powerful tool to bring about changes for future generations; they may raise their children without gender biased ideas and they may promote gender equality. Whether they may seize this opportunity will depend on their perception of societal rules as unfair - which is closely connected to their awareness of women's rights-, their own self-image, and the fear that their children may be ostracized as future adults because they will have deviating opinions and may show different behaviour from what is the norm.

remained her property. That is why she was entitled to it in case the marriage would end by separation, divorce or death of the husband. Cerna and Wallace, 1999, p. 635.

695 It is estimated that in India over 7,000 women die each year because their in-laws are not satisfied with the dowry. Cerna and Wallace, 1999, p. 635.

696 See section 3.5.3 on the law of inheritance.

697 Also see section 3.3.4 on widowhood.

698 Cerna and Wallace, 1999, p. 636 


\subsubsection{Personal Laws}

In multicultural States, like Australia, Canada, India, Nigeria, Tanzania, and the USA, governments struggle with the dilemma between doing justice to the right of their the indigenous, ethnic, or religious groups to a cultural identity, and the possible violations of individual rights of members of these groups when cultural rules are applied. ${ }^{699} \mathrm{In}$ order to avoid discrimination of minority groups, and to help them preserving their identity, many States want to accommodate them by giving them special rights or exempting them from certain national legal rules, particularly in the sphere of family law. ${ }^{700}$ Some States go as far as to create autonomous areas or declare that for certain groups so-called 'personal laws' will be applicable instead of the national laws in order to guarantee that a group's identity will be protected and preserved. ${ }^{701}$ No matter how well-meaning States may be in deploying these methods, they may overlook that there may be a strict hierarchy of power within such a minority group and that the power within the group may be divided unequally between the sexes.

There is a particular danger that preserving the culture of the group may go hand in hand with denying or sacrificing the individual rights of women. ${ }^{702}$ In fact, the culture of a group may collapse if women start claiming the human rights they are legally entitled to. ${ }^{703}$ Realization of this danger may induce leaders to go to great lengths to maintain the status quo and oppose any changes, while the group's women may restrain themselves from demanding fulfilment of their rights since they do not want to be held responsible for the disappearance of the group's cultural identity. ${ }^{704}$

699 Ayelet Shachar, 2001, p. 1.

700 The Constitution of Bangladesh, for example recognized the principles of equality and non-discrimination. However, their application is limited to the public sphere; it is felt that legal provisions based on these principles are inapplicable to personal laws. Sara Hossain, 'Equality in the Home: Women's Rights and Personal Laws in South Asia', in: Rebecca Cook (ed.), Human Rights of Women: National and International Perspectives, University of Pennsylvania Press, Philadelphia, 1994, p. 474.

701 Kymlicka distinguished between two types of multicultural accommodations. The first type of rules, which he calls 'external protections', are meant to promote justice among groups. The second type of rules, which he named 'internal restrictions', are intended to make it difficult for individuals within the group to change the group's cultural traditions. Ayelet Shachar, 2001, pp. 17-18.

702 There are a few well-known cases in this respect. In the Lovelace case a Canadian woman of Indian descent was denied her right to settlement in the reservation she was born in because she married a nonIndian. The same rule does not apply to Indian men who marry non-Indian women. For further details see section 3.6.3.2.3.

An US American case dealing with discrimination of Indian women is the Santa Clara Pueblo v. Martinez case (436 US 49, 1978). In this case Julia Martinez, a member of the Santa Clara Pueblo Indian tribe and also a USA citizen, married a non-tribe member. As a result according to the Pueblo family law rules their children were not considered to be Pueblo Indians and thus were not entitled to health care, education or housing assistance. After their mother's death they would have to leave the reservation. These rules do not apply to the children of Pueblo Indian men who marry non-tribe women; their offspring automatically is accepted as belonging to the tribe. The US Supreme Court sanctioned the discrimination against Pueblo women who marry outside the tribe and their children by upholding the Pueblo Indian family law rules, in the interest of 'the tribe's cultural survival'. See Ayelet Shachar, 2001, pp. 18-20.

703 Especially with groups that vehemently oppose any form of assimilation, images of women and of the ideal family life become the group's symbols of its authentic cultural identity. Ayelet Shachar, 2001, p. 36.

704 Women are put under enormous pressure to be loyal to their own cultural group and to forsake their 
A consequence of the system of personal laws may be that customs and traditions become static and inflexible because it is in the group's interest to have and maintain rules that are different from the mainstream, since this legitimizes their separate social existence. ${ }^{705}$

From the above it has become clear that women who are subjected to a personal law system are in a very tight spot. They are put before the choice of claiming their individual rights and thus run the risk of ostracism, or remaining loyal to their cultural group by waiving their rights. In almost all cases the very identity of a cultural group will depend on women not claiming their rights. If too many women would persist in receiving what they are entitled to according to their national laws, the whole personal law status of their croup may collapse.

\subsubsection{Culture and the Change of Time}

A characteristic of culture is that it is flexible and that it will change over time. Though this may be to women's benefit, vigilance is called for in those situations where some parts of culture are retained, while other parts have been discarded. Especially in States that were former colonies there is a danger that clinging to a group's own identity and cultural rules, ignores the fact that their culture already underwent certain changes, mostly brought about by colonization and the influence of Western ideas. ${ }^{706}$ The result may be that women's interests are hurt because the former security and status the women had may have been changed with the result that their position has become unbalanced or worse than it used to be.

An example may be found in Africa, where introduction of the typically Western system of individual land titles has resulted in depriving women of a place to live and a plot of land to grow their food on. Originally land was held by clans, and at the head of a clan was the patriarch. However, it was the patriarch's duty to see to it that every clan member had access to and property rights of land. This meant that unmarried women in the clan, like daughters, sisters and widowed mothers, could not be deprived of a home and the possibility to feed themselves. Holding on to the system of patriarchy resulted in distributing the land titles among the male clan heads. The influence of individualism and materialism, however, has induced many title holders, who may never have been the ones who did any agricultural work, to sell the ancestral land and settle in the cities, discarding their age old duty to take care of their unmarried female relatives and leaving them destitute in the rural areas. ${ }^{707}$

In India, the custom of dowry is maintained, but the form has been adapted to modern times. Formerly the dowry would consist of gold and jewellery that would remain the

individual rights. Ayelet Shachar, 2001, p. 39. Shah Bano, the Indian Muslim divorcee who was denied maintenance according to Muslim personal law and whose case was already discussed in section 3.3.2.3. finally gave up her struggle under the huge pressure of charges that she had betrayed Muslim culture and rejected the Indian Supreme Courts's decision in her favour. Ayelet Shachar, 2001, pp. 81-83.

705 Ayelet Shachar, 2001, pp. 84-85.

706 It has become impossible for groups to isolate themselves from society at large. All groups that demand cultural protection have already been re-shaped by outside influences. Ayelet Shachar, 2001, p. 32.

707 See section 3.6.3.2.1 on individual titles. 
bride's property, but that would be managed by her husband. In case the marriage was ended, or the husband died, the woman was entitled to her dowry so she could provide for herself by capitalizing it. Nowadays, it is normal for future husbands and in-laws to demand that the dowry will consist of electrical appliances. This means that when the marriage turns sour or the woman is widowed, she is left empty handed because the consumer goods will have lost their value or may no longer exist. ${ }^{708}$

The Western demand that in negotiations with the Aboriginals in Australia the indigenes should have (male) representatives in the decision-making bodies robbed the women of their power and status in society and made it easy to overlook or ignore their rights and needs. ${ }^{709}$

Undoubtedly many more examples may be found.

Though change is natural and often beneficial for cultures, States and cultural groups should remain alert that a certain balance is preserved. It should be avoided that those customs are discarded that safeguard women's position in the cultural group while they are not offered any alternatives.

\subsubsection{Concluding Remarks}

Notwithstanding almost universal acceptance of gender equality and legal rules and policies that oppose discrimination on the basis of sex, some cultural rules, be they religious, customary or traditional in origin, may have the effect of curtailing women's opportunities and choices in life to such an extent that their legal rights are minimized or even nullified.

Restricting the effect of customary rules to women's housing rights the following pattern may be discerned. Lack of education, lack of, or limited choices in, job training, seclusion to the private sphere and the gendered division of work make it more difficult or even impossible for women to acquire an income adequate enough to provide for their own housing. Curtailment of inheritance and property rights may also contribute to women's dependency on others for where and how they are housed. The consequence of dependency is vulnerability; many women have no other choice but to remain in inadequate housing, and even violent households, and they may become homeless when those they depend on can, or will no longer house them.

Stereotyped ideas about men and women's characteristics and roles in society are so ingrained that it is very difficult to abolish them. Although men are also pushed into roles that may deprive them of certain rights and privileges, and that may burden them with certain tasks and duties, on the whole they are at the receiving end of possibilities, property, and power, and their chances to deviate from societal rules, should they wish to do so, and to live autonomous lives are far better than women's.

However, culture is not fixed, but it is a social construction and thus a living and flexible concept. There is no society today that still adheres to exactly the same rules as

708 Cerna and Wallace, 1999, p. 635. Also see section 3.5.3 on the law of inheritance.

709 Diane Bell, 'Considering Gender; Are Human Rights for Women, Too? An Australian Case', in: Abdullahi Ahmed An-Na'im (ed.), Human Rights in Cross-Cultural Perspectives; A Quest for Consensus, University of Pennsylvania Press, Philadelphia, 1992, p. 343. 
it did a century ago. It is especially this ability to change that gives hope for women's future. ${ }^{710}$ Patriarchy and the male breadwinner's position, however, refer women to a secondary status in society which limits their possibilities for changing societal rules. Instigating any changes will be particularly difficult for religious women. The 'divine' nature of religion-based rules makes it psychologically hard to deviate from them. In practice, women will hardly ever get a chance to question these rules since they are mostly kept out of theological interpretation and drawing up of religious rules. Especially in multicultural societies that know the personal law system, the leaders of separate groups will benefit from maintaining culturally defined rules, even if these are harmful to women, since it is the difference from national rules that legitimizes the existence of a separate group over whom they have authority.

Considering the wide-spread existence of the gendered division of work, women's best chance of changing societal rules and banning stereotypical role models in future is that they bring up their children without gender-biased ideas. Whether women will be able to seize this opportunity will depend on their awareness and knowledge of women's human rights and on the risk that they, and their children, run of being repudiated. Women's wish to belong to a cultural group and their fear to be excluded from it will withhold them from fighting against harmful practices since they realize that life outside the group is no option. Without a possibility to procure an adequate income, they will dread becoming homeless and destitute.

Achieving legal equality is not enough; it may remain a dead letter. Empowerment of women and a change of mentality are needed to abolish stereotyped ideas and role models that stand in the way of true gender equality.

In view of enhancing women's status in society besides the women themselves, several other actors may help to change cultural rules that curb women's legal rights. Civil society organizations may play a role in informing women of their rights and working with them to fight against harmful practices. States may have the responsibility to abolish persistent cultural patterns if they have pledged themselves to achieve gender equality. International organizations and UN organs might contribute by interpreting treaty obligations and by monitoring observance of human rights obligations. The ways in which these actors may figure in achieving de facto equality will be discussed in Chapter IV.

\subsection{COMMON FEATURES AND FindingS}

In this chapter a great number of issues has been reviewed which all have in common that in some way or other they may affect women's housing rights. Since extensive concluding remarks have already been made at the end of each individual section, I will restrict myself in this place to pointing out the cohesion that may be found when examining these diverse subjects.

Time and again it has become clear that the substantial difference that may be found between the fulfilment and enjoyment of the right to adequate housing of women and men is caused by the difference in socio-economic positions that is held by females and

710 Cerna and Wallace, 1999, p. 625. 
males. In turn, this difference is brought about by structural, culturally determined discriminatory patterns that negatively affect women's societal situation and which may be found all over the world, across culture, wealth and level of development, though some are more widespread than others. In view of the complexity of all the circumstances that have to be taken into consideration, it is impossible to approach women's right to housing individually, but a holistic approach has to be taken in which all determinants are considered.

To some, though not unimportant, extent, discriminatory rules that impinge on women's housing rights are laid down in legislation and policy regulations. Discriminatory private laws may rob women of their autonomy, such as their legal capacity and their freedom of movement and residence, and may also affect their income and property, by curbing their property rights or denying them equal shares in the inheritance, so that women lack the financial means to gain and retain adequate housing and are unable to administer their own or the marital property. Particularly harrowing is the situation of women who live in a multicultural society and who are treated according to discriminatory personal family law rules because of their birth and ethnicity, while national laws are in accordance with principles of gender equality and non-discrimination. Furthermore, discriminatory labour laws and regulations may curb women's access to the labour market or ban them from well paid jobs, thus affecting their financial situation and their ability to afford adequate housing.

A much greater and more widespread manifestation of discrimination against women, however, is to be found in the culturally determined position of women in family and society that is based on gender stereotypes and ideals that put the mother and homemaker before the individual woman with autonomous rights. Unequal power positions within the family and the relegation of women to the private sphere seriously impair women's enjoyment of their human rights. Worldwide there is a gendered division of work which burdens women with unremunerated care-taking work that takes up much of their time and energy. Household work and raising children are automatically viewed as being a woman's responsibility, which first has repercussions for the girl child. In view of her future perspective as a home-maker it is not deemed very important that she receives a thorough general education and specific job-training, and in poor countries she will be kept at home to help her mother rather than her brothers so that she may even remain illiterate. But also in developed States, a girl's education may not be considered as important as a boy's and girls are often to be found in gender biased curricula where they are instructed in typical 'female' professions.

When the girl becomes a grown woman, especially with children, this lack of education and gender biased job training has serious ramifications for her possibilities on the labour market. The woman is burdened with household chores that hamper her access to the labour market and potentially prevent her finding full-time, well paid jobs because labour is organized from a man's perspective and working hours are not very flexible. The consequence of a lack of education and job-training will be that many women will only be able to find unskilled labour for which the remuneration will be less than average. Since the labour market itself is also gender biased, it is even for well educated women harder to find a well-paid position, especially those that are perceived to be a 
man's prerogative, and to break through the glass ceiling. Furthermore, also in affluent, developed States the gendered division of work hampers women to pursue a career since it is difficult and expensive to find a caretaking alternative for the work they are supposed to do at home. The outcome of the gendered division of work is that women on average are poorer than men and have virtually no possibilities of improving their financial situation, especially if they are female heads of household. Thus, for many women it is impossible to finance adequate housing themselves.

Besides these effects on a woman's right to education and employment, the gendered division of work also affects her right to property. Since a man is supposed to be the family's breadwinner, his responsibility will be to take financially care of his family. In some societies this view has led to the denial or restriction of property rights for women since it is perceived that they do not need land, a house, wealth, part of the inheritance or access to credit and loans, because the patriarch, being either their father or their partner, will take care of them. This learned helplessness has led to the total dependence of women on male relatives and partners, thus denying them autonomy and an individual right to housing with grave consequences for their entitlement to secure tenure.

The relegation of women to the private, family sphere, and men to the public sphere also has consequences for the political participation of women and thus for their ability to influence and change legislation and policies and make them more gender balanced. Historically, women were not at all involved in politics. The last few decades have seen a dramatic change, however, at least on paper. Women's right to political participation is legally recognized all over the world. Nevertheless, cultural inhibitions, among which women's care-taking responsibilities, and lack of (the right) education prevent women from translating this legal right into actual participation.

Patriarchy and the unequal power division between the sexes also is the main cause of female oppression and various forms of gender specific violence, the most pervasive being domestic violence. Violence by intimates at home renders any housing situation inadequate, irrespective of the material habitability, because women's right to security and dignity is violated.

Up till now, the standard-interpreting work as regards the right to housing, has been done from an androcentric reality and thus is not tailored to women's specific situation. It is therefore of little or no avail that in these documents mention is made that the right to housing is to be enjoyed without discrimination based on sex, because women will encounter certain barriers in trying to effectuate their right to housing that are not experienced by men. The magnitude and effect of the structural violation of all sorts of seminal human rights of women is not rightly understood.

First of all, the causes of homelessness that have been identified are only those that may be experienced by men as well: i.e. poverty, forced evictions by authorities or landlords and landowners, and loss of home because of natural and human-made disasters. Moreover, the gender-specific aspects of these causes are greatly underestimated. Furthermore, the additional causes of homelessness that are experienced only by women, such as forced evictions by intimates, domestic violence, and widowhood, are not taken into consideration at all. The androcentric reality has also clouded the perception of what is to be considered as adequate housing. Because of the gendered division of work adequate 
housing conditions are far more important to women than to men, yet women and their experience are not at the centre of attention. Further, the elements that are now recognized as comprising adequacy are focused particularly on technical and material aspects of housing. What is not taken into consideration is that in addition to material requirements, immaterial elements, such as safety, dignity, privacy and autonomy need to be fulfilled before housing can be called adequate from a woman's point of view. The housing rights of a woman will be considerably better if she receives respect as a human being at home. That is why a woman should have the ability and the means to leave any home in which this respect is lacking.

Finally, norm-interpreting instruments concentrate on forms of housing that are more or less permanent, and do not regard temporary housing or shelter. Temporary housing is, however, the day-to-day reality for more women than men on this earth and temporary is a relative time indication that may last for many years. Therefore, it is in many women's interest that adequacy-standards are extended to shelter situations. 


\section{CHAPTER IV \\ THE AdEQUACY OF EXISTING NORMS AND Procedures For WoMen's Housing RightS}

\subsection{INTRODUCTION}

It is the aim of this chapter to look into the manifold rules and regulations that all have the ability to influence women's right to adequate housing. Some of these rules will be helpful or to women's benefit, but many others will rather erect barriers that make it hard for women to fulfil their housing needs. Because the law is only one of the instruments that regulate society, ample attention will also be paid to the more obscure impact of culturally determined societal rules. It is to women's detriment that especially these implacable traditional patterns determine in the end whether legal rights may be enjoyed. An additional problem is that international organs tend not to fully understand or to underestimate their influence. Besides a study of the rules and regulations themselves, also ways and means to alter them and to make them more receptive of gender issues will be dealt with.

Before any specific rules will be reviewed, first the system of international law will be under scrutiny in section 4.2. It must be clarified why this system fails to encompass women's issues and may even work against women's interest. Since it is nevertheless to women's advantage to use the international law system, two methods are discussed that are used to influence the system in order to make it more susceptible for women's concerns. Both the strategy of women specific organs and instruments and that of gender mainstreaming have important advantages and disadvantages that will be examined.

Next to the system, also the contents of international law will be discussed in so far as this is relevant in the framework of this study. Of particular importance are the two principles that form the foundation of human rights law: equality and non-discrimination. Since all human rights instruments are premised on these principles it is of the utmost importance that there is no misunderstanding about their contents. In section 4.3 the meaning of the terms sex, gender, direct and indirect discrimination, and the various forms of the concept of equality will be reviewed.

After this more general part, section 4.4 will verify whether those rules that particularly pertain to the right to housing are in effect tailored to women's specific situation. The emphasis will be on Article 11(1) Covenant on Economic, Social and Cultural Rights, but also other international housing norms will be examined.

Assuring women's de iure equality is no guarantee that they can actually enjoy de facto equality with men. That is why ways and means are discussed in section 4.5 to overcome the most pervasive societal rules that have a negative effect on women's housing rights. It seems that a variety of actors can influence cultural rules and that even certain legal obligations exist to alter traditional patterns if these are to women's detriment.

Since the violation of women's housing rights happens in the majority of the cases in the private sphere of the family or the community by private actors, the question 
arises whether States too are responsible. In section 4.6 the rules of State responsibility will be examined and arguments will be given why the existing rules must be understood as encompassing non-State actors.

The final section of this chapter is devoted to the rules and procedures with regard to monitoring and analysis. Supervision of the implementation of housing rights regulation may take place at the international and at the domestic level, but in this study the emphasis is on the former. Next to the relevant UN treaty-bodies and the mandates of Special Rapporteurs also the role of civil society organizations will be discussed. The issue is whether supervision of women's right to adequate housing happens efficiently and effectively and whether and how the system may be improved.

\subsection{InTernational Public LaW ANd Gender; Normative AND STRATEGIC ISSUES}

\subsubsection{Introduction}

Although the actual fulfilment of the rights of the human person has to take place at the national level, it is nevertheless also in the interest of women's advancement that at the international level gender issues are becoming part and parcel of the international legal framework. Yet, the predominately State centred character of international law combined with minimal contribution and under-representation of women in both national and international decision-making organs ${ }^{1}$ makes this an area of law that may be even less receptive of women's concerns than domestic law. It is in particular the lack of interest in gender discrimination issues that causes the marginalization of women's concerns and needs on the international plane. Besides the obvious repercussions of this unresponsive attitude for those areas of international law that concentrate on the human person viz. human rights law and humanitarian law, it also has consequences for other, less apparent areas such as international customary law, the contents of the body of ius cogens, and the scope of State responsibility. ${ }^{2}$

Since time immemorial men dominate both secular and religious institutions of power and it is therefore quite logical that a female perspective has been neglected while the male perspective was long-time regarded as objective and neutral. ${ }^{3}$ Regardless of the good intentions men in power positions may have, it makes a huge difference when women participate in all sectors of society including politics. ${ }^{4}$ However, culture and custom, especially the gendered division of work, make it very hard for women to

1 It is rather ironical to notice the strict observance of geographical spreading and representation of the main forms of civilization and the principal legal systems of officials and staff in the United Nations while the gross under-representation of women is still a reality. See Hilary Charlesworth and Christine Chinkin, The boundaries of international law; A feminist analysis, Manchester University Press, Manchester, 2000, pp. 174-179.

2 State responsibility issues are dealt with in section 4.6.

Charlesworth and Chinkin, 2000, p. 4.

It goes within saying that it is not simply a quantitative matter. Having more women in power positions will not of itself make a change. However, it will help to draw attention to the specific problems women are faced with. 
enter the public spheres of decision making and economy. ${ }^{5}$ As a result 'women's issues' - stereotypically regarded as falling in the private sphere ${ }^{6}$ - are marginalized and women are discriminated against by their national legal system and their concerns play a minor role in international law. ${ }^{7}$ The most striking example of an all-pervading women's issue that was totally disregarded for a long time but which is highly important in the framework of adequate housing is the prevalence of domestic violence against women. Not only is this violence underestimated and neglected, but it may also be tacitly condoned or even sanctioned by the authorities. ${ }^{8}$

For the last 150 years women's organizations have tried to penetrate the international law bastion with gender topics, although with limited success. ${ }^{9}$ Charlesworth mentions several reasons for women's failure to make an impact on international law. ${ }^{10}$ Firstly, the shortage of female scholars in the field of international law which in her opinion still is a male stronghold. Secondly, the abstract nature of international law concepts and subjects that seems to have little bearing on women's lives. Thirdly, the international interest that is directed at differences of race, culture and nationality to the detriment of attention for discrimination based on gender. Fourthly, the positivist influence on modern international law which makes it unreceptive to feminist examination. ${ }^{11}$ Lastly, the fact that international law is primarily focused on issues of life and death, war and peace, i.e. topics dealing with prime decision-making powers that squarely fall within the male dominion.

I agree with Charlesworth that the influence of positivism on modern international law is working against women. However, also liberalism should be mentioned for its gender specific negative effects. That is why these two theories and their impact on the issue of gender discrimination will be examined in section 4.2.2 where also attention will be paid to the philosophy of naturalism.

In my opinion, Charlesworth is right in pointing out the international disinterest for gender discrimination. In section 4.2.3, I will examine the lack of a rule of general inter-

5 Charlesworth and Chinkin, 2000, p. 8.

6 It should be borne in mind, however, that a distinction of society in a public and private sphere is not by definition a bad thing. In fact it may be preferred that some parts of life fall outside of the scrutiny of the public authorities. However, the public/private dichotomy that is in existence is gendered to the detriment of women's interests. Charlesworth and Chinkin, 2000, p. 59.

7 Women's lobby, particularly since the World Conference on Human Rights in Vienna in 1993 and the Beijing Conference of 1995 has brought about some change.

8 Charlesworth and Chinkin, 2000, p. 12.

9 The best result may have been achieved in the field of international human rights law, in particular with the adoption of the Convention on the Elimination of All Forms of Discrimination Against Women. Charlesworth and Chinkin, 2000, pp. 14-16.

10 Hilary Charlesworth, 'Alienating Oscar? Feminist Analysis of International Law', Chapter 1 in: Dorinda G. Dallmeyer (ed.), Reconceiving Reality: Women and International Law, Studies in transnational legal Policy, No. 25, The American Society of International Law (ASIL), Washington, 1993, p. 2. These views are reconfirmed in Charlesworth and Chinkin, 2000, p. 17.

11 According to Charlesworth the fact that positivists view international law primarily as a system in which States voluntarily restrain themselves makes it very unlikely that structural disadvantages within States will come up as legal issues. Of course, States may decide to prohibit discrimination against women, but the positivist view does not require that the legitimacy of underlying power structures that subordinate women are examined. See Charlesworth and Chinkin, 2000, p. 28. 
national customary law as far as the prohibition of discrimination against women is concerned and I will compare this to the international standing of the prohibition of racial discrimination.

The second and fifth point Charlesworth is making in fact come down to the same matter: many issues and problems that concern women's lives are not reflected in international law. In the last few decades, strategies have been developed to further gender equality and to put women's concerns on the international agenda. In section 4.2.4 the two main strategies viz. women specific instruments and organs and gender mainstreaming will be dealt with and their potential for addressing women's housing rights will be discussed.

\subsubsection{The Foundation of Modern International Law}

The development and foundation of international law has contributed to some extent to the fact that women's issues and needs are largely ignored on the international level. International law was originally founded on ideas of natural law: a set of universal rules that are always and everywhere applicable. Actual State practice played a rather insignificant role in comparison to these absolute values. ${ }^{12}$ However, existing inequalities within society were not questioned, and indeed, concepts like slavery and discrimination against women were justified by referring to natural law. ${ }^{13} \mathrm{Up}$ till the $17^{\text {th }}$ century philosophers were convinced that the origin of (international) law rules was divine, although these godly rules could be found and understood by reason. Hugo Grotius, however, maintained that these rules would exist even if there was no god. ${ }^{14}$ After Grotius a new school of thought developed besides naturalism. The detachment from the divine origin of law and the upcoming Enlightenment created the onset of the philosophy of positivism which coincided with the emergence of the nation-State and theories about State sovereignty. ${ }^{15}$ For the development of international law, this meant that instead of focusing on universal, already existing rules that determined what States ought to do, positivist thinkers sought the foundation of law in what States actually practiced. The abstract nature of the State was stressed and States, not individuals, were seen as the main subjects of international law. ${ }^{16}$ As a consequence of the fact that no higher power was acknowledged, it was understood that the States themselves as sovereign powers made the rules of international law by concluding agreements and recognizing rules of international custom and that they could only be bound of their own volition. Ethics and morality were severed from law and consent was the key word. ${ }^{17}$

12 Malcolm Shaw, 2003, pp. 24-25.

13 Charlesworth and Chinkin, 2000, p. 26

14 Hugo Grotius, a Dutch scholar who lived from 1583 till 1645 separated international law and theology by emphasizing that actions were bound by natural law, which was based on man's own nature, independent of god. On the basis of law of nature it was possible to formulate a coherent code suitable for all times and places. Malcolm Shaw, 2003, p. 23.

15 The modern nation-State emerged after the Peace of Westphalia in 1648. Theories about State sovereignty were at that time brought forward by Bodin and Hobbes. Shaw, 2003, p. 25.

16 Malcolm Shaw, 2003, p. 28.

17 Ian Brownlie, Principles of Public International Law, $5^{\text {th }}$ ed., Clarendon Press, Oxford, 1998, p. 19. Charlesworth and Chinkin, 2000, pp. 26-28. 
Meanwhile, natural law thinking was kept simmering and regained some of its influence in the 18th century because of Locke's (liberal) ideas of the State as a social contract that was concluded by individuals (read males) and the existence of the inalienable rights of life, liberty and property. ${ }^{18}$ Under the influence of his thinking natural law was transformed into natural rights thinking which had an important impact on the American and French revolutions. ${ }^{19}$ Again, however, the 'inalienable' rights were not meant for all human beings: women and non-Caucasians were excluded. ${ }^{20}$ It looked like naturalism was going to disappear altogether in the $19^{\text {th }}$ century, but then it had an important revival after the Nazi atrocities had been committed in World War II and it gained a firm foothold as regards the ethical standards of international law expressed by the principle of non-aggression and the development of human rights law. ${ }^{21}$ For the first time women were included since the basis of human rights law is formed by the principles of non-discrimination and equality irrespective of sex or other features. ${ }^{22}$

A third theory which is important for understanding women's position in international law is liberalism. Liberal theories which started with the Enlightenment emphasized individualism and freedom from interference. ${ }^{23}$ Thus a dichotomy was created between 'public' and 'private' spheres. The boundary between public and private spheres is not set in stone, however, but may be shifted and is in fact shifting under the influence of economic and social developments. ${ }^{24}$ The distinction between public and private spheres plays an important role in defining the scope of international law. Generally speaking, it can be said that on the international level diplomatic and economic relations as well as international governmental organizations are understood to belong to the public sphere and thus fall under the scope of international law. Whatever happens in the private sphere of a State is the State's own affair and does not concern other States. ${ }^{25}$ The law of State responsibility e.g. distinguishes between public action for which States are responsible and private acts for which they do not have to answer internationally. Also human rights law has largely been focused on public, State-sanctioned, violations rather than on violations that do not have an apparent direct link to the State. ${ }^{26}$ Among the subjects that are accepted as belonging to the State's private sphere are culture, religion, and family law.

18 Malcolm Shaw, 2003, pp. 26 and 248.

9 Malcolm Shaw, 2003, p. 26.

20 It may be recalled that the French revolutionaries were not amused when Olympe de Gouges claimed that the French 'Déclaration des droits de l'homme et du citoyen' only bestowed rights on men and that in the spirit of equality and freedom women should also be included. In 1791 she published the 'Déclaration des droits de la femme et de la citoyenne' and was punished for her audacity by decapitation under the Guillotine. Hannelore Schröder, Olympe de Gouges; Verklaring van de rechten van de vrouw en burgeres, Kok Agora, Kampen, 1989, pp. 16-23.

21 Malcolm Shaw, pp. 52-53.

22 See the UN Charter, in particular the Preamble.

23 Nicola Lacey, 'Feminist Legal Theory and the Rights of Women', in: Karen Knop, ed., Gender and Human Rights, Oxford University Press, Oxford, 2004, p. 21.

24 The most recent developments that bring about such a shift are privatisation and globalisation. Charlesworth and Chinkin, 2000, p. 30.

25 The growing attention for human rights law and humanitarian law has had the effect that international concern is increasing in areas that hitherto had remained firmly within the domestic jurisdiction of the State.

26 Charlesworth and Chinkin, 2000, pp. 30-31. 


\subsubsection{Consequences and Strategies}

According to feminist legal theory, the influence of naturalism, positivism, and liberalism has had specific, mostly negative consequences for the position of women's issues in international law. Subsequently, this view on the impact of liberalism, positivism and naturalism will be discussed as well as possible strategies to counterbalance these negative effects.

The liberal distinction between public and private spheres is to the detriment of women's interests because the distinction is not neutral, but thoroughly gendered. ${ }^{27}$ Locke understood the national private sphere as pertaining to the home and the family, and according to him this was the terrain where women should be found. He regarded politics and economic life as belonging to the public sphere and the domain of men. ${ }^{28} \mathrm{It}$ is perfectly understandable that he made this particular distinction since it reflects the social patterns of the society in which he lived. ${ }^{29}$ Hence, it is also a typical Western idea that is not always applicable to non-Western societies. ${ }^{30}$ However, these gendered ideas about public and private spheres were also applied on the international level with the effect that some of the issues that figure high on women's priority list are not covered by international law, but are left to national regulation. Culture, tradition, custom and religion, containing numerous rules that disadvantage women, thus fell under the handsoff policy. One of the results of the liberal revulsion of State interference in private affairs is the blind spot that was developed for domestic violence. ${ }^{31}$

For the advancement of women's rights it is obviously important that the public sphere, both nationally and internationally, is extended to cover women specific problems and needs. ${ }^{32}$ Not just to bring taboo issues out into the open or to emphasize their importance, but also to make international examination possible and to give women the chance to bring pertinent issues of disadvantage to a higher level of monitoring. A positive development in this regard is that the matter of violence against women is gradually being brought under the scrutiny of international human rights law..$^{33}$ This also has important repercussions for the scope of State responsibility since a large part of the violent acts happens at the hands of private persons and yet under certain conditions States may be held responsible as well. ${ }^{34}$ For women's equality it is imperative that harmful cultural customs and traditions are also made the subject of discussion and examination

\footnotetext{
Charlesworth and Chinkin, 2000, p. 56.

Charlesworth and Chinkin, 2000, p. 30.

Liberals institutionalized the smallest community, i.e. the nucleus patriarchal family, as the basic socioeconomic unit of society. Charlesworth and Chinkin, 2000, p. 56

30 Charlesworth and Chinkin, 2000, p. 58.

31 It must be noted, however, that although many modern liberalists still see the home and the family as the primary private spheres, they understand the complications when faced with child abuse and domestic violence. Nicola Lacey, 2004, p. 22.

32 It is one of the most important aims of the Women's Convention that no distinction is made between violations against women's rights happening in the public or the private sphere.

33 In view of the importance that is attached to States' consent an important goal would be the entry into force of an international Convention on the Elimination of Violence against Women that would replace the 1994 Declaration on this subject.

34 See section 4.6 on State responsibility. Also Charlesworth and Chinkin, 2000, pp. 148-151.
} 
at the international level. ${ }^{35}$ Besides States, international governmental organizations and international organs, also civil society organizations, particularly women civil society organizations must make a concerted effort in transferring women's issues from the private into the public sphere. ${ }^{36}$

With a view to women's right to adequate housing I am in favour of the liberal concept of the individual who can operate autonomously and who is equal with other individuals. ${ }^{37}$ This is admittedly a Western idea and it may not be easily applicable to all societies, but I still see it as the best protection against abuse and intimidation if women, as well as men, be granted an individual, autonomous right to housing rather than that this right is regarded as a collective or family right. However, the socio-economic position of women calls for vigilance when it comes down to the liberal focus on individuals' own choice. Systematic patterns of exclusion and disadvantage of women, like women's under-representation in various occupations and decision-making bodies, cannot and should not be justified by pointing to the freedom of choice. ${ }^{38}$

The positivist focus on States' consent explains why such great importance is attached to international conventions and international customary law as sources of international law to the detriment of general (ethical) principles like justice, equality, equity, and fairness. This is also the reason why some States resist the establishment of a body of ius cogens rules as the highest source of international law because it has the potential of overriding the State's will. Ius cogens rules find their origin in the fact that States have acted according to general principles of law for such a long time that the link between a State's practice and these rules has been severed and the rules continue to exist irrespective of an individual State's consent. ${ }^{39}$ For the furtherance of women's rights the positivist focus on consent means that the best strategy currently is to induce States to bind themselves by ratifying or acceding to the Women's Convention and other human rights instruments that are based on the principles of equality and non-discrimination, and to persuade those States parties that have made reservations to withdraw them. In addition, a general customary rule, preferably a ius cogens rule, prohibiting discrimination against women should be pursued because such a rule would be all-inclusive-covering gender equality in general instead of being focused on specifically mentioned rights - and problems as regards non-ratifying States, reservations and non-States parties could be avoided. $^{40}$

35 Abdullahi An-Na im proposes a method of internal discourse combined with cross cultural dialogue that might be useful in this respect. See section 4.5 on culture and gender stereotyping, in particular subsection 4.5.4.2.1. on reactive measures.

36 The current success of international attention for violence against women is due to the combined efforts of women civil society organizations, the Special Rapporteur on Violence against Women and CEDAW.

37 See Shelley Wright, 'Economic Rights, Social Justice and the State: A Feminist Reappraisal', in: Dorinda G. Dallmeyer (ed.), Reconceiving Reality: Women and International Law, Studies in transnational legal Policy, No. 25, The American Society of International Law (ASIL), Washington, 1993, p. 129. However, the liberal idea of equality tends to remain stuck with ideas of formal equality rather than substantive equality. Nicola Lacey, 2004, p. 20. Also see section 4.3 .2 on the principle of equality.

38 Nicola Lacey, 2004, p. 20.

39 In 1969 the principle of ius cogens was codified in the Vienna Convention on the Law of Treaties. See in particular Artice 53. Also Ian Brownlie, 1998, pp. 514-517.

40 Section 4.2 .3 will discuss international customary law in more detail. 
The positivist idea of the State as a depersonalized entity overlooks the fact that only those people who hold power positions determine what the State's concerns are and, because of the State centred focus, also determine which subjects are of importance to international law. As a consequence, women's issues will not play any role of significance in international relations for two reasons. ${ }^{41}$ Firstly, women are under-represented in State organs and thus have little say in what is put on the political agenda. Secondly, because of the public/private dichotomy women's substantive rights are relegated to the national private sphere with the logical effect that such rights will only sparsely come up at the international level. Besides the already mentioned strategy of taking women's issues out of the private and putting them into the public sphere, efforts must be concentrated on having more women participating in policy-making and decision-making procedures. ${ }^{42}$

With the upsurge of natural law thinking and the renewed interest for the rights of the human person, male as well as female, expressed in human rights instruments in the $20^{\text {th }}$ century, also different expectations as regards the role of governments arose. Instead of the reserved attitude that was demanded from the (Liberal) authorities during the $19^{\text {th }}$ century, the new role required active governmental organs that took responsibility for their populations. Government interference was even accepted as a tool to bring about societal change. ${ }^{43}$ Within international human rights law, however, also a (gendered) dichotomy was created between the different types of human rights. Civil and political rights, typically professed as belonging to the 'male' public sphere, were perceived as being more important and more suitable for international scrutiny and justiciability than economic, social and cultural rights which were deemed to belong to the State's domestic sphere and thus were largely left to the State's discretion. Because of the gendered division of work and the stereotypical societal roles attributed to women and men, it is to women's disadvantage that economic, social and cultural rights, such as the right to housing were formulated rather vague and undetermined and perceived as not being as justiciable as civil and political rights, neither at the domestic nor at the international level. That is why the interdependence, interrelatedness and indivisibility of all human rights cannot be stressed enough. ${ }^{44}$ Economic, social and cultural rights are as important as civil and political rights and international monitoring may stimulate States to make an effort towards their progressive realization. ${ }^{45}$ A step forward would be enabling the Committee on Economic, Social and Cultural Rights (CESCR) to hear individual and groups' complaints and to hold enquiries in cases of violations of economic, social and

41 According to Wright women are buried beneath at least two layers of public/private distinctions with the result that they do not have any standing as subject or persons under international law and that their interests are not represented when mention is made of the 'people's' wishes. Shelley Wright, 1993, p. 130.

42 See section 3.6.2 on political participation of women.

43 Malcolm Shaw, 2003, p. 54.

44 That the tide has turned towards re-assessment of the interdependence, interrelatedness and indivisibility of all human rights may be discerned from the inclusion of all kinds of human rights in both the ICERD and the Women's Convention and the explicit statement to this effect during the 1993 World Conference on Human Rights in Vienna. See UN doc. A/CONF.157/23, Vienna Declaration and Programme of Action, 12 July 1993, para. 5.

45 It may be noticed that under the complaints procedure of Article 14 of ICERD more complaints are received on alleged violations of ESC rights, including the right to housing, than of CPR rights. 
cultural rights by adopting an Optional Protocol to that effect. ${ }^{46}$ If the fulfilment of women's economic and social rights lags behind that of men's, justiciability may in many cases be possible by appealing to the obligations under the principles of equality and non-discrimination.

\subsubsection{Customary Law and Gender}

If there would be an international customary law rule prohibiting discrimination against women, this would be to women's advantage. No longer would they depend on their State to ratify human rights instruments or adopt national laws that contain the principles of equality and non-discrimination, or whether or not the State would have made reservations pertaining to these provisions; instead all States would be under an obligation to refrain from discriminating against women and protect them from discrimination by third parties. ${ }^{47}$ A general prohibition of discrimination against women would also cover issues that have not (yet) been codified. Furthermore, customary law would also oblige non-State actors to refrain from discriminating women in private law relationships. ${ }^{48}$ Moreover, the acknowledgment of such a customary law rule would show States' commitment to women's cause and thus be important moral support.

An indication in favour of the existence of a customary rule with regard to discrimination against women is that a prohibition on discrimination on the basis of sex is contained in the UN Charter and in the Universal Declaration on Human Rights. ${ }^{49}$ Although the latter document is not a treaty, it is nevertheless one of the most authoritative human rights instruments, and it may be maintained that it is - at least partlybinding on the ground of containing customary law. ${ }^{50}$ Another indication is the ever growing amount of resolutions and declarations promoting gender equality and nondiscrimination that are adopted by the General Assembly. ${ }^{51}$ Moreover, the huge amount

46 Possibilities of an Optional Protocol will be discussed in more detail in section 4.8 on the role of monitoring.

47 Malcolm Shaw, 2003, p. 69. Oscar Schachter, International Law and Practice, 1991, in: Steiner, Henry, J., and Philip Alston, International Human Rights in Context; Law, Politics, Morals, second edition, Oxford University Press, 2000, p. 228

48 Theodor Meron, 'The Continuing Role of Custom in the Formation of International Humanitarian Law', in: The American Journal of International Law, Vol. 90:235, 1996, p. 246.

49 See the preamble of the UN Charter and Artice 2 of the Universal Declaration in which it is provided that 'Everyone is entitled to all the rights and freedoms set forth in this Declaration, without distinction of any kind, such as $[\ldots]$ sex $[\ldots]$.

50 Henry, J.Steiner, and Philip Alston, International Human Rights in Context; Law, Politics, Morals, second edition, Oxford University Press, 2000, p. 143 and 229. A. Robertson and J.G. Merrills, Human Rights in the World; An introduction to the study of the international protection of human rights, third edition, Manchester University Press, Manchester, 1992, p. 27. Shaw, 2003, p. 260.

51 The current trend towards consensus is to the detriment of creating a clear case of opinio iuris because refraining from a formal voting procedure makes it impossible to prove whether a State backs up a certain rule or issue to such an extend that it can be maintained that it has agreed because it thinks it is or should be a legal obligation to follow such a rule. An additional problem is that in order to accommodate as many participants as possible the contents of a text is usually watered down. 
of States parties to the Women's Convention might be proof that discrimination against women is (almost) universally condemned. ${ }^{52}$

However, before a right is to be regarded as part of the body of international customary law, there must be a general practice and opinio iuris to this effect. ${ }^{53}$ In the case of discrimination against women it cannot be maintained that there is a worldwide general practice to prevent, prohibit, or abolish discrimination against women. In fact, the situation is quite the contrary; women are globally discriminated against on a daily basis. However, as far as customary law is concerned, violation of a practice does not automatically mean that a rule of customary law would not exist. In fact, international case law proves that the general practice need not be rigorously uniform or consistent. ${ }^{54}$ In Nicaragua $v$. USA the International Court of Justice went as far as stating that breaches of a rule of customary law might even reaffirm this rule as long as the breach was justified by appealing to exceptions contained in the rule itself and the act was generally regarded as a violation of the rule and not accepted as a new rule of customary law. ${ }^{55}$ Especially as regards the formation of customary human rights and humanitarian law it may be acceptable that more weight is attached to opinio iuris than to general practice. ${ }^{56}$ Therefore, the fact that women are discriminated against does not automatically mean that no rule of customary law would exist.

The second requirement that has to be fulfilled is that there is opinio iuris which signifies that States act in a certain way because they believe that they are legally obliged to do so. What was decisive in Nicaragua $v$. USA was that although a violation had taken place, there was opinio iuris, that the action undertaken by the USA, i.e. the illegal use of force, was indeed a violation of a rule of customary law. In my opinion, however, there is no universal opinio iuris that discrimination against women should be prohibited. This is different with regard to the prohibition of racial discrimination. ${ }^{57}$ Since the decolonisation started after World War II, racial discrimination was universally rejected and the subject received mainstream attention in worldwide fora, most importantly in the UN General Assembly, because it was intrinsically linked to issues of nationality and self-determination of the newly arising States. The opinio iuris as regards the prohibition of racial discrimination was felt so strongly that it not only became a rule of international customary law, but that it was even generally accepted as one of the

52 In May 2005180 of the192 independent States in the world had ratified the Women's Convention.

53 Article 38, paragraph 1 of the Statute of the International Court of Justice states under b) that the two constitutive elements of international custom are 'evidence of a general practice accepted as law'. Also see Shaw, 2003, pp. 68-84. Ian Brownlie, 1998, pp. 5-11. Malanczuk, Peter, Akehurst’s Modern Introduction to International Law, $7^{\text {th }}$ rev. ed., Routledge, London and New York, 1997, pp. 39-45.

54 See for instance Anglo-Norwegian Fisheries case, International Court of Justice, ICJ Reports, 1951, paras 116 and 131; Nicaragua v. Unites States, International Court of Justice, ICJ Reports, 1986, para. 14. Also Shaw, 2003, pp. 73-74; Bronwlie, 1998, pp. 5-6 and Malanczuk, 1997, pp. 41-43.

55 Nicaragua v. Unites States, International Court of Justice, ICJ Reports, 1986, para. 186. Also Shaw, 2003, pp. 73-74 and Malanczuk, 1997, pp. 41-42.

56 Theodor Meron, 1996, pp. 239-240.

57 Despite the similarity in circumstances there was a striking difference between the world's (and the UN's) reaction to the system of apartheid in South-Africa and the suppression of women by the Taliban regime in Afghanistan. While considerable political and economic pressure was brought to bear on the South-African Government to abolish apartheid, no such sanctions were taken against the Taliban for the dehumanization of Afghan women. In fact internationally it was treated as an Afghan domestic issue. 
few peremptory norms belonging to the body of ius cogens. ${ }^{58}$ An indication of the global rejection of racial discrimination may be found in the fact that the focus of all international human rights instruments that dealt with the principle of non-discrimination after World War II was primarily on abolishing discrimination against people who were not from white Anglo-Saxon descent. Typically, race and colour figure first in these instruments as grounds on which discrimination is prohibited. ${ }^{59}$

The fact that in actual life people are still discriminated against because of their race or colour is overruled by the universal opinio iuris that such treatment is a violation of a rule of customary law.

That there is a national interest in the abolition of discrimination against women is not recognized in many States. Yet, women play a crucial role in the family and if they are empowered to fulfil their rights, their families and in particular their children will benefit from it. Women who are destitute are not in a position to contribute to society and the children of these women are in fact a lost generation. Therefore, the advancement of women is not only a matter of human rights and social justice, but it is also a prerequisite for sustainable societies and economies. ${ }^{60}$ Lack of understanding the importance of women's contribution may explain why despite the great similarity between sex and racial discrimination - people are treated as non-persons because of a birth-given feature that cannot be changed, and there is no objective, reasonable or biological motive to treat people differently because of this feature - sex discrimination was not internationally recognized as being of the same gravity as racial discrimination. ${ }^{61}$ This is all the more galling if it is considered that quantitatively speaking more persons are victims of sex discrimination than of racial discrimination. Besides the fact that $53 \%$ of the world's population is female and that sex discrimination is omnipresent, also issues of double discrimination i.c. sex discrimination within race/ethnic context often go unchallenged. ${ }^{62}$

In addition, several States and societies in the world openly express the opinion that the existing differences between women and men justify that women are treated differ-

58 Charlesworth and Chinkin, 2000, p.16. Also Restatement (Third) The Foreign Relations Law of the United States, American Law Institute, 1987, Vol. 2, 161, section 702: Customary International Law of Human Rights. Shaw, 2003, p. 257 and Brownlie, 1998, p. 515. Some scholars even maintain that prohibition of racial discrimination is part of the body of ius cogens, the most powerful set of human rights standards that no State may deviate from. See Malanczuk, 1997, p. 58 and Brownlie, 1998, p. 515.

59 Interestingly enough, in the latest major human rights instrument, the International Convention on the Protection of the Rights of All Migrant Workers and Members of Their Families, which entered into force in 2003, sex features first before race and colour in the enumeration of prohibited grounds to discriminate on. See Article 7.

60 Beijing Platform for Action. UN doc. A/CONF.177/20 and A/CONF.177/20/Add 1, Beijing Declaration and Platform for Action, Fourth World Conference on Women, 15 September 1995 in particular paras 43-58.

61 During the drafting procedure of the Women's Convention Hungary, Pakistan and Togo for instance made specific statements pertaining to their point of view that discrimination of women should not be placed on the same level as discrimination occurring under repressive and racist regimes. Laura Reanda, 'The Commission on the Status of Women', in: Philip Alston (ed.), The United Nations and Human Rights: A Critical Appraisal, Clarendon Press, Oxford, 1992, p. 288.

62 Ingrid Westendorp, 'Double discrimination; racism and sexism combined, in: Fons Coomans et al. (eds.) Rendering Justice to the Vulnerable, Liber Amicorum in Honour of Theo van Boven, Kluwer Law International, The Hague/London/Boston, 2000, pp. 299-310. Also Charlesworth and Chinkin, 2000, p. 17. 
ently. ${ }^{63}$ This difference in treatment and in rights generally entails that women have less rights and have a lower status in society when compared to men. Therefore, there is no universal acceptance as to equality between women and men and non-discrimination of women. The huge amount of States that have ratified the Women's Convention also is no proof to the contrary. Several States that have become parties to the Convention have made reservations as to some of the core Articles of the Convention or have declared that they will let religious rules prevail should these rules clash with the provisions as contained in the treaty. ${ }^{64}$ Furthermore, some States parties belie the object and purpose of the Convention by their maintenance of national laws or systems of personal laws that discriminate against women. That is why the number of States parties is misleading since some of them do not really show legal conviction (opinio iuris) that women and men should have equal rights, but may have ratified the Convention for other reasons, like prestige and reputation.

In view of the above I can only conclude, that there is as yet no general rule of customary law that prohibits discrimination against women. Moreover, I would say that there is no regional custom either. From the Asylum case it has become clear that proof of the existence of a regional custom requires a practice that is far more uniform and consistent than required for a general custom, where a few-albeit minor or less interestedStates may deviate from the rest without upsetting the rule. ${ }^{65}$ As far as the opinio iuris element is concerned, it might be maintained that this is for instance to be found in the States of North-West Europe, the USA and Canada. However, the huge amount of instances of violations of women's rights in these States, like unequal representation of women in decision making bodies, the difference in income between women and men, the occurrence of domestic violence, the difficulties women encounter in attaining leading positions, and the continuing traditional gendered division of work, show that the element of general practice is not fulfilled. Therefore, the principle of non-discrimination of women is not even a regional custom.

As has been stated before, the best short term strategy to achieve the fulfilment of the human rights of women is to persuade States to ratify the Women's Convention and other international human rights instruments that guarantee equality of both genders and to persuade States parties that have made reservations to these conventions to withdraw them. ${ }^{66}$ Thus the lack of general opinio iuris and State practice as regards the prohibition on gender discrimination may be counterbalanced by the self-binding effect of ratifica-

63 Several examples have been mentioned in this study. See in particular section 3.7 on structural discrimination inherent in cultural patterns.

64 Articles 2, 5 and 16 can be considered as the core articles of the Convention. In 2004 no less that 32 State parties had made a reservation to one or more of these Articles (this information is to be found on CEDAW's homepage at: <http://www.un.org/womenwatch/daw/cedaw>). In my opinion far-reaching reservations to these provisions, or reservations that state that the Convention will only be applicable when this does not contravene religious rules, are, in accordance with Article 19(c) of the Vienna Convention on the Law of Treaties incompatible with the object and purpose of the Convention. That is why such States should not be regarded as parties to the Convention.

65 Asylum case (Colombia v. Peru), International Court of Justice, ICJ Reports, 1950, p. 266. Also see Malcolm Shaw, 2003, pp. 87-88. Peter Malanczuk, 1997, p. 41.

66 In fact this is the strategy that is followed by CEDAW at the moment. It is also the strategy propagated in the Beijing Platform for Action, 1995 in particular para. 230. 
tion or accession. ${ }^{67}$ For the long run, however, it is to be preferred that gender equality and the prohibition of sex-discrimination become part and parcel of international customary law and ultimately of the body of ius cogens. In order to achieve this goal a change of mentality of some States and societies will be indispensable. Since this will meet with cultural defences, discretion must be used and changes must be stimulated from the inside of societies rather than by outside interference. ${ }^{68}$

\subsubsection{Strategies to Put Women's Issues on the International Agenda}

After World War II, and the adoption of the Universal Declaration on Human Rights, women's general equality rights became an issue of international concern for the first time. Since then two main strategies have been deployed in order to further women's cause. In the following sub-sections first the strategy of creating women specific organs and instruments will be discussed which was initiated by the creation of the UN Commission on the Status of Women (CSW). Next, the gender mainstreaming approach, which has become popular since the 1990s, will be dealt with.

\subsubsection{Women Specific Organs and Instruments}

The first general women specific organ, the UN Commission on the Status of Women (CSW) was established in 1946 as a subsidiary body of the UN Commission on Human Rights. ${ }^{69}$ Although its status was soon elevated to functional commission of ECOSOC, thus becoming a sister organ of the Commission, it has never held an equal position because of restricted budgetary allocations and a more limited mandate. ${ }^{70}$ The CSW was intended to be the main policy-making body of the UN with regard to all aspects of women's rights and issues, but it was explicitly not given any powers of examining or investigating any instances of discrimination against women. ${ }^{71}$ Standard-setting was not intended to be part of the CSW's mandate either because it was deemed unnecessary to draw up a special convention since women's rights were perceived to be included in the global human rights instruments drawn up by the Commission on Human Rights as well as in those that were adopted by specialized agencies. ${ }^{72}$ When the need for special

67 Furthermore, treaty provisions have the advantage of bringing precision in the normative content and ratifications are essential for the purpose of monitoring.

68 See section 4.5 on culture and gender stereotyping.

69 The Commission on the Status of Women consists of 45 members who are appointed by governments. For more information on the CSW see <www.un.org/womenwatch/daw/csw $>$.

70 The longest CSW session lasted three weeks, but that was an exception. For a considerable period the Commission was only allowed to meet biennially and only for two weeks at a stretch. Under pressure of its parent body ECOSOC it had to reduce its agenda and it was subjected to strict control. It was unable to create subsidiary machinery like the Commission on Human Rights. Laura Reanda, 1992, pp. 266-271.

71 The reasons for not giving the CSW any real power to examine and investigate situations of discrimination of women or to take measures as regards compliance with UN standards, must be sought in the view that was held at the time by the majority of States that women's position is so deeply embedded in traditional customs and practices that it is unsuited for fact-finding missions or complaints procedures. Laura Reanda, 1992, p. 274.

72 Laura Reanda, 1992, p. 281. 
instruments became clear because women's issues did not receive adequate attention in general human rights organs and conventions, the CSW created its own standard-setting role. As many of the instruments that were adopted in the beginning only had a limited scope, were not widely ratified, and knew no implementation provisions, there is no need to go into all of them here. Worth mentioning, however, is the (1952) Convention on the Political Rights of Women which grants women equal rights to vote, be eligible for election in all public bodies and to hold office and exercise all public functions. ${ }^{73} \mathrm{Of}$ further importance are the Convention and Recommendation on Consent to Marriage, Minimum Age for Marriage, and Registration of Marriages because these two instruments are specifically aimed at dealing with problems ensuing from discriminating traditional customs and practices. ${ }^{74}$

Dissatisfied with the limited scope and impact of these specific rights instruments, the CSW aimed at creating an instrument that would cover all aspects of discrimination against women. First the Declaration on the Elimination against All Forms of Discrimination was drafted (1967) which was followed by the Convention on the Elimination against All Forms of Discrimination (Women's Convention, 1979). ${ }^{75}$ The creation of the Women's Convention is undoubtedly one of the main achievements of the CSW. Although the Commission had expressed the wish to supervise adherence to the Women's Convention itself, the General Assembly decided to include the establishment of a body of independent experts in the Convention. ${ }^{76}$

Paradoxically, the broader the attention for women's issues became in the framework of the UN, particularly after the institution of the International Women's Year (1975), the Women's Decade (1976-1985), and the three world conferences on women's rights held during this decade (Mexico City, Copenhagen and Nairobi), the less important and influential the CSW became until it hit rock bottom in 1980 when it's role had become so insignificant that it was even proposed at the GA that the Commission be abolished. Instead, however, it was decided to adopt a contrary proposal tabled by ECOSOC at the recommendation of the CSW to revitalize the Commission by giving it a co-ordinating role within the UN gender mainstreaming strategy. ${ }^{77}$ That is why I will come back to the $\mathrm{CSW}$ in the next sub-section.

The Women's Convention that entered into force in 1981 is based on the principle of non-discrimination and it includes a wide range of human rights. An important aspect is

73 The Convention on the Political Rights of Women was adopted by the General Assembly on 20 December 1952, and entered into force on 7 July 1954. In July 2005 the Convention has 119 State parties, many of which have made reservations, however. See: <http://untreaty.un.org/English/bible/ enlishinternetbible/partI/Chapter XVI/treaty1.asp>, last consulted on 25 July 2005.

74 The Convention was adopted by the GA in 1962 and the Recommendation in 1965. Neither instrument has any implementation provisions, but only know reporting on a voluntary basis. The Commission's wish to create only one legally binding document on this subject was rejected by ECOSOC because it was felt that cultural practices could only be changed in the long run by way of education and long-term programmes. Laura Reanda, 1992, p. 284

75 The General Assembly adopted the Convention on the Elimination of All Forms of Discrimination Against Women on 18 December 1979. The Convention entered into force on 3 September 1981.

76 Laura Reanda, 1992, p. 288.

77 Laura Reanda, 1992, p. 295. 
that no distinction is made between public and private spheres, ${ }^{78}$ and that in its aim at $d e$ facto equality between women and men, it summons States parties to abolish cultural and traditional patterns that disadvantage women and might put them in a subjective position. ${ }^{79}$ Furthermore, it endorses a policy of temporary positive action in order to accelerate de facto equality. ${ }^{80}$ Besides these positive aspects the Women's Convention also has some negative sides. The language of the Convention is vague and resembles a political statement rather than a legally binding document. ${ }^{81}$ Moreover, the working of the Convention is seriously hampered by a multitude of reservations a fair number of which affect the core Articles of the Convention. ${ }^{82}$ As far as women's right to land and housing is concerned, it is a weakness that these rights are only mentioned in the context of rural women. ${ }^{83}$

Article 17 of the Convention had the effect that the second and legally speaking most important, UN women specific organ saw the light of day: the Committee on the Elimination of All Forms of Discrimination Against Women (CEDAW). This Committee, consisting of twenty-three independent experts is faced with several difficulties that affect its supervisory role.

First of all, it was decided that CEDAW would not convene in Geneva like the other human rights monitoring committees, but that the Committee would alternate between Vienna and New York. Without being consulted about it, the Committee was moved altogether to New York in 1995. The effect of being located there is that CEDAW is rather isolated in relation to other human rights monitoring bodies and has to put a lot of time and effort in keeping in touch with those bodies. Furthermore, location in New York means that CEDAW is not serviced by the Office of the United Nations High Commissioner for Human Rights (OHCHR) in Geneva, but by the Division for the Advancement

78 From Artice 1 of the Convention it becomes clear that discrimination against women is prohibited in the political, economic, social, cultural, civil or any other field, implying the private sphere. This is notably different from the definition of racial discrimination in Article 1(1) of the Convention on the Elimination of All Forms of Racial Discrimination which defines racial discrimination as 'any distinction, exclusion, restriction or preference based on race, colour, descent, or national or ethnic origin which has the purpose or effect of nullifying or impairing the recognition, enjoyment or exercise, on an equal footing, of human rights and fundamental freedoms in the political, economic, social, cultural or any other field of public life' (emphasis added).

79 Article 5(a) of the Convention reads: 'State parties shall take all appropriate measures: a) To modify the 'social and cultural patterns of conduct of men and women, with a view to achieving the elimination of prejudices and customary and all other practices which are based on the idea of the inferiority of the superiority of either of the sexes or on stereotyped roles for men and women.

80 Article 4(1) reads: 'Adoption by State parties of temporary special measures aimed at accelerating de facto equality between men and women shall not be considered discrimination as defined in the present Convention, but shall in no way entail as a consequence the maintenance of unequal or separate standards; these measures shall be discontinued when the objectives of equality of opportunity and treatment have been achieved.'

81 Laura Reanda, 1992, p. 287.

82 Articles 2 (abolishment of discrimination against women), 5 (abolishing de facto impediments), and 16 (equality of women in marriage and family relations) together may be considered to be the heart of the Convention.

83 In the framework of this study Article 14(2), paragraphs $\mathrm{g}$ and $\mathrm{h}$ are of particular importance. These provisions will be dealt with in detail in section 4.4.3 on Article 14 Women's Convention. 
of Women (DAW) which is situated in New York. ${ }^{84}$ Location in New York is not totally disadvantageous, however. Convening in the UN headquarters means sitting in the heart of the organization and being able to maintain easy links with other sectors within the UN which is an advantage in respect to gender mainstreaming. Furthermore, being serviced by DAW may be better than having to share the service of the OHCHR with six other treaty bodies.

A serious difficulty CEDAW was faced with was an extremely restricted meeting time. From the outset the Convention was ratified by a great many States that have to submit a report within a year after the Convention has entered into force for them and every four years after the initial one. Moreover, there may be the need to ask for reports on an exceptional basis (Article 18(1)) and the Committee has the task to make General Recommendations based on the examination of reports and received from States parties under Article 21. Yet Article 20 of the Convention stipulates that CEDAW will convene only once a year for a two week period. In 1993 CEDAW was allowed to expand its convening time with one week and since 1997 the Committee meets twice a year for a three week period. Even this extension is not enough to dispose of the enormous backlog of work that has accumulated. Therefore, the Committee has also formed pre-session working groups that convene twice a year for five working days immediately after the Committee's regular session. ${ }^{85}$

A last difficulty CEDAW was faced with was the limited monitoring ability since the Convention only provides for the reporting procedure of Article 18. As a follow-up of the Vienna World Conference on Human Rights of 1993 and the recommendations laid down in the Vienna Declaration and Programme of Action, ${ }^{86}$ plans were made to repair this deficiency by adopting an Optional Protocol to the Convention. ${ }^{87}$ Since the Optional Protocol (OP) entered into force on 10 December 2000, the Committee has two additional monitoring instruments at its disposal: ${ }^{88}$ the individual and group complaint procedure (OP, Article 2$)$ and the inquiry procedure (OP, Article 8$).{ }^{89}$ Both procedures will receive further attention in section 4.7.

84 DAW, formerly called the Branch for the Advancement of Women, used to be located in Vienna until 1995 when the division was relocated to New York. Due to understaffing CEDAW could not be serviced properly especially when the Committee had to convene in New York and it was proposed in 1990 that CEDAW be serviced by the Centre for Human Rights in Geneva. In the meantime the situation has improved considerably which had an important impact on the effectiveness of CEDAW's work. See Roberta Jacobson, 'The Committee on the Elimination of Discrimination against Women', in: Philip Alston (ed.), The United Nations and Human Rights: A Critical Appraisal, Clarendon Press, Oxford, 1992, pp. 451-452. Also Silvia Cartwright, 'The Committee on the Elimination of Discrimination Against Women', in: Kelly D. Askin and Dorean M. Koenig (eds), Women and International Human Rights Law, Vol. 2, Transnational Publishers, Inc., Ardsley, New York, 1999 p. 169.

85 Silvia Cartwright, 1999, pp. 170-171 and 177.

86 Vienna Declaration and Programme of Action, UN doc. A/CONF.157/23, 12 July 1993, para. 40.

87 Silvia Cartwright, 1999, pp. 179-181.

88 Since the Optional Protocol (OP) has to be ratified separately, CEDAW may only use the additional monitoring instruments as regards the State parties to the OP. In July 2005 already 71 States had ratified the Protocol.

89 For a detailed review of the strengths and weaknesses of the OP see Mireille Bijnsdorp, 'The Strength of the Optional Protocol to the United Nations Women's Convention', in: Netherlands Quarterly of Human Rights, Vol. 18, No. 3, August 2000, pp. 329-355. 
Despite all the shortcomings of the Women's Convention and the difficulties CEDAW was and is faced with, there is no question that both the Convention and its supervisory body have achieved a great deal towards putting women's issues in the international spotlight. ${ }^{90}$ The fact that more than $90 \%$ of the world's States have ratified the Convention is encouraging, especially since the great majority of them regularly fulfils its reporting procedure. Also the speed with which the Optional Protocol entered into force and the ratification by already $40 \%$ of the Convention's States parties is reason for optimism. Very good work has also been done by the Committee in drawing up its General Recommendations. ${ }^{91}$ In particular General Recommendation No. 19 on Violence Against Women is an excellent standard-setting document that has successfully mended the serious shortcoming that the issue of violence against women was not included in the Convention. $^{92}$

In the framework of this study two additional women specific UN organs should be mentioned: the Special Rapporteur on violence against women and the Special Rapporteur on harmful traditional practices. The UN Commission on Human Rights decided in 1994 to appoint a Special Rapporteur on violence against women, including its causes and consequences. ${ }^{93}$ Since that time the Special Rapporteur has published numerous reports that were important eye-openers as regards the multifarious forms and scope of gender specific violence that is suffered by women all over the world. ${ }^{94}$ The Sub-Commission on the Promotion and Protection of Human Rights appointed a Special Rapporteur on harmful traditional practices affecting the health of women and the girl child in 1996. Although the focus of the reports published by the Special Rapporteur has been female genital mutilation, such a mandate opens perspectives as regards the examination of other customs and practices some of which directly affect women's right to housing. ${ }^{95}$

\subsection{Observations as regards the Women Specific Strategy}

Although it was appropriate that separate mechanisms were created within the UN to deal with human rights in general and human rights of women, at the outset these two mechanisms (CSW and CEDAW) were not equipped with equal power or facilities. Those organs and secretariats that occupied themselves with women's human rights found themselves in an isolated and unfavourable position concerning budgetary and personal allocations, meeting time, mandates, and supervisory possibilities. ${ }^{96}$ Further-

90 Many countries hardly considered women's rights at all till the treaty was established. Roberta Jacobson, 1992, p. 444.

91 In July 2005 CEDAW had already published 25 General Recommendations. See CEDAW's internet site at: $<$ www.un.org/womenwatch/daw/cedaw/>.

92 CEDAW, General Recommendation number 19, Violence against women, UN doc. A/47/38, 1992.

93 The mandate was fulfilled by Ms Radhika Coomaraswamy from Sri Lanka from March 1994 till July 2003. In August 2003 she was succeeded by Dr Yakin Ertürk from Turkey.

94 All reports published by the Special Rapporteur on violence against women may be found at http:// www.ohchr.org/english/issues/women/rapporteur/annual.htm.

95 Reports by the Special Rapporteur on harmful traditional practices affecting the health of women and the girl child, a mandate that has been fulfilled by Mrs Halima Embarek Warzazi from Morocco, can be found at the homepage of the Sub-Commission on the Promotion and Protection of Human Rights at: $<$ http://www.ohchr.org/english/bodies/subcom/index.htm>.

96 Roberta Jacobson, 1992, p. 463. Meanwhile CEDAW has succeeded to improve its situation. 
more, the creation of separate organs also had the effect that a women's ghetto was created because general human rights bodies did not take women's specific position into account (any more), but left this to the women specific organs.

A rather delicate matter is the predominance of female members in women specific organs and functions. Governments tend to push female candidates forward during election time for women (and children) specific organs while hardly any women are considered when candidates for general human rights organs and functions have to be proposed. ${ }^{97}$ Although undoubtedly the quality of the average female candidate is at least as high as that of the average male candidate, due to prejudice the value of an (almost) all-female organ may be questioned to such an extent that the organ may not be taken as seriously as other bodies that know a principal male membership. The solution to this dilemma is not so easy. I would consider it to be an advantage that a body that concerns itself with women's issues consists predominantly of female members because for them the female perspective comes naturally. However, with the purpose of ensuring that an organ has enough political weight, and in order to take the wind out of the criticasters' sails, it might be a good idea to include more male members. Another incentive to involve more men might be that it is in the interest of women's advancement to gain male support. ${ }^{98}$

Despite the important setbacks, it cannot be denied that the status of women has improved over the last sixty years albeit not everywhere to the same extent and in some respects more than in others. Specific organs and instruments concentrating on women's position were able to draw the world's attention to gender specific problems and needs. The women specific strategy even has succeeded in creating awareness for women's equality rights in States that before had never taken women's position into consideration. The fact that gender equality and non-discrimination have been incorporated into virtually every national legislative system is an important step forward.

As far as women's right to housing is concerned, there is potential in the women specific strategy as well. For instance, based on Articles 14(2)(g)(h), 2 and 5 of the Convention, CEDAW can address women's right to land and housing not only in the reporting procedure by asking critical questions and making recommendations in the concluding observations, but the Committee might also issue a General Recommendation on the subject. ${ }^{99}$ Both the mandate of the Special Rapporteur on violence against women and that of the Special Rapporteur on traditional practices offer openings to denounce specific problems and situations that negatively affect women's housing rights. The latter could for instance focus on customs and traditions that deny women access and right to

97 There is a discernible difference between elected and appointed functions within the framework of the UN. While States still favour men when for instance members for supervisory bodies have to be nominated and elected, UN organs try to achieve a better gender balance as far as appointed functions are concerned. A recent positive example may be found in Article 36 (8) a (iii) of the 1998 ICC Statute in which it is stipulated that in the selection of judges a fair representation of female and male judges must be realized. Malcolm Shaw, International Law, $5^{\text {th }}$ ed., Cambridge University Press, Cambridge, 2003, p. 63.

98 Evidently, more women should be nominated and elected in the other supervisory human rights bodies which are momentarily dominated by male members.

99 The possibility of a specific General Recommendation will be further discussed in section 4.7. 
land and housing, while the former might deal with adequate housing conditions in the framework of her study on domestic violence. ${ }^{100}$

\subsubsection{Gender Mainstreaming}

Already after the Nairobi conference in 1985 and the adoption by the GA of the Nairobi Forward Looking Strategies to the Year 2000, the beginning of a shift was made from concentrating on women specific activities to the strategy of mainstreaming. At the time, the weaknesses of the women-specific approach were recognized as well as the fact that though successes had been achieved, the over-all position of women had not been improved. ${ }^{101}$ The mainstreaming strategy received a boost after the Fourth World Conference on Women in Beijing in 1995 and the adoption of the Beijing Declaration and Platform for Action. ${ }^{102}$ Mainstreaming does not mean that women's issues are added to the already existing policies, but that gender will be placed within pre-existing structures of an organization or programme. ${ }^{103}$ In 1997 ECOSOC defined gender mainstreaming as follows:

'[...] the process of assessing the implications for women and men of any planned action, including legislation, policies or programmes, in all areas and at all levels. It is a strategy for making women's as well as men's concerns and experiences an integral dimension of the design, implementation, monitoring and evaluation of policies and programmes in all political, economic and societal spheres so that women and men benefit equally and inequality is not perpetuated. The ultimate goal is to achieve gender equality. ${ }^{104}$

ECOSOC requested all UN bodies, including specialized organizations, functional and regional commissions to adopt and implement policies for the advancement of women. ${ }^{105}$ With every plan, programme or policy measure gender aspects should be taken into account. ${ }^{106}$ As was already mentioned above, the mainstreaming strategy meant a revitalisation for the CSW because there was a definitive need for a co-ordinating body that would evaluate and monitor all the different mainstreaming activities both on the

100 I will come back to the potential monitoring abilities as regards housing rights of CEDAW and the two Special Rapporteurs in section 4.7.

101 Laura Reanda, 1992, pp. 295-298.

102 UN doc. A/CONF.177/20 and A/CONF.177/20/Add 1, Beijing Declaration and Platform for Action, Fourth World Conference on Women, 15 September 1995.

103 The UN Secretary-General defines mainstreaming as: 'the placing of an issue within the pre-existing institutional, academic and discursive framework. It is the opposite of marginalization [...]', UN doc. E/CN.4/1999/67, The question of integrating the human rights of women throughout the United Nations system, Report of the Secretary-General, 28 January 1999, para. 7.

104 ECOSOC Agreed Conclusions, 1997/2 contained in UN doc. A/52/3, Report of the Economic and Social Council for 1997, 18 September 1997.

105 For information on the integration of a gender perspective in the work of the human rights treaty bodies see Anne Gallagher, 'Ending the Marginalization: Strategies for Incorporating Women into the United Nations Human Rights System', particularly section III on Gender and the Treaty Bodies in: Human Rights Quarterly, Volume 19, Number 2 May 1997, pp. 294-309.

106 ECOSOC resolution 2001/41, Mainstreaming a gender perspective into all policies and programmes in the United Nations system, 26 July 2001. 
national and on the international level. ${ }^{107}$ The CSW's monitoring role was strengthened within the context of a reporting system in which governments, intergovernmental organizations, non-governmental organizations and the various sectors of the UN system are involved. ${ }^{108}$ Since 1997 the Office of the Special Adviser to the Secretary-General on Gender Issues and the Advancement of Women was charged to oversee, monitor and report on progress made as regards gender mainstreaming in the whole of the UN. ${ }^{109}$

Incorporating gender mainstreaming in legislation and policies will require changes in organizations, procedures, decision-making, cultures, and relationships, particularly the relationship between women and men. ${ }^{110}$ Therefore, a strong political commitment is necessary to follow it through as well as the mobilization of men since focusing solely on women will not bring about the necessary changes in gender roles.

\subsection{Observations as regards Gender Mainstreaming}

One of the major disadvantages of gender mainstreaming is the danger that women's issues will be snowed under in the avalanche of problems and needs existing worldwide. Taking a gender perspective into account may become just another perspective to consider. That is why it is stressed that gender equality should be one of the core considerations in any plan, policy or programme. However, there is no formula that can be applied in every context and specific gender analysis must be performed, before it may be clear what exactly is needed and what needs to be considered in a certain situation to do justice to the gender perspective. ${ }^{111}$

Data collection is one of the pillars on which policy making rests. It goes without saying that statistics are needed to provide essential information for governments and international organizations. However, it is not so easy to collect meaningful sex disaggregated data for gender mainstreaming policies because concepts, definitions and methods used in data collection may reflect gender roles and relations in society. ${ }^{112}$ Furthermore, once it has been established that inequalities do exist, a deeper analysis should be made in order to establish the causes and implications of these inequalities since otherwise a policy may be devised that is not effective. ${ }^{113}$

Although the UN calls upon State members to put gender equality in the mainstream of their legislative and policy activities and urges them to further women's representation in policy- and decision-making organs on all levels, it is essential that a gender

107 See e.g. ECOSOC resolution 2001/4, Proposals for a multi-year programme of work for the Commission on the Status of Women for 2002-2006, 24 July 2001, which entails the adoption of a work programme for the effective implementation of the Beijing Platform for Action.

108 The Commission still suffered from budgetary constraints, however. Laura Reanda, 1992, p. 299.

109 Gender Mainstreaming: Strategy for Promoting Gender Equality, Office of the Special Advisor on Gender Issues and Advancement of Women (OSAGI), August 2001, at: <http://www.un.org/womenwatch/ osagi>.

110 Gender Mainstreaming: An Overview, United Nations, 2002, pp. 1 and 9.

111 Gender Mainstreaming: An Overview, United Nations, 2002, pp. 2-5.

112 Energy statistics for instance concentrate on the percentage of households with access to electricity. It would be useful to distinguish between female and male headed households given the discrepancies in average income levels. Furthermore, better insights would be gained if data were collected on energy users by sex and type of use since women may have different energy needs than men.

113 Office of the Special Adviser on Gender Issues and Advancement of Women, Gender Mainstreaming. An Overview, United Nations, New York, 2002, p. 23. 
balance is also achieved in UN bodies, organs and functions. Especially more female members should be included in general human rights bodies and functions in order to promote and safeguard an effective female perspective in all activities.

The gender mainstreaming strategy has the potential to have both an indirect and a direct effect on the realization of adequate housing for women because all kinds of general human rights organs and organizations take gender issues into consideration which may strengthen women's general equal rights position, while others may put women's right to adequate housing directly into the mainstream of their activities.

International agencies like the United Nations Educational, Scientific and Cultural Organization (UNESCO), the United Nations International Children's Emergency Fund (UNICEF), the United Nations Development Programme (UNDP), the World Health Organizations (WHO), and the International Labour Organization (ILO) all have established gender divisions or have issued reports focusing on gender issues. Their different angles on human rights of women, contribute to a better understanding of the complexity of the disadvantaged position many women may find themselves in. Especially the fact that these agencies inform and educate people on gender stereotyping and harmful practices may contribute to the advancement of women's right to housing since custom and tradition may be important impediments as regards the fulfilment of this right. ${ }^{114}$

UN-Habitat has followed up on the mainstreaming strategy by adopting ten gender mainstreaming principles, the most relevant of which in this context is the requirement of women's equitable participation at all levels of decision-making within the human settlement field. ${ }^{115}$ Moreover, UN-Habitat has a Gender Policy Unit that addresses gender equality also with specific projects. ${ }^{116}$

As a result of the gender mainstreaming strategy, the Human Rights Committee (HRC) decided to replace its considerations on Article 3 of the Convention ${ }^{117}$ in the rather skimpy General Comment No. 4 on Equality between the sexes ${ }^{118}$ by the far more substantial General Comment No. 28 on Equality of rights between men and women. ${ }^{119}$ This has the effect that better monitoring is possible on a number of rights that directly or indirectly impinge on women's housing rights because the Committee requests specific sex disaggregated data on these rights in State reports. ${ }^{120}$

114 See section 4.5.4.1 on international agencies.

115 See <http://www.unhabitat.org/programmes/genderpolicy/approach.asp >, last consulted on August 2005.

116 See $<$ www.unhabitat.org/genderpolicy $>$, UN-Habitat Gende Policy Unit Homepage.

117 Article 3 of the ICCPR reads: 'The State parties to the present Covenant undertake to ensure the equal right of men and women to the enjoyment of all civil and political rights set forth in the present Covenant.'

118 Human Rights Committee, General Comment No. 4: Equality between the sexes (Art. 3), 30 July 1981.

119 Human Rights Committee, General Comment No. 28: Equality of rights between men and women (Art. 3), 29 March 2000.

120 In General Comment No. 28 the HRC asks State parties to report on practices that confine women in the house (para. 14), the capacity of women to own property and the existence of traditions in which they are being treated like property themselves (para. 19), women's right to enjoy privacy (para. 20), equal rights in marriage including the matrimonial regime as regards ownership or administration of property as well as property distribution upon the dissolution of marriage and the equal inheritance rights upon the death of one of the spouses (paras 23-26). Of indirect value to the right to housing are the demands made as regards equal rights of girls and boys in education (para. 28), women's participation in public affairs (para. 29), and labour laws and customs and traditions that discriminate against women. 
The Committee on the Elimination of all Forms of Racial Discrimination (CERD) has also issued a General Recommendation in which it acknowledged that racial discrimination does not always affect women and men equally or in the same way. That is why States parties are requested to furnish specific information concerning discrimination of women and further to provide all relevant data on racial or ethnic groups in a sexdisaggregated manner. ${ }^{121}$

After years of debate, the CESCR has recently effectuated the gender mainstreaming strategy by adopting General Comment No. 16 on the equal right of men and women to the enjoyment of all economic, social and cultural rights. ${ }^{122}$ In the Comment the Committee stresses the importance of de iure as well as de facto equality of women and men. ${ }^{123}$ For the fulfilment of the right to housing it is important that the CESCR points out that States parties must see to it that women have a right to own, use or otherwise control housing, land and property on an equal basis with men, and that they should have access to the necessary resources to do so. ${ }^{124}$

In 2002 the Commission on Human Rights requested its Special Rapporteur on adequate housing to conduct a special study on women and housing. ${ }^{125}$ Meanwhile the Special Rapporteur has submitted a first study in $2003,{ }^{126}$ and a progress report in $2005 .{ }^{127}$

\subsubsection{Concluding Remarks}

Although attention for women's issues and rights is warranted at the international level, international law has not been very accommodating as regards women's interests. This is to women's disadvantage since international law may support women's struggle at the national level, particularly by way of monitoring domestic implementation. According to feminist theory, the unreceptive attitude is partly due to the positivist influence that caused international law to be focused on States rather than on individuals, and on conventions and customary law rather than on general principles of law and social justice. ${ }^{128}$ In addition, States are viewed as depersonalized entities, thus passing over the

121 Committee on the Elimination of all Forms of Racial Discrimination, General Recommendation No. 25, Gender Related Dimensions of Racial Discrimination, 20 March 2000.

122 UN doc. E/C.12/2005/3, Committee on Economic, Social and Cultural Rights, General Comment No. 16 , Article 3: the equal right of men and women to the enjoyment of all economic, social and cultural rights, 13 May 2005. This General Comment will be discussed in more detail in section 4.7.2.4.2.

123 See paras 6-15 in which the concepts of sex, gender, direct and indirect discrimination are explained.

124 See para. 28.

125 Commission on Human Rights resolution 2002/49 on Women's equal ownership of, access to and control over land and the equal rights to own property and to adequate housing, 23 April 2002. The mandate and the reports of the Special Rapporteur on Housing will be discussed in section 4.7.3.1.

$126 U N$ doc. E/CN.4/2003/55, Women and adequate housing; Study by the Special Rapporteur on adequate housing as a component of the right to an adequate standard of living, and on the right to non-discrimination, 26 March 2003.

127 UN doc. E/CN.4/2005/43, Study by the Special Rapporteur on adequate housing as a component of the right to an adequate standard of living, Miloon Kothari, 25 February 2005.

128 Fortunately, in the last few decades there is a noticeable development in the direction of humanization of international law. See Menno T. Kamminga, De humanisering van het volkenrecht, Oratie uitgesproken op 23 maart 2001, Universitaire Pers Maastricht, Maastricht, 2001. 
fact that States consist of people who do not form a homogenous group but who have different interests and unequal opportunities for influencing politics.

Furthermore, feminist theory holds the influence of liberalism responsible for causing a schism between what are considered to be public and private affairs of a State. This dichotomy, whose origin rests with the traditional division of work, has proved to be an important impediment for women to enter the public sphere of decision-making, while it also serves as a watershed that prevents public scrutiny of some of the issues that are important to many women, like domestic violence. Although it may not be desirable to level the division between public and private spheres altogether, it is imperative for women's advancement and equality that some women's rights issues are lifted out of the private sphere and put into the public sphere and thus under the scope of international public law. The limited numbers of women who participate in policy- and decisionmaking organs do not have enough influence to put women's issues squarely on the political agenda. That is why determined action is needed from international organizations and civil society organizations.

The international disinterest for discrimination of women is striking when compared to racial discrimination. While the prohibition of racial discrimination is recognized as incompatible with international customary law and is even accepted as a rule of ius cogens, women's right to equality and non-discrimination has not reached the same status despite the great similarity between the two forms of discrimination. One of the main reasons for this difference may be the perceived lack of national interest. That is why governments must not only be convinced of the persistent and pervasive character of discrimination against women but also of the gravity of its effect. Women's advancement will not only benefit women themselves, but it is also in the interest of next generations and the State's welfare as a whole.

In view of the fact, that great store is set by State sovereignty and consent, the best method to improve women's position on the international level is to induce States to unconditionally commit themselves to abolish discrimination against women either by ratifying human rights conventions, in particular the Women's Convention, or by acknowledging a rule of customary law prohibiting discrimination against women. In the past few decades two different strategies have been deployed to persuade States of the importance of women's issues and to put discrimination against women on the international agenda: women specific organs and instruments and gender mainstreaming. It has become clear that both methods have advantages and disadvantages. While the women specific strategy is capable of focusing on particular areas of discrimination quickly and efficiently, one of the drawbacks is that the special organs experienced disfavouring in comparison with general human rights bodies as regards funding and mandates. Furthermore, the women specific strategy has the effect that general monitoring agencies have the tendency to ignore discrimination against women in their work because that is thought to be the terrain of the women specific mechanisms. Gender mainstreaming mends the latter deficiency to some extent because all human rights bodies, irrespective of their focus, have to take the gender perspective into account. The downside is, however, that there is no blueprint that can be generally applied so that it is not always clear what the gender perspective of an issue is and how the agency should 
act on it. Furthermore, bringing the gender perspective into the mainstream of an organ's activities runs the risk of dilution, since discrimination against women may become yet another matter that has to be examined.

From the above it may be clear that the two strategies should be used simultaneously because they complement each other well and may to some extent cross out each other's disadvantages. The examples that have been given have shown that both strategies also have potential concerning women's right to adequate housing.

\subsection{PRINCIPLES OF EQUALITY AND NON-DisCRIMINATION}

\subsubsection{Introduction}

Human rights instruments, be they international, regional, or national all base themselves on the principles of equality and non-discrimination. The purpose of this section is to determine what these principles entail and whether they are adequate in helping to achieve the fulfillment of women's human rights, particularly the right to adequate housing, on an equal footing with men.

The first section will look into the concept of equality. Several definitions exist and different approaches are possible. Since affirmative action is regarded as an important instrument for achieving equality, this measure is also discussed. Furthermore, the concept of equity is compared to the concept of equality since there is much confusion as regards these two terms.

In section 4.3.3 the principle of non-discrimination will be discussed. While international human rights instruments prohibit discrimination against women on the basis of sex, feminist thinking has moved on since the adoption of these treaties and meanwhile recognizes that discrimination against women also entails discrimination based on gender. The difference between sex and gender will be clarified.

Section 4.3.4 will determine whether the provisions on equality and non-discrimination in human rights instruments that are most pertinent for this study are effective to realize women's right to adequate housing.

\subsubsection{Principle of Equality}

The concept of equality has been the subject of discussion since the time of Aristotle who understood equality as sameness in a formal way. ${ }^{129}$ According to his view like cases

129 Those who approach the concept of equality in a formal way, focus on a formula or a policy, but do not include a specific content. Those who occupy themselves with substantive equality use a certain criterion by which distribution is to be assessed. Aristotle had a formal view of equality because he sought formal justice; 'justice is thought to be, and is, equality, not, however, for all, but only for equals. And inequality is thought to be, and is, justice; neither is this for all, but only for unequals'. Dworkin for instance, focuses on the content of equality and thus seeks substantive equality. According to him the equal concern of the State should result in a form of material equality that he calls equality of resources. Louis Pojman, and Robert Westmoreland (eds.), Equality; Selected Readings, Oxford University Press, New York/Oxford, 1997, pp. 2-3 and 24-25 and Ronald Dworkin, Sovereign Virtue; The Theory and Practice of Equality, Harvard University Press, Cambridge, Massachusetts, 2000, p. 3 respectively. Also Titia 
should be treated alike, while unlike cases should be treated unalike in proportion to their unlikeness. The application of this perception of equality, which may still be found today, to the relation between women and men entails that women are only entitled to the same treatment as men if their situation is the same. ${ }^{130}$ The focus therefore is on the same treatment. This approach of equality can also be called the sameness approach. It is a formal view that follows the law to the letter; as soon as two cases are not the same a different treatment is called for. ${ }^{131}$ What is striking in this reasoning is that the standard that is used to decide whether cases are the same is not a 'neutral' standard, but it reflects men and their situation. ${ }^{132}$ Women, who want to be treated equally, must see to it that they conform to this male standard. Consequently, as soon as women are perceived as being different, this means that they deviate from the norm and thus are excluded. Their treatment will be less or worse than the treatment men will receive. ${ }^{133}$

The focus of equality, however, does not necessarily have to be on the same treatment; it may also be on equal access, creating equal opportunities, or achieving an equal result. Such a focus implies that the treatment of women and men may be different, as long as a certain goal is achieved. According to the difference approach it is accepted that inherent and cultural differences exist between women and men, however underlying these differences is a human commonality. ${ }^{134}$ Therefore, the different circumstances should be taken into account in order to achieve an equal result. Thus the difference approach does not aim at formal equality, like the sameness approach, but tries to achieve substantive equality.

The danger of both the sameness and difference approach is that they may reinforce the inequality between women and men. ${ }^{135}$ The inherent and cultural differences between

Loenen, Het gelijkheidsbeginsel, Ars Aequi Libri, Nijmegen, 1998, pp. 19-32.

130 Brenda Cossman, 'Equality, Difference and Feminist Legal Theory', in: Feminist Legal Theory, Special Issue, The Thatched Patio, Vol. 3, no. 4, International Centre for Ethnic Studies, July/August 1990, pp. 24-25.

131 Martha Minow, Making All the Difference; Inclusion, Exclusion, and American Law, Cornell University Press, Ithaca and London, 1990, pp. 146-147. Also Catherine MacKinnon, 'Difference and Dominance: On Sex Discrimination', in: Robert K. Fullinwider and Claudia Mills (eds.), The Moral Foundation of Civil Rights, Maryland, Rowman and Littlefield, 1986, pp. 144-149.

132 H. Charlesworth, C. Chinkin and S. Wright, 'Feminist approaches to international law', in: American Journal of International Law 85, 1991, pp. 613-645. Also Minow, 1990, pp. 211-212, MacKinnon, 1986, p. 146.

133 Titia Loenen, 'Rethinking Sex Equality as a Human Right', in: Netherlands Quarterly of Human Rights, Vol. 3, 1994, p. 255.

134 Besides the legal theories of the sameness and difference approach there is also a third theory that is called the dominance approach, that is brought forward by Catherine MacKinnon. It is premised on the idea that the difference between women and men is basically a difference in power, i.e. men have power and thus are treated superior, while women lack power and thus are abused and subjugated. Though I agree that in many cases the difference comes down to a power imbalance, I think that it is superfluous to deal with the dominance approach separately since in my view it is part of the difference approach. See for the dominance approach Catherine MacKinnon, 1986, pp. 151-156.

135 The flaws in both theories become apparent in the case of pregnancy. According to the sameness approach no special recognition should be given to pregnancy. The (male) standard is that a person is not pregnant; therefore women will be treated equally to men as long as they are not pregnant. According to the difference approach pregnancy is a major difference between the sexes. Therefore, special laws and measures about pregnancy are called for. However, although these laws and measures are intended to guarantee substantive equality or equality of result in the sense that women, even though they are pregnant, have the right to (retain) employment, in practice stressing this difference will result in negative 
the sexes are largely ignored in the sameness approach. Women and men are treated exactly the same, notwithstanding biological differences or any disadvantages women may encounter in society. Consequently, it does not dissolve any of the problems women may encounter in realizing their rights, so that the outcome may remain unequal. It is important to achieve formal or de iure equality as regards housing rights because it is the legal foundation women can base their claims on. If, however, no further measures are taken, this legal rule may remain a dead letter. Formal equality overlooks for instance that cultural rules may exist that inhibit women from performing gainful employment or that women are discriminated against on the labour market with the result that the income of the average woman is considerately lower than that of the average man. These factors, and others, may make it almost impossible for women to finance their housing.

A positive aspect of the sameness approach is that it emphasizes the inherent equal worth of women and men.

The difference approach on the other hand, acknowledges that women and men are in some respects inherently or culturally different and allows for unequal treatment, as long as this difference in treatment will lead to an equal result for both sexes. ${ }^{136}$ In this way substantive or de facto equality can be achieved because this approach pays heed to underlying cultural structures that influence women's socio-economic position. For instance, if the goal is that every adult should be able to provide for her or his own housing, and this is in fact the case with regard to most men but not in respect to most women, it would be possible to take special measures for homeless single mothers by offering them a package of temporary shelter, child care facilities and job training. Such a measure would take into account that many women may trail behind men as regards, schooling, job perspective, and average income and are, moreover, traditionally burdened with caretaking responsibilities. The fact that this specific group of women would be treated differently is justified by the fact that there is equality of result; these women like most adult men will be able to provide for their own housing.

Though the difference approach to equality is to be preferred over the sameness approach, it has also an important drawback; much emphasis is put on the fact that women are not the same as men, which may be confused as being inherently unequal, or inferior.

In order to achieve substantive equality the focus may be on creating equal access, chances or opportunities for women. Though these measures are potentially very helpful and may well improve women's situation, there is still a chance that the desired result, fulfilment of a certain right, will not be achieved. For instance, although many States have removed several barriers-like changing inheritance laws and discarding the custom that denies women legal capacity-in order to guarantee equal access of both sexes to land, this has not resulted in equal numbers of women and men having property rights to land. Still the economically disadvantaged position of many women prevents them from acquiring a plot of land, while cultural rules may inhibit them from claiming their rightful share in the inheritance. That is why the form of equality that should be aimed

stereotypes of women and employers may decide against employing a woman because in the event of her pregnancy they may have to pay for pregnancy and maternity leave. In this way the special measures for women reinforce discrimination against them. Brenda Cossman, 1990, pp. 26-27.

136 Catharine MacKinnon, 1986, p. 145. Brenda Cossman, 1990, pp. 25 and 31. 
at is equality of result. ${ }^{137}$ If the aim is that at any given time the fulfilment of a certain right should be on the same level for women and men, all kinds of measures, legal and otherwise, can and should be taken until this result is achieved. If the focus is on creating chances and opportunities or access, legal and policy measures may tend to stop when these have been attained while the ultimate goal, equal realization, still may not be achieved.

An important tool that may be used in order to achieve equality of result is affirmative action, also called temporary special measures. The fact that women as a group have been discriminated against for centuries and as a consequence are generally in a disadvantaged socio-economic position, justifies that special measures are taken that bring about the advancement of women. ${ }^{138}$

Notwithstanding the obvious negative consequences it may under certain circumstances have for individual men, affirmative action is not to be considered as discrimination of men. ${ }^{139}$

Not every measure that empowers women and works to their advancement falls within the category of affirmative action. General policy measures that combat discrimination and further the equality of women and girl children are to be regarded as normal implementations of these principles. Only measures that are taken to accelerate concrete goals for women of de facto equality are to be considered as affirmative action. ${ }^{140}$ Examples in this regard are quotas as regards female representation in political or public bodies, and numerical goals to be achieved in education and employment. ${ }^{141}$

Although affirmative action is meant to be only temporary as a sort of stopgap solution that may be used only as long as the unequal situation exists, it seems to me that some of these measures may be needed for a very long period indeed because equality

137 According to CEDAW equality of results is the 'logical corollary of de facto or substantive equality'. CEDAW General Recommendation No. 25, on Article 4, paragraph 1, on temporary special measures, 2004. Sandra Fredman warns that there is a danger in focusing on results since these may have been brought about by a successful assimilationist policy, i.e. the underlying gendered differences are still intact, and the increased number of participating women must be attributed to the fact that women have adapted to the male patterns. Sandra Fredman, 'Beyond the Dichotomy of Formal and Substantive Equality: Towards a New Definition of Equal Rights', in: Ineke Boerefijn, Fons Coomans, Jenny Goldschmidt, Rikki Holtmaat, Ria Wolleswinkel (eds.), Temporary Special Measures; Accelerating de facto Equality of Women under Article 4(1) UN Convention on the Elimination of All Forms of Discrimination Against Women, Intersentia, Antwerpen-Oxford-New York, 2003, pp. 114-115.

138 Some scholars call this an asymmetrical approach to discrimination of women because special treatment is given indiscriminately to women as a group. The general disadvantaged situation of women justifies that measures are taken that may be over-inclusive because not all women may find themselves in the same disadvantaged position. The opposite of this method is called the symmetrical approach; it focuses on individual cases and before a woman might be entitled to a special measure she will have to prove that she has been discriminated against in a specific, concrete case. See Titia Loenen, 1994, pp. 268-270. Also see Martha Minow, 1990, p. 49.

139 CEDAW General Recommendation No. 25, para. 18.

140 Ibidem, para. 19.

141 Hanna Beate Schöpp-Schilling, 'Reflections on a General Recommendation on Artice 4(1) of the Convention on the Elimination of All Forms of Discrimination Against Women', in: Ineke Boerefijn, Fons Coomans, Jenny Goldschmidt, Rikki Holtmaat, Ria Wolleswinkel (eds.), Temporary Special Measures; Accelerating de facto Equality of Women under Artice 4(1) UN Convention on the Elimination of All Forms of Discrimination Against Women, Intersentia, Antwerpen-Oxford-New York, 2003, p. 30. 
between women and men will depend to a large extent on a change of mentality in society and this is a slow process. ${ }^{142}$

\subsubsection{Equity}

There is much confusion about the meaning of the term equity. Scholars, States and human rights organizations sometimes use equality and equity as interchangeable terms. ${ }^{143}$ Since the consequences of applying either concept may make a huge difference, further clarification is needed.

From a purely grammatical point of view equity would seem to be a useful term; it is used as a synonym for natural justice and its basic meaning is evenness or fairness. The premise is that if situations differ the treatment may be different as long as the result is fair. This would seem to concur with equality of result.

In practice, however, equity is used by some cultural and religious societies, for instance Muslim and Hindu, to justify that women are treated differently and that they have subjugated positions in the family. ${ }^{144}$ From a universal human rights point of view this difference may equate to discrimination because the 'fair' result that is to be achieved may not be synonymous with an equal result. Some societies that use the equity system are in fact based on the idea that men are superior to women in the order of society. A man is regarded as head of the household and in this position he may take all kinds of decisions like forbidding his wife to find gainful employment, thus making her financially dependent. The justification for this unequal balance of power is that a woman is compensated for her lack of power and autonomy because her husband is under the obligation to provide her with everything she may need. An important flaw of these equity systems is, however, that they are based on the ideal of the harmonious family. Fairness and balance fly out of the window, however, if women are abused, rejected, divorced or widowed. Keeping women dependent is a fertile soil for suppression. Moreover, in many cases it is unclear what women think of their place in society since it is typical of these societies that women's voices are hardly ever heard in decision-making bodies and there may be some doubt whether they are legally literate enough to make informed choices.

142 The result of affirmative action should be closely monitored. As soon as the required result has been achieved, the measures should be discontinued. Ibidem, para. 20.

143 Janet Saltzman Chafetz, e.g. has entitled her book 'Gender Equity', though no definition of equity is given, chapter after chapter deals with equality. Janet Saltzman Chafetz, Gender Equity; An Integrated Theory of Stability and Change, Sage Publications, Newbury Park/London/New Delhi, 1990. Also see e.g. the combined third and fourth periodic report of Zambia submitted to CEDAW, UN doc. CEDAW/ C/ZAM/3-4, 12 August 1999 and the Report of the Economic Commission for Africa on Sub-Regional High Level Policy Seminar on Gender Equity, Social and Economic Empowerment of Women, Lusaka, Zambia, 6-8 April 1998.

144 Equity may be invoked to preserve the interests of the privileged. At the Fourth World Conference on Women in 1995 the concept of equity was used to counter claims to equality of women and girls. Especially Islamic States argued that equal rights to inheritance were unacceptable since the different roles of men and women require an equitable distribution of assets corresponding to the different responsibilities. Hilary Charlesworth and Christine Chinkin, The boundaries of international law; A feminist analysis, Manchester University Press, Manchester, 2000, p. 80. 
A problem of a different order is that in common law systems the term equity may have a totally different meaning because it may refer to a system of rules developed since mediaeval times and applied by the Chancellors of England and the Courts of Chancery and the Chancery Division of the High Court, as contrasted with the body of principles and rules of the common law developed and applied by the common law courts. ${ }^{145}$

It may be clear that equality and equity cannot be used as synonyms, and that States or societies that apply an equity standard do not live up to the obligations of equality between women and men they may have under international or regional human rights instruments. Furthermore, civil and common-law systems hold such different views as regards equity that it will only add to the confusion if this term is used.

\subsubsection{Principle of Non-Discrimination}

Applying the principle of non-discrimination will prevent that people are excluded from enjoying their human rights and it will further their equality. The international human rights instruments that are most pertinent for this study all condemn discrimination based on sex. It is unclear, however, what is meant by this concept, especially in view of the fact that the perception of what discrimination against women entails may have changed since the adoption of the international instruments. Feminist scholars now also speak about discrimination based on gender, and it seems that CEDAW, for one, is also defining discrimination against women in this way. Clarifying this issue is important since discrimination based on gender allegedly has a much broader scope than discrimination based on sex. Furthermore, analysing the basis and scope of discrimination gives better insights in the ways how to eliminate it. After dealing with the concepts of sex and gender discrimination, the last sub-section will go into the distinction between direct and indirect discrimination.

\subsubsection{Discrimination Based on Sex}

The concept of discrimination based on sex used to be understood as encompassing any form of discrimination against women. A few decades ago, it was thought that prohibiting discrimination on this ground would be enough to guarantee women's equal rights with men. Nowadays, feminist scholars perceive the term sex discrimination as too restrictive. The term inadequately expresses that women are not only discriminated against because of their genitalia, but also because of underlying socio-economic perceptions about women. Still, in order to clarify the complexity of the matter, it might be helpful to reserve the term sex discrimination for that form of discrimination against women that is based on biological differences between women and men.

However, not every distinction based on biological differences should be regarded as sex discrimination. In fact, the sex criterion is used in a three-tiered approach to distinguish women from men and each approach has different effects and warrants different measures.

145 The Oxford Companion to Law, Clarendon Press, Oxford, 1980, pp. 424-426. 
The first approach is based on women's actual physiological condition as regards their child bearing capabilities. The second approach is concerned with the difference in physical strength between women and men and women's potential fertility. The third approach uses sex as the distinguishing criterion to bestow rights or to impose duties.

As far as the first approach is concerned it can be said that treating women differently because of their actual physiological condition pertaining to childbearing may be useful and even necessary. For instance, a woman who is pregnant or who has recently given birth may need protection and special treatment like pregnancy leave or the guarantee that her job is still available when she returns to the work floor after having given birth. Another example is that pregnant and menstruating girls and women need specific health care and facilities in refugee camps. Special facilities may also be needed for women who are lactating. If employed, they should get the chance to nurse their babies in a separate room during working hours.

It should be avoided that this kind of treatment of women, that is justified and to their benefit, is called discrimination, since this term has a negative connotation. ${ }^{146}$

The second approach distinguishes women from men because of their differences in physical strength and their potential fertility. These are dubious criteria, however, that in certain circumstances amount to sex discrimination. The presumption that women have less muscular power than men is based on the average woman and the average man. That is why careful consideration and evaluation is needed as regards legislature or policy measures that use this criterion since a general distinction of this kind may be discriminatory towards women. Muscular strength is a biological factor that is individually determined. Banning all women from work that involves heavy lifting, for example, may exclude some women from doing a well-paid job that some men, who have less than average strength, are incapable of performing. This is typically an example of the overprotected legal measures that are taken with the best intentions, but which have the effect of discriminating women on the basis of their sex. ${ }^{147}$

On the other hand, based on the fact that most women will be physically less strong than most men and thus are not always able to fend for themselves, it is justified that special protective measures are taken in cases of gender based violence, like the establishment and upkeep of shelters for battered women. Again, those measures that are justified and to women's benefit should not be called discrimination.

The potential fertility of women is a distinguishing criterion that should be closely guarded because it may also have the effect of discriminating women. Particularly

146 Also Titia Loenen, 'Het discriminatiebegrip', in: A.W. Heringa, J. Hes, L. Lijnzaad (eds.), Het Vrouwenverdrag: een beeld van een verdrag ..., Maklu Uitgevers, Antwerpen-Apeldoorn, 1994, p. 5 Martha Minow agrees that such measures may be justified but at the same time she points out the danger of negative stereotypes that such special benefits may invoke and that may be to women's disadvantage on the work floor. Martha Minow, Making All the Difference; Inclusion, Exclusion, and American Law, Cornell University Press, Ithaca and London, 1990, p. 41.

147 Examples are the ILO Conventions on Underground Work (1935) and on Maximum Weight (1967) respectively prohibiting the employment of women of every age in underground work and determining that the maximum weight women are to transport manually must be 'substantially less than that permitted for adult male workers'. Valerie Oosterveld, 'Women and Employment', in: Kelly D. Askin and Dorean M. Koenig (eds.), Women and International Human Rights Law, Vol. 1, Transnational Publishers, Inc., Ardsley, New York, 1999, p. 371. 
labour law regulations may exclude women from doing hazardous jobs, like working with chemicals and radiation with a view to protecting women's fertility or their potential foetuses. Women who want to become pregnant, and their possible children may indeed benefit from such rules, but women as a group are not potentially pregnant. General legislative measures of this sort affect all women while some of them do not want any children or do not want any more of them, are infertile or are menopausal. Women who are aware of the health hazards of a certain job, but who are willing to take it because of the higher than average pay check, incidentally the same reason why some men are prepared to take this risk, should be allowed to make their own decisions. ${ }^{148}$

The third approach entails that legislation, policy measures or custom use the sex criterion to bestow either of the sexes with rights, or impose either of the sexes with duties. For example, in some societies only men have property rights or are entitled to the inheritance, while only women must observe purdah. The reason why sex is such an important distinguishing element is that a whole set of prejudicial assumptions concerning characteristics, abilities, and preferred roles in society is attached to being either a woman or a man. In general, the distinction is not neutral; women are deemed to be inferior and are disadvantaged. This approach to sex as a distinguishing criterion should be called discrimination based on gender.

From the above it may be clear that not every legal, customary, or policy distinction between women and men based on biological differences should be abolished. Sometimes a distinction may be justified and to women's advantage. That is why the term discrimination based on sex should only be used for those distinctions that are made on account of biological differences that cannot be justified and that are to women's detriment. The next sub-section will go into the intricacies of gender discrimination.

\subsubsection{Discrimination Based on Gender}

Gender is a complex term that causes much confusion, on the one hand because the scholarly understanding of gender is different from the grammatical one, ${ }^{149}$ and on the other because scholars vary with their descriptions. ${ }^{150}$ That is why an authoritative defini-

148 Catharine MacKinnon may have a point when she states that women get protected out of jobs because of their fertility. Catherine MacKinnon, 1987, p. 150. The ILO has also progressed from excluding all women, like in the 1921 White Lead (Painting) Convention, to merely excluding pregnant women and nursing mothers from coming into contact with dangerous substances such as in the 1971 Benzene Convention. Valerie Oosterveld, 1999, p. 370.

149 Gender is described as 'The classification by which words are grouped as feminine, masculine, or neuter; or the sex of a person', in: Webster's Universal Dictionary and Thesaurus, Geddes \& Grosset Ltd, New Lanark, Scotland, and as 'grammatical grouping of words (nouns and pronouns) into classes (masculine, feminine and neuter) in the Oxford Advanced Learner's Dictionary of Current English, Oxford University Press, London.

150 Gender is described by Lacey as 'the socially constructed meaning of sex', Nicola Lacey, 'Feminis Legal Theory and the Rights of Women', in: Karen Knop (ed.), Gender and Human Rights, Oxford University Press, Oxford, 2004, p. 15. Charlesworth and Chinkin describe gender as: '[...] the excess cultural baggage associated with biological sex. "Gender" draws attention to aspects of social relations that are culturally contingent and without foundation in biological necessity.' Hilary Charlesworth and Christine Chinkin, The boundaries of international law; A feminist analysis, Manchester University Press, Manchester, 2000, p. 3. Saltzman Chafetz's definition is 'the socioculturally constructed compo- 
tion is needed that can be used by States and any human rights bodies or organizations that concern themselves with combating discrimination or monitoring compliance to the principles of non-discrimination and equality. ${ }^{151}$

Notwithstanding the variety in descriptions, the feminist view of gender comes down to regarding it as a set of supposed differences society uses in order to distinguish between women and men. These supposed differences find their basis in the fact that certain characteristics and abilities are ascribed to either of the sexes as if they were general, inherent, and unchangeable. These suppositions may elaborate factually existing biological differences, but this is not necessarily the case. For instance, the assumption that women are naturally inclined and better able than men to raise children, is based on the biological fact that women can bear children. The assumptions that women do not possess the necessary characteristics for leadership positions or political functions, while initiative, leadership and power are characteristics that are typically attributed to persons of the male sex, cannot be linked to any biological fact.

The assumptions about women's characteristics and abilities taken together constitute the ideas about their gender and determine to a large extent women's socio-economic position in society and the roles they are expected to play therein. ${ }^{152}$

Despite cultural, religious and developmental differences among the many countries and societies in the world, a few similar ideas as regards supposed ideal roles of women and men in society based on gender exist worldwide. The most important of these common phenomena that have a bearing on the right to housing are patriarchy, the gendered division of work, and violence against women.

The system of patriarchy, based on the idea of leadership qualities of men, entails that a male should be the head of the household and in this function he has the property rights over land and housing and he chooses the domicile.

The division of work is based on the supposition that women are naturally suited for care-taking work and are best kept in the private sphere, while men are gainfully employed in the public sector in order to provide for their families. If women do enter the job market, the gendered ideas about suitable work finds it continuation in the fact that

nents attached to each sex'. Janet Saltzman Chafetz,, 1990, p. 28. Gender was understood by the feminist activists in the 1970 s as 'a social construction rather than a "natural" fact. Cynthia Carter and Linda Steiner, 'Introduction to Critical Reading: Media and Gender', in: Cyntia Carter and Linda Steiner (eds.), Critical Readings: Media and Gender, Open University Press, Maidenhead, 2004, p. 3.

151 It is very fortunate that in July 2004 CEDAW has taken it upon itself to draft a General Comment on Article 2 of the Women's Convention. It is to be hoped that this Comment will give clear definitions of equality, equity, and discrimination, and, perhaps most importantly, will clarify the concept of gender since States and human rights bodies do not always understand what is meant by this concept and think that they have fulfilled their obligations when they abolish, or monitor the abolishment, of discrimination based on sex. During its $31^{\text {st }}$ session CEDAW held a day of general discussion on $21^{\text {st }}$ July 2004, in order to take the first step towards such a General Comment. A small working group has been formed that will submit its first concept to the plenary meeting in 2005 .

152 As has been mentioned before in section 3.7 on Structural discrimination inherent in cultural patterns, men are also forced to take up a certain role in society. Although this may entail that they are burdened with certain duties and responsibilities, on the whole they have more possibilities to take their life in their own hands. As far as housing is concerned, the gendered construction of men's lives entails that they have far more perspective of being able to finance their own housing or of being the heir of a property. Moreover, the great majority of victims of violence at home are women, not men. 
the majority of women are employed in the care-taking, cleaning, nursing and servicing sector; jobs that have the common characteristics of low status, low pay and hardly any career possibilities. The result of the gendered division of work is that many women remain dependent on men for their housing all their lives; they cannot provide for their own housing, nor can they escape or influence an inadequate housing situation. If housing is no longer provided for them, for instance in case of divorce or widowhood, women may become homeless.

Violence against women, particularly in the domestic sphere, is based on the societal assumption that women are inferior to men and that men are naturally suited to exercise authority. Domestic violence is worldwide one of the most important factors that render the housing situation for women inadequate because women lack security, dignity and privacy in their own home.

Every distinction based on gender is to women's detriment since it is grounded on prejudice and stereotyping; it will perpetuate women's subordination in society and it will curb the full realization of women's human rights. Therefore, any distinction based on gender is unjustified and should be eradicated in the interest of empowering women and enabling them to realize their human rights.

\subsubsection{Direct and Indirect Discrimination}

While the terms sex and gender discrimination denote which sort of discrimination we are dealing with in the sense of which distinguishing factor triggers the discriminatory acts, the terms direct and indirect discrimination are concerned with the manifestation of discrimination; overt or covert.

Direct discrimination against women will manifest itself in legislation or customary rules by openly denying girls and women certain rights or obliging them to act in a certain way. ${ }^{153}$ Examples are denying girls the right to education, imposing dress codes on women, forbidding women to drive a car, and banning women from night work. Direct discrimination may be tackled by abolishing sex discriminatory laws, by adopting laws that prohibit discrimination based on sex, and by instigating monitoring and complaint mechanisms that keep a watchful eye and interfere when necessary.

However, though abolishing direct discrimination is a necessary step that has to be taken, it may result in mere formal or de iure equality, since it will not grapple with the underlying social constructions that perpetuate discrimination against women in practice. Achieving de iure equality cannot be missed as a legal basis, but it is only the first step that must be followed up by the tearing down of the barriers that impede the implementation of equality in practice.

The characteristic of indirect discrimination is that it is not so easy to detect because provisions and policies may be formulated in a 'sex-neutral' way and yet only have negative consequences for women. ${ }^{154}$ This effect is the result of the many societal rules

153 Titia Loenen, 'Rethinking Sex Equality as a Human Right', in: Netherlands Quarterly of Human Rights, Vol. 3, 1994, p. 259.

154 Nicola Lacey describes it as: 'the existence of arrangements which, though facially neutral, in fact serve to exclude or disadvantage a disproportionate number of women (or indeed men.)', Nicola Lacey, 2004, 
that are based on a male, instead of a neutral, standard and that do not take account of women's socio-economic position in society. An example is the different treatment of part-time workers. In the Bilka case ${ }^{155}$ the German department store Bilka Kaufhaus had a policy that excluded part-time workers from its occupational pension scheme. Though the policy was targeted at all part-timers without distinction as to sex, in practice particularly women were hit by the measure since the great majority of part-time workers are female. Because of the gendered division of work women who do paid employment have to combine it with household tasks. Faced with this double burden, many women are unable to cope with full-time employment, particularly since inflexible working hours are the norm that does not take any care-taking responsibilities into account.

Tackling indirect discrimination entails that underlying societal rules and notions are acknowledged, modified and abolished that create a disadvantaged position for women. Legal rules will not suffice; other means and methods should be used that change the biased, stereotypical ideas about societal roles of women and men. Successful abolition of indirect discrimination will result in practical or de facto equality of women and men.

\subsubsection{Adequacy and Applicability of the Most Pertinent Provisions}

In this sub-section a few major international human rights instruments will be discussed that include the principles of equality and non-discrimination and besides contain provisions on housing or housing related rights. These are the Covenant on Economic, Social and Cultural Rights (ICESCR), the Covenant on Civil and Political Rights (ICCPR), the Convention on the Elimination of all forms of Discrimination Against Women (Women's Convention), the Convention on the Rights of the Child (ICRC), and the Convention on the Protection of the Rights of All Migrant Workers and Members of Their Families (ICMW).

Articles 2(2) ICESCR, 2(1) and 26 ICCPR, 1 Women's Convention, 2(1) CRC, and 7 ICMW all prohibit discrimination on the basis of sex. The term 'sex' in these provisions refers to the distinction between women and men based on their genital differences. ${ }^{156}$ The term 'gender' is not mentioned in any of these documents, and it would seem unlikely that the drafters of these treaties would have used the term 'gender' as the set of assumed differences that underlie women's and men's role in society as is done by feminists today. ${ }^{157}$ In view of women's emancipation since the adoption of these instruments, and especially with respect to the surge this emancipation took after the World Conference on Human Rights in Vienna in 1993, it would be illuminating to have a

p. 14. Also Loenen, NOHR, 1994, p. 260.

155 Bilka Kaufhaus GmbH v. Karin Weber van Hartz, Europen Court of Justice of the European Communities, Case 170/84, 13 May 1986.

156 There is a recent tendency to also understand 'sexual orientation' as included in the term 'sex'. This is for instance done by the Human Rights Committee and the Committee on Economic, Social and Cultural Rights. See $U N$ doc. E/CN.4/Sub.2/2004/24, 18 June 2004, para. 22.

157 As mentioned before, CEDAW started working on a General Recommendation on Article 2 of the Women's Convention in July 2004. During the Day of General Discussion Ms Maria Regina Tavares Da Silva declared that although the term 'sex' is used in the text of the Convention, this term has always been interpreted by the Committee as containing gender factors since this was considered to be in accordance with the spirit of the Convention. 
modern interpretation of the relevant provisions by the respective supervising bodies. Unfortunately, up till now CEDAW, the Committee on Economic, Social and Cultural Rights (CESCR), ${ }^{158}$ the Committee on the Rights of the Child (CRC), and the Committee on Migrant Workers (CMW) ${ }^{159}$ have not made any General Comments on the interpretation of their respective Articles. The Human Rights Committee (HRC) is the only monitoring body to shed some light on the non-discrimination provision in Articles 2(1) and 26 in its General Comment No. 18. Although the HRC clarifies and further defines what should be understood by the term discrimination as used in the Covenant, it does not elaborate on the term 'sex'. 160

Non-discrimination provisions that merely prohibit differentiating between women and men tend to remain rather formal. With reference to housing and housing related rights this means that before the law women may not be discriminated against. In practice, these provisions are not very helpful since the underlying social and economic differences between women and men do not surface and thus the reasons why it is more difficult for women to fulfill their right to adequate housing remain in the dark. Women's cause would be advanced if the relevant monitoring bodies would not only clarify the terminology, but would also be on the same wavelength as regards viewing discrimination against women. Preferably, they should follow the lead CEDAW should take as the most authoritative body dealing with women's rights in clarifying and interpreting the relevant terms and explaining how the underlying socio-economic factors should be handled. If the supervisory bodies all issue the same message this will improve the understanding of what is expected from States parties and from other bodies that apply the principle of non-discrimination, and it will put an end to the current confusion, in which everyone is left to make their own interpretation. ${ }^{161}$

158 The Committee on Economic, Social and Cultural Rights did however request a member of the SubCommission on the Promotion and Protection of Human Rights to undertake a study on non-discrimination as enshrined in Article 2, paragraphs 2 of the ICESCR. In his subsequent working paper (UN doc. E/CN.4/Sub.2/2004/24, 18 June 2004) Mr Emmanual Decaux thoroughly analyses the concept of nondiscrimination. Although section 22 of the study is entitled 'gender discrimination', this term is not defined and in the text of the section itself the terms sex and gender are used interchangeably. $\mathrm{Mr}$ Decaux seems to understand the term 'sex' in a broad way, however. In his opinion the Women's Convention addresses the phenomenon of discrimination based on sex too restrictive because issues pertaining to discrimination against men are not included. It is my understanding, however, that the Women's Convention was specifically adopted to address the discrimination women encounter in society. Men cannot derive any rights from this Convention just like adults cannot derive any rights from the Convention on the Rights of the Child. That this is also CEDAW's opinion may be clear from General Recommendation 25 in which it is stated in section 5 that: 'The Convention goes beyond the concept of discrimination used in many national and international legal standards and norms. While such standards and norms prohibit discrimination on the ground of sex and protect both men and women from treatment based on arbitrary, unfair and/or unjustifiable distinctions, the Convention focuses on discrimination against women, emphasizing that women have suffered, and continue to suffer from various forms of discrimination because they are women.'

159 The Committee on Migrant Workers (CMW) had its first session in March 2004 and therefore has not yet published any General Comments.

160 CCPR General Comment No. 18: Non-discrimination, 10 November 1989.

161 Examples are the above mentioned report by Mr Decaux The definition of gender stated at HABITAT II in Istanbul in 1996 which was borrowed from a CSW contact group and reads: "the word "gender" [...] was intended to be interpreted and understood as it was in ordinary, generally accepted usage'. Report of 
Articles 3 ICCPR, 3 ICESCR, 2 Women's Convention, and 4 ICRC proclaim equality for all individuals who are citizens of the States parties as regards realization of the rights contained in the respective conventions, while Article 4 of the Women's Convention allows for affirmative action in order to achieve equality between women and men. ${ }^{162}$ Up till now, the CRC has not issued a General Comment on Article 4 of the ICRC.

Articles 3 of the ICCPR and ICESCR are identical except of course for the fact that they refer to a different set of rights. In these Articles the States parties undertake to 'ensure the equal right of men and women to the enjoyment' of the rights enumerated in the respective Covenants.

The HRC has issued three General Comments that may contribute to the understanding of the meaning of equality in Article 3 of the ICCPR. In two connected General Comments, the Committee made it clear that implementation of the Covenant is not restricted to legislation, because such measures may not be sufficient. In General Comment No. 3 on implementation at the national level it is stated that States parties may be under the obligation to take refuge in specific activities in order to achieve the goal of ensuring the enjoyment of all rights set forth in the Covenant. ${ }^{163}$ In General Comment No. 4 on equality between the sexes, the Committee states that prevention of sex discrimination 'requires not only measures of protection but also affirmative action designed to ensure the positive enjoyment of rights'. Enacting laws is not deemed to be enough but the role of women in practice should be regarded in order to ascertain what measures 'in addition to purely legislative measures of protection, have been or are being taken to give effect to the precise and positive obligations under Article $3[\ldots]{ }^{164}{ }^{164}$ Finally, in General Comment No. 28 on equality of rights between men and women, the Committee reiterates its Comments No. 3 and No. 4 by stating that States parties are held to take in addition to protective measures, other measures to achieve effective and equal empowerment of women. This means that they should achieve equality of result. Another important notion in this General Comment is that States parties should not only eliminate discrimination against women in the public sphere, but also in the private sector. Furthermore, it is pointed out that tradition, history, and culture including religion, may not be used to impair women's equality before the law or inhibit their equal enjoyment of the rights set forth in the Covenant. ${ }^{165}$ The views of the HRC are particularly pertinent in light of the broad application of Article 26 of the Covenant which is understood to serve as a safety

the United Nations Conference on Human Settlements, Istanbul, 3-14 June 1996, Annex V, Statement on the Commonly Understood Meaning of the Term "Gender". The Statute of the International Criminal Court of 1998, in which 'gender' is understood as referring 'to the two sexes, male and female, within the context of society. The term "gender" does not indicate any meaning different from the above'. See Article 7(3). The use of the terms sex and gender in these documents may illustrate that clarification and consistency in the application of these terms would not be a luxury.

162 The ICMW does not contain a general Article concerning equality. Several provisions dealing with specific rights, however, stipulate that migrant workers shall enjoy equality of treatment with nationals of the State of employment, for instance as regards: 'Access to housing, including social housing schemes, and protection against exploitation in respect of rents'. See Article 43(1)(d).

163 CCPR General Comment No. 3: Implementation at the national level (Art. 2), 1981, para. 1.

164 CCPT General Comment No. 4: Equality between the sexes (Art. 3), para. 2.

165 CCPR General Comment No. 28, Equality of Rights between Men and Women (Art. 3), 2000. 
net also for rights protected in other treaties, such as the Women's Convention and the ICESCR. ${ }^{166}$

It has taken the CESCR longer to agree on a text for a general comment on Article 3. The Committee started working on it in May 2002 and three years later the text of General Comment No. 16 was adopted. ${ }^{167}$ A highly positive element of this General Comment is that it incorporates the definition of discrimination against women as it is contained in the Women's Convention. This means that the scope of the prohibition of discrimination against women with regard to economic, social and cultural rights is extended to the private sphere. This is significant since many discriminating acts and circumstances that defer women from enjoying equal housing rights may be found there. In addition, States parties are required to take direct steps to eliminate prejudice, customary and other practices that perpetuate the notion of superiority of one sex over the other, and gender stereotyping. Another positive side of this Comment is that it gives clear explanations of the concepts of gender and of direct and indirect discrimination. Furthermore, temporary special measures are acknowledged as a means to accelerate the achievement of de facto equality of women. ${ }^{168}$ Under the heading of specific legal obligations it is stated that the obligations under Article 11(1) require that 'women have a right to own, use or otherwise control housing, land and property on an equal basis with men, and to access necessary resources to do so'. It is regrettable, that no concrete examples are given as to what these obligations entail and which steps States parties should actually take. In order to do justice to women's specific housing situation and to (further) comply with the gender mainstreaming strategy, the CESCR might consider to adopt a General Comment on the right to housing for women in which it can specify the obligations of States parties and make them aware of the drawbacks and pitfalls that may be encountered by women in realizing their housing rights. ${ }^{169}$

At the moment there is no General Recommendation on Article 2 of the Women's Convention as CEDAW only started working on it in July 2004. Analysis of Article 2 learns, however, that equality is to be achieved both de iure and de facto. Paragraphs a) (first part), b), c) and g) of Article 2 of the Convention are focused on achieving de iure equality which follows from the use of phrases like: to embody in their national constitutions; to adopt appropriate legislative measures; to establish legal protection; and to repeal discriminatory national penal provisions. The last part of paragraph a), and paragraphs d), e), and f) of Article 2, however, particularly aim at attaining equality in practice.

166 In Broeks v. the Netherlands (Communication 172/1984), UN doc. A/42/40, 1987, the Human Rights Committee stated that complaints of discrimination as regards the enjoyment of any human right may be brought under Artice 26 of the ICCPR provided that the States concerned has ratified the First Optional Protocol to the Covenant. The wide scope of Article 26 was reiterated by the ICCPR in 1989 in General Comment No. 18 on Non-discrimination in para. 12. Also Andrew Byrnes, 'Using Law and Procedures to Advance Women's Human Rights', in: Kelly D. Askin and Dorean M. Koenig (eds), Women and International Human Rights Law, Vol. 2, Transnational Publishers, Inc., Ardsley, New York, 2000, p. 92. Titia Loenen, 'Rethinking Sex Equality as a Human Right', in: Netherlands Quarterly of Human Rights, Vol. 3, 1994, p. 261.

167 UN doc. E/C.12/2005/3, CESCR General Comment No. 16, Article 3: the equal right of men and women to the enjoyment of all economic, social and cultural rights, 13 May 2005.

168 The full text of General Comment No. 16 may be found in Annex 4.

169 See section 4.7 where the idea for such a general comment is worked out in detail. 
Chapter IV

This becomes clear from the use of wording like: to pursue all appropriate means and take all appropriate measures, and refrain from any act or practice that is discriminating. That 'all appropriate measures' may also mean extra-legal measures, may be read in the text of Article 5 in which the phrase 'all appropriate measures' is elaborated as including reforming social and cultural patterns. All things considered, there is a strong indication that the term equality in Article 2 should be interpreted as encompassing equality of result. This also seems to be the opinion of CEDAW as expressed in General Recommendation No. 25 on temporary special measures. ${ }^{170}$ The Committee states that a purely formal legal approach of equality is considered to be insufficient. States parties should aim at substantive equality by giving women equal starts and empowering them. Identical treatment of women and men is not deemed enough to achieve equality of result. Rather, biological, socially and culturally constructed differences between women and men should be considered in order to tackle the existing inequality. ${ }^{171}$ The special measures, or affirmative action, allowed by Article 4(1) are to be considered as part of a necessary strategy to achieve substantive equality. ${ }^{172}$

\subsubsection{Concluding Remarks}

The principle of equality lies at the basis of all human rights instruments that are relevant to this study. Since the inception of these treaties, progressive thinking about this concept has cumulated in the belief that next to de iure equality, which demands that all national legislation is in line with this principle, it is of utmost important to achieve de facto equality. The ultimate form of equality in practice may be equality of result. For women it entails that the fulfilment of their human rights, like the right to adequate housing, should at any time be on the same level with that of men. In order to achieve equality of result permanent and temporary measures may be taken. A permanent tool is the application of the principle of non-discrimination; if women are not excluded from enjoying human rights equality will be the result. An important temporary tool is affirmative action; special measures intended to accelerate the equal participation of women in society or the enjoyment of women of their human right. Although such measures may be focused solely on (a specific group of) women they may not be considered as discriminating men.

Equality of result may be regarded as a highly useful yardstick to measure whether the goal of equality has been achieved. However, as far as the right to housing is concerned it can only be of relative importance since equality between women and men in this respect is no indication of the quality or adequacy of the housing situation.

Discrimination against women is usually transcribed as a prohibition to discriminate on the ground of sex. However, it may be recognized that a three-tiered approach exists as to sex as a factor to distinguish between women and men. According to the first approach sex is understood as the actual physiological conditions women may find themselves in

170 CEDAW General Recommendation No. 25, on Article 4, paragraph 1, of the Convention on the Elimination of All Forms of Discrimination against Women, on temporary special measures, 2004.

171 Ibidem, paras 8-10.

172 Ibidem, para. 18. 
that pertain to their childbearing capabilities. The relevant circumstances are menstruation, pregnancy, childbirth and the period immediately following it, and lactation. Women who find themselves in any of these situations may be in need of protection or specific measures. Therefore, such measures that are to women's advantage and that enable them to enjoy their equal rights without being inhibited by their childbearing capabilities cannot be considered as sex discrimination.

The second approach to sex is more problematic. Views about physical strength and potential fertility of women may be used both to women's benefit and to their detriment. It is to women's detriment when certain physical characteristics are presupposed and used as if applicable in a general way. Legislation and measures based on the supposition that all women have little physical strength or are potentially pregnant, may result in overprotection and exclusion of large quantities of women. This may particularly be the case with regard to regulations pertaining to heavy or hazardous types of work, typically work that will earn an income sufficient enough to provide for adequate housing. Thus such measures may for some women come down to sex discrimination.

On the other hand, for a certain category of women, or women in specific circumstances, it may be highly relevant that they are protected either because they lack physical strength or because they wish to become or are pregnant. For instance specific protection measures premised on the idea that women are the weaker party in cases of domestic violence are very much in the interest of the adequacy of women's housing situation. Therefore, vigilance is called for when physical characteristics are used as arguments to take special measures that protect women; generalization should be avoided if the possibility exists that they may result in sex discrimination.

The third approach to sex is to attach to the genital difference between women and men a set of assumptions pertaining to qualities, roles and abilities that is completely unconnected to actual or relevant biological conditions but that in practice is used as the justification why women should be excluded from certain rights or be burdened with certain tasks. This social construction that goes beyond biological facts should be called gender. As prejudice and stereotyping lie at the basis of determining gender, this approach is always to be considered as discrimination and therefore should be combated and abolished. However, legislative measures may not be enough since ideas about gender are fixed in society and culture. That is why a change of mentality is called for that may be brought about by education and information. As far as the right to housing is concerned, it is of particular importance that patriarchy, the gendered division of work and violence against women would be abolished. Together they are the cause that women have less or no influence on where and how they are housed, that many of them are incapable of financing adequate housing for themselves and that they lack security, dignity and privacy in their own home.

As far as the interpretation of the most pertinent treaty provisions is concerned, it can be said that the concepts of sex and gender discrimination are in need of further clarification and consistency among the major human rights monitoring bodies. It would be particularly useful if CEDAW would issue a general recommendation in which these concepts are clarified and which could be considered as the most authoritative interpretation by States and human rights organs and organizations. 
Chapter IV

With regard to the interpretation of the principle of equality between women and men a promising trend is to be discerned. According to the HRC, CEDAW and the CESCR equality entails both de iure and de facto equality. It is important, however, that this understanding of equality is translated into concrete demands as regards measures that are to be taken by States parties. For women's housing rights this would mean that next to the normally required non-discriminatory legislation and policies in respect to property rights, inheritance, access to credits and loans, etc., special measures, like the abolition of customary laws and traditional practices or the granting of special housing subsidies for female heads of household, may be requested until the fulfilment of women's right to adequate housing is at the same level as men's.

\subsection{INTERNATIONAL HOUSING NORMS}

\subsubsection{Introduction}

In the context of this chapter it is useful to recapitulate to what extent a woman's perspective has or has not been included in those provisions that are directly concerned with the right to housing and that are contained in the main international human rights instruments. Comments will be made on the existing situation and recommendations will be made as to possible improvements. The first section will go into Article 11(1) of the International Covenant on Economic, Social and Cultural Rights (ICESCR). Since this provision has been further interpreted by the Committee on Economic, Social and Cultural Rights (CESCR) in General Comment No. 4 on Adequate Housing and General Comment No. 7 on Forced Evictions, these two general comments will be studied as well. In section 4.4.3 Article 14(2) of the Women's Convention will be discussed. Given that this Convention mentions the right to housing only in the context of rural women, the provision is not immediately applicable to the housing situation of all women in a country. Section 4.4.4 will go into Article 5(e)(iii) of the Convention on the Elimination of All Forms of Racial Discrimination (ICERD). Article 27(3) of the International Convention on the Rights of the Child (ICRC) is the subject of section 4.4.5, while the last section will examine the specifics of Article 43(1)(d) of the International Convention on the Protection of the Rights of All Migrant Workers and Members of Their Families (ICRMW).

\subsubsection{Article 11(1) Covenant on Economic, Social and Cultural Rights}

Article 11(1) is probably the most important international human rights provision concerning the right to adequate housing. ${ }^{173}$ The question is to what extent Article 11(1) ICESCR is applicable to women's housing situation. The wording of this provision is rather dubious from a woman's point of view since States parties are held to recognize

173 This is also the point of view of the CESCR, see General Comment No. 4, The right to adequate housing (Art. 11(1) of the Covenant), 13 December 1991, para. 3: 'Article 11(1) of the Covenant is the most comprehensive and perhaps the most important of the relevant provisions'. On Article 11(1) also see Chapter II, in particular section 2.2 . 
the right to an adequate standard of living, including adequate housing, of everyone, both for himself and for his family. ${ }^{174}$ However, that this right is not meant to be exclusively male related may be inferred from Article 2(2) which prohibits discrimination of the rights contained in the Covenant on any ground, including sex. ${ }^{175}$ Furthermore, Article 11(1) must be read in conjunction with Article 3 which applies the principle of equality between women and men in relation to all the rights mentioned in the Convention. ${ }^{176}$ Any remaining doubt about the inclusion of women has been taken away by the CESCR in its General Comment No. 4 on the right to adequate housing. ${ }^{177}$ In section 6 of this Comment it is stated that the wording of Article 11(1) must be understood in the societal context of the 1960s when stereotyped ideas about gendered roles of women and men prevailed and when it was perceived as logical that the man of the household, being the traditional breadwinner, would provide for housing for his partner and his children. Commensurate to the changed societal patterns the Committee, however, interprets this provision in 1991 as equally applicable to individual women and female-headed households.

Thus far it has only been proven that according to the CESCR as regards Article 11(1) formal equality exists between women and men. The next question is whether this provision and its monitoring Committee go a step further and also request substantive equality between women and men concerning adequate housing. This would be true if the provision and its interpretation take the actual impediments into account that women encounter in fulfilling their housing rights, when States parties are questioned on these barriers, have to report on them, and are duty bound to level them, all under the supervision of the Committee. Since substantive equality cannot be deduced from the text of Article 11(1), it is essential to look into the two general comments on this Article.

\subsubsection{General Comment No. 4}

In General Comment No. 4 the concept of adequacy is further clarified in section $8 .{ }^{178}$ Despite the Committee's statement in section 6 of this Comment on gender equality, many gender specific circumstances that de facto influence the adequacy of women's housing situation are not brought up. In addition, the fact that stereotyped roles still

174 The exact text of Article 11(1) reads: 'The State parties to the present Covenant recognize the right of everyone to an adequate standard of living for himself and his family, including adequate food, clothing and housing and to the continuous improvement of living conditions. The State parties will take appropriate steps to ensure the realization of this right, recognizing to this effect the essential importance of international co-operation based on free consent' (emphasis added).

175 The relevant part of Article 2(2) reads: 'The State parties to the present Covenant undertake to guarantee that the rights enunciated in the present Covenant will be exercised without discrimination of any kind as to $[\ldots]$ sex $[\ldots]$.'

176 Article 3 of the Covenant reads: 'The State parties to the present Covenant undertake to ensure the equal right of men and women to the enjoyment of all economic, social and cultural rights set forth in the present Covenant.'

177 For the full text of General Comment No. 4 see Annex 2.

178 The various aspects determining adequacy that are mentioned in section 8 are: a) legal security of tenure, b) availability of services, c) affordability, d) habitability, e) accessibility, f) location and g) cultural adequacy. For further details of section 8 General Comment No. 4, see section 2.4, and section 3.4. 
influence the socio-economic position of women is largely ignored. However, explicit mentioning is imperative in order to create awareness of these special circumstances and to make gender specific monitoring possible.

For instance, with regard to legal security of tenure no mention is made of the possibility of harassment and threats coming from intimates. That domestic violence is also a threat to security and safety at home is essential for understanding many women's housing situation. ${ }^{179}$ Furthermore, for many women tenure is also threatened and violated in situations where traditional practices allow relatives or in-laws to evict them because their fathers or husbands have passed away. ${ }^{18}$

Availability of services is formulated neutrally but actually facilities like safe drinking water, the provision of energy for cooking, washing facilities, refuse disposal, and site drainage are much more in the interest of women than of men in view of the fact that domestic work traditionally is on women's plate. ${ }^{181}$ Therefore women's access to these services should be the focal point.

Concerning affordability, the point of view is expressed that the percentage of housing-related costs should in general be commensurate with income levels. However, it should be acknowledged that there is a huge gap between the income levels of women and men. Women's wages in general will be under the average income level. Therefore vigilance is called for and an 'acceptable' percentage of housing costs should not be based on the average income since this will mean that adequate housing will be disproportionately costly or even too expensive for the majority of women who have to provide housing for themselves and/or their families. ${ }^{182}$

Under habitability, no mention is made of the fact that in general women run higher risks of falling ill because of unhealthy housing situations since they spend much more time in the house doing all kinds of chores. Especially the exposure to smoke, dampness, triatomine insects, and polluted water has a negative effect on women's health. ${ }^{183}$ This is particularly serious in those countries where women's access to health care is lower than men's.

Although with regard to accessibility mention is made of several disadvantaged groups that are in need of extra support, the vast group of female headed households, including widows and divorcees, is not referred to. ${ }^{184}$

Concerning location no attention is paid to the fact that in some countries women are traditionally relocated without their consent because they have to move to their husband's community upon marriage or because there is legislation determining that a married man may decide the family's place of residence. ${ }^{185}$ Furthermore, it should be taken into consideration that more women than men are at risk because larger numbers

\footnotetext{
179 See section 3.3.5 on domestic violence.

180 See section 3.3.2.4 on evicted women.

181 See section 3.4.4 on technical and infrastructure deficiencies.

182 See section 3.2.3.2 on employment.

183 For particulars see section 3.4.4.1 on habitability and health problems.

184 See section 3.2.4 on female headed households.

185 See section 3.7 .3 on custom and tradition.
} 
of women live on dangerous sites - either disaster prone areas or polluted sites- simply because living there is cheaper or for free and women on average are poorer than men. ${ }^{186}$

Finally, the aspect of cultural adequacy draws attention to the importance of building in such a way that the cultural identity and diversity of housing is preserved. However, it might be more in the interest of women to focus on safety building, i.e. build housing in such a way that harassed women can easily call for help. This may be at the cost of some privacy but more public scrutiny might forestall men from battering.

In view of the culturally determined home-centred life of most women in this world, it should also have been stressed that women are to be informed, consulted and involved in any decisions about the construction of houses and neighbourhoods. After all, women's vast experience in this regard may constitute an invaluable contribution.

Section 10 of General Comment No. 4 mentions several steps that States parties should take immediately. In order to do justice to women's specific situation it might be added that another step that should be taken without delay is the abolition of all legislation, policy measures and practices that inhibit women from fulfilling their housing rights on an equal footing with men. Of particular importance are those rules and practices that make women dependent on men for their housing situation such as discriminating inheritance laws, denying women legal capacity, withholding equal rights to property and/or administration of property and denying women a free choice of residence. ${ }^{18}$

Finally, section 12 requests States to make an inventory of the population's housing situation and subsequently to adopt a national housing strategy while section 13 calls upon States parties to provide the Committee with particular information on those groups in society that are vulnerable and disadvantaged with regard to housing, such as the homeless and low-income groups. In order to highlight women's housing situation it is vital that all this information should be gathered and provided in sex-disaggregated data. Otherwise women's particular difficulties as regards housing may go unnoticed with the effect that ineffective legislative or policy measures will be recommended and taken. ${ }^{188}$

\subsubsection{General Comment No. 7}

General Comment No. 7 is based upon the idea that all persons should have a certain degree of security of tenure which will protect them against forced eviction, harassment and other threats. ${ }^{189}$ In section 11 of the Comment the CESCR points out that some people, particularly women, suffer disproportionately from forced evictions. The Committee rightly states that homeless women are vulnerable to acts of violence and sexual abuse, and that it is harder for them to find alternative housing because they are discriminated against with regard to procuring property rights or gaining access to accommo-

186 See section 3.3.3 on natural and human-made disasters.

187 More about discriminating national laws in section 3.5 on private law issues.

188 It should be noticed that the Committee's reporting guidelines also date back to 1991 and do not include the request to provide sex-disaggregated data with regard to housing. $U N$ doc. E/C.12/1991/1, Revised general guidelines regarding the form and contents of reports to be submitted by State parties under Articles 16 and 17 of the International Covenant on Economic, Social and Cultural Rights, 17 June 1991, Article 11 under 3, The right to adequate housing.

189 The full text of General Comment No. 7 may be found in Annex 3. 
Chapter IV

dation or credit. States are urged by the Committee not to evict in the first place, and to provide safe alternative housing when evictions cannot be avoided.

What is not covered by General Comment No. 7 and what nevertheless should be noted to understand women's housing situation, is that women are not only evicted by public authorities and third-parties who indiscriminately remove whoever is living on a certain plot or premises they want for other purposes, but in addition many women are evicted by intimates. This type of eviction is likely to happen at a time when a woman is already vulnerable because her father or her husband has died. Relatives or in-laws will claim the house to which they are entitled according to law or custom and tradition and may no longer allow the woman to stay in her parental or marital home. These practices happen in large parts of the world and yet many authorities do not interfere notwithstanding that many women formally have equal rights to the property. ${ }^{190}$ This type of eviction is psychologically more damaging for a woman than being evicted by strangers since she is abandoned and rendered destitute by the very people she is related to by blood or family ties.

In section 4 of General Comment 7 it is pointed out that eviction is not prohibited when carried out in accordance with the law and in conformity with the provisions of international human rights conventions. Subsequently, section 12 spells out some of the circumstances in which eviction is permissible, among which is mentioned persistent non-payment of rent. This statement in its generality is very difficult to reconcile with women's specific situation. As has been mentioned above under affordability, women's socio-economic position greatly differs from men's. Both in developed and developing countries the average income women earn is lower than men's. This may even be the case when women and men do exactly the same job or perform work of equal value. ${ }^{191}$ That is why the acceptable amount of housing costs should be determined by ratio of a person's income. At present, more women than men are unable to pay the rent for adequate housing while rent increases will much sooner force women to give up their rented housing. That is why it is incorrect to assume that non-payment of rent would generally justify eviction. Moreover, it should be pointed out that States have obviously failed their obligation to support the needy with housing subsidies or protect them against unfair rent increases if a considerable number of people cannot afford the rent for adequate housing. ${ }^{192}$

190 Although exact figures are not available, it is highly likely that far more women are evicted because of traditional practices than due to well-documented spectacular eviction schemes that figure prominently in the media. Also see sections 3.3.2.4 on evicted women and 3.3.4 on widowhood.

191 The reasons why women earn less than men include that world-wide women have enjoyed less education and job training than men, so they have to work in low-paid jobs. Traditional 'women's work' is held in lower esteem and is therefore paid less than 'men's work'. Many women can only work part-time because they also have to raise their children and do the household. Many women work in the informal sector where they are not protected by labour laws and where the wages are often below the legal minimum. Even well educated women may be discriminated against on the work floor because they do not receive the same salary as their male comparators and they are passed over for promotion. Also see section 3.2.3.2 on employment.

192 According to section 8(c) of General Comment No. 4: 'State parties should establish housing subsidies for those unable to obtain affordable housing, as well as forms and levels of housing finance which adequately reflect housing needs.' 
It is not enough to merely mention that women are disproportionately affected by eviction, but situations should be specified so that it becomes clear what States parties should be aware of and what is considered as unacceptable by the CESCR. For example, homeless women not only run an increased risk of being (sexually) abused by strangers, but inadequate housing conditions also heighten the incidence of domestic violence. This risk factor should also be taken into consideration when alternative (emergency) housing is being offered.

A specific gendered economic effect of eviction is that many women lose their source of income because they can no longer pursue the informal income generating activities they normally deploy in and about their homes like growing and marketing vegetables, selling eggs or other produce, or performing some kind of cottage industry.

Because of the gendered division of work evicted women experience particular hardship in fulfilling their traditional family supporting tasks. Cooking food, fetching water and washing clothes become very burdensome. In addition, women's social networks are sooner severed because their contacts tend to concentrate on the home and family.

Girls' social rights may be in particular danger of being violated because of evictions. Many girls have to drop out of school after the eviction because in times of poverty families will characteristically favour their sons' education over their daughters'. In addition, girls may be (morally) forced to enter into early marriage in order to alleviate the family's burden. ${ }^{193}$

\subsubsection{Article 14(2) Women's Convention}

Unfortunately, access and right to land and housing are not contained in a separate Article in the Women's Convention. At the initiative of the Indian representative in the CSW, however, Article 14 was included that deals with the specific plight and the particular circumstances of rural women. ${ }^{194}$ In this provision the equal rights to land and housing are contained in paragraph 2, (g) and (h) respectively. ${ }^{195}$ According to CEDAW's reporting guidelines States report on an Article to Article basis. ${ }^{196}$ This is also the way

193 See section 3.3.2.4 on evicted women.

194 The proposal to include a specific Article on rural women was submitted by Egypt, India, Indonesia, Iran, Pakistan, Thailand and the United States. For the history of Article 14 see Lars Adam Rehof, Guide to the Travaux Préparatoires of the United Nations Convention on the Elimination of All Forms of Discrimination Against Women, Martinus Nijhoff Publishers, Dordrecht/Boston/London, 1993, pp. 153161. Also J.E. Biesheuvel-Vermeijden, 'Artikel 14: Loon naar werken', in: A.W. Heringa, J. Hes, L. Lijnzaad (eds), Het Vrouwenverdrag: een beeld van een verdrag ..., Maklu Uitgevers, Antwerpen, Apeldoorn, 1994, pp. 203-204.

195 The relevant paragraphs read: '14(2) State parties shall take all appropriate measures to eliminate discrimination against women in rural areas in order to ensure, on a basis of equality of men and women, that they participate in and benefit from rural development and, in particular, shall ensure to such women the right $(\mathrm{g})$ To have access to agricultural credit and loans, marketing facilities, appropriate technology and equal treatment in land and agrarian reform as well as in land resettlement schemes, (h) To enjoy adequate living conditions, particularly in relation to housing, sanitation, electricity and water supply, transport and communications.'

196 For initial reports the rule is that a State party deals specifically with every Article in parts I, II and II of the Convention, for subsequent period reports it is provided that they are to be structured so as to follow the Articles of the Convention. UN doc. HRI/GEN/2/Rev.1/Add.2, Guidelines issued by the Committee 
in which CEDAW will ask additional questions or makes any comments. Although this is a logical and efficient manner of dealing with State reports, in the case of housing rights it considerably limits the Committee's monitoring opportunities because in principle, the rights to land and housing now only come up, and rather sparsely at that, in the context of rural women. It goes without saying that also urban women have extensive and pressing needs as regards housing and they too deserve international support and monitoring. Of course it is possible for CEDAW to broach the issue of housing rights or elements of it under various provisions of the Convention. Still, the Committee's involvement would be made easier and clearer if it would adopt a General Recommendation on the right to land and to adequate housing. ${ }^{197}$ The basic character of the rights to land and housing and the existing impediments women experience in fulfilling these rights would certainly merit such special attention by the Committee.

\subsubsection{Article 5(e)(iii) Convention on the Elimination of All Forms of Racial Discrimination}

Under Article 5 of ICERD, States parties are held to prohibit and eliminate racial discrimination and to guarantee the enjoyment of all kinds of human rights, among which economic, social and cultural rights. The right to housing is mentioned in paragraph (e)(iii) of this provision. ${ }^{198}$ The Convention is focused on the distinguishing elements of race, colour, national and ethnic origin, and in the body of the treaty there is no reference to the element of sex at all. ${ }^{199}$ This is to be regretted since many women all over the world suffer from double discrimination when racism becomes an issue in addition to the discrimination they experience already because of the fact that they are women. ${ }^{200}$ The focus on racial discrimination used to be so strict that for many years CERD refused to take any particular circumstances of women into account, ${ }^{201}$ even after such a request

on the Elimination of Discrimination against Women for all reports submitted after 31 December 2002, 5 May 2003, para. D.2 and E.2 respectively.

197 The idea for a general recommendation on land and housing has been worked out in more detail in section 4.7.2.4.1

198 The text of Article 5(e)(iii) reads: 'In compliance with the fundamental obligations laid down in Article 2 of this Convention, State parties undertake to prohibit and to eliminate racial discrimination in all its forms and to guarantee the right of everyone, without distinction as to race, colour, or national or ethnic origin, to equality before the law, notably in the enjoyment of the following rights: [...] (e) Economic, social and cultural rights, in particular: [...] (iii) The right to housing.'

199 The only reference to 'sex' as a distinguishing element is to be found in the Preamble where the basis of the Charter of the United Nations is reiterated in that human rights and fundamental freedoms should be observed for all, without distinction as to race, sex, language or religion.

200 Ingrid Westendorp, 'Double Discrimination; Racism and Sexism Combined', in: Fons Coomans et. al. (eds), Rendering Justice to the Vulnerable; Liber Amicorum in Honour of Theo van Boven, Kluwer Law International, The Hague, 2000, pp. 300-303.

201 In the context of the complaint procedure of Article 14 of the Convention, a case in point is YilmazDogan v. the Netherlands. A woman with the Turkish nationality who resided in the Netherlands had lodged a complaint with CERD because her employer had requested and received the Cantonal Court's permission to fire her, although she was pregnant at the time. During the Court's session the employer had expressed the view that foreign female employees should quit working when they were pregnant just like Dutch women would. Moreover, he alleged that foreign women who have children will stay home at the slightest set-back under the pretext of being ill. Although CERD ruled that Mrs Yilmaz-Dogan's 
was made by the UN in the framework of gender mainstreaming. ${ }^{202}$ Meanwhile, this omission has, at least in theory, been repaired by the adoption of General Recommendation No. 25 on gender related dimensions of racial discrimination ${ }^{203}$ and the subsequent adaptation of the general guidelines in which States parties are now specifically requested to provide sex-disaggregated data in view of the fact that racial discrimination may have a different impact upon women. ${ }^{204}$ Hence, CERD has created a possibility for itself to request gender specific data as regards the right to housing and to monitor its implementation under the Convention. ${ }^{205}$

\subsubsection{Article 27(3) Convention on the Rights of the Child}

Children's right to adequate housing is referred to in the context of the right to an adequate standard of living contained in Article 27(3) of the Convention on the Rights of the Child. ${ }^{206}$ The Article mentions in paragraph 1 that the provision is applicable to every child, thus no distinction is made between girls and boys. The Convention is based on the principle of non-discrimination contained in Article 2 of the treaty where, inter alia, discrimination of the child or of her/his parents or guardians on the basis of sex is prohibited.

The right to housing only plays a minor role in this Convention since apparently children do not have an independent right to housing, but their housing conditions primarily depend on the provision of such by their parents or care-takers. Nevertheless, it might be warranted to request information from States parties on legislation and protection mechanisms as regards the housing conditions of girls in view of the higher risks they run as regards sexual abuse especially in inadequate housing conditions like emergency housing or homelessness. Demanding sex-disaggregated data in this respect would fit in with the gender mainstreaming strategy that is propagated by the $\mathrm{UN}^{207}$

right to work under Article 5(e)(i) had been violated, no attention was paid to the obvious sexist side of the case, although it is clear that only a woman could have been the victim of such an expression of racist discrimination. UN doc. CERD/C/36/D/1/1984, 29 September 1988, Communication No. 1/1984, A. Yilmaz-Dogan v. The Netherlands.

202 In 1996 CERD's chairman publicly announced that it was the Committee's purpose to deal with issues of racism, while discrimination of women should be left to CEDAW. Anne Gallagher, 'Ending the Marginalization: Strategies for Incorporating Women into the United Nations Human Rights System', in: Human Rights Quarterly, Vol. 19, 1997, p. 304.

203 CERD General Recommendation No. 25: Gender related dimensions of racial discrimination, 20 March 2000 .

204 UN doc. CERD/C/70/Rev.5, General Guidelines regarding the form and contents of reports to be submitted by State parties under Article 9, paragraph 1, of the Convention, 5 December 2000, in particular para. 9.

205 CERD's monitoring possibilities are discussed further in section 4.7.2.

206 The text of Article 27(3) reads in full: 'State parties in accordance with national conditions and within their means shall take appropriate measures to assist parents and others responsible for the child to implement this right [to an adequate standard of living $(I W)]$ and shall in the case of need provide material assistance and support programmes, particularly with regard to nutrition, clothing and housing.'

207 For more details on monitoring possibilities of the CRC see section 4.7.2. 


\subsubsection{Article 43(1) Convention on Migrant Workers}

The International Convention on the Protection of the Rights of All Migrant Workers and Members of their Families (ICRMW) contains a provision on the right to housing in Article $43(1)(d) .{ }^{208}$ The Convention entered into force on 1 July 2003. Like all international human rights instruments, the Convention strongly focuses on the principle of non-discrimination, and in the enumeration of grounds on which any distinction is prohibited 'sex' is mentioned first. ${ }^{209}$ Although it is early days to say anything about the effectiveness of the Convention and in January 2006 it still only had 34 States parties, the point must be made that the (housing) situation of many women migrant workers in several States is so bad that the Committee might consider devoting one of its first general comments to it. ${ }^{210}$ The number of female migrant workers is growing yearly and especially the group of domestic workers is highly vulnerable and in need of extra protection. As a rule, these women will live in with the family they work for and sometimes they are kept in slave-like conditions. ${ }^{211}$ At the very least, the Committee should request sexdisaggregated data on migrant workers and ask specifically to report on the housing situation of female domestic workers.

\subsubsection{Concluding Remarks}

None of the housing rights provisions that have been discussed is adequately geared to women's specific circumstances and housing needs. This is serious since if a clear women's perspective is lacking at the international level, how can States parties be admonished for not including or effectuating a women's view into their domestic housing rights rules and regulations.

In line with the women specific strategy CEDAW might adopt a General Recommendation that would make structural and effective monitoring of the right to housing of all women, and not just those living in rural areas, possible in the framework of the Women's Convention.

In keeping with the gender mainstreaming strategy of the UN women's perspective should be (further) taken into account by the CESCR, CERD, the CRC and the CMW. Inclusion of a women's perspective in Article 11(1) by the CESCR is particularly pertinent since this provision is the most important international housing rights norm

208 The text of Article 43(1) reads: 'Migrant workers shall enjoy equality of treatment with nationals of the State of employment in relation to ... (d) access to housing, including social housing schemes, and protection against exploitation in respect of rents.'

209 The principle of non-discrimination is contained in Article 7 which reads: 'State parties undertake, in accordance with the international instruments concerning human rights, to respect and to ensure to all migrant workers and members of their families within their territory or subject to their jurisdiction the rights provided for in the present Convention without distinction on any kind such as sex, race, colour, language, religion or conviction, political or other opinion, national, ethnic or social origin, nationality, age, economic position, property, marital status, birth or other status.'

210 Also see section 4.7.2 on monitoring possibilities for the CMW.

211 For examples see section 3.4.4.3 on women migrant workers. 
contained in a human rights instrument, not in the least because it has been extensively interpreted and clarified by the two General Comments 4 and 7 .

Concrete suggestions and recommendations for improvement of the monitoring task of all five supervisory bodies will be given in section 4.7.

\subsection{CUlture ANd GENDER Stereotyping}

\subsubsection{Introduction}

Every culture comprises a set of societal rules of behaviour. These prescriptions may deviate from legal rules and procedures and may even contravene or undermine them. Within the UN human rights framework the prime provision that deals with the abolition of discriminatory cultural patterns and gender stereotyping is Article 5 of the Women's Convention. ${ }^{212}$ One of the purposes of this section is to determine whether, and if so which, legal obligations ensue from Article 5 and to find out whether any other human rights provisions explicitly or implicitly call on states to abolish discriminatory customs and traditions.

Since it has become clear that cultural determinants may stand between women and the fulfilment of their human rights, among which the right to adequate housing, the next sub-section will go into the obstacles for change. Attention will be paid to the theories of universality and cultural diversity, the problems faced by the system of personal laws and the very nature of cultural patterns that makes it a barrier that is hard to overcome.

Possibilities for change are the subject of the last sub-section. Several actors may find and use ways to abolish discriminatory cultural patterns or to change them in such a way that equality between women and men may be achieved. The actors that will be discussed are international agencies, public authorities, civil society organizations, and individual women.

\subsubsection{Legal Interference with Cultural Patterns}

There is a definite tension between culture, in the sense of a set of behavioural rules and habits, and human rights law. On the one hand, it is internationally acknowledged and laid down in human rights instruments that culture is to be preserved. ${ }^{213}$ On the other

212 The exact text of Article 5 reads: 'State parties shall take all appropriate measures: (a) To modify the social and cultural patterns of conduct of men and women, with a view to achieving the elimination of prejudices and customary and all other practices which are based on the idea of the inferiority or the superiority of either of the sexes or on stereotyped roles for men and women; (b) To ensure that family education includes a proper understanding of maternity as a social function and the recognition of the common responsibility of men and women in the upbringing and development of their children, it being understood that the interest of the children is the primordial consideration in all cases.'

213 Article 27 of the ICCPR and Article 10(1) of the ICESCR dictate that culture must be protected and preserved. Art. 13(c) of the Women's Convention demands that women are enabled to participate on an equal footing with men in all aspects of cultural life. Also see Diane Bell, 'Considering Gender; Are Human Rights for Women, Too? An Australian Case', in: Abdullahi Ahmed An-Na'im (ed.), Human Rights in Cross-Cultural Perspectives; A Quest for Consensus, University of Pennsylvania Press, Philadelphia, 1992, p. 341. 
hand, some behaviour that is culturally imposed is rejected and characterized as violating human rights. ${ }^{214}$ In many cases where there is a conflict between the right to culture, including freedom of religion, and gender equality rights, women's rights may be sacrificed in favour of culture. ${ }^{215}$ In international human rights law, however, there is no supremacy of the right to culture over the right to non-discrimination of women. From a grammatical point of view no hierarchy is given in the enumeration of the grounds on which discrimination is prohibited in the various instruments: race, colour, sex, language, religion, or other grounds that may be mentioned, all seem to be on the same level. The question is whether women's individual human rights should be favoured over the group right to cultural identity in cases where these rights clash and women's rights are obviously violated. In the following relevant provisions of international human rights instruments will be analysed in this respect.

\subsubsection{Article 5 Women's Convention}

According to Article 5 of the Women's Convention States parties shall take all appropriate measures to modify social and cultural patterns in such a way that prejudices and customary and other practices which are based on the idea of inferiority or superiority of either of the sexes or on stereotyped roles for men and women are eliminated. Furthermore, States parties shall ensure that maternity is understood as a social function and that the upbringing and development of children is a common responsibility of men and women. ${ }^{216}$

The use of the word 'shall' is significant since it expresses a command, thus imposing an obligation on the States parties. Therefore, Article 5 demands instantaneous action. It goes without saying that modifying social and cultural patterns and eliminating prejudice may take a long time, but this does not affect States parties' duty to start immediately.

In order to fulfil the obligations contained in Article 5, States are to use 'all appropriate measures'. This means that if legislature is not effective other measures must be used until the desired result has been achieved. Since the goal of the provision is a change of mentality and societal behaviour to such an extent that equality between women and

214 Examples that come to mind are cultural customs like sati (widow burning), female circumcision, and foot binding, all of which are legally prohibited everywhere in the world.

215 Several examples were mentioned in section 3.7 supra.

216 From the travaux préparatoires it becomes clear that the first paragraph of Article 5 met with much assent. In the first draft already, which was proposed by the Philippines in $U N$ doc. E/CN.6/573 of 6 November 1973, the basis was laid for the final text. The original proposal read: 'State parties undertake to adopt immediate, effective appropriate measures, particularly in the fields of teaching, education, culture and information, with a view to educating public opinion and to directing national aspirations towards the eradication of prejudice and the abolition of customary and all other practices which are based on the idea of inferiority of women.' More discussion was needed as regards the second paragraph of Article 5 since some states wanted to stress the social value of motherhood, while others felt that this would maintain women and men in complementary roles which might work to women's disadvantage. Finally, consensus could be achieved over the text that the upbringing and development of children is the responsibility of both fathers and mothers. Lars Adam Rehof, Guide to the Travaux Préparatoires of the United Nations Convention on the Elimination of All Forms of Discrimination Against Women, Martinus Nijhoff Publishers, Dordrecht/Boston/London, 1993, pp. 77-88. 
men has been realized, it stands to reason that the law will not always be the most effective tool. $^{217}$

With respect to the realization of women's right to housing and housing related rights, Article 5 is of eminent importance. As has become clear from the gender related factors discussed in Chapter III of this study, the inability of many women to fulfil their right to adequate housing is largely due to cultural patterns and stereotypical behaviour of both women and men. Many of the problems women struggle with that have a bearing on their housing rights might be reduced or solved if Article 5 would be duly implemented. Paragraph (a) of Article 5 induces States parties to combat discriminatory customary prescriptions and to ban stereotypical thinking. It would be important in this context to influence attitudes as regards property rights, inheritance, political participation, freedom of movement and settlement, access to schooling and job training, and the male breadwinner model. Furthermore, the paragraph obliges States to eradicate the idea of inferiority of women which may be seen as the primary cause of domestic violence against women. Paragraph (b) obligates States parties to affect public opinion in such a way that the gendered division of work will be changed and men, too will take up care-taking responsibilities towards their children. As has become clear, the huge burden many women carry as regards care-taking tasks at home and in the community stands in their way to develop themselves and become autonomous individuals who are able to provide for their own housing situation.

Article 5 takes a clear stance as to discriminatory cultural prescriptions. If there is a conflict between the rules pertaining to equal realization of women's individual human rights and cultural regulations that have the effect of keeping women in an unequal, submissive position, States shall make a choice in favour of women's human rights and they shall abolish these cultural rules notwithstanding the international obligation to respect culture. ${ }^{218}$ In cases where two different human rights of two citizens clash, a decision will have to be made as to which one will prevail. Although this is not always an easy choice, in the end a fair outcome may be found based on all relevant circumstances. The conflict between the right to retain a cultural pattern and women's right to equality, however, is of a different magnitude. It is not a case of sacrificing one human right for another; the choice to maintain biased, stereotypical cultural prescriptions may have a devastating effect on all human rights of virtually all women of the society concerned.

Moreover, it is not a choice between the rights of two citizens; the choice is between an individual's entitlement to her human rights, and a group's interest to maintain certain culturally determined traditions and habits. Most international human rights instruments,

217 CEDAW stated that 'the existence of stereotyped conceptions of women, owing to socio-cultural factors, [..] perpetuates discrimination based on sex and hinders the implementation of Article 5 of the Convention' and urged State parties to 'adopt education and public information programmes, which will help eliminate prejudices and current practices that hinder the full operation of the principle of the social equality of women' in General Recommendation No. 3, Education and public information programmes, 1987.

218 Van Maarseveen already wrote in 1987 that Article 5 of the Women's Convention contains the principle of cultural change. He reckoned that cultural change might consist of feminizing culture, especially cultural habits that may be found in legislation and policy. Henc van Maarseveen, 'Internationaal vrouwenrecht. Een afzonderlijk rechtsgebied?', in: H. van Maarseveen, D. Pessers, M.J. Gunning (eds.), Internationaal recht en vrouwen (Deel 1 Commentaren), Tjeenk-Willink, Zwolle, 1987, pp. 74-75. 
like the Women's Convention, are focused on individuals as the recipients of the rights, not groups. ${ }^{219}$ An individual's right to participate in culture should be protected. ${ }^{220}$ The duty to preserve the cultural characteristics of a group will never go as far as to impose on a State the duty to undermine or annihilate the human rights of individuals who belong to this group.

Finally, those cultures that are particularly known for their repressive character typically deny women access to decision-making bodies so that it is impossible to maintain that the decision to retain certain harmful traditional rules is democratically sanctioned.

Article 5 does not stand on its own; it is a logical sequence of Article 2(f) of the Women's Convention in which it is stipulated that equality of women should be achieved both de iure and de facto. ${ }^{221}$ In indicating that de facto equality must be one of the two goals and that to achieve this goal all appropriate measures have to be taken, Article 2(f) forms the legal basis for the legal and extra-legal measures that must be used in order to realize the obligations ensuing from Article 5.22

That is why States parties that have made a reservation to Article 5, but not to Article 2(f) are not exempted from abolishing discriminatory cultural rules, for if they do not use all appropriate measures to further women's equality, they will violate their obligation to achieve de facto equality.

The Women's Convention seems to leave no doubt that women are entitled to enjoy their human rights on an equal footing with men, and that cultural patterns, including stereotyped roles in society that inhibit women from fully developing themselves are to be abolished. The next sub-section will determine whether there are any other human rights provisions that also make a choice in favour of human rights and against discriminatory cultural rules.

\subsubsection{Other relevant Human Rights Provisions}

Another human rights provision that explicitly calls upon States to interfere in cultural patterns, albeit under particular and restricted circumstances, is Article 24(3) of the

219 CEDAW defends the rights of women and rejects cultural habits and stereotyping for instance in its General Recommendations 21 and 25 where it respectively rejects polygamous marriages and the persistence of gender-based stereotypes by referring the State parties' obligation contained in Article 5(a).

220 See Article 27(1) Universal Declaration of Human Rights, Article 27 ICCPR, and Article 15(1)(a) ICESCR.

221 The exact text of Article 2(f) reads: 'State parties condemn discrimination against women in all its forms, agree to pursue by all appropriate means and without delay a policy of eliminating discrimination against women and, to this end, undertake: [...] (f) To take all appropriate measures, including legislation, to modify or abolish existing laws, regulations, customs and practices which constitute discrimination against women'.

222 This is also the opinion of Rebecca Cook who states that Articles 2(f) and 5(a) combined 'strongly reinforce the commitment to eliminate all forms of discrimination, since many pervasive forms of discrimination against women rest not on law as such but on legally tolerated customs and practices of national institutions'. She explicitly mentions personal law systems and religious institutions. Rebecca Cook, 'State Accountability Under the Convention on the Elimination of All Forms of Discrimination Against Women' in: Rebecca J. Cook (ed.), Human Rights of Women, National and International Perspectives, University of Pennsylvania Press, Philadelphia, 1994, pp. 239-240. 
Convention of the Rights of the Child. ${ }^{223}$ In the relevant paragraph it is stipulated that: 'States parties shall take all effective and appropriate measures with a view to abolishing traditional practices prejudicial to the health of children'. Since virtually all States in the world are party to this Convention, ${ }^{224}$ and no explicit reservations have been made as to this specific paragraph of Article $24,{ }^{225}$ it may be assumed that there is a worldwide consensus that under certain conditions it is acceptable to forego tradition, as part of culture, in the interest of a person's human rights. From the travaux préparatoires it becomes clear that 'health' is to be interpreted rather broadly. It would include, for instance, the traditional practice of son preference. ${ }^{226}$ The phrase 'all effective and appropriate measures' to achieve this goal seems to be more focused on a change of mentality than on justiciable rules. ${ }^{227}$

An important soft law provision preferring human rights to cultural patterns in case of a possible clash may be found in Article 4 of the Declaration on the Elimination of Violence against Women, which reads in part: 'States should condemn violence against women and should not invoke any custom, tradition or religious consideration to avoid their obligations with respect to its elimination. ${ }^{228}$

More general human rights provisions may also impose an obligation to do away with cultural traditions should these prevent the realization of a person's human rights. The Human Rights Committee for one interprets Article 3 ICCPR on equality rights between women and men in this sense. In General Comment No. 28 the HRC points out that the inequality of women is embedded in tradition, history, and culture including religion. States parties have the obligation to ensure that tradition, and religious or cultural rules are not used as justifications for violations of women's right to equality before the law or of the equal enjoyment of the rights contained in the Covenant. States parties should specifically mention in their reports to the Committee which measures they have taken to eradicate such practices. ${ }^{229}$ Thus the HRC clearly puts the universal human right principle of equality as contained in Article 3 of the ICCPR above cultural prescrip-

223 Although the CRC has not yet adopted a General Comment on Article 24, this provision is one of the subjects under scrutiny in General Comment No. 4, Adolescent health and development in the context of the Convention on the Rights of the Child, UN doc. CRC/GC/2003/4, 1 July 2003. Particularly relevant is para. 24 of this document which reads: 'In light of Articles 3, 6, 12, 19 and 24(3) of the Convention, State parties should take all effective measures to eliminate all acts and activities which threaten the right to life of adolescents, including honour killings. The Committee strongly urges State parties to develop and implement awareness-raising campaign, education programmes and legislation aimed at changing prevailing attitudes, and address gender roles and stereotypes that contribute to harmful traditional practices. [...].'

224 In October 2004192 States had ratified the Convention on the Rights of the Child; this was also the number of independent States at that moment. See Status of ratification of the Convention on the Rights of the Child at <www.ohchr.org/english/law/crc-ratify.htm>, consulted on 6 October 2004.

225 See overview of Declarations and reservations to the Convention on the Rights of the Child, at $<$ www ohchr.org/english/law/crc-reserve.htm>, consulted on 6 October 2004.

226 Sharon Detrick, A Commentary on the United Nations Convention on the Rights of the Child, Kluwer Law International, The Hague, 1999, pp. 414-419.

227 Jan Willems, Wie zal de Opvoeders Opvoeden? Kindermishandeling en het Recht van het Kind op Persoonswording, T.M.C. Asser Press, Den Haag, 1998, p. 950.

228 UN doc. A/RES/48/104, Declaration on the Elimination of Violence against Women, 20 December 1993

229 CCPR General Comment No. 28, Equality of Rights between Men and Women (Art. 3), 2000, para. 5. 
tions. This seems a logical choice since the object and purpose of the provision is to achieve de iure and de facto equality and the latter is impossible if cultural patterns are maintained that refer women to a subordinate position in society and that deny them the full realization of the rights they are entitled to under the Covenant.

Unfortunately, the CESCR is not as explicit in its recently adopted General Comment No. 16 on Article 3 of the ICESCR. Although it is admitted that women are often denied equal enjoyment of economic, social and cultural rights because of tradition and custom, and it is stressed that the mandate of Article 3 is to achieve de facto equality in addition to de iure equality, there is no clear requirement to eradicate harmful customary practices. That abolition of such rules may be warranted may be inferred from the statement that in order to achieve substantive equality, States parties are expected to concern themselves with the effects of laws, policies, and practices, and to ensure that they do not uphold, but rather alleviate, the inherent disadvantage that particular groups experience. ${ }^{230}$

In conclusion, it may be said that Article 5 of the Women's Convention, albeit the most explicit and comprehensive, is not the only legally binding treaty provision that demands ousting cultural patterns if they inhibit the enjoyment of universal human rights. In view of the high regard in which the HRC is held, its stance that cultural, traditional and religious prescriptions may not be used as a justification to rob women of their equal rights is of particular importance.

\subsubsection{Obstacles for Changing Cultural Patterns}

Although in theory international human rights instruments seem to lean in favour of universal human rights and the abolition of cultural rules should the two clash, in practice the human rights of many women, including the right to adequate housing, may be sacrificed in order to maintain a community's cultural, traditional or religious identity. On the international plane some States make it clear that they do not acknowledge the universal value of human rights. Instead, they prefer the system of cultural diversity. Within States a choice may be made to uphold personal law systems that stick to cultural behavioural rules in order to accommodate cultural minorities and avoid unrest although the mainstream law system may be in conformity with universal human rights norms. On the individual or family level the very nature of cultural rules may make it hard for women to reject them. In the following these obstacles for change will be looked into consecutively.

\subsubsection{Universality versus Cultural Diversity}

The age-old philosophy of natural law enjoyed an important upsurge after the Second World War when the atrocities that had been committed induced modern philosophers and legal scholars to embrace with renewed strength the idea that every individual would be endowed with a set of inalienable rights. These rights would retain their value notwithstanding the political colour or cultural background of any given State or community. It was an ideal climate to lay down these ideas about the inherent worth and dignity of every

230 CESCR General Comment No. 16, Article 3: the equal right of men and women to the enjoyment of all economic, social and cultural rights, 13 May 2005, paras 5-8. 
human being and the rights to which she or he was entitled in the Universal Declaration of Human Rights. ${ }^{231}$ After the first euphoria, however, embodiment of the rights contained in the Universal Declaration in legally binding instruments proved to be a different cup of tea. ${ }^{232}$ It was not until 1966 that the human rights ideals were cast in a legal form, and then the notion of interrelatedness, inter-dependence and indivisibility of all kinds of human rights was somewhat diluted by the adoption of different covenants for civil and political rights, and for economic, social and cultural rights. ${ }^{233}$

Gradually, the universal character of the human rights laid down in the Universal Declaration was openly criticized by some of the newly emerging States. ${ }^{234}$ Some of these States perceived the idea of universal rights as a Western concept that was incompatible with their culture. Instead of universality of norms these States were far more in favour of the idea of cultural diversity or relativism. According to the latter theory, all cultures are equally valid, although they may have different notions about human rights. ${ }^{235}$ Cultural relativists will find rights primarily in the cultural context, based on tradition and/or religious teachings. ${ }^{236}$ It is argued that the imposition of a universal human rights system may therefore be viewed as a new form of Western imperialism and interference in internal affairs. ${ }^{237}$ To some degree it is possible to sympathize with this attitude since large parts of the world, and therefore many cultures, were not involved in the drafting of the human rights norms when they were laid down in international instruments. ${ }^{238}$

231 A.H. Robertson and J.G. Merrills, Human Rights in the World; An introduction to the study of the international protection of human rights, $3^{\text {rd }}$ ed., Manchester University Press, Manchester and New York, 1992, p. 7.

232 This was the result of the cold war politics. States from the capitalist West emphasized that civil and political rights are the most crucial or even the only true human rights, while socialist and communist States held that economic and social rights were the more important. See e.g. Hilary Charlesworth and Christine Chinkin, The boundaries of international law; A feminist analysis, Manchester University Press, Manchester, 2000, p. 206.

233 However, this decision may not be as dramatic as it seemed since almost all States that have ratified one Covenant, also have ratified the other. Important exceptions being the USA (only the ICCPR) and China (only the ICESCR).

234 At the time of the drafting of the Universal Declaration the world counted about 60 independent states.

235 Abdullahi Ahmed An-Na'im, 'Toward a Cross-Cultural Approach to Defining International Standards of Human rights; The Meaning of Cruel, Inhuman, or Degrading Treatment or Punishment', in: Abdullahi Ahmed An-Na im, (ed.), Human Rights in Cross-Cultural Perspectives; A Quest for Consensus, University of Pennsylvania Press, Philadelphia, 1992, p. 24.

236 Richard Falk, 'Cultural Foundations for the International Protection of Human Rights', in: Abdullahi Ahmed An-Na im, (ed.), Human Rights in Cross-Cultural Perspectives; A Quest for Consensus, University of Pennsylvania Press, Philadelphia, 1992, p. 45.

237 Christina M. Cerna and Jennifer C. Wallace. 'Women and Culture', in: Kelly D. Askin and Dorean M. Koenig (eds.), Women and International Human Rights Law, Vol. 1, Transnational Publishers, Inc., Ardsley, New York, 1999, pp. 626-627. Also Henry, J.Steiner and Philip Alston, International Human Rights in Context; Law, Politics, Morals, second edition, Oxford University Press, 2000, pp. 366-367. Also Abdullahi Ahmed An-Na im, 1992, p. 38.

238 It should be noted, however, that the drafting of the Universal Declaration was not the exclusive Western affair it is sometimes depicted to have been. States that negotiated about, and had a substantial impact on the text, included Chile, China, Egypt, Iran, Lebanon, the Philippines, and Uruguay. Moreover, at the World Conference on Human Rights in Vienna in 1993, more than 170 States reaffirmed that 'the universal nature of human rights is beyond question', and that 'it is the duty of States, regardless of their political, economic and cultural systems, to promote and protect all human rights and fundamental freedoms'. Advisory Council on International Affairs (a council consisting of experts that advises the Dutch 
However, the same can be said of women, since their influence in the drafting and adoption of international human rights law was also minimal. ${ }^{239}$ It is impossible for women to reinvent every rule of law; instead it is better to try to remodel human rights law in such a way that justice is done to the particular position of women. In the same vein, it is far more beneficial in view of the interdependence that exists among the countries in the world today to reconcile ideas about human rights than it is to remain antagonists. Moreover, the rejection of universalism may be more concerned with the strong aversion that is felt towards the West than with the actual contents of human rights since similar ideas about dignity and welfare of human beings, and notions about right and wrong may be found at the basis of many of the world's cultures and religions. ${ }^{240}$ Furthermore, universalism should not be regarded as a rigid concept; culturally induced variations as to the form in which most of the rights are to be implemented may be left to a State's discretion. $^{241}$

The likelihood of reconciling cultural interpretations with universalism will find its limit, however, in radical cultural notions that see culture as the only source of rights and therefore reject the idea of individuals having rights simply because of the fact that they are human beings. This radical notion is diametrically opposed to human rights theory which is premised on the thought that every human being, female or male, has inalienable rights irrespective of culture, place or time. ${ }^{242}$ Adherents to radical forms of cultural relativism will put the common good of a community above an individual's plight. In fact, from their point of view individuals only merit rights because they belong to a certain culture or religion. The rights individuals may have are more accurately called

Minister for Foreign Affairs), report on Universality of Human Rights and Cultural Diversity, No. 4, The Hague, 4 June 1998, pp. 11-13.

239 See e.g. Eva Brems, 'Enemies or Allies? Feminism and Cultural Relativism as Dissident voices in Human Rights Discourse', in: Human Rights Quarterly, Vol. 19, 1997, pp. 137-141.

240 A.H. Robertson and J.G. Merrills, 1992, pp. 9-14. Theo van Boven points out that it is especially in times of need that people irrespective of their cultural background will appreciate the value of human rights. Therefore, the victims' experience and appreciation says more about the existence of common values than any of the arguments used by religious and secular leaders who will denounce the concept of human rights because it is not in their best interest. Theo van Boven, 'General Course on Human Rights', in: European University Institute, Florence, Collected Courses of the Academy of European Law; The Protection of Human Rights in Europe, Volume IV, Book 2, Martinus Nijhoff Publishers, The Hague/London/ Boston, 1993, pp. 11-13. Also see the report on Universality of Human Rights and Cultural Diversity by the Dutch Advisory Council on International Affairs, in which it is stated that relativism tends to exaggerate the differences, and that there are striking similarities as far as fundamental principles are concerned. The Hague, 4 June 1998, p. 10.

241 Jack Donnelly distinguishes the following categories from rigid universalism to rigid relativism: 1) radical universalism does not take any account of culture for the validity of moral rights and rules; 2) weak cultural relativism recognizes a comprehensive set of universal human rights, but allows for occasional and limited local variations and exceptions; 3 ) strong cultural relativism holds that culture is the principal source of the validity of moral rights and rules. A few basic universal human rights are accepted, but a wide range of variation for most rights is allowed; 4) radical cultural relativism holds that culture is the only source of the validity of moral rights or rules. Jack Donnelly, Universal Human Rights in Theory and Practice, Cornell University Press, Ithaca and London, 1989, pp. 109-114.

242 According to human rights theory primarily human beings are entitled to these rights and not groups. In the International Bill of Rights there is one important exception and that is the right of peoples to selfdetermination. Donnelly, 1989, pp. 19-20. 
privileges since they are attached to a certain status or position within the community. ${ }^{243}$ Because of traditional role models and gender stereotyping women's status in society will be different than men's. Although the difference in status will be justified as the 'natural complementarily' creating an equitable balance between the sexes, in reality women are viewed as of less inherent worth than men. A logical consequence is that women can never have privileges equal to those of men since their status in society is inferior. Thus, women will not be house proprietors, but they may be bestowed with the privilege to live in a certain house because they are the daughter, sister, wife or mother of the proprietor. Consequently, a woman's housing condition will always depend on the goodwill of one man or another and if for some reason the connection between her and her benefactor is severed, the privilege may cease to exist.

In conclusion, it can be said that cross-cultural basic ideas about right and wrong exist and that there is therefore good hope that a universally acceptable cultural interpretation of human rights law may be achieved. However, rejection of the idea of individual rights, as is done by radical cultural relativists, cannot be reconciled with the concept of equal human rights of women. In view of gender stereotyping and traditional patterns withholding inherent individual rights is primarily to the detriment of women. It will perpetuate the inequality between women and men and it may prove to be an insurmountable obstacle for the realization of women's rights.

\subsubsection{Personal Laws ${ }^{244}$}

Some States want to have it both ways; on the one hand they pledge to uphold international human rights law and they ratify human rights instruments, while on the other hand they want to accommodate cultural, ethnic or religious groups in society that wish to retain their own traditional legal systems that deviate from human rights norms. The problem may be that by being accommodating States may leave group members vulnerable to injustice within the group, especially since accommodation may even strengthen the hierarchical order that is maintained within the group. ${ }^{245}$

Most cultural rules that negatively influence women's rights are family law regulations that mirror traditional societies firmly premised on stereotyped roles for women and men. They may be based on practices from time immemorial and/or religious tradi-

243 Mahnaz Afkham, 'Cultural Relativism and Women's Human Rights', in: Kelly D. Askin and Dorean M Koenig (eds.), Women and International Human Rights Law, Vol. 2, Transnational Publishers, Inc., Ardsley, New York, 2000, p. 481. Also Donnelly, who puts it thus: 'To defend traditional society is to reject a society based on equal, inalienable, universal personal rights in favor of a status-based society. To prefer traditional society to liberalism is to reject a society of equal and autonomous individuals with inalienable rights in favor of a society of unequal, regulated occupants of social roles, incorporated into the community. Traditional society and human rights cannot be combined without violence to both.' See Donnelly, 1989, pp. 76-77.

244 Also see section 3.7.4 on Personal laws.

245 Ayelet Shachar calls this phenomenon 'the paradox of multicultural vulnerability' (her italics) by which she means that 'individuals inside the group can be injured by the very reforms that are designed to promote their status as group members in the accommodating, multicultural state'. Ayelet Shachar, Multicultural Jurisdictions; Cultural Differences and Women's Rights, Cambridge University Press, Cambridge, 2001, p. 3. 
tions that have a 'divine' character. Sex is used as a distinguishing characteristic to bestow privileges or impose duties. Although both women and men have duties, men's duties, like the duty to support their families, come with important privileges. Their role is to be decision-makers, money handlers, and property holders, in short holding power positions. Women, however, have the duty to take care of others and to obey some male superior or other, ranging from father, brother, husband, uncle or son, according to their stage of life or particular circumstances. The consequence of women's subordinate position in society is that the rights they have are dependent privileges, precariously pending on the goodwill of their male 'superiors', possible changes in the circumstances, and their own compliance with the rules.

As far as the rights to land and housing are concerned, such a system may make it almost impossible for women to have property rights over these goods or to make any independent decisions as to where and how they live, even when they are subjected to violence in the home they dwell in. Consequently, retaining such systems will entail the violation of women's rights, not in the least women's rights to equality and non-discrimination. Proclaiming adherence to human rights and at the same time allowing birth or descent to determine whether a woman may actually enjoy these rights cannot go together. A pledge in favour of human rights entails upholding these rights for everyone.

\subsubsection{The Nature of Cultural Patterns}

In view of the historical and/or religious roots of cultural patterns, they are so much ingrained in people that they seem to be part of a person's personality, impossible to shed since they appear to reflect the natural order, unchangeable and sacred. ${ }^{246}$ Moreover, these prescriptions will echo the current power structures.

Women, provided that they are able to sustain themselves and that they are aware of the fact that their human rights are violated, are basically caught between a rock and a hard place. If they comply with the societal rules of their cultural group they will benefit from a sense of belonging and familial support, however at the cost of waiving many of their rights and remaining dependent on others. ${ }^{247}$ If they choose to eschew the cultural prescriptions and claim their human rights they may be able to enjoy these rightsalthough they still have to wait and see whether they will succeed in doing so in society at large - but the price they may have to pay is that they are completely left to their own devices, without the support of their families and communities. Indeed, they may be ostracized because they are accused of betraying their own culture and 'collaborating' with imperialistic Western powers. ${ }^{248}$ The natural inclination to be part of a community may be so strong that women reject 'Western' ideas about equality and non-discrimination

246 Abdullahi Ahmed An-Na'im, 1992, p. 23. Also Richard Falk, 1992, p. 46.

247 Corinne Packer is convinced that in sub-Saharan Africa women who are aware of their lower social status have no other option but to accept the status quo including the harmful cultural practices since their lower economic, financial and educational status makes it impossible for them to leave. Corinne Packer, Using Human Rights to Change Tradition; Traditional Practices Harmful to Women's Reproductive Health in sub-Saharan Africa, Intersentia, Antwerpen-Oxford-New York, 2002, p. 48.

248 Ayelet Shachar, 2001, p. 39. Also Cerna and Wallace, 1999, p. 646. 
in favour of their traditional system since the aversion for outsiders and their systems is greater than the indignation of being treated unfairly by their own.

Sanctions against women who opt out of a cultural system may be stimulated by those who are in power positions since they are the ones who benefit from the status $q u o$ and who will seize every opportunity to resist change. ${ }^{249}$

\subsubsection{Actors Who May Change Cultural Patterns}

Cultural changes may be initiated and supported at different levels. In the following sub-sections the possible influence and changing potential of international agencies, public authorities, civil society organizations, and individuals will be discussed.

\subsubsection{International Agencies}

On the international plane a variety of international agencies can and do try to influence cultural patterns that have a negative impact on women's human rights. Among the tasks these agencies have taken upon themselves, are informing and educating people about human rights of women, existing gender inequalities, stereotyping, and harmful practices, while some of them also train local staff. In this sub-section attention will be paid to the programmes and actions of the most prominent of these agencies within the framework of the United Nations.

The United Nations Educational, Scientific and Cultural Organization (UNESCO) promotes cultural diversity and pluralism, but at the same time is aware of the secondary role many women are forced to play. It is felt that due to globalization new emphasis is put on cultural specificities. Since women are often regarded as bearers of their culture, many societies attach great value to the 'appropriate' conduct of women. The politicization of both culture and gender affects women's rights and the understanding of the place culture should take up in development. According to UNESCO 'we must avoid the dual pitfalls of both Western bias and cultural relativism, ${ }^{250}$ UNESCO has a special Gender Mainstreaming Resource Center that regularly publishes reports on gender and culture issues and also maintains a website. ${ }^{251}$ The core themes that are tackled by the centre include education, science and technology, communication and information (among which the promotion of a balanced and non-stereotypical portrayal of women in the media), and culture.

The United Nations International Children's Emergency Fund (UNICEF) recognizes that gender discrimination starts very early in a girl's life because of the family and community structures. ${ }^{252}$ Therefore, UNICEF tries to influence traditional behavioural patterns

249 Abdullahi Ahmed An-Na im, 1992, p. 27.

250 UNESCO, Our Creative Diversity, Chapter 5 Gender and Culture, UNESCO Publishing, 2003, available at: <www.unesco.org/culture/policies/ocd/htm.eng/chapter5.html >, last consulted 10 February 2005.

251 UNESCO, Culture, Women, Gender Equality Website at: < portal.unesco.org/en/ev.php_URL>, last consulted on 11 February 2005.

252 UNICEF, Gender equality site at: <www.unicef.org/gender/index>, consulted on 18 April 2005. 
in order to promote equality within the family and the transformation of gender roles. UNICEF is aware of the fact that this may conflict with societal values and cultural norms.

Not only children, girls and boys, are made aware of equal rights and shared responsibilities, but also parents. UNICEF emphasizes the importance of empowering women since recognition and respect for their rights will help to fulfil the rights of children. ${ }^{253}$

Since 1997 UNICEF has taken up gender mainstreaming as a strategy to achieve gender equality. It is particularly the Gender and Development (GAD) Unit that works to implement UNICEF's policy in this regard. Important programmes and projects include 'Water, Environment and Sanitation', that is intended to make the procurement of water as safe and easy as possible for women, the promotion of girls' enrolment in education, and the battle against various forms of violence against women and girls, especially the custom of early marriage. ${ }^{254}$

The United Nations Development Programme (UNDP) pays ample attention to gender issues in its global, regional and national reports. ${ }^{255}$ The 1995 global report exclusively dealt with the topic of 'Gender and human development'. One of its conclusions is that in order to achieve gender equality stereotyped images of women and men must be eliminated. The UNDP observes that development is endangered if it is not engendered and that cultural barriers that prevent the exercise of equal rights must be identified and removed. $^{256}$

The United Nations Development Fund for Women (UNIFEM) provides financial and technical assistance to programmes that promote women's human rights, political participation and economic security. ${ }^{257}$ UNIFEM focuses on women's empowerment and gender equality and this may entail the elimination of negative cultural attitudes and practices, ${ }^{258}$ though the organization most of the time refers to cultural barriers implicitly rather than explicitly.

According to the World Health Organizations (WHO) girls' and women's rights may be violated with serious negative impacts on their health from before birth till old age. The organization acknowledges that gender stereotyping of women's and men's roles and rights contributes to the persistence of violence against women both in and outside of the home. In order to improve women's situation the WHO has developed a number of policies and tools. Gender mainstreaming is high on the agenda in order to achieve that all of the WHO's activities comprise gender as an important factor and that all health professionals are aware of the ways in which gender may affect health. ${ }^{259}$

253 See for instance UNICEF, The Child in the Family at: <www.unicef.org/childfamily/index 24039. html>, consulted on 11 February 2005.

254 See for example the UNICEF Factsheet on Early Marriage, available at $<$ www.unicef.org $>$.

255 See UNDP, Human Development Reports, at: <http://hdr.undp.org/reports/view_reports.cfm?theme= $18 \&$ themename $=$ Gender $>$, consulted on 23 April 2005

256 Human Development Report 1995, Gender and human development, Overview: The revolution for gender equality; available on the internet at: $<$ http://hdr.undp.org/reports/global/1995/en $>$.

257 See UNIFEM's internet site at: <http//www.unifem.org $>$.

258 See for instance UNIFEM's publication 'Pathway to Gender Equality', which is available on the internet site.

259 The WHO has a specific 'Gender, women and health' website at: < http://www.who.int/gender/main streaming/en>. 
From the outset, the International Labour Organization (ILO) acknowledged the difference in circumstances between women and men as regards the labour market. ${ }^{260}$ However, the sort of conventions and recommendations that were adopted in the first decades rather affirmed stereotyped ideas about women's and men's roles in society. ${ }^{261}$ These early instruments can be characterized as (overly) protective and paternalistic. Their scope was too broad since they had the effect that all women were banned from certain kinds of dangerous or heavy work or working night shifts, instead of protecting only those women who may indeed need temporary protection i.e. pregnant and nursing women. ${ }^{262}$ An additional effect was that these measures prevented women from doing some of the better paid jobs or from making promotion. ${ }^{263}$ The last forty years, however, a shift has been made from protection to non-discrimination. One of the most important Conventions may be the 'Equal Remuneration Convention' that stipulates that women and men should receive equal pay for work of equal value. ${ }^{264}$ It was a significant step forward since other instruments, like the Universal Declaration (Art. 23(2)), still based themselves on the idea of equal pay for equal work; this entails that women can only receive the same salary if they do exactly the same work as their male comparator. The ILO's conception acknowledges that to do justice to women workers, the value of the work should be appraised objectively especially since many women are concentrated in professions where there are no male comparators. An important breach with the traditional familyrole pattern was the adoption of the 'Workers with Family Responsibilities Convention'. ${ }^{265}$ This Convention may be regarded as a supplement to the Discrimination (Employment and Occupation) Convention of 1958 that does not cover distinctions made on the basis of family responsibilities. According to the ILO ' $[\ldots]$ a change in the traditional role of men as well as the role of women in society and in the family is needed to achieve full equality between men and women'. ${ }^{266}$

The ILO also disseminates information about all kinds of gender issues in relation to work on the internet, and the organization has been cited as a good practice example within the UN framework in integrating gender in its programme and budget. ${ }^{267}$

On the basis of Articles 2(f) and 5 of the Women's Convention, CEDAW is eminently equipped to broach cultural patterns that negatively affect the fulfilment of women's human rights. From its general recommendations on States' reports under Article 18 of the

260 Already in its first session in 1919 the ILO adopted two conventions that targeted women specifically: the Maternity Protection Convention, ILO Convention No. 3, and the Night Work (Women) Convention, ILO Convention No. 4.

261 Women's family and social roles were protected and safeguarded by ILO Conventions. Moreover, women were banned from those sectors of work that were considered to be incompatible with society's image of women. See Valerie L. Oosterveld, 'Women and Employment', in: Kelly D. Askin and Dorean M. Koenig (eds.), Women and International Human Rights Law, Vol. 1, Transnational Publishers, Inc., Ardsley, New York, 1999, p. 369.

262 Ibidem, p. 370

263 Ibidem, p. 373.

264 Equal Remuneration Convention, ILO Convention No. 100, adopted on 6 June 1951 and entered into force 23 May 1953.

265 Workers with Family Responsibilities Convention, ILO Convention C 156, adopted on 3 June 1981, entered into force 11 August 1983

266 Workers with Family Responsibilities Convention, preamble.

267 See the ILO's website on gender: www.ilo.org/public/English/gender.htm. 
Convention it becomes clear that CEDAW makes ample use of this ability. ${ }^{268}$ CEDAW has in fact created the possibility to comment on any negative cultural influences that affect the rights contained in the Women's Convention by stipulating in its Guidelines for State reports that 'The report should outline any restrictions or limitations, even of a temporary nature, imposed by law, practice or tradition, or in any other manner on the enjoyment of each provision of the Convention' (emphasis added). ${ }^{269}$ It may therefore not be a surprise that CEDAW explicitly referred to Article 5 as regards its first views under the Optional Protocol concerning a complaint about a domestic violence case in Hungary. ${ }^{270}$ CEDAW noted that traditional attitudes and stereotypes regarding the roles of women and men in the family contribute to violence against women. Up till now CEDAW has not adopted a comprehensive general recommendation on Article 5, however.

\subsubsection{Public Authorities ${ }^{271}$}

Despite the fact that they may be highly reluctant to do so, public authorities should play a vital role in bringing about cultural change. The great majority of States in the world has ratified one or more human rights conventions in which women's right to equality and non-discrimination has been laid down and/or has incorporated these principles into their constitutions and other legislation. Nevertheless, at the same time there is no country, developed or developing, which does not retain cultural rules that discriminate against women and make it difficult or even impossible for women to fulfil their human rights on an equal footing with men.

The reluctance to deal with discriminatory cultural prescriptions may have different causes. In the first place legislature and State policy may be permeated with gender stereotypes that reflect an inferior status of women in society. These rules may be regarded as the natural order of things to such a degree that they are not recognized as being discriminatory. If public authorities are aware of the existence of certain societal rules that have a negative impact on women's rights, they may not wish to tackle them because they think it is not their task or they doubt that it is possible to have an impact. Multicultural States, including those that condone personal law systems, may be conscious of the fact that ethnic, religious or minority groups maintain certain cultural patterns that are to women's detriment, but they fear to intervene because it may cause public unrest or the leaders of these groups are so powerful that the authorities may not be a match. Moreover, many public authorities are erroneously under the impression that women have made a conscious choice to belong to a certain group or that they can easily sever

268 CEDAW's monitoring of arts. 2(f) and 5 is discussed in detail in section 4.8 infra. Also see Rikki Holtmaat, Naar ander recht en beleid; De betekenis van artikel 5 a VN-Vrouwenverdrag voor het uitbannen van structurele genderdiscriminatie, Ministerie van Sociale Zaken en Werkgelegenheid, Den Haag, juli 2004, pp. 35-45.

269 Guidelines issued by the Committee on the Elimination of Discrimination against Women for all reports submitted after 31 December 2002, contained in $U N$ doc. HRI/GEN/2/Rev.1/Add.2, 5 May 2003, para. D.2.5.

270 CEDAW, Communication no. 2/2003, Ms A.T. v. Hungary, views of 25 January 2005. For more details see section 4.7.2

271 The term public authorities is used in a broad sense; it comprises officials and organs both at the central and at the local level. 
all connections. By assuming such an individual choice, the authorities in fact shirk their responsibilities and deny the manifold obstacles women will have to overcome should they decide to leave their cultural group. ${ }^{272}$

Public authorities that wish to attain de facto equality of women will not have a choice but to deal with cultural patterns. They have several tools at their disposal that should be employed simultaneously. The first set, consisting of reactive measures, aims at banning gender discrimination from legislature and society, while the second set focuses on proactive measures so as to prevent future discriminatory prescriptions.

\subsection{Reactive Measures}

Public authorities that are reluctant to interfere in cultural habits should realize that they themselves already determine and perpetuate customs through their legislation and policy making. In fact, part of gender stereotyping is induced by rules that are imposed by public organs. That is why existing legislation and policies should be analyzed with a view to detect which rules are discriminatory or have the effect of perpetuating gender stereotyped ideas that negatively influence women's status in society and their ability to fulfil their rights, including the right to housing. ${ }^{273}$ For instance, if governments have special tax benefits for breadwinners, if they condone the practice that women on average earn smaller wages than men, if part-time work is legally facilitated for individuals who have care-taking responsibilities, if policy documents speak about problems encountered by 'working' mothers, while the term 'working' fathers is non-existent, and if State-provided child-care services are sparse and expensive, this is an implicit message that it is presumed that women stay at home and take care of the children, and that only mothers, and not fathers, who wish to be gainfully employed are faced with a problem. This complex set of rules and policy choices will indeed perpetuate the traditional choice of the man of the household being full time employed while the woman will remain economically dependent because she stays at home or works only part-time because this is financially and practically the most attractive option.

Other reactive measures public authorities should take are banning negative stereotypical images of women from all sources of information that influence the public at large like radio, television, newspapers, internet, advertising and schoolbooks. ${ }^{274}$

Although changing the culture is no easy accomplishment in any society and may take a lot of time, public authorities will encounter most difficulties in those States that have traditional or fundamentalist societies or in which powerful ethnic or religious groups have been able to claim their personal law system. An-Na im suggests that change may be brought about by initiating an internal discourse, supported by cross-cultural dialogue. In his view, governments should see to it that those cultural rules that do not conform to universal human rights standards, like gender discriminatory regulations, are openly

272 The 'right of exit' argument suggests that a woman whose rights are violated within the group should abandon the only life that is known to her and lets her cope on her own with problems like lack of education and income, not to mention emotional stress. Ayelet Shachar, 2001, p. 41.

273 Rikki Holtmaat, Naar ander recht en beleid; De betekenis van artikel 5a VN-Vrouwenverdrag voor het uitbannen van structurele genderdiscriminatie, Ministerie van Sociale Zaken en Werkgelegenheid, Den Haag, juli 2004, p. 41.

274 Rikki Holtmaat, 2004, pp. 77-78. 
debated with a view to determine how they may be brought in line with international human rights obligations. Solutions to internal controversies may be found by looking at other States that are also involved in the same process. ${ }^{275}$ I fully agree that cultural changes cannot be imposed from the outside, but should be supported from within a society. Without broad public support they will never take roots. Although the method suggested by An-Naim may be the only one having potential of achieving results without causing an uproar, it is rather doubtful whether it will have enough impact in those fundamentalist countries where women do not take part in public life. How can there be a fruitful internal discourse resulting in more equality for women if women's voices are not heard?

Some multicultural States that have ratified human rights instruments and have brought their constitution and other legislation in conformity with these standards are faced with powerful personal law groups that strongly oppose cultural change in favour of women's human rights. If these States wish to take their human rights obligations towards women seriously, their only option is to find a way of reconciling these opposing interests. The accommodation of personal law groups should not go as far as sustaining practices that violate human rights, no matter how authentic or traditional these practices are claimed to be. ${ }^{276}$ Therefore, States should start by making an inventory of customs and traditions that deny women their equal rights. ${ }^{277}$ In some instances, it may be possible to use An-Na im's method of internal discourse, at least with the groups' leaders, in order to achieve reconciliation. However, those customs that cause women suffering, either physical, economical or social, should be abolished immediately. ${ }^{278}$ If these governments do not embark upon a struggle against discriminatory personal laws they act in violation of their human rights obligation and women's equality rights will remain a dead letter.

\subsection{Pro-active Measures}

In addition to the reactive measures that have been mentioned above, public authorities also have several tools at their disposal to prevent future discriminatory societal rules towards women. First of all, a watchful eye should be kept on new legislation and policies issued by any of the State's legislative bodies, be it at the central or local level. The media may be used to launch information campaigns aimed at changing stereotypical images of women and men. ${ }^{279}$ Although the focus of such campaigns should be

275 Abdullahi Ahmed An-Na im, 1992, p. 28

276 UNDP, Human Development Report 2004; Cultural Liberty in Today’s Diverse World, UNDP, New York, 2004, p. 58.

277 In respect to India the UNDP states: 'Personal laws of all communities have been criticized for disadvantaging women, and there are strong arguments for reforming almost all traditional (and usually patriarchal) laws and customs in the country, bringing Hindu and Muslim personal or customary laws in line with gender equality and universal human rights. [...] What is needed is internal reform of all customary laws, upholding gender equality rather than imposing identical gender-biased, prejudicial laws across all communities.' UNDP, 2004, p. 57.

278 According to Falk the human rights discourse takes precedence over contrary cultural practices if the suffering is intolerable. Richard Falk, 1992, p. 49.

279 In the Netherlands the Government, particularly the Ministry of Social Affairs and Employment, has launched several radio and television campaigns in the form of short commercial like messages in which 
on women, it is also highly important to question the male stereotypical image. Men, too, are forced into certain roles, and although in many cases male stereotyping may be positive for them since they are presumed to have certain qualities that are held in high regard like leadership and courage, they are also restricted in their choices because of the stereotyped idea of how a man should behave. ${ }^{280}$

In order to prevent negative female stereotypes being used by third parties, directives should be issued concerning the depiction of women in the media, advertising and schoolbooks. Furthermore, public authorities should closely work together and support - financially and otherwise - organizations that aim at the advancement of the position of women. For instance, institutions that actively combat gender stereotyping may be subsidized, ${ }^{281}$ while at the community level, authorities should closely co-operate with, and provide facilities for, already existing grassroots civil society organizations since these associations stand a better chance of achieving results than any top down approach. Finally, some extreme forms of harmful stereotyping like violent pornography may be criminalized.

\subsection{In Conclusion}

Public authorities that wish to improve women's empowerment should not be daunted by strong opposition against cultural change. They should bear in mind that culture is in itself a paradoxical concept; consisting both of age-old traditions and continuous change. ${ }^{282}$ Traditional customs that are harmful for women should be discarded or may be replaced by other rules that can be reconciled with human rights standards. ${ }^{283}$ Arguments that cultural change is impossible or will by definition take several generations may be countered by pointing at the remarkable reversal that recently happened in Rwanda. Faced with a dramatically reduced number of male adults, legislation and policies were introduced that completely contravened traditional thinking about women's roles in society. The percentage of female politicians was skyrocketed to the number one position in the world, while girls and women can now hold property, inherit, and be heads of households. Such a radical governmental intervention cannot but have a huge positive effect on women's and men's thinking about appropriate gender roles.

for instance girls are encouraged to take break away from typical female careers and therefore to take science in school (Marie kiest exact), girls and women are forewarned that they are supposed to be economically independent citizens (Een slimme meid is op haar toekomst voorbereid), and the gender stereotypical division of work, especially in the private sphere is brought up for discussion (Wie doet er thuis nu eigenlijk wat).

280 Therefore, the Norwegian law that compels fathers to take up a certain period of parental leave after their child has been born, met with great approval of CEDAW. Rikki Holtmaat, 2004, pp. 39 and 78. See $U N$ doc. CEDAW/C/SR.277, para. 486.

281 The Dutch Government e.g. subsidized a talk show that initiated public discussion on the topic of men's role in the household as fathers and care takers (Mannen in de hoofdrol). At www.wiedoetwat.nl/pers/ home.asp?, last consulted on 18 January 2005.

282 Abdullahi Ahmed An-Na im, 1992, p. 27.

283 For example in a few societies the act of female genital mutilation of girls has been exchanged for a coming of age ceremony. No blood is spilled anymore, but the symbolic remains. 


\subsubsection{Civil Society Organizations}

Both international and national civil society organizations may play a part in the abolition of cultural practices that form barriers as regards the realization of women's rights. Outsiders, such as international civil society organizations, must restrain themselves from imposing their ideas and instead should play a role in the background. Their task should be the provision of information and training of local staff. Furthermore, they should consistently point out violations of women's rights to governments and international monitoring bodies, since they are better equipped to do so than local organizations who have to co-operate with the authorities. ${ }^{284}$

A far more important part is to be played by national or local (women's) civil society organizations, especially those that work at the grassroots level. Women and men belonging to the same culture and who speak the same language can make a real difference when they explain what rights women and men have, why certain customs and traditions are harmful for women and maybe what alternatives are available. Very good results have been achieved in this way with regard to the practice of female genital mutilation. It should be noted that the target group should not only consist of women, but also of men. Many men are not aware that some cultural practices that they have known for all their lives are actually harmful for women. Even men who think of themselves as superior to women and who would not wish to alter traditional practices for their wives may think quite differently when they realize that their daughters are next in line for being discriminated against and for facing an insecure future particularly at the hands of their partners and in-laws.

\subsubsection{Women Themselves (Bearers of Culture)}

Lack of knowledge and education is the first obstacle for changing cultural practices that negatively affect women's status in society. Many women may not be aware of the fact that they have rights or that societal constructions relegate them to inferior positions. They have grown up with the idea that they have certain roles to play in society, or that they have to take certain practices in their stride and this has become so much part of their own identity that they do not realize that compliance with stereotypical images is in fact making them powerless and subjugated in relation to men. ${ }^{285}$ For instance, when during a wide-scale research in Central and Eastern Europe women were asked whether they suffered from domestic violence, many answered that they were no victims because the habit of wife battering was so widespread that it was accepted as a fact of life and not recognized as a violation. ${ }^{286}$

284 Civil society organizations may keep the pressure up by continuously naming and shaming States that violate their obligations under the Women's Convention. Rikki Holtmaat, 2004, p. 78. Also see section 4.7.4.

285 Cerna and Wallace, 1999, pp. 644-645.

286 In Ukraine domestic violence turned out to be so widespread that the general feeling was that a nonviolent existence is impossible. Many women did not think of themselves as victims but simply 'got used to' what they considered a normal lifestyle. International Helsinki Federation for Human Rights, Women 2000; An Investigation into the Status of Women's Rights in Central and South-Eastern Europe and the Newly Independent States, IHF, 2000, p. 485. 
Education, both general literacy and human rights education is therefore the key prerequisite. Women, who are aware of the fact that their rights are violated, should try to improve their circumstances, preferably together with other women who are in the same situation. The authorities and civil society organizations can help here with specific support programmes. Particular attention should be paid to the situation of single mothers and battered women. Instead of remaining victims, these women should be enabled to become autonomous citizens.

Though the ultimate aim is a structural cultural change resulting in the advancement and empowerment of women, a pragmatic use might be made of the fact that women are still regarded as the bearers of culture and that the existing gendered division of work is such that women take up the greater part of raising their children. If women themselves are well informed about their rights and the consequences of choices and preferences in education that may be made in respect to their daughters and sons, they may be induced to start raising their children in a different way, breaking with traditional patterns. Though this is no short term solution, at least women themselves may bring about a change for the next generation.

\subsubsection{Concluding Remarks}

No society in the world is exempt from retaining cultural rules and habits that have a detrimental effect on women's rights. Nevertheless, interference in traditions and customs is still perceived as irreverence for a people's culture. Many public authorities are reluctant to intervene although inaction entails sacrificing women's human rights. If women's right to adequate housing is taken seriously, however, abolishing traditions of female subjugation and gender stereotyping are a prerequisite. Formal equality is inadequate if societal rules forestall de facto realization. In fact, many States are legally obliged to forego cultural rules if these negatively affect women's right to equality and non-discrimination. The prime provision in this regard is Article 5 of the Women's Convention, although also other provisions, like Article 2(f) of the Women's Convention, Article 24(3) CRC, Article 3 ICCPR, and, to a lesser extent, Article 3 ICESCR, may be used as the legal basis for intervention.

Attempts to change cultural habits will meet with much resistance and obstacles at different levels. At State level legislation and policies may be influenced by gender stereotypical thinking. Governments, especially of fundamentalist or multicultural States, may be reluctant to intervene on behalf of women because they fear powerful cultural groups or because they think that it is not their task or legal right to do so. Furthermore, public authorities may think that their interference will not yield results, meanwhile forgetting that by their own legislation and policies they are already strengthening and perpetuating stereotypes. At the community and family level the very nature of cultural rules may form the biggest obstacle. Societal behavioural rules have become so much part of people's identity that they are very hard to question or to discard.

Although public authorities are best equipped to bring about a cultural change because of their legislative and policy making abilities, there are also other actors who may contribute. International agencies and international and national civil society organi- 
zations may pull their weight by informing and educating people about their rights and the harmful character of some cultural practices for women. Lastly, women may make their reputation as bearers of culture true. They should use the most powerful weapon they have in traditional societies and start raising their children in a non-biased way.

\subsection{STATE RESPONSIBILITY}

\subsubsection{Introduction}

State responsibility is a fundamental principle of international law, based on the notions of State sovereignty and equality of States. Originally, it was only accepted and applied to situations where one State had committed an internationally unlawful act against another State. If such an infringement caused damage to the other State, automatically the duty to make reparation would arise. ${ }^{287} \mathrm{With}$ the international acceptance of human rights and humanitarian law standards, State responsibility was also assumed in situations where States had committed wrongful acts as regards their own populations. ${ }^{288}$ Still more recently, it was recognized that under certain, restricted, conditions, States may also be held responsible for acts that have been committed by non-State actors against other non-State actors. ${ }^{289}$

In the following, first the concept of State responsibility will be discussed; precisely which conditions must be met before a State can be held responsible. In section 4.6.3 acts and omissions are examined that would violate the State's obligations as regards women's housing rights. Following the typology of obligations, these acts and omissions are categorized according to the duties to respect, protect and fulfil the right to housing. In order to ascertain whether the State is (co)responsible for an act of a non-State actor, the principle of due diligence may be used. Application of this principle to violations of women's housing rights is the subject of section 4.6.4. Finally, the legal consequences of State responsibility, including the different forms of reparation, are examined in section 4.6.5.

\subsubsection{The Concept of State Responsibility}

The concept of State responsibility ${ }^{290}$ has primarily been developed in customary law and in case law. ${ }^{291}$ The International Law Commission (ILC) 'finalized' its codifying

287 Malcolm Shaw, International Law, $5^{\text {th }}$ ed., Cambridge University Press, Cambridge, 2003, p. 694.

288 Theo van Boven claims that States are responsible for violations of their human rights obligations both to other States, based on the erga omnes character of these obligations, and to persons within their jurisdiction 'whenever these persons are the victims of violations of internationally recognized human rights committed by that State'. See UN doc. E/CN.4/Sub.2/1993/8, 2 July 1993, Study concerning the right to restitution, compensation and rehabilitation for victims of gross violations of human rights and fundamental freedoms, Final report submitted by Mr Theo van Boven, Special Rapporteur, para. 45.

289 See e.g. Jan Willems, Wie zal de Opvoeders Opvoeden? Kindermishandeling en het Recht van het Kind op Persoonswording (Who will educate the educatiors? Child abuse and the right of the child to become a person), T.M.C. Asser Press, Den Haag, 1998, particularly chapter 13, pp. 631-820.

290 State responsibility has to be distinguished from state accountability. The latter term involves a duty to provide an explanation for an internationally unlawful act while the first entails a duty to provide repara- 
work on this issue in November 2001 by adopting the Draft Articles on State Responsibility and submitting them to the UN General Assembly. ${ }^{292}$ From these sources it has become clear that a State is responsible for a wrongful act or omission when three conditions have been fulfilled:

a) the State is bound by an international obligation;

b) this obligation has been breached;

c) the breach is attributable to the State. ${ }^{293}$

In the framework of this book, the study of the concept of State responsibility is limited to cases of violations of women's housing rights both by State and non-State actors. Consequently, first it has to be determined that an international obligation as regards women's right to adequate housing does exist. That this is the case may be induced from the fact that the great majority of States have willingly ratified or have acceded to international human rights conventions that either explicitly contain the right to adequate housing, ${ }^{294}$ or that implicitly cover this right because they stipulate that women are entitled to equality and non-discrimination as regards other human rights contained in such conventions that attribute to, or are necessary for obtaining, adequate housing such as the right to property, the right to privacy, freedom of residence and the right to equal pay for work of equal value. ${ }^{295}$ The principle of pacta sunt servanda entails that States parties to such conventions are henceforward bound to comply with them in good faith. The fact that human rights conventions contain obligations towards a State party's own population instead of towards another State, does not in any way affect or diminish the existence of an international obligation.

An international obligation is breached when an act of the State is not in conformity by what is required of it by that obligation. ${ }^{296}$ Violation of women's right to adequate housing may happen in various ways and stages since the State is obliged to respect,

tion for an internationally wrongful act. Menno T. Kamminga, Inter-State Accountability for Violations of Human Rights, Proefschrift, Rijksuniversiteit Leiden, 1990, pp. 4-5.

291 Only a few treaty rules pertaining to State responsibility existed, the most important of which Article 3 of the Fourth Hague Convention of 1907 on the Laws and Customs of War on Land. Antonio Cassese, International Law, Oxford University Press, Oxford, 2001, pp. 182-183. Martin Dixon, Textbook on International Law, $5^{\text {th }}$ ed., Oxford University Press, Oxford, New York, 2005, p. 228.

292 The International Law Commission (ILC) already started its codifying work on State responsibility in 1956. On the history of the codification by the ILC see James Crawford, The International Law Commission's Articles on State Responsibility; Introduction, Text and Commentaries, Cambridge University Press, Cambridge, 2002, pp. 1-60.

293 ILC, Draft articles on Responsibility of States for internationally wrongful acts, adopted in November 2001, Articles 1 and 2.

294 Such as the International Covenant on Economic, Social and Cultural Rights in Article 11(1), the Women's Convention in Article 14(h) with regard to rural women, and the Convention on the Rights of the Child in Article 27(3) in respect to children.

295 For instance the International Covenant on Civil and Political Rights which covers the right to equal remuneration for work of equal value (Art. 7(a)(i)) and the right to freedom of residence (Art. 12), and the Women's Convention which contains the right to equal remuneration for work of equal value (Art. 11(d)), freedom to choose residence and domicile (Art. 15(3)), and the equal right o both spouses to ownership, acquisition, management, administration, enjoyment and disposition of property (Art. 16(h)) .

296 ILC Draft articles, Article 12. 
protect and fulfil this right. Examples of different breaches will be discussed in subsection 4.6.3.

The State is an abstract entity. That is why it will only be responsible if violations can be imputed to it as is the case with acts of State organs and State officials. ${ }^{297}$ This also extends to acts that have been committed ultra vires, and the acts of persons or entities that are not State organs but that are empowered to exercise particular governmental tasks, or that are acting on the instruction or control of the State. ${ }^{298}$ Moreover, under certain conditions, the State may also be held responsible for violations by non-State actors. ${ }^{299}$

According to the ILC the legal consequences of an internationally wrongful act for which the State is responsible comprise the continued duty to perform the obligation, the cessation of the violating act, assurances and guarantees of non-repetition, and, in cases of damage, a duty to make reparation. ${ }^{300}$

Reparation is the general term for all forms, both material and immaterial, of indemnifying a victim for violations that have been suffered. ${ }^{301}$ Restitution is the most desirable form of reparation since it denotes that the situation is to be restored as much as possible to the situation prior to the violation. ${ }^{302}$ Obviously, this form is not applicable in cases where irreversible damage has occurred, like the death of the victim. Compensation is in order when restitution is not a possibility. It indicates monetary indemnification for financially assessable damage. Rehabilitation is the provision of legal, medical and psychological care as well as the restoration of dignity and reputation. Satisfaction may consist of such actions as acknowledgement of the unlawful character of the act, formal apologies, expressions of regret, and punishment of the perpetrator. According to some studies on reparation it may also comprise cessation and assurances and guarantees of non-repetition. ${ }^{303}$ From an international law point of view, I think that the distinction

297 Theodor Meron, Human Rights and Humanitarian Norms as Customary Law, Clarendon Press, Oxford, 1989, pp. 155-159. Ian Brownlie, Principles of Public International Law, $5^{\text {th }}$ ed., Clarendon Press, Oxford, 1998, p. 449.

298 ILC Draft articles, Articles 4-11. Antonio Cassese, 2001, pp. 187-191.

299 The principle of due diligence may be used to determine whether the State is (co)responsible for a violation by a non-State actor. 'A breach of human rights which is initially not imputable to a state, having been committed by either a private or by an unidentified person, can generate state responsibility not because of the act itself, but because of the lack of due diligence [...] by allowing the act to take place either with its support or acquiescence or by not taking measures designed to prevent the act or to punish those responsible.' Theodor Meron, 1989, p. 171. The principle of due diligence and its application will be discussed in section 4.7.4.

300 ILC Draft articles, Articles 29, 30 and 31 respectively.

301 See $U N$ doc. E/CN.4/Sub.2/1993/8, 2 July 1993, Final report submitted by Mr Theo van Boven, Special Rapporteur, Chapter IX on Proposed Basic Principles and Guidelines, particularly sections 8-11 on Forms of Reparation. See the Basic Principles and Guidelines on the Right to a Remedy and Reparation for Victims of Gross Violations of International Human Rights Law and Serious Violations of International Humanitarian Law, adopted by the UN General Assembly in its resolution 60/147 of 16 December 2005.

302 This basic principle of reparation was first established by the Permanent Court of International Justice in the Chorzów Factory case, PCIJ, Series A, No. 17, 1928, pp. 47-48.

303 The ILC Draft Articles only mention restitution, compensation and satisfaction as forms of reparation, while cessation and assurances and guarantees of non-repetition are mentioned as separate legal consequences of internationally wrongful acts. The UN Basic Principles and Guidelines on the Right to a Remedy and Reparation for Victims of Gross Violations of International Human Rights Law and Serious Violations of International Humanitarian Law, however, acknowledge also rehabilitation and guarantees 
made by the ILC in the Draft Articles on State Responsibility is more correct since reparations are made for wrongful acts in the past, while cessation and non-repetition seek to foreclose future violations. Moreover, cessation and assurances of non-repetition are the ordinary legal obligations that ensue from a harmful act. Whether, and in what form reparation has to be made must be assessed after it has become clear that the State is indeed responsible for the harmful act.

The different forms of reparation may be applied singly or in combination with each other. Tailoring the application of legal consequences to violations of women's housing rights is the subject of sub-section 4.6.5.

\subsubsection{Acts and Omissions that Involve State Responsibility}

Not only acts, but also omissions may constitute violations of State obligations..$^{304}$ Following the typology of obligations, the right to housing entails the duties to respect, protect and fulfil this right. ${ }^{305}$ As far as women's housing rights are concerned, these obligations cannot be separated from the obligations to respect, protect and fulfil the rights to gender equality and non-discrimination.

In the following sub-sections examples from a victim's point of view will be given of violations of housing rights that would entail State responsibility. Many of these examples will be applicable to the right to adequate housing of men and children, too. Some violations, however, typically reflect women's situation. The examples are distinguished on the basis of the obligations to respect, to protect and to fulfil. This classification is used to allow better insights into the broad spectrum of violations, but is not meant to be strict; sometimes there may be good arguments to put an example (also) in a different category. Furthermore, the examples mentioned are by no means meant to be exhaustive, but may be the most obvious or the most serious forms of violations that bring about State responsibility. Finally, it should be pointed out that it may be easier to find clear examples as regards the duties to respect and to protect as the duty to fulfil is rather complex and vague inasmuch as this particular modality of realizing the right to adequate housing depends to a large extent on political choices and economic possibilities.

\subsubsection{The Duty to Respect}

The duty to respect entails that the public authorities recognize the right to adequate housing and should not interfere with people's ability to acquire and maintain their own housing. ${ }^{306}$

of non-repetition as forms of reparation, while cessation is included under the heading of satisfaction. On this matter see James Crawford, 2002, pp. 28 and 31-34.

304 Martin Dixon, 2005, p. 230. Also Malcolm Shaw, 2003, p. 696.

305 The typology of obligations was originally developed by Henry Shue in his book Basic Rights, Subsistence, Affluence and US Foreign Policy, Princeton, New Jersey 1980. The method was subsequently used by Special Rapporteur Asbjørn Eide in his reports on the Right to Food and also by Special Rapporteur Rajindar Sachar in his first Progress Report on the Right to Housing. Sachar extended the duties of to respect, to protect and to fulfil with the duties to recognize and to promote. See section 2.5.1.

306 See $U N$ doc. E/CN.4/Sub.2/1993/15, of 22 June1993 on The right to adequate housing: progress report 
An obvious violation of the duty to respect is forced evictions. ${ }^{307}$ People who have found a place to live are forced to leave without an adequate alternative because the public authorities want to use the land of the inhabitants for other purposes. The Committee on Economic, Social, and Cultural Rights has concluded in its General Comment No. 7, that forced evictions are prima facie a violation of the right to adequate housing. ${ }^{308}$ As a consequence of forced eviction people are turned out into the streets, sometimes without any of their possessions, exposed to a variety of dangers that affect their health and may even endanger their lives like extreme weather conditions, lack of clean drinking water, unhealthy sanitary conditions, and (sexual) abuse. This latter danger is even more prominently present in the case of homeless women.

The duty to respect women's housing rights may also be violated by adopting and/or perpetuating discriminatory legislation, policies, and customs as regards women's rights to property, including rent, inheritance, freedom of settlement, political participation, and access to credit and loans, to such an extent that women are impeded from procuring adequate housing by themselves and thus are structurally dependent on others for a place to live. States that do not respect women's autonomous right to housing usually regard women as legal minors or secondary citizens who cannot act independent of some male 'guardian' or other, be it their father, brother, uncle, husband, father- or brother-inlaw, or son. Consequently, these States are responsible if these women become homeless with all dire consequences because no male guardian is able or willing to house them.

Examples are abundant like the Hindu widows (and their children) in South-East Asia, who are dejected by their in-laws and who cannot possibly obtain a place to live by themselves because they are denied all means that would enable them to acquire housing autonomously. As a consequence, they live under inhuman and degrading circumstances in the streets, begging and prostituting themselves without any hope of escaping this situation. ${ }^{309}$ Or the situation of female returnees after the war in Kosovo who were unable to access their former dwelling, either parental or marital home, because it had been customarily seized by male relatives of their late fathers or husbands. ${ }^{310}$ The same is true for parts of Africa and Asia where inheritance laws have the effect that upon their return female IDPs will find themselves homeless and economically destitute because their late husband's relatives are entitled to take possession of his land and housing after his death. ${ }^{311}$

submitted by Mr Rajindar Sachar, paras 66-68.

307 See section 3.3.2 infra for a detailed discussion of forced evictions.

308 In General Comment No. 7 on Forced Evictions, the UN Committee on Economic, Social and Cultural Rights defines forced evictions as: 'the permanent or temporary removal against their will of individuals, families and/or communities from the homes and/or land which they occupy, without the provision of, and access to, appropriate forms of legal or other protection'. UN doc. E/C.12/1997/4, para. 4.

309 See section 3.3.4 on widowhood.

310 See section 3.3.2 on forced evictions.

311 Simon Bagshaw, 'Property restitution for internally displaced persons: developments in the normative framework', in: Scott Leckie (ed.), Returning Home: Housing and Property Restitution Rights of Refugees and Displaced Persons, Transnational Publishers, Ardsley, 2003, p. 387. 


\subsubsection{The Duty to Protect}

The duty to protect is usually perceived to mean that public authorities should defend people's human rights against acts of non-State actors. ${ }^{312}$ With regard to the right to housing, however, this should be broadened to any situation in which public authorities can use their powers or influence in order to protect people's housing situation. Whether or not a State has failed its duty to protect will depend on the extent to which protection is possible and the actions that have been taken.

In some cases protection should be given against the forces of nature. Some locations are extremely dangerous. Examples are hillsides that are susceptible to landslides, foothills of volcanoes, and charlands (plots of land that emerge in a river or adjacent to its banks) which will disappear again as soon as the river has flooded because of the continuing process of accretion and erosion. The poorest people, the majority of whom are women, will settle in such dangerous locations because the land is for free or very cheap. Public authorities are responsible if people lose their lives, their housing and their possessions if they allow them to settle down in such areas instead of offering them safe alternatives. ${ }^{313}$

Another failure with respect to the duty to protect against natural disasters is the lack of an effective and early warning system. ${ }^{314}$ Information of upcoming catastrophes may not reach women or not in time because it is spread in public places that are not frequented by women, or the information is in writing, while the majority of the illiterate are women. Sometimes public authorities announce warnings only in the official language that cannot be understood by ethnic minorities. ${ }^{315}$

In the following examples of the duty to protect, non-States parties are involved. It may be clear, that not every violation inflicted by a non-State actor will (also) be the responsibility of the State. Many violations may be classified as common crimes or torts for which only the perpetrating individual should be held accountable. Sometimes, however, the circumstances are such that violations by non-State actors fall into the scope of State responsibility. ${ }^{316}$ This is the case when the State and its organs have not exercised

312 This is also the perception of Sachar in his first progress report. See $U N$ doc. E/CN.4/Sub.2/1993/15, paras 69-72.

313 In the Öneryildiz v. Turkey case (18 June 2002) the European Court of Human Rights came to the conclusion that Turkey had violated Article 2 (right to life) of the European Convention on Human Rights and Fundamental Freedoms because the authorities had failed to inform the public and had allowed people to settle next to a garbage dump in spite of the fact that they had been informed that there was a substantial danger of methane gas explosion. When an explosion did take place on 28 April 1993 some ten dwellings were buried under by the ensuing landslide and 39 people were killed. See Menno T. Kamminga, 'Europees Hof voor de Rechten van de Mens, 18 juni 2002, Öneryildiz t. Turkije', in: Tijdschrift voor Milieu en Recht, 2005, nr. 13.

314 A recent example was the December 2004 Indian Ocean Tsunami that cost thousands of people their lives because there was no warning system.

315 Also see section 3.3.3 on natural and human-made disasters.

316 Celina Romany states that States can especially be held responsible for systematic private male violence against women. She mentions two reasons for her statement: States systematically fail to provide protection for women from private actors and thus become complicit in the violation, and the State is responsible if it fails to fulfil its obligation to prevent and punish violence against women in a nondiscriminatory way. Celina Romany, 'State Responsibility Goes Private', in: Rebecca J. Cook (ed.), 
due diligence to prevent the violation or to investigate and punish the crime. ${ }^{317}$ The intricacies of due diligence shall be dealt with in sub-section 4.6.4.

Failures to protect may also be found in situations of temporary housing like safe houses and shelters for battered women, centres for asylum-seekers or refugee camps. Women, who have already been victims of violence, are victimized yet again if they have to live in constant fear, are harassed or abused in the very places where they hope to find safety. ${ }^{318}$ Although the actual violations happen at the hands of private persons, public authorities can and should take adequate measures in order that these places of refuge do in fact offer shelter.

A very common blunder is the failure to keep addresses of shelters for battered women secret. Clearly the authorities have failed in their duty to protect and are responsible if women are harassed, abused or even killed by their (former) partners while they are housed in such a 'safe'-house. 319

It is understood that the home should be a safe haven; a place where a person can live in security and dignity. If a woman is battered in her own home, many of her rights are infringed. Most obvious is perhaps the violation of her right to physical integrity, and in extreme circumstances (maybe) even, the very right to life itself. A woman's mobility rights may be violated in cases where she is policed by her husband and forbidden to leave the house without his permission. Some women are virtual prisoners within their own homes. Living in constant fear of being molested makes home into a hell. Every 'wrong' step may trigger a bout of violence, though many times it will be unclear why fault was found. Indeed the 'punishment' that is meted out may be quite random. ${ }^{320}$ Living in such unsafe conditions will render the housing situation inadequate and dangerous. The pervasive and structural character of domestic violence all over the world in all layers of society makes it a crime that squarely falls within the scope of State responsibility.

In certain instances, States may fail their duty to protect tenants against their landlords. If there is no or inadequate legislation to keep the level of rents in check, some

Human Rights of Women, National and International Perspectives, University of Pennsylvania Press, Philadelphia, 1994, p. 99.

317 According to Rebecca Cook the State will bear responsibility of it 'facilitates, conditions, accommodates, tolerates, justifies, or excuses private denials of women's rights [...]. The state will be responsible not directly for the private acts, but for its own lack of diligence to prevent, control, correct, or discipline such private acts through its own executive, legislative, or judicial organs'. Rebecca Cook, 'State Accountability Under the Convention on the Elimination of All Forms of Discrimination Against Women', in: Rebecca J. Cook (ed.), Human Rights of Women, National and International Perspectives, University of Pennsylvania Press, Philadelphia, 1994, p. 229.

318 See section 3.4.5.4 on female refugees and internally displaced women.

319 In the Netherlands, e.g. addresses of safe houses are not so difficult to obtain. Many women living in such shelters are harassed by their (former) partners who make it very unsafe for them to leave the house. In March 2004 for example, a man succeeded in tracing his wife time and again by way of accessing internet data of their common health insurance company. When he caught her in front of the fourth shelter she had taken refuge in, he killed her in the presence of their three children. The Dutch newspaper NRC Handelsblad, 26 March 2004.

320 See for instance Rhonda Copelon, Intimate Terror: Understanding Domestic Violence as Torture, in: Rebecca J. Cook (ed.), Human Rights of Women, National and International Perspectives, University of Pennsylvania Press, Philadelphia, 1994, pp. 116-152. 
landlords may demand exorbitant prices that will exceed the affordability of the housing. ${ }^{321}$ If this results in a fair number of people becoming homeless because there is no alternative adequate housing at a cheaper price available, State responsibility is at stake. Many women, particularly from developed countries, mention eviction because of persistent non-payment of rent as one of the most important causes of homelessness. ${ }^{322}$ Rent increases will hit women far worse than men because many women, especially female heads of households, will be in a weaker economic position. For several reasons the average income of women is lower than that of men. ${ }^{323}$ As a result, the average woman has less money to spend than the average man and thus will sooner be the victim of this cause for eviction. $^{324}$

In some States, it is condoned that living-in domestic servants, especially immigrants, live in slave-like circumstances. ${ }^{325}$ Labour laws may not extend to these female migrant workers so that they do not enjoy the protection that native workers will. In many cases, these women are robbed from their freedom and besides being exploited by their employers, they may also be physically and sexually abused. If these women succeed in bringing their deplorable circumstances into the open, public authorities of some States will fail to prosecute and punish the abusing employers.

A last example is the failure to protect women against certain traditional practices that among other rights, deny them the right to adequate housing. The practice that is perhaps the most degrading and inhuman is levirate; widows themselves are regarded as part of the estate and therefore are 'inherited' by their late husband's heir, usually his brother or other male relative. Complying with this custom may be a woman's only option to keep a roof over her head. ${ }^{326}$

\subsubsection{The Duty to Fulfil}

It is not easy to determine when the duty to fulfil the right to housing has been violated to such an extent that it is a matter of State responsibility. The duty 'to fulfil' is the ultimate layer of obligations that States have to comply with. However, how and when they realize it is to a large degree left to the States' discretion; it will depend on political choices as regards budgetary allocations and economic possibilities. Therefore, it cannot be maintained that the concept of State responsibility is always applicable if the right to housing has not been realized in a particular State. On the other hand, if a State fails to take certain actions that are due irrespective of the economic situation or stage of devel-

321 Committee on Economic, Social and Cultural Rights, General Comment no. 4, the right to adequate housing, 1991, UN doc.E/1992/23, para. 8(c) on affordability.

322 See section 3.3.2 on forced evictions.

323 The majority of women work in 'female' occupations which are typically undervalued and less remunerated than comparable 'male' jobs. Hilary Charlesworth and Christine Chinkin, The boundaries of international law; A feminist analysis,Manchester University Press, Manchester, 2000, p. 16.

324 In Canada, for example, the number of homeless women, especially sole support mothers, has increased enormously because of non-payment of rent. Single parent families enter the shelter system at twice the rate of two parent families. Between 1988 and 1996 the number of female-headed families in the hostel system increased by $13 \%$.

325 See section 3.4.5.3 on women migrant workers.

326 See section 3.3 .4 on widowhood. 
Chapter IV

opment of the State, with the result that women are structurally discriminated against as regards their right to adequate housing, it may be asserted that the State is responsible for violating its duty to fulfil and as a consequence is obliged to make reparation.

An example of such a situation is the failure to adopt and/or to enforce effective legislation and policies that guarantee gender equality and non-discrimination. The results of such a failure will be that women will not be able on an equal footing with men to procure adequate housing by themselves. This is evident when sex-disaggregated data are studied: women will not own, rent or be able to access land and housing on the same level as men.

Furthermore, public authorities may fail to disseminate housing related information in an adequate and gender neutral way. The information may concern available council housing, building sites, rights to basic services, and housing subsidies. Particularly the poor and the illiterate may thus be deprived of an opportunity to fulfil their housing rights.

A last example concerns the failure to make easily accessible remedies available, be they in the criminal, administrative or private law sphere, that people can use if their housing rights have been violated. Even non-legal remedies may be an option if they are more effective. In many States remedies are organized in such a way that they are too expensive or complicated for the poor and illiterate. Moreover, information about available remedies, including reparation, may not be disseminated in such a way that the poor, homeless and illiterate will know where to turn to in case their housing rights are affected.

\subsubsection{Due Diligence}

For many women serious violations of their right to adequate housing will happen at the hands of private persons in the domestic sphere; they are battered by their partners, they live in temporary housing where they are harassed or abused by co-occupiers or by their former partners, or they are subjected by their families to undergo degrading and inhuman traditional practices like levirate. All these violations have an enormous negative impact on women's rights to dignity, security, and safety at home, some of the most important aspects of the right to adequate housing.

The notion that the State may also be responsible for human rights violations even though the actual harm is inflicted by a non-State actor was expressed for the first time by the Inter-American Court of Human rights in the Velázquez-Rodriguez case. ${ }^{327}$ According to the Court under certain conditions the State and its organs have to exercise

327 Inter-American Court of Human Rights in the Velásquez-Rodriguez v. Honduras case, Judgment of 29 July 1988, OAS/ser.L./V./III.19, doc. 13, where the Government was held responsible for the disappearance of individuals, although the actual abductions had been carried out by private persons.

Also see Article 18 of the Maastricht Guidelines on 'Acts by Non-State Entities': 'The obligation to protect includes the state's responsibility to ensure that private entities or individuals, [...] do not deprive individuals of their economic, social and cultural rights. states are responsible for violations of economic, social and cultural rights that result from their failure to exercise due diligence in controlling the behaviour of such non-state actors' (emphasis added). Theo van Boven, Cees Flinterman, Ingrid Westendorp (eds.), The Maastricht Guidelines on Violations of Economic, Social and Cultural Rights, SIM Special No. 20, SIM, Utrecht, 1998, p. 9. 
due diligence to prevent violations and/or to investigate and punish the crimes. Furthermore, they will have to provide for reparation. ${ }^{328}$

It may be clear that, unlike the perpetrating citizen, the State will not be held responsible for a single negligent act. State responsibility will only be assumed if there is a consistent pattern of inaction or ineffective action from the side of the public authorities who are aware that structural harm is being caused on a certain group in society. ${ }^{329}$ Over the last few decades, it has been acknowledged that violence against women is a widespread and structural violation of human rights, inflicted both by State and non-State actors. Because of its structural nature it has been recognized by several international (human rights) bodies that States may tacitly condone such violence to happen. That is why they have followed the Inter-American Court's example and also accept that under certain conditions States may be (co)responsible because of a lack of due diligence.

For instance CEDAW stated in its General Recommendation no. 19:

'[...] Under general international law and specific human rights covenants, States may also be responsible for private acts if they fail to act with due diligence to prevent violations of rights or to investigate and punish acts of violence, and for providing compensation'. ${ }^{330}$

Immediately after the Second World Conference on Human Rights in Vienna in 1993, the UN General Assembly adopted the Declaration on the Elimination of Violence against Women. ${ }^{331}$ After defining violence against women as a violation of the rights and fundamental freedoms of women in its preamble, the Declaration stipulates that States should not excuse violence against women by referring to custom or tradition, but that they should exercise due diligence to prevent, investigate and punish acts of violence against women no matter whether these acts have been committed by State actors or by private persons. $^{332}$

328 Literally the Court found that: 'An illegal act which violates human rights and which is initially not directly imputable to the state (for example, because it is the act of a private person or because the person responsible has not been identified) can lead to international responsibility of the state, not because of the act itself but because of the lack of due diligence to prevent the violation or to respond to it as required by the Convention'. [...] 'The State has a legal duty to take reasonable steps to prevent human rights violations and to use the means at its disposal to carry out a serious investigation of violations committed within its jurisdiction, to identify those responsible, to impose the appropriate punishment and to ensure the victim adequate compensation.'

329 Rebecca Cook, 'State Responsibility for Violations of Women's Human Rights', in: Harvard Human Rights Journal, Vol. 7, Spring 1994, p. 151.

330 CEDAW, General Recommendation No. 19 on Violence Against Women, 1992, UN doc. A/47/38, 1992, para. 9.

331 General Assembly resolution 48/104, UN doc. A/48/49, 1993.

332 Art. 4(c), Declaration on the Elimination of Violence against Women, which reads: 'States should condemn violence against women and should not invoke any custom, tradition or religious consideration to avoid their obligations with respect to its elimination. States should pursue by all appropriate means and without delay a policy of eliminating violence against women and, to this end, should: [...] c) Exercise due diligence to prevent, investigate and, in accordance with national legislation, punish acts of violence against women, whether those acts are perpetrated by the State or by private persons'. 
In 1994 the UN appointed a Special Rapporteur on the subject of violence against women who paid ample attention to State responsibility in her reports. ${ }^{333}$ In her 1996 report she wrote that:

'[...] unlike for direct State action, the standard for establishing State complicity in violations committed by private actors is more relative. Complicity must be demonstrated by establishing that the State condones a pattern of abuse through pervasive non-action. Where States do not actively engage in acts of domestic violence or routinely disregard evidence of murder, rape or assault of women by their intimate partners, States generally fail to take the minimum steps necessary to protect their female citizens' rights to physical integrity and, in extreme cases, to life. This sends a message that such attacks are justified and will not be punished. To avoid such complicity, States must demonstrate due diligence by taking active measures to protect, prosecute and punish private actors who commit abuses. 334

Recently, the Human Rights Committee reaffirmed that in order to fulfil its positive obligations under the Covenant a State not only has a duty to protect its citizens from violations by its agents:

'[...] but also against acts committed by private persons or entities that would impair the enjoyment of the Covenant rights in so far as they are amenable to application between private persons or entities. There may be circumstances in which a failure to ensure Covenant rights as required by Article 2 would give rise to violations by States Parties of those rights, as a result of States Parties' permitting or failing to take appropriate measures or to exercise due diligence to prevent, punish, investigate or redress the harm caused by such acts by private persons or entities. ${ }^{335}$

The pervasive and structural character of domestic violence makes it the prime example of a violation by non-State actors of women's housing rights for which States also bear responsibility. Worldwide, public authorities fail to take effective legislative or policy measures to prevent domestic violence because they regard it as a private affair or they go along with the culturally accepted view that women may be battered by their partners. They tacitly condone such practices when they do not make effective efforts to investigate reports of violence, or when they do not adopt or effectuate effective legislation to prosecute and punish the perpetrators or to protect the victims by creating and maintaining safe shelters or by evicting the batterer. Furthermore, they may fail to provide effective remedies and reparation so that victims remain living in inadequate circumstances or become homeless. Thus, State authorities become accomplices of domestic violence and are responsible alongside the actual culprits. ${ }^{336}$

333 Radhika Coomarswamy was appointed as Special Rapporteur on Violence Against Women by the UN Commission on Human Rights in its resolution 1994/45 of 4 March 1994. Already in her Preliminary report she addresses the issue of State responsibility and States' obligations. UN doc. E/CN.4/1995/42, paras 99-112. Ms Coomaraswamy was succeeded as Special Rapporteur by Dr Yakin Ertürk in August 2003.

334 UN doc. E/CN.4/1996/53, 5 February 1996, para. 33.

335 Human Rights Committee, General Comment no. 31 [80] Nature of the General Legal Obligations Imposed on States Parties to the Covenant, 26 May 2004, UN Doc CCPR/C/21/Rev.1/Add.13, para. 8.

336 Kenneth Roth, 'Domestic Violence as an International Human Rights Issue', in: Rebecca J. Cook (ed.), 


\subsubsection{Legal Consequences and Policy Implications of State Responsibility}

After it has been assessed that a harmful international act has occurred for which a State is responsible, several legal consequences will ensue. ${ }^{337}$ In this sub-section examples of possible consequences and implications of violations of women's right to adequate housing will be looked at. ${ }^{338}$

The first legal consequence of a harmful act will be that the original obligation remains unaffected. In case a State has bound itself to uphold the right to adequate housing and/or the rights to equality and non-discrimination of women, it will continue to be bound by its obligations irrespective of the fact that it has breached these rights.

As is the case with any illegal harmful act, national or international, one of the primary legal obligations will be the cessation of this act. In the framework of this study this may entail the termination of forced evictions, the abolition of discriminatory legislation and policies that deny women access to land or housing, or putting a stop to harmful practices that keep women in a subjugated position making them dependent on others for their housing situation. It may also entail stopping public release of information about locations of safe houses.

In the framework of this study assurances and guarantees of non-repetition may mean the adoption of legislation that ensures gender equality and non-discrimination, followed up by the deployment of effective policies to enforce such legislation. This may for instance require active campaigns against customary practices that deny women the equality rights legally conferred on them. Such campaigns should entail information and education on the illegal and harmful effects of such practices, and they should be backed up by legal remedies in case violations do occur.

Under relevant circumstances, guarantees of non-repetition may also mean the prohibition of settling down on dangerous sites while simultaneously offering accessible locations that are safe. The establishment of an effective, gender neutral early warning system relating to foreseeable upcoming natural disasters also falls under this category.

In cases of violence against women, non-repetition may be guaranteed by making refugee camps secure by planning their location and lay-out in such a way that women, also unaccompanied women, can safely make use of all facilities, and by employing relief staff who have received special training to make them aware of gender specific pitfalls and dangers. ${ }^{339}$ Measures guaranteeing safe housing for battered women may imply the provision of secret locations for shelters, and legislation that is easily enforceable as regards eviction of the perpetrator from the family home and/or the legal provision of interdicts precluding the batterer from coming in or near the family residence.

Human Rights of Women; National and International Perspectives, University of Pennsylvania Press, Philadelphia, 1994, p. 330.

337 ILC Draft Articles 28-31.

338 The examples mentioned are not meant to be exhaustive. They have not been chosen randomly but reflect violations discussed in this study, either in the present chapter or in other chapters.

339 For more concrete examples see section 3.4.5.4.2 on female refugees. 
Non-repetition may also be ensured by making easily accessible remedies available. The problem with many remedies is that their threshold is too high for those people who need them most; the poor, the homeless, and the illiterate. ${ }^{340}$ Many procedures are complicated, time consuming and costly. People may need (expensive) legal counsel to find their way in the maze of criminal, administrative or private law remedies. Furthermore, if procedures last too long this may result in people becoming homeless or staying homeless for a long time. Particularly in developing countries, the best solution may be the creation of special legal or non-legal bodies that have the authority to take fast and effective decisions in cases of housing rights violations. Access to such bodies should be free of charge while legal counsel should be provided for those who cannot afford it themselves. A prerequisite would be, however, that information about the existence and accessibility of such housing bodies is generally disseminated.

If harm has been done, reparation is called for. Which form is adequate in a certain situation will depend on the type of violation and the damage that has been suffered.

Restitution is reparation in kind that in the case of housing may take two forms; people are enabled to return to their original homes or they are offered equally adequate alternative housing. For instance returnees, whether they are refugees or IDPs, should receive reparation in this form. When it is not possible to go back to their original abodes, possibly because meanwhile their houses have been destroyed or taken by other people who cannot easily move out, returnees should receive alternative housing in a location as close as possible to the original site and in an environment most suitable to them. Furthermore, restitution is the best option for people who have been illegally dispossessed by forced evictions. If it has become impossible for them to return to their original houses because their dwellings have been demolished or the purpose of the area has meanwhile been irrevocably changed, ${ }^{341}$ they too should be offered alternative housing. An alternative, safe location is the necessary option for people who have to be relocated because they live or used to live on extremely dangerous sites.

Restitution is also an option for battered women after they have separated from their former partners. If they wish to continue to live in the family home, they should be enabled to do so. This may mean that the batterer has to leave the home in order that the victim can be re-installed. If victims of domestic violence are too afraid to remain in, or return to the family home because they feel like sitting ducks at an address that is wellknown to their former partner and batterer, restitution may consist of offering them alternative housing in a location where their safety is guaranteed.

Lastly, restitution should be given to widows who have been traditionally dispossessed by their in-laws; if possible they too should be re-installed in the family home.

340 Also see Theo van Boven who states that the most marginalized and the most destitute who face racial discrimination lack the benefit of legal and other remedies to improve their condition. Theo van Boven, 'Common Problems Linked to Remedies Available to Victims of Racial Discrimination', in: United to Combat Racism; Dedicated to the World Conference against Racism, Racial Discrimination, Xenophobia and Related Intolerance, UNESCO, Paris, 2001, pp. 95-97.

341 A recent example is the location next to the former airport of Athens where a group of Roma used to live. In 2004 this whole area has been transformed into an Olympic stadium. See COHRE, Global Survey on Forced Evictions, Violations of Human Rights, No. 9, April 2003, p. 60. 
Compensation is an option if restitution is for some reasons not possible or advisable. Monetary indemnification may be offered to people who have lost their homes and who would rather have money instead of alternative housing because they want to be able to choose for themselves where they are going to live. For example, victims of domestic violence may be so afraid of their former partners that they wish to settle someplace so secret or so far away that it may fall outside of the administrative area of the (local) authorities. People who have been the victims in an ethnic conflict may not want to return to their original location either.

Housing subsidies may under certain conditions also be considered a form of compensation. For instance, it may be paid to women who have been evicted by their landlords because they are structurally unable to pay the rent for the reason that legislation regulating the affordability of rented housing is lacking or insufficient.

Furthermore, compensation may be offered in addition to restitution, for example to recompense physical or mental harm suffered during forced evictions, abuse at refugee camps or shelters, or at the hands of intimate relations. Compensation may also be given for the loss of possessions because of forced evictions or because of foreseeable natural disasters for which the victims had not been warned in time.

Rehabilitation may consist of offering legal, medical, or psychological help to victims of violence. On the other hand, it may also entail psychological help or courses for batterers. For destitute women who have become homeless because of discriminatory traditional practices, a comprehensive programme might be developed in order to re-establish their dignity and make them self-reliant. Such a programme might comprise (temporary) housing, schooling or job training, child-care or issuing micro credit; whatever is needed to enable them to procure adequate housing by themselves.

Satisfaction encompasses all kinds of reparation that do not fit into the other categories. Acknowledgement of the unlawful character of the eviction may be important for evictees who have been treated like social pariahs and criminals because they had no other alternative but to settle down on 'illegal' sites. It may also be an option in situations where women have been persistently discriminated against; acknowledging that they have been treated wrongfully — because they were deprived of their human rights - will improve their self-esteem and may empower them.

For victims of violence a very important form of satisfaction will be that the perpetrator is held accountable. In cases of domestic violence a form of satisfaction may be the knowledge that the batterer is forced to contribute to alternative housing of the victim.

\subsubsection{Concluding Remarks}

The great majority of States have bound themselves to respect, protect and fulfil women's right to adequate housing, either directly, because women's right to adequate housing is acknowledged, or indirectly because the principles of gender equality and non-discrimination have been adopted. If the State's obligations are breached and these violations can be attributed to the State, the State can be held responsible for them.

Though there is substantive evidence that over the last few decades human rights bodies have accepted the possibility of State responsibility in instances of persistent and 
Chapter IV

structural violations inflicted by non-State actors, such as domestic violence, the ILC Draft Articles on State Responsibility do not encompass such cases. Since violations of women's human rights, including their housing rights, predominantly occur in the private sphere by private individuals, it is in women's interest that work on the rules on State responsibility is continued until these rules cover women's reality. Particular attention should be paid to the concept of due diligence since this is a fair and reasonable tool to determine the State's co-responsibility.

Once it is has been established that women's housing rights have been violated entailing State responsibility, several legal consequences and implications will follow. Besides continuance of the obligation, and cessation of the violation, assurances and guarantees of non-repetition are called for. It is imperative that these obligations comprise on the one hand eradication of discriminatory legislation, policies, and cultural practices that deny women access to land, housing and property, while on the other hand legislation and policies are to be adopted that enforce women's rights to equality and non-discrimination. Moreover, accessible legal and/or non-legal remedies should be made available that are also within reach of the dispossessed and the illiterate. Preferably, special bodies should be created that have the authority to take swift and effective measures in cases where housing rights are infringed.

If any damage has been caused by a harmful act for which the State is responsible, reparation should be made. The damage that women may suffer from housing rights infringements may be severe since they may be forced to live in inhuman and degrading circumstances. Reparation may take various forms; restitution, compensation, rehabilitation, and satisfaction. Which type(s) of reparation will be most suitable will depend on the seriousness and the nature of the violation and the gravity of the damage that has been suffered. In many cases, restitution may be preferred because it entails restoration to the situation before the violation occurred. Since restitution may not always be possible or desirable, other forms of reparation may provide good alternatives, either separately or jointly and render some form of justice in order to make women's right to housing a reality.

\subsection{MONITORING AND ANALYSES}

\subsubsection{Introduction}

Monitoring housing rights in the framework of the UN is possible from different angles and at different levels. Several supervisory committees, political organs and civil society organizations have the potential to take up the challenge to monitor women's right to adequate housing as it is incorporated in various human rights instruments. The mandate of some of them is very broad and they may cover the housing rights of virtually all women, while others are restricted to supervising the housing rights of particular groups of women.

Monitoring has different aspects. It entails determining whether and how States are implementing the rights contained in the conventions they have become party to. This presupposes clarity about the substantive provisions and about States' obligations. It is of particular importance that certain acts and omissions are recognized and condemned 
as constituting barriers to or violations of women's housing rights. This is only possibly if clear insights have been gained by in-depth study of situations and practices. ${ }^{342}$

Although all actors discussed here may contribute to the supervision of women's right to adequate housing, not all of them make use of their possibilities or do not use them effectively. That is why the focus of this section is on suggesting ways and means of improving their monitoring roles.

In the first sub-section the supervisory bodies of the main international human rights conventions that contain the right to adequate housing will be discussed. The Committee on the Elimination of All Forms of Discrimination Against Women (CEDAW) and the Committee on Economic, Social and Cultural Rights (CESCR) will be the focal point because they are the main players in this regard, but attention will also be paid to other monitoring bodies that may pull their weight, viz. the Committee on the Elimination of All Forms of Racial Discrimination (CERD), the Committee on the Rights of the Child (CRC), and the Committee on Migrant Workers (CMW).

These treaty bodies have different tools at their disposal to monitor the implementation of their respective conventions by the States parties. They are all using the reporting procedure and they can all adopt general recommendations in order to further interpret treaty provisions or to call attention to certain harmful situations that need to be dealt with. However, only CEDAW, CMW and CERD have the possibility, on an optional basis, to examine individual and group complaints, while CEDAW is the only one of these Committees that can use an inquiry procedure.

Section 4.7.3 will review the role of several Special Rapporteurs and Representatives whose mandates authorize them to monitor women's right to housing. Most relevant is of course the mandate of the Special Rapporteur on Adequate Housing, but also the mandate-holders on violence against women, on harmful traditional practices, on internally displaced persons and on migrant workers, directly come across situations in which the housing rights situation of women is violated or might be improved. Although the reports of Special Rapporteurs do not stricto sensu have legal consequences, their recommendations entail certain political and moral implications to mend situations that are in violation of international obligations. Moreover, their studies give clear insights into existing wrongs.

In the last section, attention will be paid to the role of international and national civil society organizations. Such organizations have an important signalling function and they may work as go-betweens between international organizations and populations. In the past such organizations have played an important role as to the furtherance of the right to adequate housing in general and they may also be of significant help in the improvement of the housing rights of women.

342 Philip Alston describes the treaty supervisory system as 'holding States accountable for non-compliance with their treaty obligations by means of an objective and constructive dialogue, on the basis of comprehensive information and inputs from all interested parties'. UN doc. E/CN.4/1997/74, Effective Functioning of Bodies Established pursuant to United Nations Human Rights Instruments, Final Report by Mr Philip Alston on the long-term effectiveness of the United Nations human rights treaty system, 27 March 1997, para. 9. 
Chapter IV

\subsubsection{UN Human Rights Treaty Bodies}

\subsubsection{Reporting Procedure}

The reporting procedure is a useful mechanism at the disposal of all treaty bodies which supervise the main UN human rights instruments. Shortly after ratifying or acceding to the human rights instrument, States have to submit a report assessing the situation pertaining to the realization of the rights contained in the relevant treaty at that moment. Subsequently, States parties are under the obligation to submit reports on a regular basis in order to show any progressive developments. ${ }^{343}$ The preceding reports are used as benchmarks from which can be measured whether any progress has been achieved. During the constructive dialogue that is held between the supervisory committee and the State party upon submission of the reports, additional information may be requested by the Committee and clarifications may be offered by the States' representatives. Furthermore, the Committee has the opportunity to express its opinion on positive and negative aspects that have come to its attention through the reports or by way of other sources and to make in its concluding observations suggestions and recommendations. All monitoring bodies have guidelines in which they stipulate how States parties should inform them about the state of affairs pertaining to their respective treaties. Most Committees prefer the States parties to report on an article by article basis. ${ }^{344}$ This gives structure to the reporting and it eases the assessment of any progress or regress made with regard to the fulfilment of a right contained in a particular provision. If supervisory bodies wish to gain clear insights into the particulars of any human right situation, it is therefore important to ask the right questions from States parties.

In this section those provisions in human rights treaties will be studied that are most useful to monitor the housing rights of women, either directly or indirectly. Besides treaty articles, also provisions contained in general recommendations may be of value in the reporting procedure since they may offer opportunities to request specific information. The relevant treaty bodies will be dealt with consecutively, with the greatest emphasis on CEDAW and the CESCR. The discussion of each treaty body will encompass a listing of possible questions and topics pertaining to women's housing rights that, if dealt with by States parties, would offer better insights into women's housing situation and might suggest possible ways of improvement.

\subsection{CEDAW}

Since the Women's Convention lacks an explicit and comprehensive provision on the rights to housing and land, the Committee's possibility to monitor the realization of these rights is rendered more complicated but is by no means unfeasible. Several provisions in the treaty offer a legal basis for CEDAW to assess and monitor women's housing and land rights in States parties. However, the consequence of the lack of an explicit

343 The relevant reporting procedures are mentioned in Articles 16 and 17 ICESCR, Article 18 Women's Convention, Article 9 ICERD, Article 44 ICRC, and Articles 73 and 74 ICMW.

344 See for instance $U N$ doc. E/C.12/1991/1, Revised guidelines issued by CEDAW for all reports submitted after 31 December 2002, 5 May 2003. 
provision is that many issues do not come up naturally during the reporting process, but must be prompted by the Committee. CEDAW's reporting guidelines, which were revised in 2003, are general and do not go into any detailed questions. They basically come down to requesting States parties to deal with every substantive provision in the Convention and in General Recommendations and to describe the de iure and the de facto situation, practical availability, effect, and implementation of remedies for violation of these provisions. Using this method means that there is no coverage of issues that are not explicitly mentioned in the Convention/General Recommendations. However, it is CEDAW's practice to supply in advance to each reporting State a list of specific issues or questions that have to be dealt with in the forthcoming report. ${ }^{345}$ These questions are based on information received from several sources pertaining to women's rights situation in a State party. Thus CEDAW's scope to broach subjects and ask questions is broadened.

In order to monitor the realization of women's rights to housing and land CEDAW may make use of the following provisions.

The first article that may be useful is Article 2 on the eradication of both de iure and de facto discrimination against women. In order to bring into the open any discriminatory legislation or policy regulation that might undermine women's right to housing, States parties already are requested to report on existing property laws, inheritance laws and any personal law systems that may be maintained. It is important to request that answers are accompanied by sex-disaggregated data as regards the number of female and male house owners and women and men having property rights pertaining to land. ${ }^{346}$

If it is clear that more women than men are homeless or inadequately housed, CEDAW should recommend the State party to develop, in accordance with Article 4(1) of the Convention, temporary special measures with a view to achieving equality between women and men. The focus should especially be on measures that will alleviate and solve the dearth situation of female heads of households. ${ }^{347}$ It should be emphasized that such specific programmes and measures are not to be regarded as discriminatory towards men as long as inequality exists between the sexes. ${ }^{348}$

Reporting on Article 5 on social and cultural patterns should provide information on any female exogamy traditions that result in married women losing their claims on their

345 UN doc. HRI/GEN/2/Rev.1/Add.2, Guidelines issued by CEDAW for all reports submitted after 31 December 2002, 5 May 2003, para. H.2.1. Also see Annex X of $U N$ doc. A/59/38, 2004, under A. Presession working group, paras 7-11.

346 In fact all reporting should be substantiated by valid statistical data. This follows from CEDAW General Recommendation No. 9 on Statistical data concerning the situation of women (eighth session, 1989) in which it is stated that such data are absolutely necessary in order to understand the real situation of women. Furthermore, in CEDAW's reporting guidelines it is stated that: 'A report should include sufficient data and statistics disaggregated by sex relevant to each article and the general recommendations of the Committee to enable it to assess progress in the implementation of the Convention.' Reporting Guidelines, para. C.4.

347 Because of the overall disadvantages position of these women the solution will be to take measures that are a combination of offering housing in special working women's hostels, day-care facilities for their children, job training and access to micro-credit so that these women's life is put on the rails in such a way that they can become economically independent and will consequently be able to take care of their own housing and that of their dependents.

348 See CEDAW General Recommendation No. 25 on Temporary special measures (thirtieth session, 2004) Article 18. 
family's or community's property, in particular land and housing. Moreover, any widow practices such as levirate or cottage grabbing and/or burning by the late husband's relatives should be reported on. ${ }^{349}$ Lastly, reports should make note of cultural or stereotypical influences in society that put women in an inferior or subjugated position since this may cause domestic violence which in turn will render the housing situation inadequate because of the battered women's lack of dignity and security at home. ${ }^{350}$

Reporting pertaining to Article 13 on economic and social life should contain sexdisaggregated data in respect to family benefits in particular housing subsidies that are received and information on recipients of bank loans, mortgages and other forms of financial credit. In this respect, States should make it known whether they use the male breadwinner model to determine eligibility to any benefits and what policies have been developed in the framework of the contents of Article 13 to ensure access for female heads of households.

Article 14 on the situation of rural women offers a direct possibility for CEDAW to structurally request information on housing since this right is explicitly mentioned in paragraph (h) on adequate living conditions. ${ }^{351}$ In view of the fact that in many developing States there is a lack of basic facilities in rural areas compared to urban areas, it is important to request specific information on the availability and cost of electricity, water, drainage, and waste collection. Particularly for rural women, the access and right to land may be indivisibly attached to the right to adequate housing. Therefore, reporting on paragraph $(\mathrm{g})$ of Article 14 should go into any laws, regulations and policies as regards rights of women and men to land. Particular mention should be made of how gender is taken into account in situations of land reforms and resettlement schemes.

In Article 15 of the Convention women's equal rights before the law are dealt with. Reporting on paragraphs 2 and 3 should contain information on any legislation restricting women's legal capacity to conclude contracts in respect to real estate. In addition, any customary laws or traditional practices that prevent women from exercising their legal right to manage their own property should be investigated and reported on. ${ }^{352}$

349 Although it is CEDAW's habit to inquire after the situation of widows and the custom of levirate, the fact that widowhood may cause large scale homelessness has thus far eluded scrutiny. It did not even come up as a point of concern as far as the extensive congregations of homeless widows in India and Bangladesh are concerned. See $U N$ doc. A/55/38, Session 22, February 2000, paras 54-90 on India, and $U N$ doc. A/59/38, Session 31, July 2004, paras 235-267 on Bangladesh. Also see section 3.3.4 on widowhood in this study.

350 I will come back to the issue of violence against women later while discussing CEDAW's General Recommendations No. 12 and No.19 on violence against women.

351 Also see section 4.4.3, Article 14(2) Women's Convention.

352 In General Recommendation No. 21, CEDAW recognizes that restricting women's legal capacity will deny them legal autonomy and will restrict them in their ability to provide for themselves and their dependents. Unfortunately, however, in this context no mention is made of the right to housing. It is important, however, to make States parties understand that denying or restricting a woman's legal capacity to administer her own property may result in male guardians or husbands selling the very house a woman is living in without her consent. Furthermore, the comments of the Committee pertaining to Article 15 only focus on the legal situation. This is understandable since the article deals with equality before the law, but nevertheless States parties should be requested to elaborate on any customary and traditional practices that may make it impossible for women to exercise their legal rights in practice. See General Recommendation No. 21 on marriage and family relations, 1994, para. 8. 
Paragraph 4 of Article 15 contains an important element of the right to housing i.e. the freedom to choose one's own residence. Legal restrictions, but particularly traditional customs like guardian systems for women or female exogamy may severely restrict or nullify women's rights in this respect. It is therefore important that States are explicitly requested to gather information on this issue. ${ }^{353}$

The last provision to be found in the Convention itself that has a direct bearing on women's right to adequate housing is Article 16 on marriage and family relations. Paragraph (c) emphasizes that married women have the same rights and responsibilities as their spouses both during marriage and at its dissolution. In combination with paragraph (h) pertaining to the acquisition and management of property, this part of Article 16 is to be considered as a lex specialis for married women in relation to Article 15 which sets out the rules concerning equal property rights for women in general. ${ }^{354} \mathrm{It}$ is indeed important to monitor whether the realization of these rights might be adversely affected once a woman gets married, since it is not unusual in many cultures and societies to regard the male partner of the marriage as the head of the household and the main or even sole decision-maker as regards the marital property and sometimes even as far as the personal property of the wife is concerned. ${ }^{355}$

Dissolution of a marriage may happen because of separation/divorce or by the death of one of the partners. Reporting should go into the specifics of legal or customary law systems, like personal law systems, and practices that discriminate against women once the marriage is dissolved because of separation/divorce. In many States, the financial contribution of the male breadwinner to the household is appreciated much more than the non-remunerative care-taking contribution of the female homemaker. Thus the marriage property may be attributed disproportionately to the male partner, while the woman's share is so small that it may seriously impair her chances of acquiring adequate housing by herself. ${ }^{356}$

Reporting on the consequences of the dissolution of the marriage because of the death of the husband should concentrate on discriminatory widow practices rather than on inheritance laws since the latter may already be dealt with under Article 2. As has previously been shown in this study, for many women widowhood is the cause of inade-

353 Strangely enough the comments on Article 15(4) in General Recommendation No. 21 only deal with the freedom to choose one's domicile - defined by the Committee as 'the country in which a person intends to reside' - and do not go into the freedom to choose one's residence at all. Therefore, specifics about all kinds of restrictions on women's freedom of choice with regard to their residence are not taken into consideration. General Recommendation No. 21, 1994, para. 9.

354 In its comments on Article 16 of the Convention in General Recommendation No. 21, the Committee refers back to Article 15(1) and directly refers to housing by stating that: 'The right to own, manage and dispose of property is central to women's right to enjoy financial independence, and in many countries will be critical to her ability $[\ldots]$ to provide adequate housing and nutrition for herself and for her family.' See para. 26 .

355 CEDAW points to this danger in General Recommendation No. 21, para. 17. Also see paras 30-32 on marital property.

356 In para. 28 of General Recommendation No. 21 CEDAW points out that granting men a greater share of property at the end of the marriage is discriminatory and seriously affects women's ability to divorce their husbands or to support herself and her dependents. 
quate housing or homelessness since they lack legal or customary claims to the family home after their husband's death. ${ }^{357}$

The last provision that should be dealt with in respect to the right to adequate housing is not contained in the Convention itself, but is elaborated by CEDAW in General Recommendations No. 12 and particularly No. 19 on violence against women. CEDAW has stated in General Recommendation No. 19 that gender specific violence is to be considered discrimination against women. Therefore, such violence will fall within the scope of Article 1 of the Convention. Reporting on domestic violence, should explicitly include the battered women's housing situation. Up till now CEDAW's focus is primarily on the criminal law aspects, while equal attention should be paid to the socio-economic consequences of domestic violence. It should be recognized that the adequacy of a woman's housing right is affected when she lives in constant danger of physical assault in her own home while also her rights to property and privacy are violated. Socioeconomic violations may call for other methods of redress than violations of civil and political rights. That is why in addition to, or instead of criminal law measures, CEDAW should recommend the use of civil and/or administrative law measures, such as restraining orders, interdicts and the possibility to have the perpetrator contribute financially to his ex-partner's housing. After all, the most common criminal law remedies to domestic violence, fining or, less frequently, imprisoning the perpetrator, will also adversely affect the financial situation of his partner and their children and thus are not always the best option.

Furthermore, the Committee always stresses the importance of providing enough shelters where battered women can turn to. Although important, the quantity of shelters is only part of the solution. Especially for victims of domestic violence shelters should meet with certain quality standards. In the first place the shelter should be safe which entails that the address is secret and not made known to the batterer. Further, the safety of the women within the shelter itself should be guaranteed which will much sooner be the case when the safe house is specifically destined for battered women instead of being a general shelter for the homeless. Another important point is that women should be able to bring all their children. In many States sons of twelve years and older are not allowed to live in the shelter, and many mothers are reluctant to leave these children behind with an aggressive father.

Although in many cases safe houses are indispensable, the institution of a system of shelters takes for granted that it should be the woman and her children, i.e. the victims who are supposed to leave behind the family home, the familiar neighbourhood, the friends, the school, or even their own place of residence, while the perpetrator can continue his life in his familiar surroundings. Therefore, the Committee should point to the option that legislation and other measures might alternatively entail that the perpetrator is evicted from the family home, will be forbidden to enter the neighbourhood or may even be ordered to leave town so that his family can continue to live in peace and security in their own home.

357 That CEDAW is aware of the problems concerning widowhood becomes clear from paras 34 and 35 of General Recommendation No. 21 where it is said that any legal or customary provisions relating to inheritance laws contravene the Convention and should be abolished. 


\subsection{Specific Questions}

Like all monitoring bodies CEDAW depends on information received on a certain State party before it is able to rightly assess women's rights situation. Whether this information is comprehensive or faulty is determined by several factors. Some States' reports will be more honest or elaborate than others and civil society organizations in one State are more active, better equipped or organized than in another. That is why using a system of ad hoc lists bears the danger that it is possible to miss out on important issues. Especially with regard to rights not explicitly contained in the Convention, like the right to housing, it would be better to use a more or less fixed set of questions to be answered by all States parties. With a view to the provisions mentioned above, CEDAW may be advised to request States parties to investigate and provide information on the following questions pertaining to housing rights issues categorized as much as possible according to the Convention's provisions and General Recommendation No. 19.

\section{Relevant questions}

\section{Housing and land}

- Specify the percentage of females who are homeless compared to the number of males.

- Are there any restrictions, legal or otherwise, that prevent women from owning property, in particular real estate?

- Specify the percentage of registered female house owners as compared to the percentage of male house owners. Differentiate between sole owners and co-owners.

- Specify the percentage of female land owners and females who have other property rights pertaining to land in comparison to males.

\section{Article 2}

- Does the law differentiate between females and males with regard to the right to inherit from relatives and/or spouses, in particular in respect to housing and land?

- Are there any personal law systems and/or traditional customs that inhibit women from claiming their legal share in the inheritance?

\section{Article 4(1)}

- If a disproportionate number of the homeless are female indicate the specifics of any special programmes that have been developed in order to house homeless women.

- Indicate whether any temporary special measures have been taken in order to alleviate the housing situation of homeless or inadequately housed female heads of household.

\section{Article 5}

- Are women traditionally regarded as dependent on males for instance by the retention of the male breadwinner model?

- Does the Government campaign against the dependency of girls and women by stimulating and disseminating images of girls as future autonomous persons who have to 
generate their own income and who may be responsible for their own housing situation?

- Are there any widow practices that affect the widow's housing situation?

- Does the custom of levirate exist and if so, which measures have been developed to abolish it?

\section{Article 13}

- Is there a system of benefits or subsidies for people who cannot afford adequate housing and what are the requirements that have to be fulfilled in order to receive such a benefit or subsidy?

- Are women in any way legally or customarily restricted to receive bank loans, mortgages or other forms of financial credit?

- Is a system of micro-credits available?

\section{Article 14}

- Are facilities like electricity, water supply and drainage available and affordable in rural areas?

- How is gender taken into consideration in situations of land reforms and resettlement schemes?

\section{Article 15}

- Is women's legal capacity equal to men's as regards the purchase and/or managing of real estate or is it in any way affected by legal or customary rules?

\section{Article 16}

- Does marriage affect a woman's right or ability to purchase and manage her own and/or the marital property?

- Is there a legal or customary practice of male guardianship over women?

- Is women's freedom to choose their own residence in any way restricted, or affected by marriage?

- Is it legally possible that a man disposes of the family home without his wife's consent?

- Is care-taking work in the home/family regarded as an economically valuable contribution towards the household upon divorce?

\section{General Recommendation No. 19}

- Are there any shelters specifically for battered women either provided by the authorities or otherwise?

- What measures are taken to guarantee the safety of battered women in shelters?

- How long may women stay in a shelter and what options are open to them when they have to leave?

- May women bring all their children with them or are there any restrictions, especially as regards male children? 
- Which civil law measures can be taken against the perpetrator of domestic violence?

- Are there any legal possibilities to evict a batterer and/or to re(install) the victim in the family home?

\subsection{CESCR}

Monitoring women's right to adequate housing would seem to be unproblematic for the Committee on Economic, Social and Cultural Rights since the Covenant contains a specific provision on the right to housing, Article 11(1) which is further elaborated in General Comments No. 4 and No. 7, as well as a provision on equality between women and men, Article 3 the obligations of which were recently worked out in detail in General Comment No. $16 .{ }^{358}$

This legal framework that is at the Committee's disposal to monitor women's right to adequate housing has already been extensively discussed in section 4.4.2 supra. It has become clear that neither the text of Article 11(1), nor the contents of the two General Comments are sufficiently geared to women's specific problems as regards the fulfillment of their housing rights. That is why the CESCR has to make an additional effort to encompass women's situation in the monitoring process.

A few options are open to the CESCR: the reporting guidelines may be altered in such a way that they cover women's specific problems and situations; in addition to the information that States parties habitually provide on the basis of the reporting guidelines, they may be requested to report specifically on women's housing rights; or the Committee adopts a General Comment on housing rights of women.

Contrary to CEDAW's reporting guidelines, the CESCR has drawn up an extensive list of topics and questions of principal concern that must all be explained and answered in the periodic reports. ${ }^{359}$ Unfortunately, however, the CESCR's Reporting Guidelines date back to 1991 and lack sufficient gender awareness. The first part of these Guidelines deals with the reporting related to general provisions of the Covenant. It might be noticed that as far as the guidance on Article 2(2) is concerned, ${ }^{360}$ only specific information is requested on the possible extent and justification of different treatment of non-nationals; no information has to be provided on situations of discrimination based on sex. In the second part that relates to specific rights, no guidance at all is offered as regards the reporting on Article 3 concerning the duty to ensure the equal right of men and women to the enjoyment of all rights set forth in the Covenant. ${ }^{361}$

358 CESCR General Comment No. 16, Art. 3: the equal right of men and women to the enjoyment of all economic, social and cultural rights, 13 May 2005

359 UN doc. E/C.12/1991/1, Revised General Guidelines regarding the form and contents of reports to be submitted by States parties under Articles 16 and 17 of the International Covenant on Economic, Social and Cultural Rights, 17 June 1991.

360 Article 2(2) of the ICESCR reads: 'The States parties to the present Covenant undertake to guarantee that the rights enunciated in the present Covenant will be exercised without discrimination of any kind as to race, colour, sex, language, religion, political or other opinion, national or social origin, property, birth or other status.'

361 Meanwhile, this omission has been repaired with the adoption of General Comment No. 16 in which the 
The guidelines pertaining to Article 11 continue along the same lines. States parties are requested to provide information on the standard of living, both with regard to the population in general and differentiated in respect to socio-economic, cultural and other groups within society, but no specific information on the situation of women is demanded. Neither are sex-disaggregated data requested as regards the poorest $40 \%$ of the population while feminization of poverty is a topical subject within the UN.

As far as the right to adequate housing is concerned, the guidelines provide a long list of questions covering virtually all aspects of housing that have been discussed in the two General Comments. ${ }^{362}$ Again, sex disaggregated data are not demanded and in spite of the extensiveness of the topics raised in the list, no attention is drawn to women's specific situations. ${ }^{363}$

Still, in the State reports and in the Committee's concluding observations women's perspective in general receives increasing attention because in practice the CESCR does request sex-disaggregated information from the States parties and it makes use of its ability to request additional information pertaining to women's situation. From time to time, the particular circumstances of single mothers and widows have the Committee's attention. ${ }^{364}$ Notwithstanding this development, it cannot be maintained that women's housing rights are dealt with in a comprehensive and structured manner.

In view of the fact that the Committee attaches great importance to dealing with State reports in an efficient way so that issues of principal concern receive methodical attention and it wishes to avoid that issues are raised in an ad hoc manner, ${ }^{365}$ it is advisable to revise the Reporting Guidelines in the light of Committee's General Comment No. 16. The list of specific questions that is to be found in the next sub-section might be included. Obviously, there is some overlapping with the issues that may be raised by CEDAW.

\subsection{Specific Questions}

According to the Committee in General Comment No. 16 'women have a right to own, use or otherwise control housing, land and property on an equal basis with men, and to access necessary resources to do so ${ }^{366}$ Furthermore, the States parties' obligation to protect women in their rights is not restricted to the public sphere, but encompasses the conduct of non-State actors. ${ }^{367}$ With a view to ensuring that structural attention is paid to the specific conditions and problems that influence women's ability to fulfil their right to adequate housing the following topics might be raised.

obligations ensuing from Article 3 are extensively elaborated.

362 For easy reference the relevant questions about Article 11 and specifically the right to adequate housing have been attached in Annex 5.

363 The total omission is particularly strange if the guidelines on Article 11 are compared with for instance those on Articles 12 and 13 where sex disaggregated data is repeatedly requested.

364 For example single mothers in Canada, E/1999/22, para. 398; widows in Cameroon, E/2000/22, para. 323; single mothers in Trinidad and Tobago, E/2003/22, para. 275.

365 See the Overview of the working methods of the Committee on Economic, Social and Cultural Rights, to be found on the CESCR's website, <www.ohchr.org/english/bodies/cescr/workingmethods.htm>, last consulted on 9 February 2006.

366 CESCR General Comment No. 16, para. 28. Also see section 4.4.2.3 of this study.

367 CESCR General Comment No. 16, para. 20. 


\section{$\underline{\text { Relevant questions }}$}

\section{General}

- Indicate the percentage of women among the poorest segment of society. Is the number of poor women growing disproportionately if compared to men? What are the causes of this feminization of poverty and what measures have been taken to counter this trend?

- Is the right to housing perceived as an individual right or as an entitlement for families?

- Specify the percentage of females who are homeless compared to the number of males.

- Are there any restrictions, legal or otherwise, that prevent women from owning property, in particular real estate?

- Specify the percentage of registered female house owners as compared to the percentage of male house owners. Differentiate between sole owners and co-owners.

- Specify the percentage of female land owners and females who have other property rights pertaining to land in comparison to males.

- Is a system of micro-credits available?

- Does the law differentiate between females and males with regard to the right to inherit from relatives and/or spouses, in particular in respect to housing and land?

- Are there any personal law systems and/or traditional customs that inhibit women from claiming their legal share in the inheritance?

- Is women's legal capacity equal to men's as regards the purchase and/or the management of real estate or is it in any way affected by legal or customary rules?

- How is gender taken into consideration in situations of land reforms and resettlement schemes?

- Is care-taking work in the home/family regarded as an economically valuable contribution towards the household upon divorce?

\section{Security of tenure}

Threats to security and safety at home do not always come from the outside. Particularly for women it is important that the threats coming from the inside are not overlooked.

- Is it is legally possible that a man disposes of the family home without his wife's consent?

- Do women have an autonomous right to privacy or is only the right to privacy of a family protected?

- What measures have been taken to protect women from domestic violence?

- Are there any shelters specifically for battered women either provided by the authorities or otherwise?

- What measures are taken to guarantee the safety of battered women in shelters?

- How long may women stay in a shelter and what options are open to them when they have to leave.

- Which civil and/or administrative law measures can be taken against the perpetrator of domestic violence? 
Chapter IV

- Are there any legal possibilities to evict a batterer and/or to re(install) the victim in the family home?

- Which measures are taken to guarantee the safety of women, particularly single women in emergency shelters like refugee camps or centres for asylum seekers?

The phenomenon of forced evictions not only happens in the public sphere or in the relation between tenant and landlord, but especially for women, also in the private sphere. The following questions pertain to situations where women run the risk of being put out on the street by intimates.

- Is the practice of female exogamy common? If so, how is women's right to housing and land guaranteed when their marriage ends either by separation or death?

- Are there any widow practices that affect the widow's housing situation?

- Are widows and their children protected against eviction from the family home by the late husband's relatives and are any remedies available to them?

\section{Availability of services}

- Is women's experience the focal point when decisions have to be made about the availability of services, facilities, and infrastructure?

\section{Affordability}

- How is the income gap between women and men taken into consideration when the percentage of housing costs is determined?

- Is there a system of benefits or subsidies for people who cannot afford adequate housing and what are the requirements that have to be fulfilled in order to receive such a benefit or subsidy?

- Are women in any way legally or customarily restricted to receive bank loans, mortgages or other forms of financial credit?

\section{Habitability}

- Are women informed about the consequences of unhealthy housing conditions, like cooking indoors on wood, kerosene oil and liquid petroleum gas? If so, are recommendations made for healthier alternatives or is any (financial) help offered?

\section{Accessibility}

- If a disproportionate number of the homeless are female indicate the specifics of any special programmes that have been developed in order to house homeless women.

- Indicate whether any particular measures have been taken in order to alleviate the housing situation of homeless or inadequately housed female heads of household.

\section{Freedom of residence}

- Is women's freedom to choose their own residence in any way restricted, or affected by marriage? 


\section{Cultural adequacy}

- Is the fact that most women's lives are centred in and about the house taken into consideration when housing is constructed?

\subsection{CERD}

As has been pointed out in section 4.4 on international housing norms, the Committee on the Elimination of all forms of Racial Discrimination may monitor the compliance with the right to housing under Article 5(e) (iii) of the Convention. The reluctance of the Committee to get involved in gender specific problems has also been indicated previously. Nevertheless, since the adoption in 2000 of General Recommendation No. 25 on gender related dimensions of racial discrimination ${ }^{368}$ and in view of the fact that States parties are specifically requested to provide sex-disaggregated data, ${ }^{369}$ some change may be discerned. From time to time situations of double discrimination against women based on gender and on national or ethnic origin are pointed out to States parties. However, up till now women's right to housing has not received the attention it deserves. ${ }^{370}$

In respect of the object and purpose of the Convention on the Elimination of All Forms of Racial Discrimination, violation of women's housing rights might be raised in the following situations.

First of all, if there are indigenous populations or minority and descent-based groups in a certain State the emphasis will be on the equal treatment of those groups in comparison to the rest of the population. However, in addition to the race or ethnic factor, the housing rights of women who belong to such a group may be inhibited because they suffer from discrimination based on gender, not only in society at large like women in general, but also because their rights may be negatively affected by customary rules and traditional patterns that are maintained within such a group. That is why CERD should request sex disaggregated data on housing of such populations and emphasize that within indigenous and minority groups women's right to adequate housing is to be respected and protected.

Another group of women that would benefit from CERD's attention is female migrant workers. In some States many of the female domestic servants are from a different racial or ethnic origin. The housing situation of these women is one of the points of concern that might explicitly be raised by CERD. The women, who usually come from poor developing countries, usually live in their employer's home where they may be completely isolated and unprotected. Their accommodation may be utterly inadequate and the right to live in dignity and security of many of these women is violated because they are (sexually) abused by their employer or members of his family. Sometimes their

368 CERD General Recommendation No. 25: Gender related dimensions of racial discrimination, 20 March 2000.

$369 U N$ doc. CERD/C/70/Rev.5, General Guidelines regarding the form and contents of reports to be submitted by States parties under Article 9, paragraph 1, of the Convention, 5 December 2000, in particular para. 9.

370 See CERD's annual reports since the adoption of General Recommendation No. 25: UN documents A/56/18, 2001, A/57/18, 2002, A/58/18, 2003, A/59/18, 2004. 
passports are taken, and because many of them not even speak the language, they do not know where to go when they are mistreated. Even if they manage to request for help the officials may turn a blind eye. Their employers get away with treating them so badly because the State discriminates against these foreigners particularly in the exercise of its labour laws. The Committee might request information on protecting mechanisms for these women and available remedies in case they are abused.

In other countries, female migrants become susceptible to abuse because immigration laws make them totally dependent on their husbands. If it is the husband who originally immigrated in order to find employment, their spouses' permit to stay may be temporary and may depend on whether or not they remain with their husband. ${ }^{371}$ In cases of domestic violence this may entail that women have the choice between enduring the battering over an indefinite period of time-i.e. until they are entitled to a personal permit to stay_or leaving their husband which automatically means leaving the country. This is not always feasible or desirable especially when there are children.

Finally, the housing rights of female refugees and other displaced women may be the Committee's concern especially since the security and safety in refugee camps or shelters is the States parties' obligation. Many women in such emergency housing do not find the refuge they are looking for, but may still live in fear of, or experience discrimination and/or (sexual) abuse because of their racial or ethnic descent.

\subsection{CRC}

It has already been indicated in section 4.4.5 supra that under the Convention on the Rights of the Child children do not have an independent right to adequate housing. Under normal circumstances, their parents or other care-takers are primarily responsible for their living conditions. Should these persons not be in a position to supply adequate housing, the States parties to the Convention are obliged to provide within their means (material) assistance and support programmes. ${ }^{372}$ Furthermore, States parties will be directly responsible for the living conditions of unaccompanied foreign children. ${ }^{373} \mathrm{On}$ the whole, the Committee's task to monitor enjoyment of the right to housing of girls is rather restricted. Yet, especially with regard to situations of domestic violence, it is important that the CRC requests information on protection mechanisms and remedies within States parties in situations where housing conditions have become unsafe.

Furthermore, it is clear that (unaccompanied) girls run a high risk of (sexual) abuse when they are homeless or accommodated in emergency housing like refugee camps, centres for asylum seekers or homeless shelters. Supervising the security and safety of girls in such situations deserves particular attention and should be addressed in State Reports.

371 This is the situation in the Netherlands where the spouse's permit to stay is temporary for a period of three years.

372 See Article 27 (2) and (3) Convention on the Rights of the Child.

373 'States should ensure that separated and unaccompanied children have a standard of living adequate for their physical, mental, spiritual and moral development. As provided in Article 27 (2) of the Convention, States shall provide material assistance and support programmes, particularly with regard to nutrition, clothing and housing.' General Comment No. 6, Treatment of unaccompanied and separated children outside their country of origin, CRC/GC/2005/6, 1 September 2005, para. 44. 
Up till now, the CRC has shown that it is aware of specific discrimination of girls and their susceptibility to violence. ${ }^{374} \mathrm{~A}$ specific link between violence and girls' right to adequate housing has not been made in any structural way, however.

\subsection{CMW}

The Committee on Migrant Workers is the newest treaty body. It held its first session in March 2004 and it has submitted its first annual report in 2005. Once initial reports have been examined, the Committee is advised to pay particular attention to the housing situation of female domestic workers and request information on protection mechanisms for women who suffer at the hands of their employers. ${ }^{375}$

In addition, housing rights of female family members of migrant workers should be a point of concern. It should be avoided that the position in the family of these women and girls is weakened because they become completely dependent on their husband/ father for their residence permit. It has been proven that dependency may trigger domestic violence. ${ }^{376}$

\subsubsection{Complaints Procedure}

In this section, the complaints procedures pertaining to the Women's Convention, the ICERD and the ICMW will be discussed. Of the seven main international human rights instruments, the Convention on the Rights of the Child and the ICESCR do not have an optional petition procedure. For several years now attempts have been made to draft an Optional Protocol to the ICESCR containing a complaints procedure for individuals and perhaps also for groups. ${ }^{377} \mathrm{Up}$ till now, these attempts have not been very successful. The same arguments against petitioning the CESCR are used over and over again. The most important objections pertain to the justiciability of economic, social and cultural rights, which is denied by some States or perceived as being much more difficult in comparison to civil and political rights; the possible unwarranted interference in a State's domestic affairs since the fulfilment of economic, social and cultural rights is supposed to cost more money than the realization of civil and political rights and budget allocations are believed to be strictly at the State's discretion; the supposed vagueness of the content of economic, social and cultural rights which would make these rights unsuitable for scrutiny by a supervisory body; fear for a flood of complaints particularly against those States that have the best record for complying with international norms; and the lack of treaty status of the CESCR as a subsidiary body of ECOSOC which would make it unfit

374 For instance the de facto discrimination faced by girls in the Philippines, Nepal and Yemen, and their vulnerability in cases of domestic violence in the case of Mongolia. $U N$ doc. CRC/C/150, 21 December 2005 , paras $123,316,762$ and 553 respectively.

375 It should be noted, however, that many of the receiving States in which the maltreatment of female domestic workers is a known problem, are not parties to the Convention.

376 Up till now none of the Western European States where these problems are encountered by female members of migrant workers have ratified the Convention.

377 Already at the World Conference on Human Rights in Vienna, 1993, the Commission on Human Rights was encouraged to adopt an optional protocol to the ICESCR. The CESCR, who is in favour of being able to hear complaints, submitted a first draft optional protocol to the Commission in 1997. UN doc. E/CN.4/1997/105. 
to hear complaints. Those in favour of having a complaints procedure point to the benefits that might ensue. Most important perhaps is the possibility of putting an end to the existing asymmetry between economic, social and cultural rights on the one hand and civil and political rights on the other, and of further clarifying and defining the rights contained in the ICESCR by studying concrete situations in which the violation of these rights are involved. The advocates refute the objections mentioned above by pointing out that the obligations pertaining to economic, social and cultural rights are increasingly dealt with by courts at the national and regional level thus proving that these rights are justiciable or that they contain at least justiciable elements. Fear of interference in domestic financial affairs is countered by stressing that States have to give their express consent before they can be submitted to any international examination and that, moreover, the complaint mechanism would take the level of economic development into account because of the concept of progressive realization. Furthermore, it is pointed out that the content of civil and political is not always clear either, but that this does not seem to constitute a problem. The dreaded flood of complaints failed to occur with other supervisory bodies because of the strict rules of admissibility. Finally, the special position of the CESCR should not be a problem since ECOSOC could easily give the Committee a mandate the hear complaints.

Among the advocates there is disagreement whether only some of the rights contained in the Covenant should be susceptible to the petition procedure, the so-called 'à la carte' approach, or whether a comprehensive scope would be preferable. ${ }^{378}$

In my view it is to women's disadvantage that they cannot petition the Committee as an ultimate remedy when their housing rights are violated. After all, Article 11(1) is the most important international provision on adequate housing and it would be an important signal if a gender neutral body like the CESCR would take women's issues into account in dealing with concrete situations of violation. It would undoubtedly create more insights in how gender backgrounds work against women when they try to realize their right to adequate housing.

\subsection{CEDAW}

On 6 October 1999 the General Assembly adopted an Optional Protocol to the Women's Convention containing, inter alia, the competence of the Committee to receive and consider complaints from individuals or groups within its jurisdiction. ${ }^{379}$ The Optional

378 In 2002, the Commission on Human Rights appointed an open-ended Working Group which is entrusted with the task of discussing the possibility of a complaints procedure with all parties involved, and whose goal it is to make concrete suggestions. The parties that are consulted by the Working Group are States, members of supervisory bodies, Special Rapporteurs, UN organizations, bodies, programmes and specialized agencies, national human rights institutions and civil society organizations. See the reports that have been submitted by the Working Group so far: UN docs. E/CN.4/2004/44, E/CN.4/2005/52 and E/CN.4/ 2006/47.

379 According to Article 2: 'Communications may be submitted by or on behalf of individuals or groups of individuals, under the jurisdiction of a State party, claiming to be victims of a violation of any of the rights set forth in the Convention by that State party. Where a communication is submitted on behalf of individuals or groups of individuals, this shall be with their consent unless the author can justify acting on their behalf without such consent.' $U N$ doc. A/RES/54/4, Optional Protocol to the Convention on the Elimination of All Forms of Discrimination against Women, 15 October 1999. 
Protocol entered into force on 22 December 2000 when the tenth ratification had been received. $^{380}$

The views adopted by the Committee on the second communication ${ }^{381}$ that was received are relevant in the framework of this study since the complaint was about a case of domestic violence. ${ }^{382}$

The author, Ms A.T. a Hungarian national, claimed that she was a victim of a violation of Articles 2(a), (b), and (e), 5(a) and 16 of the Women's Convention. She alleged that although she had been subjected to regular and severe domestic violence, Hungary did not adequately protect her. Firstly, because it was impossible for her to go to a shelter since none were equipped to accommodate her and her two children as one of them is fully disabled. Furthermore, Ms A.T. was not protected in her own home because no protection or restraining orders were available under Hungarian law. The residence was co-owned by her and her (former) partner and the author's motion for injunctive relief (in order to award her exclusive use of the apartment) was rejected by court because the offender was protected in his right to property. Thus he was allowed entry to the residence even though he continued to harass and threaten the author and their children.

According to CEDAW, the author's rights under Articles 2 (a), (b) and (e) had been violated since Hungary had failed to protect her effectively against battering by her (former) partner. It was noted that the batterer's rights to property and privacy should not prevail over the victim's rights to life, and physical and mental integrity. Furthermore, CEDAW was of the opinion that the victim's rights under Articles 5 and 16 had been violated because the preservation of traditional practices in Hungary contributed to violence against women. Moreover, the Committee pointed to the impossibility for the victim to flee to a shelter and the failure of both civil and criminal proceedings to ban the offender from the apartment.

The Committee recommended the State party to provide a safe home for the author and her children, to award her appropriate child support and legal assistance and to offer her compensation in proportion to the physical and mental harm that she had undergone and the gravity of the violations of her rights.

As regards measures concerning domestic violence in Hungary in general, CEDAW recommended respect, protection, promotion and fulfilment of women's human rights, including their right to be free from domestic violence; protection for victims of domestic violence; implementation of the national strategy for the prevention and treatment of family violence; training of judges, lawyers and law enforcement officials on the Women's Convention; implementation of CEDAW's concluding comments pertaining to Hungary of 2002 as regards the introduction of a specific law on domestic violence and provision for protection and exclusion orders and support services, including shelters; prompt

380 In October 2005 already 76 States had signed the Optional Protocol and 76 States had become party to it

381 As regards the first complaint that was received by CEDAW it was decided that the case was inadmissible because the author had not exhausted local remedies and the disputed facts occurred prior to the entry into force of the OP for the State party and did not continue after that date. CEDAW Communication No.: 1/2003, Ms B.-J. v. Germany, Decision adopted on 14 July 2004, para. 8.8.

382 Communication No.: 2/2003, Ms A.T. v. Hungary, Views adopted on 26 January 2005. 
Chapter IV

investigation of alleged cases of domestic violence; access to justice and effective remedies for victims; and rehabilitation and programmes for offenders. ${ }^{383}$

This decision is promising and shows the great potential of the Optional Protocol in dealing with concrete situations of violations, even of rights that are not explicitly mentioned in the Convention. ${ }^{384}$ It is a bit disappointing, however, that the Committee, missed the chance to broach the violations of the socio-economic rights of the victim, but instead concentrated on her right to physical integrity. The infringement of the victim's right to housing is not mentioned at all. Moreover, it should have been pointed out that by protecting the perpetrator's rights to property and privacy by means of rejecting the author's relief order in court, her rights to property and privacy were violated not only by the batterer but also by the State party. One of the greatest strengths of the Women's Convention is that it comprises civil, political, economic, social, cultural, and development rights. That is why it is unfortunate that the Committee did not make use of this strength, but instead concentrated in the traditional way on civil and political rights. If in future complaints are lodged about situations of domestic violence it is to be preferred that the Committee points out that besides the violation of the victim's rights to life, physical and mental integrity, also her rights to housing, property and privacy are infringed.

Furthermore, it is mentioned in the Committee's views that criminal proceedings, which took more than three years, resulted in the offender's conviction and a fine amounting to the equivalent of US\$ 365. Although the sum of the fine is ridiculously low for repeated infliction of severe pain, physical damage and infringement of several other human rights, it might have been pointed out by the Committee that this money is lost for the entire household. Therefore, it might have been suggested that instead of a fine, it would have been better if the batterer had been compelled to contribute financially to the housing situation of his victim.

It is positive that the Committee repeatedly mentions the necessity of having civil law measures at the disposal of domestic violence victims in addition to criminal law measures. However, especially in this particular case where it is clear that going to a shelter is not an adequate solution, CEDAW should have urged the State party to take all protective measures so that the victim and the children can remain in the family home (which apparently meets with the physically challenged child's needs) and that the offender is forced to accept a financial arrangement disowning him of his half of the apartment. Restitution is always the preferred form of reparation and in this case it would have been possible.

\subsection{CERD}

On the basis of Article 14 of the International Convention on the Elimination of All Forms Racial Discrimination, its monitoring Committee may investigate complaints lodged by an individual or a group of persons claiming to be the victim of racial discrimination. This may only be done if the State concerned is a party to the Convention and has declared

383 Also see: Ineke Boerefijn, 'Domestic violence against women in international law', in: Ingrid Westendorp and Ria Wolleswinkel (eds.), Violence in the domestic sphere, Intersentia, Antwerp, Oxford, 2005, pp. 44-46.

384 The right to physical integrity as such is not guaranteed by the Women's Convention. 
that it recognizes the competence of CERD to receive such complaints. The procedure for consideration of communications received by CERD from individuals or groups claiming to be the victims of a violation of the Convention became operational in 1982 when ten States parties had declared that they accepted the Committee's competence in that regard. In 2005 CERD had published 33 opinions and decisions on complaints received. A few of these communications dealt with alleged violations of the right to housing as contained in Article 5(e)(iii) of the Convention, ${ }^{385}$ none of which, however, had gender implications.

It is not unthinkable, however, that in the future complaints may be lodged about situations where women are denied adequate housing not only because of their racial or ethnic, or national descent, but also because of their gender. Possible situations have been pointed out in section 4.7.2.1.3 on CERD's reporting procedure. Especially women belonging to indigenous peoples, minority and descent-based groups or migrant populations may be the victims of such incidents of double discrimination.

It is to be hoped that CERD will be alert to these situations and explicitly deal with elements of gender discrimination whenever they occur. Total disregard for gender as a discriminating factor, such as occurred in the Yilmaz-Dogan case, is to be avoided. ${ }^{386}$

\subsection{CMW}

Article 77 of the Convention on the Rights of All Migrant Workers and Members of their Families provides that the CMW may receive and consider communications from or on behalf of individuals claiming that their rights under the Convention have been violated if the State concerned is a party to the Convention and if it has recognized the Committee's competence to receive such complaints.

The Article will become operative once ten States have accepted the Committee's competence in this regard, which has not yet happened.

\subsubsection{Inquiry Procedure}

Of the five monitoring bodies that are discussed in this section, only CEDAW has the option to hold an inquiry into alleged grave and structural violations of women's human rights. This possibility is contained in Article 8 of the Optional Protocol to the Women's Convention. ${ }^{387}$ The inquiry procedure is to be regarded as a highly valuable additional

385 See: CERD/C/42/D/4/1991, 16 March 1993, Communication No. 4/1991, L.K. v. The Netherlands; CERD/ C/57/D/13/1998, 1 November 2000, Communication No. 13/1998, Anna Koptova v. Slovak Republic; CERD/C/66/D/31/2003, 10 March 2005, Communication No. 31/2003, L.R. et.al. v. Slovak Republic.

386 See section 4.4.4 supra. Also: CERD/C/36/D/1/1984, 29 September 1988, Communication No. 1/1984, A. Yilmaz-Dogan v. The Netherlands.

387 Article 8 of the OP reads: '1) If the Committee received reliable information indicating grave or systematic violations by a State party of rights set forth in the Convention, the Committee shall invite that State party to cooperate in the examination of the information and to this end to submit observations with regard to the information concerned; 2) Taking into account any observations that may have been submitted by the State Party concerned as well as any other reliable information available to it, the Committee may designate one or more of its members to conduct an inquiry and to report urgently to the Committee. Where warranted and with the consent of the State party, the inquiry may include a visit to its territory; 3) After examining the findings of such an inquiry, the Committee shall transmit these findings 
means to monitor compliance with the Convention. Especially since the procedure may be based on information received from other sources than complaints of individuals or groups of individuals, thus lowering the threshold and offering protection to victims or members of their family. It means that inquiry in a certain State party is possible based on reliable information received from civil society organizations. ${ }^{388}$ Although the procedure itself is conducted confidentially, the findings are published which is an important means of political pressure. ${ }^{389}$ Furthermore, States parties may be invited to report on any measures that have been taken as a result of the inquiry in their periodic reports so that a certain degree of follow-up is guaranteed. ${ }^{390}$

CEDAW conducted its first inquiry already in 2003 after having received in the previous year information from two civil society organizations on numerous cases of abduction, rape and murder of women in and in the region of Ciudad Juárez, in Mexico. ${ }^{391}$ It may be said that the procedure was a success, which of course does not mean that all problems have been solved or that past wrongs have been amended. Mexico fully cooperated with the Committee and accepted that two of its members conducted an investigation on its territory. Based on the Committee's findings and recommendations, a variety of measures has been taken by the Mexican Government. Furthermore, it is important that it was acknowledged that women's human rights had been breached in Mexico.

The lesson to be learnt from the Mexican experience is that if States parties cooperate, it is possible to really dig into serious violations of women's human rights in a relatively short time and to come up with feasible suggestions and recommendations. In view of the limited means and time at the Committee's disposal, the possibilities to conduct such inquiries are of course restricted.

Nonetheless it would be extremely important if CEDAW would also conduct inquiries into large-scale violations of women's social, economic and cultural rights. Based on the information in this study, in particular two well-documented situations of systematic

to the State party concerned together with any comments and recommendations; 4) The State party concerned shall, within six months of receiving the findings, comments and recommendations transmitted by the Committee, submit its observations to the Committee; 5) Such an inquiry shall be conducted confidentially and the cooperation of the State party shall be sought at all stages of the proceedings.'

388 It goes without saying that CEDAW is only competent as regards States parties that have ratified the OP and that have not made use of the opting-out clause contained in Article 10 reading: '1. Each State party may, at the time of signature or ratification of the present Protocol or accession thereto, declare that it does not recognize the competence of the Committee provided for in Articles 8 and 9.'

389 In any case a summary of the activities undertaken will be included in the annual report prepared in accordance with Article 21 of the Convention and Article 12 of the OP. See Rule 80 of the Rules of procedure of the Committee contained in Annex I of $U N$ doc. A/56/38, 2001. Furthermore, CEDAW may decide to make public a separate report of its findings and recommendations as it has done in the case of Mexico.

390 According to Article 9: '1) The Committee may invite the State party concerned to include in its report under Article 18 of the Convention details of any measures taken in response to an inquiry conducted under Article 8 of the present Protocol; 2) The Committee may, if necessary, after the end of the period of sex months referred to in Article 8.4, invite the State party concerned to inform it of the measures taken in response to such an inquiry.'

391 UN doc. CEDAW/C/2005/OP.8/Mexico, 27 January 2005. 
violations of women's rights would appropriately lend themselves for an inquiry procedure. $^{392}$

In the first place, an inquiry might provide important insights into the structural violations of women's right to land in Africa. Although Africa is not the only continent where women's right to land is violated, women in Africa belong to the poorest in the world and they have the least opportunities. It is a continent where about $80 \%$ of the agrarian produce is the result of women's work, while women own approximately $8 \%$ of the land. Access to and right to property of land is inextricably attached to the right to housing in an agrarian community. Several African States have pledged themselves to the principles of equality and non-discrimination of women by becoming a party to the Women's Convention while they have also ratified the Optional Protocol. It is high time that a thorough investigation is conducted which will expose the reasons why nevertheless the fulfilment of women's right to land fails miserably in these States.

A second inquiry might be conducted into the dispossession of widows. Despite the international obligations ensuing from Article 5 of the Women's Convention, widowhood remains the cause of homelessness and inadequate housing for tens of thousands of women. For instance in Bangladesh where, based on cultural practices, widows are denied access to or property rights of land and housing on such a large scale that huge communities of widows live together in bustees (squatter camps) where they have to beg or prostitute themselves in order to survive. ${ }^{393}$

\subsubsection{General Comments/Recommendations}

\subsection{CEDAW}

Article 21 of the Women's Convention empowers CEDAW to make general recommendations based on the examination of reports and information received from States parties. General recommendations are addressed to States parties in order to further explain provisions contained in the Convention and to express the Committee's views on the obligations assumed by States parties.

In January 2004, CEDAW had adopted twenty-five general recommendations. ${ }^{394}$ Those recommendations adopted till 1991 are generally short and modest, addressing procedural issues rather than substantive provisions. Since 1991, however, the Committee is in the habit of adopting general recommendations on specific provisions or themes. These recommendations are meant to give States parties guidance on the application of the Convention in particular situations.

Since 1999, CEDAW follows a three-stage process for the formulation of general recommendations. First a session is devoted to a general discussion between the Com-

392 Although the problem of domestic violence might seem to be an obvious choice for an inquiry procedure in the framework of adequate housing for women, it is not my first choice because CEDAW already pays ample attention to domestic violence during the reporting procedure, while it has also been the subject of the second complaint procedure. Moreover, specific research and inquiry into domestic violence has also been conducted by the Special Rapporteur on Violence against Women.

393 See section 3.3.4 on widowhood.

394 For an overview and the contents of the various General Recommendations see: <http://www.un.org/ womenwatch/daw/cedaw/recommendations/index.html>. 
mittee, civil society organizations and others on the topic of the general recommendation. One or more Committee members are then asked to draft the general recommendation, which is discussed at the next session of the Committee in one of its working groups. The third stage is the adoption of the revised draft by the Committee in one of its next sessions.

The Committee started working on the twenty-sixth General Recommendation in July 2004 with an open debate on Article 2 of the Convention. It is to be hoped that the Committee will use the chance to elaborate on the terms discrimination based on sex and gender, direct and indirect discrimination, and de iure and de facto equality. Many States need guidance and clarification by way of elucidating examples so that they understand which action has to be taken in order to fulfil their obligation to ensure equality and non-discrimination for women. For equal rights of women pertaining to housing and land it is important that CEDAW will stress in this general recommendation that the term 'equality' in this provision should be read as equality of result. ${ }^{395}$

It has become clear in the course of this study that the law is only a limited instrument to achieve fulfillment of women's human rights because much depends on societal change. With regard to women's disadvantaged socio-economic situation, other disciplines are needed and should be used to bring about a change of mentality. However, it is of the utmost importance that CEDAW starts working on a clear and comprehensive general recommendation on Article 5. ${ }^{396}$ The fact that there is a great diversity in cultural backgrounds and expertise among its members is an important advantage. It is to be foreseen that it will be extremely hard to achieve global acceptance, but CEDAW's stance on Article 5 should be clear; it is impossible to achieve substantive equality of women if at the same time traditional patterns are safeguarded. Many of the reasons why women's right to housing is difficult or impossible to fulfil do not find their origin in the law, but find their basis in societal habits and cultural stereotypes. If these root causes are not eliminated, legal rules will at best only provide some relief. The Committee deals with the obligations under Article 5 in an extensive but rather piecemeal fashion. ${ }^{397}$ Increasingly, States parties are requested to go into any traditional habits or

395 For further comments on the preferred contents of a General Recommendation on Article 2 of the Convention see section 4.3 on Principles of equality and non-discrimination. Also Ingrid Westendorp, Article 2 of the Convention on the Elimination of All Forms of Discrimination against Women, background paper for CEDAW's general discussion on 21 July, 2004.

396 In the beginning of its existence CEDAW already adopted a General Recommendation on Article 5. The text of which reads: 'The Committee on the Elimination of Discrimination against Women, Considering that the Committee on the Elimination of Discrimination against Women has considered 34 reports from States parties since 1983, Further considering that, although the reports have come from States with different levels of development, they present features in varying degrees showing the existence of stereotyped conceptions of women, owing to socio-cultural factors, that perpetuate discrimination based on sex and hinder the implementation of Article 5 of the Convention, Urges all States parties effectively to adopt education and public information programmes, which will help eliminate prejudices and current practices that hinder the full operation of the principle of the social equality of women. General Recommendation No. 3, 1987 (sixth session).'

397 After the adoption of General Recommendation No. 3, Article 5 was also the subject of General Recommendations No. 12 and No.19 where a direct connection was made between negative and inferior images of women and violence against women. In General Recommendation No. 21 on family law compliance with Article 5 was seen as indispensable for the realization of the rights contained in Article 16 , 
cultural attitudes while reporting under other substantive articles in the Convention instead of asking them to report on Article 5 as an independent obligation. ${ }^{398}$ Though in this way immediate insights may be offered on how a certain legal right is ousted by cultural habits, still, it would have its benefits to deal with the obligations under Article 5 in a more structured manner. In a specific General Recommendation the Committee might start by naming and defining harmful attitudes like patriarchy, exogamy, and son preference that affect virtually all aspects of women's life from the cradle till the grave, instead of referring in general and abstract terms to cultural attitudes as is the current practice in concluding observations. If States parties are requested to enumerate all cultural habits and stereotypical ideas that exist about women's and men's socio-economic position, traditional patterns may come to light that cannot be linked to specific rights contained in the Convention, but that nevertheless should be abolished in the interest of women's equality. Furthermore, the adoption of a comprehensive General Recommendation on Article 5 would stress its importance and would guarantee that traditional patterns and gender stereotyping are a recurring theme in all State reports even if no specific questions are asked. Adopting a general recommendation may also be the best option if the Committee wishes to emphasize the importance of adequate housing for women and to create for itself the possibility to supervise this right in a structured manner. In view of the fact that in many parts of the world housing and land are inseparable, I would suggest that these two rights are taken together. The haphazard way in which the Committee is now forced to monitor compliance with these rights, would be repaired by adopting a general recommendation specifying the States parties' obligations in this regard. For the contents of such a general recommendation I refer to sections 4.7.2.1.1 and 4.7.2.1.1.1 where all sorts of aspects and questions that may come up with regard to the rights to housing and land have already been discussed.

\subsection{CESCR}

As from its third session, the Committee on Economic, Social and Cultural Rights has started to prepare general comments based on provisions contained in the Covenant on Economic, Social and Cultural Rights. In 2005 it had adopted eighteen General Comments, several of which are of particular importance in the framework of women's housing rights and have already been reviewed in detail in other parts of this study.

Considering the important influence of General Comments No. 4 and No. 7 on the development and the understanding of the right to adequate housing, it would be highly desirable if the Committee would take it upon itself to elaborate on the dimensions of this right even further by adopting a General Comment on the right to housing for women. Moreover, it would fit in with the Committee's tendency to increasingly pay more attention to the particular difficulties women encounter as regards the fulfilment of their

and in General Recommendation No. 25 the abolishment of prevailing gender relations and negative gender stereotypes was presented as one of the three goals of the Convention. Also see, Rikki Holtmaat, Naar ander recht en beleid; De betekenis van artikel 5 a VN-Vrouwenverdrag voor het uitbannen van structurele genderdiscriminatie, Ministerie van Sociale Zaken en Werkgelegenheid, 2004, pp. 31-34.

398 Rikki Holtmaat, 2004, p. 45. 
rights under the Covenant. Since the CESCR may be considered as the highest (legal) authority on the right to housing, the impact may be considerable.

The extensive list of topics and questions already enumerated in section 4.7.2.1.2.1 might be addressed in such a general comment.

\subsection{CERD}

CERD may make general recommendations based on Article 9(2) of the Convention on the Elimination of All Forms of Racial Discrimination. Between 1972 and 2006 the Committee has used this ability by adopting 31 General Recommendations. In the framework of this study the most important one is General Recommendation No. 25 on gender-related dimensions of racial discrimination in which CERD expresses the intent to integrate gender perspectives, incorporate gender analysis and use gender-inclusive language in its sessions, working methods, concluding observations, early warning mechanisms and urgent action procedures, and general recommendations. ${ }^{399}$ In view of the original reluctance CERD showed to take gender issues into account, and the long time it took before a general recommendation on gender perspectives was adopted, it is to be hoped that the Committee has indeed entered upon a new avenue. In any case, it is important that States parties are requested to include sex-disaggregated data in their reports and to describe factors that affect the equal enjoyment of women of the rights under the Convention. ${ }^{400}$ Bringing cases of double discrimination into the open is the first step towards addressing them. It is not to be expected, however, that CERD may be induced to adopt a specific general recommendation focusing on gender aspects in relation to the right to housing as laid down in Article 5(e)(iii) of the Convention.

\subsection{CRC}

Article 45(d) of the Convention on the Rights of the Child provides that the Committee on the Rights of the Child may adopt general recommendations on specific articles, provisions and themes of the Convention. Either one of the Committee members takes the initiative, or the Committee decides to develop a general comment based on a topic that has been discussed during a General Day of Discussion.

Up till 2006 the CRC has adopted seven General Comments two of which broach the subject of adequate housing. In General Comment No. 7 on Implementing child rights in early childhood, the Committee reiterates the States parties' obligation to assist and support parents or other care-takers in their task to provide their children with inter alia adequate housing. ${ }^{401}$ In General Comment No. 6 on Treatment of unaccompanied and separated children outside their country of origin the Committee underscores the vulnerability of

399 CERD General Recommendation No. 25: Gender related dimensions of racial discrimination, 20 March 2000 , para. 4.

400 Ibidem, para. 6.

401 'The Committee notes with concern that even the most basic standard of living is not assured for millions of young children, despite widespread recognition of the adverse consequences of deprivation. All possible means should be employed, including "material assistance and support programmes" for children and families (Art. 27.3), in order to assure to young children a basic standard of living consistent with rights.' General Comment No. 7, Implementing child rights in early childhood, CRC/C/C/7, 1 November 2005, para. 26. 
unaccompanied children and clearly formulates that for want of parents or other care-takers the States parties are obliged to provide these children with what they need, including adequate housing. ${ }^{402}$

Because of the very basic need of adequate living conditions for children it may be warranted that a specific general comment be devoted to Article 27. In such a comment the Committee should first of all clarify what constitutes adequate living conditions, including adequate housing, for children. By way of preparation before Habitat II, a group of experts from UNICEF and UNCHS met in February 1996 in order to discuss the relevance of the Children's Convention to the goals of the Istanbul conference. ${ }^{403}$ The outcome of this meeting was a declaration in which it was inter alia stated that a healthy home for a child includes a safe and sufficient water supply, safe and accessible sanitation and waste management, but also protection from traffic and other hazards and freedom from exposure to pollution, radiation and disease, and from excessive noise and overcrowding. ${ }^{404}$ At Habitat II the Committee on the Rights of the Child stated that it believes that the right to housing must not be interpreted narrowly, but as a right to live somewhere in security, peace and dignity. This will certainly also entail protection in cases of domestic violence, including sexual abuse.

Furthermore, the Committee should make clear what sort of assistance States parties should offer parents and other care-takers in order to enable them to provide their children with adequate living conditions. When is the State supposed to get involved and what is the extent of the material assistance that should be provided?

Moreover, it should be clarified what the States parties' obligations are as regards the living conditions, including housing, of unaccompanied children, not only those of foreign descent, but also of children of national descent. In many States large groups of street children are completely deprived of housing while others are accommodated in temporary shelters. Measures to secure the safety of those children are a point of concern. It goes without saying that in such a General Comment ample attention should be paid to the specific circumstances and vulnerabilities of girls.

\subsection{CMW}

Article 73(7) of the Convention on the Rights of All Migrant Workers and Members of their Families stipulates that the CMW may make recommendations based, in particular, on the examination of the reports and any observations presented by States parties. In view of the fact that the Committee's work has only just started, it seems rather premature to speculate on possible general recommendations. Based on the Committee's future experience with reporting States a general recommendation on female domestic workers, including their housing situation, might be advisable.

402 General Comment No. 6, Treatment of unaccompanied and separated children outside their country of origin, CRC/GC/2005/6, 1 September 2005 .

403 Implementation Handbook for the Convention on the Rights of the Child, prepared for UNICEF by Rachel Hodgkin and Peter Newell, UNICEF, 1998, pp. 362-363.

404 Children's Rights and Habitat, Declaration and Report of the Expert Seminar, UNICEF, UNCHS/ Habitat, 1996. 
Chapter IV

\subsubsection{Special Rapporteurs}

In the course of this study already much attention has been paid to the work of various Special Rapporteurs who have a thematic mandate that has a direct or indirect bearing on the subject matter. A Special Rapporteur is appointed by a UN Charter-based organ and has a different task compared to the treaty bodies that have been dealt with before. Her or his mandate pertains to a certain theme which she/he is requested to examine and report on. The Special Rapporteur is not restricted to treaty provisions or hindered by the lack of ratifications or the submission of reservations like the treaty bodies, but can examine the assigned theme with respect to any State. However, if she/he would like to conduct an inquiry on the territory of certain State, then of course the principle of State sovereignty prescribes that explicit permission is needed. Since the Special Rapporteur is appointed by resolution of a policy organ, there are, strictly speaking, no legal obligations attached to the outcome of the investigation, but there are political and moral implications as regards conclusions and recommendations drawn up by the Special Rapporteur. What the exact impact of a Rapporteur's report will be is hard to assess. At the moment there are rather too many Special Rapporteurs and it may be seriously doubted whether their reports receive the attention they deserve. ${ }^{405}$ In any case, the insights provided by Special Rapporteurs may be very useful and their monitoring abilities are a valuable addition to the work done by UN treaty bodies.

In the following sections, the most relevant thematic mandates i.e. on housing, violence against women, harmful traditional practices, internally displaced persons and migrant workers will be reviewed with the goal to determining how the respective mandate-holders might broaden and improve their monitoring potential in respect of women's housing rights.

\subsubsection{Special Rapporteur on Adequate Housing}

In Chapter II the reports of the two Special Rapporteurs on Adequate Housing have already been discussed extensively. The first Special Rapporteur, ${ }^{406}$ was not appointed by the Commission on Human Rights, but by its Sub-Commission. That is why his mandate was restricted to examination and reporting on the issue of housing. He based himself on the groundwork laid by the Committee on Economic, Social and Cultural Rights, especially its General Comments No. 4 and No. 7, and has worked out many relevant aspects of the right to adequate housing in detail. ${ }^{407}$ Since he hardly paid any attention to gender aspects, his work will not be discussed here any further.

Much more pertinent are the reports by the Commission on Human Rights Special Rapporteur ${ }^{408}$ who, in addition to examination and reporting is mandated to providing

405 See the site of the Office of the UN High Commissioner for Human Rights at: <www.ohchr.org/english/ bodies/chr/special/index.htm>.

406 The first Special Rapporteur on adequate housing was Justice Rajindar Sachar who was appointed in 1992

407 See in particular sections 2.3 and 2.4.

408 The UN Commission on Human Rights appointed Mr Miloon Kothari as its Special Rapporteur on adequate housing in October 2000 
advice, responding to individual complaints, visiting countries, and engaging in promotional activities. The mandate-holder was specifically requested by the Commission to apply gender perspectives in his work. ${ }^{409}$ In 2005 the Special Rapporteur had already submitted two reports specifically dealing with women's right to adequate housing 410 while he also paid attention to gender aspects in his annual reports ${ }^{411}$ and his countryspecific reports. ${ }^{412}$ Since the contents of the two specific reports have already been discussed in detail in section 2.7 , I will not repeat it again in this place, but merely give some suggestions and recommendations for future work.

The Special Rapporteur has contacted UN women's organs, UN Habitat, other Special Rapporteurs, civil society organizations, and States, ${ }^{413}$ and has gained keen insights in the complexity of the multifaceted problems women face as regards the realization of their right to adequate housing. He has come to the conclusion that it is impossible to approach the right to adequate housing in a singular way, but that an indivisible human rights approach is needed. ${ }^{414}$ That is why he would like the Commission to expand his mandate to encompassing the rights to land, property and inheritance. ${ }^{415}$ Furthermore, he has been struck by the great diversity among women and the different barriers they have to overcome. That is why he wants to study, among other subjects, the problem of multiple discrimination faced by women because of their race, ethnicity, caste, disability, health or other factors. ${ }^{416}$

The two reports on women's right to adequate housing submitted by the Special Rapporteur are excellent in presenting an overview of the broad spectrum of problems faced by women in fulfilling their housing rights. However, it might be advisable if subsequent reports would focus on specific subjects in a structured way and provide in-depth insights in the problems that have to be overcome. Just as he has done in respect of his general annual reports, the next stage should be to dig into the core causes and provide concrete suggestions for improvement. As far as his mandate is concerned, it would seem that expansion is unnecessary and might even work against him. He is quite right about the fact that an indivisible human rights approach is required, but he should just put it into practice. An expansion of his mandate with the rights to property, land and inheritance might turn out to be too restrictive and he may lose the opportunity to take yet other rights into consideration. Furthermore, the Special Rapporteur may not do

409 Commission on Human Rights Resolution 2000/9, 17 April 2000. Also see sections 2.3 and 2.5.

410 UN docs. E/CN.4/2003/55, 26 March 2003 and E/CN.4/2005/43, 25 February 2005, both entitled Women and adequate housing.

411 UN docs. E/CN.4/2001/51, 25 January 2001, E/CN.4/2002/59, 1 March 2002, E/CN.4/2003/5, 3 March 2003, E/CN.4/2004/48, 8 March 2004, and E/CN.4/2005/48, 3 March 2005.

412 UN docs. E/CN.4/2003/5/Add. 1, Occupied Palestinian territories, January 2002, E/CN.4/2003/5/Add. 2, Romania, January 2002, E/CN.4.2003/5/Add. 3, Mexico, March 2002, E/CN.4/2004/48/Add. 1, Peru, March 2003, E/CN.4/2004/48/Add. 2, Afghanistan, September 2003, E/CN.4/2005/48 Add. 2, Kenya, February 2004, E/CN.4/2005/48/Add. 3, Brazil, June 2004.

413 In 2003 all States received an extensive questionnaire on women and adequate housing. The questionnaire is available at: <www.ohchr.org/english/issues/housing/docs/questionnaireEn.doc $>$.

$414 U N$ doc. E/CN.4/2005/43, 25 February 2005, para. 17.

415 UN doc. E/CN.4/2003/55, 26 March 2003, para. 81 and E/CN.4/2005/43, 25 February 2005, summary and para. $79(\mathrm{~d})$.

416 E/CN.4/2005/43, 25 February 2005, para. 69. 
women a favour by stressing existing disparities. This may give States the chance to hide behind cultural differences and justify certain situations by pointing to different circumstances. It might therefore be advisable to concentrate first on those factors that women worldwide have in common. Only after the more general groundwork has been covered, specific circumstances that affect the housing situation of women should be examined in depth.

In view of the above, the Special Rapporteur might first concentrate on situations that affect all or most women in the world and subsequently cover themes and situations that affect smaller groups of women or only play a role in certain regions. The housing rights of the girl-child may be a good starting point, followed by the effect of marriage on a woman's possibility to exercise her right to housing. In view of the great number of women worldwide living in temporary shelters for various reasons, this type of housing also deserves to be investigated on a priority basis as well as the housing situation of female heads of household. Subsequently, the more specific situations deserve an indepth study starting with widowhood because of the huge numbers of women in SouthEast Asia and Africa who are affected. Other specific situations warranting attention are detention, multiple discriminations, and natural or human made disasters, including the reparation for returnees.

\subsubsection{Special Rapporteur on Violence against Women $^{417}$}

The Special Rapporteur on violence against women, its causes and consequences, has produced an impressive number of reports in which various situations of violence against women have been extensively examined. ${ }^{418}$ It is a regrettable though, that the mandate has been focused so much on violations of civil and political rights while more emphasis might have been put on violations of economic, social and cultural rights. The more so since the disadvantaged socio-economic position of women makes them susceptible to violence, while one of the consequences of gender specific violence is that it diminishes or annihilates women's enjoyment of their socio-economic rights such as housing. ${ }^{419}$

One of the most important conclusions drawn by the Special Rapporteur maybe that unequal power positions facilitate men's dominance and lead to violence and discrimination against women. The male patriarchal ideology therefore may be regarded as the main cause for violence against women. ${ }^{420}$ This finding belies the conclusion reached in many States that incidents of violence at home can be explained or even justified by pointing to alcohol or drug abuse or inadequate housing conditions. Although all kinds of circumstances do play a part and may exacerbate situations of abuse, or may even

417 The first mandate-holder, Ms Radhika Coomaraswamy (Sri Lanka) was appointed by the UN Commission on Human Rights in March 1994. She remained in office till July 2003. She was succeeded by Dr. Yakin Ertürk (Turkey) in August 2003.

418 All reports can be found on the internet at: <www.ohchr.org/english/issues/women/rapporteur/index.htm>.

419 That is why in the context of this study one of the most important reports by the Special Rapporteur is the addendum on: 'Economic and social policy and its impact on violence against women', UN doc. E/CN.4/2000/68/Add.5, 24 February 2000

$420 U N$ doc. E/CN.4/1999/68, Report by the Special Rapporteur on Violence against Women, 10 March 1999, para. 31. Also see section 3.3.5 on domestic violence. 
trigger violence, the true reason why domestic violence is so widespread is that a great many women worldwide depend on their partner for housing. This is also why it is so difficult for them to leave and why they have to endure abuse for an indefinite period of time especially if there are children. ${ }^{421}$ The unremitting attention of the Special Rapporteur for domestic violence, also in her country specific reports, and her attention for the particular hardships women suffer in cases of relocation and forced evictions are helpful for understanding women's housing rights. ${ }^{422}$ The Special Rapporteur would further women's right to adequate housing even more if she would explicitly explain the link between this right and situations of domestic violence and forced evictions. It should be acknowledged that far more women are inadequately housed than ordinarily presumed since adequacy not only consists of material aspects but also of dignity, peace and security at home.

\subsubsection{Special Rapporteur on Harmful Traditional Practices}

From 1996 till 2005 the UN Sub-Commission for the Promotion and Protection of Human Rights created the mandate to investigate and report on traditional practices that affect the health of women and the girl child. ${ }^{423}$ Although the Special Rapporteur submitted her final report in 2005 and she considers that these practices have been fully identified and that further action should be taken by other mechanisms, ${ }^{424}$ it is still pertinent to look into this specific mandate in the framework of this study. It seems to me that mandate-holder has interpreted her task too restrictively because she has understood the concept of health too narrowly. 'Health' not only comprises physical but also psychological well-being, but the Special Rapporteur has focused on instances of bodily harm.

She has concentrated disproportionately on female circumcision, while other harmful practices did not receive the attention they merit. Undoubtedly, female circumcision is a serious problem that should be dealt with, but other practices may have equally devastating effects on girls' and women's lives. For instance, more emphasis might have been put on the practice of son preference since it is so widespread and it may have negative effects on virtually all of women's human rights. Son preference may not only result in female foeticide and infanticide, but also in withholding girls and women basic rights like adequate food, health care, education and inheritance. Thus this practice creates a girl's socio-economic disadvantaged position with the result that she is not able to sustain herself in later life, but will be dependent on men till the end of her days. Besides the psychological effect that she will feel like a secondary citizen, dependency also bears the danger of physical violence as has been explained before. ${ }^{425}$

421 This was also the Special Rapporteur's opinion in her specific report on Brazil on the issue of domestic violence, $U N$ doc. E/CN.4/1997/47/Add.2, para. 24, and again in $U N$ doc. E/CN.4/2000/68/Add.5, para. 8.

422 See in particular $U N$ doc. E/CN.4/2000/68/Add.5, paras 52-57.

423 The Special Rapporteur on harmful traditional practices was Ms Halima Warzazi (Morocco).

$424 U N$ doc. E/CN.4/Sub.2/2005/36, Ninth report and final report on the situation regarding the elimination of traditional practices affecting the health of women and the girl child, prepared by Ms Halima Embarek Warzazi, 11 July 2005.

425 See e.g. section 4.7.3.2 on the Special Rapporteur on violence against women, and 3.3.5 on domestic violence. 
Other harmful practices that should have been investigated more closely are female exogamy, polygamy, levirate, and sororate. ${ }^{426}$ All these customs create a situation of subordination and dependency, making women susceptible to domestic violence and denying them the right to be autonomous persons.

Finally, in many States of the world widows are subjected to the most gruesome rituals. ${ }^{427}$ Besides the devastating effects these may have on the widows' physical and mental health, they may also result in the widows' dispossession and homelessness.

In view of the above, it appears that the study of harmful traditional practices is not anything like finished. On the contrary, it would seem that a functionary with a broad mandate should be put to work.

\subsubsection{Mandates Pertaining to Internally Displaced Persons (IDPs) and Refugees}

In 1992, the UN Secretary-General appointed a representative (RSG) on internally displaced persons at the request of the Commission on Human Rights. The mandate-holder who was appointed remained in office till July $2004 .^{428}$ In September of the same year, the Secretary-General appointed a successor with a slightly different mandate i.e. on the human rights of internally displaced persons. ${ }^{429}$ Meanwhile, the Sub-Commission for the Promotion and Protection of Human Rights had appointed one of its members as Special Rapporteur on housing and property restitution in the context of the return of refugees and internally displaced persons in $2001 .^{430}$ All three mandates are relevant in the framework of this section. Furthermore, it should be noted that many of the causes and consequences pertaining to IDPs are equally applicable to the situation of refugees. That is why any suggestions and recommendations may be applied both to people who did, and those who did not cross the border of their own country when they fled or were evicted from their homes.

Since the great majority of IDPs and of refugees are women and (their) children, ${ }^{431}$ the monitoring mandates of the functionaries mentioned above may contribute to the improvement of the housing situation of these particular groups of women. ${ }^{432}$

In 1998 the RSG drew up the 'Guiding Principles on Internal Displacement' for which there is a growing acceptance at the international level. ${ }^{433}$ In his reports, the Rep-

426 Sororate is the custom of marriage of a man to his wife's sister, usually after the wife has died or proved sterile.

427 See section 3.3.4 on widowhood.

428 The RSG on internally displaced persons was Mr Francis Deng (The Sudan).

429 The RSG on the human rights of IDPs is Prof. Walter Kälin (Switzerland). All reports published by the two mandate-holders may be found on the internet at: <www.ohchr.org/enlish/issues/idp/annual.htm $>$.

430 The Sub-Commission's Special Rapporteur is Mr Paulo Sérgio Pinheiro (Brazil).

431 This has been repeatedly affirmed. See e.g. UN doc. E/CN.4/2005/84, Mass exoduses and displaced persons, Report of the Representative of the Secretary-General on the human rights of internally displaced persons, Walter Kälin, 31 December 2004, para. 65.

432 Also see section 3.4.5.4 on female refugees and internally displaced women.

433 The Guiding Principles are contained in $U N$ doc. E/CN.4/1998/53/Add.2, Guiding Principles on Internal Displacement, 11 February 1998. The document was e.g. acknowledged as an important international framework for the protection of IDPs in the Outcome Document of the UN World Summit 2005. See $U N$ doc. A/RES/60/1, 24 October 2005, para. 132. 
resentative repeatedly mentions that he is aware of the fact that women constitute the majority of the IDPs and that it is therefore important to include a gender perspective. Although this awareness is expressed in several of the principles, ${ }^{434}$ still there are a few lacunae pertaining to women's housing situation. This may be taken up by the present RSG who has stated that he has the intention to promote the dissemination and acceptance of the norms underlying the Guiding Principles among national, regional and international actors and who has also shown to be aware of women's particular problems. ${ }^{435}$

In Principle 11 concerning every human being's right to dignity and physical, mental and moral integrity, several acts are mentioned against which IDPs should be protected. Although mention is made of rape, other acts of gender-specific violence, and sexual exploitation, attention might have been drawn explicitly to the fact that many women, who are temporarily housed, particularly in camps, have to be protected against their fellow IDPs. ${ }^{436}$ The fact that women's safety in temporary housing conditions is not only endangered from the outside, but also from the inside, should be made known to any authorities or organizations who bear responsibility for the protection of these women.

Principle 17 pertains to the right to respect for family life. What is lacking is a warning to be alert of an increase in domestic violence in situations of inadequate or temporary housing situations. ${ }^{437}$ The respect for family life finds it boundary in situations of abuse. In the interest of women's human rights, including housing, domestic violence should never be regarded as a private or family affair. Section V of the Guidelines deals with the principles relating to return, resettlement and reintegration. Principle 28 paragraph 1 reminds the competent authorities that IDPs should not be forced to return to their homes or to resettle elsewhere, but that this should happen on a voluntary basis. In paragraph 2 it is therefore stated that the full participation of IDPs should be ensured in the planning and management of their return or resettlement. This formulation is gender neutral and passes over the fact that in practice it is often forgotten to ask women whether they agree. Many problems arise because only male heads of families or male village elders participate in any decision-making in this regard. That is why it should be impressed upon the authorities that they engage women in the decision-making process and ensure themselves of their consent.

Finally, Principle 29 deals with the acquisition of property by IDPs who decide to resettle elsewhere, and the repossession of property of returnees. This principle is also formulated in a gender neutral way which fails to take account of the additional barriers women face in this regard. On average, it is far more difficult for women with their disadvantaged socio-economic position to acquire and maintain housing and land than it is for men. Therefore, the authorities should provide specific assistance for women who wish to resettle elsewhere, maybe in the form of temporary special measures. Women,

434 See e.g. Principle 4(2) where attention is drawn to the specific protection and assistance required by expectant mothers, mothers with young children, and female heads of household, and Principle 7 (3)(d) where authorities are urged to involve women in the planning and management of relocation schemes.

435 See $U N$ doc. E/CN.4/2005/84, paras $65-68$ and para. 82.

436 See e.g. UN doc. E/CN.4/1998/54, para. 210.

437 See e.g. the report by Walter Kälin on the Protection of Internally Displaced Persons in Situations of Natural Disaster; A Working Visit to Asia, 27 February to 5 March 2005, p. 18. Also, UN doc. E/CN.4/1996/52, para. 46. 
especially widows and orphaned girls who wish to return and reclaim their former land and homes may encounter impediments in the form of discriminatory inheritance laws or customary practices denying them access and property rights. Therefore, it should have been stressed that the competent authorities should abolish any discriminatory legislation that hinders women's property rights in any way while vigilance is needed to ensure that these women are not dispossessed by relatives, in-laws, or communities. These women's rights, especially if they are heads of households, should prevail over any customary practices.

Issues pertaining to the repossession of housing and other property of refugees and IDPs are the specific field of study of the Special Rapporteur who received his mandate from the Sub-Commission on the Promotion and Protection of Human Rights in $2001 .^{438}$ Property restitution and compensation for refugees and IDPs is an extremely difficult issue often complicated by discriminatory attitudes towards the dispossessed people, lack of official property documentation, demolition of houses, and occupation of land and housing by others who oftentimes have been relocated themselves. ${ }^{439}$ For women, as has been mentioned above, the recovering of property is even more difficult because in addition to general impediments they are faced with other barriers in the form of discriminatory laws and customary practices. Attached to his final report, the Special Rapporteur issued a set of Principles on Housing and Property Restitution for Refugees and Displaced Persons. These principles are based on the idea of gender equality and States are urged to ensure that: 'all national policies related to the right to housing, land and property restitution fully guarantee the rights of women and girls to be protected from discrimination and to equality in both law and practice'. ${ }^{440}$ It is to be doubted that this standard phrase will amount to anything other than formal equality on the domestic level. What should have been done was to elaborate on concrete situations of traditional practices that prevent women and girls from recovering property and stress that such customs are to be eradicated in order to safeguard women's substantive equal right to restitution in practice. Stereotypical ideas that see women as secondary citizens who cannot hold property and who cannot be heads of household, the male breadwinner model, and male guardianship structures denying women legal capacity, are in many cases the true barriers why women cannot reclaim their former land or housing and why others feel justified in withholding it from them.

438 Special Rapporteur Paulo Sérgio Pinheiro on Housing and property restitution in the context of the return of refugees and internally displaced persons, has issued four reports: E/CN.4/Sub.2/2002/17, Working paper; E/CN.4/Sub.2/2003/11, Preliminary report; E/CN.4/Sub.2/2004/22, Progress report; E/CN.4/ Sub.2/2005/17, Final report.

439 In his working paper the Special Rapporteur gives an overview of the generally existing impediments. He does not, however, go into the specific situation of women.E/CN.4/Sub.2/2002/17, paras 43-59.

$440 U N$ doc. E/CN.4/Sub.2/2005/17, Annex on Principles on Housing and Property Restitution for Refugees and Displaced Persons, 28 June 2005, paras 4 and 19.3 respectively. 


\subsubsection{Special Rapporteur on Migrant Workers}

In 1999 the mandate of the special Rapporteur on the Human Rights of Migrants was created by the Commission on Human Rights. ${ }^{441}$ It is specifically stipulated in the mandate that the mandate-holder is to take a gender perspective into account and to give special attention to the occurrence of multiple discrimination and violence against migrant women. Migrants, both female and male may experience the interplay of different grounds of discrimination, such as gender, race and religion, resulting in exclusion, disadvantage and abuse affecting all sorts of rights among which the right to housing. ${ }^{442}$

Of all the reports that have been published, the most important one in the context of this study is the 2004 annual report because of its focus on the human rights of female migrant domestic workers. ${ }^{443}$ In June 2003 the Special Rapporteur requested information on the situation of migrant domestic workers by means of a questionnaire from States, international organizations, civil society organizations, and international experts. The great majority of female migrant domestic workers live in their employer's house. ${ }^{444}$ They are extremely vulnerable to abuse because of several reasons. In many States domestic work is not recognized as formal employment and therefore domestic workers are excluded from all sorts of labour legislation and many workers do not even have a written contract. Furthermore, their residence in the receiving State may depend entirely on the private employment relationship with their employer, which makes it hard for them to report instances of abuse since they risk to be repatriated. In many cases employers withhold their migrant workers' papers or their passports which has the effect of confining them to the house since in many States it is forbidden to go into the streets without proper documentation. Even if they flee an abusive employer's house they often have nowhere to go because there are no shelters available for them.

In addition to situations of domestic violence and sexual abuse, the quality of the housing situation of many domestic workers is deplorable; they have to share a room with the children or the elderly they take care of, with other domestic workers or they are accommodated in sheds, kitchens or bathrooms. Many do not have any privacy at all.

The Special Rapporteur suggests many ways of improvement, among which the recommendation that legislation should be developed in the receiving State that makes recruitment of migrant domestic workers only possible by way of a written contract in which all kinds of particulars are laid down. ${ }^{445}$ One of the issues that should be regulated in such a contract is the domestic worker's accommodation. Adequate lodgings with respect for the worker's privacy and the possibility to complain in cases of abuse would improve the domestic workers' situation. Any improvement will depend on how

441 The first mandate holder was Ms Gabriela Rodríguez Pizarro (Mexico) who was succeeded in August 2005 by Mr Jorge Bustamante (Mexico). All reports by the two Special Rapporteurs on migrant workers are available at: <www.ohchr.org/english/issues/migration/rapporteur/annual.htm>.

442 UN doc. E/CN.4/2006/73, Migrant workers, Report of the Special Rapporteur on the human rights of migrants, Jorge Bustamante, 30 December 2005, para. 67,

$443 U N$ doc. E/CN.4/2004/76, Migrant workers, report of the Special Rapporteur, Ms Gabriela Rodríguez Pizarro, 12 January 2004.

444 Also see section 3.4.5.3 on women migrant workers.

445 Ibidem, paras 70-92. 
seriously the protection of these migrant workers is taken by the receiving States. The fact that domestic work, stereotypically female work, may not even be regarded as formal employment, does not bode well. It is to be hoped that the Special Rapporteur will remain alert to situations of abuse especially since the hands of the CMW are still bound for lack of ratifications by the most pertinent States.

\subsubsection{Civil Society Organizations}

The role of human rights civil society organizations as actors on the international plane is increasing. Especially since the early 1990s they have gradually gained access to various UN organs because their particular knowledge and expertise is recognized and valued. ${ }^{446}$ Civil society organizations may provide UN monitoring bodies with valuable information on human rights situations and violations, especially since they may have the expertise and facilities to conduct thorough and detailed investigations while members of supervisory bodies cannot be expected to be experts on all legal systems and all practices they are supposed to examine. ${ }^{447}$ On the domestic level, they may keep a watchful eye on the implementation of international standards and principles and on the follow-up of any recommendations that have been made. Furthermore, they may help in disseminating at the domestic level reports, concluding observations and general recommendations made by treaty bodies and Special Rapporteurs. ${ }^{448}$ As far as the right to housing is concerned, many regional and international organizations have been created that conduct in-depth studies into the intricacies of the right to adequate housing and that seek the attention of UN organs, such as the Committee on Economic, Social and Cultural Rights and the Special Rapporteur on adequate housing in order to advise them on issues of standard setting and supervision. ${ }^{449}$ Two of these organizations stand out because of their size and influence: the Habitat International Coalition (HIC) which has its seat in Mexico City, ${ }^{450}$ and the Centre on Housing Rights and Evictions (COHRE) which is based in Geneva. ${ }^{451}$

Especially during the World Conference on Human Rights in Vienna in 1993 the massive number of human rights civil society organizations became clear and indeed

446 Kerstin Martens, 'Professionalised Representation of Human Rights Civil society organizations to the United Nations', in: The International Journal of Human Rights, Vol. 10, No. 1, March 2006, p. 19.

447 Andrew Clapham, 'UN human rights reporting procedures: An NGO perspective', in: Philip Alston, and James Crawford (eds.), The Future of UN Human Rights Treaty Monitoring, Cambridge University Press, Cambridge, 2000, pp. 180-181.

448 Ibidem, p. 191.

449 In his study on Women and adequate housing, Special Rapporteur Miloon Kothari mentions several civil society organizations who play a key role in the promotion and protection of women's right to adequate housing. UN doc. E/CN.4/2003/55, Women and adequate housing, 26 March 2003, paras 69-73.

$450 \mathrm{HIC}$ is an independent, international, non-profit movement of some 400 organizations and individuals working in the area of human settlement from 80 countries in both North and South. A shared set of objectives bind and shape HIC's commitment to communities working to secure housing and improve their habitat conditions. See HIC's homepage on the internet at: <www.hic-net.org>.

451 COHRE promotes and protects human rights on a global level. There are four thematic programmes: women and housing rights, housing property restitution, litigation, and water rights. Furthermore COHRE maintains three regional programmes: COHRE Asia \& Pacific, COHRE Africa, and COHRE Americas. See COHRE's homepage at: $<$ www.cohre.org $>$. 
how many of them are focused on the realization of human rights for women. ${ }^{452}$ Their combined pressure stimulated inter alia the adoption of the Optional Protocol to the Women's Convention, led to the creation of the mandate of the Special Rapporteur on Violence against Women, and boosted the gender mainstreaming efforts within the UN. ${ }^{453}$ The gender expertise of women's rights civil society organizations is particularly needed in the UN monitoring process, ${ }^{454}$ since many monitoring organs do not have adequate knowledge of women's issues or do not know how to incorporate a gender perspective into their research. ${ }^{455}$

The role of international civil society organizations is restricted, however, as far as the implementation of women's housing rights at the domestic level is concerned. Time and again it has been shown that the most important reason for women's disadvantaged socio-economic position, and consequently their inability to fulfil their right to housing, is to be found in cultural, traditional, and religious stereotyping and discrimination. It is argued, that international civil society organizations should not intervene because this may be perceived as meddling in domestic affairs or even as tools of Western imperialism and in the end may have a counterproductive effect on the advancement of women's human rights. Next to their signalling function international civil society organizations should therefore concentrate on assisting national organizations by providing them with information, financing, and training.

Empowerment and de facto equality of women at the national level can only be achieved when a change of mentality is brought about and national civil society organizations, particularly grassroots organizations are indispensable in this process. ${ }^{456} \mathrm{Such}$ changes must come from the inside and it is primarily the women themselves who should join hands to level cultural barriers, promote their housing rights and monitor their implementation. National organizations have an important task in providing information and educating women and men on the housing rights women are rightfully entitled to.

\subsubsection{Concluding Remarks}

It has become clear from the above that a great diversity of organizations, organs and individuals is potentially able to define, promote, protect and monitor women's housing rights. Although much progress has already been made and many opportunities have been seized to further women's housing rights, there is still ample room for improvement.

452 In addition to specific women's rights organizations nearly all important human rights Civil society organizations have createdwomen's rights programmes nowadays. See e.g. Amnesty International's women's programme at <web.amnesty.org/library/eng-373/index>, the Women's Rights programme of Human Rights Watch at <www.hrw.org/women>, HIC's specific programme on Women and Adequate Housing at $<$ www.hic-net.org/indepth.asp?PID=29>, and COHRE's Women's Housing Rights programme at $<$ www.cohre.org/wkframe.htm $>$.

453 More than 800 civil society organizations participated in the Conference. See on the internet the site of the Office of the High Commissioner for Human Rights, World Conference on Human Rights, 14-25 June 1993, Vienna, Austria, at: <www.unhchr.ch/html/menu5/wchr/htm>

454 With regard to women's right to adequate housing see for instance COHRE's publication, Women and Housing Rights, Sources 5, Geneva, September 2000.

455 Andrew Clapham, 2000, p. 192.

456 Also see section 4.7 .4 on civil society organizations. 
Chapter IV

Some options have hitherto not been used, such as CEDAW's possibility to adopt a General Recommendation on housing and land, while other possibilities have not yet been used effectively for lack of specificity, like the CESCR's General Comments on housing.

Monitoring entails raising the right topics and asking the right questions. Using standard phrases calling upon States to be mindful of women's right to housing will not yield the required results and nor will the use of gender neutral recommendations. Furthering women's right to adequate housing effectively will require, as has been attempted in the framework of this study, to be as precise as possible in order to bring all particulars into the open. Monitoring bodies should delve into the core causes of women's inability to fulfil their housing rights and in the process they should not shun to investigate the underlying cultural patterns that negatively affect women's socio-economic position.

Obviously, there is a lot of overlap among the various mandates. Not only among treaty bodies, like CEDAW and the CESCR that may focus to a great extent on the same issues, but also between treaty bodies and Special Rapporteurs, like the CMW and the Special Rapporteur on Migrant Workers. This should not be considered as a problem, but rather as an advantage since their respective roles are complementary in character. For those States that have become party to more than one human rights convention, overlap will not cause any extra effort provided that national reporting commissions co-operate and coordinate effectively. The danger that the same right or obligation is interpreted differently by different monitoring bodies and that subsequently contradicting recommendations are made, must be solved by the monitoring bodies by means of close coordination and by avoiding serious discrepancies. ${ }^{457}$

Civil society organizations play their own indispensable part in the monitoring process. At the national level they may influence public opinion, provide information and education on housing rights and supervise the implementation of international obligations. International civil society organizations may also monitor implementation and they are best equipped to form a bridge between populations and international monitoring organs that they may provide with information pertaining to national situations and whose attention they may draw to violations.

\section{8}

\section{CONCLUSION}

A great many legal and societal rules and procedures exist at the international and at the national level that each in their own way have the potential to influence the chances that women succeed in fulfilling their housing rights. Since women's housing situation is on average worse than men's and it seems to be far more difficult for women to realize adequate housing by themselves, it is important to closely examine existing regulations and systems in order to determine whether they are in any way discriminatory or perhaps fail to encompass the intricacies of women's issues. Only if there is clarity why rules and systems do not work to women's benefit can ways and strategies be developed to change them.

457 Eric Tistounet, 'The Problem of Overlapping among Different Treaty Bodies', in: Philip Alston, and James Crawford (eds.), The Future of UN Human Rights Treaty Monitoring, Cambridge University Press, Cambridge, 2000, p. 400. 
First, the relevant system and normative contents of international law were examined. Several reasons were found why international law is not susceptible to women's issues. The system of international law is focused on States and what States actually do, leaving hardly any room for examining the underlying societal backgrounds. As far as the contents of international law is concerned, there is a certain dichotomy between public and private spheres. This schism is experienced in human rights law as a division between civil and political rights on the 'public' side, which makes these rights stronger and more accessible for close examination at the international level, and economic, social and cultural rights on the 'private' or domestic side, which largely leave them to the State's discretion and narrow the space for effective international scrutiny. At the national level the dichotomy between public and private spheres is gendered with the result that men dominate the public sphere of politics and economy and that women's issues are relegated to the private sphere of the family with limited involvement by public authorities. The consequence of women's minimal participation in State and public affairs is that their influence on the shaping of international law is also small.

In spite of the shortcomings, it is nevertheless profitable to use the international legal system, particularly the human rights system, to further women's right to adequate housing. At the international level it is possible to lay down the core housing norms that are to be universally met, while the supervisory system may urge States to bide by these rules at the domestic level and, may offer in case of violations, means of recourse and redress.

In the last few decades, two strategies have been followed to put women's issues on the international agenda. The first entails the creation and promotion of women specific mechanisms and instruments. This has proved to be a good strategy because it draws attention to particular problems women are faced with and it may offer specific solutions. Yet, a major flaw is the risk that women's issues are left to these specific machineries which may result in marginalization. According to the gender mainstreaming method, gender is to be placed within pre-existing structures of all human rights organizations and programmes so that attention for and action on women's issues will be safeguarded. This method is gradually yielding results since gender 'neutral' organizations and mechanisms nowadays make an effort to include a women's perspective in their work. The major flaw of this approach is that women's affairs are in danger of being overlooked in the multitude of problems and issues these general organs are faced with. That is why the best results will be achieved when both methods are used simultaneously in a complementary manner.

The two principles that form the foundation of international human rights law, i.e. equality and non-discrimination were considered next. The basic tenet is that all people, notwithstanding their differences, are inherently equal and that nothing and nobody should for any reason deny or inhibit the realization and enjoyment of their human rights. Because of the very fundamental character of these principles it is imperative that their contents are very clear and that they should have the effect that women's human rights, including housing rights, are furthered. If the foundation is rocky it is improbable that rules that are built on them will yield the desired result.

The precise definition of gender equality and discrimination against women has proven to be problematic, however. It is in women's interest that equality is achieved 
both formal or de iure and substantive or de facto. Too often equality is only understood in the formal sense with the result that in theory women have the same rights as men, but in practice women are unable to effectuate them. De iure equality is indispensable since it is the legal foundation women can base their claims on, but it should be stressed that the ultimate goal is equality of result. In view of the prevalent disadvantaged socioeconomic position most women find themselves in equal result may entail that women and men are treated differently. It is even possible that in the interest of accelerating the achievement of equality between women and men temporary special measures are taken until the disparity between the two sexes has been overcome.

As far as sex as a distinguishing factor between women and men is concerned, a three-tiered approach may be discerned. Rules and regulations that treat women differently because of their reproductive capacity may be justified or even be warranted when they are in women's interest; hence such rules should not be defined as discrimination. This is the case when women experience an actual biological need of protection or special measures, e.g. in cases of pregnancy, child birth, menstruation and lactation.

However, also rules and regulations exist that are based on supposed physical differences between the two sexes. If women are in actual need of protection, such as maybe the case in respect of domestic violence, protective regulations are justified, but when women are generalized as a group this may result in over-protection which will constitute discrimination based on sex. For instance, women may be denied access to heavy or dangerous work because as a group of people they are presumed to be physically weak or potentially pregnant.

The most pervasive and most difficult form of discrimination against women is cloaked as societal rules of 'normal' behaviour. Worldwide prejudicial ideas about the ideal roles of women and men in society exist that are based on ascribed typical abilities or characteristics of women and men. Actual biological differences are used as a pretext to construct intricate behavioural rules that determine all aspects of women's and men's lives. These rules are not neutral, but time and again put women in a disadvantaged or subjugated position if compared to men. This type of discrimination should be called gender discrimination since it has nothing to do with sex, but is an artificial construction. It is of great importance for the fulfilment of women's human rights including housing that gender discrimination is recognized as such and that appropriate measures are taken to abolish it.

Study of the most pertinent international treaty provisions containing the principles of equality and non-discrimination has learnt that there is reason for moderate optimism. Although the concepts of sex and gender discrimination are still in need of much more detailed explanation and interpretation by the treaty bodies, there is a definite trend to acknowledge the harmful effect of stereotypical attitudes. Furthermore, there is acknowledgment that international scrutiny should extend to the private sphere since gendered constructions sit deep in the heart of family and community life. As far as the concept of equality is concerned, there seems to be an inclination towards accepting de facto equality as the ultimate goal that has to be achieved while de iure equality is regarded as the necessary stepping stone. Finally, temporary special measures appear to be generally accepted by the treaty bodies as adequate instruments to achieve substantive equality for 
women. It is imperative, however, that this understanding of equality is brought home to States parties and translated into concrete demands for measures and policies that remove the barriers that stand in women's way of fulfilling their housing rights to the same extent as men.

Despite its great importance, equality between the sexes is only one side of the coin since the principle does not guarantee that women are adequately housed. In the worst case scenario application of this principle will mean that women are housed equally bad as men or even that men's housing standard is lowered to women's level. That is why the focus should not exclusively be on equality, but also on the question to what extent the most important international housing norms are tailored to women's specific housing needs and situations. It seems that all of them fail in some way or other in this regard.

Article 11(1) ICESCR and its interpreting General Comments No. 4 and No. 7 lack precision as far as women's housing situation is concerned. Although the Comments make references to women's specific situation and impress upon States parties that women have an equal right to housing, they fail to take vital circumstances into account that determine women's housing situation. As a consequence, States parties do not receive sufficient guidance. They are insufficiently requested to look into and overcome those underlying barriers that make the fulfilment of women's housing rights so hard. Consequently, also the monitoring of women's housing situation is deficient.

The Women's Convention does not contain a comprehensive provision on housing rights since Article 14(2) only covers the housing rights of rural women while some housing elements may come up by way of other Articles in the Convention. Articles 5(e)(iii) ICERD, 27(3) CRC, and 43(1) ICMW have in common that they are formulated in a gender neutral way and that if the respective treaty bodies do not explicitly take a gender perspective into account starting with requesting sex-disaggregated data and questioning underlying gender determinants, those circumstances that determine girls' and women's housing rights in practice remain uncovered.

In States where women's de iure equality is legally assured, their de facto enjoyment of the right to equality is largely determined by societal rules of behaviour. Traditional patterns that ascribe women secondary roles in society and that deny them autonomy undermine their capacity to fend for themselves and to provide for their own housing. Culture, tradition and religion most of the time are treated as unchangeable and untouchable by authorities. In reality, however, cultural rules are continuously changing and States that have pledged themselves to achieve equality between women and men are held to abolish or alter them if their effect is to withhold women substantive equality. Several provisions contained in international human rights instruments require legal action to change public mentality and societal behaviour; this applies obviously, but not exclusively, to Article 5 of the Women's Convention. The obstacles that will be encountered in changing cultural patterns will be substantial, but various actors at different levels may help to overcome them.

Culture is an issue in the contesting human rights theories of universality and cultural diversity. According to the first theory every human being has inherent rights irrespective of sex, culture, or background. According to adherents of cultural diversity or relativism, the rights, or rather privileges are determined by the societal context. Since women and 
men are believed to have different roles in society, they cannot enjoy the same privileges. That is why according to this philosophy the goal is not to achieve equality between the sexes, but complementariness or equity. Concretely this will mean that women are not supposed to be providers or proprietors of real estate, but if they take on their attributed care-taking tasks, their male partner or male relatives will be responsible for providing them with adequate housing. This system may work satisfactorily for all parties as long as relationships are loving and respectful, but will fail miserably as soon as relationships turn violent or if for some reason the male benefactor ceases to look after the woman. States that are radical advocates of cultural relativism will hardly ever comply with universal human rights instruments. Other, less fundamental States may try to reconcile their international human rights obligations with their national interest to maintain peace and order by condoning personal law systems that are based on unequal power positions for men and women for certain cultural or religious groups. Sometimes they try to avoid their duty to intervene in such cultures by making reservations to Article 5 and/or 2 of the Women's Convention. Still, if they have ratified other human rights instruments, especially the ICCPR, this will not relieve them of their responsibility. A stance in favour of maintaining traditional rules consequently means a vote against women's equality; it is impossible to reconcile both at the same time.

At the international level several international agencies, such as UNESCO, UNICEF, UNDP, UNIFEM, WHO, and the ILO do their best to influence cultural patterns that are harmful for women by informing and educating people of the adverse effects. The role of CEDAW goes much further since States that are party to the Women's Convention have a legal obligation to eradicate gender discrimination. Therefore, the Committee may demand that at the national level States parties take both reactive and pro-active measures in order to combat, abolish and prevent cultural rules that work to the detriment of women's human rights. Other actors that play an important part are civil society organizations and individuals themselves. Although international organizations should remain in the background and restrict themselves to informing, financing, and facilitating, national grassroots organizations are in a position to influence public opinion by explaining human rights on the one hand and harmful effects of cultural rules on the other. In the end, it will come down to individual women and men to bring about an essential change by regarding each other as equals and by giving up privileges and sharing responsibilities. Mothers can make a virtue of their traditional task of raising the children by impressing upon the next generation that the sex of a person is never a justification for discrimination.

The fact that women's housing rights are mainly violated in the private or family sphere at the hands of private actors begs the question to what extent the existing rules of State responsibility are applicable. Since international law is focused on States and on State actions or omissions, the system of State responsibility is also primarily directed at situations where the State or its officials violate international obligations as regards other States. With the growing importance of human rights and humanitarian law it has been acknowledged that State responsibility also applies in situations where States violate the rights of their own citizens.

The violation of women's human rights, including their housing rights, however, mainly takes place in the privacy of the family, at the hands of intimates. The rules on State 
responsibility drafted by the ILC do not cover such situations, although human rights bodies generally accept that States are responsible when violations by non-State actors are widespread and structural and the State consistently fails to exercise due diligence to prevent these violations or when it falls short in investigating and punishing them. Because of the obvious disregard for women's reality, work on the rules of State responsibility should continue in order to bring home the point that the UN, as well as individual States take women's empowerment seriously and that all rules, including international law, should encompass a gender perspective.

As far as respecting, protecting, and fulfilling women's housing rights are concerned, detailed examples were given of how and when State responsibility as regards women's housing rights violations should be understood, both in cases where the perpetrator is the State itself and, as the case maybe, when the violations are inflicted by private parties. As a result of State responsibility several legal consequences will ensue. The most important of which are the obligations of cessation of the violation, assurances and guarantees of non-repetition and various forms of reparation that may be tailored to the seriousness and the nature of the violations and the gravity of the damage that has been inflicted. The preferred form of reparation is restitution which may entail that a woman is re-installed or enabled to return to her home or offered adequate alternative housing.

The last section of this chapter went into the possibilities different actors have as regards defining, interpreting and monitoring compliance with the rules pertaining to women's housing rights at the domestic level. Although some progress has been made, it cannot be maintained that a gender perspective is incorporated effectively in the work of these supervisory bodies. The treaty bodies' major fallacy is that they appear to assume that insights may be gained and solutions may be found by giving general, abstract, gender-neutral comments that in fact reflect platitudes rather than indicating women's specific needs and problems, and pinning down the fundamental cultural barriers that have a negative effect on women's socio-economic position.

CEDAW is hampered by the fact that the rights to housing and land are not comprehensively contained in the Women's Convention and up till now this Committee has not drafted a General Recommendation to overcome this defect. As a result, housing rights are dealt with haphazardly because it will depend more or less on chance whether the subject is raised. Until a General Recommendation has been adopted an interim solution may be to systematically request States parties to provide specific information on women's housing rights. Suggestions to this effect are included in this study. Depending on the complaints CEDAW may receive in future, the Committee may have a chance to further define the right to adequate housing based on concrete situations and to indicate in which cases States have violated this right. It would be helpful if the link between adequate housing and domestic violence would be acknowledged. While CEDAW has to wait and see what complaints may be filed, it can take up the issue of adequate housing actively by conducting inquiry procedures.

The CESCR has shown some tardiness in incorporating a gender perspective in its supervisory work. Although the situation is improving, especially since the adoption of General Comment No. 16, the Committee's efforts lack the required precision to pin point the underlying barriers that complicate the fulfilment of women's housing rights. 
The Committee could improve the situation by altering its Guiding Principles. Furthermore, it would seem logical that the two existing General Comments on Housing are supplemented by a specific comment on women's housing rights.

It is disappointing that after so many years of discussion the CESCR still does not have a petition procedure at its disposal. Reviewing concrete situations considerably enhance insights into the complex nature of women's disadvantaged socio-economic position and which hurdles have to be taken.

Other relevant treaty bodies, i.e. CERD, the CRC and the CMW may further the housing rights of certain groups of women if they make use of their supervisory potential in this regard. Up till now, however, these Committees have not been mindful of encompassing a gender perspective as regards the right to housing in their supervisory work.

Several of the UN Special Rapporteurs have a mandate that enables them to examine and comment on women's housing rights. The work done by the Special Rapporteur on adequate housing is obviously the most important. Because of the lack of a clear understanding how women are manoeuvred into a disadvantaged position and the complicated nature of women's housing rights that requires an indivisible human rights approach, and maybe even a multidisciplinary approach, it would be very useful if the mandate-holder would produce a successive series of reports that give a detailed overview of all aspects that influence a woman's ability to realize her housing rights from early childhood till old age.

Other Special Rapporteurs may shed their light on particular causes of women's disadvantaged situation or may tackle specific elements of women's housing rights.

Finally, civil society organizations also have an important role to play. Besides their own informing, educating, and supervising tasks at the domestic level, their vision and insights are of invaluable importance to UN monitoring bodies. Next to information provided by housing rights organizations, also the involvement of women's civil society organizations is to be welcomed.

Only if women's reality is fully taken into account can any headway be expected in fulfilling women's right to adequate housing. 


\section{Chapter V CONCLUSIONS AND RECOMMENDATIONS}

\subsection{Taking the Gender Perspective into Account}

If the realization of women's right to adequate housing is to be improved, it is unavoidable that gender is taken into consideration as a determining factor. However, there are some dangers attached to including gender in housing rights legislation, programmes and policies and it is therefore imperative that this is done with great care. First of all, because reacting on women's perspective, i.e. departing from a reality in which women are generally burdened with the majority of reproductive work and are on average poorer than men and less autonomous, bears the danger of perpetuating gender differences between women and men. Gender determinants have been so ingrained in people's brains that it is very hard to shake loose of them, and it is virtually impossible to be unbiased.

Furthermore, women are not a homogenous group, and e.g. women from the South or from certain religious denominations may not recognize themselves in the image or ideal of woman as it is perceived in the North. Still, I feel that not too much emphasis should be put on the differences among the women in the world, but that first of all the common ground should be covered and analysed so that a start can be made with finding solutions for those barriers that are encountered by women all over the world.

If women's right to adequate housing is to be fulfilled, the complex and indivisible relationship between this right and many other economic, social, political and civil human rights has to be taken into account. Special links exist with the principles of equality and non-discrimination, the right to a livelihood (employment), the right to land and property, the right to health and a safe environment, education, food, information, privacy and family life, security of the person, freedom of movement, including freedom to choose one's residence, and participation in public decision-making. The realization of women's right to housing is not merely a matter of legal rules and regulations, but is to a large extent determined by cultural and traditional patterns that unfavourably affect the implementation of legal norms on women's reality. States play a vital role in this regard since they are not only responsible for housing rights violations caused by their own actions and omissions, but they should also protect women from violations caused by private persons in the family and community sphere. In particular, cultural and traditional patterns that harm women's interests should be tackled by using all available means. When States fail to take adequate measures and women's right to housing is violated, especially when this happens on a large scale or in a structural manner, they may be held responsible for the consequences. Culture is susceptible to change, however, and States may use their influence to change it for the better. Other actors that may play their part are international agencies, CSOs both on the national and international plane, and women themselves. 
There are no easy solutions to this quandary, however, and it should be realized that any short-term solutions to women's housing situation are apt to be based on the existing gender inequality. Therefore, these solutions merely amount to treatment of the symptoms, but do not eradicate the root causes of inequality. It is possible to bring some (temporary) relief, at least to specifically targeted women, but when the gender inequality will remain intact, other groups of women, or a succeeding generation of women will yet again encounter the same barriers in fulfilling their housing rights.

Consequently, long-term solutions have to be rather drastic since women's substantive equality as regards housing rights cannot be attained if traditional patterns are safeguarded.

Long-term strategies will have to start with addressing the housing rights of the girl child. The way in which girls are raised, the importance attached to their virginity and chastity, the assumptions about their future role in society as adults, the protection and understanding they receive in abusive situations, the claims they have or will have in future to land, housing and possibly inheritance, and all kinds of other factors together determine whether they will succeed in realizing their housing rights as women. Starting from the beginning of women's life will open up the possibility to scrutinize customs and influence traditional practices like son preference and the gendered division of education and job training that lay the foundation for women's disadvantaged position where housing is concerned. Such in-depth examination is not only necessary in poor developing States, but also in wealthy industrialised States since the bias against women starts at an early age all over the world. Solutions must be found in a change of mentality and the authorities should actively campaign to achieve such a change by way of information and education. Moreover, legal measures should be taken, like compulsory yet free education for all children, a ban on negative stereotypes of girls and women in schoolbooks, advertising and the media, and the criminalization of female foeticide.

When girls enter marriage or another form of co-habitation, they may experience yet other impediments to exercise their housing rights. The occurrence of traditional practices such as patriarchy, female exogamy, polygamy, the male breadwinner model, the gendered division of work, especially unremunerated care-taking of children, the sick and the elderly, the disregard of the economic value of a housewife's contribution to the household, societal acceptance of a man's prerogative to discipline his wife, and other determinants will decide whether the married woman is adequately housed, will be able to leave an abusive household, and whether she can cope on her own if the marriage, or other form of co-habitation, ends in a separation, divorce or death.

Again, both sociological and legal methods should be used to achieve that women are empowered to procure adequate housing conditions.

Campaigns should be directed at picturing women as autonomous persons, equal in every aspect with men. A re-assessment of labour should take place and the gendered division of work must be abolished as much as possible. In any case, public opinion should be altered in such a way that care-taking work is regarded as the responsibility of both women and men. Legal measures may include the abolition of the male breadwinner prerogatives and discriminatory laws as regards marital property and divorce, regulation 
of co-ownership or other property rights of land and housing for couples, and the criminalization of domestic violence.

Short-term solutions should concentrate on specific groups of women whose housing situation is particularly inadequate and who need help to improve their housing circumstances. First, those particular housing situations should be tackled that may be found all over the world, irrespective of wealth or level of development.

Taking into consideration that a substantive part of the world's women live in temporary housing situations, sometimes for an extended period of time, it is warranted that the adequacy of such refuges is specifically under scrutiny. Women living in squatter camps, homeless shelters either general or specifically for battered women, refugee or IDP camps and centres for asylum seekers, should at the very least be provided with the most basic elements of the right to housing. In any case, their safety should be guaranteed both against external threats and from people who share the temporary housing with them. Security of tenure should be offered in the sense that they may stay in temporary housing until another satisfactory solution has been found. Basic facilities should be available and any discrimination between women and men as regards benefits, the distribution of food-parcels, water or other supplies must be avoided. Women's privacy should be respected as much as possible and they should be able to remain together with their family, especially with all their children. Furthermore, it is important that these women participate in any decision-making pertaining to the temporary shelter.

At the moment it is estimated that on average $30 \%$ of the households in the world are headed by a woman and that this number is growing. Because of the various socioeconomic disadvantages experienced by women, female heads of household have a very hard time acquiring and maintaining adequate housing for themselves and their dependents. Especially women who have had no or little education or job-training and belong to the poorest segment of society, need help in order to become economically independent, while women who have care-taking responsibilities for children, sick or elderly persons, need assistance in order to be able to combine this care-taking work with remunerated labour. Creative solutions must be found because it is in these women's, their dependents' and the State's interest that female heads become self-sufficient. For those women who are educated or who have learned a profession it may be enough that they receive an equal opportunity to enter the labour market, that they receive equal remuneration for work of equal value, that they get equal access to credit and loans, and that day-care facilities exist in abundance and are free or cheap.

For others, whose outlook to find a job that would earn them enough income to afford adequate housing is bleak, positive action is needed in the form of a combination of measures. For example, they and their charges may be fed and housed in special working women's hostels where day-care facilities for their children or other dependents are available and where they can follow education, especially in the form of job training. Furthermore, for those women who wish to set up their own business, microcredits should be available and advice should be offered. Of course, such measures will cost money, but it will be paid back many times over since these women will no longer be a burden of society, but they will contribute to it, while their children will get a chance 
to education and a better life and in their turn will contribute to society and development rather than burden it.

When the housing rights of large groups of women as mentioned above have been secured, the housing situation of specific groups should be targeted. For instance, proposals should be made to improve the housing situation of women who face double discrimination because of their race, ethnicity, disability, or religion.

An example of a practice at the regional level, especially in some States in Asia and Africa, which should be dealt with, is the housing rights of widows. Traditional beliefs and practices like taboos, widow cleansing rituals, female exogamy, levirate, and polygamy may render the widow's housing situation inadequate or even result in her becoming homeless. Eradication of beliefs that put a woman's life in the service of her husband, that make her morally responsible for her husband's death and that regard her as a commodity that is part of her husband's estate, is to be the first priority. In addition, discriminatory legal rules as regards the inheritance have to go and it should be guaranteed that dispossessed widows have access to justice.

In conclusion, it may be said that taking a gender perspective into account will entail a process that encompasses legal measures, but also other methods and strategies. Solutions can only be found if women's housing rights are considered in a holistic way and the help of disciplines like sociology and anthropology is indispensable in this process. Of course, the legal foundation with respect to equal rights for women should be sound, since women's empowerment depends on their ability to have recourse to the legal system.

\section{2}

\section{EXISTING LEGAL NORMS}

It has become evident, that especially at the national level certain norms will have to be abolished before women stand a chance of fulfilling their housing rights. Some norms may seem to be gender neutral at face value, but may discriminate against women in indirect ways in practice or may fail to encompass women specific circumstances. Moreover, some discriminatory practices may as yet have escaped legal attention but their coverage by legal rules is indispensable for women's empowerment. First, attention will be paid to those norms that must be eradicated because they put women in an unfavourable position.

Obviously, legal rules and regulations that deny girls and women human rights or discriminate against them so that they are hampered in acquiring or retaining adequate housing should be abolished. Norms that fall within this category are rules that deny (married) women the right to property, that ban women from participating in public life and public decision-making, that deny girls access to (certain types of) schooling or job training, that deny women the right to (some kinds of) employment, or that deny them a share in the inheritance or award them a much lesser part than their male counterparts.

Existing personal law systems should also be dealt with, since these constructions create injustice and inequality within the population. While the national constitution and other acts may be in line with international norms as regards equality and non-discrimination, at the same time ethnic or religious groups are allowed to retain discriminatory rules in family and community that seriously impede women in fulfilling their housing 
rights. Since it is an illusion that women belonging to such ethnic or religious groups can exercise their free choice, and may leave the group if they feel discriminated against, it is the authorities who should stand up to the leaders of such groups and demand adherence to national and international human rights standards by all segments of the population.

Although abolition of discriminatory national rules and regulations is undoubtedly in the interest of women's housing rights, it is to be expected that attempts will meet with much resistance. Some groups have a vested interest in retaining the status quo. Equal rights of women and men entail sharing (scarce) resources and thus reducing the shares of those who are now privileged. New methods of dividing land and property must be created to replace existing systems which means disrupting age-old traditional systems. That is why, societies must be persuaded from the inside to bring about a change. Outside help should be restricted to information and human rights education. If societies themselves are not convinced of the advantages of empowering women, outside interference may have the counterproductive result of entrenchment in traditional customs.

\subsubsection{Feminizing Existing Standards}

Many standards, both at the national and the international level reflect societal realities as they existed several decades ago, or are gender neutral at face value, but in practice disadvantage women and put up barriers as regards women's fulfilment of their housing rights.

Modifying such rules in order to make them take women's perspective into account takes a lot of caution since, as has been mentioned above, there is a certain danger that existing discriminatory patterns are perpetuated. Still, if the only possible short-term solution to improve women's housing situation is to alleviate typically gendered circumstances that are based on inequality between women and men, sometimes pragmatic decisions should be made. At least, the situation of some women is improved, and as long as the existing inequality is kept in mind, more structural solutions may be achieved in the long run. Thus, if for example, female ownership still is a bridge too far, an option for co-ownership is the best result that may be achieved at a certain point in time. If domestic violence is not accepted as a separate crime, inclusion of wife battering in the definition of assault is a step in the right direction. When eviction of male perpetrators in cases of domestic violence is still unthinkable, at least legislation should be passed that provides for adequate temporary housing where female victims can find accommodation. As long as female heads of household are in general less capable of securing adequate housing for themselves and their offspring, adaptation of existing rules in order to give priority to such households when housing subsidies are distributed is a fair solution.

Modification, like temporary special measures is necessary as a stopgap until society is organized in such a way that women are equally equipped to fulfil their housing rights because the basic conditions for women and men in respect of resources and responsibilities have become equal. 


\subsubsection{Developing New Norms}

It is important that new housing rights norms are developed, both at the national and the international level, which are based on the explicit notion that both women and men have an autonomous right to adequate housing. At the moment too many women are unable to choose where and how they are housed because they depend on male partners or relatives to determine their housing conditions. This dependence is caused for a large part by the unfavourable socio-economic position many women find themselves in which has the effect that they cannot afford adequate housing by themselves, but it is also created by gendered traditional societal rules and customs that regard housing as a right of families, and reject the idea of individual women claiming housing for themselves.

Especially on the international human rights level, an example should be set by adopting new housing norms that incorporate existing realities both for women and men, but at the same time make it clear that current inequalities and discriminatory patterns should be eradicated. Thus, typical causes of homelessness and inadequate housing for women like domestic violence, eviction by intimates, and widowhood, should be taken into account, but the underlying patterns of socio-economic inequality of women should be analysed and condemned as well. The same is true for gender specific consequences of homelessness and inadequate housing. Up till now, norms have been formulated in a gender neutral way, which ignore the fact that it is much harder for women than for men to cope with homelessness and inadequate housing. While attention should be paid to these differences, simultaneously it should be recognized that such discrepancies stem from culturally determined views on women's sexuality and the gendered division of work which burdens women with household chores irrespective of the circumstances.

Particularly, a new General Comment on adequate housing, incorporating women's perspective by the CESCR, and a General Recommendation on women's rights to land and housing by CEDAW, would be helpful for the further clarification, interpretation and implementation of the right to adequate housing.

Since inequality and discrimination lie at the heart of most violations of women's human rights, including their housing rights, it is important that CEDAW as the most authoritative (quasi) legal body specialized in women's rights, adopts a General Recommendation clarifying the concepts of gender, sex, direct and indirect discrimination, and formal and substantive equality, so that States, international human rights bodies and relevant non-State actors may use and apply the Committee's interpretations in their regulatory and monitoring work.

At the national level it is vital that existing unwillingness of the judiciary and public administration to implement gender equality as regards housing rights should be overcome and that legal remedies should be devised that have low thresholds both in respect of easy access and as regards financial implications.

\subsection{MONITORING Potential}

It has been shown in this study that there is great potential for monitoring women's right to adequate housing both by United Nations organs and bodies, and by national and 
international CSOs. The concept of monitoring is used in a broad sense, encompassing in-depth studies on housing needs and problems, critical reflections on how housing rights are to be interpreted and implemented, exposing housing rights violations, and making suggestions and recommendations for improvement.

Within the human rights framework of the United Nations, various organs, committees, and mandate-holders have the opportunity to contribute to a better understanding and actual improvement of women's housing rights. Because of the indivisibility of all human rights and the complexity involved with gender issues, it is possible to approach housing from different perspectives that in fact complement one another.

Several monitoring bodies may broaden and enhance their influence on women's housing rights. The right to adequate housing is first and foremost the expertise of the CESCR and it is imperative that this Committee not only focuses on technical and material aspects of housing, but also encompasses a gender side to its housing rights assessment. Particularly, immaterial elements, such as safety, dignity, privacy and autonomy need to be fulfilled before housing can be called adequate from a woman's point of view.

CEDAW should seize the possibility to monitor issues concerning rights to land and housing in a general manner, and not restrict itself to the situation of rural women. In particular, the implementation of Articles 2, 5 and 16 of the Women's Convention will determine whether women will be successful in fulfilling their housing rights or whether they find legal and societal obstructions on their way.

Treaty bodies like CERD, the CRC and the CMW that already monitor housing rights in specific circumstances all have the possibility to include gender aspects in their examinations.

Especially, the individual complaints procedure may prove to be a valuable tool in pinpointing barriers and problems women will encounter and in determining how exactly their rights are violated. It is therefore of the highest importance that the CESCR also disposes of this important mechanism.

Various Special Rapporteurs and Special Representatives are in a position in which they can promote and advance women's housing rights. Of course, the Special Rapporteur on adequate housing already is engaged in the examination and promotion of women's housing rights. Since he has already mapped out the situation of women's housing rights in general, it would be advisable to concentrate on particular aspects of it in his specific reports on women's housing. It would be most beneficial if he would conduct in-depth studies on the specific obstacles women have to face such as the influence of marriage on property rights, and discriminatory practices like son preference and female exogamy.

Another mandate-holder that may play an important role is the Special Rapporteur on violence against women. Violence against women is not restricted to civil and political rights, but extends to social and economic rights. The disadvantaged socio-economic position of women makes them susceptible to violence, while one of the consequences of gender specific violence is that it diminishes or annihilates women's enjoyment of their socio-economic rights such as housing.

In assessments of violence in the domestic sphere, it should therefore be pointed out that in addition to women's right to physical integrity also their housing rights are in- 
fringed since the adequacy of any housing situation is nullified in situations of domestic violence.

Because the main cause of women's disadvantaged position with respect to securing and maintaining adequate housing is to be found in traditional practices and gender stereotypes, it is desirable that an independent expert would be entrusted with a broad mandate to investigate and monitor the existence of practices, beliefs and customs that are harmful to the realization of women's human rights in general and their housing rights in particular. The mandate of the expert who had been appointed by the UN Sub-Commission was restricted to studying and reporting on harmful practices and her work was mainly focused on female genital mutilation. It is necessary, however, that a Special Rapporteur is appointed whose mandate also encompasses conducting fact-finding missions, providing advice, responding to individual complaints, and engaging in promotional activities.

The mandate-holders involved with issues concerning migrant workers, refugees and IDPs, may also contribute to improving women's (temporary) housing situation by taking a gender perspective into account. There is particularly much room for improvement as far as the safety of temporary housing conditions are concerned.

In addition to monitoring and analysis taking place in the framework of the UN, an important role can be played by national and international civil society organizations. Civil society organizations play their own indispensable part in the monitoring process. At the national level they may influence public opinion, provide information and education on housing rights and supervise the implementation of international obligations. International civil society organizations may also monitor implementation and they are best equipped to form a bridge between populations and international monitoring organs which they may provide with information pertaining to national implementation and whose attention they may draw to violations.

\section{$5.4 \quad$ FiNAL REMARKS}

From this study it has become clear, that as far as the right to adequate housing is concerned, gender makes a considerable difference. Although specific attention for women is warranted, it should be borne in mind that they are not per se a vulnerable group. They are not so much in need of protection, but of empowerment. Women's right to adequate housing already exists. What needs to be done is getting rid of all the impediments caused by cultural and traditional views and discriminatory laws and practices that stand between women and their housing rights. 


\author{
COMMITTEe ON ECONOMIC, SOCIAL AND Cultural RightS \\ General COMMENT No. 3
}

AnNeX 1

The Nature of States Parties Obligations (Art. 2, par. 1): 14/12/90

1. Article 2 is of particular importance to a full understanding of the Covenant and must be seen as having a dynamic relationship with all of the other provisions of the Covenant. It describes the nature of the general legal obligations undertaken by States parties to the Covenant. Those obligations include both what may be termed (following the work of the International Law Commission) obligations of conduct and obligations of result. While great emphasis has sometimes been placed on the difference between the formulations used in this provision and that contained in the equivalent Article 2 of the International Covenant on Civil and Political Rights, it is not always recognized that there are also significant similarities. In particular, while the Covenant provides for progressive realization and acknowledges the constraints due to the limits of available resources, it also imposes various obligations which are of immediate effect. Of these, two are of particular importance in understanding the precise nature of States parties obligations. One of these, which is dealt with in a separate general comment, and which is to be considered by the Committee at its sixth session, is the 'undertaking to guarantee' that relevant rights 'will be exercised without discrimination ...'.

2. The other is the undertaking in Article 2(1) 'to take steps', which in itself, is not qualified or limited by other considerations. The full meaning of the phrase can also be gauged by noting some of the different language versions. In English the undertaking is 'to take steps', in French it is 'to act' ('s'engage à agir') and in Spanish it is 'to adopt measures' ('a adoptar medidas'). Thus while the full realization of the relevant rights may be achieved progressively, steps towards that goal must be taken within a reasonably short time after the Covenant's entry into force for the States concerned. Such steps should be deliberate, concrete and targeted as clearly as possible towards meeting the obligations recognized in the Covenant.

3. The means which should be used in order to satisfy the obligation to take steps are stated in Article 2(1) to be 'all appropriate means, including particularly the adoption of legislative measures'. The Committee recognizes that in many instances legislation is highly desirable and in some cases may even be indispensable. For example, it may be difficult to combat discrimination effectively in the absence of a sound legislative foundation for the necessary measures. In fields such as health, the protection of children and mothers, and education, as well as in respect of the matters dealt with in Articles 6 to 9, legislation may also be an indispensable element for many purposes.

4. The Committee notes that States parties have generally been conscientious in detailing at least some of the legislative measures that they have taken in this regard. It wishes to emphasize, however, that the adoption of legislative measures, as specifically foreseen by the Covenant, is by no means exhaustive of the obligations of States parties. Rather, the phrase 'by all appropriate means' must be given its full and natural meaning. While each State party 
must decide for itself which means are the most appropriate under the circumstances with respect to each of the rights, the 'appropriateness' of the means chosen will not always be self-evident. It is therefore desirable that States parties' reports should indicate not only the measures that have been taken but also the basis on which they are considered to be the most 'appropriate' under the circumstances. However, the ultimate determination as to whether all appropriate measures have been taken remains one for the Committee to make.

5. Among the measures which might be considered appropriate, in addition to legislation, is the provision of judicial remedies with respect to rights which may, in accordance with the national legal system, be considered justiciable. The Committee notes, for example, that the enjoyment of the rights recognized, without discrimination, will often be appropriately promoted, in part, through the provision of judicial or other effective remedies. Indeed, those States parties which are also parties to the International Covenant on Civil and Political Rights are already obligated (by virtue of Arts. 2 (paras 1 and 3), 3 and 26) of that Covenant to ensure that any person whose rights or freedoms (including the right to equality and nondiscrimination) recognized in that Covenant are violated, 'shall have an effective remedy' (Art. 2(3)(a)). In addition, there are a number of other provisions in the International Covenant on Economic, Social and Cultural Rights, including Articles 3, 7(a)(i), 8, 10(3), 13(2)(a), (3) and (4) and 15(3) which would seem to be capable of immediate application by judicial and other organs in many national legal systems. Any suggestion that the provisions indicated are inherently non-self-executing would seem to be difficult to sustain.

6. Where specific policies aimed directly at the realization of the rights recognized in the Covenant have been adopted in legislative form, the Committee would wish to be informed, inter alia, as to whether such laws create any right of action on behalf of individuals or groups who feel that their rights are not being fully realized. In cases where constitutional recognition has been accorded to specific economic, social and cultural rights, or where the provisions of the Covenant have been incorporated directly into national law, the Committee would wish to receive information as to the extent to which these rights are considered to be justiciable (i.e. able to be invoked before the courts). The Committee would also wish to receive specific information as to any instances in which existing constitutional provisions relating to economic, social and cultural rights have been weakened or significantly changed.

7. Other measures which may also be considered 'appropriate' for the purposes of Article 2(1) include, but are not limited to, administrative, financial, educational and social measures.

8. The Committee notes that the undertaking 'to take steps ... by all appropriate means including particularly the adoption of legislative measures' neither requires nor precludes any particular form of government or economic system being used as the vehicle for the steps in question, provided only that it is democratic and that all human rights are thereby respected. Thus, in terms of political and economic systems the Covenant is neutral and its principles cannot accurately be described as being predicated exclusively upon the need for, or the desirability of a socialist or a capitalist system, or a mixed, centrally planned, or laisser-faire economy, or upon any other particular approach. In this regard, the Committee reaffirms that the rights recognized in the Covenant are susceptible of realization within the context of a wide variety of economic and political systems, provided only that the interdependence and indivisibility of the two sets of human rights, as affirmed inter alia in the preamble to the Covenant, is recognized and reflected in the system in question. The Committee also notes the relevance in this regard of other human rights and in particular the right to development.

9. The principal obligation of result reflected in Article 2(1) is to take steps 'with a view to achieving progressively the full realization of the rights recognized' in the Covenant. The 
term 'progressive realization' is often used to describe the intent of this phrase. The concept of progressive realization constitutes a recognition of the fact that full realization of all economic, social and cultural rights will generally not be able to be achieved in a short period of time. In this sense the obligation differs significantly from that contained in Article 2 of the International Covenant on Civil and Political Rights which embodies an immediate obligation to respect and ensure all of the relevant rights. Nevertheless, the fact that realization over time, or in other words progressively, is foreseen under the Covenant should not be misinterpreted as depriving the obligation of all meaningful content. It is on the one hand a necessary flexibility device, reflecting the realities of the real world and the difficulties involved for any country in ensuring full realization of economic, social and cultural rights. On the other hand, the phrase must be read in the light of the overall objective, indeed the raison d'être, of the Covenant which is to establish clear obligations for States parties in respect of the full realization of the rights in question. It thus imposes an obligation to move as expeditiously and effectively as possible towards that goal. Moreover, any deliberately retrogressive measures in that regard would require the most careful consideration and would need to be fully justified by reference to the totality of the rights provided for in the Covenant and in the context of the full use of the maximum available resources.

10. On the basis of the extensive experience gained by the Committee, as well as by the body that preceded it, over a period of more than a decade of examining States parties' reports the Committee is of the view that a minimum core obligation to ensure the satisfaction of, at the very least, minimum essential levels of each of the rights is incumbent upon every State party. Thus, for example, a State party in which any significant number of individuals is deprived of essential foodstuffs, of essential primary health care, of basic shelter and housing, or of the most basic forms of education is, prima facie, failing to discharge its obligations under the Covenant. If the Covenant were to be read in such a way as not to establish such a minimum core obligation, it would be largely deprived of its raison d'être. By the same token, it must be noted that any assessment as to whether a State has discharged its minimum core obligation must also take account of resource constraints applying within the country concerned. Article 2(1) obligates each State party to take the necessary steps 'to the maximum of its available resources'. In order for a State party to be able to attribute its failure to meet at least its minimum core obligations to a lack of available resources it must demonstrate that every effort has been made to use all resources that are at its disposition in an effort to satisfy, as a matter of priority, those minimum obligations.

11. The Committee wishes to emphasize, however, that even where the available resources are demonstrably inadequate, the obligation remains for a State party to strive to ensure the widest possible enjoyment of the relevant rights under the prevailing circumstances. Moreover, the obligations to monitor the extent of the realization, or more especially of the nonrealization, of economic, social and cultural rights, and to devise strategies and programmes for their promotion, are not in any way eliminated as a result of resource constraints. The Committee has already dealt with these issues in its General Comment 1 (1989).

12. Similarly, the Committee underlines the fact that even in times of severe resources constraints whether caused by a process of adjustment, of economic recession, or by other factors the vulnerable members of society can and indeed must be protected by the adoption of relatively low-cost targeted programmes. In support of this approach the Committee takes note of the analysis prepared by UNICEF entitled 'Adjustment with a human face: protecting the vulnerable and promoting growth, 1 / the analysis by UNDP in its Human Development Report 1990 2/ and the analysis by the World Bank in the World Development Report 1990 3/. 
13. A final element of Article 2(1), to which attention must be drawn, is that the undertaking given by all States parties is 'to take steps, individually and through international assistance and cooperation, especially economic and technical ...'. The Committee notes that the phrase 'to the maximum of its available resources' was intended by the drafters of the Covenant to refer to both the resources existing within a State and those available from the international community through international cooperation and assistance. Moreover, the essential role of such cooperation in facilitating the full realization of the relevant rights is further underlined by the specific provisions contained in Articles 11, 15, 22 and 23. With respect to Article 22 the Committee has already drawn attention, in General Comment 2 (1990), to some of the opportunities and responsibilities that exist in relation to international cooperation. Article 23 also specifically identifies 'the furnishing of technical assistance' as well as other activities, as being among the means of 'international action for the achievement of the rights recognized ...'.

14. The Committee wishes to emphasize that in accordance with Articles 55 and 56 of the Charter of the United Nations, with well-established principles of international law, and with the provisions of the Covenant itself, international cooperation for development and thus for the realization of economic, social and cultural rights is an obligation of all States. It is particularly incumbent upon those States which are in a position to assist others in this regard. The Committee notes in particular the importance of the Declaration on the Right to Development adopted by the General Assembly in its resolution 41/128 of 4 December 1986 and the need for States parties to take full account of all of the principles recognized therein. It emphasizes that, in the absence of an active programme of international assistance and cooperation on the part of all those States that are in a position to undertake one, the full realization of economic, social and cultural rights will remain an unfulfilled aspiration in many countries. In this respect, the Committee also recalls the terms of its General Comment 2 (1990).

\section{Notes}

1/ G.A. Cornia, R. Jolly and F. Stewart, eds., Oxford, Clarendon Press, 1987.

2/ Oxford, Oxford University Press, 1990.

3/ Oxford, Oxford University Press, 1990. 


\section{COMMITTEe ON ECONOMIC, Social AND Cultural Rights General Comment No. 4}

ANNEX 2

The Right to Adequate Housing (Art.11 (1)): 13/12/91

1. Pursuant to Article 11(1) of the Covenant, States parties 'recognize the right of everyone to an adequate standard of living for himself and his family, including adequate food, clothing and housing, and to the continuous improvement of living conditions'. The human right to adequate housing, which is thus derived from the right to an adequate standard of living, is of central importance for the enjoyment of all economic, social and cultural rights.

2. The Committee has been able to accumulate a large amount of information pertaining to this right. Since 1979, the Committee and its predecessors have examined 75 reports dealing with the right to adequate housing. The Committee has also devoted a day of general discussion to the issue at each of its third (see E/1989/22, para. 312) and fourth sessions (E/ 1990/23, paras 281-285). In addition, the Committee has taken careful note of information generated by the International Year of Shelter for the Homeless (1987) including the Global Strategy for Shelter to the Year 2000 adopted by the General Assembly in its resolution 42/191 of 11 December 1987 1/. The Committee has also reviewed relevant reports and other documentation of the Commission on Human Rights and the Sub-Commission on Prevention of Discrimination and Protection of Minorities 2/.

3. Although a wide variety of international instruments address the different dimensions of the right to adequate housing 3/ Article 11(1) of the Covenant is the most comprehensive and perhaps the most important of the relevant provisions.

4. Despite the fact that the international community has frequently reaffirmed the importance of full respect for the right to adequate housing, there remains a disturbingly large gap between the standards set in Article 11(1) of the Covenant and the situation prevailing in many parts of the world. While the problems are often particularly acute in some developing countries which confront major resource and other constraints, the Committee observes that significant problems of homelessness and inadequate housing also exist in some of the most economically developed societies. The United Nations estimates that there are over 100 million persons homeless worldwide and over 1 billion inadequately housed $4 /$. There is no indication that this number is decreasing. It seems clear that no State party is free of significant problems of one kind or another in relation to the right to housing.

5. In some instances, the reports of States parties examined by the Committee have acknowledged and described difficulties in ensuring the right to adequate housing. For the most part, however, the information provided has been insufficient to enable the Committee to obtain an adequate picture of the situation prevailing in the State concerned. This General Comment thus aims to identify some of the principal issues which the Committee considers to be important in relation to this right. 
6. The right to adequate housing applies to everyone. While the reference to 'himself and his family' reflects assumptions as to gender roles and economic activity patterns commonly accepted in 1966 when the Covenant was adopted, the phrase cannot be read today as implying any limitations upon the applicability of the right to individuals or to female-headed households or other such groups. Thus, the concept of 'family' must be understood in a wide sense. Further, individuals, as well as families, are entitled to adequate housing regardless of age, economic status, group or other affiliation or status and other such factors. In particular, enjoyment of this right must, in accordance with Article 2(2) of the Covenant, not be subject to any form of discrimination.

7. In the Committee's view, the right to housing should not be interpreted in a narrow or restrictive sense which equates it with, for example, the shelter provided by merely having a roof over one's head or views shelter exclusively as a commodity. Rather it should be seen as the right to live somewhere in security, peace and dignity. This is appropriate for at least two reasons. In the first place, the right to housing is integrally linked to other human rights and to the fundamental principles upon which the Covenant is premised. This 'the inherent dignity of the human person' from which the rights in the Covenant are said to derive requires that the term 'housing' be interpreted so as to take account of a variety of other considerations, most importantly that the right to housing should be ensured to all persons irrespective of income or access to economic resources. Secondly, the reference in Article 11(1) must be read as referring not just to housing but to adequate housing. As both the Commission on Human Settlements and the Global Strategy for Shelter to the Year 2000 have stated: 'Adequate shelter means ... adequate privacy, adequate space, adequate security, adequate lighting and ventilation, adequate basic infrastructure and adequate location with regard to work and basic facilities - all at a reasonable cost'.

8. Thus the concept of adequacy is particularly significant in relation to the right to housing since it serves to underline a number of factors which must be taken into account in determining whether particular forms of shelter can be considered to constitute 'adequate housing' for the purposes of the Covenant. While adequacy is determined in part by social, economic, cultural, climatic, ecological and other factors, the Committee believes that it is nevertheless possible to identify certain aspects of the right that must be taken into account for this purpose in any particular context. They include the following: (a) Legal security of tenure. Tenure takes a variety of forms, including rental (public and private) accommodation, cooperative housing, lease, owner-occupation, emergency housing and informal settlements, including occupation of land or property. Notwithstanding the type of tenure, all persons should possess a degree of security of tenure which guarantees legal protection against forced eviction, harassment and other threats. States parties should consequently take immediate measures aimed at conferring legal security of tenure upon those persons and households currently lacking such protection, in genuine consultation with affected persons and groups. (b) Availability of services, materials, facilities and infrastructure. An adequate house must contain certain facilities essential for health, security, comfort and nutrition. All beneficiaries of the right to adequate housing should have sustainable access to natural and common resources, safe drinking water, energy for cooking, heating and lighting, sanitation and washing facilities, means of food storage, refuse disposal, site drainage and emergency services. (c) Affordability. Personal or household financial costs associated with housing should be at such a level that the attainment and satisfaction of other basic needs are not threatened or compromised. Steps should be taken by States parties to ensure that the percentage of housingrelated costs is, in general, commensurate with income levels. States parties should establish 
housing subsidies for those unable to obtain affordable housing, as well as forms and levels of housing finance which adequately reflect housing needs. In accordance with the principle of affordability, tenants should be protected by appropriate means against unreasonable rent levels or rent increases. In societies where natural materials constitute the chief sources of building materials for housing, steps should be taken by States parties to ensure the availability of such materials. (d) Habitability. Adequate housing must be habitable, in terms of providing the inhabitants with adequate space and protecting them from cold, damp, heat, rain, wind or other threats to health, structural hazards, and disease vectors. The physical safety of occupants must be guaranteed as well. The Committee encourages States parties to comprehensively apply the Health Principles of Housing 5/ prepared by WHO which view housing as the environmental factor most frequently associated with conditions for disease in epidemiological analyses; i.e. inadequate and deficient housing and living conditions are invariably associated with higher mortality and morbidity rates. (e) Accessibility. Adequate housing must be accessible to those entitled to it. Disadvantaged groups must be accorded full and sustainable access to adequate housing resources. Thus, such disadvantaged groups as the elderly, children, the physically disabled, the terminally ill, HIV-positive individuals, persons with persistent medical problems, the mentally ill, victims of natural disasters, people living in disaster-prone areas and other groups should be ensured some degree of priority consideration in the housing sphere. Both housing law and policy should take fully into account the special housing needs of these groups. Within many States parties increasing access to land by landless or impoverished segments of the society should constitute a central policy goal. Discernible governmental obligations need to be developed aiming to substantiate the right of all to a secure place to live in peace and dignity, including access to land as an entitlement. (f) Location. Adequate housing must be in a location which allows access to employment options, health-care services, schools, child-care centres and other social facilities. This is true both in large cities and in rural areas where the temporal and financial costs of getting to and from the place of work can place excessive demands upon the budgets of poor households. Similarly, housing should not be built on polluted sites nor in immediate proximity to pollution sources that threaten the right to health of the inhabitants. (g) Cultural adequacy. The way housing is constructed, the building materials used and the policies supporting these must appropriately enable the expression of cultural identity and diversity of housing. Activities geared towards development or modernization in the housing sphere should ensure that the cultural dimensions of housing are not sacrificed, and that, inter alia, modern technological facilities, as appropriate are also ensured.

9. As noted above, the right to adequate housing cannot be viewed in isolation from other human rights contained in the two International Covenants and other applicable international instruments. Reference has already been made in this regard to the concept of human dignity and the principle of non-discrimination. In addition, the full enjoyment of other rights - such as the right to freedom of expression, the right to freedom of association (such as for tenants and other community-based groups), the right to freedom of residence and the right to participate in public decision-making - is indispensable if the right to adequate housing is to be realized and maintained by all groups in society. Similarly, the right not to be subjected to arbitrary or unlawful interference with one's privacy, family, home or correspondence constitutes a very important dimension in defining the right to adequate housing.

10. Regardless of the state of development of any country, there are certain steps which must be taken immediately. As recognized in the Global Strategy for Shelter and in other international analyses, many of the measures required to promote the right to housing would only 
require the abstention by the Government from certain practices and a commitment to facilitating 'self-help' by affected groups. To the extent that any such steps are considered to be beyond the maximum resources available to a State party, it is appropriate that a request be made as soon as possible for international cooperation in accordance with Articles 11(1), 22 and 23 of the Covenant, and that the Committee be informed thereof.

11. States parties must give due priority to those social groups living in unfavourable conditions by giving them particular consideration. Policies and legislation should correspondingly not be designed to benefit already advantaged social groups at the expense of others. The Committee is aware that external factors can affect the right to a continuous improvement of living conditions, and that in many States parties overall living conditions declined during the 1980s. However, as noted by the Committee in its General Comment 2 (1990) (E/1990/23, annex III), despite externally caused problems, the obligations under the Covenant continue to apply and are perhaps even more pertinent during times of economic contraction. It would thus appear to the Committee that a general decline in living and housing conditions, directly attributable to policy and legislative decisions by States parties, and in the absence of accompanying compensatory measures, would be inconsistent with the obligations under the Covenant. 12. While the most appropriate means of achieving the full realization of the right to adequate housing will inevitably vary significantly from one State party to another, the Covenant clearly requires that each State party take whatever steps are necessary for that purpose. This will almost invariably require the adoption of a national housing strategy which, as stated in paragraph 32 of the Global Strategy for Shelter, 'defines the objectives for the development of shelter conditions, identifies the resources available to meet these goals and the most costeffective way of using them and sets out the responsibilities and time-frame for the implementation of the necessary measures'. Both for reasons of relevance and effectiveness, as well as in order to ensure respect for other human rights, such a strategy should reflect extensive genuine consultation with, and participation by, all of those affected, including the homeless, the inadequately housed and their representatives. Furthermore, steps should be taken to ensure coordination between ministries and regional and local authorities in order to reconcile related policies (economics, agriculture, environment, energy, etc.) with the obligations under Article 11 of the Covenant.

13. Effective monitoring of the situation with respect to housing is another obligation of immediate effect. For a State party to satisfy its obligations under Article 11(1) it must demonstrate, inter alia, that it has taken whatever steps are necessary, either alone or on the basis of international cooperation, to ascertain the full extent of homelessness and inadequate housing within its jurisdiction. In this regard, the revised general guideines regarding the form and contents of reports adopted by the Committee (E/C.12/1991/1) emphasize the need to 'provide detailed information about those groups within ... society that are vulnerable and disadvantaged with regard to housing'. They include, in particular, homeless persons and families, those inadequately housed and without ready access to basic amenities, those living in 'illegal' settlements, those subject to forced evictions and low-income groups.

14. Measures designed to satisfy a State party's obligations in respect of the right to adequate housing may reflect whatever mix of public and private sector measures considered appropriate. While in some States public financing of housing might most usefully be spent on direct construction of new housing, in most cases, experience has shown the inability of Governments to fully satisfy housing deficits with publicly built housing. The promotion by States parties of 'enabling strategies', combined with a full commitment to obligations under the right to adequate housing, should thus be encouraged. In essence, the obligation is to demon- 
strate that, in aggregate, the measures being taken are sufficient to realize the right for every individual in the shortest possible time in accordance with the maximum of available resources. 15. Many of the measures that will be required will involve resource allocations and policy initiatives of a general kind. Nevertheless, the role of formal legislative and administrative measures should not be underestimated in this context. The Global Strategy for Shelter (paras 66-67) has drawn attention to the types of measures that might be taken in this regard and to their importance.

16. In some States, the right to adequate housing is constitutionally entrenched. In such cases the Committee is particularly interested in learning of the legal and practical significance of such an approach. Details of specific cases and of other ways in which entrenchment has proved helpful should thus be provided.

17. The Committee views many component elements of the right to adequate housing as being at least consistent with the provision of domestic legal remedies. Depending on the legal system, such areas might include, but are not limited to:

(a) legal appeals aimed at preventing planned evictions or demolitions through the issuance of court-ordered injunctions;

(b) legal procedures seeking compensation following an illegal eviction;

(c) complaints against illegal actions carried out or supported by landlords (whether public or private) in relation to rent levels, dwelling maintenance, and racial or other forms of discrimination;

(d) allegations of any form of discrimination in the allocation and availability of access to housing; and

(e) complaints against landlords concerning unhealthy or inadequate housing conditions. In some legal systems it would also be appropriate to explore the possibility of facilitating class action suits in situations involving significantly increased levels of homelessness.

18. In this regard, the Committee considers that instances of forced eviction are prima facie incompatible with the requirements of the Covenant and can only be justified in the most exceptional circumstances, and in accordance with the relevant principles of international law. 19. Finally, Article 11(1) concludes with the obligation of States parties to recognize 'the essential importance of international cooperation based on free consent'. Traditionally, less than 5 per cent of all international assistance has been directed towards housing or human settlements, and often the manner by which such funding is provided does little to address the housing needs of disadvantaged groups. States parties, both recipients and providers, should ensure that a substantial proportion of financing is devoted to creating conditions leading to a higher number of persons being adequately housed. International financial institutions promoting measures of structural adjustment should ensure that such measures do not compromise the enjoyment of the right to adequate housing. States parties should, when contemplating international financial cooperation, seek to indicate areas relevant to the right to adequate housing where external financing would have the most effect. Such requests should take full account of the needs and views of the affected groups.

Notes

1/ Official Records of the General Assembly, Forty-third Session, Supplement No. 8, addendum (A/43/8/Add.1). 
Annex 2

2/ Commission on Human Rights resolutions 1986/36 and 1987/22; reports by Mr. Danilo Türk, Special Rapporteur of the Sub-Commission (E/CN.4/Sub.2/1990/19, paras 108-120; E/CN.4/Sub.2/1991/17, paras. 137-139); see also Sub-Commission resolution 1991/26.

3/ See, for example, Article 25(1) of the Universal Declaration on Human Rights, Article 5(e)(iii) of the International Convention on the Elimination of All Forms of Racial Discrimination, Article 14(2) of the Convention on the Elimination of All Forms of Discrimination against Women, Article 27(3) of the Convention on the Rights of the Child, Article 10 of the Declaration on Social Progress and Development, section III (8) of the Vancouver Declaration on Human Settlements, 1976 (Report of Habitat: United Nations Conference on Human Settlements (United Nations publication, Sales No. E.76.IV.7 and corrigendum), chap. I), Article 8(1) of the Declaration on the Right to Development and the ILO Recommendation Concerning Workers' Housing, 1961 (No. 115).

4/ See footnote 1/.

5/ Geneva, World Health Organization, 1990. 


\section{COMMITTEe ON ECONOMIC, SOCIAL AND Cultural RightS General Comment No. 7}

AnNeX 3

\title{
The Right to Adequate Housing (Art.11.1): Forced Evictions: 20/05/97
}

1. In its General Comment No. 4 (1991), the Committee observed that all persons should possess a degree of security of tenure which guarantees legal protection against forced eviction, harassment and other threats. It concluded that forced evictions are prima facie incompatible with the requirements of the Covenant. Having considered a significant number of reports of forced evictions in recent years, including instances in which it has determined that the obligations of States parties were being violated, the Committee is now in a position to seek to provide further clarification as to the implications of such practices in terms of the obligations contained in the Covenant.

2. The international community has long recognized that the issue of forced evictions is a serious one. In 1976, the United Nations Conference on Human Settlements noted that special attention should be paid to 'undertaking major clearance operations should take place only when conservation and rehabilitation are not feasible and relocation measures are made'. 1/ In 1988, in the Global Strategy for Shelter to the Year 2000, adopted by the General Assembly in its resolution 43/181, the "fundamental obligation [of Governments] to protect and improve houses and neighbourhoods, rather than damage or destroy them' was recognized. 2/ Agenda 21 stated that 'people should be protected by law against unfair eviction from their homes or land'. 3/ In the Habitat Agenda Governments committed themselves to 'protecting all people from, and providing legal protection and redress for, forced evictions that are contrary to the law, taking human rights into consideration; [and] when evictions are unavoidable, ensuring, as appropriate, that alternative suitable solutions are provided'. 4/

The Commission on Human Rights has also indicated that 'forced evictions are a gross violation of human rights'. 5/ However, although these statements are important, they leave open one of the most critical issues, namely that of determining the circumstances under which forced evictions are permissible and of spelling out the types of protection required to ensure respect for the relevant provisions of the Covenant.

3. The use of the term 'forced evictions' is, in some respects, problematic. This expression seeks to convey a sense of arbitrariness and of illegality. To many observers, however, the reference to 'forced evictions' is a tautology, while others have criticized the expression 'illegal evictions' on the ground that it assumes that the relevant law provides adequate protection of the right to housing and conforms with the Covenant, which is by no means always the case. Similarly, it has been suggested that the term 'unfair evictions' is even more subjective by virtue of its failure to refer to any legal framework at all. The international community, especially in the context of the Commission on Human Rights, has opted to refer to 'forced evictions', primarily since all suggested alternatives also suffer from many such defects. The term 'forced evictions' as used throughout this general comment is defined as 
the permanent or temporary removal against their will of individuals, families and/or communities from the homes and/or land which they occupy, without the provision of, and access to, appropriate forms of legal or other protection. The prohibition on forced evictions does not, however, apply to evictions carried out by force in accordance with the law and in conformity with the provisions of the International Covenants on Human Rights.

4. The practice of forced evictions is widespread and affects persons in both developed and developing countries. Owing to the interrelationship and interdependency which exist among all human rights, forced evictions frequently violate other human rights. Thus, while manifestly breaching the rights enshrined in the Covenant, the practice of forced evictions may also result in violations of civil and political rights, such as the right to life, the right to security of the person, the right to non-interference with privacy, family and home and the right to the peaceful enjoyment of possessions.

5. Although the practice of forced evictions might appear to occur primarily in heavily populated urban areas, it also takes place in connection with forced population transfers, internal displacement, forced relocations in the context of armed conflict, mass exoduses and refugee movements. In all of these contexts, the right to adequate housing and not to be subjected to forced eviction may be violated through a wide range of acts or omissions attributable to States parties. Even in situations where it may be necessary to impose limitations on such a right, full compliance with Article 4 of the Covenant is required so that any limitations imposed must be 'determined by law only insofar as this may be compatible with the nature of these [i.e. economic, social and cultural] rights and solely for the purpose of promoting the general welfare in a democratic society'.

6. Many instances of forced eviction are associated with violence, such as evictions resulting from international armed conflicts, internal strife and communal or ethnic violence.

7. Other instances of forced eviction occur in the name of development. Evictions may be carried out in connection with conflict over land rights, development and infrastructure projects, such as the construction of dams or other large-scale energy projects, with land acquisition measures associated with urban renewal, housing renovation, city beautification programmes, the clearing of land for agricultural purposes, unbridled speculation in land, or the holding of major sporting events like the Olympic Games.

8. In essence, the obligations of States parties to the Covenant in relation to forced evictions are based on Article 11.1, read in conjunction with other relevant provisions. In particular, Article 2.1 obliges States to use 'all appropriate means' to promote the right to adequate housing. However, in view of the nature of the practice of forced evictions, the reference in Article 2.1 to progressive achievement based on the availability of resources will rarely be relevant. The State itself must refrain from forced evictions and ensure that the law is enforced against its agents or third parties who carry out forced evictions (as defined in paragraph 3 above). Moreover, this approach is reinforced by Article 17.1 of the International Covenant on Civil and Political Rights which complements the right not to be forcefully evicted without adequate protection. That provision recognizes, inter alia, the right to be protected against 'arbitrary or unlawful interference' with one's home. It is to be noted that the State's obligation to ensure respect for that right is not qualified by considerations relating to its available resources.

9. Article 2.1 of the Covenant requires States parties to use 'all appropriate means', including the adoption of legislative measures, to promote all the rights protected under the Covenant. Although the Committee has indicated in its General Comment No. 3 (1990) that such measures may not be indispensable in relation to all rights, it is clear that legislation 
against forced evictions is an essential basis upon which to build a system of effective protection. Such legislation should include measures which (a) provide the greatest possible security of tenure to occupiers of houses and land, (b) conform to the Covenant and (c) are designed to control strictly the circumstances under which evictions may be carried out. The legislation must also apply to all agents acting under the authority of the State or who are accountable to it. Moreover, in view of the increasing trend in some States towards the Government greatly reducing its responsibilities in the housing sector, States parties must ensure that legislative and other measures are adequate to prevent and, if appropriate, punish forced evictions carried out, without appropriate safeguards, by private persons or bodies. States parties should therefore review relevant legislation and policies to ensure that they are compatible with the obligations arising from the right to adequate housing and repeal or amend any legislation or policies that are inconsistent with the requirements of the Covenant.

10. Women, children, youth, older persons, indigenous people, ethnic and other minorities, and other vulnerable individuals and groups all suffer disproportionately from the practice of forced eviction. Women in all groups are especially vulnerable given the extent of statutory and other forms of discrimination which often apply in relation to property rights (including home ownership) or rights of access to property or accommodation, and their particular vulnerability to acts of violence and sexual abuse when they are rendered homeless. The non-discrimination provisions of Articles 2.2 and 3 of the Covenant impose an additional obligation upon Governments to ensure that, where evictions do occur, appropriate measures are taken to ensure that no form of discrimination is involved.

11. Whereas some evictions may be justifiable, such as in the case of persistent non-payment of rent or of damage to rented property without any reasonable cause, it is incumbent upon the relevant authorities to ensure that they are carried out in a manner warranted by a law which is compatible with the Covenant and that all the legal recourses and remedies are available to those affected.

12. Forced eviction and house demolition as a punitive measure are also inconsistent with the norms of the Covenant. Likewise, the Committee takes note of the obligations enshrined in the Geneva Conventions of 1949 and Protocols thereto of 1977 concerning prohibitions on the displacement of the civilian population and the destruction of private property as these relate to the practice of forced eviction.

13. States parties shall ensure, prior to carrying out any evictions, and particularly those involving large groups, that all feasible alternatives are explored in consultation with the affected persons, with a view to avoiding, or at least minimizing, the need to use force. Legal remedies or procedures should be provided to those who are affected by eviction orders. States parties shall also see to it that all the individuals concerned have a right to adequate compensation for any property, both personal and real, which is affected. In this respect, it is pertinent to recall Article 2.3 of the International Covenant on Civil and Political Rights, which requires States parties to ensure 'an effective remedy' for persons whose rights have been violated and the obligation upon the 'competent authorities (to) enforce such remedies when granted'.

14. In cases where eviction is considered to be justified, it should be carried out in strict compliance with the relevant provisions of international human rights law and in accordance with general principles of reasonableness and proportionality. In this regard it is especially pertinent to recall General Comment 16 of the Human Rights Committee, relating to Article 17 of the International Covenant on Civil and Political Rights, which states that interference with a person's home can only take place 'in cases envisaged by the law'. The Committee 
observed that the law 'should be in accordance with the provisions, aims and objectives of the Covenant and should be, in any event, reasonable in the particular circumstances'. The Committee also indicated that 'relevant legislation must specify in detail the precise circumstances in which such interferences may be permitted'.

15. Appropriate procedural protection and due process are essential aspects of all human rights but are especially pertinent in relation to a matter such as forced evictions which directly invokes a large number of the rights recognized in both the International Covenants on Human Rights. The Committee considers that the procedural protections which should be applied in relation to forced evictions include: (a) an opportunity for genuine consultation with those affected; (b) adequate and reasonable notice for all affected persons prior to the scheduled date of eviction; (c) information on the proposed evictions, and, where applicable, on the alternative purpose for which the land or housing is to be used, to be made available in reasonable time to all those affected; (d) especially where groups of people are involved, government officials or their representatives to be present during an eviction; (e) all persons carrying out the eviction to be properly identified; (f) evictions not to take place in particularly bad weather or at night unless the affected persons consent otherwise; (g) provision of legal remedies; and (h) provision, where possible, of legal aid to persons who are in need of it to seek redress from the courts.

16. Evictions should not result in individuals being rendered homeless or vulnerable to the violation of other human rights. Where those affected are unable to provide for themselves, the State party must take all appropriate measures, to the maximum of its available resources, to ensure that adequate alternative housing, resettlement or access to productive land, as the case may be, is available.

17. The Committee is aware that various development projects financed by international agencies within the territories of State parties have resulted in forced evictions. In this regard, the Committee recalls its General Comment No. 2 (1990) which states, inter alia, that 'international agencies should scrupulously avoid involvement in projects which, for example ... promote or reinforce discrimination against individuals or groups contrary to the provisions of the Covenant, or involve large-scale evictions or displacement of persons without the provision of all appropriate protection and compensation. Every effort should be made, at each phase of a development project, to ensure that the rights contained in the Covenant are duly taken into account'. 6/

18. Some institutions, such as the World Bank and the Organisation for Economic Cooperation and Development (OECD) have adopted guidelines on relocation and/or resettlement with a view to limiting the scale of and human suffering associated with forced evictions. Such practices often accompany large-scale development projects, such as dam-building and other major energy projects. Full respect for such guidelines, insofar as they reflect the obligations contained in the Covenant, is essential on the part of both the agencies themselves and States parties to the Covenant. The Committee recalls in this respect the statement in the Vienna Declaration and Programme of Action to the effect that 'while development facilitates the enjoyment of all human rights, the lack of development may not be invoked to justify the abridgement of internationally recognized human rights' (Part I, para. 10).

19. In accordance with the guidelines for reporting adopted by the Committee, State parties are requested to provide various types of information pertaining directly to the practice of forced evictions. This includes information relating to (a) the 'number of persons evicted within the last five years and the number of persons currently lacking legal protection against arbitrary eviction or any other kind of eviction', (b) 'legislation concerning the rights 
of tenants to security of tenure, to protection from eviction' and (c) 'legislation prohibiting any form of eviction'. 7/

20. Information is also sought as to 'measures taken during, inter alia, urban renewal programmes, redevelopment projects, site upgrading, preparation for international events (Olympics and other sporting competitions, exhibitions, conferences, etc.) 'beautiful city' campaigns, etc. which guarantee protection from eviction or guarantee rehousing based on mutual consent, by any persons living on or near to affected sites'. 8/ However, few States parties have included the requisite information in their reports to the Committee. The Committee therefore wishes to emphasize the importance it attaches to the receipt of such information.

21. Some States parties have indicated that information of this nature is not available. The Committee recalls that effective monitoring of the right to adequate housing, either by the Government concerned or by the Committee, is not possible in the absence of the collection of appropriate data and would request all States parties to ensure that the necessary data is collected and is reflected in the reports submitted by them under the Covenant.

\section{Notes}

1/ Report of Habitat: United Nations Conference on Human Settlements, Vancouver, 31 May-11 June 1976 (A/CONF.70/15), chap. II, recommendation B.8, para. C (ii).

2/ Report of the Commission on Human Settlements on the work of its eleventh session, Addendum (A/43/8/Add.1), para. 13.

3/ Report of the United Nations Conference on Environment and Development, Rio de Janeiro, 3-14 June 1992, Vol. I (A/CONF.151/26/Rev.1(vol.I), annex II, Agenda 21, chap. 7.9 (b).

4/ Report of the United Nations Conference on Settlements (Habitat II) (A/CONF.165/ 14), annex II, The Habitat Agenda, para. 40 (n).

5/ Commission on Human Rights resolution 1993/77, para. 1.

6/ E/1990/23, annex III, paras. 6 and 8 (d).

7/ E/C.12/1999/8, annex IV.

8/ Ibid. 



\begin{abstract}
ANNEX 4

\author{
COMMITTEe ON ECONOMic, Social AND Cultural Rights \\ GenERAL COMMENT No. 16
} Article 3: The Equal Right of Men and Women to the Enjoyment of All Economic,
Social and Cultural Rights: 13/05/05
\end{abstract}

\title{
Introduction
}

1. The equal right of men and women to the enjoyment of all human rights is one of the fundamental principles recognized under international law and enshrined in the main international human rights instruments. The International Covenant on Economic, Social and Cultural Rights (ICESCR or the Covenant) protects human rights that are fundamental to the dignity of every person. In particular, Article 3 of this Covenant provides for the equal right of men and women to the enjoyment of the rights it articulates. This provision is founded on Article 1(3) of the United Nations Charter and Article 2 of the Universal Declaration of Human Rights. Except for the reference to the ICESCR, it is identical to Article 3 of the International Covenant on Civil and Political Rights (ICCPR), which was drafted at the same time as the ICESCR.

2. The travaux preparatoires state that Article 3 was included in the Covenant, as well as in the ICCPR, to indicate that beyond a prohibition of discrimination, 'the same rights should be expressly recognized for men and women on an equal footing and suitable measures should be taken to ensure that women had the opportunity to exercise their rights [...]. Moreover, even if Article 3 overlapped with Article 2(2), it was still necessary to reaffirm the equal rights of men and women. That fundamental principle, which was enshrined in the Charter of the United Nations, must be constantly emphasized, especially as there were still many prejudices preventing its full application'. 1/ Unlike Article 26 of ICCPR, Articles 3 and 2(2) of the ICESCR are not stand-alone provisions, but should be read in conjunction with each specific right guaranteed under Part III of the Covenant.

3. Article 2(2) of the ICESCR states a guarantee of non-discrimination on the basis of sex among other grounds. This provision and the guarantee of equal enjoyment of rights by men and women in Article 3 are integrally related and mutually reinforcing. Moreover, elimination of discrimination is fundamental to the enjoyment of economic, social and cultural rights on a basis of equality.

4. The Committee on Economic, Social and Cultural Rights (CESCR) has taken particular note of factors negatively affecting the equal right of men and women to the enjoyment of economic, social and cultural rights in many of its general comments, including those on the right to adequate housing, $2 /$ the right to adequate food, $3 /$ the right to education, 4 / the right to the highest attainable standard of health, 5/ and the right to water. 6/ The Committee also routinely requests information on the equal enjoyment by men and women of the rights 
guaranteed under the Covenant in its list of issues in relation to States parties' reports and during its dialogue with States parties.

5. Women in particular, are often denied equal enjoyment of their human rights, by virtue of the lesser status ascribed to them by tradition and custom or as a result of overt and covert discrimination. Many women experience distinct forms of discrimination, due to the intersection of sex with such factors as race, colour, language, religion, political and other opinion, national or social origin, property, birth, or other status, such as age, ethnicity, disability, marital, refugee or migrant status, resulting in compounded disadvantage. $7 /$

\section{Conceptual Framework}

\section{Equality}

6. The essence of Article 3 of the ICESCR is that the rights set forth in the Covenant are to be enjoyed by men and women on a basis of equality, a concept that carries substantive meaning. While expressions of formal equality may be found in constitutional provisions, legislation and policies of governments, Article 3 also mandates the equal enjoyment of the rights in the Covenant for men and women in practice.

7. The enjoyment of human rights on the basis of equality between men and women must be understood comprehensively. Guarantees of non-discrimination and equality in international human rights treaties mandate both de facto and de jure equality. De jure (or formal) equality and de facto (or substantive) equality are different but interconnected concepts. Formal equality assumes that equality is achieved if a law or policy treats men and women in a neutral manner. Substantive equality is concerned, in addition, with the effects of laws, policies and practices and with ensuring that they do not maintain, but rather alleviate, the inherent disadvantage that particular groups experience.

8. Substantive equality for men and women will not be achieved simply through the enactment of laws or the adoption of policies that are gender-neutral on their face. In implementing Article 3, States parties should take into account that such laws, policies and practice can fail to address or even perpetuate inequality between men and women, because they do not take account of existing economic, social and cultural inequalities, particularly those experienced by women.

9. According to Article 3, States parties must respect the principle of equality in and before the law. The principle of equality in the law must be respected by the legislature when adopting laws, by ensuring that those laws further equal enjoyment of economic, social and cultural rights by men and women. The principle of equality before the law must be respected by administrative agencies, and courts and tribunals, and implies that those authorities must apply the law equally for men and women.

\section{Non-discrimination}

10. The principle of non-discrimination is the corollary of the principle of equality. Subject to what is stated in paragraph 15 on temporary special measures, it prohibits differential treatment of a person or group of persons based on his/her or their particular status or situation, such as race, colour, sex, language, religion, political and other opinion, national or social 
origin, property, birth, or other status, such as age, ethnicity, disability, marital, refugee or migrant status.

11. Discrimination against women is 'any distinction, exclusion or restriction made on the basis of sex which has the effect or purpose of impairing or nullifying the recognition, enjoyment or exercise by women, irrespective of their marital status, on a basis of equality of men and women, of human rights and fundamental freedoms in the political, economic, social, cultural, civil or any other field'. 8/ Discrimination on the basis of sex may be based on the differential treatment of women because of their biology, such as refusal to hire women because they could become pregnant; or stereotypical assumptions, such as tracking women into low-level jobs on the assumption that they are unwilling to commit as much time to their work as men.

12. Direct discrimination occurs when a difference in treatment relies directly and explicitly on distinctions based exclusively on sex and characteristics of men or of women, which cannot be justified objectively.

13. Indirect discrimination occurs when a law, policy or programme does not appear to be discriminatory on its face, but has a discriminatory effect when implemented. This can occur, for example, when women are disadvantaged compared to men with respect to the enjoyment of a particular opportunity or benefit due to pre-existing inequalities. Applying a genderneutral law may leave the existing inequality in place, or exacerbate it.

14. Gender affects the equal right of men and women to the enjoyment of their rights. Gender refers to cultural expectations and assumptions about the behavior, attitudes, personality traits, and physical and intellectual capacities of men and women, based solely on their identity as men or women. Gender-based assumptions and expectations generally place women at a disadvantage with respect to substantive enjoyment of rights, such as freedom to act and to be recognized as autonomous, fully capable adults, to participate fully in economic, social and political development, and to make decisions concerning their circumstances and conditions. Gender-based assumptions about economic, social and cultural roles preclude the sharing of responsibility between men and women in all spheres that is necessary to equality.

\section{Temporary Special Measures}

15. The principles of equality and non-discrimination, by themselves, are not always sufficient to guarantee true equality. Temporary special measures may sometimes be needed in order to bring disadvantaged or marginalized persons or groups of persons to the same substantive level as others. Temporary special measures aim at realizing not only de jure or formal equality, but also de facto or substantive equality for men and women. However, the application of the principle of equality will sometimes require that States parties take measures in favour of women in order to attenuate or suppress conditions that perpetuate discrimination. As long as these measures are necessary to redress de facto discrimination, and are terminated when de facto equality is achieved, such differentiation is legitimate. 9/ 


\section{States Parties' Obligations}

\section{General Legal Obligations}

16. The equal right of men and women to the enjoyment of economic, social and cultural rights is a mandatory and immediate obligation of States parties. 10/

17. The equal right of men and women to the enjoyment of economic, social and cultural rights, like all human rights, imposes three levels of obligations on States parties - the obligation to respect, to protect and to fulfill. The obligation to fulfill further contains duties to provide, promote and facilitate.11/ Article 3 sets a non-derogable standard for compliance with the obligations of States parties as set out in Articles 6 through 15 of the ICESCR.

\section{Specific Legal Obligations}

\section{Obligation to Respect}

18. The obligation to respect requires States parties to refrain from discriminatory actions that directly or indirectly result in the denial of the equal right of men and women to their enjoyment of economic, social and cultural rights. Respecting the right obliges States parties not to adopt, and to repeal laws and rescind policies, administrative measures and programmes that do not conform with the right protected by Article 3. In particular, it is incumbent upon States parties to take into account the effect of apparently sex-neutral laws, policies and programmes and to consider whether they could result in a negative impact on the ability of men and women to enjoy their human rights on a basis of equality.

\section{Obligation to Protect}

19. The obligation to protect requires States parties to take steps aimed directly towards the elimination of prejudices, customary and all other practices that perpetuate the notion of inferiority or superiority of either of the sexes, and stereotyped roles for men and women. States parties' obligation to protect under Article 3 of the ICESCR includes inter alia, the respect and adoption of constitutional and legislative provisions on the equal right of men and women to enjoy all human rights and the prohibition of discrimination of any kind; the adoption of legislation to eliminate discrimination and to prevent third parties from interfering directly or indirectly with the enjoyment of this right; the adoption of administrative measures and programmes, as well as the establishment of public institutions, agencies and programmes to protect women against discrimination.

20. States parties have an obligation to monitor and regulate the conduct of non-state actors to ensure that they do not violate the equal right of men and women to enjoy economic, social and cultural rights. This obligation applies, for example, in cases where public services have been partially or fully privatized.

\section{Obligation to Fulfill}

21. The obligation to fulfill requires States parties to take steps to ensure that in practice, men and women enjoy their economic, social and cultural rights on a basis of equality. Such steps should include: 
- Availability and accessibility of appropriate remedies, such as compensation, reparation, restitution, rehabilitation, guarantees of non-repetition, declarations, public apologies, educational programmes and prevention programmes.

- Establishment by States parties of appropriate venues for redress such as courts and tribunals or administrative mechanisms that are accessible to all on the basis of equality, including the poorest and most disadvantaged and marginalized men and women.

- Development of monitoring mechanisms to ensure that the implementation of laws and policies aimed at promoting the equal enjoyment of economic, social and cultural rights by men and women do not have unintended adverse effects on disadvantaged or marginalized individuals or groups, particularly women and girls.

- Design and implementation of policies and programmes to give long-term effect to the economic, social and cultural rights of both men and women on the basis of equality. These may include the adoption of temporary special measures to accelerate women's equal enjoyment of their rights, gender audits, and gender-specific allocation of resources.

- Human rights education and training programmes for judges and public officials.

- Awareness-raising and training programmes on equality for workers involved in the realization of economic, social and cultural rights at the grassroots level.

- Integration in formal and non-formal education of the principle of the equal right of men and women to the enjoyment of economic, social and cultural rights, and promotion of equal participation of men and women, boys and girls, in schools and other education programmes. - Promotion of equal representation of men and women in public office and decision-making bodies.

- Promotion of equal participation of men and women in development planning, decisionmaking and in the benefits of development and all programmes related to the realization of economic, social and cultural rights.

\section{Specific Examples of States Parties' Obligations}

22. Article 3 is a cross-cutting obligation and applies to all of the rights stated in Articles 6 to 15 of the Covenant. It requires addressing gendered social and cultural prejudices, providing for equality in the allocation of resources and promoting the sharing of responsibilities in the family, community and public life. The examples provided in the following paragraphs may be taken as guidance on the ways in which Article 3 applies to other rights in the Covenant, but are not intended to be exhaustive.

23. Article 6(1) of the Covenant requires States parties to safeguard the right of everyone to the opportunity to gain a living by work which is freely chosen or accepted and to take the necessary steps to achieve the full realization of this right. Implementing Article 3 in relation to Article 6 requires inter alia, that, in law and in practice, men and women have equal access to jobs at all levels and all occupations and that vocational training and guidance programmes, in both the public and private sectors, provide men and women with the skills, information and knowledge necessary for them to benefit equally from the right to work.

24. Article 7(a) of the Covenant requires States parties to recognize the right of everyone to enjoy just and favourable conditions of work and to ensure among other things, fair wages and equal pay for work of equal value. Article 3 in relation to Article 7 requires, inter alia, that the State party identifies and eliminates the underlying causes of pay differentials, such as gender-biased job evaluation or the perception that productivity differences between men and women exist. Furthermore, the State party should monitor compliance by the private 
sector with national legislation on working conditions through an effectively functioning labour inspectorate. The State party should adopt legislation that prescribes equal consideration in promotion, non-wage compensation and equal opportunity and support for vocational or professional development in the workplace. Finally, the State party should reduce the constraints faced by men and women in reconciling professional and family responsibilities by promoting adequate policies for childcare and care of dependent family members.

25. Article 8(1)(a) of the Covenant requires States parties to ensure the right of everyone to form and join trade unions of his or her choice. Article 3 in relation to Article 8 requires allowing men and women to organize and join trade workers associations, that address their specific concerns. In this regard, particular attention should be given to domestic workers, rural women, women working in female-dominated industries and women working at home, who are often deprived of this right.

26. Article 9 of the Covenant requires that States parties recognize the right of everyone to social security, including social insurance, and to equal access to social services. Implementing Article 3 in relation to Article 9 requires, inter alia, equalizing the compulsory retirement age for both men and women; ensuring that women receive the equal benefit of public and private pension schemes; and guaranteeing adequate maternity leave for women, paternity leave for men, and parental leave for both men and women.

27. Article 10(1) of the Covenant requires that States parties recognize that the widest possible protection and assistance should be accorded to the family, and that marriage must be entered into with the free consent of the intending spouses. Implementing Article 3 in relation to Article 10 requires States parties, inter alia, to provide victims of domestic violence, who are primarily female, with access to safe housing, remedies and redress of physical, mental and emotional damage; to ensure that men and women have an equal right to choose if, whom and when to marry - in particular, the legal age of marriage for men and women should be the same, and boys and girls should be protected equally from practices that promote child marriage, marriage by proxy, or coercion; and to ensure that women have equal rights to marital property and inheritance upon their husband's death. Gender based violence is a form of discrimination that inhibits the ability to enjoy rights and freedoms, including economic, social and cultural rights, on a basis of equality. States parties must take appropriate measures to eliminate violence against men and women and act with due diligence to prevent, investigate, mediate, punish and redress acts of violence against them by private actors.

28. Article 11 of the Covenant requires States parties to recognize the right of everyone to an adequate standard of living for him/herself and his/her family, including adequate housing (11(1)) and adequate food (11(2)). Implementing Article 3 in relation to Article 11(1) requires that women have a right to own, use or otherwise control housing, land and property on an equal basis with men, and to access necessary resources to do so. Implementing Article 3 in relation to Article 11(2) also requires States parties, inter alia, to ensure that women have access to, or control over, means of food production, and actively address customary practices under which women are not allowed to eat until the men are fully fed, or are only allowed less nutritious food. 12/

29. Article 12 of the Covenant requires States parties to undertake steps towards the full realization of the right of everyone to the enjoyment of the highest attainable standard of physical and mental health. The implementation of Article 3 in relation to Article 12 requires, at a minimum, the removal of legal and other obstacles that prevent men and women from accessing and benefiting from healthcare on a basis of equality. This includes, inter alia, 
addressing the ways in which gender roles affect access to determinants of health, such as water and food; the removal of legal restrictions on reproductive health provisions; the prohibition of female genital mutilation; and the provision of adequate training for health care workers to deal with women's health issues. 13/

30. Article 13(1) of the Covenant requires States parties to recognize the right of everyone to education and in 13(2)(a), that primary education shall be compulsory and available free to all. Implementing Article 3 in relation to Article 13 requires, inter alia, the adoption of legislation and policies to ensure the same admissions criteria for boys and girls in all levels of education. States parties should ensure, in particular through information and awareness raising campaigns, that families desist from giving preferential treatment to boys in sending their children to school, and that curricula promote equality and non-discrimination. States parties must create favourable conditions to ensure the safety of children, in particular girls, on their way to and from school.

31. Article 15(1)(a) and (b) of the Covenant require States parties to recognize the right of everyone to take part in cultural life and to enjoy the benefits of scientific progress. Implementing Article 3 in relation to Article 15(1)(a) and (b) requires, inter alia, overcoming institutional barriers and other obstacles, such as those based on cultural and religious traditions, which prevent women from fully participating in cultural life, science education and scientific research, and directing resources to scientific research relating to the health and economic needs of women on an equal basis with those of men.

\section{Implementation at the National Level}

\section{Policies and Strategies}

32. The most appropriate ways and means of implementing the right under Article 3 of the Covenant will vary from one State party to another. Every State party has a margin of discretion in adopting appropriate measures in complying with its primary and immediate obligation to ensure the equal right of men and women to the enjoyment of all their economic, social and cultural rights. Among other things, States parties must, inter alia, integrate into national plans of action for human rights, appropriate strategies to ensure the equal right of men and women to the enjoyment of economic, social and cultural rights.

33. These strategies should be based on systematic identification of policies, programmes and activities relevant to the situation and context within the State, as derived from the normative content of Article 3 of the Covenant and spelled out in relation to the levels and nature of State parties' obligations referred to in paragraphs 16 to 21 of this present General Comment. The strategies should give particular attention to the elimination of discrimination in the enjoyment of economic, social and cultural rights.

34. States parties should periodically review existing legislation, policies, strategies and programmes in relation to economic, social and cultural rights, and adopt any necessary changes to ensure that they are consonant with their obligations under Article 3 of this Covenant.

35. The adoption of temporary special measures may be necessary to accelerate the equal enjoyment by women of all economic, social and cultural rights and to improve the de facto position of women. 14/ Temporary special measures should be distinguished from permanent policies and strategies undertaken towards equality of men and women. 
36. States parties are encouraged to adopt temporary special measures to accelerate the achievement of equality between men and women in the enjoyment of the rights under the Covenant. Such measures are not to be considered discriminatory in themselves as they are grounded in the State's obligation to eliminate disadvantage caused by past and current discriminatory laws, traditions and practices. The nature, duration and application of such measures should be designed with reference to the specific issue and context, and should be adjusted as circumstances require. The results of such measures should be monitored with a view to being discontinued when the objectives for which they are undertaken have been achieved.

37. The right of individuals and groups of individuals to participate in decision-making processes which may affect their development must be an integral component of any policy, programme or activity developed to discharge governmental obligations under Article 3 of the Covenant.

\section{Remedies and Accountability}

38. National policies and strategies should provide for the establishment of effective mechanisms and institutions where they do not exist, including administrative authorities, ombudspersons and other national human rights institutions, courts and tribunals. These institutions should investigate and address alleged violations relating to Article 3 and provide remedies for such violations. States parties, for their part, should ensure that such remedies are effectively implemented.

\section{Indicators and Benchmarks}

39. National policies and strategies should identify appropriate indicators and benchmarks on the right to equal enjoyment by men and women of economic, social and cultural rights in order to effectively monitor the implementation by the State party of its Covenant obligations in this regard. Disaggregated statistics within specific timeframes are necessary to measure the progressive realization of economic, social and cultural rights by men and women where appropriate.

\section{Violations}

40. States parties must fulfill their immediate and primary obligation to ensure the equal right of men and women to the enjoyment of economic, social and cultural rights.

41. The principle of equality between men and women is fundamental to the enjoyment of each of the specific rights enumerated in the Covenant. Failure to ensure formal and substantive equality in the enjoyment of any of these rights constitutes a violation of that right. Elimination of de jure as well as de facto discrimination is required for the equal enjoyment of economic, social and cultural rights. Failure to adopt, implement, and monitor effects of laws, policies and programmes to eliminate de jure and de facto discrimination with respect to each of the rights enumerated in Articles 6 to 15 of the Covenant constitutes a violation of those rights.

42. Violations of the rights enshrined in the Covenant can occur through the direct action of, failure to act or omission by, States parties or through their institutions or agencies at the 
national and local levels. The adoption and undertaking of any retrogressive measures that affect the equal right of men and women to the enjoyment of the all the rights set forth in the Covenant constitutes a violation of Article 3.

Notes

1/ Draft International Covenants on Human Rights Report of the Third Committee. A/53/65 (17 December 1962).

2/ Committee on Economic, Social and Cultural Rights (hereinafter CESCR), General Comment No. 4 The Right to Adequate Housing (Art 11(1) (1991) at para. 6; CESCR General Comment No. 7, The Right to Adequate Housing (Art. 11(1):Forced Evictions, at para. 10.

3/ CESCR, General Comment No.12 The Right to Adequate Food (Art. 11 at para. 26, 1999.

4/ CESCR, General Comment No. 11 Plans for Primary Education (Art.14) (1999) at para. 3; General Comment No. 13 The Right to Education (art. 13) (1999) at paras 6(b), 31 \& 32.

5/ CESCR, General Comment No. 14 The Right to the Highest Attainable Standard of Health (Art. 12) (2000) at paras 18-22.

6/ CESCR, General Comment No. 15, The Right to Water (Arts. 11 \& 12) (2000) at paras13-14.

7/ Cf. Committee on the Elimination of Racial Discrimination, General Comment 25, Gender Related Dimensions of Racial Discrimination (2000).

8/ As defined in Article 1 CEDAW.

9/ However, there is one exception to this general principle: reasons specific to an individual male candidate may tilt the balance in his favour, which is to be assessed objectively, taking into account all criteria to the individual candidates. This is a requirement of the principle of proportionality.

10/ CESCR, General Comment No. 3, The Nature of States Parties Obligations (Art. 2(1) (1990).

11/ According to CESCR General Comment Nos. 12 and 13, the obligation to fulfill incorporates an obligation to facilitate and an obligation to provide. In the present General Comment, the obligation to fulfill also incorporates an obligation to promote towards the elimination of all forms of discrimination against women.

12/ Other examples of obligations and possible violations of Article 3 in relation to Article 11(1) and (2) are further discussed in CESCR General Comment No.12, The Right to Adequate Food, E/C. 12/1999/5 (1999) para. 26.

13/ CESCR General Comment No. 14, The right to the highest attainable standard of health, E/C.12/2000/4, paras $18-21$.

14/ Reference is made in this regard to General Recommendation 25 on Article 4.1 of CEDAW, General Comment 13 of the CESCR, and the Limburg Principles on the Implementation of the ICESCR. 



\begin{abstract}
ANNEX 5
ReVised General Guidelines Regarding THE Form AND CONTENTS OF Reports to Be Submitted by States Parties Under Articles 16 ANd 17 of THE INTERNATIONAL COVENANT ON ECONOMIC, SOCIAL AND CULTURAL RIGHTS (17 JUNE 1991)
\end{abstract}

\title{
Article 11 of the Covenant
}

1. (a) Please supply information on the current standard of living of your population, in respect of both the aggregate and different socio-economic, cultural, and other groups within the society. How has the standard of living changed over time (e.g., compared with 10 years ago and 5 years ago) with regard to these different groups? Has there been a continuous improvement of living conditions for the entire population or for what groups?

(b) In case your Government has recently submitted reports relevant to the situation with respect to all or some of the rights contained in Article 11 to the United Nations or a specialized agency, you may with to refer to the relevant parts of those reports rather than repeat the information here.

(c) Please indicate the per capita GNP for the poorest 40 per cent of your population. It there a 'poverty line' in existence in your country and, if so, what is the basis for this line?

(d) Please indicate your country's Physical Quality of Life Index.

[...]

\section{The Right to Adequate Housing}

(a) Please furnish detailed statistical information about the housing situation in your country.

(b) Please provide detailed information about those groups within your society that are vulnerable and disadvantaged with regard to housing. Indicate, in particular:

(i) The number of homeless individuals and families;

(ii) The number of individuals and families currently inadequately housed and without ready access to basic amenities such as water, heating (if necessary), waste disposal, sanitation facilities, electricity, postal services, etc. (in so far as you consider these amenities relevant in your country). Include the number of people living in over-crowded, damp, structurally unsafe housing or other conditions which affect health;

(iii) The number of persons currently classified as living in 'illegal' settlements or housing;

(iv) The number of persons evicted within the last five years and the number of persons currently lacking legal protection against arbitrary eviction or any other kind of eviction;

(v) The number of persons whose housing expenses are above any government-set limit of affordability, based upon ability to pay or as a ratio of income;

(vi) The number of persons on waiting lists for obtaining accommodation, the average length of waiting time and measures taken to decrease such lists as well as to assist those on such lists in finding temporary housing; 
(vii) The number of persons in different types of housing tenure by: social or public housing; private rental sector; owner-occupiers; 'illegal' sector; and other.

(c) Please provide information on the existence of any laws affecting the realization of the right to housing, including:

(i) Legislation which gives substance to the right to housing in terms of defining the content of this right;

(ii) Legislation such as housing acts, homeless person acts, municipal corporation acts, etc;

(iii) Legislation relevant to land use, land distribution; land allocation, land zoning, land ceilings, expropriations including provisions for compensation; land planning, including procedures for community participation;

(iv) Legislation concerning the rights of tenants to security of tenure, to protection from eviction; to housing finance and rental control (or subsidy), housing affordability, etc;

(v) Legislation concerning building codes, building regulations and standards and the provision of infrastructure;

(vi) Legislation prohibiting any and all forms of discrimination in the housing sector, including groups not traditionally protected;

(vii) Legislation prohibiting any form of eviction;

(viii) Any legislative repeal or reform of existing laws which detracts from the fulfilment of the right to housing;

(ix) Legislation restricting speculation on housing or property, particularly when such peculation has a negative impact on the fulfilment of housing rights for all sectors of society;

(x) Legislative measures conferring legal title to those living in the 'illegal' sector;

(xi) Legislation concerning environmental planning and health in housing and human settlements.

(d) Please provide information on all other measures taken to fulfil the right to housing, including:

(i) Measures taken to encourage 'enabling strategies' whereby local community-based organizations and the 'informal sector' can build housing and related services. Are such organizations free to operate? Do they receive Government funding?

(ii) Measures taken by the State to build housing units and to increase other construction of affordable, rental housing;

(iii) Measures taken to release unutilized, under-utilized or mis-utilized land;

(iv) Financial measures taken by the State including details of the budget of the Ministry of Housing or other relevant Ministry as a percentage of the national budget;

(v) Measures taken to ensure that international assistance for housing and human settlements is used to fulfil the needs of the most disadvantaged groups;

(vi) Measures taken to encourage the development of small and intermediate urban centres, especially at the rural level;

(vii) Measures taken during, inter alia, urban renewal programmes, redevelopment projects, site upgrading, preparation for international events (Olympics, expositions, conferences, etc.), 'beautiful city campaigns', etc., which guarantee protection from eviction or guaranteed rehousing based on mutual agreement, by any persons living on or near to affected sites;

(e) During the reporting period, have there been any changes in national policies, laws and practices negatively affecting the right to adequate housing? If so, please describe the changes and evaluate their impact. 


\section{Committee on Economic, Social and Cultural Rights}

Reporting Guidelines Pertaining to Article 11

4. Please give details on any difficulties or shortcomings encountered in the fulfilment of the rights enshrined in Article 11 and on the measures taken to remedy these situations (if not already described in the present report).

5. Please indicate the role of international assistance in the full realization of the rights enshrined in Article 11. 



\section{SAMENVATTING}

\section{VROUWEN EN HUISVESTING: GENDER MAAKT VERSCHIL}

\section{Inleidende opmerkingen}

Het doel van deze studie is het inzichtelijk maken van de rol die gender speelt ten aanzien van de realisatie van het recht op huisvesting van vrouwen. De term gender wordt gedefinieerd als het complex van veronderstelde stereotiepe eigenschappen en rollen die vrouwen en mannen in de familie en in het maatschappelijke leven worden toegedicht. In relatie tot de rechten van de mens heeft gender in deze betekenis een negatieve connotatie omdat de cultureel bepaalde rol van vrouwen mogelijkerwijs de realisatie van hun mensenrechten in de weg staat.

Het recht op huisvesting van vrouwen wordt onderzocht in de context van de Verenigde Naties. Hoewel de uiteindelijke verwezenlijking van huisvesting zal plaatsvinden op nationaal niveau, is ervoor gekozen de aandacht te richten op de inhoud en de reikwijdte van dit recht op internationaal niveau. De internationaal-rechtelijke norm dient te worden beschouwd als richtsnoer voor de minimaal op nationaal niveau te bereiken standaard. Gezien de bijna wereldwijde aanvaarding van de meest belangrijke internationale mensenrechtenverdragen, is het mogelijk dat internationale toezichthoudende organen enige invloed en druk uitoefenen op Staten partijen met betrekking tot de naleving van deze norm en, onder bepaalde voorwaarden, tevens een belangrijke rol kunnen spelen ten aanzien van de juridische beoordeling in welke gevallen het recht op huisvesting wordt geschonden. De in het boek genoemde voorbeelden van nationale situaties dienen te worden beschouwd als illustraties van goede en slechte praktijken.

In dit boek wordt het recht op huisvesting holistisch benaderd, zodat naast juridische, ook sociologische, antropologische, economische en politicologische aspecten aan bod komen. Verder gaat deze studie uit van de onlosmakelijke verbondenheid en onderlinge beïnvloeding en afhankelijkheid van economische, sociale en culturele rechten enerzijds en politieke- en burgerrechten anderzijds.

Een studie als deze bergt het gevaar in zich dat de traditionele rolverdeling tussen vrouwen en mannen wordt bevestigd. Echte veranderingen die leiden tot meer gelijkheid tussen vrouwen en mannen en die zullen bewerkstelligen dat vrouwen een autonoom recht op huisvesting krijgen alsmede de mogelijkheid zelf in hun recht op huisvesting te voorzien, zullen veel tijd in beslag nemen en kunnen alleen bereikt worden door een cultuuromslag. Aangezien het echter ook belangrijk is dat op korte termijn concrete verbeteringen worden doorgevoerd, is het onvermijdelijk dat sommige maatregelen gebaseerd zijn op de bestaande situatie. Dit is niet schadelijk zolang men zich ervan bewust is dat de bestaande situatie ongewenst is en men blijft streven naar materiële gelijkheid tussen vrouwen en mannen. 


\section{De inhoud van deze studie}

In het eerste deel van dit boek (hoofdstuk II) wordt een inventarisatie gegeven van de belangrijkste bepalingen betreffende het recht op behoorlijke huisvesting en worden de voornaamste organen en instanties besproken die een bijdrage hebben geleverd aan de ontwikkeling van dit mensenrecht sinds de Tweede Wereldoorlog. Het eerste internationale instrument waarin het recht wordt genoemd is de Universele Verklaring van de Rechten van de Mens. Het recht op huisvesting wordt genoemd als een van de onderdelen van het recht op een behoorlijke levensstandaard in Artikel 25(1). Na de Universele Verklaring werd het recht verankerd in verschillende internationale en regionale mensenrechtenverdragen, waarvan de belangrijkste het Internationaal Verdrag inzake Economische, Sociale, en Culturele Rechten is. In Artikel 11(1) van dit Verdrag, wordt huisvesting wederom genoemd in het kader van het recht op een behoorlijke levensstandaard. Dat dit artikel in de loop van de tijd is uitgegroeid tot de invloedrijkste bepaling op het gebied van huisvestingsrechten is te danken aan de aandacht en het werk dat aan dit recht is besteed door het toezichthoudende Comité; het VN Comité inzake Economische, Sociale en Culturele Rechten. Een groot deel van dit hoofdstuk is dan ook gewijd aan het werk van dit Comité, alsmede aan de rapporten van de twee Speciaal Rapporteurs die zich in de loop van de jaren met de huisvestingsproblematiek hebben beziggehouden. ${ }^{1}$

Al snel werd duidelijk dat het recht op behoorlijke huisvesting veel meer inhoudt dan het hebben van een dak boven het hoofd. Het gaat niet om huisvesting, maar om behoorlijke huisvesting. Vastgesteld werd dat in ieder geval de volgende elementen moeten zijn vervuld eer huisvesting 'behoorlijk' kan worden genoemd: zekerheid van beschikkingsrecht (security of tenure); beschikbaarheid van basisvoorzieningen, materialen en infrastructuur; betaalbaarheid; bewoonbaarheid; toegankelijkheid; locatie; en culturele geschiktheid. Vooral het eerste aspect is van groot belang. Het beschikkingsrecht heeft niet alleen betrekking op het eigendomsrecht, maar ook op pachtrecht, bezitsrecht en zelfs op gebruiksrecht. Indien iemand een van deze rechten op huisvesting bezit, dient zij/hij beschermd te worden tegen inbreuken van buitenaf, zowel door de overheid als door derden. Aangezien gedwongen uitzettingen (forced evictions) een van de meest voorkomende schendingen van het huisvestingsrecht is, heeft het Comite beslist dat illegale gedwongen illegale uitzettingen prima facie dienen te worden beschouwd als een schending van het recht op huisvesting.

Tegenover en voortvloeiende uit deze rechten, bestaan verplichtingen van de overheid welke ingedeeld kunnen worden in een drietal categorieën.

Allereerst dient de overheid het recht op huisvesting te respecteren. Dit houdt in dat burgers de kans moeten krijgen zelf in hun huisvesting te voorzien en dat de overheid

1 De eerste Speciaal Rapporteur, Justice Rajindar Sachar (1991-1995), werd door de VN Subcommissie ter Bevordering en Bescherming van de Rechten van de Mens uit zijn midden benoemd. De Subcommissie is een door de VN Commissie van de Rechten van de Mens ingesteld adviesorgaan bestaande uit onafhankelijke deskundigen. Het mandaat van deze Rapporteur was beperkt tot het doen van onderzoek en het rapporteren hierover. De tweede Speciaal Rapporteur, Miloon Kothari (2000-heden) werd aangesteld door de Commissie van de Rechten van de Mens zelf. Zijn mandaat is veel breder en bestrijkt ook het bezoeken van Staten waarvan vermoed wordt dat het recht op huisvesting wordt geschonden en het reageren op klachten en noodsituaties. 
zich dient te onthouden van acties en maatregelen die dat recht zouden kunnen dwarsbomen. In de eerste plaats vallen daar uiteraard gedwongen uitzettingen onder.

De tweede categorie verplichtingen valt onder de noemer beschermen. Dit houdt in dat de kwaliteit van de huisvestingssituatie van de bevolking in zijn geheel niet achteruit mag gaan en dat de overheid zijn burgers moet beschermen tegen inbreuken op het huisvestingsrecht door derden. Indien niet adequaat wordt opgetreden tegen structurele schendingen van het huisvestingsrecht door niet-statelijke actoren, kan de overheid, onder bepaalde omstandigheden, mede verantwoordelijk worden gehouden (due diligence).

Tenslotte heeft de overheid de plicht het recht op huisvesting te realiseren. Het uiteindelijke doel is dat alle burgers behoorlijk gehuisvest zijn. Dit doel hoeft niet meteen na toetreding tot het Verdrag inzake Economische, Sociale, en Culturele Rechten te worden bereikt, maar mag geleidelijk worden gerealiseerd. De staat komt een discretionaire bevoegdheid toe bij het maken van beleidskeuzes en daarbij mogen de economisch en financiële positie van de staat een rol spelen.

Door enkele staten wordt de juridische afdwingbaarheid van het recht op huisvesting in twijfel getrokken. Zij beschouwen behoorlijke huisvesting voor allen meer als een ideaal, dan als een recht. Daar staat tegenover dat de laatste jaren in zeker 50 staten het recht op huisvesting is opgenomen in de nationale wetgeving waardoor de afdwingbaarheid van (aspecten van) dit recht in een toenemend aantal zaken voor de nationale rechter aan de orde wordt gesteld. Op internationaal niveau zijn het Comité inzake Economische, Sociale en Culturele Rechten en de twee Speciaal Rapporteurs inzake huisvesting het erover eens dat op zijn minst een aantal aspecten van het recht op huisvesting juridisch afdwingbaar is.

Opvallend is dat gedurende enige tientallen jaren noch bij de vaststelling van huisvestingsrechten, noch bij het bepalen van overheidsverplichtingen, enige aandacht is besteed aan de verschillende maatschappelijke posities van vrouwen en mannen. Na de Wereldconferentie inzake de Rechten van de Mens in Wenen in 1993 groeide echter het besef dat gender een factor van belang is ten aanzien van de verwezenlijking van iemands mensenrechten. Sinds die tijd hebben geleidelijk aan steeds meer VN-organen aandacht aan de huisvestingsproblematiek van vrouwen besteed, met als hoogtepunt de rapporten van de VN Speciaal Rapporteur inzake het recht op behoorlijke huisvesting, Miloon Kothari, die uitdrukkelijk de opdracht heeft gekregen huisvestingsrechten van vrouwen te onderzoeken. $^{2}$

In het tweede deel van deze studie (hoofdstuk III) worden allerlei factoren onder de loep genomen die op de een of andere manier het recht op huisvesting van vrouwen beïnvloeden. Allereerst worden de meest voorkomende oorzaken van dakloosheid en slechte huisvesting onderzocht. De belangrijkste oorzaak is ongetwijfeld armoede. Het armoede probleem op de wereld is echter niet gender neutraal. Onder de armen zijn meer vrouwen dan mannen en de kloof tussen de seksen wordt alleen maar groter. Een verklaring voor dit fenomeen is dat vrouwen over het algemeen een achterstand hebben ten opzichte van mannen voor wat betreft opleiding, kansen op de arbeidsmarkt, de hoogte van hun inkomen en de omvang van hun bezit. Bovendien groeit en aantal alleen-moeder

2 Zie zijn rapporten inzake vrouwen en behoorlijke huisvesting: $U N$ doc. E/CN.4/2003/55 van 26 maart 2003 en $U N$ doc. E/VN.4/2005/43 van 25 februari 2005. 
gezinnen. ${ }^{3}$ Een belangrijke factor is de gender-bepaaldheid van werk. Ongeacht de culturele achtergrond of de mate van ontwikkeling van een samenleving, is het wereldwijd de gewoonte om vrouwen te belasten met onbetaalde zorgtaken. Dit heeft tot gevolg dat vrouwen minder tijd en energie overhouden voor betaalde arbeid. Bovendien speelt het een rol bij het bepalen van onderwijs- en beroepskeuzes van meisjes en jongens. Een goede opleiding wordt belangrijker geacht voor jongens aangezien wordt verwacht dat zij in hun latere leven een gezin moeten onderhouden, terwijl een opleiding voor meisjes overbodig wordt geacht gezien de verwachting dat er later een partner voor hen zal zorgen. Een en ander betekent dat het recht op huisvesting van meisjes en vrouwen veelal een afhankelijk recht is en dat zij autonomie ontberen.

Een tweede belangrijke oorzaak van dakloosheid is gedwongen uitzettingen. Hoewel deze oorzaak zowel voor vrouwen als mannen geldt, zijn de gevolgen niet gender-neutraal. Dakloze vrouwen zijn heel kwetsbaar en worden vaak het slachtoffer van (seksueel) misbruik. Ook rampen, of het nu natuurrampen of conflictsituaties betreft, hebben vaak gender bepaalde gevolgen. Het zijn vooral vrouwen die door natuurrampen worden getroffen, omdat zij gezien hun zwakke financiële positie gedwongen zijn in gebieden te wonen waarvan de veiligheid niet gegarandeerd kan worden maar waar de huisvestingskosten dientengevolge laag zijn. In conflictsituaties zijn het vooral vrouwen en kinderen die worden opgevangen in (vluchtelingen)kampen waar zij vaak ten prooi vallen aan (seksueel) geweld en uitbuiting.

Naast deze drie oorzaken die ook voor mannen gelden, bestaan er nog twee oorzaken voor dakloosheid en slechte huisvesting die uitsluitend voor vrouwen gelden: huiselijk geweld en weduwschap. Huiselijk geweld komt overal ter wereld in alle lagen van de bevolking voor. De zwakke economische en sociale positie van vrouwen verhinderd vaak dat zij zelfstandig huisvesting kunnen bekostigen, voor zover het al maatschappelijk geaccepteerd wordt dat vrouwen alleen wonen. Daardoor hebben veel vrouwen geen andere keus dan op straat te gaan leven als zij de mishandelingen thuis niet langer willen of kunnen accepteren.

Weduwschap is hoofdzakelijk in delen van Afrika en Azië een groot probleem. Vooral het culturele gebruik van exogamie is er debet aan dat vele weduwen na de dood van hun partner niet meer terug kunnen keren, noch aanspraak kunnen maken op het huis van hun vader. Als hun schoonfamilie weigert hen nog langer onderdak te verschaffen, staan zij op straat.

In dit deel van de studie is vervolgens uitgezocht of er verschil is tussen vrouwen en mannen ten aanzien van het hebben, c.q. het moeten ontberen van behoorlijke huisvesting. Gezien de traditionele, stereotiepe rolverdeling tussen vrouwen en mannen, draait het leven van de meeste vrouwen meer om het huis en het huishouden dan dat van mannen. Dit betekent dat slechte huisvesting, zoals het ontbreken van basisvoorzieningen als water, elektriciteit, vuilnisophaal en riolering, het leven van vrouwen moeilijker maakt aangezien zij degenen zijn van wie wordt verwacht dat zij huishoudelijke klussen als koken en wassen uitvoeren ongacht de huisvestingssituatie. Bovendien lopen vrouwen meer

3 Geschat wordt dat 30\% van alle gezinnen ter wereld eenoudergezinnen zijn terwijl in circa $90 \%$ van deze gezinnen die alleenstaande ouder vrouw is. Vrouwelijke gezinshoofden behoren tot de allerarmsten ter wereld. 
gezondheidsrisico's in slechte huisvestingsomstandigheden omdat zij bijvoorbeeld meer in contact komen met rookgassen als op hout, olie of mest gekookt moet worden, of omdat zij het meest in aanraking komen met vervuild water.

In het tweede deel van hoofdstuk III zijn rechten en regelingen onderzocht die van invloed zijn op de huisvestingssituatie van vrouwen, maar die niet direct het recht op huisvesting betreffen. Eerst is gekeken naar privaatrechtelijke regelingen, zoals het recht op eigendom en bezit, waaronder handelingsbekwaamheid van vrouwen en het huwelijksvermogensrecht. Andere thema's die aan bod komen zijn het erfrecht, het bestaan van verschillende juridische systemen van Personen- en Familierecht naast elkaar in één staat (Personal law systems), en het recht van vrije vestiging.

Vervolgens is aandacht besteed aan een aantal mensenrechten dat de realisering van het recht op huisvesting in belangrijke mate bepaalt. Achtereenvolgens worden het recht op politieke participatie, het recht op eigendom in publiekrechtelijke betekenis, het recht op privacy, het recht op arbeid en de menselijke waardigheid behandeld.

Aangezien in dit hoofdstuk telkens naar voren komt dat juridische ongelijkheid tussen vrouwen en mannen in het overgrote deel van de wereld niet het hoofdprobleem voor vrouwen is, maar dat veeleer structurele culturele patronen tot gevolg hebben dat vrouwen ten opzichte van mannen worden achtergesteld, is het laatste deel gewijd aan discriminatoire stereotiepe denkbeelden zoals deze worden gevormd door cultuur, religie en traditie.

In het derde deel van dit boek (hoofdstuk IV) wordt onderzocht of de bestaande regels en procedures adequaat zijn om het recht op huisvesting van vrouwen te verwezenlijken. Eerst wordt bekeken of het internationale recht, dat door feministische onderzoekers als androcentrisch wordt beschouwd, wel geschikt is om huisvestingsrechten van vrouwen te bevorderen en te beschermen. Bovendien wordt aandacht besteed aan de verschillende methoden om gender specifieke problemen van vrouwen voor het internationale voetlicht te brengen.

Vervolgens worden de basisprincipes van de rechten van de mens, het gelijkheidsbeginsel en het non-discriminatie beginsel nader beschouwd. Geconcludeerd wordt dat preciezere definitie en verduidelijking van sekse- en gender-discriminatie noodzakelijk is teneinde de juiste toepassing ervan op nationaal niveau te stimuleren.

$\mathrm{Na}$ dit meer algemene deel, wordt de aandacht gericht op de geschiktheid van de bestaande specifieke internationale bepalingen betreffende het recht op behoorlijke huisvesting, alsmede op de daaruit voortvloeiende interpretaties van dit recht door de bevoegde organen. Geconcludeerd kan worden, dat de bestaande bepalingen en de uitleg daarvan geen recht doen aan de specifieke omstandigheden waarin veel vrouwen verkeren. Met name de zeven reeds genoemde elementen die tezamen bepalen of huisvesting behoorlijk kan worden genoemd, houden onvoldoende rekening met verschillen die tussen vrouwen en mannen bestaan op grond van gender-bepaalde veronderstellingen. Het meest opvallend is wellicht dat uitsluitend is uitgegaan van schendingen van het recht op huisvesting van buitenaf, door de overheid of door derden, terwijl de voor vele vrouwen veel belangrijkere schendingen van binnenuit, door partner (huiselijke geweld) en (schoon)familie (gedwongen uitzettingen) niet in aanmerking zijn genomen. Bij het aspect 'betaalbaarheid' wordt geen rekening gehouden met het feit dat onbetaalde zorgtaken voornamelijk door vrouwen worden uitgevoerd en dat vrouwen meer dan mannen parttime of in het informele circuit 
werken, zodat 'redelijke' woonlasten veelal niet door vrouwen kunnen worden opgebracht. Ook de visie op andere elementen, zoals de beschikbaarheid van basisvoorzieningen, materialen en infrastructuur, de bewoonbaarheid en de toegankelijkheid, doet onvoldoende recht aan bestaande gender verschillen waardoor staten onvoldoende gestimuleerd worden een gender perspectief in hun huisvestingsbeleid op te nemen. Een groot probleem is dat het recht op huisvesting nog te vaak wordt beschouwd als een recht van een gezin of familie, waardoor voorbij wordt gegaan aan de bestaande ongelijkheid en afhankelijkheid binnen deze verbanden. Het is voor de bevordering en verbetering van de huisvestingssituatie van vrouwen dan ook noodzakelijk dat het recht op behoorlijke huisvesting uitdrukkelijk wordt beschouwd als een autonoom recht van ieder mens.

Aangezien in hoofdstuk III de conclusie was getrokken dat vooral culturele gebruiken en stereotiepe denkbeelden de verwezenlijking van het recht op huisvesting van vrouwen in de weg staan, is in de vijfde paragraaf van hoofdstuk IV onderzocht welke juridische mogelijkheden en verplichtingen bestaan om voor vrouwen schadelijke praktijken uit te bannen. Het recht op cultuur is een heikel onderwerp en wanneer de mensenrechten van vrouwen tegenover het recht van cultuur van een bevolkingsgroep komen te staan, delven de rechten van vrouwen vaak het onderspit. Vooral in staten met politiek sterke, op religie gebaseerde groepen, komt het regelmatig voor dat vrouwen die tot deze bevolkingsgroepen behoren geen aanspraak kunnen maken op de in de nationale wetgeving vastgelegde gelijkheid, maar vooral wat betreft personen- en familierechtelijke, alsmede erfrechtelijke kwesties, achtergesteld worden volgens traditionele gewoonten. Het is echter niet zo dat staten machteloos hoeven of moeten toezien. Met name Artikel 5 van het Vrouwenverdrag legt staten partijen de verplichting op schadelijke traditionele gebruiken af te schaffen en stereotiepe denkbeelden ten aanzien van maatschappelijke rollen van vrouwen en mannen te doorbreken. Naast de nationale overheid zijn er nog andere actoren die hierin een belangrijke rol kunnen spelen, zoals internationale gouvernementele organen en organisaties, niet-gouvernementele organisaties, en uiteindelijk vrouwen en mannen zelf. Bovendien kan worden gesteld dat de verplichting zoals vastgelegd in Artikel 5 van het Vrouwenverdrag ook voortvloeit uit andere, meer algemene mensenrechtenverdragen wanneer in de betreffende bepalingen inzake gelijkheid en non-discriminatie wordt geëist dat gelijkheid tussen de seksen niet alleen de iure, maar ook de facto bereikt dient te worden.

In paragraaf zes van hoofdstuk IV komt staatsaansprakelijkheid aan bod. In deze paragraaf wordt nader onderzocht wat de verplichtingen het recht op huisvesting te respecteren, te beschermen en te realiseren precies inhouden voor wat betreft de gender specifieke situatie van vrouwen. Vastgesteld wordt dat de verplichting het recht op huisvesting te respecteren wordt geschonden indien discriminatoire wetgeving wordt ingevoerd of gesauveerd en/of discriminatoire gewoonten en gebruiken in stand worden gehouden. Gezien de kwetsbare positie van dakloze vrouwen dient de overheid bijzonder alert te zijn in gevallen van onvermijdelijke gedwongen uitzettingen en ervoor te zorgen dat behoorlijke alternatieve huisvesting wordt aangeboden.

De verplichting het recht op huisvesting te beschermen dient ruim te worden opgevat. Hier valt niet alleen bescherming tegen inbreuken van buitenaf onder, maar ook van binnenuit. Met name in geval van structurele situaties van huiselijk geweld dient de overheid handelend op te treden en mishandelde vrouwen een veilige woonomgeving te 
garanderen. Tevens houdt deze verplichting in dat protectie wordt geboden tegen natuurgeweld als redelijkerwijs kan worden voorzien dat bepaalde locaties gevaarlijk zijn. Onbemiddelde vrouwen dient een goedkoop en veilig alternatief te worden geboden zodat zij zich niet hoeven te vestigen aan de voet van vulkanen, op door erosie aangetaste heuvels, op charlands, ${ }^{4}$ of op andere gevaarlijke locaties. Bovendien houdt deze verplichting in dat de huurprijzen onder controle worden gehouden en worden afgestemd op het veelal lagere inkomen van vrouwen.

De verplichting tot realisering van het recht op huisvesting tenslotte, zal onder andere zijn geschonden indien vrouwen in het algemeen niet in staat zijn op gelijke voet met mannen hun recht op huisvesting te verwezenlijken. Het is van belang dat goedkope, laagdrempelige en effectieve rechtsmiddelen beschikbaar worden gesteld aan vrouwen wier huisvestingsrecht is geschonden.

Aangezien de meeste schendingen van het huisvestingsrecht van vrouwen in de privésfeer gebeurt, door privé-personen, ligt het misschien niet voor de hand de staat hiervoor aansprakelijk te stellen. Toch is het redelijk de staat (mede) verantwoordelijk te houden indien er sprake is van structurele schendingen die op grote schaal plaatsvinden. Indien de staat hier niet of onvoldoende tegen optreedt, kan de staat aansprakelijk worden gehouden (due diligence) en treedt bij geleden schade de verplichting tot reparatie in.

Het laatste en meest omvangrijke deel van hoofdstuk IV gaat in op de verschillende mogelijkheden die met name VN-organen en -organisaties hebben om het recht op huisvesting van vrouwen nader te interpreteren en toezicht uit te oefenen op de naleving ervan op nationaal niveau.

Alhoewel sinds de jaren negentig enige progressie is geboekt, kan niet worden beweerd dat alle VN organen en organisaties voldoende doordrongen zijn van het besef dat zij een gender component dienen te integreren in hun toezichthoudende beleid en procedures. Maar al te vaak worden algemene, gender-neutrale commentaren gegeven op nationale situaties en wordt ten aanzien van de interpretatie van het recht voorbij gegaan aan voor vrouwen specifieke problemen of door culturele gebruiken opgeworpen hindernissen.

Het Comité dat toezicht houdt op de naleving van het Vrouwenverdrag, CEDAW, wordt bij de interpretatie van, en het toezicht op het recht op huisvesting van vrouwen belemmerd omdat dit recht niet als zodanig in het Vrouwenverdrag is opgenomen, maar slechts een onderdeel vormt van Artikel 14 waarin aandacht wordt gevraagd voor de problematiek van plattelandsvrouwen. CEDAW maakt bovendien te weinig gebruik van de haar ten dienste staande bepalingen en middelen om huisvesting van vrouwen in het algemeen aan de orde te stellen in de dialoog met staten partijen. Een oplossing zou kunnen worden gevonden in het aannemen van een Algemene Aanbeveling betreffende het recht op land en huisvesting. Dit zou het toezichthoudende werk meer structuur geven en het zou staten partijen in verband met de regelmatig terugkerende rapportageverplichting ertoe nopen regelmatig over de huisvestingsproblematiek van vrouwen na te denken en volgens de geldende richtlijnen te handelen.

Het Comité inzake Economische, Sociale en Culturele Rechten is zeer aarzelend gebleken ten aanzien van het doorvoeren van een gender-perspectief in zijn toezichthoudende werk. Tot op heden is nauwelijks aandacht besteed aan specifieke knelpunten

4 Eilandjes in het midden van de rivier die in geval van overstroming onder water komen te staan. 
die de verwezenlijking van het recht op huisvesting voor vrouwen bemoeilijken. Gezien het feit dat het Comité in het verleden twee Algemene Aanbevelingen heeft aangenomen inzake het recht op behoorlijke huisvesting, zou het gewenst zijn indien het Comité een aanvullende Aanbeveling zou aannemen betreffende het recht op behoorlijke huisvesting van vrouwen.

Ook de Comités die toezicht uitoefenen op het Internationaal Verdrag inzake de Uitbanning van alle Vormen van Rassendiscriminatie, het Verdrag inzake de Rechten van het Kind, en het Verdrag inzake de Rechten van Migranten en leden van hun gezin zouden meer gebruik kunnen en moeten maken van de hun geboden mogelijkheden om het recht op huisvesting van bepaalde groepen vrouwen en meisjes onder de aandacht te brengen.

Verder is er een aantal Speciaal Rapporteurs dat de mogelijkheid heeft het recht op huisvesting van vrouwen verder te bevorderen en commentaar te leveren op de naleving daarvan op nationaal niveau.

Tenslotte is een rol weggelegd voor niet-gouvernementele organisaties, zowel nationaal als internationaal. Zij hebben de mogelijkheid de bevolking over het recht op huisvesting van vrouwen te informeren, zij kunnen de afschaffing van bepaalde schadelijke gewoontes bevorderen, en zij kunnen bestaande wantoestanden an toezichthoudende organen rapporteren.

Deze studie heeft duidelijk gemaakt dat gender wel degelijk een belangrijke rol speelt als het om de verwezenlijking van het recht op huisvesting voor vrouwen gaat. Hoewel speciale aandacht voor de problemen van vrouwen geboden is, dienen zij niet als een kwetsbare groep te worden beschouwd. Vrouwen hebben niet zo zeer bescherming nodig maar hen moet de mogelijkheid geboden worden de hun toekomende rechten te realiseren. Het recht op huisvesting van vrouwen bestaat al. Wat er moet gebeuren is het afschaffen van discriminatoire regelgeving en traditionele gebruiken die de verwezenlijking van het recht op huisvesting van vrouwen in de weg staan. 


\section{BIBLIOGRAPHY}

\section{BOOKS AND ARTICLES}

Abdel Halim, Asma, 'Challenges to the Application of International Women's Human Rights in the Sudan', in: Cook, Rebecca (ed.), Human Rights of Women; National and International Perspectives, Pennsylvania University Press, Philadelphia, 1994, pp. 397-421

Acar, Feride, Gamze Ege, 'Women's Human Rights in Disaster Contexts: How can CEDAW help?', in: DAW, Environmental Management and the Mitigation of Natural Disasters: a Gender Perspective, Report of the Expert Group Meeting, EGM/NATDIS, Ankara, Turkey, November 2001

Advisory Council on International Affairs, Universality of Human Rights and Cultural Diversity, advisory report to the Dutch Ministers for Foreign Affairs, Defense and Development Cooperation, The Hague, 4 June 1998

Afkhami, Mahnaz, 'Cultural Relativism and Women's Human Rights', in: Askin, Kelly D., Dorean M. Koenig (eds.), Women and International Human Rights Law, Volume 2, Transnational Publishers, Inc., Ardsley, New York, 2000, pp. 479-486

Agarwal, Bina, A field of one's own; Gender and land rights in South Asia, Cambridge University Press, Cambridge, 1994

Akcar, Sengul, 'Grassroots Women's Collectives - Roles in Post-Disaster Effort: Potential for Sustainable Parnership and Good Governance (Lessons learned from the Marmara Earthquake in Turkey)', in: DAW, Environmental Management and the Mitigation of Natural Disasters: a Gender Perspective, Report of the Expert Group Meeting, EGM/NATDIS, Ankara, Turkey, November 2001

Allen, Tim and Alan Thomas (eds.), Poverty and Development into the 21st Century, The Open University in association with Oxford University Press, Oxford, 2000

Allen, Tim and Alan Thomas (eds.), Half a century of development, Open University in association with Oxford University Press, Oxford, 2000

Alma de Leon, Corazon, 'Integration of Public Administration and the Science of Disasters', in: DAW, Environmental Management and the Mitigation of Natural Disasters: a Gender Perspective, Report of the Expert Group Meeting, EGM/NATDIS, Ankara, Turkey, November 2001

Alston, Philip, The United Nations and Human Rights: A Critical Appraisal, Clarendon Press, Oxford, 1992

Alston, Philip, and James Crawford (eds.), The Future of UN Human Rights Treaty, Cambridge University Press, Cambridge, 2000

American Law Institute, Restatement (Third) The Foreign Relations Law of the United States, Vol. 2, 161, section 702: Customary International Law of Human Rights, 1987

An-Na im, Abdullahi Ahmed, 'State Responsibility Under International Human Rights Law to Change Religious and Customary Laws', in: Cook, Rebecca (ed.), Human Rights of Women; National and International Perspectives, Pennsylvania University Press, Philadelphia, 1994, pp. 167-188 
Bibliography

An-Na im, Abdullahi Ahmed (ed.), Human Rights in Cross-Cultural Perspectives; A Quest for Consensus, University of Pennsylvania Press, Philadelphia, 1992

Arenas Ferriz, Angeles, 'The Relevance of Considering a Gender Perspective in Damage Assessment and Recovery Strategies. A Case Study in El Salvador, Central America', in: DAW, Environmental Management and the Mitigation of Natural Disasters: a Gender Perspective, Report of the Expert Group Meeting, EGM/NATDIS, Ankara, Turkey, November 2001

Arrey, Florence Rita, 'Legislative and Judicial Treatment of Family Relations in Cameroon', in: Bringing International Human Rights Home; Judicial Colloquium on the Domestic Application of the Convention on the Elimination of All Forms of Discrimination against Women and the Convention on the Rights of the Child, United Nations, New York, 2000, pp. 138-140

Askin, Kelly D., Dorean M. Koenig (eds.), Women and International Human Rights Law, Volume 1, Transnational Publishers, Inc., Ardsley, New York, 1999

Askin, Kelly D., Dorean M. Koenig (eds.), Women and International Human Rights Law, Volume 2, Transnational Publishers, Inc., Ardsley, New York, 2000

Bagshaw, Simon, 'Property restitution for internally displaced persons: development in the normative framework', in: Leckie, Scott (ed.), Returning Home: Housing and Property Restitution Rights of Refugees and Displaced Persons, Transnational Publishers, Ardsley, 2003, pp. 375-392

Banning, Theo van, The Human Right to Property, School of Human Rights Research Series, Volume 14, Intersentia, Antwerpen, Oxford, New York, 2002

Batelaan, Pieter, Fons Coomans, The International Basis for Intercultural Education Including Anti-Racist and Human Rights Education, International Association for Intercultural Education, 1995

Bell, Diane, 'Considering Gender; Are Human Rights for Women, Too? An Australian Case', in: An-Na'im, Abdullahi Ahmed (ed.), Human Rights in Cross-Cultural Perspectives; A Quest for Consensus, University of Pennsylvania Press, Philadelphia, 1992, pp. 339-362

Beyani, Chaloka, 'Towards a More Effective Guarantee of Women's Rights in the African Human Rights System', in: Cook, Rebecca (ed.), Human Rights of Women; National and International Perspectives, Pennsylvania University Press, Philadelphia, 1994, pp. 285-306

Bijnsdorp, Mireille, 'The Strength of the Optional Protocol to the United Nations Women's Convention', in: Netherlands Quarterly of Human Rights, Vol. 18, No. 3, August 2000, pp. 329-355

Boerefijn, Ineke, Mignon M. van der Liet, Senders, Titia Loenen, (eds.), Het voorkomen en bestrijden van geweld tegen vrouwen; Een verdiepend onderzoek naar het Nederlandse beleid in het licht van de verplichtingen die voortvloeien uit het Vrouwenverdrag, Ministerie van Sociale Zaken en Werkgelegenheid, Den Haag, juli 2000

Boerefijn, Ineke, et al (eds.), Temporary Special Measures; Accelerating de facto equality of women under article 4(1) UN Convention on the Elimination of All Forms of Discrimination Against Women, Intersentia, Antwerpen/Oxford/New York, 2003

Boerefijn, Ineke, 'Domestic violence against women in international law', in: Westendorp, Ingrid and Ria Wolleswinkel (eds.), Violence in the domestic sphere, Intersentia, Antwerp/Oxford, 2005, pp. 35-58 
Boven, Theo van, "“Political” and "Legal” Control Mechanisms: Their Competition and Coexistence', in: Human Rights in Perspective; A Global Assessment, Oxford, 1992, pp. 36-60

Boven, Theo van, 'General Course on Human Rights', in: European University Institute, Florence, Collected Courses of the Academy of European Law; The Protection of Human Rights in Europe, Volume IV, Book 2, Martinus Nijhoff Publishers, The Hague/London/ Boston, 1993, pp. 9-106

Boven, Theo van, 'The International System of Human Rights: an Overview', in: United Nations, Manual on Human Rights Reporting, United Nations, Geneva, 1997, pp. 3-18

Boven, Theo van, Cees Flinterman, Ingrid Westendorp (eds.), The Maastricht Guidelines on Violations of Economic, Social and Cultural Rights, SIM Special No. 20, SIM, Utrecht, 1998

Boven, Theo van, Cees Flinterman, Ingrid Westendorp (eds.), Human Rights, Maastricht Perspectives, Maastricht Centre for Human Rights, Maastricht University, 1999

Boven, Theo van, 'Common Problems Linked to Remedies Available to Victims of Racial Discrimination', in: UNESCO, United to Combat: Racism; Dedicated to the World Conference against Racism, Racial Discrimination, Xenophobia and Related Intolerance, UNESCO, Paris, 2001, pp. 91-104

Brems, Eva, 'Enemies or Allies? Feminism and Cultural relativism as Dissident voices in Human Rights Discourse', in: Human Rights Quarterly, Vol. 19, 1997, pp. 136-164

Brownlie, Ian, Principles of Public International Law, 5th edition, Clarendon Press, Oxford, 1998

Bunch, Ch., 'Women's Rights as Human Rights: Toward a Re-Vision of Human Rights', in: Human Rights Quarterly, Vol. 12, No. 4, November 1990, pp. 486-498

Burgers, H., 'The right to cultural identity', in: UNESCO, Human Rights in a Pluralist World; Individuals and Collectivities, UNESCO, 1990, pp. 251-253

Burnet, Jennie, E. and the Rwanda Initiative for Sustainable Development, 'Culture, Practice and Law: Women's Access to Land in Rwanda', in: Muthoni Wanyeki, L. (ed.), Women and Land in Africa; Culture, Religion and Realizing Women's Rights, Zed Boods, New York, 2003, pp. 176-206

Butegwa, F., 'Using the African Charter on Human and Peoples' Rights to Secure Women's Access to Land in Africa', in: Cook, Rebecca (ed.), Human Rights of Women; National and International Perspectives, Pennsylvania University Press, Philadelphia, 1994, pp. 495-514

Byrnes, Andrew, 'Using Law and Procedures to Advance Women's Human Rights', in: Askin, Kelly D., Dorean M. Koenig (eds.), Women and International Human Rights Law, Volume 2, Transnational Publishers, Inc., Ardsley, New York, 2000, pp. 79-118

Çağatay, Nilüfer, Gender and Poverty, Working Paper Series, UNDP, Social Development and Poverty Elimination Division, May 1998

Cartwright, Dame Silvia, 'The Committee on the Elimination of Discrimination Against Women’, in: Askin, Kelly D., Dorean M. Koenig (eds.), Women and International Human Rights Law, Volume 2, Transnational Publishers, Inc., Ardsley, New York, 2000, pp. 165-181

Cassese, Antonio, International Law, Oxford University Press, Oxford, 2001 
Bibliography

Córdova Plaza, Rosío, 'Gender roles, inheritance patterns, and female access to land in an ejidal community in Veracruz, México', in: Zoomers, Annelies and Gemma van der Haar (eds.), Current Land Policy in Latin America: Regulating Land Tenure under NeoLiberalism, Royal Tropical Institute, Amsterdam, 2000, pp. 161-173

Cerna, Christina, M. and Jennifer C. Wallace, 'Women and Culture', in: Askin, Kelly D., Dorean M. Koenig (eds.), Women and International Human Rights Law, Volume 1, Transnational Publishers, Inc., Ardsley, New York, 1999, pp. 623-650

Charlesworth, H., C. Chinkin, S. Wright, 'Feminist Approaches to International Law', in: American Journal of International Law, Vol. 85, 1991, pp. 613-645

Charlesworth, Hilaray and Christine Chinkin, The boundaries of international law; A feminist analysis, Manchester University Press, Manchester, 2000

Charlesworth, Hilary, 'Alienating Oscar? Feminist analysis of international law', in: Dallmeyer, Dorinda G. (ed.), Reconceiving Reality: Women and International Law, Studies in Transnational Legal Policy, No. 25, ASIL, Washington, D.C., 1993, pp. 1-18

Chhachhi, Amrita, The State, Religious Fundamentalism and Women: Trends in South Asia, Working Paper, Sub-series on Women, History and Development: Themes and Issues, No. 8, Institute of Social Studies, The Hague, September 1988

Chowdhury, Mahjabeen, 'Women's Technological Innovations and Adaptations for Disaster Mitigation: A Case Study of Charlands in Bangladesh', in: DAW, Environmental Management and the Mitigation of Natural Disasters: a Gender Perspective, Report of the Expert Group Meeting, EGM/NATDIS, Ankara, Turkey, November 2001

Chowdhury, Najma and Barbara J. Nelson, 'Redefining Politics: Patterns of Women's Political Engagement from a Global Perspective', in: Nelson, Barbara and Najma Chowdhury, Women and Politics Worldwide, Yale University, New Haven, 1994, pp. 3-24

Christopher, Karen et al., Gender Inequality in Poverty in Affluent Nations: The Role of Single Motherhood and the State, Working Paper \#00-12, Center for Research on Child Wellbeing, 28 January 2000

Clapham, Andrew, 'UN Human Rights Reporting Procedures: An NGO Perspective', in: Alston, Philip, and James Crawford (eds.), The Future of UN Human Rights Treaty, Cambridge University Press, Cambridge, 2000, pp. 175-200

COHRE, Global Survey on Forced Evictions, Violations of Human Rights, No. 9, April 2003

COHRE, Women and Housing Rights, Sources No. 5, COHRE, Geneva, September 2000

Cook, R.J., 'State Responsibility for Violations of Women's Human Rights', in: Harvard Human Rights Journal, Vol. 7, Spring 1994, pp. 125-175

Cook, R.J., 'Women's International Human Rights Law: The Way Forward', in: Cook, Rebecca (ed.), Human Rights of Women; National and International Perspectives, Pennsylvania University Press, Philadelphia, 1994, pp. 3-36

Cook, Rebecca (ed.), Human Rights of Women; National and International Perspectives, Pennsylvania University Press, Philadelphia, 1994

Cook, Rebecca, J., 'Accountability in International Law for Violations of Women's Rights by Non-state Actors', in: Dallmeyer, Dorinda, G., Reconceiving Reality: Women and International Law, The American Society of International Law, Washington, D.C., 1993, pp. 93-116

Cook, Rebecca, J., 'State Accountability Under the Convention on the Elimination of All Forms of Discrimination Against Women', in: Cook, Rebecca (ed.), Human Rights of Women; National and International Perspectives, Pennsylvania University Press, Philadelphia, 1994, pp. 228-256 
Coomans, Fons, De internationale bescherming van het recht op Onderwijs, Stichting NJCM-Boekerij, Leiden, 1992

Coomans, Fons, Fred Grünfeld, Ingrid Westendorp and Jan Willems (eds.), Rendering Justice to the Vulnerable, Liber Amicorum in Honour of Theo van Boven, Kluwer Law International, The Hague/London/Boston, 2000

Coomans, Fons, 'Reviewing Implementation of Social and Economic Rights: An Assessment of the "Reasonableness" Test as Developed by the South African Constitutional Court', in: Zeitschrift für ausländisches öffentliches Recht unde Völkerrecht, Heidelberg Journal of International Law, Band 65, Nr. 1, Verlag W. Kohlhammer, 2005, pp. 167-196

Coomaraswamy, R., 'To Bellow like a Cow: Women, Ethnicity, and the Discourse of Rights', in: Cook, Rebecca (ed.), Human Rights of Women; National and International Perspectives, Pennsylvania University Press, Philadelphia, 1994, pp. 39-57

Coomaraswamy, R., Reinventing International Law: Women's Rights as Human Rights in the International Community, Edward A. Smith Lecture in the Human Rights Program, Harvard Law School, Cambridge, 1997

Coomaraswamy, R. \& L.M. Kois, 'Violence Against Women', in: Askin, Kelly D., Dorean M. Koenig (eds.), Women and International Human Rights Law, Volume 1, Transnational Publishers, Inc., Ardsley, New York, 1999, pp. 177-218

Copelon, R., 'Intimate Terror: Understanding Domestic Violence as Torture', in: Cook, Rebecca (ed.), Human Rights of Women; National and International Perspectives, Pennsylvania University Press, Philadelphia, 1994, pp. 116-152

Cossman, Brenda, 'Equality, Difference and Feminist Legal Theory', in: Feminist Legal Theory, Speical Issue, The Thatched Patio, Vol. 3, No. 4, International Centre for Ethnic Studies, July/August 1990, pp. 24-33

Craven, M.C.R., The International Covenant on Economic, Social and Cultural Rights; A Perspective on its Development, Oxford University Press, New York, 1995

Crawford, James, The International Law Commission's Articles on State Responsibility; Introduction, Text and Commentaries, Cambridge University Press, Cambridge, 2002

Dallmeyer, Dorinda G. (ed.), Reconceiving Reality: Women and International Law, Studies in Transnational Legal Policy, No. 25, The American Society of International Law, Washington, D.C., 1993

Dankelman, Irene, 'Gender and Environment: Lessons to Learn', in: DAW, Environmental Management and the Mitigation of Natural Disasters: a Gender Perspective, Report of the Expert Group Meeting, EGM/NATDIS, Ankara, Turkey, November 2001

DAW, Environmental Management and the Mitigation of Natural Disasters: a Gender Perspective, Report of the Expert Group Meeting, EGM/NATDIS, Ankara, Turkey, November 2001

DAW, Women 2000: Woman and decision-making, United Nations, October 1997

Deere, Carmen Diana and Magdalena León, 'Neo-liberal agrarian legislation, gender equality, and indigenous rights: the impact of new social movements', in: Zoomers, Annelies and Gemma van der Haar (eds.), Current Land Policy in Latin America: Regulating Land Tenure under Neo-Liberalism, Royal Tropical Institute, Amsterdam, 2000, pp. 75-92 
Desai, Sonalde, 'Engendering Population Policy', in: Krishnaraj, M., R. Sudarshan, A. Shariff (eds.), Gender, Population and Development, Oxford University Press, Delhi, 1998

Detrick, Sharon, A Commentary on the United Nations Convention on the Rights of the Child, Kluwer Law International, The Hague, 1999

Dixon, Martin, Textbook on International Law, 5th edition, Oxford University Press, Oxford/New York, 2005

Donders, Yvonne, M., Towards a Right to Cultural Identity?, Intersentia, Antwerpen, 2002

Donnelly, Jack, Universal Human Rights in theory and Practice, Cornell University Press, Ithaca and London, 1989

Drzemczewski, Andrew, The right to respect for private and family life, home and correspondence; as guaranteed by Article 8 of the European Convention on Human Rights, Council of Europe, Strasbourg, 1984

Dworkin, Ronald, Sovereign Virtue; The Theory and Practice of Equality, Harvard University Press, Cambridge, Massachusetts, 2000

Eide, A., C. Krause, and A Rosas (eds.), Economic, Social and Cultural Rights; A Textbook, Dordrecht/Boston/London, 1995

Engle, Karen, 'After the Collapse of the Public/Private Distinction: Strategizing Women's Rights', in: Dallmeyer, Dorinda, G., Reconceiving Reality: Women and International Law, The American Society of International Law, Washington, D.C., 1993, pp. 143-156

Equality now, Words and Deeds; Holding Governments Accountable in the Bijing +10 Review Process, Women's Action 16.5, Update March 2004

Etzioni, Amitai, The Limits of Privacy, Basic Books, New York, 1999

Falk, Richard, 'Cultural Foundations for the International Protection of Human Rights', in: An-Na im, Abdullahi Ahmed (ed.), Human Rights in Cross-Cultural Perspectives; A Quest for Consensus, University of Pennsylvania Press, Philadelphia, 1992, pp. 44-64

Farha, Leilani, 'Women and Housing', in: Askin, Kelly D., Dorean M. Koenig (eds.), Women and International Human Rights Law, Volume 1, Transnational Publishers, Inc., Ardsley, New York, 1999, pp. 483-532

Fitzpatrick, J., 'The Use of International Human Rights Norms to Combat: Violence Against Women', in: Cook, Rebecca (ed.), Human Rights of Women; National and International Perspectives, Pennsylvania University Press, Philadelphia, 1994, pp. 532-572

Fordham, Maureen, 'Challenging Boundaries: A Gender Perspective on Early Warning in Disaster and Environmental Management', in: DAW, Environmental Management and the Mitigation of Natural Disasters: a Gender Perspective, Report of the Expert Group Meeting, EGM/NATDIS, Ankara, Turkey, November 2001

Fredman, Sandra, 'Beyond the Dichotomy of Formal and Substantive Equality: Towards a New Definition of Equal Rights', in: Boerefijn, Ineke, et al (eds.), Temporary Special Measures; Accelerating de facto equality of women under article 4(1) UN Convention on the Elimination of All Forms of Discrimination Against Women, Intersentia, Antwerpen/ Oxford/New York, 2003, pp. 111-118

Fullinwider, Robert K. and Claudia Mills (eds.), The Moral Foundation of Civil Rights, Rowman and Littlefield, Maryland, 1986 
Galal Saad, Samia, 'Environmental Management and Natural Disasters Mitigation: Middle Eastern Gender Perspective', in: DAW, Environmental Management and the Mitigation of Natural Disasters: a Gender Perspective, Report of the Expert Group Meeting, EGM/NATDIS, Ankara, Turkey, November 2001

Gold, J., 'Strengthening the soft international law of exchange arrangements', in: American Journal of International Law, Vol. 77, No. 3, July 1983, pp. 443-489

Graham, Angus, 'Gender Mainstreaming Guidelines for Disaster Management Programmes, A Principled Socio-Economic and Gender Analysis (SEAGA) Approach', in: DAW, Environmental Management and the Mitigation of Natural Disasters: a Gender Perspective, Report of the Expert Group Meeting, EGM/NATDIS, Ankara, Turkey, November 2001

Haeri, Shahla, 'Obedience versus Autonomy: Women and Fundamentalism in Iran and Pakistan', in: Marty, Martin E. and R. Scott Appleby (eds.), Fundamentalisms and Society; Reclaiming the Sciences, the Family and Education, Volume 2, The University of Chicago Press, Chicago and London, 1993, pp. 181-213

Hamilton, Carolyn, Kate Standley (eds.), Family Law in Europe, Butterworths, London, Dublin, Edinburgh, 1995

Hardacre, Helen, 'The Impact of Fundamentalisms on Women, the Family, and Interpersonal Relations', in: Marty, Martin E. and R. Scott Appleby (eds.), Fundamentalisms and Society; Reclaiming the Sciences, the Family and Education, Volume 2, The University of Chicago Press, Chicago and London, 1993, pp. 129-150

Hardacre, Helen, 'The New Religions, Family, and Society in Japan', in: Marty, Martin E. and R. Scott Appleby (eds.), Fundamentalisms and Society; Reclaiming the Sciences, the Family and Education, Volume 2, The University of Chicago Press, Chicago and London, 1993, pp. 294-312

Hassan, Yasmeen, 'Stove Burning, Acid Throwing, and Honor Killings', in: Askin, Kelly D., Dorean M. Koenig (eds.), Women and International Human Rights Law, Volume 2, Transnational Publishers, Inc., Ardsley, New York, 2000, pp. 587-611

Hatem, Mervat, 'The Paradoxes of State Feminism in Egypt', in: Nelson, Barbara and Najma Chowdhury, Women and Politics Worldwide, Yale University, New Haven, 1994, pp. 226-242

Henig, Ruth and Simon Henig, Women and Political Power, Europe since 1945, Routledge, London and New York, 2001

Heringa, Aalt Willem, Joyce Hes, Liesbeth Lijnzaad, Het Vrouwenverdrag: een beeld van een verdrag ..., Maklu Uitgevers, Antwerpen - Apeldoorn, 1994

Hernandez Truyol, Berta Esperanza, 'Human Rights through a Gendered Lens: Emergence, Evolution, Revolution', in: Askin, Kelly D., Dorean M. Koenig (eds.), Women and International Human Rights Law, Volume 1, Transnational Publishers, Inc., Ardsley, New York, 1999, pp. 3-39

Hevener, N., 'An Analysis of Gender Based Treaty Law: Contemporary Developments in Historical Perspective', in: Human Rights Quarterly, Vol. 8, No. 1, February 1986, pp. $70-88$

Hewitt, Tom, 'Half a century of development', in: Allen, Tim and Alan Thomas (eds.), Poverty and Development into the 21st Century, The Open University in association with Oxford University Press, Oxford, 2000, pp. 289-308

Higgins, R., Problems \& Process; International Law and How We Use It, Oxford, 1994 
Holtmaat, Rikki, Naar ander recht en beleid; De betekenis van artikel 5 a VN-Vrouwenverdrag voor het uitbannen van structurele genderdiscriminatie, Ministerie van Sociale Zaken en Werkgelegenheid, Den Haag, juli 2004

Hossain, Sara, 'Equality in the Home: Women's Rights and Personal Laws in South Asia', in: Cook, Rebecca (ed.), Human Rights of Women; National and International Perspectives, Pennsylvania University Press, Philadelphia, 1994, pp. 465-494

Howland, Courtney, W., 'Women and Religious Fundamentalism', in: Askin, Kelly D., Dorean M. Koenig (eds.), Women and International Human Rights Law, Volume 1, Transnational Publishers, Inc., Ardsley, New York, 1999, pp. 533-622

Human Rights Watch Publications, Sacrificing Women to Save the Family; Domestic Violence in Uzbekistan, Vol. 13, No. 4 (D), July 2001

Human Rights Watch Publications, Seeking Protection: Addressing Sexual and Domestic Violence in Tanzania's Refugee Camps, October 2000

Ilumoka, Adetoun O., 'African Women's Economic, Social and Cultural Rights', in: Cook, Rebecca (ed.), Human Rights of Women; National and International Perspectives, Pennsylvania University Press, Philadelphia, 1994, pp. 307-325

International Helsinki Federation for Human Rights, Women 2000; An Investigation into the Status of Women's Rights in Central and South-Eastern Europe and the Newly Independent States, Agens-Werk, Geyer + Reisser, Vienna, 2000

International Law Commission, Draft articles on Responsibility of States for internationally wrongful acts, adopted by the International Law Commission at: its fifty-third session, November 2001

International League for Human Rights, Combating Violence Against Women, Report of a Conference Sponsored in Collaboration with the International Women's Rights Action Watch, International League for Human Rights, New York, March 1993

IWRAW, Culture, Custom and Women's Human Rights: CEDAW Convention Article Five, United Nations, 1999

Jacobson, Roberta, 'The Committee on the Elimination of Discrimination against Women', in: Alson, Philip, The United Nations and Human Rights: A Critical Appraisal, Clarendon Press, Oxford, 1992, pp. 444-472

Janis, M.W., 'The European Court of Human Rights', in: Janis, M.W. (ed.), International Courts for the Twenty-First Century, Kluwer Academic Publishers, 1992, pp. 105-116

Kambel, Ellen-Rose, 'Mijn land of ons land', in: Nemesis, Nr. 5, september/oktober 1999, pp. 144-151

Kamminga, Menno, T., Inter-State Accountability for Violations of Human Rights, Rijksuniversiteit Leiden, 1990

Kamminga, Menno, T., 'Europees Hof voor de Rechten van de Mens, 18 juni 2002, Öneryildiz t. Turkije', in: Tijdschrift voor Milieu en Recht, Nr. 13, 2005

Kälin, Walter, Protection of Internally Displaced Persons in Situations of Natural Disaster; A Working Visit to Asia, United Nations, 27 February to 5 March 2005

Knop, Karen (ed.), Gender and Human Rights, Oxford University Press, Oxford, 2004

Krishnaraj, M., R. Sudarshan, A. Shariff (eds.), Gender, Population and Development, Oxford University Press, Delhi, 1998 
Lacey, Nicola, 'Feminist Legal Theory and the Rights of Women', in: Knop, Karen (ed.), Gender and Human Rights, Oxford University Press, Oxford, 2004, pp. 13-56

Leckie, S., 'The Right to Housing', in: Eide, A., C. Krause, and A Rosas (eds.), Economic, Social and Cultural Rights; A Textbook, Dordrecht/Boston/London, 1995, pp. 107-124

Leckie, S., Towards an International Convention on Housing Rights: Options at: Habitat: II, Issue Papers on World Conferences, No. 4, American Society of International Law, December 1994

Leckie, Scott (ed.), Returning Home: Housing and Property Restitution Rights of Refugees and Displaced Persons, Transnational Publishers, Ardsley, 2003

Lijnzaad, Liesbeth, Reservations to UN-Human Rights Treaties; Ratify and Ruin?, Martinus Nijhoff, Dordrecht/Boston/London, 1994, pp. 362-364

Loenen, Titia, 'Artikel 1: Het discriminatiebegrip', in: Heringa, Aalt Willem, Joyce Hes, Liesbeth Lijnzaad, Het Vrouwenverdrag: een beeld van een verdrag ..., Maklu Uitgevers, Antwerpen - Apeldoorn, 1994, pp. 1-13

Loenen, Titia, 'Rethinking Sex Equality as a Human Right', in: Netherlands Quarterly of Human Rights, Vol. 3, 1994, pp. 253-270

Loenen, Titia, Het gelijkheidsbeginsel, Ars Aequi Libri, Nijmegen, 1998

Maarseveen, Henc van, 'Internationaal vrouwenrecht. Een afzonderlijk rechtsgebied?', in: Maarseveen, H. van, D. Pessers, M.J. Gunning (eds.), Internationaal recht en vrouwen, Deel 1 Commentaren, Tjeenk-Willink, Zwolle, 1987, pp. 69-80

MacKinnon, Catherine, A., 'Difference and Dominance: On Sex Discrimination', in: Fullinwider, Robert K. and Claudia Mills (eds.), The Moral Foundation of Civil Rights, Rowman and Littlefield, Maryland, 1986, pp. 539-543

Malanczuk, P., Akehurst's Modern Introduction to International Law, 7th rev. ed., Routledge, 1997

Maldonado, Jorge, E., 'Building "Fundamentalism" from the Family in Latin America', in: Marty, Martin E. and R. Scott Appleby (eds.), Fundamentalisms and Society; Reclaiming the Sciences, the Family and Education, Volume 2, The University of Chicago Press, Chicago and London, 1993, pp. 214-239

Martens, Kerstin, 'Professionalised Representation of Human Rights NGOs to the United Nations', in: The International Journal of Human Rights, Vol. 10, No. 1, March 2006, pp. 19-30

Marty, Martin E. and R. Scott Appleby (eds.), Fundamantalism and Society; Reclaiming the Sciences, the Family and Education, Volume 2, The University of Chicago Press, Chicago and London, 1993

McGrew, Anthony, 'Sustainable globalization? The global politics of development and exclusion in the new world order', in: Allen, Tim and Alan Thomas (eds.), Poverty and Development into the 21st Century, The Open University in association with Oxford University Press, Oxford, 2000, pp. 345-364

Medina, Cecilia, 'Towards a More Effective Guarantee of the Enjoyment of Human Rights by Women in the Inter-American System', in: Cook, Rebecca (ed.), Human Rights of Women; National and International Perspectives, Pennsylvania University Press, Philadelphia, 1994, pp. 257-284

Meron, Theodor, Human Rights and Humanitarian Norms as Customary Law, Clarendon Press, Oxford, 1989 
Bibliography

Meron, Theodor, 'The Continuing Role of Custom in the Formation of International Humanitarian Law', in: The American Journal of International Law, Vol. 90:235, 1996, pp. 238-249

Michael Quinn, D., 'Plural Marriage and Mormon Fundamentalism', in: Marty, Martin E. and R. Scott Appleby (eds.), Fundamentalisms and Society; Reclaiming the Sciences, the Family and Education, Volume 2, The University of Chicago Press, Chicago and London, 1993, pp. 240-293

Mikayelyan, Armine, 'Earthquake Mitigation from a Gender Perspective in Armenia', in: DAW, Environmental Management and the Mitigation of Natural Disasters: a Gender Perspective, Report of the Expert Group Meeting, EGM/NATDIS, Ankara, Turkey, November 2001

Ministerie van Justitie, Projectbureau 'Huiselijk geweld', Project voorkomen en bestrijden 'huiselijk geweld', plan van aanpak, Den Haag, 14 februari 2001

Minow, Martha, Making All the Difference; Inclusion, Exclusion, and American Law, Cornell University Press, Ithaca and London, 1990

Mourik, M.J.A. van, Nieuw Erfrecht, Studiepockets Privaatrecht 59, derde druk, Kluwer, Deventer, 2002

Muthoni Wanyeki, L. (ed.), Women and Land in Africa; Culture, Religion and Realizing Women's Rights, Zed Boods, New York, 2003

Nelson, Barbara and Najma Chowdhury, Women and Politics Worldwide, Yale University, New Haven, 1994

Office of the Special Adviser on Gender Issues and Advancement of Women, Gender Mainstreaming: An Overview, United Nations, New York, 2002

Olsen, Frances, 'International Law: Feminist Critiques of the Public/Private Distinction', in: Dallmeyer, Dorinda, G., Reconceiving Reality: Women and International Law, The American Society of International Law, Washington, D.C., 1993, pp. 157-170

Oosterveld, Valerie, L., 'Women and Employment', in: Askin, Kelly D., Dorean M. Koenig (eds.), Women and International Human Rights Law, Volume 1, Transnational Publishers, Inc., Ardsley, New York, 1999, pp. 367-402

Orstad, Lynn, 'Tools for Change: Emergency Management for Women', in: $D A W$, Environmental Management and the Mitigation of Natural Disasters: a Gender Perspective, Report of the Expert Group Meeting, EGM/NATDIS, Ankara, Turkey, November 2001

Ouinsou, Conceptia, 'Inheritance Rights or Women's Role in Succession in the Customary Law of Benin', in: Bringing International Human Rights Home, Judicial Colloquium on the Domestic Application of the Convention on the Elimination of All Forms of Discrimination against Women and the Convention on the Rights of the Child, United Nations, New York, 2000, pp. 129-134

Packer, Corinne, Using Human Rights to Change Tradition; Traditional Practices Harmful to Women's Reproductive Health in sub-Saharan Africa, Intersentia, Antwerpen/Oxford/New York, 2002

Pearson, Ruth, 'Rethinking Gender Matters in Development', in: Allen, Tim and Alan Thomas (eds.), Poverty and Development into the 21 st Century, The Open University in association with Oxford University Press, Oxford, 2000, pp. 383-402 
Bibliography

Pojman, Louis, P. and Robert Wetmoreland (eds.), Equality; Selected Readings, Oxford University Press, New York/Oxford, 1997

Rahman, Atiur, Ismail Hossain, Birds in a larger cage, Social Watch, 2001

Rao, P.K., Sustinable Development, Economics and Policy, Center for Development Research Princeton, N.J. Blackwell, Malden, 1999

Reanda, Laura, 'The Commission on the Status of Women', in: Alson, Philip, The United Nations and Human Rights: A Critical Appraisal, Clarendon Press, Oxford, 1992, pp. 265-303

Rehof, Lars, Adam, Guide to the Travaux Préparatoires of the United Nations Convention on the Elimination of All Forms of Discrimination Against Women, Martinus Nijhoff Publishers, Dordrecht/Boston/London, 1993

Report of the Sub-Regional High Level Policy Seminar on Gender Equity, Social and Economic Empowerment of Women, Lusaka, Zambia, 6-8 April 1998

Robertson, A., and J.G. Merrills, Human Rights in the World; An introduction to the study of the international protection of human rights, third edition, Manchester University Press, Manchester, 1992

Romany, Celina, 'State Responsibility Goes Private', in: Cook, Rebecca (ed.), Human Rights of Women; National and International Perspectives, Pennsylvania University Press, Philadelphia, 1994, pp. 85-115

Römkens, Renée, 'Geweld in de Huiselijke Sfeer', in: Boerefijn, Ineke, Mignon M. van der Liet, Senders, Titia Loenen, (eds.), Het voorkomen en bestrijden van geweld tegen vrouwen; Een verdiepend onderzoek naar het Nederlandse beleid in het licht van de verplichtingen die voortvloeien uit het Vrouwenverdrag, Ministerie van Sociale Zaken en Werkgelegenheid, Den Haag, juli 2000, Hoofdstuk 4

Roth, Kenneth, 'Domestic Violence as an International Human Rights Issue', in: Cook, Rebecca (ed.), Human Rights of Women; National and International Perspectives, Pennsylvania University Press, Philadelphia, 1994, pp. 326-339

Rugh, Andrea, B., 'Reshaping Personal Relations in Egypt', in: Marty, Martin E. and R. Scott Appleby (eds.), Fundamentalisms and Society; Reclaiming the Sciences, the Family and Education, Volume 2, The University of Chicago Press, Chicago and London, 1993, pp. 151-180

Rutten, Susanne, Erven naar Marokkaans recht; Aspecten van Nederlands internationaal privaatrecht bij de toepasselijkheid van Marokkaans erfrecht, Intersentia, Antwerpen, 1997

Sachar, Rajindar, The right to adequate housing, United Nations Human Rights Study Series, No. 7, New York and Geneva, 1996

Saltzman Chafetz, Janet, Gender Equity; An Integrated Theory of Stability and Change, Sage Publications, Newbury Park/London/New Delhi, 1990

Schachter, Oscar, International Law in Theory and Practice, Dordrecht, 1991

Schöpp-Schilling, Hanna Beate, 'Reflections on a General Recommendation on Article 4(1) of the Convention on the Elimination of All Forms of Discrimination Against Women', in: Boerefijn, Ineke, et al (eds.), Temporary Special Measures; Accelerating de facto equality of women under article 4(1) UN Convention on the Elimination of All Forms of Discrimination Against Women, Intersentia, Antwerpen/Oxford/New York, 2003, pp. $15-34$ 
Bibliography

Schermers, H.G., N.M. Blokker, International Institutional Law; Unity within diversity, 3rd revised ed., The Hague/London/Boston, 1995

Schröder, Hannelore, Olympe de Gouges; Verklaring van de rechten van de vrouw en burgeres, Kok Agora, Kampen, 1989

Senders, Mignon, 'Women and the Right to Adequate Housing', in: Netherlands Quarterly of Human Rights, 2, 1998, pp. 175-200

Sequeira, Nora, 'Risk Management: an Alternative Perspective in Gender Analysis', in: DAW, Environmental Management and the Mitigation of Natural Disasters: a Gender Perspective, Report of the Expert Group Meeting, EGM/NATDIS, Ankara, Turkey, November 2001

Sewall, Rebecca P., 'Reconstructing Social and Economic Rights in Transitional Economies', in: Schuler, Margaret A. (ed.), From Basic Needs to Basic Rights, 155, 1995Shachar, Ayelet, Multicultural Jurisdictions; Cultural Differences and Women's Rights, Cambridge University Press, Cambridge, 2001

Shaw, Malcolm N., International Law, 5th edition, Cambridge, 2003

Singh, Kirti, 'Obstacles to Women's Rights in India', in: Cook, Rebecca (ed.), Human Rights of Women; National and International Perspectives, Pennsylvania University Press, Philadelphia, 1994, pp. 375-396

Steiner, Henry, J., Philip Alston, International Human Rights in Context; Law, Politics, Morals, 2nd edition, Oxford University Press, Oxford, 2000

Stichting Habitat: Platform, Van Shanghai tot Terneuzen; Voorbeelden van vrouwen in lokaal bestuur, 2000

Stokes, Wendy, Women in Contemporary Politics, Polity Press, Cambridge/Malden, 2005

Thomas, Alan, 'Poverty and the End of Development', in: Allen, Tim and Alan Thomas (eds.), Poverty and Development into the 21 st Century, The Open University in association with Oxford University Press, Oxford, 2000, pp. 3-22

Thomas, Cheryl, 'Domestic Violence', in: Askin, Kelly D., Dorean M. Koenig (eds.), Women and International Human Rights Law, Volume 1, Transnational Publishers, Inc., Ardsley, New York, 1999, pp. 219-256

Thomas, Dorothy and Robin Levi, 'Common Abuses Against Women', in: Askin, Kelly D., Dorean M. Koenig (eds.), Women and International Human Rights Law, Volume 1, Transnational Publishers, Inc., Ardsley, New York, 1999, pp. 139-176

Tistounet, Eric, 'The Problem of Overlapping among Different Treaty Bodies', in: Alston, Philip, and James Crawford (eds.), The Future of UN Human Rights Treaty, Cambridge University Press, Cambridge, 2000, pp. 383-402

UNDP, Human Development Report 1995; Gender and human development, United Nations, New York, 1995

UNDP, Human Development Report 2004; Cultural Liberty in Today's Diverse World, United Nations, New York, 2004

UNESCO, Education for All, The challenge of achieving gender parity in basic education; a statistical review, 1990-1998, United Nations, 2002

UNESCO, Human Rights in a Pluralist World; Individuals and Collectivities, UNESCO, 1990

UNESCO, United to Combat: Racism; Dedicated to the World Conference against Racism, Racial Discrimination, Xenophobia and Related Intolerance, UNESCO, Paris, 2001 
UNICEF, The State of the World's Children, 1999

UNIFEM, Pathway to Gender Equality; CEDAW, Beijing and the MDGs, United Nations, 2004

United Nations, Action in the Field of Human Rights, United Nations Publication, 1994

United Nations, Bringing International Human Rights Law Home; Judicial Colloquium on the Domestic Application of the Convention on the Elimination of All Forms of Discrimination against Women and the Convention on the Rights of the Child, United Nations, New York, 2000

United Nations, Manual on Human Rights Reporting, United Nations, Geneva, 1997

United Nations, UN Action in the Field of Human Rights, United Nations Publication, 1988

United Nations, Women in Politics and Decision-Making in the Late Twentieth Century, A United Nations Study, Martinus Nijhoff Publishers, Dordrecht, Boston, London, 1992

Verhey, Lucas, Horizontale werking van grondrechten, in het bijzonder van het recht op privacy, Tjeenk Willink, Zwolle, 1992

Westendorp, Ingrid, 'Double discrimination; racism and sexism combined', in: Coomans, Fons, Fred Grünfeld, Ingrid Westendorp and Jan Willems (eds.), Rendering Justice to the Vulnerable, Liber Amicorum in Honour of Theo van Boven, Kluwer Law International, The Hague/London/Boston, 2000, pp. 299-310

Westendorp, Ingrid, Article 2 of the Convention on the Elimination of All forms of Discrimination Against Women, background paper for CEDAW's general discussion, 21 July 2004

Westendorp, Ingrid and Ria Wolleswinkel (eds.), Violence in the domestic sphere, Intersentia, Antwerp/Oxford, 2005

Wield, David and Joanna Chataway, 'Unemployment and making a living', in: Allen, Tim and Alan Thomas (eds.), Poverty and Development into the 21st Century, The Open University in association with Oxford University Press, Oxford, 2000, pp. 99-124

Willems, Jan, Wie zal de Opvoeders Opvoeden? Kindermishandeling en het Recht van het Kind op Persoonswording, T.M.C. Asser Press, Den Haag, 1998

World Bank, World Development Report 2000/2001: Attacking Poverty, Oxford University Press, Oxford, 2001

Wright, Shelley, 'Economic Rights, Social Justice and the State: A Feminist Reappraisal', in: Dallmeyer, Dorinda, G., Reconceiving Reality: Women and International Law, The American Society of International Law, Washington, D.C., 1993, pp. 117-142

Zenabaworke, Tadesse, 'Women and Land Rights in the Third World: The Case of Ethiopia', in: Muthoni Wanyeki, L. (ed.), Women and Land in Africa; Culture, Religion and Realizing Women's Rights, Zed Boods, New York, 2003, pp. 67-95

Zoomers, Annelies and Gemma van der Haar, 'Introduction: regulating land tenure under neo-liberalism', in: Zoomers, Annelies and Gemma van der Haar (eds.), Current Land Policy in Latin America: Regulating Land Tenure under Neo-Liberalism, Royal Tropical Institute, Amsterdam, 2000, pp. 17-26

Zoomers, Annelies and Gemma van der Haar (eds.), Current Land Policy in Latin America: Regulating Land Tenure under Neo-Liberalism, Royal Tropical Institute, Amsterdam, 2000 
Bibliography

\section{UN DOCUMENTS}

A/48/393, Development and international economic co-operation: effective mobilization and integration of women in development., 20 September 1993

A/50/37, Report of the Preparatory Committee for the UN Conference on Human Settlements (HABITAT: II), 25 July 1995

A/52/3, Report of the Economic and Social Council for 1997, 18 September 1997

A/52/38/Rev, 1, Report of CEDAW's $17^{\text {th }}$ session, 1997

A/53/38/Rev. 1, Report of CEDAW's $18^{\text {th }}$ and $19^{\text {th }}$ sessions, 1998

A/54/38/Rev. 1, Report of CEDAW's $20^{\text {th }}$ and $21^{\text {st }}$ sessions, 1999

$\mathrm{A} / 55 / 280$ /Add. 2, Elimination of all forms of religious intolerance, interim report prepared by Abdelfattah Amor, 9 August 2000

$\mathrm{A} / 55 / 342$, Globalization and its impact on the full enjoyment of all human rights,

Premilinary report of the Secretary-General, 31 August 2000

$\mathrm{A} / 55 / 38$, Report of CEDAW's $22^{\text {nd }}$ and $23^{\text {rd }}$ sessions, 2000

A/56/18, Report of CERD, 2001

A/56/38, Report of CEDAW's $24^{\text {th }}$ and $25^{\text {th }}$ sessions, 2001

A/57/28, Report of CEDAW's $26^{\text {th }}$ and $27^{\text {th }}$ sessions and Exceptional session, 2002

A/58/18, Report of CERD, 2003

A/59/18, Report of the Committee on th Elimination of Racial Discrimination, 2004

$\mathrm{A} / 59 / 38$, Report of CEDAW's $30^{\text {th }}$ and $31^{\text {st }}$ sessions, 2004

$\mathrm{A} / 60 / 38$, Report of CEDAW's $32^{\text {nd }}$ and $33^{\text {rd }}$ sessions, 2005

A/CONF.165, United Nations Conference on Human Settlements (HABITAT: II), conference papers, 1996

A/CONF.165/14, Annex II, The Istanbul Declaration on Human Settlements, 14 June 1996A/CONF.165/PC.1/INF.8, The Vancouver Declaration on Human Settlements, United Nations Conference on Human Settlements, Vancouver, Canada, 31 May to 11 June 1976A/CONF.165/PC.3/4, The Habitat: Agenda, 26 October 1995

A/CONF.177/20 and, A/CONF.177/20/Add.1, Beijing Declaration and Platform for Action, Fourth World Conference on Women, 15 September 1995

A/RES/54/4, Optional Protocol to the Convention on the Elimination of All Forms of Discrimination against Women, 15 October 1999

CEDAW General Recommendation No. 3, on the implementation of Article 5 of the Convention, 1987

CEDAW General Recommendation No. 5, Temporary special measures, 1988

CEDAW General Recommendation No. 9, Statistical data concerning the situation of women, 1989

CEDAW General Recommendation No. 12, Violence against women, 1989

CEDAW General Recommendation No. 19, Violence against women, 1992

CEDAW General Recommendation No. 21 on Equality in marriage and family relations, 1991

CEDAW General Recommendation No. 25, on Article 4, paragraph 1, of the Convention on the Elimination of All Forms of Discrimination against Women, on temporary special measures, 2004

CEDAW/C/BGD/3-4, Third and fourth periodic reports of States parties, Bangladesh, 1 April 1997

CEDAW/C/BTN/1-3, Combined initial, second and third reports of States parties, Bhutan, 20 January 2003 
CEDAW/C/CMR/1, Initial reports of States parties, Cameroon, 9 May 1999

CEDAW/C/GIN/1-3, Combined initial, second and third periodic reports of States parties, Guinea, 6 March 2001

CEDAW/C/MEX/3-4, Third and fourth periodic reports of States parties, Mexico, 7 March 1997

CEDAW/C/TZA/2-3, Second and third periodic reports of States parties, United Republic of Tanzania, 30 September 1996

CERD General Recommendation No. 22: Article 5 and refugees and displaced persons, 24 August 1996

CERD General Recommendation No. 25, Gender related dimensions of racial discrimination, 20 March 2000

CERD/C/70/Rev.5, General Guidelines regarding the form and contents of reports to be submitted by States parties under Article 9, paragraph 1, of the Convention, 5 December 2000CESCR General Comment No 3 on the nature of States parties obligations (Art. 2, para. 1 of the Covenant), 14 December 1990

CESCR, General Comment No. 4, The right to adequate housing (Art. 11(1) of the Covenant), 13 December 1991

CESCR, General Comment No. 7, The right to adequate housing (Art. 11(1) of the Covenant); forced evictions, 20 May 1997

CHR General Comment No. 6, The right to life (Art. 6), 30 April 1982

CHR, General Comment No. 16, The right to respect of privacy, family, home and correspondence, and protection of honour and reputation (Art. 17), 8 April 1988

Commission on Human Rights, Resolution 1993/103, Promoting the realization of the right to adequate housing, 4 March 1993

Commission on Human Rights resolution 2002/49, Women's equal ownership of, access to and control over land and the equal rights to own property and to adequate housing, 23 April 2002

CRC General Comment No. 6, Treatment of unaccompanied and separated children outside their country of origin, 1 September 2005

$\mathrm{CRC} / \mathrm{C} / 150,39^{\text {th }}$ session of the Committee on the Rights of the Child, 21 December 2005

E/1999/22; A/C.12/1998/26, Supp. 2, CESCR, Report on the eighteenth and nineteenth sessions, 1998

E/2000/22; E/C.12/1999/11, Supp. 2, CESCR, Report on the twentieth and twenty-first sessions, 1999

E/2001/22; E/C.12/2000/21, Supp. 2, CESCR, Report on the twenty-second, twenty-third and twenty-fourth session, 2000

E/2002/22; E/C.12/2001/17, Supp. 2, CESCR, Report on the twenty-fifth, twenty-sixth and twenty-seventh sessions, 2001

E/2003/22; E/C.12/2002/13, Supp. 2, CESCR, Report on the twenty-eighth and twenty-ninth sessions, 2002

E/2004/22; E/C.12/2003/14, Supp. 2, CESCR, Report on the thirtieth and thirty-first sessions, 2003

E/2005/22; E/C.12/2004/9, Supp. 2, CESCR, Report on the thirty-second and thirty-third sessions, 2004

E/C.12/1995/11, Letter addressed by Mr Philip Alston, Chairperson of the Committee on Economic, Social and Cultural Rights, to Mr. Wally N'Dow, Assistant SecretaryGeneral, United Nations Centre for Human Settlements (HABITAT), 21 July 1995 
E/C.12/2001/10, Poverty and the International Covenant on Economic, Social and Cultural Rights, Statement adopted by the Committee, 4 May 2001

E/CN.4/1987/17, Annex, The Limburg Principles on the Implementation of the International Covenant on Economic, Social and Cultural Rights

E/CN.4/1994/18, Human Rights and extreme poverty, Note by the Secretary-General, 1 February 1994

E/CN.4/1995/101, Report of the seminar on extreme poverty and the denial of human rights, 15 December 1994

E/CN.4/1995/42, Preliminary report by the Special Rapporteur on violence against women, its causes and consequences, Radhika Coomaraswamy, 22 November 1994

E/CN.4/1997/105, Draft optional protocol to the International Covenant on Economic, Social and Cultural Rights, 18 December 1996

E/CN.4/1997/47/Add.2, Report on the mission to Brazil on the issue of domestic violence (15-26 July 1996), report by the Special Rapporteur on violence against women, its causes and consequences, Radhika Coomaraswamy, 21 January 1997

E/CN.4/1997/74, Effective Functioning of Bodies Established pursuant to United Nations Human Rights Instruments, Final report by Mr. Philip Alston on enhancing the long-term effectiveness of the United Nations human rights treaty system, 27 March 1997E/CN.4/1997/74, Effective Functioning of Bodies Established Pursuant to United Nations Human Rights Instruments; Final report on enhancing the long-term effectiveness of the United Nations human rights treaty system, Philip Alston, 1996

E/CN.4/1999/48, Human rights and extreme poverty, Report submitted by Ms. A.M. Lizin, 29 January 1999

E/CN.4/1999/50, Effects of structural adjustment policies on the full enjoyment of human rights, Report by Mr. Fantu Cheru, 24 February 1999

E/CN.4/1999/68, Violence against women in the family, report by the Special Rapporteur on violence against women, its causes and consequences, Radhika Coomaraswamy, 10 March 1999

E/CN.4/1999/NGO/95, Integration of the Human Rights of Women and the Gender Perspective, Violence Against Women, Written statement submitted by Human Rights Advocates, a NGO in special consultative status, 11 March 1999

E/CN.4/2001/51, Report of the Special Rapporteur on the right to adequate housing, Mr. Miloon Kothari, 25 January 2001

E/CN.4/2000/52, Human rights and extreme poverty, Report submitted by Ms. A.M. Lizin, 25 February 2000

E/CN.4/2002/59, Report of the Special Rapporteur on the right to adequate housing as a component of an adequate standard of living, Mr. Miloon Kothari, 1 March 2002

E/CN.4/2002/83, Cultural practices in the family that: are violent towards women, Report of the Special Rapporteur on violence against women, its causes and consequences, Ms. Radhika Coomaraswamy, 31 January 2002

E/CN.4/2003/5, Report of the Special Rapporteur on the right to adequate housing as a component of the right to an adequate standard of living, and on the right to nondiscrimination, Mr. Miloon Kothari, 3 March 2003

E/CN.4/2003/5/Add. 1, Occupied Palestinian territories, Mr. Miloon Kothari, January 2002E/CN.4/2003/5/Add. 2, Romania, Mr. Miloon Kothari, January 2002

E/CN.4.2003/5/Add. 3, Mexico, Mr. Miloon Kothari, March 2002 
E/CN.4/2004/44, Report of the open-ended working group to consider options regarding the elaboration of an optional protocol to the International Covenant on Economic, Social and Cultural Rights on its first session, 15 March 2004

E/CN.4/2003/55, Women and adequate housing, study by the Special Rapporteur on adequate housing Miloon Kothari, 26 March 2003

E/CN.4/2004/48, Report of the Special Rapporteur on the right to adequate housing as a component of an adequate standard of living, Mr. Miloon Kothari, 8 March 2004

E/CN.4/2004/48/Add. 1, Peru, Mr. Miloon Kothari, 8 March 2004

E/CN.4/2004/48/Add. 2, Afghanistan, Mr. Miloon Kothari, September 2003

E/CN.4/2004/76, Migrant workers, Report of the Special Rapporteur, Ms. Gabriela Rodríguez Pizarro, 12 January 2004

E/CN.4/2005/43, Women and adequate housing, study by the Special Rapporteur on adequate housing, Mr. Miloon Kothari, 25 February 2005

E/CN.4/2005/48, Report of the Special Rapporteur on the right to adequate housing as a component of the right to an adequate standard of living, Miloon Kothari, 3 March 2005

E/CN.4/2005/48 Add. 2, Kenya, Mr. Miloon Kothari, February 2004

E/CN.4/2005/48/Add. 3, Brazil, Mr. Miloon Kothari, June 2004

E/CN.4/2005/52, Report of the open-ended working group to consider options regarding the elaboration of an optional protocol to the International Covenant on Economic, Social and Cultural Rights on its second session, 10 February 2005

E/CN.4/2005/84, Mass exoduses and displaced persons, Report of the Representative of the Secretary-General on the human rights of internally displaced persons, Walter Kälin, 31 December 2004

E/CN.4/2006/47, Report of the open-ended working group to consider options regarding the elaboration of an optional protocol to the International Covenant on Economic, Social and Cultural Rights on its third session, 2006

E/CN.4/2006/73, Migrant workers, Report of the Special Rapporteur on the human rights of migrants, Jorge Bustamante, 30 December 2005

E/CN.4/Sub.2/1989/19, Realization of Economic, Social and Cultural Righrs, Preliminary Report, Mr. Danilo Türk, 19 June 1989

E/CN.4/Sub.2/1990/19, Realization of Economic, Social and Cultural Rights, Progress Report, Mr. Danilo Türk, 6 July 1990

E/CN.4/Sub.2/1992/15, The right to adequate housing, working paper, Mr.Rajindar Sachar, Special Rapporteur, 12 June 1992

E/CN.4/Sub.2/1993/15, The right to adequate housing, progress report, Mr.Rajindar Sachar, Special Rapporteur, 22 June 1993

E/CN.4/Sub.2/1993/16, Preliminary report on human rights and extreme poverty, Special Rapporteur Mr. Leandro Despouy, 2 July 1993

E/CN.4/Sub.2/1993/8, Study concerning the right to restitution, compensation and rehabilitation for victims of gross violations of human rights and fundamental freedoms, Final report submitted by Mr. Theo van Boven, Special Rapporteur, 2 July 1993

E/CN.4/Sub.2/1994/20, The right to adequate housing, second progress report, Mr.Rajindar Sachar, Special Rapporteur, 21 June 1994

E/CN.4/Sub.2/2000/13, Globalization and its impact on the full enjoyment of human rights, Preliminary report, J. Oloka-Onyango and Deepika Udagama, 15 June 2000

E/CN.4/Sub.2/2002/17, The return of refugees' or displaced persons' property, Working paper by Mr. Paulo Sérgio Pinheiro, 12 June 2002 
Bibliography

E/CN.4/Sub.2/2002/17, The return of refugees' or displaced persons' property, Working paper by Mr. Paulo Sérgio Pinheiro, 12 June 2002

E/CN.4/Sub.2/2003/11, Housing and property restitution in the context of the return of refugees and internally displaced persons, Preliminary report by Mr. Paulo Sérgio Pinheiro, 16 June 2003

E/CN.4/Sub.2/2003/11, Housing and property restitution in the context of the return of refugees and internally displaced persons, Preliminary report Special Rapporteur, Paulo Sérgio Pinheiro, 16 June 2003

E/CN.4/Sub.2/2004/22, Housing and property restitution in the context of the return of refugees and internally displaced persons, Progress report of the Special Rapporteur, Paulo Sérgio Pinheiro, 8 June 2004

E/CN.4/Sub.2/2004/24, Study on non-discrimination as enshrined in article 2, paragraph 2, of the International Covenant on Economic, Social and Cultural Rights, Working paper prepared by Emmanuel Decaux, 18 June 2004

E/CN.4/Sub.2/2005/17, Housing and property restitution in the context of the return of refugees and internally displaced persons, Final report of the Special Rapporteur, Paulo Sérgio Pinheiro, 28 June 2005

E/CN.4/Sub.2/2005/36, Ninth report and final report on the situation regarding the elimination of traditional practices affecting the health of women and the girl child, Ms. Halima Embarek Warzazi, 11 July 2005

E/CN.4/Sub.2/RES/1997/19, Sub-Commission resolution on Women and the right to adequate housing and to land and property, 27 August 1997

E/CN.4/Sub.2/RES/1998/15, Sub-Commission resolution on Women and the right to land, property and adequate housing, 21 August 1998

ECOSOC resolution 2001/4, Proposals for a multi-year programme of work for the Commissionon the Status of Women for 2002-2006, 24 July 2001

ECOSOC resolution 2001/41, Mainstreaming a gender perspective into all policies and programmes in the United Nations system, 26 July 2001

General Assembly Resolution 37/221, International Year of Shelter for the Homeless, 20 December 1982

General Assembly Resolution 41/120, Setting international standards in the field of human rights, 4 December 1986

General Assembly Resolution 43/181, Global Strategy for Shelter to the Year 2000, 23 December 1988

General Assembly Resolution 46/164, United Nations conference on Human Settlements, 19 December 1991

General Assembly Resolution 47/180, United Nations Conference on Human Settlements (Habitat: II), 22 December 1992

General Assembly Resolution 48/104, Declaration on the Elimination of Violence against Women, 20 December 1993

General Assembly Resolution 52/93, Improvement of the situation of women in rural areas, 12 December 1997

General Assembly Resolution 60/147, Basic Principles and Guidelines on the Right to a Remedy and Reparation for Victims of Gross Violations of International Human Rights Law and Serious Violations of International Humanitarian Law, 16 December 2005

HRC General Comment No. 3, Implementation at: the national level (Art. 2), 1981

HRC General Comment No. 4, Equality between the sexes (Art. 3), 30 July 1981 
HRC General Comment No. 18, Non-discrimination, 1989

HRC General Comment No. 28, Equality of rights between men and women (Art. 3), 2000

HRI/GEN/2/Rev.1/Add.2, Revised guidelines issued by CEDAW for all reports submitted after 31 December 2005, 5 May 2003

Sub-Commission Resolution 1991/26, Promoting the realization of the right to adequate housing, 29 August 1991

Sub-Commission Resolution 1992/26, Promoting the realization of the right to adequate housing, 27 August 1992

Sub-Commission Resolution 1993/36, Promoting the realization of the right to adequate housing, 27 August 1993

Sub-Commission Resolution 1997/19, Women and the right to adequate housing and to land and property, 27 August 1997

\section{CASES}

Chorzów Factory Case, Permanent Court of International Justice, PCIJ, Series A, No. 17, 1928

Anglo-Norwegian Fisheries case, International Court of Justice, ICJ Reports, 1951

Asylum case (Colombia v. Peru), International Court of Justice, ICJ Reports, 1950

Nicaragua v. United Sates, International Court of Justice, ICJ Reports 1986

Velásquez Rodríguez Case, Inter-American Court of Human Rights, Series C, No. 4, 29 July 1988

Bilka Kaufhaus GmbH v. Karin Weber von Hartz, Case 170/84, European Court of Justice of the European Communities, 13 May 1986

CCPR/C/13/D/24/1977, Communication No. 24/2977, Sandra Lovelace v. Canada, 30 July 1981

CCPR, Communication 172/1984, Broeks v. The Netherlands, 1987

CEDAW, Communication No. 1/2003, Ms. B.-J. v. Germany, Decision adopted on 14 July 2004

CEDAW, Communication No. 2/2003, Ms. A.T. v. Hungary, Views adopted on 26 January 2005

CERD/C/36/D/1/1984, Communication No. 1/1984, A. Yilmaz-Dogan v. The Netherlands, 29 September 1988

CERD/C/42/D/4/1991, Communication No. 4/1991, L.K. v. The Nehterlands, 16 March 1993

CERD/C/57/D/13/1998, Communication No. 13/1998, Anna Koptova v. Slovak Republic, 1 November 2000

CERD/C/66/D/31/2003, Communication No. 31/2003, L.R. et al v. Slovak Republic, 10 March 2005

\section{WEBSITES}

Amnesty International, Women's programme at: <web.amnesty.org/library/eng-373/index > CEDAW's General Recommendations at: $<$ www.un.org/womenwatch/daw/cedaw/recommendations/index.html $>$

Centre on Housing Rights and Evictions (COHRE) at: <www.cohre.org>

CESCR's Working methods at: <www.ohchr.org/english/bodies/cescr/workingmethods.htm> 
Bibliography

COHRE's Women's Housing Rights programme at: <www.cohre.org/wkframe.htm>

Commission on the Status of Women, <www.un.org/womenwatch/daw/csw>

Committee on the Elimination of All Forms of Discrimination Against Women,

$<$ www.un.org/womenwatch/daw/cedaw $>$

Declarations and reservations to the Convention on the Rights of the Child

$<$ www.ohchr.org/english/law/crc-reserve.htm>, consulted on 6 October 2004

ESCR, Library of ESCR case law, <ESCR-Net.org>, consulted on 2006

Fourth World Conference on Women Platform for Action, Violence against women $<$ www.un.org/womenwatch/daw/beijing/platform/violence.htm>, consulted on 28 August 2001

Habitat: International Coalition, <www.hic-net.org>

Hammeal-Urban, R., J. Davies, Federal Housing and Domestic Violence: Introduction to Programs, Policy and Advocacy Opportunities, Building Comprehensive Solutions to Domestic Violence, Violence Against Women Online Resources, Publication \#6, A Policy and Practice Paper, $<$ www.vaw.umn.edu/FinalDocuments/fedhouse.asp>, consulted on 18 August 2001

HIC's specific programme on Women and Adequate Housing, $<$ www.hic-net.org/indepth.asp?PID=29>

Human Rights Watch, Women's Rights programme, <www.hrw.org/women>

Human Rights Watch Publications, Sacrificing Women to Save the Family; Domestic Violence in Uzbekistan, Vol. 13, No. 4 (D),

$<$ www.hrw.org/reports/2001/Uzbekistan>, consulted on 11 July 2001

Human Rights Watch Publications, Seeking Protection: Addressing Sexual and Domestic Violence In Tanzania's Refugee Camps, <www.hrw.org/reports/2000/tanzania>, consulted on 10 October 2000

IFAD, Asia-The Role of Women's Workload in Passing on Poverty to the Next Generation, <www.ifad.org/gender/learning/role/workload/in_generation.htm>, consulted on 15 April 2003

IFAD, The Issue of Poverty among Female-Headed Households in Africa, $<$ www.ifad.org/gender/learning/challenges/women/60.htm>, consulted on 15 April 2003

Inter-Parliamentary Union, Women in Politics, <www.ipu.org/iss-e/women.htm $>$, consulted on 19 January 2004

International Labour Organization, The Feminization of Poverty, $<$ www.ilo.org/public/english/bureau/inf/pkits/women3.htm>, consulted on 10 June 2002

Korieh, Chima Jacob, Widowhood among the Igbo of Eastern Nigeria, Thesis for the Degree of Master of Philosophy, Bergen, Norway, 1996, <www.uib.no/hi/korieh/chima.html>, consulted on 9 May 2001

Lewin, Tamar, Zero-Tolerance Policy Is Challenged, The New York Times, 11 July 2001, $<$ www.nytimes.com/2001/07/1.../11DOME.html>, consulted on 11 July 2001

Mannen in de hoofdrol, <www.wiedoetwat.nl/pers/home.asp>, consulted on 18 January 2005

McLanahan, Sara and Erin Kelly, The Feminization of Poverty: Past and Future, $<$ www.olin.wustl.edu/Macarthur/working\%20papers/wp-mclanahan3.htm>, consulted on 10 June 2002

Morris, Marika, Women, poverty and Canadian public policy in an era of globalization, Canadian Research Institute for the Advancement of Women (CRIAW), Presentation to the International Colloquium: Globalization, Societies, Cultures, Congress of the Social Sciences and Humanities, Edmonton, Canada, 29 May 2000, 
$<$ www.criaw-icref.ca/Poverty_and_globalization.htm>

National Coalition for the Homeless, Domestic Violence and Homelessness, Fact Sheet \#8, April 1999, <nch.ari.net/domestic.html>, consulted on 10 May 2001

Nieuw Erfrecht; De veranderingen, <www.notaris.nl/nieuws/nieuwerfrecht/nl.html >, consulted on 1 May 2002

Office of the High Commissioner for Human Rights, World Conference on Human Rights, 14-25 June 1993, Vienna, Austria, <www.unhcr.ch/html/menu5/wchr/htm>

Office of the Special Advisor on Gender Issues and Advancement of Women (OSAGI), $<$ www.un.org/womenwatch/osagi $>$

Owen, Margareth, Empowering Widows in Development, the Status of Widows in 10 countries, Seclusion and Exclusion, $<$ www.oneworld.org/empoweringwidows/10countries/>, consulted on 18 April 2001

Partij van de Arbeid, Manifest Stop Huiselijk Geweld!, Aangeboden aan de Minister van Justitie en de Minister van Binnenlandse Zaken, 9 mei 2000, $<$ www.pvda.nl/hot/09052000manifest.tpl>, consulted on 16 August 2001

Perkins, Annabelle, Gender and Inheritance Law Reform in Maharashtra, $<$ www.prout.org/pna/inheritance-india.html>, consulted on 17 April 2003

Preece, Alun, Rishi Mohan, Hindu personal law in India; A comparison of its administration by the British and India post independence, $<$ www.mlj.com.my/free/articles/preece\&mohan.htm>, consulted on 17 April 2003

Questionnaire on women and adequate housing, Special Rapporteur on adequate housing, $<$ www.ohchr.org/english/issues/housing/docs/questionnaireEn.doc $>$

Regional Task Force on the Homeless, Domestic Violence and Homelessness, $<$ www.co.san-diego.ca.us/rtfh/victims.html>, consulted on 10 May 2001

Reports by the Special Rapporteur on internal displacement, $<$ www.ohchr.org/english/issues/idp/annual.htm>

Reports by the Special Rapporteur on migrant workers, <www.ohchr.org/english/issues/migration/rapporteur/annual.htm>

Reports by the Special Rapporteur on violence against women, its causes and consequences, $<$ www.ohchr.org/english/issues/women/rapporteur/index.htm>

Status of ratification of the Convention on the Rights of the Child, $<$ www.ohchr.org/english/law/crc-ratify.htm>, consulted on 6 October 2004

The National Center for Victims of Crime, Domestic Violence, $<$ www.ncvc.org/infolink/info14.htm>, consulted on 28 August 2001

The World Bank, Credit and financial services, Gender in agriculture, $<$ www.worldbank.org/gender/module/issues/credit.htm>, consulted on 16 April 2003

The World Factbook, <www.cia.gov/cia/publications/factbook/geos/ku.html>, consulted on 15 December 2003

Understanding the Law of Inheritance of the Qur'an,

$<$ www.understanding-islam.com/related/text.asp?type=article\&aid=14\&sscatid $>$, consulted on 17 April 2003

United Nations Treaty Collection, $<$ untreaty.un.org/English/bible/englishinternetbible/partI/ChapterXVI/treaty1.asp>

UN-HABITAT, Gender Policy Unit, <www.unhabitat.org/genderpolicy>

UN-HABITAT, Gender Policy Unit, Gender Mainstreaming Approach, $<$ www.unhabitat.org/programmes/genderpolicy/approach.asp $>$, consulted on 1 August 2005 
Bibliography

UNHCR, <www.unhcr.ch/refworld/refworld/legal/instrume/women/polrts_e.htm>, consulted on 2 February 2004

UNIFEM, Microcredit: More than Access to Money, Statement by Noeleen Heyzer, Executive Director, <www.unifem.undp.org/newsroom/speeches/mcpanel.html>, consulted on 5 June 2000

Women 2000, Women and decision-making, Division for the Advancement of Women,

October 1997, <www.un.org/womenwatch/daw/public/w2oct97/Part3en.htm>, consulted on 11 July 2002

Women and Global Human Rights, Homelessness,

$<$ www.webster.edu/ woolflm/homeless.html $>$, consulted on 9 August 2001

Women and Global Human Rights, Spousal Abuse: A Global Problem,

$<$ www.webster.edu/ woolflm/domesticviolence.html $>$, consulted on 9 August 2001 


\section{INDEX ${ }^{*}$}

access to credit and loans, 2.3.1, 2.6, 2.7, 2.8, 3.1, 3.2.3.4, 3.2.4, 3.3.3.3, 3.3.3.5, 3.8, 4.3.5, 4.6.3.1.

accessibility, 2.4, 2.6, 2.8, 3.4.2, 3.4.3, 4.6.5, 4.7.2.1.2.1.

affordability, $2.4,2.6,2.8,3.4 .2,3.4 .3,4.4 .2 .1,4.4 .2 .2,4.6 .3 .2,4.6 .5,4.7 .2 .1 .2 .1$.

battered women, $2.3 .3,3.4 .5,3.4 .5 .1,3.6 .4 .3,5.1$.

CEDAW General Recommendations

General Recommendation No. 19, 3.3.5.2, 3.3.5.3, 4.2.4.1, 4.6.4, 4.7.2.1.1, 4.7.2.1.1.1.

General Recommendation No. 21, 4.7.2.1.1, 4.7.2.1.1.1.

General Recommendation No. 25, 4.3.4, 4.4.4.

CERD General Recommendation No. 25, 4.7.2.1.3, 4.7.2.4.3.

CESCR General Comments

General Comment No. 3, 2.3.2, 2.5.1, 2.6.

General Comment No. 4, 2.3.2, 2.3.3, 2.4, 2.8, 3.3.2.4, 3.4.2, 3.6.6, 4.2.4.2.1, 4.4.1, 4.4.2, 4.4.2.1.

General Comment No. 7, 2.3.2, 2,4, 2.5.1, 3.3.2.2., 3.3.2.4, 4.4.1, 4.4.2.2.

General Comment No. 16, 4.2.4.2.1, 4.3.4, 4.7.2.1.2, 4.7.2.1.2.1, 4.8.

Civil Society Organizations (CSOs), 2.2, 2.3.1, 2.3.2, 2.3.3, 2.4, 2.7, 3.2.5, 3.3.2.4,

3.3.3.4, 3.3.5.4.3, 3.4.5.1, 3.4.5.4.2.1, 3.6.2.6, 3.6.2.7, 3.6.3.2.1, 3.6.3.3, 3.6.3.5,

$3.6 .7,3.7 .6,4.1,4.2 .2 .1,4.2 .5,4.5 .1,4.5 .4,4.5 .4 .2 .2,4.5 .4 .3,4.5 .4 .4,4.5 .5,4.7 .1$, 4.7.2.1.1.1, 4.7.2.3, 4.7.2.4.1, 4.7.3.1, 4.7.3.5, 4.7.4, 4.7.5, 4.8, 5.1, 5.3.

Commission on Human Rights Special Rapporteur

on adequate housing, 2.1, 2.3, 2.3.3, 2.6, 2.7, 2.8, 4.2.4.2.1, 4.7.3.1, 4.7.4, 4.8, 5.3 on migrant workers, 4.7.3.5, 4.7.5, 5.3.

on violence against women, 3.3.5.3, 3.4.5.4.1, 4.2.4.1, 4.2.4.1.1, 4.6.4, 4.7.3.2, 4.7.4, 5.3 .

Committee against Discrimination of Women (CEDAW), 2.3.3, 2.7, 3.6.2.2, 3.6.2.3, 4.2.4.1, 4.3.3, 4.3.4, 4.3.5, 4.4.3, 4.4.7, 4.5.4.1, 4.6.4, 4.7.1, 4.7.2.1, 4.7.2.1.1, 4.7.2.1.1.1, 5.2.2, 5.3.

Committee against Racial Discrimination (CERD), 2.7, 4.2.4.2.1, 4.4.4, 4.4.7, 4.7.1, 4.7.2.1.3, 4.7.2.2.2, 4.7.2.4.3, 4.8, 5.3.

* Terms followed by section numbers. 
Index

Committee on Economic, Social and Cultural Rights (CESCR), 2.1, 2.2, 2.3, 2.3.1, 2.3.2, 2.3.3, 2.4, 2.5, 2.5.1, 2.5.2, 2.6, 2.7, 2.8, 3.3.2.3, 3.3.2.4, 3.4.1, 3.4.2, 3.6.3.4.1, 3.6.6, 4.2.2.1, 4.2.4.2.1, 4.3.4, 4.3.5, 4.4.1, 4.4.2, 4.4.2.2, 4.4.7, 4.5.2.2, 4.7.1, 4.7.2.1, 4.7.2.1.2, 4.7.2.2, 4.7.2.4.2, 4.7.4, 4.7.5, 4.8, 5.2.2, 5.3.

Committee on the Rights of the Child (CRC), 2.7, 4.3.4, 4.4.7, 4.5.5, 4.7.1, 4.7.2.1.4, 4.7.2.4.4, 4.8, 5.3.

Committee on Migrant Workers (CMW), 4.3.4, 4.4.7, 4.7.1, 4.7.2.1.5, 4.7.2.2.3, 4.7.2.4.5, 4.7.5.3, 4.7.5, 4.8, 5.3.

compensation, 2.3.2, 2.3.3, 2.5.2, 3.4.5.4.1, 3.6.3.2.1, 3.6.3.4.2, 3.6.3.5, 4.6.4, 4.6.5, 4.6.6, 4.7.2.2.1, 4.7.3.4.

Convention on the Elimination of All Forms of Discrimination Against Women (Women's Convention), 2.2, 2.3.1, 3.2.3.1, 3.5.5, 3.6.2.2, 4.2.2.1, 4.2.3, 4.2.4.1, 4.2.5, 4.3.4, $4.4 .1,4.4 .3,4.4 .7,4.5 .1,4.5 .2 .1,4.5 .2 .2,4.5 .4 .1,4.5 .5,4.7 .2 .1 .1,4.7 .2 .2,4.7 .2 .2 .1$, 4.7.2.3, 4.7.2.41, 4.7.4, 4.8, 5.3.

Convention on the Rights of the Child (ICRC), 2.2, 2.3.1, 3.2.3.1, 4.3.4, 4.4.1, 4.4.5, 4.7.2.1.4, 4.7.2.2, 4.7.2.4.4

credit and loans, 2.3.1, 2.3.2, 2.6, 2.7, 2.8, 3.1, 3.2.1, 3.2.3, 3.2.3.4, 3.2.4, 3.2.6, 3.2.7, 3.3.2.4, 3.3.3.3, 3.3.3.5, 3.3.3.6, 3.6.3.2, 3.6.3.2.3, 3.8, 4.3.5, 4.4.2.2, 4.6.3.1, 4.6.5, 4.7.2.1.1, 4.7.2.1.1.1, 4.7.2.1.2.1, 5.1.

cultural adequacy, $2.4,2.8,3.4 .2,4.4 .2 .1,4.7 .2 .1 .2 .1$.

cultural diversity, 4.5.1, 4.5.3, 4.5.3.1, 4.5.4.1, 4.8.

cultural patterns, 3.1, 3.4.5.4.2, 3.4.6, 3.6.7, 3.7, 3.7.1, 3.7.6, 4.3.4, 4.5.1, 4.5.2, 4.5.2.1, 4.5.2.2, 4.5.3, 4.5.3.3, 4.5.4, 4.5.4.1, 4.5.4.2, 4.7.2.1.1, 4.7.5, 4.8,

culture(s), 2.3.3, 2.4, 2.7, 2.8, 3.2.3, 3.2.3.1, 3.2.3.2, 3.2.3.5, 3.2.6, 3.3.4.2, 3.3.5.2, 3.3.5.3, 3.3.5.5, 3.4.4.3, 3.4.5.1, 3.4.5.4.2, 3.4.6, 3.5.3.3, 3.6.2.1, 3.6.2.3.2, 3.6.2.5, $3.6 .2 .6,3.6 .3 .2 .4,3.6 .3 .3,3.7 .1,3.7 .3,3.7 .4,3.7 .5,3.7 .6,3.8,4.2 .1,4.2 .2,4.2 .2 .1$, $4.2 .4 .2,4.3 .4,4.3 .5,4.5,4.5 .1,4.5 .2,4.5 .2 .1,4.5 .2 .2,4.5 .3 .1,4.5 .3 .3,4.5 .4 .1$, 4.5.4.2.1, 4.5.4.2.3, 4.5.4.3, 4.5.4.4, 4.5.5, 4.7.2.1.1, 4.8, 5.1.

custom(s), 2.7, 3.2.3.5, 3.2.7, 3.3.2.4, 3.3.2.5, 3.3.4.1, 3.3.4.2, 3.3.4.4, 3.3.5.4.1, 3.5.2.1, 3.5.2.2, 3.5.2.3, 3.5.3.2, 3.5.3.3, 3.5.3.5, 3.5.4, 3.5.5, 3.6.3.2.1, 3.6.3.2.4, $3.7 .1,3.7 .3,3.7 .4,3.7 .5,4.2 .1,4.2 .2 .1,4.2 .3,4.2 .4 .1,4.2 .4 .1 .1,4.2 .4 .2 .1,4.3 .2$, $4.3 .3 .1,4.4 .2 .2,4.5 .1,4.5 .2 .2,4.5 .4 .1,4.5 .4 .2 .1,4.5 .4 .2 .3,4.5 .4 .3,4.5 .5,4.6 .3 .1$, 4.6.3.2, 4.6.4, 4.7.2.1.1, 4.7.2.1.1.1, 4.7.2.1.2.1, 4.7.3.3, 4.7.3.4, 5.1, 5.2, 5.2.2, 5.3.

customary law, 2.6, 3.3.3.6, 3.3.4.2, 3.5.2.2, 3.5.2.3, 3.5.2.4, 3.5.3.2, 3.5.3.3, 3.6.3.2.2, 3.6.3.5, 4.2.1, 4.2.2.1, 4.2.3, 4.2.5, 4.3.5, 4.6.2, 4.7.2.1.1.

decision-making, 2.3.2, 2.4, 2.7, 2.8, 3.2.1, 3.2.3, 3.2.3.3, 3.2.7, 3.3.3.3, 3.3.3.5, 3.4.3, $3.4 .5 .4 .2,3.6 .2 .1,3.6 .2 .2,3.6 .2 .3,3.6 .2 .3 .2,3.6 .2 .3 .3,3.6 .2 .3 .4,3.6 .2 .3 .5,3.6 .2 .4$, 3.6.2.5, 3.6.2.6, 3.6.2.7, 3.6.3.2.1, 3.6.7, 3.7.5, 4.2.1, 4.2.2.1, 4.2.3, 4.2.4.2, 4.2.4.2.1, 4.2.5, 4.3.2.1, 4.5.2.1, 4.7.3.4, 5.1, 5.2. 
dignity, $2.2,2.3 .2,2.3 .3,2.4,2.6,2.8,3.1,3.2 .2,3.3 .4 .5,3.3 .5 .1,3.4 .2,3.4 .5$, $3.4 .5 .1,3.4 .6,3.6 .1,3.6 .3 .2 .1,3.6 .4 .4,3.6 .6,3.6 .7,3.8,4.3 .3 .2,4.3 .5,4.5 .3 .1$, $4.6 .2,4.6 .3 .2,4.6 .4,4.6 .5,4.7 .2 .1 .1,4.7 .2 .1 .3,4.7 .2 .4 .4,4.7 .3 .2,4.7 .3 .4,5.3$.

direct discrimination, $2.7,4.1,4.3 .3,4.3 .3 .3,4.3 .4,4.7 .2 .4 .1,5.2$.

disasters

human-made disasters, 2.3.2, 3.1, 3.3.1, 3.3.3, 3.3.3.1, 3.3.3.2, 3.3.3.3, 3.3.3.4, 3.3.3.5, 3.3.3.6, 3.3.3.7, 3.4.5.4, 3.4.5.4.1, 3.6.3.3, 3.8, 4.7.3.1.

natural disasters, $2.3 .2,3.1,3.3 .1,3.3 .3,3.3 .3 .1,3.3 .3 .2,3.3 .3 .3,3.3 .3 .4,3.3 .3 .5$, 3.3.3.6, 3.3.3.7, 3.4.4.3, 3.4.5.4, 3.4.5.4.1, 3.6.3.3, 3.8, 4.6.3.2, 4.6.5, 4.7.3.1.

divorcees, 3.4.1, 3.4.5, 3.4.5.1, 3.4.5.2, 3.6.3.2.1, 4.4.2.1.

domestic violence, $2.3 .3,2.7,3.1,3.3 .3 .5,3.3 .5 .1,3.3 .5 .2,3.3 .5 .3,3.3 .5 .4,3.3 .5 .4 .1$, 3.3.5.4.2, 3.3.5.4.3, 3.3.5.5, 3.4.2, 3.4.5, 3.4.5.1, 3.4.5.4.3, 3.6.1, 3.6.2.5, 3.6.2.7, $3.6 .4 .1,3.6 .4 .3,3.6 .4 .4,3.6 .6,3.6 .7,3.7 .2,3.7 .3,3.8,4.2 .1,4.2 .2 .1,4.2 .3$, $4.2 .4 .1 .1,4.2 .5,4.3 .5,4.4 .2 .1,4.4 .2 .2,4.5 .2 .1,4.5 .4 .1,4.5 .4 .4,4.6 .3 .2,4.6 .4,4.6 .5$, 4.6.6, 4.7.2.1.1, 4.7.2.1.1.1, 4.7.2.1.2.1, 4.7.2.1.3, 4.7.2.1.4, 4.7.2.1.5, 4.7.2.2.1, 4.7.2.4.4, 4.7.3.2, 4.7.3.3, 4.7.3.4, 4.7.3.5, 4.8, 5.1, 5.2.1, 5.2.2, 5.3.

due diligence, $2.5 .1,3.6 .4 .3,4.6 .1,4.6 .3 .2,4.6 .3,4.6 .4,4.6 .6,4.8$.

duty to fulfil, $2.6,4.6 .3,4.6 .3 .3,4.6 .6,4,8$.

duty to protect, $4.6 .3,4.6 .3 .2,4.6 .4,4.6 .6,4.8$.

duty to respect, $4.6 .3,4.6 .3 .1,4.6 .6,4.8$.

education, $2.2,2.3 .2,2.3 .3,2.7,2.8,3.1,3.2 .1,3.2 .2,3.2 .3 .1,3.2 .3 .2,3.2 .3 .3,3.2 .3 .5$, 3.2.4, 3.2.7, 3.3.2.4, 3.3.3.3, 3.3.4.4, 3.3.5.5, 3.4.3, 3.4.5.4, 3.4.5.4.1, 3.4.5.4.2, 3.5.3.5, 3.6.2.3, 3.6.2.3.3, 3.6.2.6, 3.6.2.7, 3.6.5, 3.7.3, 3.7.6, 3.8, 4.3.2, 4.3.3.3, $4.3 .5,4.4 .2 .3,4.5 .4 .1,4.5 .4 .4,4.6 .5,4.7 .3 .3,4.7 .5,5.1,5.2,5.3$.

effective control, 3.5.2.2, 3.6.3.2, 3.6.3.2.4, 3.6.3.5, 3.6.7.

employment, $2.2,2.3 .1,2.3 .3,2.4,3.1,3.2 .1,3.2 .3,3.2 .3 .1,3.2 .3 .2,3.2 .3 .5,3.2 .4$, 3.2.5, 3.2.6, 3.3.4.3, 3.4.4.3, 3.4.5.3, 3.5.3.3, 3.5.4, 3.6.1, 3.6.2.3.3, 3.6.2.3.5, 3.6.2.7, 3.6.5, 3.6.7, 3.7.2, 3.7.3, 3.8, 4.3.2, 4.3.2.1, 4.3.3.3, 4.7.2.1.3, 4.7.3.5, 5.1, 5.2.

equity, 4.2.2.1, 4.3.1, 4.3.2.1, 4.8.

family home, $2.3 .3,3.3 .5 .4 .2,3.3 .5 .4 .3,3.3 .5 .5,3.5 .2 .3,4.6 .5,4.7 .2 .1 .1,4.7 .2 .1 .1 .1$, 4.7.2.1.2.1, 4.7.2.2.1.

female heads of household, $2.7,3.2 .4,3.2 .7,3.3 .2 .4,3.3 .3 .5,3.3 .4 .4,3.4 .3,3.4 .4 .3$, 3.4.5.4.2, 3.4.6, 3.6.3.2.1, 3.6.3.3, 3.6.3.5, 3.6.5, 3.8, 4.3.5, 4.6.3.2, 4.7.2.1.1, 4.7.2.1.1.1, 4.7.2.1.2.1, 4.7.3.1, 5.1, 5.2.1.

female-headed households (FHHs), 2.4, 3.2.1, 3.2.4, 3.2.7, 3.4.5.4, 3.6.3.2.1, 3.6.3.3, 4.4.2.

feminization of poverty, $3.1,3.2 .1,3.2 .3,3.2 .3 .2,3.2 .3 .5,3.2 .4,3.2 .5,3.2 .7,4.7 .2 .1 .2$, 4.7.2.1.2.1. 
Index

forced eviction(s), 2.3.2, 2.3.3, 2.4, 2.5.1, 2.5.2, 2.6, 2.7, 3.1, 3.3.1, 3.3.2, 3.3.2.1, 3.3.2.2, 3.3.2.3, 3.3.2.4, 3.3.2.5, 3.3.3.5, 3.4.2, 3.4.5, 3.6.3.4.2, 3.8, 4.4.1, 4.4.2.2, 4.6.3.1, 4.6.5, 4.7.2.1.2.1, 4.7.3.2.

freedom of residence, $2.3 .2,2.8,3.3 .5 .2,3.4 .2,3.4 .4 .3,3.5 .1,3.5 .4,3.5 .5,3.8,4.4 .2 .1$, 4.6.2, 4.7.2.1.1.1, 4.7.2.1.2.1, 5.1

gender mainstreaming, $2.7,4.1,4.2 .1,4.2 .4,4.2 .4 .1,4.2 .4 .2,4.2 .4 .2 .1,4.2 .5,4.3 .4$, $4.4 .4,4.4 .5,4.4 .7,4.5 .4 .1,4.7 .4,4.8$.

globalization, $2.3 .3,2.7,3.1,3.2 .5,3.2 .7,3.4 .5 .3,4.5 .4 .1$.

Grameen bank, 3.2.3.4

habitability, $2.4,2.8,3.4 .2,3.4 .4,3.4 .4 .1,3.4 .6,3.8,4.4 .2 .1,4.7 .2 .1 .2 .1$

health, 2.3.1, 2.3.2, 2.3.3, 2.4, 2.7, 2.8, 3.2.2, 3.2.3.2, 3.2.4, 3.2.6, 3.3.5.1, 3.4.2, $3.4 .4,3.4 .4 .1,3.4 .4 .2,3.4 .4 .3,3.4 .5 .1,3.4 .5 .3,3.4 .5 .4,3.4 .5 .4 .1,3.4 .5 .4 .2$

3.4.5.4.3, 3.4.6, 3.5.4, 3.6.2.3, 3.7.3, 4.2.4.1, 4.3.3.1, 4.4.2.1, 4.5.2.2., 4.5.4.1, 4.6.3.1, 4.7.2.1.2.1, 4.6.2.4.4, 4.7.3.1, 4.7.3.3, 4.7.3.3, 5.1,

Human Rights Committee (HRC), 4.2.4.2.1, 4.3.4, 4.5.2.2, 4.6.4, 4.3.5, 4.5.2.2.

indirect discrimination, $2.7,3.5 .3 .4,3.6 .1,4.1,4.3 .3,4.3 .3 .3,4.3 .4,4.7 .2 .4 .1,5.2$.

infrastructure, $2.3 .1,2.3 .2,2.3 .3,2.4,2.8,3.2 .3 .3,3.4 .2,3.4 .4,3.4 .4 .2,3.4 .6,3.6 .2 .1$, 3.6.2.5, 3.6.3.4.2, 4.7.2.1.2.1

inheritance, $2.7,3.1,3.2 .1,3.2 .3,3.2 .3 .5,3.2 .7,3.3 .2 .5,3.3 .3 .7,3.3 .4 .2,3.3 .4 .4$, $3.3 .4 .5,3.4 .3,3.4 .6,3.5 .1,3.5 .2 .1,3.5 .3,3.5 .3 .1,3.5 .3 .2,3.5 .3 .3,3.5 .3 .4,3.5 .3 .5$, 3.5.5, 3.6.3.2.1, 3.6.3.5, 3.7.2, 3.7.3, 3.7.6, 3.8, 4.3.2, 4.3.3.1, 4.3.5, 4.4.2.1, 4.5.2.1, 4.6.3.1, 4.7.2.1.1, 4.7.2.1.1.1, 4.7.2.1.2.1, 4.7.3.1, 4.7.3.3, 4.7.3.4, 5.1, 5.2.

internally displaced persons (IDPs), 2.3.2, 2.3.3, 2.8, 3.3.3.5, 3.4.2, 3.4.5.4, 3.4.5.4.1, 3.4.5.4.3, 3.4.6, 3.6.3.3, 4.6.3.1, 4.6.5, 4.7.1, 4.7.3, 4.7.3.4, 5.1, 5.3.

international agencies, $2.5 .2,4.2 .4 .2 .1,4.5 .1,4.5 .4,4.5 .4 .1,4.5 .5,4.8,5.1$.

International Convention on the Elimination of All Forms of Racial Discrimination (ICERD), 2.2, 2.3.1, 4.4.1, 4.4.4, 4.7.1, 4.7.2.2.2, 4.7.2.4.3.

International Convention on the Protection of the Rights of All Migrant Workers and Members of their Families (ICMW), 2.2, 2.3, 2.3.1, 4.3.4, 4.4.1, 4.4.6, 4.7.1, 4.7.2.3, 4.7.2.4.5.

International Covenant on Civil and Political Rights (ICCPR), 2.2, 2.6, 3.6.2.2, 3.6.4.2, 4.3.4, 4.5.2.2, 4.5.5, 4.6.4, 4.8.

International Covenant on Economic, Social and Cultural Rights (ICESCR), 2.1, 2.2, 2.3.1, 2.3.2, 2.3.3, 2.4, 2.5.1, 2.5.2, 2.6, 3.2.3.1, 3.2.3.2, 3.3.2.3, 3.6.3.4.2, 4.1, 4.3.4, $4.4 .1,4.4 .2,4.5 .2 .2,4.5 .5,4.7 .2 .1 .2,4.7 .2 .2,4.7 .2 .4 .2,4.8$.

international law, $2.3 .2,2.3 .3,3.3 .2 .2,3.3 .4 .5,3.3 .5 .2,3.3 .5 .5,3.4 .5 .4 .1,3.4 .6,4.1$, $4.2 .1,4.2 .2,4.2 .2 .1,4.2 .5,4.6 .1,4.6 .2,4.8$. 
job-training, 3.2.4, 3.7.3, 3.8, 5.1.

justiciability, $2.2,2.3 .2,2.3 .3,2.6,2.8,4.2 .2 .1,4.7 .2 .2$.

land, 2.3.1, 2.3.2, 2.3.3, 2.4, 2.5.1, 2.7, 2.8, 3.2.3, 3.2.3.4, 3.2.3.5, 3.3.2.2, 3.3.2.4, 3.3.2.5, 3.3.3.3, 3.3.3.5, 3.3.3.6, 3.3.3.7, 3.3.4.2, 3.3.4.3, 3.3.4.4, 3.3.4.5, 3.4.2, $3.4 .3,3.4 .4 .3,3.4 .5 .1,3.4 .5 .4 .3,3.4 .6,3.5 .1,3.5 .2 .1,3.5 .2 .2,3.5 .2 .3,3.5 .3 .2$, 3.5.3.3, 3.5.3.4, 3.5.4, 3.6.1, 3.6.2.3.3, 3.6.3.1, 3.6.3.2, 3.6.3.2.1, 3.6.3.2.2, 3.6.3.2.3, 3.6.3.2.4, 3.6.3.3, 3.6.3.4.1, 3.6.3.4.2, 3.6.3.5, 3.6.7, 3.7.2, 3.7.3, 3.7.5, $3.8,4.2 .4 .1,4.2 .4 .2 .1,4.3 .2,4.3 .3 .2,4.3 .4,4.4 .3,4.5 .3 .2,4.6 .3 .1,4.6 .3 .2,4.6 .3 .3$, 4.6.5, 4.6.6, 4.7.2.1.1, 4.7.2.1.1.1, 4.7.2.1.2.1, 4.7.2.3, 4.7.2.4.1, 4.7.3.1, 4.7.3.4, 4.7.5, 4.8, 5.1, 5.2, 5.2.2, 5.3.

legal capacity, 3.1, 3.5.1, 3.5.2, 3.5.2.1, 3.5.2.2, 3.5.2.4, 3.5.5, 3.8, 4.3.2, 4.4.2.1, 4.7.2.1.1, 4.7.2.1.1.1, 4.7.2.1.2.1, 4.7.3.4.

levirate, 3.3.4.2, 3.3.4.3, 3.5.2.1, 3.6.3.2.1, 3.6.3.2.3, 4.6.3.2, 4.6.4, 4.7.2.1.1, 4.7.2.1.1.1, 4.7.3.3, 5.1.

location, $2.4,2.8,3.3 .3 .3,3.4 .2,3.4 .4,3.4 .4 .3,3.4 .5 .4,3.5 .4,4.4 .2 .1,4.6 .3 .2,4.6 .5$

marriage (marital) property, 3.5.2, 3.5.2.1, 3.5.2.2, 3.5.2.3, 3.8, 4.7.2.1.1, 4.7.2.1.1.1, 5.1, 5.3.

personal laws, $2.7,3.3 .4 .2,3.3 .4 .4,3.5 .2 .1,3.5 .2 .4,3.5 .3 .2,3.5 .3 .5,3.5 .5,3.7 .1,3.7 .4$, 3.7.6, 4.2.3, 4.5.1, 4.5.3, 4.5.4.2, 4.5.4.2.1, 4.7.2.1.1, 4.7.2.1.1.1, 4.7.2.1.2.1, 4.8, 5.2.

political participation, $2.7,3.1,3.2 .3 .3,3.6 .1,3.6 .2,3.6 .2 .1,3.6 .2 .2,3.6 .2 .3 .1$, 3.6.2.3.2, 3.6.2.3.3, 3.6.2.6, 3.6.2.7, 3.6.7, 3.8, 4.5.2.1, 4.5.4.1, 4.6.3.1.

poverty, $2.3 .1,2.3 .2,2.3 .3,2.7,3.1,3.2 .1,3.2 .2,3.2 .3,3.2 .3 .1,3.2 .3 .2,3.2 .3 .4$, 3.2.3.5, 3.2.4, 3.2.5, 3.2.6, 3.2.7, 3.3.1, 3.3.3.2, 3.4.6, 3.6.1, 3.6.5, 3.8, 4.4.2, 4.7.2.1.2, 4.7.2.1.2.1.

principle of equality, $2.2,2.3 .1,2.6,2.7,2.8,3.2 .3 .1,3.2 .3 .2,3.2 .7,3.3 .3 .1,3.3 .4 .2$, 3.3.4.4, 3.5.1, 3.5.2, 3.5.2.1, 3.5.2.4, 3.5.3, 3.5.3.2, 3.5.3.5, 3.5.5, 3.6.2.1, 3.6.2.3.2, $3.6 .3 .2,3.6 .3 .2 .1,3.6 .3 .5,3.6 .5,3.7 .1,3.7 .3,3.7 .6,3.8,4.1,4.2 .1,4.2 .2,4.2 .2 .1$, $4.2 .3,4.2 .4,4.2 .4 .1 .1,4.2 .4 .2,4.2 .4 .2 .1,4.2 .5,4.3 .1,4.3 .2,4.3 .3,4.3 .3 .2,4.3 .4$, $4.3 .5,4.4 .2,4.4 .2 .1,4.5 .2,4.5 .2 .2,4.5 .3 .2,4.5 .4 .1,4.5 .4 .2,4.5 .5,4.6 .2,4.6 .3$, 4.6.3.3, 4.6.5, 4.6.6, 4.7.2.3, 4.7.3.4, 4.8, 5.1, 5.2, 5.2.2.

principle of non-discrimination, $2.3 .1,2.3 .3,2.4,2.7,2.8,3.5 .3 .2,3.5 .5,3.6 .3 .2$, 3.6.3.4.2, 3.6.3.5, 3.8, 4.1, 4.2.2, 4.2.2.1, 4.2.3, 4.2.4.1, 4.2.4.1.1, 4.5.2, 4.3, 4.3.1, $4.3 .3,4.3 .3 .2,4.3 .4,4.3 .5,4.4 .5,4.4 .6,4.5 .2,4.5 .3 .2,4.5 .3 .3,4.5 .4 .1,4.5 .4 .2$, $4.5 .5,4.6 .2,4.6 .3,4.6 .3 .3,4.6 .5,4.6 .6,4.7 .2 .3,4.7 .2 .4 .1,4.8,5.1,5.2$.

privacy, 2.3.2, 2.4, 2.5.1, 2.8, 3.1, 3.3.2.3, 3.3.5.1, 3.3.5.4.1, 3.3.5.4.3, 3.4.2, 3.4.4.1, $3.4 .5,3.4 .5 .1,3.4 .5 .3,3.4 .6,3.6 .1,3.6 .4,3.6 .4 .1,3.6 .4 .2,3.6 .4 .3,3.6 .4 .4,3.6 .7,3.8$, 4.3.3.2, 4.3.5, 4.4.2.1, 4.6.2, 4.7.2.1.1, 4.7.2.1.2.1, 4.7.2.2.1, 4.7.3.5, 4.8, 5.1, 5.3. 
Index

property, $2.3 .2,2.5 .1,2.7,2.8,3.1,3.2 .1,3.2 .3,3.2 .3 .4,3.2 .3 .5,3.2 .6,3.3 .2 .3$,

3.3.2.4, 3.3.2.5, 3.3.3.3, 3.3.3.5, 3.3.3.6, 3.3.3.7, 3.3.4.1, 3.3.4.2, 3.3.4.3, 3.3.4.4,

$3.3 .4 .5,3.3 .5 .1,3.3 .5 .4 .2,3.3 .5 .5,3.4 .3,3.4 .5 .4 .1,3.4 .6,3.5 .1,3.5 .2,3.5 .2 .1$,

3.5.2.2, 3.5.2.3, 3.5.2.4, 3.5.3.3, 3.5.3.4, 3.5.5, 3.6.1, 3.6.2.3.3, 3.6.3, 3.6.3.1,

3.6.3.2, 3.6.3.2.1, 3.6.3.2.3, 3.6.3.2.4, 3.6.3.3, 3.6.3.4, 3.6.3.4.1, 3.6.3.4.2, 3.6.3.5,

$3.6 .7,3.7 .2,3.7 .3,3.7 .5,3.7 .6,3.8,4.2 .2,4.2 .4 .2 .1,4.3 .2,4.3 .3 .1,4.3 .3 .2,4.3 .4$,

4.3.5, 4.4.2.1, 4.4.2.2, 4.5.2.1, 4.5.3.2, 4.5.4.2.3, 4.6.2, 4.6.3.1, 4.6.6, 4.7.2.1.1,

4.7.2.1.1.1, 4.7.2.1.2.1, 4.7.2.2.1, 4.7.2.3, 4.7.3.1, 4.7.3.4, 5.1, 5.2, 5.3.

public authorities, 2.3.2, 2.5.1, 3.1, 3.3.2.2, 3.3.2.4, 3.3.5.4.1, 3.3.5.4.3, 3.4.5, 3.4.5.1, 3.4.5.4.2.1, 3.6.1, 3.6.3.2.1, 3.6.3.4.1, 3.6.4.1, 3.6.4.2, 3.6.4.3, 3.6.4.4, 3.6.7, 3.8, $4.2 .1,4.2 .2 .1,4.4 .2 .2,4.5 .1,4.5 .4,4.5 .4 .2,4.5 .4 .2 .1,4.5 .4 .2 .2,4.5 .4 .2 .3,4.5 .4 .3$, $4.5 .4 .4,4.5 .5,4.6 .3 .1,4.6 .3 .2,4.6 .3 .3,4.6 .4,4.6 .5,4.7 .2 .1 .1 .1,4.7 .2 .1 .2 .1,4.7 .3 .4$, $4.8,5.1,5.2$.

refugees, $2.3 .1,2.3 .2,2.3 .3,2.8,3.3 .1,3.3 .3 .4,3.3 .3 .5,3.3 .5 .2,3.4 .1,3.4 .2,3.4 .4 .3$, 3.4.5, 3.4.5.4, 3.4.5.4.1, 3.4.5.4.2, 3.4.5.4.2.1, 3.4.5.4.3, 3.4.6, 3.6.3.3, 4.3.3.1, 4.6.3.2, 4.6.5, 4.7.2.1.2.1, 4.7.2.1.3, 4.7.2.1.4, 4.7.3.4, 5.1, 5.3.

rehabilitation, $2.6,3.6 .3 .2 .1,4.6 .2,4.6 .5,4.6 .6,4.7 .2 .2 .1$.

religion, 3.4.6, 3.6.2.1, 3.6.2.3.2, 3.7.1, 3.7.2, 3.7.6, 4.2.2, 4.2.2.1, 4.3.4, 4.5.2, 4.5.2.2, 4.5.3.1, 4.7.3.5, 4.8, 5.1.

reparation, 2.5.1, 3.6.3.4, 3.6.3.4.1, 4.6.1, 4.6.2, 4.6.3.3, 4.6.4, 4.6.5, 4.6.6, 4.7.2.2.1, 4.7.3.1, 4.8.

restitution, 3.6.3.2.1, 3.6.3.3, 4.6.2, 4.6.5, 4.6.6, 4.7.2.2.1, 4.7.3.4, 4.8.

returnees, 3.4.4.3, 3.6.3.3, 4.6.3.1, 4.6.5, 4.7.3.1, 4.7.3.4.

safe house, 3.3.5.4.3, 3.4.1, 3.4.5, 3.4.5.1, 3.4.6, 3.6.4.3, 4.6.3.2, 4.6.5, 4.7.2.1.1.

satisfaction, 4.6.2, 4.6.5, 4.6.6.

security of tenure, $2.3 .1,2.3 .2,2.4,2.5 .1,2.6,2.7,2.8,3.3 .2 .3,3.3 .3 .3,3.4 .2,3.4 .5$, 3.6.1, 3.6.3.1, 3.6.3.4, 3.6.3.4.1, 3.6.3.4.2, 3.6.3.5, 3.6.7, 4.4.2.1, 4.4.2.2, 4.7.2.1.2.1, 5.1.

shelter, 2.3.1, 2.3.2, 2.3.3, 2.4, 2.5.1, 2.6, 2.7, 2.8, 3.1, 3.2.2, 3.2.6, 3.3.1, 3.3.2.2, 3.3.2.4, 3.3.3.4, 3.3.3.5, 3.3.3.7, 3.3.4.3, 3.3.5.2, 3.3.5.4.3, 3.3.5.5, 3.4.1, 3.4.5, 3.4.5.1, 3.4.5.4, 3.4.5.4.3, 3.4.6, 3.6.4.3, 3.8, 4.3.2, 4.3.3.1, 4.6.3.2, 4.6.4, 4.6.5, 4.7.2.1.1, 4.7.2.1.1.1, 4.7.2.1.2.1, 4.7.2.1.3, 4.7.2.1.4, 4.7.2.2.1, 4.7.2.4.4, 4.7.3.1, 4.7.3.5, 5.1.

Special Rapporteur (general), 2.2, 4.1, 4.7.1, 4.7.3, 4.8. (also see Commission on Human Rights Special Rapporteur and Sub-Commission on Human Rights Special Rapporteur)

State obligations, 2.3.2, 2.3.3, 2.5, 2.5.1, 2.6, 2.8, 3.6.3.4, 3.6.3.4.2, 4.6.3.

State responsibility, 3.3.5.1, 4.1, 4.2.1, 4.2.2, 4.2.2.1, 4.6, 4.6.1, 4.6.2, 4.6.3, 4.6.3.2, $4.6 .3 .3,4.6 .4,4.6 .5,4.6 .6,4.8$. 
structural adjustment programme (SAP), 2.3.2, 3.2.6.

Sub-Commission on Human Rights Special Rapporteur

on adequate housing, 2.1, 2.3, 2.3.2, 2.3.3, 2.4, 2.5.1, 2.6, 2.7, 2.8, 3.3.2.3, 4.7.3.1.

on harmful traditional practices, 4.2.4.1, 4.2.4.1.1, 4.7.3.3, 5.3.

tradition, $2.7,3.2 .3 .5,3.3 .2 .4,3.3 .2 .5,3.3 .4 .1,3.3 .4 .4,3.4 .4 .3,3.5 .2 .3,3.5 .3 .2,3.5 .3 .3$, 3.5.3.5, 3.5.5, 3.6.2.1, 3.6.2.3.2, 3.6.3.2.1, 3.6.3.2.3, 3.6.3.2.4, 3.6.7, 3.7.1, 3.7.3,

3.7.4, 4.2.2.1, 4.2.4.1.1, 4.2.4.2.1, 4.3.4, 4.4.2.2, 4.5.1, 4.5.2.1, 4.5.2.2, 4.5.2.2,

4.5.3.1, 4.5.3.2, 4.5.4.1, 4.5.4.2.1, 4.5.4.2.3, 4.5.4.3, 4.5.5, 4.6.4, 4.7.2.1.1, 4.7.3.3, 4.8 .

universality, $2.7,4.5 .1,4.5 .3 .1,4.8$.

widowhood, 2.3.1, 2.3.3, 3.1, 3.3.1, 3.3.4, 3.3.4.1, 3.3.5.1, 3.8, 4.3.3.2, 4.7.2.1.1, 4.7.2.3, 4.7.3.1, 5.2.2

widows, $2.7,3.3 .1,3.3 .3 .3,3.3 .3 .7,3.3 .4 .1,3.3 .4 .2,3.3 .4 .3,3.3 .4 .4,3.3 .4 .5,3.4 .1$, 3.4.5, 3.4.5.2, 3.4.5.4.3, 3.5.2.1, 3.5.3.2, 3.5.3.3, 3.5.3.4, 3.6.3.2.1, 3.6.3.2.3, 3.6.3.3, 3.6.3.5, 3.7.3, 4.4.2.1, 4.6.3.1, 4.6.3.2, 4.6.5, 4.7.2.1.1, 4.7.2.1.1.1, 4.7.2.1.2, 4.7.2.1.2.1, 4.7.2.3, 4.7.3.3, 4.7.3.4, 5.1. 



\section{Curriculum Vitae}

Ingrid Westendorp was born in Brunssum, the Netherlands on 21 July 1956. She finished grammar school (Atheneum) in 1975 after which she was professionally trained as a secretary. Next to her job, she did a part-time teacher training course in English $(M O-A)$ from which she graduated in 1979. Until she started working with the University of Maastricht in 1986, first as the secretary of the International and European Law Department, and later also as the Co-ordinator of the Maastricht Centre for Human Rights, she lived a few years in Greece and gave birth to her son Leonidas. Beside her work for the International and European Law Department, she studied law with the Netherlands Open University, from which she graduated in 1998. Since that time she has worked for the same Department as Lecturer in Law, especially woman and law and international law. 



\section{SCHOOL OF HUMAN RIGHTS RESEARCH SERIES}

The School of Human Rights Research is a joint effort by human rights researchers in the Netherlands. Its central research theme is the nature and meaning of international standards in the field of human rights, their application and promotion in the national legal order, their interplay with national standards, and the international supervision of such application. The School of Human Rights Research Series only includes English titles that contribute to a better understanding of the different aspects of human rights.

Editorial Board of the Series: Prof. dr C. Flinterman (Utrecht University), Prof. dr W.J.M. van Genugten (Tilburg University), Prof. dr A.P. van Goudoever (Utrecht University), Prof. dr M.T. Kamminga (Maastricht University), Prof. dr P.A.M. Mevis (Eras $\neg$ mus University Rotterdam) and dr H. Werdmölder (Utrecht University)

Published titles within the Series:

1 Brigit C.A. Toebes, The Right to Health as a Human Right in International Law ISBN 90-5095-057-4

2 Ineke Boerefijn, The Reporting Procedure under the Covenant on Civil and Political Rights. Practice and Procedures of the Human Rights Committee ISBN 90-5095-074-4

3 Kitty Arambulo, Strengthening the Supervision of the International Covenant on Economic, Social and Cultural Rights. Theoretical and Procedural Aspects ISBN 90-5095-058-2

4 Marlies Glasius, Foreign Policy on Human Rights. Its Influence on Indonesia under Soeharto

ISBN 90-5095-089-2

5 Cornelis D. de Jong, The Freedom of Thought, Conscience and Religion or Belief in the United Nations (1946-1992)

ISBN 90-5095-137-6

6 Heleen Bosma, Freedom of Expression in England and under the ECHR: in Search of a Common Ground. A Foundation for the Application of the Human Rights Act 1998 in English Law

ISBN 90-5095-136-8

7 Mielle Bulterman, Human Rights in the External Relations of the European Union ISBN 90-5095-164-3 
Esther M. van den Berg, The Influence of Domestic NGOs on Dutch Human Rights Policy. Case Studies on South Africa, Namibia, Indonesia and East Timor ISBN 90-5095-159-7

Ian Seiderman, Hierarchy in International Law: the Human Rights Dimension ISBN 9050951651

10 Anna Meijknecht, Towards International Personality: the Position of Minorities and Indigenous Peoples in International Law ISBN $905095166 \mathrm{X}$

11 Mohamed Eltayeb, A Human Rights Approach to Combating Religious Persecution. Cases from Pakistan, Saudi Arabia and Sudan ISBN 90-5095-170-8

12 Machteld Boot, Genocide, Crimes Against Humanity, War Crimes: Nullum Crimen Sine Lege and the Subject Matter Jurisdiction of the International Criminal Court ISBN 90-5095-216-X

13 Corinne Packer, Using Human Rights to Change Tradition. Traditional Practices Harmful to Women's Reproductive Health in sub-Saharan Africa ISBN 90-5095-226-7

14 Theo R.G. van Banning, The Human Right to Property ISBN 90-5095-203-8

$15 \quad$ Yvonne M. Donders, Towards a Right to Cultural Identity? ISBN 90-5095-238-0

16 Göran K. Sluiter, International Criminal Adjudication and the Collection of Evidence: Obligations of States ISBN 90-5095-227-5

17 Nicola Jägers, Corporate Human Rights Obligations: in Search of Accountability ISBN 90-5095-240-2

18 Magdalena Sepúlveda, The Nature of the Obligations under the ICESCR ISBN 90-5095-260-7

19 Mitsue Inazumi, Universal Jurisdiction in Modern International Law: Expansion of National Jurisdiction for Prosecuting Serious Crimes under International Law ISBN 90-5095-366-2

20 Anne-Marie de Brouwer, Supranational Criminal Prosecution of Sexual Violence ISBN 90-5095-533-9

21 Jeroen Gutter, Thematic Procedures of the United Nations Commission on Human Rights and International Law: in Search of a Sense of Community ISBN 90-5095-557-6 
22 Hilde Reiding, The Netherlands and the Development of International Human Rights Instruments

ISBN 978-90-5095-654-3 